\author{
SZEGEDI TUDOMÁNYEGYETEM \\ BÖLCSÉSZETTUDOMÁNYI KAR \\ NEVELÉSTUDOMÁNYI DOKTORI ISKOLA \\ PSZICHOLÓGIA DOKTORI PROGRAM
}

\title{
TÁNCZOS TÍMEA
}

\section{A VERBÁLIS FLUENCIA ÉS A MUNKAMEMÓRIA ÉLETKORI VÁLTOZÁSAI ÉS SZEREPÜK AZ ISKOLAI TELJESÍTMÉNYBEN}

\author{
Ph.D-értekezés
}

Témavezető:

Dr. Németh Dezső

habilitált egyetemi docens

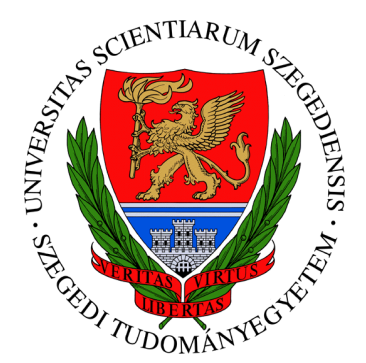

2014 


\section{TARTALOMJEGYZÉK}

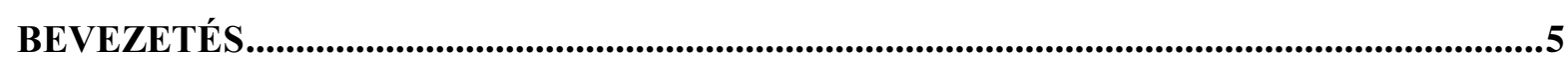

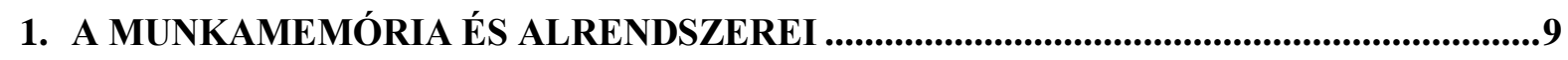

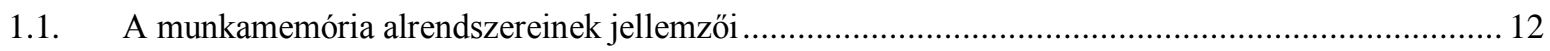

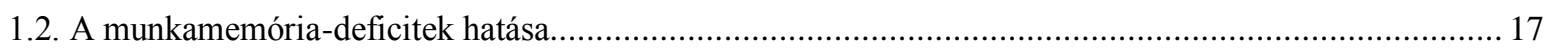

2. A VÉGREHAJTÓ FUNKCIÓK ÉS KOMPONENSEIK ..............................................19

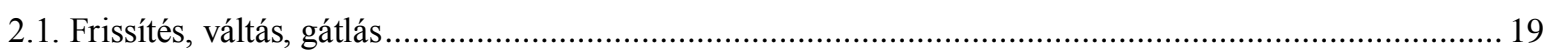

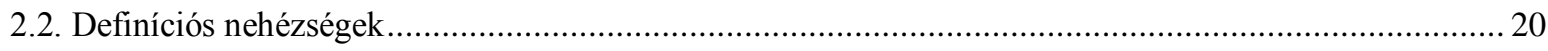

2.3. A végrehajtó funkciók tanulmányozásának relevanciája .............................................................2 24

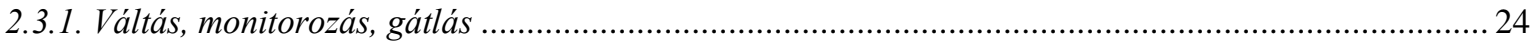

3. A MUNKAMEMÓRIA IDEGRENDSZERI HÁTTERE ÉS NEUROPSZICHOLÓGIÁJA26

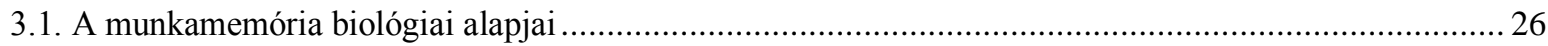

3.2. A verbális munkamemóriával kapcsolatos neuropszichológiai eredmények ......................................29

3.2.1. Munkamemória-deficitek különbözö neurológiai és pszichiátriai kórképekben................................29

4. A VÉGRHEJATÓ FUNCIÓK IDEGRENDSZERI HÁTTERE ÉS

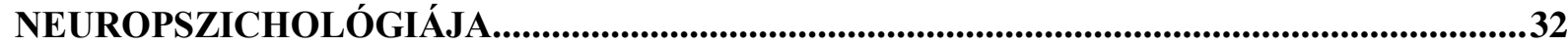

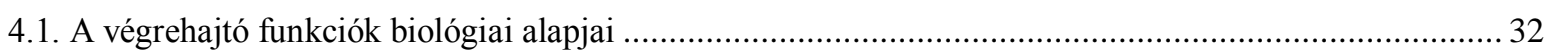

4.2. A végrehajtó funkciókkal kapcsolatos neuropszichológiai eredmények ........................................ 34

4.2.1. A végrehajtófunkció-deficitek különbözö neurológai és pszichiátriai kórképekben ............................ 34

4.2.2. A munkamemória és a végrehajtófunkció-deficitek különbözö fejlödési és tanulási zavarokban.......... 43

\section{A MUNKAMEMÓRIA ÉS A VÉGREHAJTÓ FUNKCIÓK NÉHÁNY MÉRŐELJÁRÁSA46}

5.1. A verbális rövid távú memória és a komplex munkamemória mérőeljárásai .....................................46

5.2. A komplex munkamemória mérőeljárásainak alkalmazási lehetőségei ........................................49

5.3. A végrehajtó funkciók mérése és alkalmazási lehetőségei .......................................................50

5.4.1. A verbálisfluencia-tesztek (Betü- és szemantikusfluencia-teszt) jellemzői ......................................53

6. A MUNKAMEMÓRIA ÉS A VÉGREHAJTÓ FUNKCIÓK ÉLETKORI VÁLTOZÁSAI..55

6.1. A munkamemória fejlődése és hatása a kognitív folyamatok müködésére........................................55

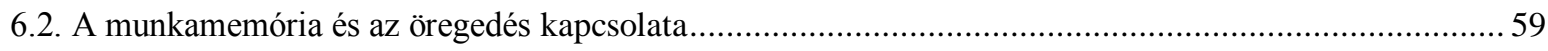

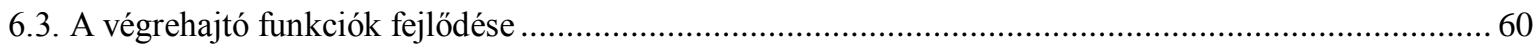

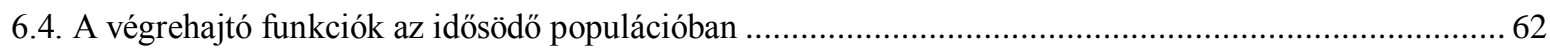

7. A MUNKAMEMÓRIA ÉS A VÉGREHAJTÓ FUNKCIÓK SZEREPE AZ ISKOLAI

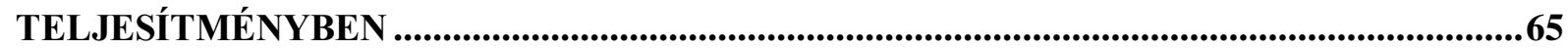




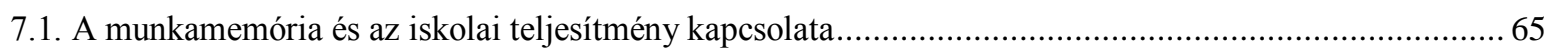

7.2. A végrehajtó funkciók és az iskolai teljesítmény kapcsolata ...................................................... 70

8. A VIZSGÁLATSOROZAT FELÉPÍTÉSE ................................................................73

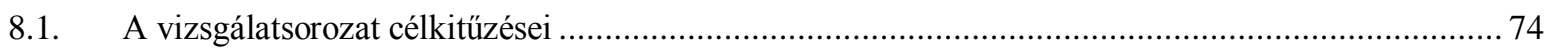

9. A VIZSGÁLATSOROZAT MÓDSZERTANA ......................................................................77

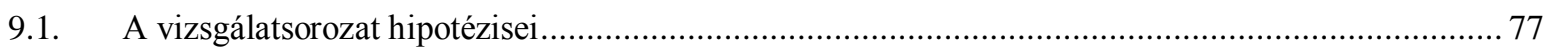

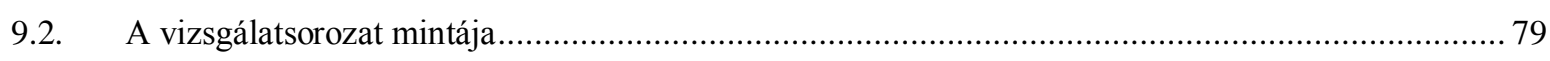

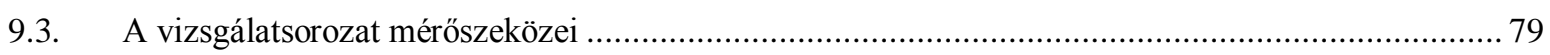

10. AZ ELSŐ VIZSGÁLAT $\ldots \ldots \ldots \ldots \ldots \ldots \ldots \ldots \ldots \ldots \ldots \ldots \ldots \ldots \ldots \ldots \ldots \ldots \ldots \ldots \ldots \ldots \ldots \ldots \ldots \ldots \ldots \ldots \ldots \ldots \ldots \ldots \ldots \ldots \ldots \ldots \ldots \ldots \ldots \ldots . . \ldots . \ldots \ldots 2$

A HALLÁSI MONDATTERJEDELEM TESZT ÉLETKORI VÁLTOZÁSAI ........................82

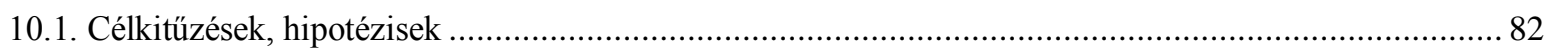

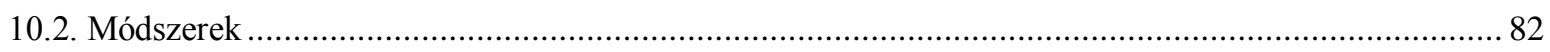

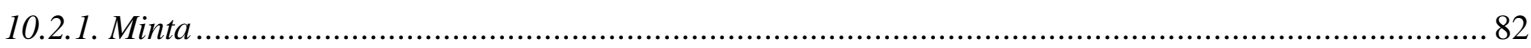

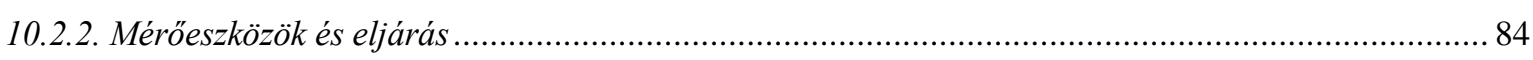

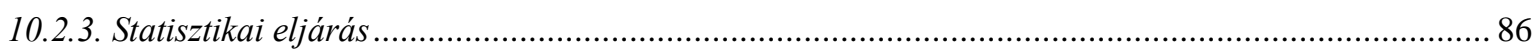

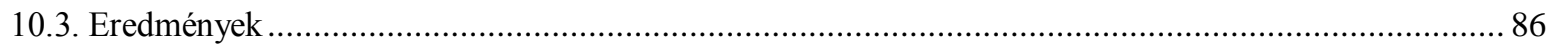

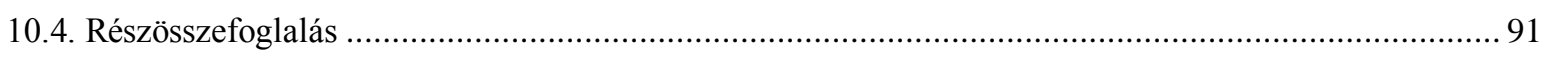

11. A MÁSODIK VIZSGÁLAT ................................................................................................93

A VÉGREHAJTÓ FUNKCIÓK (BETÜFLUENCIA-TESZT) FEJLŐDÉSE GYEREKKORTÓL IDÓSKORIG .............................................................................93

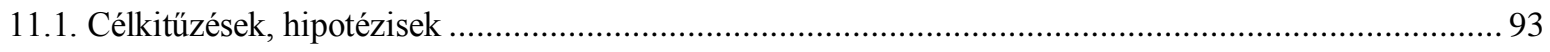

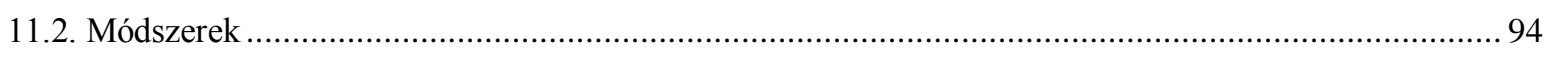

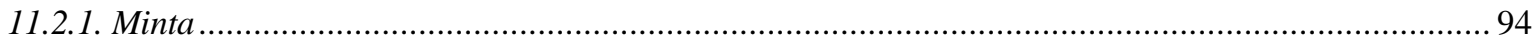

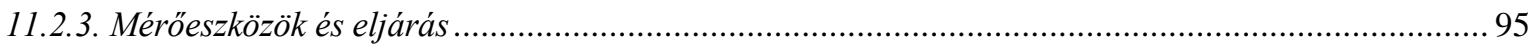

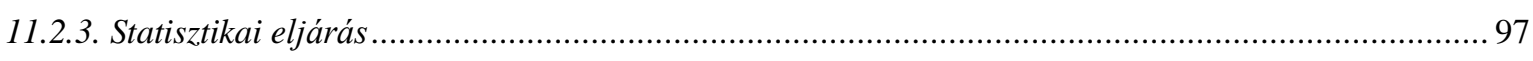

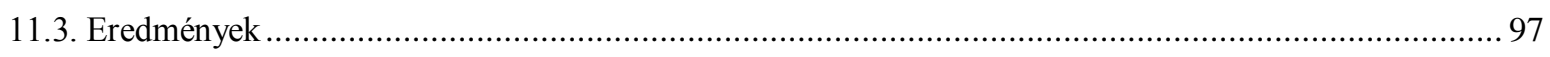

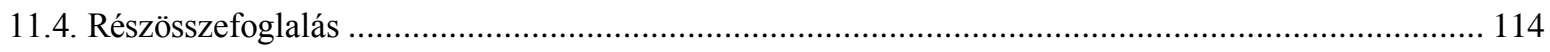

11.A HARMADIK VIZSGÁLAT .............................................................................................116

A VÉGREHAJTÓ FUNKCIÓK (SZEMANTIKUS FLUENCIA TESZT) FEJLŐDÉSE GYEREKKORTÓL IDÖSKORIG ...............................................................................116

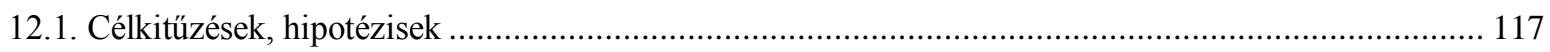

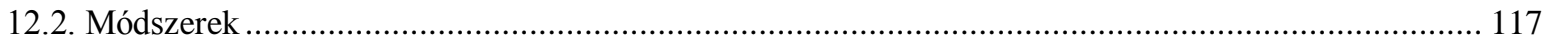

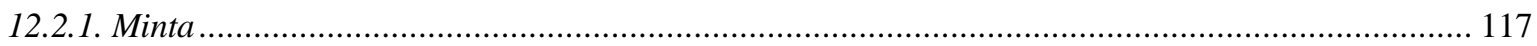




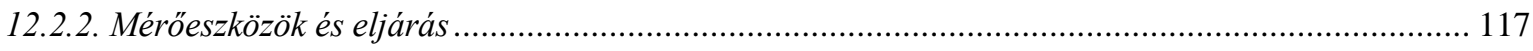

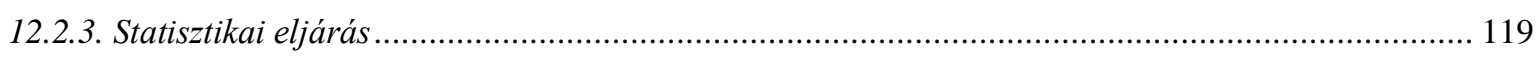

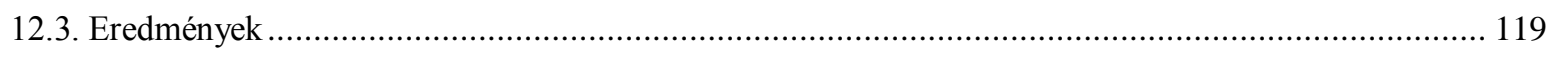

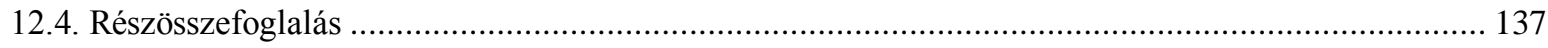

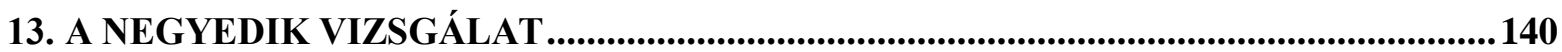

A KOGNITÍV FUNKCIÓK ÉS AZ ISKOLAI TELJESÍTMÉNY KAPCSOLATA ..............140

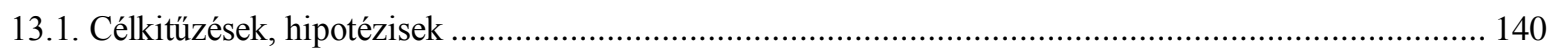

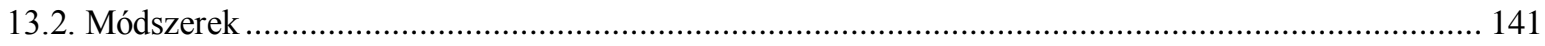

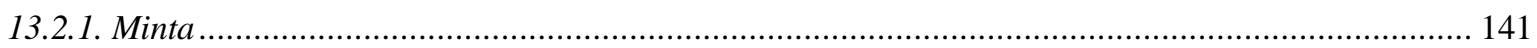

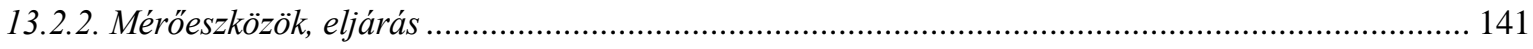

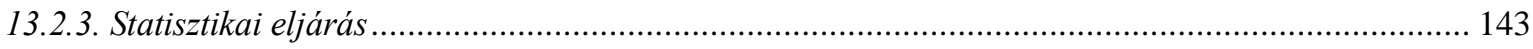

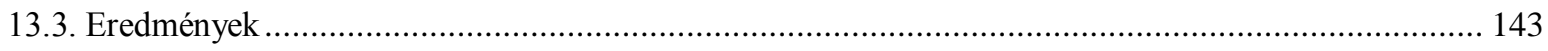

13.3.1. A magyar nyelv és irodalom tantárgyon nyújtott teljesitmény bejósló faktorai ............................ 143

13.3.2. A matematika tantárgyon nyújtott teljesitmény bejósló faktorai ................................................ 144

13.3.3. A környezetismeret tantárgyon elért teljesitmény bejósló faktorai ........................................... 145

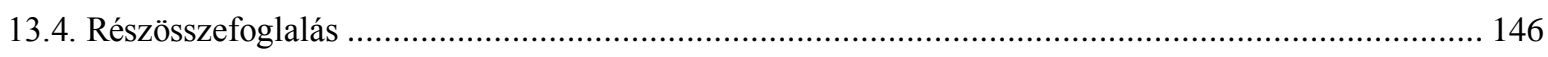

14. A MUNKAMEMÓRIA ÉS A VÉGREHAJTÓ FUNKCIÓK FEJLESZTÉSI LEHETÖSÉGEI ..................................................................................................................................150

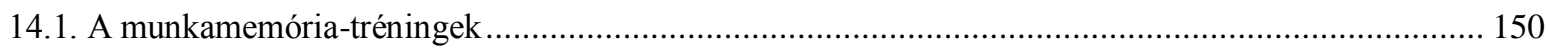

14.1.1. A munkamemória-tréningek számitógépes változatai......................................................... 151

14.1.2. A transzfer szerepe és a munkamemória-tréningek hatása a különbözö kognitív funkciókra ........... 153

14.2. A végrehajtó funkciók tréningje és rehabilitációja ................................................................ 158

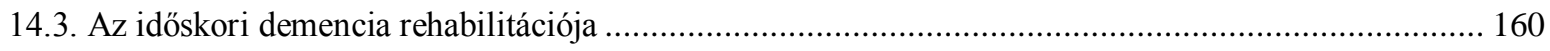

ÖSSZEGZÉS ÉS TOVÁBBI KUTATÁSI LEHETŐSÉGEK..................................................... 162

KÖSZÖNETNYILVÁNÍTÁS ...................................................................................................170

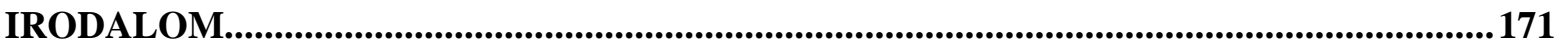

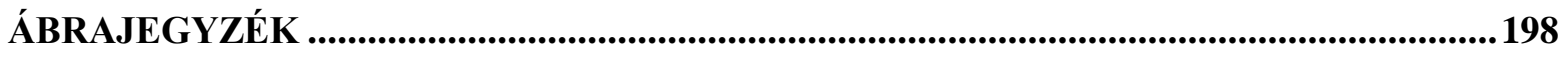

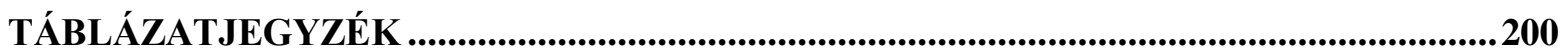

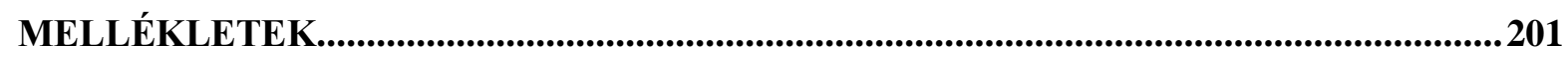




\section{BEVEZETÉS}

A kognitív tudományok megjelenésével alapvetően változott az a szemléletmód, ahogy az emberi képességekről gondolkodunk. A kognitív pszichológia módszertana és elméleti fejlődése, valamint a kognitív idegtudomány és neuropszichológia biológiai megközelítése ráirányította a figyelmet arra, hogy az emberi megismeréssel kapcsolatban nem beszélhetünk „nagy” funkciókról, mint a gondolkodás, emlékezet vagy tanulás. Nem egy emlékezeti vagy tanulási rendszer van, hanem számos, nem csak egy gondolkodásmód létezik, hanem mind pszichológiai szinten, mind az agyi hálózatok szintjén ezek egymástól jól elkülöníthetőek. Tehát fókuszáltabb funkciókban kell gondolkodnunk. Ez nemcsak a pszichológiát és az idegtudományt érinti, de a nyelvészetet, az orvostudományt és a neveléstudományt is (Csépe, 2005, 2011; Racsmány, 2007; Kállai, Bende, Karádi és Racsmány, 2008).

A disszertációban lépéseket teszünk a kognitív idegtudomány, kognitív pszichológia, neuropszichológia és a neveléstudomány „közös nevezőre” hozására. Ezek természetesen jelen esetben csak kis lépések lesznek. A munkamemória-rendszer és a végrehajtó funkciók vizsgálatán keresztül teszünk kísérletet arra, hogy körüljárjuk és bemutassuk, milyen lehetőségeink vannak a tanuláshoz kötődő megismerési funkciók fókuszáltabb feltérképezésére, valamint, hogy ezek a funkciók hogyan segíthetnek a tanulási folyamatok és az iskolai teljesítmény bejóslásában.

A disszertáció célja, hogy a jól körülhatárolt megismerési funkciók (például a munkamemória rendszerek és a végrehajtó funkciók) különböző fejlődési aspektusait megvizsgáljuk, és ezek kapcsolatát feltérképezzük az iskolai teljesítménnyel. A disszertációban négy nagy empirikus kutatást mutatunk be. Az 1., a 2. és a 3. vizsgálatban a hallási mondatterjedelem teszt, a betűfluencia -és a szemantikus fluencia teszt magyar verziójának alapjait ismertetjük. A tesztek segítségével lehetőség nyílik fókuszáltabb megismerési funkciók vizsgálatára, mivel ezek az idegrendszeri hálózatok szintjén is meglehetősen feltérképezettek. A 4. vizsgálatban a munkamemória és a végrehajtó funkciók szerepét térképeztük fel az iskolai teljesítményben.

Eredményeink nemcsak a pedagógia és az iskolapszichológia számára lehetnek fontosak, hanem a neuropszichológiai gyakorlatban is, továbbá alátámasztják, hogy a fókuszált kognitív funkciók vizsgálata interdiszciplináris megközelítésben hasznos eszközként szolgálhat az iskolai teljesítmény hátterének és egyéni különbségeinek pontosabb és részletesebb megértéséhez. Ez a típusú vizsgálati módszer segítheti a munkamemória, 
nyelvi és végrehajtó funkció károsodások detektálását tanulási nehézségekkel küzdő gyerekeknél is.

Életünk során sok olyan feladattal találkozunk, amikor valamilyen információt egyszerre kell rövidebb ideig tárolni és feldolgozni (például a követelmények változásának megfelelően frissíteni, az oda nem illö információkat legátolni stb.) Ilyen készségekre van szükségünk például a számolás, érvelés, egy előadás jegyzetelése, egy párbeszédben való részvétel, tervezés és problémamegoldás, a fluid intelligencia müködése (Cowan, Elliott, Saults, Morey, Mattox, Hismjatullina és Conway, 2005; Miyake és Shah, 1999) vagy a nyelvi megértés során. Ezen funkciók mindegyikében szükségünk van a munkamemóriára.

A munkamemória egy olyan dinamikus feldolgozó rendszer, amely limitált mennyiségü információ átmeneti tárolására és feldolgozására képes (Kane és Engle, 2002). Bizonyított tény, hogy a munkamemória kapacitása egy bizonyos terjedelmü egységben meghatározott, valamint hogy ez a terjedelem életkorfüggő és egyénenként különböző (Cowan, 2001; Gathercole, 1999; Pickering, 2001). A munkamemória kapacitásának egyéni különbségei számos okból eredhetnek, például a limitált kapacitás (Cowan, 2008) munkamemóriát korlátozó kognitívkontroll-mechanizmusok (Hasher, Lustig és Zacks, 2007; Hasher és Zacks, 1988). A fentiek miatt a disszertáció egyik fókusza a munkamemóriakapacitás fejlődésének vizsgálatára és ezek az iskolai teljesítményben meghatározó szerepére helyeződött.

A munkamemória kapacitásnak döntő szerepe van a gyerekek általános tudásának megszerzésében és az új készségek elsajátításában (Alloway, Gathercole, Adams, Willis, Eaglen és Lamont, 2005; Gathercole, Alloway, Willis és Adams, 2006; Gathercole, Pickering, Knight és Stegman, 2004). Számos vizsgálat eredményei alátámasztják, hogy a munkamemória kapacitása közvetlen kapcsolatban van az iskolai teljesítménnyel (Alloway, Gathercole, Kirkwood és Elliott, 2009; Gathercole, Lamont és Alloway, 2006; Rapport, Scanlan és Denney, 1999), például a matematikai készségek (Alloway és mtsai, 2005; Bull és Scerif, 2001; Gathercole, 1999; Mayringer és Wimmer, 2000; McLean és Hitch, 1999; Passolunghi és Siegel, 2004; Siegal és Ryan, 1989), a szókincs (Daneman és Green, 1986) a nyelvi megértés (Nation, Adams, Bowyer-Crane és Snowling, 1999; Seigneuric, Ehrlich, Oakhill és Yuill, 2000) és az olvasási képességek esetén (De Jong, 1998; Gathercole, Brown és Pickering, 2003; Gathercole, Pickering, Ambridge és Wearing, 2004; Swanson és Jerman, 2007). Az elmúlt években megnőtt azoknak a tanulmányoknak a száma, amelyek azt vizsgálják, hogy az iskolai teljesítményt mi befolyásolhatja. Főként a munkamemória, illetve a végrehajtó funkciók működését feltételezik ezek hátterében, azonban ezek szerepe 
különböző lehet az egyes tantárgyak esetében. Természetesen, egyéb tényezők is befolyásolhatják ezt, például a motiváció és a szocioökonómiai státusz.

Az elmúlt évtizedekben számos olyan nemzetközi kutatás jelent meg, amely a munkamemória és a végrehajtó funkciók egyes alkomponenseit vizsgálta. A kutatások egyik fókusza a fejlődési aspektus, aminek tanulmányozásával megérthetjük a kognitív rendszerek kialakulását, valamint az atipikus fejlődés, tanulási zavarok hátterében meghúzódó kognitív háttértényezőket is. Ugyanakkor kevés olyan kutatást találhatunk azonban, amely a teljes (vagy majdnem teljes) életkori spektrumot felölelő mintát használva, részletesen térképezné fel a végrehajtó funkciókat.

A disszertációban ezen hiányt pótoljuk hazai szinten. Felvázoljuk a munkamemória és a végrehajtó funkciók legfontosabb mérőeljárásait, ezek mérésének lehetőségeit. Bemutatjuk a komplex munkamemória egyik széles körben alkalmazott mérőeszközének, a hallási mondatterjedelem tesztnek a magyar verzióját is (Janacsek, Tánczos, Mészáros és Németh, 2009). Ezen kívül a végrehajtó funkciók hazai gyakorlatban is sürün használt mérőeljárását, a verbálisfluencia-teszteket (betüfluencia és szemantikus fluencia) ismertetjük, valamint bemutatjuk a tesztek magyar nyelvü változatát 5-89 éves korig, hangsúlyt fektetve az általánosan használt mutatók mellett a specifikusabb mutatókra is. A korábbi nemzetközi kutatásokban szintén nagy figyelmet kapott a kognitív funkciók és az iskolai teljesítmény kapcsolatának longitudinális tanulmányozása, azonban magyar nyelven ilyen jellegü vizsgálatra még nem került sor, ezért bemutatjuk az ebben a témában általunk kapott eredményeket is.

A disszertáció első és második fejezete a munkamemória és a végrehajtó funkciók témaköreibe nyújt betekintést néhány alapfogalom, az elméleti modellek és a fontosabb kutatási irányok áttekintésével. A harmadik és a negyedik fejezet a munkamemória és a végrehajtó funkciók idegrendszeri hátterét és az ezzel összefüggésben levő neuropszichológiai funkciókat elemző vizsgálatokat tárgyalja. Az ötödik fejezetben felvázoljuk a munkamemória és a végrehajtó funkciók legfontosabb mérőeszközeit ismertetjük. A hatodik fejezetben a munkamemória és a végrehajtó funkciók életkori változásait, azon belül pedig a verbálisfluencia feladatokon elért teljesítmény fejlődését taglaljuk gyerekkortól időskorig. A hetedik fejezetben a munkamemória és a végrehajtó funkciók iskolai teljesítményben meghatározó szerepét tárjuk fel. A nyolcadik fejezetben a vizsgálatsorozat felépítését, a kilencedik fejezetben pedig a módszertanát ismertetjük. A tizedik fejezetben az első vizsgálatunkat mutatjuk be, amely a komplex munkamemória egyik mérőeljárásának (hallási mondatterjedelem teszt) életkori változásait ismerteti magyar mintán. A tizenegyedik és a 
tizenkettedik fejezetben a végrehajtó funkciók fejlődését mutatjuk be gyerekkortól egészen idős korig, a második vizsgálatunk a betü, míg a harmadik vizsgálatunk a szemantikusfluencia-teszten kapott eredményeink elemzését tárgyalja. A tizenharmadik fejezetben a negyedik vizsgálatunkat ismertetjük, amely a kognitív funkciók és az iskolai teljesítmény kapcsolatát leíró elemzést tartalmazza. A tizennegyedik fejezetben a gyerekek és idősek esetében alkalmazható különböző fejlesztési lehetőségeket vesszük sorra. Az disszertációt az összegzés és a további kutatási lehetőségeket kijelölő fejezettel zárjuk.

A fejezetek közül néhány alapját korábban megjelent önálló vagy társzerzővel írt munka alkotja. Az Iskolakultúra folyóiratban megjelent tanulmány (Tánczos és Németh, 2010) keretében a munkamemória méröeljárásai kerültek bemutatásra, valamint kiemelésre került ezek szerepe az iskolai szürésben és fejlesztésben. A végrehajtó funkciók iskolában betöltött szerepéről és a verbálisfluencia-tesztekről szintén az Iskolakultúra címü folyóiratban számoltam be (Tánczos, 2012). A munkamemória és a végrehajtó funkciók kapcsolatát az iskolai teljesítménnyel az Alkalmazott Pszichológia folyóiratban publikáltuk (Tánczos, Janacsek és Németh, 2014). A betü és a szemantikus fluencia tesztek magyar nyelvü vizsgálatát 5-89 éves korig a Psychiátria Hungarica folyóiratban közöltük (Tánczos, Janacsek és Németh, 2014).

A 2013-2014-es tanévben Jedlik Ányos Doktorjelölti Ösztöndíjban részesültem, ahol kutatási témám „A végrehajtó funkciók és a munkamemória neuropszichológiája és kognitív idegtudományi megközelítése”, tehát szoros kapcsolatban áll a disszertáció témájával. 


\section{A MUNKAMEMÓRIA ÉS ALRENDSZEREI}

Az emberi emlékezet vizsgálata már több mint egy évszázada népszerü a kutatók körében. A tanulást az új információk megszerzéseként, a memóriát pedig egy olyan tudás megléteként definiálhatjuk, amely egy későbbi időpontban is elérhető (Squire, 1987). A tanulás és a memória három folyamatot foglal magában: a kódolást, a tárolást és az előhívást. A kódolás a bejövő információk tárolási folyamatát jelenti. A tárolás az információ megszerzésnek és konszolidációjának az eredménye, a memóriánk létrehozza és fenntartja a tartós emléknyomot. Az előhívás az előzőleg megtanult vagy elraktározott emlékek tudatos előhívását vagy felismerését jelenti. Atkinson és Schiffrin (1968) nevéhez köthető a modális model megalkotása, amely magában foglalta a szenzoros, a rövid és a hosszú távú memóriát is.

A szenzoros memóriának ugyan nagy információkapacitása van, azonban ezeket csak néhány miliszekundumig képes megtartani. A vizuális szenzoros emlékezetet más néven ikonikus memóriának vagy ikonikus tárnak nevezzük, míg a verbális szenzoros memóriát echoikus memóriának hívjuk. Szenzoros emlékek például a háttérzajok a memóriarendszerünkben. Ha nem raktározódnak el szenzorosmemória-nyomként, akkor nagyon gyorsan törlődnek.

A hosszú távú memóriát napokban vagy években mérjük, tartós emléknyom tárolást jelent. A kognitív pszichológiában a hosszú távú memóriát két részre oszthatjuk: deklaratív memóriára és non-deklaratív (implicit) memóriára. A deklaratív memória olyan tudást jelent, amihez tudatos hozzáférésünk van, beleértve a személyes és a világról alkotott tudást (Tulving és Markowitsch, 1998). A deklaratív memóriát további két részre oszthatjuk: szemantikus (tényekkel, eseményekkel kapcsolatos) és epizodikus (önéletrajzi) emlékezetre. Az emlékezeti, tanulási és intelligenciatesztek nagy része a szemantikus memóriát méri. Az epizodikus (önéletrajzi) emlékezetet annak személyes és szubjektív volta miatt nehéz mérni. A non-deklaratív memória olyan tudást jelent, amihez nincs tudatos hozzáférésünk, például a motoros és kognitív készségek (procedurális tudás). A procedurális tanulás számos olyan motoros készség megtanulását foglalja magában, mint a biciklizés, zongorázás vagy a balról jobbra olvasás.

Atkinson és Schiffrin (1968) nevéhez köthetjük a munkamemória elnevezést, akik szerint a rövid távú emlékezet munkamemóriaként funkcionál. Ez egy olyan rendszer, amelynek fontos szerepe van a kognitív müveletek végrehajtásában. A korai többszöröstárelméletek (Broadbent, 1957; Atkinson és Shiffrin, 1968) szerint háromféle memóriatár létezik: 
a modalitásspecifikus érzékelő tárak, melyekből az információ bekerül egy korlátozott kapacitású rövid távú tárba, és egy hosszú távú tár, melynek elméletileg korlátlan a kapacitása. Ezen elméletek egyik legfeltűnőbb hibája az volt, hogy egységesnek tartották a rövid távú tárat. A korai modális-modellt a többkomponensü és dinamikus munkamemóriamodell váltotta fel azzal, hogy ezt a hiányosságot kiküszöbölte (Baddeley és Hitch, 1974). Ez a modell az 1980-as évekre általánosan elfogadottá vált. Baddeley és Hitch (1974) úgy vélik, hogy a többkomponensü munkamemória-modell egy korlátozott kapacitású tár, melyet azzal igazoltak, hogy az egy időben végzett terheléses feladatok interferenciát okoznak és az emlékezeti teljesítményt lecsökkentik, ezzel egy időben az előhívás idejét meghosszabbítják. A vizsgálati személyeknek a munkamemória tesztekkel párhuzamosan számterjedelmi feladatokat kellett végezniük és ezek eredményeinek tanulmányozásából kapták a vizsgálat megállapításait. Megfigyelték, hogy a hatás nem egyforma erősségü, ezért azt a következtetést vonták le, hogy ez a rendszer több alrendszerre bontható. Ezek a kutatási eredmények segítettek abban, hogy a kutatók eljussanak a mai többkomponensü munkamemória-modell megközelítéshez. A munkamemória nem egyszerüen passzív tár, ami csak az információk tárolását végzi, hanem aktív információfeldolgozó rendszer, aminek segítségével műveleteket is végezhetünk, és amely további részekre tagolódik (lásd 1. ábra).

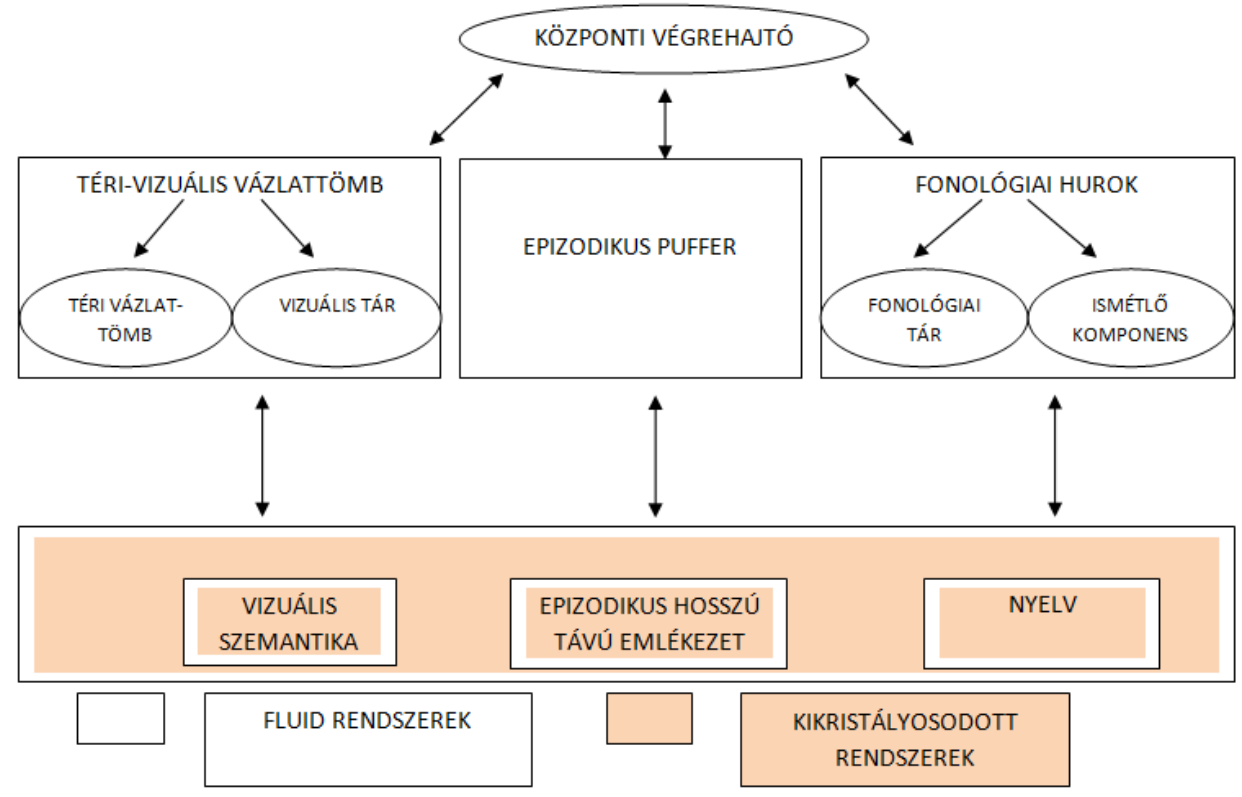

1.ábra

A Baddeley-féle munkamemória modell (Forrás: Baddeley, 2000 alapján, 421. o.) 
A munkamemória korlátozott kapacitású, amely összefüggésbe hozható az általános intelligenciával (Conway, Kane és Engle, 2003; Engle, Tuholski, Laughlin és Conway, 1999; Kyllonen és Christal, 1990), a tanulmányi eredménnyel (Bull, Espy és Wiebe, 2008; Gathercole, Pickering, Knight és Stegmann, 2004), valamint ez az egyik fö tünet az ADHD (Attention Deficit/Hyperactivity Disorder, ADHD) esetében (Martinussen, Hayden, HoggJohnson és Tannock, 2005; Willcutt, Doyle, Nigg, Faraone és Pennington, 2005). Továbbá a többkomponensủ munkamemória rendszernek továbbá jelentős szerepe van a különböző típusú információk ideiglenes tárolásában és feldolgozásban, így a tanulási folyamatokban is (Baddeley és Hitch, 1974; Baddeley, 2000, 2003; magyarul lásd Racsmány, 2007).

A munkamemória terület általános/területspecifikus aspektusai - Az eredeti munkamemória-modell szerint a központi végrehajtó az a területáltalános feldolgozó alkotóelem, amely területspecifikus komponenseket tárol (Baddeley, 1992). Shah és Miyake (1996) szerint a munkamemória rendszer két elkülönülő terület specifikus alrendszert foglal magában (verbális és téri-vizuális), amelyek egymástól függetlenül képesek fenntartani és manipulálni az információt. Azok a tanulmányok, amelyekben a rövid távú memóriát és a munkamemóriát hasonlítják össze, mindkét területen egy terület általános feldolgozó és egy területspecifikus tároló komponenst írnak le (Alloway, Gathercole és Pickering, 2006; Bayliss, Jarrold, Gunn és Baddeley, 2003), amelyek alátámasztják a Baddeley és Hitch-féle modellt. Továbbá különböző képalkotó eljárásokat használó tanulmányok is igazolják a munkamemória terület általános/specifikus komponenseit. A munkamemória müködésében fontos szerepe van a ventromediális, dorsolaterális, prefrontális és a parietális kéregnek is (Chein, Moore és Conway, 2011; Curtis és D’Esposito, 2003; Klinberg, Kawashima és Roland, 1996). A dorsolaterális PFC magasabb terhelés esetén aktiválódik főleg (Edin, Klinberg, Johansson, McNab, Tegnér és Compte, 2009; Linden, Bittner, Muckli, Waltz, Kriegeskorte, Goebel, Singer és Munk, 2003), míg a parietális lebeny a tárolási aktivitás esetében mutat magasabb érzékenységet (Todd és Marois, 2005). Továbbá a munkamemóriában megtartott elemek közti figyelemváltásért és fenntartásért felelős (Berryhill, Chein és Olson, 2011). A téma részletesebb kifejtésére a 3. fejezetben kerül sor.

A disszertáció további részében a szakirodalomban utóbbi időben bevett terminológiát alkalmazzuk (Gathercole, 1999): a fonológiai hurokra mint rövid távú emlékezetre (RTM; angolul Short-Term Memory, STM) hivatkozva, ugyanis itt csupán az információ rövid idejü tárolása a feladat. A munkamemória (Working Memory, WM) terminológiát ellenben olyan esetekben említik, ahol a tárolás mellett az információ manipulálására is szükség van (Engle, Kane és Tuholski, 1999; Daneman és Merickle, 1996; Service és Tujulin, 2002). Ez utóbbi, ha 
verbális alapú, akkor a Baddeley-féle munkamemória-modellben a fonológiai hurok és a központi végrehajtó együttesét jelenti. A téri vázlattömb és a vizuális tár együttes aktivációja szükséges a téri-vizuális munkamemória (Spatial-Visual Working Memory-SVWM) müködéséhez (Baddeley, 2003).

\subsection{A munkamemória alrendszereinek jellemzői}

Az elmúlt évtized szakirodalma (Gathercole, 1999) megkülönbözteti az alrendszerek között a fonológiai hurkot, vagyis a fonológiai/verbális rövid távú emlékezetet, ahol csak az információ rövid idejü tárolása a feladat, valamint a munkamemóriát, ahol a tárolás mellett szükség van az információ feldolgozására is (Engle és mtsai, 1999; Daneman és Merikle, 1996, Cowan, Towse, Hamilton, Saults, Elliott, Lacey, Moreno és Hitch, 2003; Service és Tujulin, 2002). Ha verbális alapú a munkamemória, akkor a Baddeley-féle modellben a fonológiai hurok és a központi végrehajtó együttesét értjük alatta. Müködésének a lényege a memória, a figyelem, és a percepció célnak megfelelő integrációja. Jellemző a munkamemória-rendszerre, hogy korlátozott kapacitású, hozzáférést biztosít a tudat számára az eltérő reprezentációkhoz (fenntartó funkció), fenntartja (monitorozza) és manipulálja az információkat gondolkodási feladathelyzetekben, független információkat hoz összefüggésbe és legátolja az irreleváns információkat (Baddeley, 1986).

A fonológiai hurok a beszédalapú információk ellenőrzéséért felelős és a munkamemória legintenzívebben vizsgált és legkidolgozottabb komponenseként tartják számon (Baddeley, 1992; Gathercole és Baddeley, 1993). A fonológiai hurok további két alegységre osztható fel: a fonológiai tárra, ami a verbális információ néhány másodpercig tartó megtartásáért felelős, és az artikulációs kontrollfolyamatra, ami a belső beszéden alapul. A fonológiai tár emléknyomai 1,5-2 másodperc alatt elhalványulnak, vagyis a fonológiai hurok ennyi ideig képes az információk megtartására. Az artikulációs kontrollfolyamatokkal szubvokálisan tudjuk frissíteni az emléknyomokat, mivel a folyamatok kiolvassák és visszaküldik az információt a fonológiai tárba a korai nyomelhalványulás megakadályozása érdekében (Gathercole, 1999). Minél gyorsabban zajlik le a frissítés, annál több elem marad meg az emlékezetben és annál inkább megnő az emlékezeti terjedelem. Az artikulációs kontrollfolyamatok képesek az írott információ fonológiai kóddá alakítására, és ezt be is tudják táplálni a fonológiai tárba (Zhang és Simon, 1985; Baddeley, 2000). Baddeley (2000) szerint az artikulációs kontrollfolyamat közremüködésével lehetőség van arra is, hogy vizuális információ is bekerüljön a fonológiai hurokba, például úgy, hogy hangosan kimondjuk, felolvassuk és ismételgetjük a leírt szöveget. 
A fonológiai hurok az információt nem a szemantika alapján, hanem a hangzás alapján tárolja, ezért a szeriális felidézési teljesítmény jobban károsodik olyan elemek esetében, amelyek hasonló hangzásúak vagy az artikulációs tulajdonságaikat figyelembe véve hasonlóság figyelhető meg, mint olyanoknál, amelyek jelentésben hasonlítanak egymásra. Ezt fonológiai hasonlósági hatásnak nevezzük, ami a fonológiai tár müködéséhez kapcsolható és amit először az 1960-as években írtak le (Conrad és Hull, 1964; Baddeley, 1966). A fonológiai kód alkotja a tárolás alapját, ezért a hasonló elemekhez hasonló kódok köthetők.

Vizsgálatokkal kimutatták, hogy összefüggés van az olvasási sebesség, a szóhosszúság és az 1-5 szótagszámú szavak memorizálásával kapcsolatos emlékezeti teljesítmény között, ami azon keresztül hat, hogy mennyire hosszú a hangzási idő (Baddeley, Thomson és Buchanan, 1975). A szóhosszúsági hatást úgy tudjuk a legkönnyebben magyarázni, hogy a szavak hosszúsága befolyásolja a teljesítményt, tehát minél hosszabb szavakat kell megjegyeznünk, annál rosszabb lesz a teljesítmény, mert az emlékezeti terjedelmet meghatározza az, hogy mennyi elemet tudunk két másodperc alatt kiejteni. Ebből következik, hogy akik gyorsabban beszélnek, magasabb értékeket, vagyis jobb teljesítményt érhetnek el a verbálismunkamemória-feladatokban. A gyerekek esetében a beszédszervek és azok mozgékonyságának érése, valamint az artikuláció motoros részeinek fejlödése hozzájárul ahhoz, hogy a munkamemória kapacitásuk növekedhessen. Hoosain és Salili (1988) kutatásukban kimutatták, hogy a matematikai eredmények és a számterjedelmi feladaton elért teljesítmény között gyenge a korreláció, ami igazolja a munkamemória szerepét a kognitív folyamatokban. Ezen eredmények alapján feltételezhető, hogy szoros kapcsolat van a fonológiai hurok, a nyelv és a számolás, fejszámolás között. Hoosain és Salili (1988) valamint Ellis és Hennelly (1980) vizsgálatukban különböző nemzetiségü 20 és 30 év közötti személyeket vizsgáltak. Azt találták, hogy a kínaiak számterjedelme áltagban 9,9, az angoloké átlagban 6,6, míg a walesieké 5,8. Az eredményeket a szóhosszúsági hatással indokolták: a kínaiak eredménye azzal magyarázható, hogy a számneveket ők ejtik ki a leggyorsabban. Az angol és a walesi számnevek szótagszám tekintetében ugyan egyformák, de a walesi számnevek főleg hosszú magánhangzókból állnak, ezért több időbe telik azok nevét kiejteni.

Az artikulációs kontroll, vagyis a fonológiai hurok jelenlétét bizonyítja az artikulációs elnyomási hatás is (Baddeley, Lewis és Vallar, 1984). Ez akkor fordul elö, ha hangosan vagy hangtalanul ismételgetünk valamit, például miközben egy szó- vagy számlistát kell megtanulnunk. Tehát ha egy emlékezeti feladattal párhuzamosan egy szót kell ismételgetnünk, akkor az emlékezeti kapacitás csökkenését figyelhetjük meg. Az ismételgetés lefoglalja az artikulációs kontrollfolyamatokat, ezzel pedig megakadályozza a fonológiai 
tárban levő elemek frissítését és a vizuális elemek átalakítását fonológiai kóddá, így rontja a teljesítményt. Hatása független attól, hogy mit kell a vizsgálati személynek ismételgetnie. Viszont Baddeley, Thomson és Buchanan (1975) vizsgálati eredményei kimutatták, hogy az artikulációs elnyomás kizárólag vizuális ingerek esetében tüntette el a szóhosszúsági hatást, auditoros bemutatásnál nem tapasztaltak ilyet. Ez megdönti azt a kezdetleges vélekedést, hogy mind auditoros, mind vizuális inger érkezése esetén az artikulációs elnyomási hatás teljesen kitörli a szóhosszúsági hatást. Baddeley, Lewis és Vallar (1984) további vizsgálatokban az artikulációs elnyomást az előhívásnál és a bemutatásnál is használták. Az eredmények alátámasztották a korábbi vélekedéseket (Baddeley, 2000).

A nem figyelt beszéd a fonológiai tárba kerülve károsítja az emlékezeti megtartást. Colle és Welsh (1976) vizsgálatában a felnőtt vizsgálati személyeknek vizuálisan mutattak be számokat, amiket meg kellett tanulniuk, és ezzel párhuzamosan egy idegen nyelvü szöveget hallgattak. Annak ellenére, hogy a személyek nem értették a szöveget, a teljesítményük leromlott. A vizuálisan bemutatott számtanulási feladatban nyújtott teljesítményt tehát erősen lerontják a nem figyelt értelmes és értelmetlen szavak, mivel ezek bekerülnek a fonológiai tárba. Értelmetlen szavak esetén a hatás azzal magyarázható, hogy a tárban a fonológiai információk raktározódnak és nem a szemantikusak. Ha a nem figyelt beszédnek jelentése is van, tehát a vizsgálati személyek értik a szöveget, akkor ez elvonja a figyelmet, ami a teljesítmény további csökkenéséhez vezet. Ebben az esetben a megjegyzés és a szövegmegértés színvonala is jelentős mértékben csökken. A nem figyelt zajnak nincs ilyen hatása, még akkor sem, ha annak rezgésmintázata azonos a folyamatos beszéd modulációjával (Salamé és Baddeley, 1987, 1989). Vizuálisan bemutatott ingerek esetén az artikulációs elnyomással eltünik a nem figyelt beszéd hatása, a szóhosszúsági hatás és a fonológiai hasonlósági hatás is, mivel ebben az esetben az információ nem verbális, hanem képi kód formájában raktározódik el (Colle és Welsh, 1976).

A különböző típusú információkat két modalitás alapú tároló komponensbe különítették el (Baddeley és Hitch, 1974). Az egyik alrendszer az elöbbiekben bemutatott fonológiai hurok, a másik a téri-vizuális vázlattömb, amely téri, vizuális és kinesztetikus információkat foglal egységes reprezentációkba (Baddeley, 2003). A vázlattömb egyik része a téri, a másik a vizuális információk feldolgozásáért felelős. Az információ kétféleképpen kerülhet a rendszerbe: vizuális percepció útján közvetlenül vagy képzeleti képek létrehozásával, közvetett úton. Az emlékezeti teljesítmény javul akkor, ha a vizsgálati személyek el tudják képzelni a megjegyzendő szavakat és akkor is, ha össze tudják kötni az emlékezeti képeket. Ha téri mondatokat kell megjegyezniük, akkor képzeletüket használják, 
mely olyan folyamatokat vesz igénybe, amik a vizuális percepcióhoz hasonlóak. Ha nem téri mondatokat kell megjegyezniük, akkor verbális kódok segítségével jegyzik meg az információkat, melyek müködése az auditív észleléssel megegyező folyamatokon alapszik (Paivio, 1969).

A többkomponensű, dinamikus munkamemória-modellben a központi végrehajtó felelős a munkamemória figyelmi kontrolljáért, beleértve a fókuszálást, megosztást és a figyelmi váltást (Baddeley, 2002, 2003), valamint ellenőrzi és irányítja a periférikus alrendszerek müködését (fonológiai hurok és téri-vizuális vázlattömb). Emellett kapcsolatot teremt a hosszú távú emlékezet és az alrendszerek között (Baddeley, 2003), és felelős a korlátozott erőforrások elosztásáért és a különböző müveletek végrehajtásáért, illetve az információk manipulálásáért is. A központi végrehajtó tehát egy modalitás-független információkezelő eszköz, mely figyelmi, kontrolláló rendszerként is müködik.

Baddeley és Hitch (1986) a központi végrehajtó müködésének magyarázójaként egy másik rendszert, Norman és Shallice (1986) ellenőrző figyelmi rendszerét (SAS-Supervisory Attentional System, magyarul Figyelmi Ellenőrző Rendszer) használta, mivel a központi végrehajtót inkább egy figyelmi rendszerhez hasonlították, mint egy tároló, emlékezeti rendszerhez. Ez a modell segítséget nyújt abban, hogy megértsük a központi végrehajtó müködését és az emberi viselkedés kontrolljának folyamatait. A rendszernek ellenőriznie kell a cselekvést és feladata az is, hogy különbséget tudjon tenni a rutinakciók és az új, környezeti információk között. Készségszintre fejlődhet az, hogy a specifikus ingereket és válaszokat össze tudjuk kapcsolni, amelyhez csak kevés figyelmi kontrollra van szükség.

Schneider és Shiffrin (1977) megállapította, hogy a versengő válaszok között nagyon kevés interferencia lép fel, ezért a válaszok szinte automatikusan megjelennek. Norman és Shallice (1986) szerint a viselkedés ellenőrzése egyfelől reflexszerü, túltanult cselekvésekkel történhet meg. Különböző válaszok versengése esetén a válaszok automatikus folyamatok ráhatásaként születnek meg. Ezt a folyamatot „,a tervek versengésének” nevezték el. Másfelől pedig a SAS rendszert is meghatározták, amely teret enged a szokások mellett az akarat kibontakozásának is. Ennek segítségével lehetőség nyílik a viselkedés megállítására, változtatására vagy éppen korrigálására, vagyis egy éppen folyamatban lévő séma befolyásolására, valamint fontos szerepe van még olyan helyzetekben is, amikor új vagy nehezen kivitelezhető akciókat végzünk vagy egy döntés meghozatalát hajtunk végre. Ezen elmélet alapja néhány neuropszichológiai betegség megfigyeléséből származik, ezek közül is kiemelten fontos a frontálislebeny-szindróma (Luria, 1969). Ezek a betegek gyakran „perszeverálnak”, vagyis „,beleragadnak” a rutincselekvésekbe. Ezen kívül a „felhasználási 
viselkedés" is jellemzi őket, ami azt jelenti, hogy a páciensek minden kezük elé kerülő tárgyat használnak, még akkor is, ha ez a cselekvés az adott helyzetben egyáltalán nem indokolt. A frontálislebeny-szindrómában a SAS nem tudja legátolni az aktiválódott viselkedéses sémát, mivel a rendszer megsérült (Baddeley, 2001; Racsmány, 2004).

Baddeley (2000; 2002) újabb elméletében a modell részét képezi az epizodikus puffer is, ami multimodális információk tárolásárával összeköttetést teremt a modalitásspecifikus komponensek és a hosszú távú memória között (Racsmány, 2007). Az epizodikus puffer egy limitált kapacitású rendszer, ami epizodikus abban az értelemben, hogy komplex struktúrává vagy epizóddá integrálja a számos forrásból érkező információt, beleértve a hosszú távú memóriát is (HTM). Puffer abban az értelemben, hogy az alrendszerek közötti közvetítőként funkcionál és különböző kódokat egységes multidimenzionális reprezentációkba tömörít (Baddeley, 2000, 2002, 2003).

A hétköznapokban gyakran van arra szükségünk, hogy valamilyen információt rövid ideig tárolni tudjunk és azon müveleteket végezzünk, vagy folyamatosan tudjuk frissíteni azokat a megváltozott körülményeknek megfelelően. Ezekre kerül sor például egy történet megismétlése vagy egy párbeszéd lefolytatása közben, vagy a többjegyü számokkal történő fejben számolás esetén. Az ilyen feladatok sikeres kivitelezéséhez szükségünk van a munkamemóriánkra, mivel a verbális rövid távú memória segítségével csak passzívan tudjuk tárolni az információkat.

Az egységes erőforrásrendszer-elmélet (Daneman és Carpenter, 1980; Just és Carpenter, 1992) szerint a munkamemóriában vám-rév hatás müködik a tárolás és a feldolgozás szakasza között: minél több erőforrást összpontosítunk a feldolgozásra, annál kevesebb jut a tárolásra. Az utóbbi évtizedekben számos vizsgálatban tesztelték ezt az elméletet, melyek ellentmondásos eredményeket produkáltak (Towse, Hitch és Hutton, 1998; Waters és Caplan, 1996; Németh, 2006). Függetlenül a munkamemória konstruktuma hátterében meghúzódó elméleti vitáktól, abban egyetértenek a kutatók, hogy ez egy létező rendszer, melynek fontos szerepe van az összetett kognitív feladatok megoldásában. A feladatokban produkált teljesítményre erős prediktív hatással bír a munkamemória-kapacitás, amely erős korrelációt mutat az intelligencia általános g-faktorával (Kane, Hambrick és Conway, 2005; Conway, Cowan, Bunting, Therriault és Minkoff, 2002; Kane és Engle, 2002). 


\subsection{A munkamemória-deficitek hatása}

A munkamemória korlátozott kapacitása különböző problémákat okozhat a mindennapi életben, így az iskolában a gyerekeknek nehézségeik lehetnek például a nyelvelsajátítás, a figyelem és a problémamegoldás területén is.

A területáltalános tárolórendszer és az iskolai előmenetel kapcsolatát már több kutatásban vizsgálták. A verbális munkamemória elsősorban az anyanyelv tanulásával mutatott kapcsolatot, míg a téri-vizuális memória az anyanyelvvel, a matematikával és a természettudományokkal volt összefüggésbe hozható (Thompson és Gathercole, 2006). A téri-vizuális alrendszer magasabb korrelációt mutatott az intelligenciával, mint a verbális komponens (Kane, Hambrick, Tuholski, Wilhelm, Payne és Engle, 2004). A téma bövebb kifejtésére a 10. fejezetben kerül sor.

A munkamemória-kapacitás összefügg az olvasási és az aritmetikai teljesítménnyel (Thompson és Gathercole, 2006; Raghubar, Barnes és Hecht, 2010). Alapvető szerepe van a tanulásban, például az instrukciók követésében (Engle, Carullo és Collins, 1991; Gathercole, 2008), ezáltal előrejelzi az iskolai előmenetelt is. 7 és 14 éves kor között azok a gyerekek, akiknél alacsony munkamemória-kapacitást mértek, az életkori átlaghoz képest gyengébben teljesítettek az anyanyelv, a matematika és a környezetismeret tantárgyakon (Gathercole, Brown és Pickering, 2003; Gathercole és Pickering, 2000a, 2000b; Gathercole, Pickering, Knight és Stegmann, 2004; Jarvis és Gathercole, 2003). Azok az egyetemisták, akik csökkent munkamemória terjedelemmel rendelkeznek, figyelmük könnyebben elterelhetővé válik (Conway, Cowan és Bunting, 2001), valamint sokkal jobban elkalandoznak a gondolataik, mint a magas munkamemória kapacitásúak (Kane, Conway, Miura és Colflesh, 2007). Az egyik lehetséges mechanizmus emögött a hatékony szürés képessége, az alacsony munkamemória kapacitású személyek nagyobb arányban tárolnak szükségtelenül irreleváns információkat, mint a magas munkamemória kapacitású személyek (McNab és Klinberg, 2008; Vogel, McCollough és Machizawa, 2005). Ebből következően a gyenge munkamemória az egyik fő probléma a tanulási nehézségekkel küzdő gyerekek és fiatalok esetében is (Alloway, 2009; McLean és Hitch, 1999, Kane és mtsai, 2007). Továbbá a munkamemória érintettségét figyelhetjük meg különböző klinikai populációkban is, mint pl. a traumatikus agysérülést elszenvedett betegek esetében (McDowell, Whyte és D’Esposito, 1997), a specifikus nyelvi károsodás esetében (Archibald és Gathercole, 2006), skizofrén betegeknél (Pukrop, Matuschek, Ruhrmann, Brockhaus-Dumke, Tendolkar, Bertch és Klosterkötter, 2003; Lee és Park, 2005) és koraszülötteknél is (Lucianam Lindeke, Georgieff, Mills és 
Nelson, 1999). Ezen munkamemória-deficitek felismerésének fontos szerepe van a gyerekek és a fiatalok iskolai előmenetelében, mivel a korai diagnosztika és a minél korábban megkezdett fejlesztés segítségükre lehet a lemaradások elkerülésében, azok csökkentésében. 


\section{A VÉGREHAJTÓ FUNKCIÓK ÉS KOMPONENSEIK}

A munkamemória-modellben a központi végrehajtó egy nehezebben körülírható konstruktumként szerepel, mivel Baddeley (1998) szerint nem kezelhetjük egységes rendszerként (Goldberg, 2001; Brown, 2005). Ezzel szemben Parkin (1998) vitatta a központi végrehajtó létezését. Feltérképezte a neuropszichológiai és a neuroradiológiai evidenciákat és véleménye szerint a különböző neuropszichológiai tesztek által mért funkciók eltérő neurális alapokon nyugszanak. Javasolta a központi végrehajtó fogalmának elhagyását és a végrehajtó funkciók minőségi úton történő tesztelését.

A központi végrehajtó körüli viták hatására (Parkin, 1998; Baddeley, 1998) a szakirodalomban a végrehajtó funkció kifejezés gyakran szerepel, ahogyan ezt a disszertációban is használjuk. Ezt alátámasztja továbbá, hogy a klinikai gyakorlatban is a végrehajtó funkciók elnevezés terjedt el.

A korai kutatásokban három jól elkülöníthető, de összetartozó alkotóelemet különböztettek meg. Az első a figyelmi kontroll, amelynek a szelektív figyelem és megtartott figyelem esetében van fontos szerepe. A második a kognitív flexibilitás, amely a munkamemóriával, a figyelmi váltással, az önmonitorozással és a fogalmi transzferrel van kapcsolatban. A harmadik a cél-elérés (goal-settings), ami a megfelelő kezdés, tervezés, problémamegoldás és stratégiai viselkedés hatására következik be (Lezak, 1993; Luria, 1973; Shallice, 1982; Stuss, 1992; Temple, 1997, Anderson, Anderson, Northam, Jacobs és Catroppa, 2001). Ezek a funkciók szükségesek a mindennapi életben való sikeres müködéshez. A végrehajtó funkciók érintettsége, gyengesége esetén az egyének nehezen tudják a figyelmüket összpontosítani, nehezükre esik valaminek a megtervezése, a stratégiák megalkotása és kivitelezése, valamint képtelenek a visszacsatolás megfelelő használatára és a rugalmas gondolkodásra is (Roebers, Röthlisberger, Cimeli, Michel és Neuenschwander, 2011).

\subsection{Frissítés, váltás, gátlás}

A végrehajtó funkciók disszertációban felhasznált elméleti keretét Miyake, Friedman, Emerson, Witzki, Howerter és Wager (2000) pszichometriai modellje adta, mely a látens változó elemzést alkalmazva a végrehajtó funkciókat három fó komponensre osztotta: az első a frissítés és monitorozás (updating); a második a váltás (shifting) és a harmadik a gátlás (inhibition). Frissítésen a munkamemória tartalmának frissítését és dinamikus monitorozását értjük, ami megköveteli a bejövő információ áttekintését és kódolását, továbbá megfelelően 
javítja a munkamemóriában megtartott elemeket azzal, hogy a többé már nem használatos információkat új, relevánsabb információkkal helyettesíti (Morris és Jones, 1990). Váltás alatt az irreleváns feladat készletről történő leválás és az adott feladat szempontjából releváns újabb készletre történő átváltás képességét tekintjük, tehát a váltás az összetett feladatok, a müveletek és a mentális készletek közötti rugalmas mozgást jelenti (Monsell, 1996). A gátlás fogalmán a domináns válaszok gátlását, és a folyamatok kimenetelének monitorozását értjük. Segítségével szándékosan le tudjuk gátolni a domináns, az automatikus vagy az előfeszített válaszokat (Stroop, 1935; Demeter, Csigó, Németh és Racsmány,2008). Ennek a felosztásnak az alapját a végrehajtó figyelmi rendszer adta (Engle és Kane, 2004). Miyake és munkatársai (2000) eredményei azt mutatták, hogy a végrehajtó funkciók elkülöníthető, de egymással közepesen összefüggő konstruktumok. Ezen faktorok vizsgálatát több fejlődéspszichológiai tanulmányban megismételték már (Huizinga, Dolan és Van Der Molen, 2006; Lechto, Juujarvi, Kooistra és Pulkkinen, 2003). Ennek ellenére számos vizsgálat eredményei szerint a fejlődés során a képességek jobban elkülönülnek a különféle fejlődési görbék miatt (Brocki és Bohlin, 2004; Carlson, 2005; Davidson, Amso, Anderson és Diamond, 2006; Diamond, Kirkham és Amso, 2002).

\subsection{Definíciós nehézségek}

A végrehajtó funkciók müködésének kutatásával kapcsolatos nehézségek között kell megemlítenünk azt a tényt, hogy magát a fogalmat sok esetben eltérö jelentéssel használják a szakirodalomban, például problémamegoldás (pl. Levin, Song, Ewing-Cobbs, Chapman és Mendelsohn, 2001), tervezés (pl. Shallice és Burgess, 1991) és a viselkedés kezdeményezése (pl. Shimamura, Janowsky és Squire, 1990).

A végrehajtó funkciókat egy olyan széles teoretikus fogalomként határozhatjuk meg, amely magában foglalja a figyelem gátlását és a motoros válaszokat (Diamond, Carlson és Beck, 2005), a kognitív flexibilitást (figyelmi váltás; Miyake és mtsai, 2000) és a frissítést (munkamemória; Baddeley, 2000), továbbá a gondolatok, érzelmek kontrollját és a cselekvések végrehajtását (például a célorientált viselkedést lásd Welsch, Pennington és Groisser, 1991), fóként új problémamegoldó szituációkban (Gioia, Isquith, Guy és Kenworthy, 1996). Hasonlóan, Roebers és munkatársai (2011) szerint a végrehajtó funkciók terminus számos kognitív képességet takar, például a céltudatos, rugalmas vagy adaptív cselekedeteket olyan új, komplex és/vagy bizonytalan szituációkban, amikor állandóan változó, sokrétü vagy limitált idejü végrehajtó funkciók működését igénylő feladatok 
elvégzésére van szükség (Hughes és Graham, 2002; Roebers és mtsai, 2011). A legtöbb definíció magában foglalja a munkamemóriát, a gátló funkciókat és a flexibilitást/készletváltást is. Ezek kulcsfontosságúak olyan magasabb rendü kognitív folyamatoknál, mint a logikai gondolkodás folyamata, például a nem verbális érvelés esetében. A magasabb rendủ képességek alatt értünk minden olyan információ-feldolgozó folyamatot, amelyekben a monitorozás és a kontroll alapvető szerepet játszik (Engle és Kane, 2003).

Stuss (1992) szerint a végrehajtó funkciók lehetőséget teremtenek arra, hogy az egyik koncepcióról a másikra váltsunk át, módosítsuk a viselkedésünket, különösen akkor, amikor egy kérdésre új vagy módosított információjú választ kell adnunk. Képessé tesznek minket az elszigetelt részletek egységes egésszé integrálására, az információk sokrétü keresésére és a megszerzett tudás releváns felhasználására. A végrehajtó funkciók müködése során főként az agyunk elülső (prefrontális) területei aktiválódnak (lásd 4. 1. fejezet). Denckla (1996a) szerint a prefrontális konstruktumok megfelelö müködése lecsökkenti a viselkedésben megjelenő ismétlések (perszeverációk) számát. Fontos szerepe van a viselkedés időleges szervezésében, a kezdeményezésben, a spontaneitásban és a gátlás kialakulásában is.

Az egységes definíció hiánya miatt létezik egy megegyezés, amely a végrehajtó funkciók komplexitását és fontosságát jelzi az emberi adaptív viselkedésben. Az állandóan változó környezetben a végrehajtó képességek segítenek minket abban, hogy gyorsan tudjunk váltani a gondolati készletek között, alkalmazkodni tudjunk különböző szituációkhoz, míg ugyanabban az időben le tudjunk gátolni egy oda nem illő viselkedést. Lehetővé teszik a tervkészítést, a kivitelezés megkezdését, és azt, hogy kitartsunk a feladat mellett, amíg be nem fejezzük. A végrehajtó funkciók összekapcsolják azokat a képességeket, amelyek segítségével célvezérelt módon tudjuk szervezni gondolatainkat, így ezek alapvető fontosságúak az iskolában, a munkahelyi szituációkban és a mindennapi életben egyaránt (Denckla, 1996b). A morális és etikus viselkedéshez szintén szükség van a végrehajtó funkciók megfelelő müködéséhez (Ardila és Surloff, 2004). A végrehajtó funkciók főbb fogalmait és komponenseit az 1. táblázat tartalmazza. 
1. táblázat. A végrehajtó funkciók fogalmai és komponensei (Forrás: Jurado és Rosselli, 2007. 216.o.)

\begin{tabular}{|c|c|}
\hline Kutatók & $\begin{array}{l}\text { A végrehajtó funkciók fogalmai és/vagy } \\
\text { komponensei }\end{array}$ \\
\hline Lezak (1983) & $\begin{array}{l}\text { Akarat, tervezés, szándékos cselekvés, hatékony } \\
\text { teljesítmény. }\end{array}$ \\
\hline Baddeley és Hitch (1974) & $\begin{array}{l}\text { Központi végrehajtó, fonológiai hurok, téri-vizuális } \\
\text { vázlattömb. }\end{array}$ \\
\hline Norman és Shallice (1986) & Ellenőrzö-figyelmi rendszer. \\
\hline Lafleche és Albert (1995) & $\begin{array}{l}\text { Az információk párhuzamos manipulálása: kognitív } \\
\text { flexibilitás, fogalomalkotás, célvezérelt viselkedés. }\end{array}$ \\
\hline Borkowsky és Burke (1996) & $\begin{array}{l}\text { Feladatelemzés, stratégia kontroll, stratégia- } \\
\text { monitorozás. }\end{array}$ \\
\hline $\begin{array}{c}\text { Anderson, Anderson, Northam, Jacobs és Catroppa } \\
\text { (2001) }\end{array}$ & $\begin{array}{c}\text { Figyelmi kontroll, kognitív flexibilitás, } \\
\text { célszabályozás. }\end{array}$ \\
\hline Delis, Kaplan és Kramer (2001) & $\begin{array}{l}\text { Gondolkodás flexibilitása, gátlás, probléma-megoldás, } \\
\text { tervezés, impulzus kontroll, fogalomalkotás, absztrakt } \\
\text { gondolkodás, kreativitás. }\end{array}$ \\
\hline Hobson és Leeds (2001) & $\begin{array}{l}\text { Tervezés, kezdeményezés, a cél-vezérelt viselkedés } \\
\text { megtartása és átalakítása. }\end{array}$ \\
\hline $\begin{array}{c}\text { Piguet, Grayson, Browe, Tate, Lye, Creasey, és Ridley } \\
\text { (2002) }\end{array}$ & Fogalomalkotás, érvelés, kognitív flexibilitás. \\
\hline Elliot (2003) & $\begin{array}{l}\text { Új feladatok megoldása, a viselkedés módosítása az új } \\
\text { információ fényében, stratégiák alkotása, komplex } \\
\text { cselekvések folyatatása. }\end{array}$ \\
\hline
\end{tabular}

Összegezve, a végrehajtó funkciók felelősek a gondolatok szervezéséért, stratégiává alakítsáért, az önvezérelt és célirányos folyamatok kialakításáért az észlelésben, érzelmekben, gondolatokban és cselekedetekben. A végrehajtó funkciók számos más mentális képességnek is a kulcsát adják, például az érvelés, nyelvi funkciók és a téri-vizuális reprezentációk (Stuss és Alexander, 2000). Fontos szerepük van a tervezésben, a döntéshozatalban, a célok szelekciójában és az éppen aktuális viselkedés monitorozásában, valamint az öntudat, empátia és a szociális érzékenység folyamataiban is (Temple, 1997). Lényegesek a reflexív gátlás és impulzív válaszadás folyamatában, egy folyamatban lévő cselekvés félbeszakításában és az ahhoz való visszatérésben, a figyelmi folyamatok fókuszálásában, az erőfeszítés mértékének megbecslésében, ami a sikeres feladat teljesítésének az előfeltétele. Mindezen kívül a rugalmas váltásban is (új kérdésre válaszolás, új válasz, új információ), a fluid érvelési 
képesség hatékonyságának vezetésében, a választási képességben az egész és a részletek között (például, hogy tudjuk mikor kell figyelnünk egy nagy képre és mikor kell csak az apró részletekre, tudjunk váltani a kettő között). Hozzájárul a beszéd monitorozásához és szabályozásához, a teljesítmény monitorozásához, valamint ahhoz is, hogy választani tudjunk a verbális-nonverbális és az absztrakt-konkrét feldolgozó mechanizmusok közül. Szükségünk van továbbá a végrehajtó funkciókra a hatékony és folyamatos nyelvi produkció, az összetett képességek integrációja során. Emellett az információ elhelyezésének hatékonyságában a hosszú távú tárban, az információ hosszú távú tárból való előhívása esetén, valamint a helyes szociális viselkedés alkalmazása, az érzelmi kontroll és érzelmi kifejezés szabályozása, valamint az önmegfigyelés és önanalízis folyamatában is használjuk a végrehajtó funkciókat (Tánczos, 2012).

A végrehajtó funkciók müködésére van szükség olyan új és komplex cselekvések esetében, mint a viselkedés legátlása, a teljesítmény monitorozása vagy a tervek és stratégiák formálása. Ezzel szemben az egyszerű vagy rutin feladatok, amelyeket ösztönösen hajtunk végre nem igénylik a végrehajtó funkciók müködését (Shallice és Burgess, 1990). Azonban ennél a típusú osztályozásnál figyelembe kell venni, hogy egyéni különbségek lehetnek abban a tekintetben, hogy valaki számára mennyire egyszerüek vagy komplexek a feladatok. A fejlődési különbségeket figyelembe véve például a fiatalabb gyerekek számára a legtöbb feladat új és komplex, ezért a végrehajtó funkciók működését nagyobb százalékban igényli (Stuss és Alexander, 2000).

Habár számos tanulmány született az észlelés és a viselkedés végrehajtó funkciókkal való kapcsolatáról, nagyon kevés információval szolgálnak a teszteken elért teljesítmények gyakorlati magyarázatairól. Dawson és Guare (2004) olyan gyakorlati kézikönyvet alkotott, amely az oktatási és nevelési problémák végrehajtófunkció-deficitekkel való kapcsolatát írja le. Nagy igény mutatkozik a szakmai körökben arra, hogy a klinikai, osztálytermi és az otthoni gyakorlatban hogyan kezelhetjük a különféle nevelési és mentális egészség problémákat és arra is, hogy a végrehajtó funkciók hogyan hatnak az intraperszonális, az interperszonális és a környezeti interakciókra. A disszertáció utolsó empirikus kutatása is ezt a kérdést járja majd körül, vagyis azt, hogy az iskolai teljesítményre milyen hatással van a végrehajtó funkciók fejlettsége (lásd 13. fejezet). 


\subsection{A végrehajtó funkciók tanulmányozásának relevanciája}

Az iskolai teljesítményt alapvetően határozzák meg a végrehajtó funkciók, melyek eddig kevesebb szerepet kaptak a hazai kutatásokban (Bull, Johnson és Roy, 1999; Bull és Scerif, 2001; Lehto, 1995; Ozonoff és Jensen, 1999; Thompson és Gathercole, 2006; Bull, Espy és Wiebe, 2008). A végrehajtó funkciók magas szintű müködése alapja a figyelmi, gondolkodási és probléma-megoldási folyamatoknak, amelyek az iskolai teljesítményben meghatározó szerepet játszanak. A végrehajtó funkciók felelősek a komplex kognitív tesztek alatti kognitív folyamatok szabályozásáért és monitorozásáért (Lindsay, Tomazic, Levine és Accardo, 1999; Miyake és mtsai, 2000).

A végrehajtó funkciókat számos populáció és tanulási vagy viselkedéses probléma esetében vizsgálták, például a nyelvi és nyelvmegértési problémák, matematikai nehézségek (Bull, Johnston és Roy, 1999; Bull és Scerif, 2001; Van Der Sluis, Van Der Leij és De Jong, 2005), autizmus, ADHD (Biederman, Monuteaux, Doyle, Seidman, Wilens, Ferrero, Morgan és Faraone, 2004; Willcutt, Doyle, Nigg, Faraone és Pennington, 2005) és viselkedéses problémák (Bull, Johnston és Roy, 1999; Cornoldi, Barbieri, Gaiani és Zocchi, 1999; Gathercole és Pickering, 2000a, 2000b; Lehto, 1995; Lorsbach, Wilson és Reimer, 1996; McLean és Hitch, 1999; Ozonoff és Jensen, 1999; Russell, Jarrold és Henry, 1996; Swanson, 1993, 1999; Swanson, Ashbaker és Lee, 1996). Számos kutatásban megfigyelték azt is, hogy a végrehajtó rendszer zavara részben a diszlexiához, diszkalkuliához és diszgráfiához is köthető (Reiter, Tucha és Lange, 2005; Landerl, Bevan és Butterworth, 2004; Altemeier, Abbott és Berninger, 2008). Ezekben a fejlődéspszichológiai tanulmányokban azt a következtetést vonták le, hogy a végrehajtó funkciók jó prediktorai lehetnek a teljesítménynek. A végrehajtó funkciókban mutatkozó nehézségek azért okozhatják a teljesítményben megjelenő deficiteket, mivel ebben az esetben az információk manipulálása és a kontroll funkciók nem a megfelelő szinten működnek. Ezáltal az egyes információk (például a szavak) értelmes egységbe szervezése nehézségekbe ütközik.

\subsubsection{Váltás, monitorozás, gátlás}

Miyake és munkatársai (2000) három fő végrehajtó funkciót azonosítottak, a következőkben ezek szerepét mutatjuk be röviden a különböző tantárgyak esetében.

A váltási képességek összefüggésben vannak az írási készségekkel (Hooper, Schwartz, Wakely, De Kruif és Montgomery, 2002) és az aritmetikával (Bull, Johnson és Roy, 1999; Bull és Scerif, 2001). A verbális munkamemória és így a monitorozás kapcsolatát mutatták ki az 
anyanyelvvel, míg a téri-vizuális munkamemória szerepét a matematika és természettudomány tantárgyak kapcsán emelték ki (Jarvis és Gathercole, 2003). Thompson és Gathercole (2006) 11-12 éves gyerekekkel végzett kutatásukban kimutatták, hogy a munkamemória fejlettsége meghatározza az angol és matematika tantárgyakon nyújtott teljesítményeket. Minél magasabb a gyerek munkamemória kapacitása, annál jobb teljesítményt ér el az angol és matematika tantárgyakon. A végrehajtó funkciók közül pedig a gátlással mutattak ki kapcsolatot az angol, matematika és a természettudomány tantárgyak esetében (Thompson és Gathercole, 2006; Espy, Bull és Senn, 2004). Minél jobban müködnek a gyerek gátló funkciói, annál jobban teljesít a fentebb felsorolt tantárgyakon. A gátló folyamatoknak fontos szerepe van továbbá az olvasásban (De Beni, Palladino, Pazzaglia és Cornoldi, 1998; Gernsbacher, 1993), a szövegmegértésben (Dempster és Corkhill, 1999), a szókincs elsajátításában (Dempster és Cooney, 1982). Bull és Scerif (2001) szerint a gátlás hiánya és a gyenge verbális munkamemória a végrehajtó diszfunkciók specifikus előfeltételei, és ezek állhatnak a matematika tanulása során felmerülő nehézségek hátterében. Egyes vizsgálatok eredményei szerint a váltás, a munkamemória és a gátlás azonos mértékben felelős a matematika teljesítményért (Bull és Scerif, 2001).

Ozonoff és Jensen (1999) autista gyerekek vizsgálata során megállapították, hogy a gyerekeknek nehézségeik vannak a flexbilitásban és a tervezésben, de megfelelő teljesítményt mutatnak a gátlást igénylő feladatokban. Azonban ADHD-val diagnosztizált gyerekeknél azonban ezzel ellentétes mintázatot találtak, nekik a gátlás jelent nehézséget, de nincs gondjuk a flexibilitást igénylő feladatokkal. 


\section{A MUNKAMEMÓRIA IDEGRENDSZERI HÁTTERE ÉS NEUROPSZICHOLÓGIÁJA}

\subsection{A munkamemória biológiai alapjai}

A munkamemória biológiai alapjainak feltárásában a neuropszichológia, a pszichofizika és a képalkotó eljárások eszközeit használják a leggyakrabban. A neuropszichológiai vizsgálatok a kettős disszociáció elvére épülnek. Ha egy betegnél az A képesség ép és B képesség károsodott, míg egy másik betegnél az ellentétes mintázat figyelhető meg, vagyis B képesség ép és A sérült, akkor megállapítható, hogy a két képesség hátterében két független, az adott képességre specializálódott modul található (Lukács, 2001; Vallar, 2006). Az agyi képalkotó eljárások, amiknek jó téri, de kevésbé jó idői felbontása van (például fMRI-funkcionális mágneses rezonancia, ami a vér oxigénszintjének változásait veszi alapul és a PETpozitronemissziós tomográf, ami az agy glükóz- és oxigén-anyagcseréjét vizsgálja- Rajah és D’Esposito, 2005), valamint az elekrofizikai mószerek, amiknek előnye a jó idői felbontás (EEG- elektroenkefalográfia- a nagyagykéreg áramainak változásait észleli az agykéreg felszínére helyezett elektródák segítségével-Kéri és Gulyás, 2003; ERP- eseményhez kapcsolódó potenciál - Vogel és Machizawa, 2004) segítséget nyújtanak abban, hogy jobban megérthető legyen a munkamemória mögött rejlő idegrendszeri hálózat, mivel ezekkel lehetőség nyílik egészséges és agysérült betegek vizsgálatára és ami témánk szempontjából jelentős, tanulási zavarral küzdő és atipikusan fejlődő gyerek vizsgálatára is (Gruber és Cramon, 2003; Wager és Smith, 2003; Müller és Knight, 2005). Jelen alfejezetben elsősorban az agyi képalkotókkal és elektrofiziológiai módszerekkel végzett vizsgálatokat ismertetjük, majd a 3.2-es alfejezetben a neuropszichológiai kutatásokat mutatjuk be. 


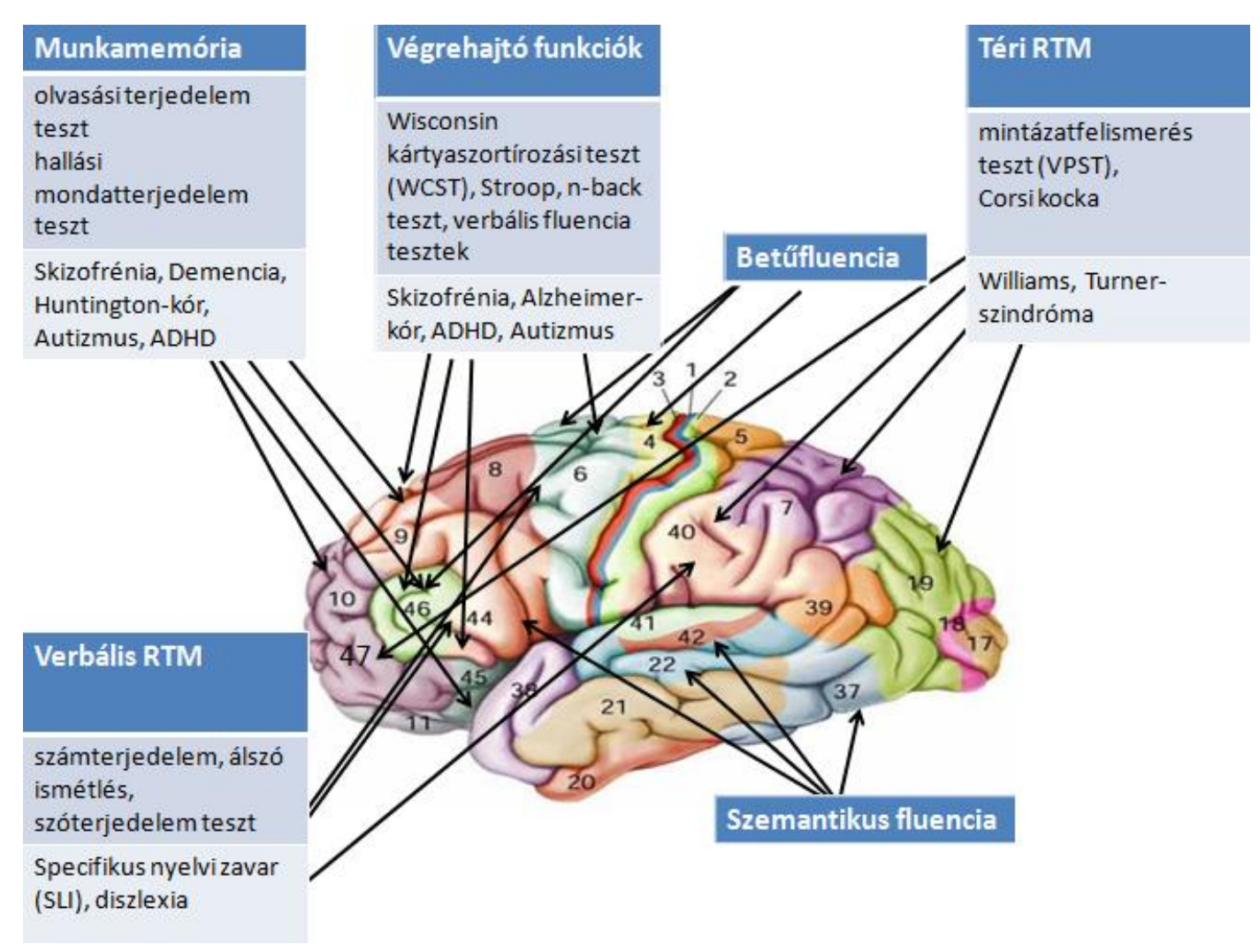

\section{2. ábra}

Az egyes munkamemória-komponensek és a végrehajtó funkciók mérőeljárásai, patológiái (Forrás: Gathercole, 1999. 412.o.)

A munkamemória egyes alrendszereinek müködése különböző agyi hálózatokhoz kötött. Ezeket a Brodmann-térkép segítségével tudjuk lokalizálni, ami az egyes agykérgi területek elkülönítését jelzi a rétegek felépítése alapján (BA - Brodmann area, magyarul lásd $\mathrm{Br}$ - Brodmann-régió). A fonológiai tár neuroanatómiai lokalizációja szempontjából fontos terület a bal oldali posterior parietális $\mathrm{Br} 40$-es terület. Az artikulációs kontroll folyamata, vagyis az ismétlési komponens helye az agyban a Broca-mező területén található, a frontális lebenyben a bal $\mathrm{Br}$ 44-es és a $\mathrm{Br}$ 6-os areák, a supplementer -és premotoros területek és a jobb cerebellum egy részének müködéséhez kapcsolható (Paulescu, Frith és Frackow, 1993; Jonides és Smith, 1997; Smith és Jonides, 1997). A komplex verbális munkamemória müködése esetén ezek mellett a bal oldali és a dorzolaterális prefrontális területek is érintettek (Br 9, 10, 45, 46 - Weismer és mtsai, 2005; Narayan és mtsai, 2005, Conant, Liebenthal, Desai és Binder, 2014, Klaassen, Evers, Groot, Backers, Veltman és Jolles, 2014). A vizuális ingerek feldolgozása és a téri kódolás a jobb inferior prefrontális $(\mathrm{Br} 47)$, a jobb anterior occipitális $(\mathrm{Br} 19,40)$ és a jobb posterior parietális $(\mathrm{Br} 6)$ areákhoz köthető ( $X u$ és Chun, 2005; Konen és Kastner, 2008; Zimmer, 2008. Zago és Tzorio-Mazoyer (2002) a vizuális feladatok megoldása során aktivációt találtak a bal inferior temporális $(\mathrm{Br} 37)$ és a bal inferior 
parietális területeken is. Tehát az előbbi müködése leginkább a jobb tarkólebenyhez, míg az utóbbi inkább a jobb fali lebenyhez kapcsolható (Gathercole, 1999). Smith és Jonides (1997) is hasonló aktivációkat figyeltek meg és véleményük szerint a munkamemória alrendszereinek müködése a következő területekkel van kapcsolatban: verbális munkamemória - bal félteke $\mathrm{Br} 6,40$, 44; téri munkamemória - jobb félteke $\mathrm{Br} 7,40,47$; végrehajtó funkciók - Br 6, 9, 46 (Smith, Jonides és Koeppe, 1996, magyarul lásd Németh, Racsmány, Kónya és Pléh, 2001). A különböző munkamemória folyamatok idegrendszeri hátterét összefoglalva lásd a 2. táblázatban.

2. táblázat. A munkamemória folyamatok és azok idegrendszeri háttere (Forrás: Németh, Racsmány, Kónya és Pléh, 2000. 407.o.)

\begin{tabular}{c|c}
\hline \hline AGYTERÜLET & FUNKCIÓ \\
\hline $\operatorname{Br} 6$ & Általános problémamegoldó \\
& (verbális + téri feladatok) \\
\hline $\operatorname{Br} 44$ & Fonológiai folyamatok feldolgozása \\
& (verbális + numerikus feladatok) \\
\hline $\operatorname{Br} 9,46$ & Munkamemória tartalmának manipulálása \\
\hline \hline
\end{tabular}

A központi végrehajtó müködését többen is tesztelték a kísérleti tesztfeltételek változtatásával. Barch, Braver, Nystrom, Forman, Noll és Cohen (1997) fiatal felnőtt vizsgálati személyeiknél a nehézséget és a tárolási terhelést egyszerre változtatták a feladat végzése során. A vizsgálat elvégzése után megállapították, hogy a tárolási terhelés hatására a bal dorsolaterális $(\mathrm{Br} 9,46)$, a bal inferior frontális $(\mathrm{Br} 6,44)$ és a bal posterior parietális területeken aktivitásnövekedés volt megfigyelhető. A jobb féltekén a frontális területeken $(\mathrm{Br}$ 44, 45, 47) találtak aktivitásnövekedést, miközben a feladat nehézségét változtatták.

Brahmbhatt, McAuley és Barch (2008) megvizsgálták az összefüggést az agyi aktivitás és a munkamemória kapacitásában megnyilvánuló életkori változások között. N-et vissza feladatot használtak és fMRI segítségével mérték fel az életkori különbségeket a neurális kapcsolatokban. 14 és 27 év közti serdülők teljesítményét figyelték meg verbális és vizuális munkamemória teszteken. Azonos életkorhoz kötött különbségeket találtak mindkét stimulus esetén a bal superior parietális kéregben és más területeken is, beleértve a bal inferior frontális lebenyt, a bal szupramarginális gyrust és a jobb cerebellumot is. 
Rajah és McIntosh (2008) fMRI-vizsgálatot végeztek fiatal és idősebb felnőtt személyeken, miközben a végrehajtó funkciók mérésére párhuzamos feladatokat kellett végrehajtaniuk. A corticális aktivitás csökkent, és az eredmények azt mutatták, hogy az idősebb személyek a jobb parahippocampalis, a jobb parietális és a jobb prefrontális területeket nagyobb százalékban aktiválták, mint a fiatalabb egyének.

Kim, Bayles és Beeson (2008) 37 idősebb (átlagéletkor=72 év) és 41 fiatalabb (átlagéletkor=22 év) vizsgálati személlyel végzett vizsgálatukban háromféle munkamemóriatesztet használtak: a számterjedelem, a szóterjedelem és a hallási mondatterjedelem tesztet. A kutatás célja az volt, hogy megvizsgálják a felnőttek nyelvfeldolgozási teljesítményét. Szignifikáns életkori hatás mutatkozott a feladatokon elért teljesítményben. Az információk növekedésével párhuzamosan a pontosság mindkét csoportban lecsökkent, ez a hatás az idősebb felnőttek esetében erősebb volt. Amikor különböző struktúrájú, de azonos számú komponensre kellett emlékezniük, pontosabban teljesítettek.

Osaka, Osaka, Kondo, Morishita, Fukuyama és Shibasaki (2003) a verbális munkamemória kapacitáskülönbségeinek neurális alapjait vizsgálták fMRI-vel. Nagy és kis munkamemóriájú csoportokba bontották a személyeket a teszteken elért eredményeik alapján. A feladatok teljesítése során jelentős aktivációt találtak a bal prefrontális kéreg, az anterior cinguláris kéreg és a temporális nyelvi kéreg területén. Az fMRI fokozott intenzitást jelzett a prefrontális kéregben a hallási mondatterjedelem teszt végrehajtásakor. A magas munkamemória terjedelmü csoportnál az anterior cinguláris kéregben a jelzés szignifikáns növekedése volt megfigyelhető. Az eredmények azt mutatták, hogy a figyelmi-kontrolláló rendszer hatékonyabban müködik a magas munkamemóriájú egyének körében.

\subsection{A verbális munkamemóriával kapcsolatos neuropszichológiai eredmények}

A 3.2 alfejezetben áttekintjük a munkamemória neuropszichológiai kapcsolódásait, vagyis, hogy a különböző agyi hálózatok sérülése, fejlődési zavara vagy alulműködése milyen típusú munkamemória-deficittel jár együtt és az milyen kognitív tüneteket eredményezhet.

\subsubsection{Munkamemória-deficitek különböző neurológiai és pszichiátriai kórképekben}

Shallice és Vallar (1990) vizsgálatukban a verbálismunkamemória-feladatokban nagyon gyenge teljesítményt találtak szavak, betűk és számok szeriális felidézésénél is - főleg auditoros bemutatásnál. Mivel téri-vizuális feladatokban nyújtott teljesítményük nem különbözött az egészséges kontrollszemélyekétől, ezért arra következtettek, hogy esetükben a 
verbális munkamemória szelektív sérülése áll fenn, továbbá véleményük szerint a csökkent teljesítmény hátterében nem a beszédpercepció, illetve beszédprodukció károsodása áll, mivel a fonológiai analízis képessége is megtartott.

Baddeley, Gathercole és Papagno (1998) vizsgálatukban azt találták, hogy verbálismunkamemória-deficit jelenlétekor a teljesítmény leromlik páros asszociációs tanulási helyzetekben, ahol a kísérleti személyeknek ismert, illetve idegen szavakból álló szópárokat kellett tanulniuk. A betegeknél minden esetben bal oldali léziót mutattak ki, főleg a frontális lebenyben, a Broca-mező környékén (Shallice és Vallar, 1990; DeRenzi és Nichelli, 1975), illetve alsó parietális és középső/felső temporális területeken (Vallar, DiBetta és Silveri, 1997; Henson, 2001, idézi Racsmány, Lukács, Németh és Pléh, 2005).

A munkamemória-folyamatokat a prefrontális kéreg mediálja és a dorsolaterális lebeny prefrontális területei lépnek müködésbe a legtöbb mentális információ-manipulálási tevékenység során (Curtis és D’Esposito, 2003). Léziós vizsgálatokban aktivációt találtak a superior prefrontális gyrus területén magasabb szintü végrehajtó folyamatok müködése közben (pl. komplex munkamemória feladatok - Du Boisgueheneuc, Levy, Volle, Seassau, Duffau és Kinkingneheun, Samson, Zhang és Dubois, 2006).

Számos kutatási eredmény igazolta, hogy a különböző pszichiátriai és neurológiai kórképek esetében is károsodhatnak a különböző munkamemória alkomponensek. Például skizofréniában a munkamemória valamennyi alrendszere károsodik (lásd például Lee és Park, 2005). A skizofrének rosszabbul teljesítenek számterjedelem tesztben, mint az egészséges kontrollszemélyek, amely a verbális munkamemória sérülésére utal (Park és Holzman, 1992; Stratta, Daneluzzo, Prosperoni, Bustini, Mattei és Rossi, 1997). A fordított számterjedelem teszten elért eredményeik még jelentősebb károsodást mutattak, amit a végrehajtó rendszer károsodásával lehet magyarázni (Morice és Delahunty, 1996). A téri munkamemória károsodását is többen megállapították (pl. Carter, Robertson, Nordahl, Chaderjian, Kraft és Shoora-Celaya, 1996, magyarul Racsmány, 2003).

Wolf, Vasic, Schonfeldt-Lecuona, Ecker és Landwehrmeyer (2009) eseményhez kötött fMRI-t használtak annak kiderítésére, hogy feltérképezzék 12 Huntington-kóros beteg munkamemóriájának funkcionális anatómiáját. 16 egészséges kontrollszemély teljesítményével hasonlították össze a munkamemória feladatokon nyújtott teljesítményüket és azt találták, hogy lassabban és kevésbé pontosan oldják meg a feladatokat, mint a kontrollszemélyek. Alacsonyabb aktivitást mutatnak a bal dorso- és ventrolaterális prefrontális kéregben, a bal inferior parietális kéregben és a bal putamenben. Az eredmények alapján a munkamemóriához kapcsolódó funkcionális rendellenességek a Huntington-kóros 
személyeknél eltérő munkamemória-hálózati csomópontokat foglalnak magukban, amik kapcsolatban vannak a kognitív kontrollal és a hangtalan ismételgetéssel.

Welland, Lubinski és Higginbotham (2002) Alzheimer típusú demenciában szenvedő betegekkel végeztek vizsgálatot, melyböl kiderült, hogy a beszélt nyelv megértése, különösen a részletek megértése és a következtetés sérült ezeknél a személyeknél, s teljesítményük korrelált a munkamemória kapacitással (korai és középső stádiumban is). A Parkinson-kórban szenvedő betegek vizsgálati eredményei azt mutatták, hogy a fonológiai hurok és az artikulációs alrendszer müködése megfelelő, ha feladatokat kell megoldaniuk a verbális információk elöhívásával párhuzamosan. Ezt az eredményt a központi végrehajtó müködési deficitjével magyarázták. Esetükben fontosnak tartják a figyelem vizsgálatát is, ami a normál határokon belül van egyszerübb feladatok esetén, de komplexebb feladatokon károsodást mutat (Graceffa, Carlesimo, Peppe és Caltagirone, 1999). 


\section{A VÉGRHEJATÓ FUNCIÓK IDEGRENDSZERI HÁTTERE ÉS NEUROPSZICHOLÓGIÁJA}

\subsection{A végrehajtó funkciók biológiai alapjai}

Hasonlóan a 3.1 alfejezetben taglalt munkamemória biológiai alapjaihoz, a végrehajtó funkciók alapjainak feltárásában is a neuropszichológia, a pszichofizika és a képalkotó eljárások eszközeit használják a vizsgálatokban, azonban a végrehajtó funkciók részben elkülönült deficiteket mutatnak.

A végrehajtó funkciók terminus az utóbbi időkben mind a laikusok, mind pedig a hozzáértők által széles körben használt kifejezéssé vált és a Baddeley-féle munkamemória modell (Baddeley, 2000) központi végrehajtójának tágabb értelmezését foglalja magában. A figyelem középpontja egyre inkább a frontális lebeny szinaptikus kapcsolataira helyeződik, ami kamaszkorig fejlődik, és nagy szerepe van az önmonitorozási és a kontroll folyamatok fejlődésében (Stuss és Alexander, 2000; Blakemore és Choudhury, 2006). A végrehajtó funkciókat és a frontális lebenyt vizsgáló kutatások először a klinikai gyakorlatban, neuropszichológiai eszközök felhasználásával jöttek létre. Ez a különböző eszközök és mérőeljárások megjelenését is maga után vonta (lásd 5. fejezet).

Faw (2003) a prefrontális lebenyt öt nagyobb müködési egységre osztotta. Az első a dorsolaterális prefrontális kéreg, amely összehangoló, koordináló funkciót tölt be a szemmozgás, a mozgástervezés és a munkamemória működésében. Ide sorolható a Brodmann-areák közül a $\mathrm{Br} 46, \mathrm{Br} 9, \mathrm{Br} 8 \mathrm{~A}, \mathrm{Br} 8 \mathrm{~B}$ és a $\mathrm{Br} 10$ egy része is. A második a ventromediális-orbitalis prefrontális régió, amely motiváló, motivátor szerepet tölt be és ezzel a késztetést, az érzelmeket, a viselkedést és a reakciókészséget szabályozza. A Br 10, Br 11, $\mathrm{Br} 12$, Br 14 és $\mathrm{Br}$ 47-es területei tartoznak ide. A harmadik a dorsomediális prefrontális kéreg, az elülső cinguláris terület, amelynek a figyelmi aktivitás szabályozásában van fontos szerepe. A Br 24, Br 25 és Br 32 areák sorolhatóak ide, valamint átfedéssel a Br 11 és Br 12 egy része, ezen kívül a limbikus rendszerrel is szoros összeköttetésben áll. A negyedik a mindkét oldali ventralis laterális prefrontális kéreg, ami „felfogó” központként a világ és saját szubjektív valóságunk megértésében segít minket. Ide sorolható a $\mathrm{Br} 45$, a $\mathrm{Br} 46$ egy része és a $\mathrm{Br} 47$ terület, valamint az orbitofrontális area $(\mathrm{Br} 11$ és $\mathrm{Br} 13)$ laterális része is. Az utolsó terület a domináns oldali ventrális laterális area, amely a beszéd szervezésében játszik szerepet. A negyedik területtel átfedésben a $\mathrm{Br} 45$ és $\mathrm{Br} 47$ areák sorolhatóak ide, amelyek a Br 44 motoros beszédmező körüli asszociációs területeket jelentik (lásd 2. ábra). 
Collette, Van der Linden, Laureys, Delfiore, Degueldre, Luxen és Salmon (2005) PETet (pozitronemissziós tomográf) használva három különböző végrehajtó funkciót (frissítés, váltás, gátlás) tanulmányoztak az agyi aktivitás szempontjából. Aktivitást találtak a bal superior parietális gyrus poszterior területén és a jobb intraparietális sulcusban. A bal oldali középső és inferior frontális gyrus szintén aktiválódott. A frissítés tanulmányozása során bilaterális aktivációkat találtak mind az anterior, mind a posterior területeken, míg a váltási folyamatok a parietális lebenyt és a bal középső és inferior frontális gyrust aktiválták (Kim, Johnson, Cilles és Gold, 2011). A gátló folyamatok a jobb oldali orbitofrontális gyrusban mutattak aktivációkat, de ennek az aktivációnak a specificitása alacsonyabb volt, mint a váltás vagy a frissítés esetében. Colette és munkatársai (2005) tanulmánya a parietális területek fontosságát emeli ki a végrehajtó funkciót mérő tesztek teljesítése során, valamint, hogy a végrehajtó rendszert nem csupán a frontális lebeny támogatja, ahogyan azt korábban gondolták. A frontális lebeny fontossága kétségtelen, ezek az eredmények alátámasztják azt az elképzelést, hogy az egész agy integritására szükség van a végrehajtó feladatok optimális teljesítéséhez (Stuss és Alexander, 2000). A prefrontális területek viselkedésszervezésben betöltött szerepe is kiemelendő, mivel a hatékony müködéshez elengedhetetlen az agy egyéb területeiről bejövő minőségi információk jelenléte (Anderson és mtsai, 2001).

Stuss (1992) három szintet különböztetett meg a frontális lebeny monitorozó tevékenységével kapcsolatban. Az első szint magában foglalja a napi rutincselekvéseket, amelyeket repetitíven hajtunk végre, ezek automatizálódottak és túltanultak (például az autóvezetés). A feldolgozás második szintje azokat a végrehajtó és ellenőrző funkciókat foglalja magában, amelyek szervezett, célvezérelt viselkedéssé alakítják az információkat. A harmadik szint az egyéni és a környezeti tudatosság folyamatának szintje. A kapcsolatok fejlődése a frontális lebeny, a limbikus és a posterior kortikális területek között a végrehajtó és ellenőrző funkciók által mediált, míg az egyéni tudatosság a prefrontális területek fejlődésével áll kapcsolatban.

Stuss és Levine (2002) a monitorozási viselkedés alatt a jobb oldali dorsolaterális frontális terület aktivációját találták, míg a bal dorsolaterális teületnek a verbális folyamatokban volt fontos szerepe. Mind a jobb, mind a bal oldali dorsolaterális frontális terület, ahogyan az inferior mediális frontális lebeny is aktiválódik azon feladatok végrehajtása során, ahol szükség van a kognitív váltásra, míg az inferior mediális frontális terültetek mediálják bizonyos aspektusait a viselkedés gátló folyamatainak. Azok a vizsgálatok, amelyek a végrehajtó képességek lokalizációjára helyezik a fókuszt, a frontális 
lebeny mellett a poszterior és a szubkortikális agyi területek fontosságát is hangsúlyozzák (Parkin, 1998; Collette és mtsai, 2005).

\subsection{A végrehajtó funkciókkal kapcsolatos neuropszichológiai eredmények}

\subsubsection{A végrehajtófunkció-deficitek különbözö neurológai és pszichiátriai kórképekben}

A központi végrehajtóval kapcsolatos neuropszichológiai vizsgálatok eredményei nem egyértelmüek. A végrehajtó funkciók neurális hátterének tanulmányozása során a kutatók kezdetben a frontális lebeny léziós betegek megfigyeléséből kaptak információkat. Azok a katonák, akik súlyosan megsérültek a háborúban, megváltozott viselkedést mutattak, valamint az is nehézséget okozott számukra, hogy a cél eléréséhez szükséges viselkedést alkalmazzák (Benson és Stuss, 1990). Azok a betegek, akiknél prefrontális sérülést azonosítottak, sérült ítélethozatalt, szervezést, tervezést és döntéshozatalt, valamint viselkedésgátlási képtelenséget és sérült intellektuális képességeket mutattak (Luria, 1973). Más frontális léziós betegeknek nehézségeik voltak az önkontroll terén és a figyelmi váltásban (Goldberg, 2001). Diszekzekutív szindrómának nevezték el azokat a viselkedéses és kognitív rendellenességeket, amelyeket a frontális betegeknél figyeltek meg (Baddeley és Wilson, 1988), amely olyan problémákat foglal magában, mint a tervezés, szervezés, absztrakciós érvelés, problémamegoldás és döntéshozatal (Ardila és Surloff, 2004; Hobson és Leeds, 2001). Vizsgálati helyzetekben a betegeknek nehézségeik vannak a készletváltás és a verbálisfluencia-feladatok teljesítése során (Milner, 1964).

Képalkotó eljárásokat használó vizsgálatok a frontális lebeny egységes invonváltságát írták le a különböző végrehajtó funkciókat mérő eljárások teljesítése során, ezen belül főként a prefronális kéreg szerepét emelték ki, azonban ma már általánosan elfogadott nézet az, hogy a végrehajtó funkciók a frontális lebeny különböző területeivel állnak kapcsolatban (Stuss és Alexander, 2000; Stuss és Levine, 2002). Ezen belül számos agyi hálózat vesz részt a müködésben, így a szubkortikális struktúrák és a thalamikus ösvények is (Monchi, Petrides, Strafella, Worsley és Doyon, 2006; Kassubek, Juengling, Ecker és Landwehrmeyer, 2005). Wager és Smith (2003) metaanalízise szerint a különböző végrehajtó folyamatok különböző agyi területekkel állnak összeköttetésben. A frontális lebeny sérültek viszonylag jó teljesítményt nyújtanak azokban a feladatokban, amelyek csak egy részfunkció mérésére szolgálnak, de a deficitek tisztán megfigyelhetők, amikor számos különböző funkciót kell koordinálni. Például kettős feladathelyzetben, amikor szükség van az információ manipulálására, a leggyakrabban az a jobb oldali inferior parietális kéreg aktiválódik, míg a 
superior frontális kéreg aktivációja akkor a legmagasabb, amikor az információ fenntartására folyamatosan szükség van, továbbá, ha az emléknyomok ideiglenes sorrendjét kell megtartani.

Megállapították, hogy a frontálislebeny-szindrómában megfigyelhető tünetek oka a központi figyelmi-ellenőrző rendszer sérülése. A központi végrehajtó müködése tehát egy frontálislebeny-funkció. D'Esposito, Detre, Alsop, Shin, Atlas és Grossman (1995) egészséges felnőtt személyekkel végzett vizsgálatukban prefrontális dorzolaterális aktivitást találtak kettős feladatok párhuzamos végzése alatt. Ha a feladatokat nem párhuzamosan végezték a vizsgálati személyek, akkor ez az aktivitás nem volt megfigyelhető. Eredményeik szerint a kettős terheléses helyzetben a központi végrehajtó működésének elengedhetetlen szerepe van. Ezt az eredményt később többen megkérdőjelezték. Bunge, Klinberg, Jacobsen és Gabrieli (2000) fMRI vizsgálatokat végeztek és mind a kettős terheléses helyzetben, mind pedig a feladatok külön végzése során frontális aktivációnövekedést mutattak ki. Nem találtak különbséget a központi végrehajtó müködésében a terhelés nélküli és a terheléses feladatok között (Németh és mtsai, 2001; Racsmány, 2003).

A különböző neurológiai betegségeket tanulmányozó neuropszichológiai vizsgálatok a striatális területek fontosságát is hangsúlyozták a végrehajtó funkciók tekintetében. Jelentős végrehajtófunkció-deficitet mutatnak a Huntington-kórral élők (Lawrence, Saahakian, Hodges, Rosser, Lange és Robbins (1996) és a Parkinson-szindrómás betegek (Petrova, Raycheva, Zhelev és Traykov, 2010). Royall, Lauterbach, Cummings, Reeve, Rummans és Kaufer (2002) szintén kiemelték a basális ganglionok és a thalamus szerepét a végrehajtó tesztek teljesítése során. Három fő neurális kört azonosítottak, melyek a frontális lebenyből erednek és a basális ganglionok, valamint a thalamus felé haladnak: a dorzolaterális prefrontális kör a tervezésben, célszelekcióban, készletváltásban, munkamemóriában és az önmonitorozásban vesz részt; a laterális orbitofrontális kör müködését igényli a kockázat felmérés és a nem megfelelő viselkedéses válaszok legátlása; az anterior cinguláris kör funkciói pedig a viselkedés monitorozásában és a hibák önellenőrzésében és javításában aktiválódik.

A frontális lebeny léziókon és a basális ganglion sérüléseken kívül számos más patológia esetében is találhatunk végrehajtó diszfunkciót. A frontális demenciában, Alzheimer-kórban és az AIDS-demenciában szenvedő betegeket szintén jellemzik a végrehajtó funkció defecitek (Elliott, 2003), valamint jelen vannak enyhe kognitív károsodás esetén is (Petrova és mtsai, 2010). Szubkortikális ischaemiás vaszkuláris demenciában a betegek szelektív károsodásokat mutatnak a végrehajtó funkciókat mérő teszteken 
(Cummings, 1994). Ezen kívül számos pszichiátriai zavarban megfigyelhetőek még a végrehajtófunkció-deficitek, beleértve a depressziót (Paelecke-Habermann, Pohl és Leplow, 2005) és a skizofréniát is (Bryson, Whelahan és Bell, 2001). Ezen zavarokban a végrehajtófunkció-deficitek kapcsolatba hozhatók a frontális lebeny károsodásával vagy diszfunkciójával, illetve a fronto-subcortikális hálózatok kapcsolatainak romlásával is.

A végreható funkciók klasszikus mérőeljárásaihoz tartoznak a betűfluencia és a szemantikus fluencia tesztek. Jól használhatóak többek között a demencia detektálásában (Barr és Brandt, 1996; Epker, Lacritz és Cullum, 1999), és a különböző típusú demenciák differenciálásában (Rosser és Hodges, 1994; Stuss, Alexander, Hamer, Palumbo, Dempster, Binns, Levine és Izukawa, 1998).

A betüfluencia feladat esetében megadott kezdőbetűkkel (K, T, A) kell egy percen belül minél több szót mondani a vizsgálati személynek. A szemantikus fluencia feladat esetében megadott kategóriákon belül (ÁLLAT, GYÜMÖLCS, ÉLELMISZERBOLT) kell a vizsgálati személynek egy percen belül minél több szót mondani.Azért esett a választásunk ezekre a betűkre és kategóriákra, mivel a betűfluencia és a szemantikus fluencia tesztek legalapvetőbb elemzési technikái 3040 éve használtak a klinikai neuropszichológiai gyakorlatban (Mészáros, Kónya és Kas, 2011 Szendi, Kiss, Racsmány, Boda, Cimmer, Vörös, Kovács, Szekeres, Galsi, Pléh, Csernay és Janka, 2006; Klivényi,Németh, Sefcsik, Janacsek, Hoffmann, Háden, Londe és Vécsi, 2012; Sefcsik, Németh, Janacsek, Hoffmann, Sciabbala, Klivényi, Ambrus, Háden és Vécsei, 2009). Ezáltal lehetőségünk nyílik összehasonlítani az eddigi eredményeket az egyes betegcsoportokat vizsgáló tanulmányok adataival is. A teszten nyújtott teljesítmény hasznos információval szolgál a nyelvi funkciókon belül a szóelőhívási stratégiákról és a lexikai-szemantikai hálózatok fejlődéséről mind gyerekkorban, mind pedig felnőttkorban.

A korábbi kutatásokban a leggyakrabban a szavak számát vizsgálták (Benton és mtsai, 1976; Benton, 1968; Miller, 1984; Rosen, 1980; Benton és Hamsher, 1989; Troyer és mtsai, 1997; Hurks és mtsai, 2004; Hurks, Vles, Hendriksen, Kalff, Feron, Kroes, Van Zeben és Jolles, 2006, Troyer, 2000; Mészáros, Kónya és Kas, 2011), illetve a hibák és perszeverációk számából következtettek az egyes neuropszichológiai károsodások meglétére (Azuma, 2004). Ezek a mutatók kevés információval szolgálnak a fluencia teljesítmény hátterében meghúzódó kognitív folyamatokról és nem adnak választ arra a kérdésre, hogy mi található egy-egy betegcsoport csökkent teljesítményének a hátterében. Újabban a teljesítménymutatók kiegészültek a klaszterek (különböző szabályok alapján alkotott minimum kételemü csoportok) számával (Troyer és mtsai, 1997; Troyer, 2000), és azok méretével (a vizsgálati 
személyek által alkotott csoportok nagysága; Troyer és mtsai., 1997; Sauzéon Lestage, Raboutet, N'Kaoua és Claverie, 2004; Fossati, Le Bastard, Ergis és Allilaire, 2003; Koren, Kofman és Berger, 2005; Reverberi, Laiacona és Capitani, 2006), illetve a váltások (szomszédos klaszterek közötti, egy klaszter és egy nem klaszterbe sorolt szó vagy két nem csoportosított szó közötti váltás) számával (Troyer és mtsai, 1997; Abwender és mtsai, 2001). Ezek a teljesítménymutatók jól használhatóak a verbálisfluencia-feladatok hátterében meghúzódó kognitív folyamatok mélyebb, minőségi elemzésére is és információkat adhatnak a szemantikus hálózat struktúrájáról és az azon belüli dinamikus interakciókról ( $S c h w a r t z$ és mtsai, 2003), továbbá árnyaltabb diagnosztikus lehetőségeket is biztosítanak. Ezen mutatók mintázata jelentős eltérést mutat a különböző pszichiátriai és neurológiai kórképekben (lásd 3. táblázat). 
3.táblázat. A betüfluncia és a szemantikus fluencia tesztek egyes mutatói a különbözö pszichiátriai és neurológiai kórképek esetén (Tánczos, Janacsek, Németh, 2014)

\begin{tabular}{|c|c|c|c|}
\hline \multirow{2}{*}{ Patológia típusa } & \multicolumn{2}{|c|}{ Érintett mutatók } & \multirow{2}{*}{ Hivatkozások } \\
\hline & Betüfluencia & Szemantikus fluencia & \\
\hline \multirow{3}{*}{ Depresszió } & & Csökkenés a szavak számában & Fossati, Le Bastard, Ergis és Allilaire (2003) \\
\hline & & Csökkenés a váltások számában & Fossati és mtsai, (2003) \\
\hline & Csökkenés a szavak számában & & Beatty, Testa és Englsh (1990) \\
\hline \multirow{2}{*}{ Skizofrénia } & \multicolumn{2}{|c|}{ Csökkenés a klaszterek számában } & $\begin{array}{c}\text { Robert, Mogneco, Marmod, Chaix, Thauby, Benoit és Beau (1997); Henry és Crawford (2004); } \\
\text { Bokat és Goldberg (2003) }\end{array}$ \\
\hline & & Csökkenés a szavak számában & Kremen, Seidman, Faraone és Tsuang (2001) \\
\hline Asperger-szindróma & & Csökkenés a szavak számában & Spek, Schatorjé, Scholte és Van Berckelaer-Onnes (2009) \\
\hline Autizmus & \multicolumn{2}{|c|}{ Csökkenés a szavak számában } & Spek, Schatorjé, Scholte és Van Berckelaer-Onnes (2009) \\
\hline \multirow{3}{*}{ ADHD (felnőttek) } & \multicolumn{2}{|c|}{ Csökkenés a szavak számában } & $\begin{array}{c}\text { Grodzinsky és Diamond, (1992); McGee, Williams és Moffitt (1989); Tucha, Mecklinger, Laufkotter, } \\
\text { Kauzinger, Paul, Klein és Lange (2005) }\end{array}$ \\
\hline & \multicolumn{2}{|c|}{ Csökkenés a szavak és a váltások számában } & Tucha és mtsai, (2005) \\
\hline & \multicolumn{2}{|c|}{ Csökkenés a klaszterek méretében } & Loge, Staton és Beatty (1990); Sergeant, Geurts és Oosterlaan (2002) \\
\hline \multirow{5}{*}{ Alzheimer- kór } & Csökkenés a szavak számában & & $\begin{array}{c}\text { Janowsky, Shimamura, Kritchevsky és Squire (1989); Monsch, Bondi, Butters, Paulsen, Salmon, } \\
\text { Brugger és Swenson, (1994); Tröster és mtsai, (1998); Gomez és White (2006); Arroyo-Anlló, } \\
\text { Lorber, Rigaleau és Gil (2011); Crossley és mtsai, (1997); Beatty, Testa és Englsh (1997); Troyer és } \\
\text { mtsai, (1998); Epker, Lacritz és Cullum (1999) }\end{array}$ \\
\hline & & Csökkenés a szavak számában & $\begin{array}{l}\text { Cerhan, Ivnik, Glenn, Tangalos, Petersen és Boeve (2002); Coen, Maguire, Swanwick, Kirby, Burke, } \\
\text { Lawlor, Qualsh és Coakley (1996); Diaz, Sailor, Cheung és Kuslansky (2004); Hart és mtsai, 1986; } \\
\text { Keilp, Gorlyn, Alexander, Stern és Prohovnik (1999); Rogers és Freedman (2008); Tierney, Black, } \\
\text { Szalai, Snow, Fisher, Nadon és Chui (2001); Tippet, Gendall, Farah és Thompson-Schill, (2004); } \\
\text { Tröster és mtsai, (1998); Vitali, Abutalebi, Tettamanti, Rowe, Scifo, Fazio, Cappa és Perani (2005); } \\
\text { Raoux, Amieva, Le Goff, Auriacombe, Carcaillon, Letenneur és Dartigues(2008) Arroyo-Anlló, } \\
\text { Lorber, Rigaleau és Gil (2011) }\end{array}$ \\
\hline & & Csökkenés a klaszterek számában & Tröster és mtsai, (1998) \\
\hline & & Csökkenés a klaszterek méretében & $\begin{array}{c}\text { Troyer és mtsai, (1998); Tröster és mtsai, (1998); March és Pattison (2003); Beatty, Testa és } \\
\text { Englsh(1997) }\end{array}$ \\
\hline & & Csökkenés a váltások számában & Epker, Lacritz és Cullum (1999) \\
\hline Korai $\mathrm{AD}$ & & Csökkenés a szavak számában & $\begin{array}{c}\text { Diaz, Sailor, Cheung és Kuslansky (2004); Monsch és mtsai, (1994); Salmon, Shimamura, Butters és } \\
\text { Smith (1988); Gomez és White (2006) }\end{array}$ \\
\hline HIV-demencia & Csökkenés a váltások számában & & Woods, Conovere, Rippeth, Carey, Gonzalez, Marcotte, Heaton és Grant (2004) \\
\hline PD- demencia & \multicolumn{2}{|c|}{ Csökkenés a váltások számában } & Troyer és mtsai, (1998) \\
\hline NDPD & \multirow{2}{*}{\multicolumn{2}{|c|}{$\begin{array}{c}\text { Csökkenés a szavak, klaszterek és váltások számában } \\
\text { Csökkenés a klaszterek méretében }\end{array}$}} & Bondi, Kaszniak, Bayles és Vance (1993) \\
\hline DPD & & & Epker, Lacritz és Cullum (1999) \\
\hline Cerebellum sérülés & \multicolumn{2}{|c|}{\begin{tabular}{|l|l|}
\multicolumn{2}{|c|}{ Csökkenés a klaszterek méretében } \\
Csökkenés a szavak számában & \\
\end{tabular}} & Leggio, Silveric, Petrosinia és Molinarib (2000) \\
\hline
\end{tabular}




\begin{tabular}{|c|c|c|c|}
\hline \multirow{2}{*}{ Patológia típusa } & \multicolumn{2}{|c|}{ Érintett mutatók } & \multirow{2}{*}{ Hivatkozások } \\
\hline & Betüfluencia & Szemantikus fluencia & \\
\hline \multirow{3}{*}{ Huntington-kór (HD) } & & Csökkenés a szavak számában & Zakzanis (1998) \\
\hline & Csökkenés a váltások számában & & Rich, Troyer, Bylsma és Brandt (1999); Ho, Sahakian, Robbins, Barker, Rosser és Hodges (2002) \\
\hline & \multicolumn{2}{|c|}{ Csökkenés a szavak számában } & $\begin{array}{c}\text { Henry, Crawford és Phillips (2004); Monsch és mtsai, (1994); Suhr és Jones (1998); Ho és mtsai, } \\
\text { (2002) }\end{array}$ \\
\hline \multirow{5}{*}{ Frontális lézió } & Csökkenés a szavak számában & & $\begin{array}{c}\text { Coslett, Bowers, Verfaille és Heilman (1991); Milner (1964); Perret (1974); Schwartz, Baldo, } \\
\text { Graves és Brugger (2003); Shimamura (1998); Rogers és Freedman (2008); Raoux és mtsai, (2008); } \\
\text { Troyer és mtsai, (1998); Tröster és mtsai, (1998) }\end{array}$ \\
\hline & Csökkenés a váltások számában & & Troyer és mtsai, (1998); Tröster és mtsai, (1998) \\
\hline & Csökkenés a klaszterek számában & & Tröster és mtsai, (1998) \\
\hline & & Csökkenés a szavak számában & Rogers, Ivanoiu, Patterson és Hodges (2006) \\
\hline & \multicolumn{2}{|c|}{ Csökkenés a szavak számában } & Shimamura (1998); Schwartz, Baldo, Graves és Brugger (2003); \\
\hline \multirow{3}{*}{ Temporális lézió } & & Csökkenés a szavak számában & Henry és Crawford (1994); Henry, Crawford és Phillips, (2004); Kavé, Kigel és Kochva (2008) \\
\hline & & Csökkenés a klaszterek számában & Raoux és mtsai, (2008) \\
\hline & & Csökkenés a klaszterek méretében & Troyer és mtsai, (1998) \\
\hline \multirow[t]{2}{*}{ Enyhe traumás agysérülés } & Csökkenés a klaszeterek számában & & $\begin{array}{l}\text { Raskin és Rearick (1996); Goldstein, Levin, Roberts, Goldman, Kalechstein, Winslo és Goldstein } \\
\text { (1996) }\end{array}$ \\
\hline & \multicolumn{2}{|c|}{ Csökkenés a szavak számában } & Henry és Crawford (2004) \\
\hline Stroke & Csökkenés a szavak számában & & Abrahams és mtsai, (2003) \\
\hline $\begin{array}{l}\text { Temporális lebeny amnézia } \\
\text { (MTLA) }\end{array}$ & & Csökkenés a szavak számában & Greenberg, Keane, Ryan és Verfaellie (2009) \\
\hline \multirow[b]{2}{*}{ Aphasia } & & Csökkenés a szavak számában & Arroyo-Anlló és mtsai, (2011) \\
\hline & \multicolumn{2}{|c|}{ Csökkenés a szavak számában } & $\begin{array}{l}\text { Adams, Reich és Flowers (1989); Ardila (2006); Caplan (2006); Sarno, Postman, Cho és Norman } \\
\text { (2005) }\end{array}$ \\
\hline HIV-demencia & Csökkenés a váltások számában & & Woods és mtsai, (2004) \\
\hline PD- demencia & Csökkenés a váltások $\mathrm{s}$ & n, de klaszterméret állandó & Troyer és mtsai, (1998) \\
\hline NDPD & Csökkenés a szavak, & ek és váltások számában & Bondi, Kaszniak, Bayles és Vance (1993) \\
\hline DPD & Csökkenés & rek méretében & Epker és mtsai, (1999) \\
\hline \multirow{2}{*}{ MCI } & & Csökkenés a szavak számában & Murphy, Rich és Troyer (2006) \\
\hline & \multicolumn{2}{|c|}{ Csökkenés a szavak számában } & Nutter-Upham, Saykin, Rabin, Roth, Wishart, Pare és Flashman (2008) \\
\hline Ischémiás vaszkuláris demencia & \multicolumn{2}{|c|}{ Csökkenés a szavak számában } & Carew, Lamar, Cloud, Grossman és Libon (1997) \\
\hline Szemantikus demencia & & Csökkenés a szavak számában & $\begin{array}{c}\text { Libon, McMillan, Gunawardena, Powers, Massimo, Khan, Morgan, Farag, Richmond, Weinstein, } \\
\text { Moore, Coslett, Chatterjee, Aguirre és Grossman (2009) }\end{array}$ \\
\hline $\begin{array}{l}\text { Subkortikális ischémiás } \\
\text { vascularis demencia (SIVD) }\end{array}$ & Csökkenés a szavak számában & & Tierney és mtsai, (2001) \\
\hline
\end{tabular}


A korábbi tanulmányok arra utalnak, hogy a betüfluencia feladat érzékenyebb a frontális lebenyt érintő kórképekre, mint a szemantikus fluencia feladat, ahol megadott kategóriába (pl. állat, gyümölcs, élelmiszerbolt) tartozó szavakat kell felsorolni (Troyer és mtsai, 1997; Abrahams, Goldstein, Simmons, Brammer, Williams, Giampietro, Andrew és Leigh, 2003). A betüfluencia feladaton nyújtott teljesítmény meghatározójaként elsősorban a prefrontális kéreg, azon belül is a dorsolaterális terület szerepét hangsúlyozták (Baldo és Shimamura, 1998; Martin, Wiggs, Lalonde és Mack, 1994; Stuss és mtsai, 1998), de emellett a frontális régióban a BA 4, 6, 44 (Birn, Kenworthy, Case, Caravella, Jones, Bandettini és Martin, 2010), a parietális kéregben a BA 1-3, 7, 39, 40, 43, a post-centrális gyrusban és az anterior temporális kéregben a BA 22 területek, valamint az insula és a putamen involválódását is kimutatták (Gaillard, Balsamo, Ibrahim és Xu, 2003; Baldo, Schwartz, Wilkins és Dronkers, 2000). A frontális régió a stratégiai szóelőhívás szempontjából kritikusabb, vagyis a betüfluencia feladat teljesítésekor szükség van a lexikai vagy a fonológiai memóriában történő stratégiai keresésre (Baldo és mtsai, 2006).

A betüfluencia feladat mellett a szemantikus fluencia tesztek is elterjedt vizsgálóeszközök a neuropszichológiai diagnosztikában pszichiátriai és neurológiai kórképek esetén és a kísérleti pszichológiai, fejlődéspszichológiai, kognitív neuropszichológiai és idegtudományi vizsgálatokban is, valamint egyike azon vizsgálati eszközöknek, amelyek széles életkori spektrumon is jól használhatóak (Benton és mtsai, 1976; Lezak, 1995; Spreen és Strauss, 1991). Ezek a feladatok a végrehajtó funkciók klasszikus mérőeljárásai közé tartoznak, valamint a teszten nyújtott teljesítmény mind gyerek, mind pedig felnőtt korban a nyelvi funkciókon belül a szóelőhívási stratégiák és a lexikai-szemantikai hálózatok fejlődéséről adhat pontosabb képet. A szemantikus fluencia tesztek hasznos mérőeszközök lehetnek a gyerekek kognitív károsodásainak feltárásában különböző fejlődési vagy genetikai rendellenességek esetében, magában foglalva az ADHD-t (Koziol és Stout, 1992; Sandler és mtsai, 1993), a korai kezdetű hydrocephalust (Brookshire és mtsai, 1995; Holler és mtsai, 1995), a Turner-szindrómát (Temple és mtsai, 1996) és a diszlexiát is (Bunn, 1995; Decker, 1989; Levin, 1990). Szintén hasznos mérőeljárásnak bizonyultak az idősebb populáció esetében is, mivel jól használhatóak többek között a demenciában szenvedő betegek elkülönítésében az egészséges személyektől (Bentham, 1997; Crossley, 1997; Diesfeldt, 1985; Salmon és mtsai, 1995; Solomon és mtsai, 1998), a különböző típusú demenciák differenciálásában (Rosser és Hodges, 1994; Caramelli és mtsai, 2007) és a temporális lebeny érintettség kimutatásában (Stuss és mtsai, 1998), mivel több tanulmány szerint a szemantikus 
fluencia a temporális lebeny sérülésekre érzékenyebb (Troyer és mtsai, 1998; Gaillard és mtsai., 2000; Martin és mtsai., 1994). Ezeken kívül gyakran használt klinikai eszközök a verbálisfluencia-tesztek a különbözö típusú pszichiátriai és agysérült személyek elkülönítésében is. A szemantikus fluencia feladaton szignifikáns károsodást mutattak ki skizofrén betegeknél (Robert és mtsai, 1997; Sautter és mtsai, 1997; Henry és Crawford, 2004d) és depressziós betegeknél is (Geffen és mtsai, 1993; Kuzis és mtsai, 1997; Norris és mtsai, 1995; Trichard és mtsai, 1995; Wolfe és mtsai, 1987).

$\mathrm{Az}$ adekvát szemantikus fluencia teljesítmény intakt lexikai tudást és hatékony keresési folyamatokat takar (Rosser és Hodges, 1994; Troyer és mtsai, 1998; Henry és Crawford, 2004a, b, c; Henry, Crawford és Phillips, 2004) és az intakt temporális lebeny szemantikus tárai fontosak az optimális szemantikus fluencia teljesítményhez (Pihlajamaki és mtsai, 2000; Greenberg és mtsai, 2009). A korábbi tanulmányok arra utalnak, hogy a szemantikus fluencia feladat érzékenyebb a temporális lebenyt érintő kórképekre, mint a betüfluencia feladat (Troyer és mtsai, 1998; Gaillard és mtsai, 2000; Martin és mtsai, 1994). A szemantikus fluencia teljesítményt részben a bal temporális lebeny BA 22, 37, 41, 42 területeihez valamint a post-centrális gyrushoz kötik (Gaillard és mtsai, 2003; Baldo és mtsai, 2006).

Klinikai szempontból fontos, hogy a szemantikus fluencia különböző mutatóinak mintázata eltéréseket mutat a különböző betegcsoportok esetében (lásd 3. táblázat). A következő vizsgálatokban különböző betegcsoportok esetében állapítottak meg a szemantikus fluencia feladaton teljesítménycsökkenést: Henry és Crawford (2004a), Bokat és Goldberg (2003) és Kremen, Seidman, Faraone és Tsuang (2001) skizofrén személyeknél, továbbá az enyhe kogitív zavar (MCI) vizsgálata során Murphy, Rich és Troyer (2006). Depressziós betegek vizsgálatában Fossati és munkatársai (2003) szerint a betegek kevesebb szót mondtak a szemantikus fluencia feladaton, mint a kontroll személyek, ép teljesítményt mutattak azonban a betüfluencia feladaton (Tarbuck és Paykel, 1995; Calev, Nigal és Chazan, 1989; Fossati, Amar, Raoux, Ergis, és Allilaire, 1999; Geffen, Bate, Wright, Rosenbilds, és Geffen, 1993). Fossati és munkatársai (1999) vizsgálatában fiatal unipolaris depressziós betegek szignifikánsan gyengébben teljesítettek a szemantikus fluencia feladaton, mint a kontroll személyek.

A különböző demenciák esetén is segítséget jelenthetnek a szemantikus fluencia feladat minőségi és mennyiségi mutatói. Carew, Lamar, Cloud, Grossman és Libon (1997) ischémiás vaszkuláris demenciában szenvedő betegeknél a szemantikus fluencia csökkent teljesítményét mutatták ki, akárcsak Libon és munkatársai (2009) a szemantikus demencia 
esetében. Hasonló eredményeket talált Zakzanis (1998) Huntington-kóros betegek vizsgálatakor is. Ezeken túl Alzheimer-kór (AD) esetében számos tanulmányban sérült szemantikus fluencia teljesítményt találtak a szavak száma tekintetében (Cerhan és mtsai, 2002; Coen és mtsai, 1996; Diaz, Sailor, Cheung és Kuslansky (2004); Keilp, Gorlyn, Alexander, Stern és Prohovnik, 1999; Rogers és Freedman, 2008; Tierney és mtsai, 2001; Tippett, Gendall, Farah és Thompson-Schill, 2004; Tröster és mtsai, 1998, Vitali és mtsai, 2005), ahogyan ez az Alzheimer-kór korai stádiumában is igaz (Salmon, Yin, Zhang, Granti és Yu, 1995; Raoux és mtsai, 2008; Monsch és mtsai, 1992; Diaz és mtsai, 2004; Gomez és White, 2006). A verbálisfluencia-tesztek minőségi elemzésében Troyer és munkatársai (1998) $\mathrm{AD}$ esetében csökkent szemantikus klaszter méretet találtak, amelyet Parkinson-kór (PD) esetében nem tudtak kimutatni. Ezzel szemben Tröster és munkatársai (1998) vizsgálatukban mind a klaszter méret, mind pedig a váltások tekintetében teljesítménycsökkenést találtak az AD és a PD esetében is (Troyer és mtsai, 1998; Tröster és mtsai, 1998; Beatty, Testa és Englsh, 1997). 
4.2.2. A munkamemória és a végrehajtófunkció-deficitek különbözö fejlödési és tanulási zavarokban

Az utóbbi évtizedben egyre több figyelem irányult a nyelvi zavarok pontos természetének felderítésére és a megkésett nyelvi fejlődés korai azonosításának lehetőségeire (például Lukács és Pléh, 2002; MacWhinney, 2002). Ezek a kérdések az iskolai teljesítmény és a tanulási zavarok szempontjából is nagyon fontosak. A kutatások kimutatták a verbális munkamemória deficitjét a specifikus nyelvi károsodás (Specific Language Impairment - SLI) esetében (Im-Bolter, Johnson és Pascual-Leone, 2006). Montgomery (1995, 2000a, 2000b, 2002), több vizsgálatából is kiderül, hogy SLI-os gyermekeknél a tárolási kapacitásban nincs különbség a kontrollcsoporthoz képest, viszont azokon a teszteken, ahol az információ manipulációjára is szükség van, ott rosszabbul teljesítenek. Például a számterjedelem teszttel mért kapacitás alig alacsonyabb az átlagnál, mivel ott csak az információ ideiglenes tárolása kell a feladat megoldásához, míg a hallási mondatterjedelem teszt esetében gyengébb lesz a teljesítmény a kontrollhoz képest.

Weismer és Evans (2002) valamint Weismer, Evans és Hesketh (1999) is hasonló eredményre jutottak, mint Montgomery és Evans (2009). Olyan kisgyermekek teljesítményét hasonlították össze életkor alapján illesztett kontrollcsoporttal, akiknél megkésett beszédfejlődést állapítottak meg. Eredményeik alapján az SLI-os gyerekek a normál kontroll szintjén teljesítettek az igaz/hamis megértési feladatokban, ám szignifikánsan gyengébben teljesítettek a szólista felidézési feladatokban. Egy másik tanulmányban Weismer, Plante, Jones és Tomblin (2005) fMRI segítségével azt is kimutatták, hogy SLI-os gyermekeknél alacsonyabb az aktiváció azokon a területeken, melyek a figyelmi és emlékezeti folyamatokban szerepet játszanak. SLI zavarban szenvedő iskoláskorú gyerekek esetén az egyszerü és az összetett nyelvtan megértése is mentálisan megterhelő feladat, ami jelentős munkamemória készletet igényel. Ezek az eredmények különösen fontosak a nyelvi fejlődés segítése szempontjából, mert rámutatnak arra, hogy érdemesebb lenne a gyermekek munkamemóriáját fejleszteni, például különböző emlékezeti stratégiákat tanítani, nem pedig specifikusan csak a nyelvre korlátozódó feladatok tartalmát gyakoroltatni.

Alloway és Archibald (2008) vizsgálatában az SLI-os csoport teljesítményében csak a verbális rövid távú emlékezeti teszteken és a munkamemória teszteken volt megfigyelhető károsodás. Riccio, Cash és Cohen (2007) kimutatták, hogy a specifikus nyelvi károsodással 
élő gyerekek csökkentett verbális kapacitással rendelkeznek. Ennek hátterében az auditoros információ munkamemóriában való feldolgozásának, megszervezésének és fenntartásának nehézségei állnak (Petruccelli, Bavin és Bretherton, 2012). Archibald és Gathercole (2007) eredményei azt mutatják, hogy a verbális tárolás károsodása valószínűleg összekapcsolódik a lassabb feldolgozással, ezzel magyarázva a gyengébb emlékezeti teljesítményt.

Figyelmi / hiperaktivitási zavarral küzdő (Attention Deficit / Hyperactivity Disorder, ADHD) gyermekeknél (Klingberg, Fernell, Olesen, Johnson, Gustafsson, Dahlström, Gillberg, Forssberg és Westerberg, 2005; Martinussen Hayden, Hogg-Johnson és Tannock, 2005), illetve felnőtteknél (Valera, Faraone, Biederman, Poldrack és Seidman, 2005; Ehlis, Bahne, Jacob, Herrmann és Fallgatter, 2008) is kimutatták a komplex verbális munkamemória és a hallás utáni megértés deficitjét (Martinussen, Hayden, Hogg-Johnson és Tannock, 2005), ami Martinussen és Tannock (2006) véleménye szerint figyelmi deficit esetén még erőteljesebben kimutatható. A számterjedelem teszten ezek a személyek a kontrollcsoport szintjén teljesítettek, ami jelzi, hogy a deficit nem a tárolásban van, hanem az információk manipulálásában (McInnes, Humphries, Hogg-Johnson és Tannock, 2003; Cornoldi, Marzocchi, Belotti, Caroli, Meo és Braga, 2001), akárcsak a nyelvi zavarok esetében. A munkamemória-deficit ADHD esetében megfigyelhető gyerekeknél (Martinussen és mtsai, 2005; Westerberg, Hirvikoski, Forssberg és Klinberg, 2004; Willcutt, Doyle, Nigg, Faraone és Pennington, 2005) és felnőtteknél is (Dowson, McLean, Bazanis, Toone, Young, Robbins és Sahakian, 2004; Marchetta, Hurks, Krabbendam és Jolles, 2008; Cubillo, Halari, Smith, Taylor és Rubia, 2012; Barkley, 2012). Az ADHD-val élőknek nehezen megy a hosszabb instrukciók követése és az azokra való emlékezés, emiatt könnyen elveszítik a figyelmi fókuszt.

Williams-szindrómás betegeknél a verbális és téri képességek disszociatív sérülése figyelhető meg (Vicari, Bellucci és Carlesimo, 2003; Lanfranchi, Cornoldi és Vianello, 2004). Verbális munkamemória kapacitásuk és nyelvi képességeik átlagosak, de téri munkamemóriájuk teljesítményében jelentős károsodás mutatható ki, mindössze néhány elem tárolására képesek (Racsmány, 2004). Velük ellentétben a Down-szindrómás gyerekek a térivizuális feladatokon értek el lényegesen jobb teljesítményt (Wang és Bellugi, 1994; Jarrold, Baddeley és Hewes, 1999; Racsmány, 2004; Levorato, Roch és Florit, 2011). Ezeknél a gyerekeknél károsodott verbális munkamemóriát találtak a kutatók, és az új szavak tanulásában is nehézségeik voltak (Jarrold, Thorn és Stephens, 2009).

A következő stratégiákkal lehetnek a szakemberek az ADHD- vel és a Williamsszindrómával élők segítségére: az instrukció részekre tagolása, a jelentésteliség és ismerősség 
érzésének növelése, memória fogasok használata (Gathercole, 2008). Martinussen (2005) metaelemzése szerint a téri-vizuális területen megjelenő deficitek sokkal súlyosabbak, mint a verbális területeken megjelenők, összehasonlítva a kontrollokkal. Mivel számos klinikai populáció esetében találkozhatunk munkamemória deficittel, ezért nagy jelentősége van annak, hogy többet tudjunk meg a biológiai hátteréről, a deficitek korai azonosításáról, a tünetetek enyhítéséről és a fejlesztő stratégiákról. A téma kifejtését bővebben lásd a 12. fejezetben.

A végrehajtó funkciókat érintő nehézségek számos fejlődési rendellenesség esetében megfigyelhetők, például a Tourette-szindróma (Pennington és Ozonoff, 1996), az ADHD (Barkley, 2012) és az autizmus (Hill, 2004). A háttérben minden esetben a frontális lebeny abnormális tevékenysége áll (Dickstein, Bannon, Castellanos és Milham, 2006; Schmitz és mtsai, 2006), ami megnehezíti a végrehajtó funkciók hatékony működését. Főként az ADHD és az autizmus említhető a végrehajtó funkciók több aspektusát érintő zavarként. Autizmusban a végrehajtó funkciók károsodása mind a gyerek, mind a felnőtt populációt érinti, főként a tervezés és a mentális flexibilitás területén, míg a gátlási kontroll nem minden esetben érintett (Hill, 2004). Az ADHD esetében a fö probléma a végrehajtó funkciókon belül a gátlási kontrollban és a túltanult válaszok elnyomásában rejlik (Pennington és Ozonoff, 1996; Desman, Petermann és Hampel, 2008). Mind az autista, mind az ADHD-val élő gyerekeknek problémát okoz a jövőbeli cselekvések tervezése (Hughes, Russell és Robbins, 1994; Scheres, Oosterlaan, Geurts, Morein-Tamir, Meiran, Schut, Vlasveld és Sergeant, 2004). A Tourette-szindrómával küzdő gyerekeknek nehézségeik vannak a verbálisfluenciatesztekben (Anderson, 2001). A környezeti faktoroknak, például a szocioökonómiai státusznak, a szülök iskolai végzettségének és a szülök intelligencia szintjének is jelentős hatása van a végrehajtó funkciók fejlödésére (Ardila, Rosselli, Matute és Guajado, 2005). 


\section{A MUNKAMEMÓRIA ÉS A VÉGREHAJTÓ FUNKCIÓK NÉHÁNY MÉRŐELJÁRÁSA}

\subsection{A verbális rövid távú memória és a komplex munkamemória mérőeljárásai}

Az 5.1 alfejezetben a disszertáció vizsgálataiban használt mérőeljárások bemutatásán lesz a hangsúly, de a teljességre törekedve néhány, a vizsgálatokban nem szereplő mérőeljárást is ismertetünk.

A munkamemória kapacitásának mérésére több tesztet dolgoztak ki (Németh és mtsai, 2001; Racsmány és mtsai, 2005), ezek közül a disszertáció vizsgálataiban használt mérőeljárások bemutatására szeretnénk helyezni a fókuszt. Ezek a tesztek más-más komponenseket mérnek a munkamemórián belül (Gathercole és Pickering, 2000; magyarul Németh és mtsai, 2001; Racsmány és mtsai, 2005). A megjegyzendő elemek általában nem függnek össze egymással, ennek segítségével ki lehet zárni a hosszú távú emlékezet hatásait. A vizsgálati személyeknek a megjegyzett elemeket rövid időn belül kell visszamondaniuk. A választóvonal ott húzható meg a teljesítményben, ahol a felidézés már nem pontos. A memóriakapacitás az a szint, amíg az adott egyén a legtöbb elemet tökéletesen fel tudja idézni (Németh, 2006). A munkamemória komponenseinek mérőeljárásait a 4. táblázatban ismertetjük.

4. táblázat. A munkamemória komponenseinek mérőeljárásai

\begin{tabular}{|c|c|c|c|}
\hline $\begin{array}{c}\text { TÉRI-VIZUÁLIS } \\
\text { VÁZLATTÖMB } \\
\text { (Téri-vizuális rövid távú } \\
\text { emlékezet) }\end{array}$ & $\begin{array}{c}\text { KÖZPONTI } \\
\text { VÉGREHAJTÓ }\end{array}$ & $\begin{array}{l}\text { FONOLÓGIAI HUROK } \\
\text { (Verbális rövid távú } \\
\text { emlékezet) }\end{array}$ & $\begin{array}{c}\text { KOMPLEX } \\
\text { MUNKAMEMÓRIA }\end{array}$ \\
\hline Corsi-kocka teszt & $\mathrm{N}$-et vissza feladat & Álszó-ismétlési teszt & $\begin{array}{c}\text { Hallási } \\
\text { mondatterjedelem } \\
\text { teszt }\end{array}$ \\
\hline $\begin{array}{c}\text { Mintázatterjedelem teszt } \\
\text { (VPST) }\end{array}$ & $\begin{array}{l}\text { Betü és szemantikus } \\
\text { fluencia teszt }\end{array}$ & Számterjedelem teszt & $\begin{array}{c}\text { Számlálási terjedelem } \\
\text { teszt }\end{array}$ \\
\hline Térkép tesztek & $\begin{array}{c}\text { Wisconsin } \\
\text { kártyaszortirozás teszt } \\
\text { (WCST) }\end{array}$ & Szóterjedelem tesztt & $\begin{array}{c}\text { Fordított } \\
\text { számterjedelem teszt }\end{array}$ \\
\hline Labirintus feladatok & Random generálás & Rey 15 szó feladat & $\begin{array}{c}\text { Olvasási terjedelem } \\
\text { teszt }\end{array}$ \\
\hline
\end{tabular}


Számterjedelem teszt (Digit Span) - A verbális munkamemóriát leggyakrabban a számterjedelem teszttel vizsgálják, amit elsőként Jacobs (1887) dolgozott ki. Egészséges személyek munkamemória terjedelme 7+/-2 elem (Miller, 1956; Baddeley, 2001). A teszt megtalálható a Wechsler-féle intelligencia tesztben is (Wechsler, 1981), ami jelentős mértékben növelte alkalmazási körét, ezáltal népszerüségét is. A Digit Span sztenderdizált, magyar nyelvü változatát Racsmány és munkatársai (2005) dolgozták ki.

Olvasási terjedelem teszt (Reading Span) - A tesztet Daneman és Carpenter dolgozta ki 1980-ban. Ez egy komplex (verbális) munkamemória feladat, amely a feldolgozó és tároló elemeket egyformán terheli. Baddeley és Hitch (1986) munkamemória modelljében a fonológiai hurok és a központi végrehajtó együttesét hivatott mérni a teszt. Népszerü vizsgálati eszköznek számít, mivel remekül bejósolja a szövegmegértési feladatokban elért teljesítményt (Daneman és Carpenter, 1980). A Reading Span sztenderdizált, magyar nyelvü változata Racsmány és munkatársai (2005) nevéhez köthető.

Hallási mondatterjedelem teszt (Listening Span) - A teszt Daneman és Blennerhasset (1984) nevéhez füződik és nagyon hasonlít az olvasási terjedelem teszthez. Eredetileg azért dolgozták ki, hogy még olvasni nem tudó gyermekek komplexmunkamemória-feladatokon nyújtott teljesítményét is tudják mérni. A teszt remekül alkalmazható az életkori változások vizsgálatára, például a munkamemória kapacitás gyermekkori fejlődésének vagy az öregedés hatásának feltérképezésére, emellett számos kutatás bizonyítja a teszt diagnosztikai értékét például nyelvi zavarok, tanulási nehézségek korai azonosításában. A teszt magyar nyelvü változatát Janacsek, Tánczos, Mészáros és Németh (2009) dolgozták ki (lásd 7. fejezet).

Álszó ismétlési teszt (Non-word repetition) - A tesztben a vizsgálati személynek egyre hosszabb, értelmetlen szavakat kell hallás után megismételnie. Az álszavak megegyeznek a vizsgálati személy anyanyelvének fonológiai szerkezetével. Az azonnali visszamondás miatt nem történik, ismételgetés, artikulációs frissítés, ezért elsősorban a fonológiai tárat terheli ez a feladat (Gathercole, Willis, Emslie és Baddeley, 1991; Racsmány és mtsai, 2005, Németh és mtsai, 2001).

Forditott számterjedelem teszt (Backward Digit Span) - A tesztben a vizsgálatvezető számokat olvas fel, a számok után egy másodperces szünetet hagy. A vizsgálati személynek az a feladata, hogy a számokat az elhangzás sorrendjével ellentétesen, vagyis visszafelé mondja el. Egy számsoron belül a számok nem ismétlődnek, és véletlenszerü sorrendben szerepelnek. Egy adott terjedelemhez négy különböző számsor tartozik. Mivel itt a verbális információ rövid idejű tárolásán túlmenően az információ manipulációjára is szükség van, ezért ez a teszt inkább a munkamemória mérőeljárásai közé sorolandó, bár nincs szükség 
olyan nagy feldolgozási követelményekre, például a hallási mondatterjedelem teszt esetében (Conway, Kane, Bunting, Hambrick, Wilhelm és Engle2005; Hutton és Towse, 2001).

Számlálási terjedelem teszt (Counting Span) - A teszt (Case, Kurland és Goldberg, 1982) a munkamemória mérésére szolgál. Előnye, hogy korábbi életkorban is felvehető, amikor már kialakult a gyerekek számlálási képessége, valamint hogy magasabb szintü matematikai képességek hiányában is felvehető, például olyan személyekkel, akik kimaradtak az iskolai oktatásból, vagy bizonyos fokú nehézségekkel rendelkeznek ilyen téren (lásd diszkalkulia). A teszt során sötétkék köröket és négyzeteket, valamint sárga köröket mutatunk a számítógép képernyőjén a kísérleti személyeknek. Az a feladatuk, hogy egyesével, hangosan számolják meg, hogy hány sötétkék kört látnak a képen, ismételjék meg ezt az utolsó számot és jegyezzék meg. Két kép után vissza kell mondaniuk a megjegyzett számokat a bemutatás sorrendjében. Ez a szám mindig kettő és nyolc közé esik, és egy számsoron belül nincs ismétlődés, valamint nem fedezhető fel semmilyen logikai szabályszerűség abban, hogyan követik egymást a számok. Továbbá fontos kikötés, hogy amint befejezték a számolást, rögtön ki kell mondaniuk az eredményt, és amint megjelenik a következö kép rögtön kezdjenek el számolni, nem tarthatnak közben szünetet, ezzel időt hagyva az ismétlésre. Annyi pontot ér el a személy, ahány számot helyesen vissza tudott mondani maximálisan. Ha nem sikerült az első két szám visszamondása, egy pontot kap az adott sorozatra. A számlálási terjedelem végső értékét a három sorozat eredményének átlaga adja, amely maximálisan hat lehet, mivel hat elemből áll a leghosszabb számsorozat.

Müveleti terjedelem teszt (Operation Span Task) - A tesztet Turner és Engle (1989) fejlesztette ki, mint a munkamemória vizsgálatát lehetővé tevő új eljárást. Hátránya, hogy 8-9 éves kor elött nem vehető fel, mivel viszonylag stabil számlálási képességhez kötött. A feladat során egyszerü matematikai egyenleteket kell hangosan megoldania a vizsgálati személyeknek, majd eldönteni, hogy helyes-e a végeredmény, és felolvasni az egyenlet utáni szót. A válaszokat szóban kérjük vissza a kísérleti személyektől. Két egyenlet után fel kell idézniük a szavakat a bemutatás sorrendjében. Ezután három egyenlet következik, tehát három szót kell memorizálni és visszamondani. A sorozat végén már hat szót kell megjegyezni, ha végig sikerült a vizsgálati személyeknek visszamondania helyes sorrendben a szavakat. Hiba esetén egy új sorozat következik, összesen három. Ennél a feladatnál is fontos kikötés, hogy az egyenletek között nem tarthatnak szünetet a résztvevők, rögtön számolniuk kell, amint megjelenik az újabb egyenlet. A számlálási terjedelem teszthez hasonlóan alakul a pontozás. A végső értéket itt is a három sorozat átlaga alapján határozták 
meg (lásd Janacsek és mtsai, 2009). A verbális rövid távú memória és a munkamemória mérőeljárásait a 5. táblázat szemlélteti.

Corsi-kocka teszt (Corsi, 1972; Lezak, 1995; Racsmány, 2004) - A teszt során kilenc darab fakocka található egy fa táblán. A vizsgálati személynek az a feladata, hogy ugyanolyan sorrendben mutasson a kockákra, ahogy azt a vizsgálatvezető tette. A végső terjedelmi mutató az a hosszúság, ahol a négy próbából hármat helyesen tudott visszamutatni.

5. táblázat. Verbális rövid távú memória -és munkamemória-tesztek

\begin{tabular}{|c|c|c|c|c|}
\hline MÉRÖELJÁRÁS & $\begin{array}{l}\text { VIZSGÁLT } \\
\text { FUNKCIÓ }\end{array}$ & FELADAT & \multicolumn{2}{|c|}{ HELYES VÁLASZ } \\
\hline $\begin{array}{l}\text { Számterjedelem } \\
\text { teszt }\end{array}$ & fonológiai RTM & $\begin{array}{l}\text { Megjegyezni, visszamondani sorrendben, } \\
\text { például: „7-2-9-1” }\end{array}$ & \multicolumn{2}{|c|}{, $7-2-9-1 ”$} \\
\hline $\begin{array}{l}\text { Álszó ismétlési } \\
\text { teszt }\end{array}$ & fonológiai RTM & $\begin{array}{l}\text { Megjegyezni, visszamondani, például: } \\
\text { „sémernyegvőterec” }\end{array}$ & \multicolumn{2}{|c|}{ „,sémernyegvőterec” } \\
\hline $\begin{array}{c}\text { Fordított } \\
\text { számterjedelem } \\
\text { teszt }\end{array}$ & fonológiai RTM & $\begin{array}{l}\text { Megjegyezni, visszamondani fordított } \\
\text { sorrendben, például: „4-9-6-1” }\end{array}$ & \multicolumn{2}{|c|}{, $1-6-9-4 "$} \\
\hline $\begin{array}{c}\text { Olvasási terjedelem } \\
\text { teszt }\end{array}$ & munkamemória & $\begin{array}{l}\text { Elolvasni, megjegyezni, visszamondani } \\
\text { sorrendben, például: „Mikor az alapos } \\
\text { takarításnak vége lett, az épület összes emeletén } \\
\text { megszünt az általános rossz illat.” és „A } \\
\text { müvészeti igazgató közölte a híres zenésszel, } \\
\text { hogy a gyengébb teljesítmény ellenére jár neki a } \\
\text { gitár.”. }\end{array}$ & \multicolumn{2}{|c|}{$\begin{array}{l}\text { „illat } \\
\text { gitár” }\end{array}$} \\
\hline $\begin{array}{l}\text { Hallási mondat- } \\
\text { terjedelem teszt }\end{array}$ & munkamemória & $\begin{array}{l}\text { Igaz/Hamis, megjegyezni, visszamondani } \\
\text { sorrendben, például: „A varrónő által gyakran } \\
\text { használt eszköz az olló.” és „A madarak } \\
\text { csőrében mindig sok a kávé.” }\end{array}$ & $\begin{array}{l}\text { "igaz" } \\
\text { "hamis" }\end{array}$ & $\begin{array}{l}\text { „olló } \\
\text { kávé” }\end{array}$ \\
\hline $\begin{array}{l}\text { Müveleti } \\
\text { terjedelem teszt }\end{array}$ & munkamemória & $\begin{array}{l}\text { Igaz/Hamis, megjegyezni, visszamondani } \\
\text { sorrendben, például: “( }(10 / 2)-3=2 \quad \text { banán”és } \\
\text { "( }\left(6^{*} 3\right)-7=13 \quad \text { kocsma” }\end{array}$ & $\begin{array}{l}\text { "igaz" } \\
\text { "hamis" }\end{array}$ & „,banán \\
\hline $\begin{array}{l}\text { Számlálási } \\
\text { terjedelem teszt }\end{array}$ & munkamemória & $\begin{array}{l}\text { Egymás után következő ábrákon megszámolni a } \\
\text { sötétkék köröket, majd sorrendben } \\
\text { visszamondani a számolások végeredményét. }\end{array}$ & \multicolumn{2}{|c|}{$\begin{array}{l}\text { A számolások } \\
\text { végeredménye. }\end{array}$} \\
\hline
\end{tabular}

\subsection{A komplex munkamemória mérőeljárásainak alkalmazási lehetőségei}

Az iskolában sok olyan feladat van, ami egyszerre igényli az új információk feldolgozását és az előzetes ismeretekhez integrálását. Ilyen iskolai feladatok például hallgatni egy másik beszélőt, írás közben kigondolni a következő szövegrészt vagy fejben számolni. A komplex 
munkamemória tesztek is hasonló követelményeket állítanak: az információ tárolása mellett szükség van annak manipulációjára is. Számos kutatás alátámasztja, hogy a komplex munkamemória-teszteken nyújtott teljesítmény jó bejóslója a tanulási nehézségeknek (lásd például Gathercole és Pickering, 2000a; 2000b; Pickering és Gathercole, 2004; McNamara és Wong, 2003).

Gathercole és Pickering (2000b) hat és hét éves gyermekeknél vizsgálta a munkamemória kapacitás és az iskolai előrehaladás kapcsolatát. Az általuk felvett tesztek: a számterjedelem, a fordított számterjedelem, az álszó ismétlési teszt, a hallási mondatterjedelem teszt, valamint a téri-vizuális vázlattömb méröeljárásai. Eredményeik szerint az iskolában gyengébben teljesítők jelentősen alacsonyabb eredményeket érnek el a komplex munkamemória (hallási mondatterjedelem teszt) és a téri-vizuális feladatokban, mint átlagosan teljesítő társaik. E tesztek jó elörejelzői lehetnek a különböző tantárgyakon elért gyengébb teljesítménynek, míg a fonológiai hurok mérőeljárásai önnmagukban nem prediktív értékűek. A téri-vizuális vázlattömb feladatai feltehetően azért jártak erősen együtt a gyengébb matematika tantárgyon nyújtott teljesítménnyel, mert ezekben is szükség van az információ tárolása mellett annak manipulációjára is, mint ahogy például a hallási mondatterjedelem feladatban is.

Pickering és Gathercole (2004) speciális tanulási igényekkel rendelkező gyermekek munkamemória teljesítményét is tanulmányozták. Négy csoportba sorolták a gyermekeket általános tanulási nehézség, nyelvi-beszédzavar, írás-olvasás zavara és egyéb viselkedéses zavar alapján. A viselkedéses zavarral küzdők átlagosan teljesítettek a vizsgálatban minden munkamemória mérőeljárásnál, mely jelzi, hogy problémájuk nem kognitív természetü, míg a másik három csoport teljesítménye gyengébb volt az egészséges kontrollcsoportéhoz képest. Az eredmények összhangban vannak azzal elképzeléssel, miszerint a munkamemória komponenseinek specifikus szerepe van a tanulás támogatásában. A komplex munkamemória tesztek diagnosztikai értéke felnőtteknél is jelentős (McNamara és Wong, 2003).

\subsection{A végrehajtó funkciók mérése és alkalmazási lehetőségei}

Az 5.3 alfejezetben olyan teszteket ismertetünk, amelyek a vizsgálatokban nem szerepelnek, de a pontosabb összkép érdekében fontosnak tartottuk ezek ismertetését is. A végrehajtó funkciók mérése olyan teszteken alapul, amelyek föként a frontális funkciók mérését foglalják magukban. Találhatunk néhány közös elemet a végrehajtó funkciók és a fentebb áttekintett központi végrehajtó méröeljárásai között. Ebben az alfejezetben azonban fókuszáltabban 
mutatjuk be a végrehajtó funkciók mérőeljárásait. az 6. táblázatban a végrehajtó funkciók fontosabb mérőeljárásait ismertetjük.

6. táblázat. A végrehajtó funkciók méröeljárásai

\begin{tabular}{|c|c|c|c|}
\hline \multicolumn{4}{|c|}{ A VÉGREHAJTÓ FUNKCIÓK MÉRÖELJÁRÁSAI } \\
\hline Teszt & Hivatkozás & Feladat & $\begin{array}{l}\text { Végrehajtó funkció } \\
\text { komponens }\end{array}$ \\
\hline $\begin{array}{l}\text { BSAT (Brixton } \\
\text { Spatial } \\
\text { Awareness Test) }\end{array}$ & $\begin{array}{l}\text { Burgess és Shallice } \\
\text { (1997) }\end{array}$ & $\begin{array}{l}\text { Egy színes kör pozíciója a személy által } \\
\text { nem tudott meghatározott szabályok } \\
\text { szerint változik oldalról oldalra, meg } \\
\text { kell jósolni a következő pozíciót. }\end{array}$ & Szabálydetekció \\
\hline $\begin{array}{l}\text { COWAT } \\
\text { (Controlled Oral } \\
\text { Word Association } \\
\text { Test) } \\
\end{array}$ & $\begin{array}{c}\text { Benton és Hamsher } \\
\text { (1989) }\end{array}$ & $\begin{array}{l}\text { A személyeknek minél több szót kell } \\
\text { mondaniuk F, A, S betűvel kezdődően. }\end{array}$ & $\begin{array}{l}\text { Válaszgenerálás } \\
\text { Gátlás }\end{array}$ \\
\hline $\begin{array}{l}\text { HSCT (Hayling } \\
\quad \text { Sentence } \\
\text { Comletion Test) }\end{array}$ & $\begin{array}{l}\text { Burgess és Shallice } \\
\text { (1997) }\end{array}$ & $\begin{array}{l}\text { Első lépésként egy be nem fejezett } \\
\text { mondat végét kell kitalálni } \\
\text { Majd egy olyan szóval kell a } \\
\text { mondatot kiegészíteni, ami } \\
\text { független a mondat kontextusától }\end{array}$ & $\begin{array}{l}\text { Kezdési sebesség } \\
\text { Válasz elnyomása }\end{array}$ \\
\hline Stroop & Stroop (1935) & $\begin{array}{c}\text { Szó: színnevek feketével írva } \\
\text { Szín: megnevezni a színt } \\
\text { Szín/szó: megnevezni amilyen színnel } \\
\text { van írva a szó }\end{array}$ & Gátlás \\
\hline $\begin{array}{l}\text { London-torony } \\
\text { feladat (TOL - } \\
\text { Tower of } \\
\text { London) }\end{array}$ & Shallice (1982) & $\begin{array}{c}3 \text { farúdon kell mozgatni a különböző } \\
\text { színű korongokat a kezdeti } \\
\text { konfigurációtól a célpozíció felé, minél } \\
\text { kevesebb lépésben }\end{array}$ & $\begin{array}{l}\text { Tervezés } \\
\text { Gátlás }\end{array}$ \\
\hline $\begin{array}{l}\text { Hanoi-torony } \\
\text { feladat (TOH - } \\
\text { Tower of Hanoi) }\end{array}$ & Simon (1975) & $\begin{array}{l}5 \text { különböző méretü korongot kell } 3 \\
\text { farúdon mozgatni a kezdeti pozíciótól a } \\
\text { cél felé, minél kevesebb lépésben }\end{array}$ & $\begin{array}{l}\text { Tervezés } \\
\text { Gátlás }\end{array}$ \\
\hline $\begin{array}{l}\text { Wisconsin } \\
\text { Kártyaszortírozási } \\
\text { felafat (WCST - } \\
\text { Wisconsin Card } \\
\text { Sorting Test) } \\
\end{array}$ & Berg (1948) & $\begin{array}{l}4 \text { ingerkártya különböző színnel, alakkal } \\
\text { és számmal van elhelyezve. Különbözö } \\
\text { kártyákat kell kiválogatni egy nem } \\
\text { tudott szabály szerint, amely } \\
\text { figyelmeztetés nélkül változik. } \\
\end{array}$ & $\begin{array}{l}\text { Készletváltás } \\
\text { Készlet fenntartása } \\
\text { Gátlás } \\
\text { Szabálykövetés } \\
\text { Fogalomalkotás } \\
\end{array}$ \\
\hline
\end{tabular}

A teszteken elért eredmények jó prediktorai lehetnek mind az iskolai érettségnek, mind pedig a későbbi iskolai teljesítménynek (Blair és Razza, 2007; Bull, Espy és Wiebe, 2008; Duncan, Dowsett, Claessens, Magnuson, Huston, Klebanov, Pagani, Feinstein, Engel, Brooks-Gunn, Sexton, Duckworth és Japel, 2007), továbbá hatással lehetnek a gyerekek tanulási aktivitására is. A korai iskolai teljesítmény bejósolhatja a fonológiai tudatosság, számolási készségek, alap számtan és a szemantikus tudás elérésének szintjét is (Anthony, Williams, McDonald és Francis, 2007). A végrehajtó funkciók több aspektusú tesztbattériáit a 7. táblázat tartalmazza. 


\begin{tabular}{|c|c|c|c|}
\hline Battéria/Eszköz & Hivatkozás & Tesztek & $\begin{array}{c}\text { Végrehajtó funkció } \\
\text { komponens }\end{array}$ \\
\hline $\begin{array}{c}\text { BADS } \\
\text { (Behavioral } \\
\text { Assessment of the } \\
\text { Dysexecutive } \\
\text { Syndrome) }\end{array}$ & $\begin{array}{l}\text { Burgess, Alderman, } \\
\text { Evans, Emslie és } \\
\text { Wilson (1998) }\end{array}$ & $\begin{array}{c}\text { Cselekvési Program Teszt, } \\
\text { Diszexekutív kérdőív, } \\
\text { Kulcskeresés, Módosított } 6 \text { elem } \\
\text { feladat, Szabályváltási feladat, Idői } \\
\text { becslés feladat, Állatkerti térkép } \\
\text { feladat }\end{array}$ & $\begin{array}{l}\text { Készletváltás, tervezés, } \\
\text { célvezérelt viselkedés, } \\
\text { becslési képességek, } \\
\text { válaszgátlás }\end{array}$ \\
\hline $\begin{array}{c}\text { BRIEF } \\
\text { (Behavior Rating } \\
\text { Inventory of } \\
\text { Executive Function) }\end{array}$ & $\begin{array}{l}\text { Gioia, Isquith, Guy és } \\
\text { Kenworthy (2000) }\end{array}$ & $\begin{array}{l}63 \text { itemes klinikai skála, } 3 \text { fó } \\
\text { faktort mér: önkontroll gátlási } \\
\text { folyamatok, flexibilitás, } \\
\text { metakogníció }\end{array}$ & $\begin{array}{l}\text { Gátlás, készletváltás, } \\
\text { érzelmi kontroll, } \\
\text { tervezés, a célvezérelt } \\
\text { viselkedés szervezése }\end{array}$ \\
\hline $\begin{array}{c}\text { CANTAB } \\
\text { (Cambridge } \\
\text { Neuropsychological } \\
\text { Test Automated } \\
\text { Battery) }\end{array}$ & $\begin{array}{l}\text { Huppert, Brayne, Gill, } \\
\text { Paykel és Beardsall } \\
\text { (1995) }\end{array}$ & $\begin{array}{l}\text { Kis és nagy körök, késleltetett és } \\
\text { nem késleltetett egyeztetése a } \\
\text { példáknak, motoros szürés, } \\
\text { mintázat felismerés, téri } \\
\text { felismerés, páros asszociációs } \\
\text { tanulás, téri terjedelem, téri } \\
\text { munkamemória, belső/külső } \\
\text { dimenzióváltás, gyors vizuális } \\
\text { információ feldolgozás, reakcióidő }\end{array}$ & $\begin{array}{l}\text { Készletváltás, készlet } \\
\text { fenntartás, } \\
\text { stratégiatervezés, } \\
\text { fogalomalkotás, } \\
\text { célvezérelt cselekvések } \\
\text { szervezése }\end{array}$ \\
\hline $\begin{array}{c}\text { D-KEFS } \\
\text { (Delis-Kaplan } \\
\text { Executive Function } \\
\text { System) }\end{array}$ & $\begin{array}{l}\text { Delis, Kaplan és } \\
\text { Kramer (2001) }\end{array}$ & $\begin{array}{l}\text { Szín-szó interferencia, tervezési } \\
\text { fluencia, szortírozási feladat, Trail } \\
\text { Making Teszt, } 20 \text { kérdés teszt, } \\
\text { Torony teszt, közmondás teszt, } \\
\text { verbálisfluencia-teszt, } \\
\text { szókontextus feladat }\end{array}$ & $\begin{array}{l}\text { Válaszgátlás, verbális és } \\
\text { tervezési fluencia, } \\
\text { fogalomalkotás, } \\
\text { készletváltás, } \\
\text { szabálydetekció, } \\
\text { tervezés, feedbackre } \\
\text { adott válasz, absztrakt } \\
\text { gondolkodás }\end{array}$ \\
\hline $\begin{array}{c}\text { FrSBe } \\
\text { (Frontal Systems } \\
\text { Behavior Scale) }\end{array}$ & $\begin{array}{l}\text { Grace és Malloy } \\
\text { (2002) }\end{array}$ & $\begin{array}{l}46 \text { itemes skála, } 3 \text { alskála, amely } \\
\text { az apátiát, diszinhibíciót és a } \\
\text { végrehajtó diszfunkciókat méri }\end{array}$ & $\begin{array}{l}\text { Gátlás, érzelmi kontroll, } \\
\text { célvezérelt cselekvések } \\
\text { szervezése }\end{array}$ \\
\hline
\end{tabular}

A különböző klinikai csoportokban a végrehajtó funkció deificitek egységes arculata mögött a többnyire globális mérőeljárások állnak (például a Wisconsin Kártyszortírozási Teszt - WCST), amelyek differenciál-diagnosztikára és minőségi elemzésre nem alkalmasak. Az általunk későbbiekben bemutatott verbálisfluencia-tesztek minőségi és mennyiségi elemzésével lehetőség nyílik a pontosabb funkcióazonosításra és a differenciál-diagnosztikára is.

Prior és Hoffman (1990) autista gyerekeket vizsgáltaktöbbek közöttaz útvesztő tanulási feladat és a módosított WCST segítségével. Eredményeik szerint az autista gyerekek mindegyik feladatban gyengébben teljesítettek és hibaszámaik is megsokszorozódtak az illesztett kontroll csoport eredményeihez képest. Ozonoff, Pennington és Rogers (1991) 8 és 20 év közötti autista gyerekeket és fiatalokat vizsgáló munkájukban a végrehajtó funkciók mérésére a WCST és a Hanoi-torony feladatokat használták. Megállapították, hogy az autizmussal élők minden feladatban gyengébben teljesítettek, mint a tipikusan fejlődő társaik. 
Hill (2004) a tervezés, flexibilitás és gátlás kapcsán is sérült végrehajtó funkciókat talált az autista csoportnál a tipikusan fejlődő csoport eredményeihez viszonyítva.

ADHD-ban a gyerekek többsége nagyon gyengén teljesít a WCST feladatban (Reader, Harris, Schuerholz és Dencla, 1994), továbbá az olyan folyamatos figyelmet és teljesítményt igénylő feladatokban is, mint a Stroop-teszt, a verbálisfluencia-tesztek és a problémamegoldási feladatok. Grodzinsky és Diamond (1992) ADHD-s fiúknál súlyos teljesítménybeli deficitet találtak a verbálisfluencia, a Stroop és az útvesztő feladatokban is, míg a lányok esetében nem volt ilyen jelentős a deficit (Nigg, Butler, Huang-Pollock és Henderson, 2002). Doyle (2005) szerint az ADHD sérült teljesítménnyel kapcsolatban áll a munkamemóriával, a válaszgátlással és a végrehajtó funkciók egyéb aspektusaival.

Channon, Pratt és Robertson (2003) Tourette-szindrómás gyerekek vizsgálatakor a gátlásban és a stratégiaalkotásban figyeltek meg teljesítménycsökkenést. Temple, Carney és Mullarkey (1996) Turner-szindrómás lányok esetében csökkent teljesítményt találtak a verbálisfluencia-teszteken, a Stroop-teszten és a Hanoi-torony feladatban, míg a WCST-ben és a London-torony feladatban az életkoruknak megfelelő teljesítményt nyújtottak.

\subsubsection{A verbálisfluencia-tesztek (Betü- és szemantikusfluencia-teszt) jellemzöi}

A verbálisfluencia-feladatokat széles körben alkalmazzák mind a klinikai gyakorlatban, mind pedig a kutatásokban. Ezek során a szavakat bizonyos szemantikus (szemantikus fluencia feladat) vagy fonológiai (betűfluencia feladat) kritériumok mentén kell előhívni a vizsgálati személyeknek, meghatározott idő alatt (Lezak, 2004). A verbálisfluencia-teszteken nyújtott teljesítmény információval szolgál a szemantikus memóriáról és a végrehajtó, ellenőrző folyamatokról is, úgy mint a stratégia keresés, kezdeményezés, valamint a válasz önmonitorozása és legátlása, amikor az szükséges (Henry, Crawford és Phillips, 2004). A téma részletesebb kifejtésére a 11. és 12 . fejezetekben kerül sor.

A legtöbb tanulmányban a verbálisfluencia teljesítményt az egy perc alatt mondott szavak száma adja. Azonban ez a típusú pontozási módszer nem elegendő a verbálisfluencia feladatok hátterében rejlö kognitív folyamatok pontos elemzésére (Hurks, Hendriksen, Vles, Kallf, Feron, Kroes, Van Zeben, Steyaert és Jolles, 2004; Troyer, 2000). Emiatt két pontozási módszer terjedt el. Az első az idő függvényében méri a szóproduktivitást, tehát a verbálisfluencia-feladatok idői elemzésével ad precízebb információkat a mögöttes folyamatokról és a lexikális szerveződés modelljén alapszik (Crowe, 1992). A második módszer, amit mi is használtunk a disszertációban bemutatott vizsgálataink során, az 
információk szisztematikus szerveződését tárja fel. Hagyományosan a teljesítmény mutatójaként leggyakrabban a helyesen generált szavak számát tekintik (Benton és Hamsher, 1976; Benton, 1968; Miller, 1984; Rosen, 1980; Benton és Hamsher, 1989; Hart, Smith és Swash, 1986; Gurd és Ward, 1989; Hanley, Dewick, Davies, Playfer és Turnbull, 1990; Paus, 1991; Crawford,Moore és Cameron, 1992; Pasquier, Lebert, Grymonprez és Petit, 1995), emellett a perszeverációk (ugyanannak a szónak a megismétlése a válaszadás folyamán) és hibák (az instrukciónak nem megfelelő kezdőbetűvel kezdődött válaszok) meglétéből illetve mértékéből próbálnak következtetni különböző neuropszichológiai eltérésekre és deficitekre (Lees és Smith, 1989; Crowe, 1992; Azuma, 2004; Henry és Crawford, 2004; Tröster, Salmon, McCullogh és Butters, 1989; Tröster, Warmflash, Osorio, Paolo, Alexander és Barr, 1995; Tröster, Fields, Testa, Paul, Blanco, Hames, Salmon és Beatty, 1998). Újabban a teljesítménymutatók kiegészültek a klaszterek számával (vagyis a mondott szavakból alkotott minimum kételemü csoportok, amelyeket különböző szabályoknak megfeleltetve sorolunk klaszterekbe (Troyer, Moscovitch és Winocur, 1997) és azok méretével (a vizsgálati személyek milyen nagyágú csoportokat hoznak létre, azaz mekkora a csoportok átlagos elemszáma (Troyer és mtsai, 1997; Reverberi, Laiacona és Capitani, 2006; Sauzéon, Lestage, Raboutet, N’Kaoua és Claverie, 2004; Fossati, Le Bastard, Ergis és Allilaire, 2003; Koren, Kofman és Berger, 2005), illetve a váltások számával (a klaszterváltás a szomszédos klaszterek közötti váltást jelenti, az éles váltás pedig a klaszter és egy nem klaszterbe sorolt szó vagy két nem csoportosított szó között jelenik meg). A két váltástípus összege alkotta az összváltások számát (Troyer és mtsai, 1997; Abwender és mtsai, 2001). A klaszterelés és a váltás egyformán fontos szerepet tölt be a sikeres verbálisfluencia-teljesítmény elemzésében (Banerjee, Grange, Steiner és White, 2011; Kavé, Kigel és Kochva, 2008; Koren, Kofman és Berger, 2005; Nash és Snowling, 2008). A váltás a kognitív flexibilitás jelzőjeként a frontálislebeny-funkciókhoz köthető. A klaszterelés, ami a lexikai-szemantikai tudáshálózatról szolgáltat információkat, inkább a temporális lebeny funkcióihoz kapcsolódik (Troyer, Moscovitch, Winocur, Alexander és Stuss, 1998a). Az újabb teljesítménymutatók jól használhatóak a verbálisfluencia-feladatok hátterében meghúzódó kognitív folyamatok és az egyes személyek teljesítményének minőségi elemzésére. 


\section{A MUNKAMEMÓRIA ÉS A VÉGREHAJTÓ FUNKCIÓK ÉLETKORI VÁLTOZÁSAI}

Az életkori változások vizsgálatára kétféle módszer áll rendelkezésünkre. Az egyik lehetőség a longitudinális (hosszmetszeti), tehát követéses jellegü vizsgálat olyan kutatási módszer, amiben az egyént hosszabb időn keresztül vizsgálják, bizonyos időszakonként újra elvégezve a méréseket. A keresztmetszeti (cross-sectional) vizsgálatok során nem ugyanazon személyek vizsgálati eredményeinek a változását tárjuk fel, hanem egy adott időpontbana fejlődés különböző fázisában lévő, általában különböző életkorú személyeket vizsgálják. A 6.1 alfejezetben keresztmetszeti vizsgálatokat ismertetünk, longitudinális vizsgálatokkal ritkábban találkozhatunk azon kutatásokban, amik a munkamemória és a végrehajtó funkciók életkori változásait vizsgálják.

\subsection{A munkamemória fejlődése és hatása a kognitív folyamatok müködésére}

Jelentős különbség figyelhető meg a munkamemória egyes alrendszereinek fejlődésében (Smith és Jonides, 1997; Gathercole, 1999; Gathercole és mtsai, 2004). A kapcsolat a térivizuális tár és a terület általános feldolgozó komponens (központi végrehajtó) között sokkal szorosabb 4-6 éves korig (Alloway, Gathercole és Pickering, 2006), amely azt jelzi, hogy ebben az életkorban a téri-vizuális vázlattömb sokkal inkább igényli a központi végrehajtó támogatását, mint a verbális tár. Fontos különbséget tennünk az életkori változásokat illetően a verbális (fonológiai hurok) és a komplex munkamemória fejlődése között, mivel eltérő sajátosságokat figyelhetünk meg a két rendszer esetében. A munkamemória komponenseinek fejlődési üteme jelentősen eltér egymástól. Míg a fonológiai hurok kapacitásának növekedése hamarabb, 10-12 éves kor körül lezárul (Gathercole, 1999), addig a komplex munkamemória-feladatokkal (hallási mondatterjedelem, olvasási terjedelem) mért komponensek fejlődése lassabb és az időskori leromlás is jobban megfigyelhető (Carpenter, Miyake és Just, 1994; Gathercole, 1999, Németh, 2006). Case, Kurland és Goldberg (1982) szerint azért nő arányosan a gyerekek életkorával a munkamemória-kapacitás, mert a képességeik fejlődésével kevesebb erőforrásra van szükségük az információ feldolgozásához, és így több erőforrás marad a tároláshoz (Németh, 2006).

A fonológiai hurok különböző mérőeljárásait használva keresztmetszeti vizsgálatokban kimutatták, hogy a verbális munkamemória teszteken nyújtott teljesítmény az 
életkorral együtt nő (Gathercole és Adams, 1994; Baddeley, Gathercole és Papagno, 1998). Azt feltételezik, hogy a kapacitásnövekedés hátterében az ismétlési mechanizmusok átalakulása áll. A rövidtávú memóriát mérő teszteken a gyerekek teljesítménye nyolc éves korig erős növekedést mutat, azután pedig már fokozatos fejlődés figyelhető meg 11-12 éves korig, amikor is a fejlődés üteme lassul 16-17 éves korig. Ennek a profilnak kivételét képezi a hallási mondatterjedelem teszten elért teljesítmény (komplex munkamemória mérőeljárás), mivel itt 9-13 éves korban is meredek emelkedést találtak. Ez arra utal, hogy a komplex munkamemória egy hosszabb fejlödési perióduson megy keresztül (Gathercole, 1999; Gathercole és mtsai, 2004).

Chiappe, Hasher és Siegel (2000) 19 éves korra teszik a komplex munkamemóriakapacitás fejlődésének végét. Cowan $(1992,1994)$ vizsgálatában megállapította, hogy az emlékezeti elöhívás során a négy és nyolc év közötti gyerekek egyre kevesebb szünetet tartanak az egyes szavak között, tehát az ismétlés adott idő alatt gyorsabbá válik, melynek egyéni eltérései erősen összefüggnek a munkamemória teszteken elért eredménnyel. A térivizuális munkamemória kapacitásának növekedése 5 éves kortól 11 éves korig egyenletes, azután pedig csökken, de egészen 49 éves korig megfigyelhető a fejlődés.

Szinte minden verbális feladatban észlelhető négy éves kor után a szóhosszúsági hatás, mivel ez befolyásolja a szavak kiejthetőségét. Az emlékezeti kapacitást meghatározza, hogy mennyi elemet tudtunk sikeresen frissíteni, mielőtt az elhalványulás bekövetkezik. Azt, hogy mennyi elemet tudunk frissíteni, meghatározza az artikuláció sebessége és a szavak közti szünetek hossza (Hoosain és Salili, 1988). A hat éves gyermekek felidézési zavarának okaként a nyomelhalványulást nevezhetjük meg, mivel ők még az információk frissítéséhez nem használják az ismétlést és ennek következtében másfél-két másodpercen belül megtörténik a nyomelhalványulás (Gathercole, 1999). Más kutatók vizsgálatai is alátámasztják azt a feltételezést, hogy nyolc éves kor után a szavak kiejtési sebessége (artikulációs sebesség) nagymértékben összefügg a munkamemória kapacitásával (Henry, 1991; Cowan, 1994).

Barrouillet, Gavens, Vergauwe, Gaillard és Camos (2009) vizsgálatot végeztek egy korábbi modell (Time-Based Resource-Sharing Model) alapján (Barrouillet, Bernardin és Camos, 2004) aminek alapfeltevése az volt, hogy az emlékezet újraaktiválja az elhalványuló emléknyomokat, mielőtt azok végleg eltűnnének. 5 és 14 év közötti gyerekeknél figyelték meg azt, hogy milyen szerepe lehet az újraaktiválási folyamatnak a munkamemória kapacitásának eltéréseiben. Ezek a gyerekek alkalmazzák a szeriális kontrollt és megállapították, hogy a reaktiválási folyamat hatékonysága hét éves kortól egészen késő 
serdülőkorig növekszik. Serdülőkorban a komplex munkamemória teljesítményének növekedése szoros kapcsolatban áll a végrehajtó és a figyelmi funkciók érésével, amely a frontális területek fejlődési folyamatainak eredményeként jelentkezik. 10-17 éves kor között az emlékezeti teljesítmény mintegy 10\%-kal nő.

10 éves korban a felidézési hibák nagy részének hátterében az interferencia áll, a nyomelhalványulás szerepe ebben a korban már csökken. Azért, hogy a gyerekek saját tanulásukat könnyebbé tegyék különböző emlékezeti módszereket alakítanak ki maguknak ebben az életkorban (Wagner, 1974; Gathercole, 1999). A hét évnél fiatalabb gyerekek esetén gyengébb felidézési teljesítményhez vezethet az, hogy még nem tudják átalakítani a vizuális információkat verbálissá. Az iskoláskorú gyerekek teljesítménye a verbális munkamemória feladatokban növekszik, ami a javuló fonológiai tudatossághoz és a temporális diszkrimináció fejlődéséhez kapcsolódik. Ezek segítségével könnyebben és jobban tudják kódolni az információt, ami jobb teljesítményt eredményez (Gathercole, 1999).

McCormack, Brown, Vousden és Henson (2000) szerint a nyolc évnél idősebb gyerekek emlékezeti terjedelme tovább fejlődik, ami úgy jelenik meg, hogy előhíváskor kevesebb szeriális hibát vétenek. Idősebb gyerekek egyidejűleg többféle modalitásban is tudják kódolni az információkat. Ez javítja a kód minőségét és megjelenik egy újabb emlékezeti forma, az epizodikus emlékezet. Ebben az életkorban nő az információfeldolgozási sebesség, valamint figyelmük időtartama és annak terjedelme alkalmassá válik arra, hogy az iskolában a feladatokat elvégezzék, a tanári utasításokat, magyarázatokat kövessék. A feldolgozási folyamatok sebessége és eredményessége serdülökorban nő, amely hatással van a tárolás eredményességére is. A feldolgozásban és a tárolásban jelentkező egyéni eltérések állandósulnak, melyre a figyelmi folyamatok egyéni különbségei szolgálnak magyarázatul.

Németh (2002) vizsgálatában a munkamemória fejlődése és a mondatmegértés kapcsolatát tanulmányozta. Megállapította, hogy gyermekeknél az önütemezett olvasással mért megértés munkamemória hatásokat mutat. A keresztmetszeti vizsgálatokból kiderül, hogy ez a hatás eltünik az életkor növekedésével és a nyelvi megértés készségszintűvé válásával.

Chiappe, Hasher és Siegel (2000) szerint megállapítható az, hogy az életkor növekedésével a komplex munkamemória teszteken hamarabb és nagyobb mértékü teljesítmény csökkenés jelentkezik, mint a verbális munkamemória esetében. Ennek hátterében az állhat, hogy a komplex munkamemóriáért felelős agyi területek szenzitívebbek 
az öregedésre, tehát hamarabb megmutatkozik a deficit a teljesítményben, míg a verbális és téri munkamemória esetén a romlás kezdete későbbre tehető.

Azon specifikus funkciók tekintetében, amelyek megmagyarázhatják a megnövekedett munkamemória kapacitást még mindig nem látunk tisztán, habár az elméletek kiemelik a feldolgozási sebesség és hatékonyság növekedését (Fry és Hale, 2000), az irreleváns információk hatékonyabb szürését és a kontrollált figyelem szerepét (Cowan, 2010). Az egyes rövidtávú -és munkamemória komponensek életkori változásait a 8. táblázatban ismertetjük.

8. táblázat. Az egyes verbális rövid távú -és munkamemória komponensek életkori változásai

\begin{tabular}{|c|c|c|c|}
\hline Életkori övezet & Vizsgált komponens & Teljesítményváltozás & Hivatkozás \\
\hline 6-12 év & Rövid távú memória & Teljesítmény növekedése & $\begin{array}{l}\text { Gathercole és Adams } \\
\text { (1994) }\end{array}$ \\
\hline 8-22 év & Rövid távú memória & Teljesítmény növekedése & $\begin{array}{c}\text { Jenkins, Myerson, Hale } \\
\text { és Fry (1999) }\end{array}$ \\
\hline 22-75 év & Rövid távú memória & $\begin{array}{c}\text { Lassú } \\
\text { teljesítménycsökkenés }\end{array}$ & $\begin{array}{c}\text { Jenkins, Myerson, Hale } \\
\text { és Fry (1999) }\end{array}$ \\
\hline 5-14 év & Komplex munkamemória & Teljesítmény növekedése & $\begin{array}{l}\text { Barrouillet, Gavens, } \\
\text { Vergauwe, Gaillard, és } \\
\text { Camos (2009) }\end{array}$ \\
\hline 5-11 év & $\begin{array}{l}\text { Téri-vizuális } \\
\text { munkamemória }\end{array}$ & Teljesítmény növekedése & $\begin{array}{c}\text { Chiappe, Hasher és } \\
\text { Siegel (2000) }\end{array}$ \\
\hline 8-22 év & $\begin{array}{l}\text { Téri-vizuális } \\
\text { munkamemória }\end{array}$ & Teljesítmény növekedése & $\begin{array}{l}\text { Jenkins, Myerson, Hale } \\
\text { és Fry (1999) }\end{array}$ \\
\hline 12-49 év & $\begin{array}{l}\text { Téri-vizuális } \\
\text { munkamemória }\end{array}$ & $\begin{array}{c}\text { Lassú } \\
\text { teljesítménynövekedés }\end{array}$ & $\begin{array}{c}\text { Chiappe, Hasher és } \\
\text { Siegel }(2000)\end{array}$ \\
\hline 22-75 év & $\begin{array}{c}\text { Téri-vizuális } \\
\text { munkamemória }\end{array}$ & $\begin{array}{c}\text { Gyors } \\
\text { teljesítménycsökkenés }\end{array}$ & $\begin{array}{c}\text { Chiappe, Hasher és } \\
\text { Siegel (2000) }\end{array}$ \\
\hline 6-19 év & Komplex munkamemória & $\begin{array}{c}\text { Gyors } \\
\text { teljesítménynövekedés }\end{array}$ & Siegel (1994) \\
\hline 17 év & Komplex munkamemória & $\begin{array}{l}\text { A teljesítmény eléri a } \\
\text { maximumát }\end{array}$ & $\begin{array}{c}\text { Barrouillet, Gavens, } \\
\text { Vergauwe, Gaillard, és } \\
\text { Camos (2009) }\end{array}$ \\
\hline 19 év & Komplex munkamemória & $\begin{array}{l}\text { A teljesítmény eléri a } \\
\text { maximumát }\end{array}$ & $\begin{array}{l}\text { Chiappe, Hasher és } \\
\text { Siegel (2000) }\end{array}$ \\
\hline 20-40 év & Komplex munkamemória & Teljesítmény csökkenése & $\begin{array}{l}\text { Chiappe, Hasher és } \\
\text { Siegel (2000) }\end{array}$ \\
\hline 40-49 év & Komplex munkamemória & Stagnálás & $\begin{array}{l}\text { Chiappe, Hasher és } \\
\text { Siegel (2000) }\end{array}$ \\
\hline 20-49 év & Komplex munkamemória & $\begin{array}{c}\text { Gyors } \\
\text { teljesítménycsökkenés }\end{array}$ & Siegel (1994) \\
\hline
\end{tabular}




\subsection{A munkamemória és az öregedés kapcsolata}

Számos bizonyítékot találunk arra, hogy a munkamemória kapacitás az életkor elörehaladtával csökken. Az egészséges öregedési folyamatokat lassabb információfeldolgozási sebesség és csökkent memória és figyelmi képességek jellemzik (Woodruff, 1997). Fiatalabb felnőttekkel összehasonlítva az idősebb személyek csökkent kapacitást mutatnak az információ megtartásában és a megtartott információ manipulálásában (De Beni, Palladino, Pazzaglia és Cornoldi, 1998; McGinnis és Zelinski, 2003; Waters és Caplan, 2003). Az életkor és a munkamemória közti korrelációk meglehetősen konzisztensek, a közepestől az erősig terjednek (DeDe, Caplan, Kemtes és Waters, 2004). Ez a mintázat azt mutatja tehát, hogy az öregedés összefüggést mutat a csökkent munkamemória kapacitással (Bopp és Verhaeghen, 2005). Ezek az eredmények csoportösszehasonlító vizsgálatokon és az egész életutat vizsgáló kutatásokon alapulnak, ahol az fiatal felnőttkortól kezdődően az életkor elörehaladtával csökkent munkamemória terjedelmet találtak (Chiappe, Hasher és Siegel, 2000; Jenkins, Myerson, Hale és Fry, 1999; Siegel, 1994).

A munkamemóra téri-vizuális és verbális komponensének öregedéssel összefüggő vizsgálataiban ellentmondásokat találhatunk. Myerson, Hale, Rhee és Jenkins (1999) szerint a munkamemórián belül a téri információ nagyobb mértékben érzékeny az öregedési folyamatokra. Nagyobb életkorral összefüggő csökkenés figyelhető meg a téri-vizuális, mint a verbális munkamemória feladatok esetében (Myerson és mtsai, 1999), és hosszabb reakcióidőket láthatunk a téri-vizuális reakcióidő feladatokban, mint a verbális tesztekben (Hale, Myerson, Rhee, Weiss és Abrams, 1996). Ezzel szemben más tanulmányokban nagyobb életkorfüggő csökkenést találtak a verbális komponens esetében (Fastenau, Denburg és Abeles, 1996; Vecchi, Richardson és Cavallini, 2005). További vizsgálatok szerint (De Ribaupierre és Ludwig, 2003; Kemps és Newson, 2006) mind a téri-vizuális, mind pedig a verbális munkamemória feladatok esetében az idősebb vizsgálati személyek gyengébb teljesítményt mutatnak, mint a fiatalabbak az összes komplex terjedelmi feladatban, ahol figyelmi vagy kontroll folyamatok szükségesek.

A munkamemória tesztekkel korábbi életkorban, akár már fiatal felnőtt kortól kezdve ki lehet mutatni az öregedéssel járó kapacitásbeli változásokat, míg a fonológiai rövid távú memória kapacitásban csak később, 40 éves életkort követően történik nagyobb teljesítménycsökkenés (Chiappe, Hasher és Siegel, 2000; Bopp és Verhaegen, 2005). Shaw, Helmes és Mitchell (2006) 18 és 57 év közötti személyeknél vizsgálták a verbális és térivizuális rövid távú memóriát, illetve a munkamemóriát. Az életkor leginkább a 
munkamemória terjedelmével korrelált, fordítottan, míg például a téri-vizuális rövid távú memória terjedelemmel nem volt szignifikáns az együttjárás. Mindezek alapján a munkamemória-kapacitás változásai mutatják legjobban az életkori hatásokat, ezek később érik el a felnőtt szintet, viszont hamarabb következik be a teljesítménycsökkenés.

\subsection{A végrehajtó funkciók fejlődése}

Denckla (1996b) szerint a gyerekek és a felnőttek között lévő különbségek jó részének hátterében a végrehajtó funkciók fejlődése áll. A végrehajtó rendszer felelős a gyerekek különböző fejlődési állomásaiban tapasztalható különbségekért is. Például a csecsemők stimulushoz kötöttek és az őket körülvevő környezet eseményeire érzékenyek. Néhány évvel idősebb gyerekek már képesek a múlt történésein gondolkodni és terveket készíteni a jövőre. Reprezentálni is tudják egy probléma többszörös aspektusait és ki tudják választani a legjobb cselekvési alternatívákat (Zelazo, Craik és Booth, 2004).

A végrehajtó funkciók szekvenciális fejlödésen mennek keresztül a gyermekkorban és ezek a fejlődési szakaszok egybevágnak a frontális lebeny érésének állomásaival. Ilyen növekedési, fejlődési időszakot figyelhetünk meg a születés és két éves kor között, hét és kilenc éves kor között, és végül a késő kamaszkorban, 16-19 éves kor között is (Anderson és mtsai, 2001). Hughes és Graham (2002) számos nehézséget azonosított a gyerekek végrehajtó funkcióinak vizsgálatában, de a legfontosabb korlátnak a gyerekek limitált nyelvi képességei tüntek. Amikor egy feladat instrukciója komplex, a verbális megértés különböző nem végrehajtó készségeket is lefoglal. A felnőtteknél használt végrehajtó funkció tesztek jó része a nyelvi készségeken alapul (pl. Stroop teszt), ezért szükség van egyszerübb, kevesebb verbális elemet tartalmazó tesztekre is a végrehajtó funkciók vizsgálatában. Az egyes végrehajtó funkciók fejlődése egyénenként eltérhet és ezen belül a különböző végrehajtó funkció komponensek is eltérő fejlődési ívet írnak le, például néhány végrehajtó komponens fejlettsége nem éri el a felnőtt szintet a késői kamaszkorig (Brocki és Bohlin, 2004). A végrehajtó funckciók komponenseinek életkori változásait a 9. táblázatban foglaltuk össze. 
9.táblázat. Az egyes végrehajtó funkció komponensek életkori változásai

\begin{tabular}{c|c|c|c}
\hline \hline Életkori övezet & Vizsgált komponensek & Teljesítményváltozás & Hivatkozás \\
\hline \hline 10 év & Gátlás, kontroll & Kialakul & Passler, 1985 \\
\hline 11 év & Gátlás, kontroll & Kialakul & Anderson, 2002 \\
\hline 15 év & Monitorozás & Teljesítmény növekedése & Anderson és mtsai, 2001 \\
\hline 12 év & Tervezés & $\begin{array}{c}\text { A teljesítmény eléri a } \\
\text { felnött szintet }\end{array}$ & $\begin{array}{c}\text { Welsh és munkatársai } \\
(1991)\end{array}$ \\
\hline 9-13 év & Tervezés & $\begin{array}{c}\text { A teljesítmény eléri a } \\
\text { felnött szintet }\end{array}$ & Anderson (2002) \\
\hline 3-5 év & Váltás & Megjelenik & Anderson, 2002 \\
\hline $7-9$ évtöl a kamaszkorig & Váltás & Teljesítmény növekedése & Anderson, 2002 \\
\hline 70 év & Flexibilitás & Teljesítmény csökkenése & Boone, 1999 \\
\hline 60 év & Gátlás, váltás & Teljesítmény csökkenése & $\begin{array}{c}\text { Zook, Welsh és Ewing } \\
(2006)\end{array}$ \\
\hline 60 év & Gátlás, váltás & Teljesítmény csökkenése & $\begin{array}{c}\text { Axelrod, Jiron és Henry } \\
(1993)\end{array}$ \\
\hline \hline
\end{tabular}

A figyelmi kontroll a végrehajtó funkciók egyik aspektusa, ami magában foglalja a szelektív figyelmet, a hosszantartó figyelmet és a válaszgátlást (Anderson, 2002). Ennek mérésére csecsemőknél sok esetben a késleltetett válasz feladatot használják (Diamond, Kirkham és Amso, 2002). Diamond és Goldman-Rakic (1989) szerint a 9 hónapos babák nem tudják teljesíteni ezt a feladatot, de 12 hónapos korukban már sikerrel oldják meg. Más tanulmányokban a legnagyobb fejlődést a gátlásban 6 és 8 éves kor között találtak, valamint megállapították azt is, hogy 10 éves korban a gyerekek már képesek legátolni az irreleváns stimulusokat és elkerülni a perszeveratív hibákat (Passler, 1985). Welsh, Pennington és Groisser (1991) szerint a gyerekek elérik a felnőttek szintjét az impulzuskontroll tekintetében 10 éves korban, 11 évesen már képesek szabályozni és ellenőrizni is cselekvéseiket (Anderson, 2002). A kamaszkort tanulmányozó fejlődéses vizsgálatok növekvő figyelmi kapacitást és feldolgozási sebességet detektáltak 15 éves kor körül (Anderson és mtsai, 2001).

A tervezés egy olyan sokoldalú aktivitás, ami ahhoz szükséges, hogy azonosítsuk és megszervezzük egy cél eléréséhez szükséges összetevőket és lépéseket (Lezak, 2004). Romine és Reynolds (2005) vizsgálatukban a tervezés szempontjából kritikus fejlődési időszaknak tekintették az 5-8 életéveket és megfigyelték, hogy ez a fejlődés egészen a korai felnőttévekig folytatódott. Ezzel szemben Welsh és munkatársai (1991) a tervezési viselkedést tekintette a fejlődés egyik utolsó állomásának, amelynek az érése 12 éves kor körül következik be. Ehhez hasonlóan Anderson (2002) szerint a tervezési készségek a felnőtt szintet 913 éves kor körül érik el. 
Anderson (2002) kutatásában megállapította, hogy a készletváltás vagy a kognitív flexibilitás képességet jelent arra, hogy gyorsan tudjunk váltani a különböző válaszkészletek között. Ez 3-5 éves kor körül jelenik meg, amikor a gyerekek egyszerü váltási feladatokat képesek teljesíteni. Ahogy a feladat szabályainak komplexitása nő, a gyerekek egyre többet hibáztak a flexibilitás tekintetében (Espy, 1997). Anderson és munkatársai (2001) szerint még hét éves korban is problémát okoz, ha többszörös dimenziókat kell észben tartani és váltani ezek között. Ez a képesség 7-9 éves kor között jelentős mértékben nő és fejlődése egészen kamaszkorig tart (Anderson, 2002). A verbális kezdeményezés és produktivitás szintén a végrehajtó funkciók közé sorolható, melyeket gyakran vizsgálnak a verbálisfluencia-tesztek segítségével (Lezak, 2004).

\subsection{A végrehajtó funkciók az idősödő populációban}

A végrehajtó funkciókat érintő életkorfüggő deficitek összefüggésben állnak a funkcionális életminőség csökkenésével 6099 éves időseknél (Grisby, Kaye, Baxter, Shetterly és Hamman, 1998). Cahn-Weiner, Malloy, Boyle, Marran és Salloway (2000) szerint a végrehajtó funkciót mérő tesztek sokkal jobban előrejelzik a mindennapi aktivitásokban megjelenő csökkenést időseknél, mint azok a tesztek, amelyek több különböző kognitív terület mérését foglalják magukban. Ezt az elképzelést támasztja alá az is, hogy abban az esetben, ha a végrehajtó funkciók épek, az egyének még akkor is képesen önállóak és produktívak maradni, ha egyéb kognitív mínuszaik vannak (Lezak, 2004). A végrehajtó funkciót mérő tesztek alkalmasak arra is, hogy bejósolják a jövőbeli változását a korai demenciának (Nathan, Wilkinson, Stammers és Low, 2001), az Alzheimer-kórnak (Rapp és Reischies, 2005) és az idősebb vezetők megnövekedett baleseti kockázatának (Daigneault, Joly és Frigon, 2002). A prefrontális kéreg érése kapcsolatban áll a végrehajtó funkciók fejlődésével, míg a csökkenés az agyban bekövetkező változásokkal hozható összefüggésbe a normál öregedést tekintve. Az emberi agy fokozatos térfogatcsökkenésen megy keresztül, ami már a korai felnőttkorban elkezdődik. Az agy néhány területe, például a hippocampus és a prefrontális területek az idősödés hatásait tekintve sebezhetőbbek (Salat, Tuch, Hevelone, Fischl, Corkin, Rosas és Dale, 2005). A különbség szignifikáns a redukció arányát tekintve a frontális kéreg és más területek, mint a temporális, parietális és occipitális kéreg között, közel 10-17\%-ban van jelen a frontális kéreg kapcsán (Haug és Eggers, 1991). Egyes kutatások szerint a teljesítménycsökkenés eléri a gyerekkori teljesítmény szintjét 64 éves korban (De Luca, Wood, Anderson, Buchanan, Proffitt, Mahony és Pantelis, 2003). Ez a csökkenés nem mutat homogén mintázatot, egyes 
részfunkciók esetében, úgymint a kognitív flexibilitás csak 70 éves kor körül mutat csökkenést (Boone, 1999), míg más tanulmányok szerint ez korábbi életkorban következik be (Robbins, James, Owen, Sahakian, Lawrence, McInnes és Rabbit, 1998; Daigneault és Braun, 1993). Az életkor növekedése korrelál a végrehajtó funkció teljesítménycsökkenésével, azonban gyakran nehézséget okoz ennek az elkülönítése az általános kognitív készségek tekintetében megfigyelhető csökkenésektől (Crawford és Channon, 2002). Egyes kutatások eredményei szerint az alacsony iskolázottság felerősíti az öregedés folyamatait, míg a magas iskolai végzettség lassabb kognitív hanyatlást eredményez az időseknél (Van Der Elst, Van Boxtel, Van Braukelen és Jolles, 2006; Grisby, Kaye, Shetterly, Baxter, Morgenstern és Hamman, 2002). Más kutatók szerint az iskolai végzettség gyenge prediktora a végrehajtó funkciók teljesítményének (Manly, Schupf, Tang és Stern, 2005; Hashimoto, Meguro, Lee, Kasai, Ishii és Yamaguchi, 2006). Az iskolai végzettség protektív hatását a kognitív funkciókra más kutatók is megfigyelték (Springer, Giladi, Peretz, Yogev, Simon és Hausdorff, 2005).

A figyelmi kontroll kapcsán Hasher és Zacks (1988) nevéhez köthető a kognitívöregedés-gátlási deficit elmélete, ami szerint az idősebb egyéneknek nehézségeik vannak az irreleváns információk és a versengő válaszok legátlásában (Hasher és Zacks, 1988; Lustig, Hasher és Tonev, 2001). Például a Stroop-teszt használatakor a kutatók életkorhoz kötött változásokat találtak a figyelmi kontroll és a gátlás terén (Rekkas, 2006; Van Der Elst és mtsai, 2006), amikor fiatalabb (átlagéletkor=20 év) és idősebb (átlagéletkor=75 év) személyeket hasonlítottak össze (Rush, Barch és Braver, 2006).

Daigneault, Braunk és Whitaker (1992) 65 évesnél fiatalabb felnőttek esetében csökkent képességeket találtak a viselkedésszervezés területén a tervezésben és az absztrakt fogalmak megértése terén. Zook, Welsh és Ewing (2006) 60 éves kortól kezdve nehézségeket talált a London-torony teszt teljesítésekor. Rönnlund, Lövdén és Nilsson (2001) vizsgálatukban 35-85 éves személyeket teszteltek. Az idősebb, személyek esetében hibákat tapasztaltak a megfelelő megoldás megtalálásában, valamint a szabályszegések számának növekedését találták a Hanoi-torony feladatban.

Különböző neuropszichológiai tesztekkel vizsgálva az életkor befolyásolja a készletváltást, azonban ellentmondás van abban a tekintetben, hogy melyik életkorban kezdődik ez a csökkenés. Haaland, Vranes, Goodwin és Garry (1987) az idősebb résztvevők esetében kevesebb perszeverációs hibát és több kategória elérését figyelték meg a WCST teljesítésekor az idősebb csoport esetében, a csökkenés csak 80 éves kor után vált kifejezetté. Mejia, Pineda, Alvarez és Ardila (1998) nem találtak szignifikáns különbséget a fiatalabb (55- 
70 éves) és az idősebb (71-85 éves) korcsoport teljesítménye között a WCST-n. Axelrod, Jiron és Henry (1993) szignifikáns növekedést talált a perszeveratív hibák tekintetében 60 éves életkorban. Crawford, Bryan, Luszcz, Obonsawin és Stewart (2000) hasonló eredményeket talált a Wisconsin Kártyaszortírozási Teszt módosított változatának végrehajtása során 60-75 éves életkorban, összehasonlítva a fiatalabb, 18-60 éves csoporttal.

$\mathrm{Az}$ életkor verbálisfluencia-teljesítményre gyakorolt hatását vizsgálva is ellentmondásosak az eredmények. Néhány vizsgálatban nem találtak életkori hatást a verbálisfluencia-teljesítményt tekintve (Crawford és mtsai, 2000; Keys és White, 2000), amit annak tulajdonítottak, hogy ez a feladat olyan nagy verbális tudáson alapul, amely jobban ellenáll az öregedési folyamatoknak. Fisk és Sharp (2004) nem talált életkorfüggő csökkenést a random betügenerálási fluencia feladaton. Ezzel szemben Brickman, Paul, Cohen, Williams, Macgreggor, Jefferson, Tate, Gunstad és Gordon (2005) az életkor növekedésével lineáris teljesítménycsökkenést találtak a verbálisfluencia-teszt esetében. A csökkenés aránya nagyobb volt a kategória, mint a betüfluencia feladat esetében (Crossley, D'Arcy és Rawson, 1997). Azonban néhány kutatásban azt találták, hogy az idősebb vizsgálati személyek kevesebb szót produkáltak, valamint a hibák és perszeverációk száma megnőtt, amelyek függetlenek a szemantikus kategória használatától (Rodriguez-Aranda és Martinussen, 2006).

Rodriguez-Aranda és Martinussen, (2006) egy metaanalízist végzett annak érdekében, hogy összehasonlítsák a szakirodalmi eredményeket az idősek teljesítményét illetően a betüfluencia teszten. Az eredmények azt mutatták, hogy a 20 -as és a 40-es évek között fejlődés van, majd egy lassú csökkenés következik a késő 60-as évekig. Innentől kezdve egy gyors teljesítménycsökkenés figyelhető meg a késő 80-as évekig, azonban számos tanulmányban nem végeztek ebben az életkorban demenciaszürést, ami viszont befolyásolhatta az eredményeket. Az iskolai végzettség verbálisfluencia-teljesítményre gyakorolt hatását számos kutatásban vizsgálták (lásd például Acevedo, Loewenstein, Barker, Harwood, Luis, Bravo, Hurwitz, Aguero, Greenfield és Duara, 2000; Ostrosky-Solis, Gutierez, Flores és Ardila, 2007). Megállapították, hogy az iskolai előmenetelnek tiszta hatása van a teljesítményre, minél magasabb az iskolai végzettség, annál jobb a teljesítmény (Plumet, Gil és Gaonac'h, 2005). 


\section{A MUNKAMEMÓRIA ÉS A VÉGREHAJTÓ FUNKCIÓK SZEREPE AZ ISKOLAI TELJESÍTMÉNYBEN}

A többkomponensü munkamemória rendszernek jelentős szerepe van a különböző típusú információk ideiglenes tárolásában és feldolgozásban, így a tanulási folyamatokban is (Baddeley és Hitch, 1974; Baddeley, 2000, 2003; Racsmány, 2007). A téri-vizuális munkamemória (téri-vizuális vázlattömb), a verbális munkamemória (fonológiai hurok), epizodikus puffer, a központi végrehajtó és általánosan a munkamemória (komplex munkamemória) működéséért specifikus agyi hálózatok felelősek, melyeket különböző mérőeljárásokkal tudunk vizsgálni (Baddeley, 2002, 2003; Gathercole, 1999; Engle és mtsai, 1999; Daneman és Merikle, 1996, Cowan és mtsai, 2003; Service ésTujulin, 2002; Racsmány és mtsai, 2005; Janacsek és mtsai, 2009).

A végrehajtó funkciók megfelelő müködése hozzájárul a figyelmi, gondolkodási és probléma-megoldási folyamatok sikeres lefutásához, amelyeknek kétségtelenül fontos szerepe van a gyerekek iskolai eredményeiben (Bull és Scerif, 2001; Bull és mtsai, 2008; McLean és Hitch, 1999; Ozonoff és Jensen, 1999; Russell és mtsai, 1996; Swanson és mtsai, 1996; Thompson és Gathercole, 2006; Thorell, Lindquist, Nutley, Bohlin és Klingberg, 2009; Best, Miller és Jones, 2009).

Az elmúlt években a kutatásokban nagy érdeklődés övezte az iskolai teljesítményt befolyásoló faktorokat. Elsősorban a munkamemória müködését, illetve a végrehajtó funkciókat hozták kapcsolatba az iskolai teljesítménnyel, azonban ezek szerepe eltérhet az egyes tantárgyak esetében (Krajewski és Schneider, 2009; Dahlin, 2011; Lu, Weber, Spinath és Shi, 2011; Bull, Espy és Wiebe, 2008).

\subsection{A munkamemória és az iskolai teljesítmény kapcsolata}

A memória funkciók és a tanulmányi teljesítmény közötti kapcsolat erősségére már számos korábbi tanulmányban rámutattak (Gathercole, Lamont és Alloway, 2006; Gathercole, Brown és Pickering, 2003; Swanson és Jerman, 2007; Bull és mtsai, 2008). Mind az olvasási készségek (Gathercole, Alloway, Willis és Adams, 2006; Seigneuric, Ehrlich, Oakhill és Yuill, 2000), mind pedig a matematikai képességek terén (Alloway és Alloway, 2010; Swanson és Sachse-Lee, 2001) kapcsolatot találtak a munkamemóriával.

Alloway, Gathercole, Adams, Willis, Eaglen és Lamont (2005) négy-ötéves gyerekek memóriamüködési készségei és a tanári értékelések eredményei közötti összefüggéseket 
tanulmányozták longitudinális vizsgálatukban. Eredményeik azt jelzik, hogy a rövid idő alatti információtárolás és -feldolgozás, valamint a hangtani szerkezetek tudatos használata (pl. rímek) döntő szerepet játszhatnak a kulcsfontosságú tantárgyaknál a gyerekek szervezett oktatásának kezdetén

Gathercole és Pickering (2000b) vizsgálatában összefüggést találtak a 6-7 éves gyerekek információtárolási és -feldolgozási képessége és a matematikai, olvasási teljesítményei között. A tesztbattéria kialakításakor fontos szempontként szerepelt, hogy a Baddeley és Hitch (1974) nevéhez füződő munkamemória modell egyes komponenseit minél részletesebben tudják mérni. A vizsgálatban részt vevő 83 főt átlagos és alacsony teljesítményű csoportokba sorolták a matematika és angol nyelvi teljesítményük alapján. Az alacsonyabb teljesítményü gyerekek gyengébben teljesítettek föként a téri-vizuális vázlattömböt mérő feladatokon. Gyakorlással ezek a gyerekek elérték a magasabb teljesítményű csoport szintjét, hibázásaik száma lecsökkent. A téri-vizuális vázlattömb fejlettsége hatással van tehát a gyerekek matematika teljesítményére, különböző gyakorlatokkal és fejlesztő foglalkozásokkal az elmaradások behozhatóak (Gathercole és Pickering, 2000b).

Gathercole, Pickering, Knight és Stegmann (2004) a munkamemória és a nemzeti tanagyag (angol, matematika és természettudományok) elsajátítása közötti kapcsolatot kutatták a 7 és 14 évesek körében. Eredményeik szerint az írás-olvasás készségek elsajátítása kapcsolatban áll a munkamemóriával, viszont a magasabb szintü készségek, mint a szövegértés és a szövegelemzés a 14 éveseknél független a munkamemória kapacitásától. Azok a gyerekek, akik általános tanulási nehézségekkel küzdenek, beleértve a matematikát és az anyanyelvet, minden a munkamemória komponenseit mérő feladat esetében gyengébb teljesítményt nyújtottak (Gathercole és mtsai, 2004). Eredményeik tehát alátámasztják Gathercole és Pickering (2000b) korábbi munkáját, miszerint a munkamemória kapacitása bejósolja a matematika és az angol nyelv tantárgyban nyújtott teljesítményt. A korai munkamemória eredmények erősen szignifikáns előrejelzői a gyerekek későbbi írás-olvasás elsajátításának, de a matematika esetében ezt nem mutatták ki. A munkamemóriát mérő tesztek eredményei igazolják az egyedi különbségeket a hétéves gyerekeknél a betüzési és írási teljesítményben (Gathercole, Brown és Pickering, 2003). Krajewski és Schneider (2009) longitudinális kutatásában az olvasási képesség, a betűzés és a fonológiai tudatosság között, valamint a matematikai képesség és a téri-vizuális vázlattömb fejlettsége között magas korrelációt találtak. Ezek az eredmények rámutatnak az alapismeretek és a kognitív 
képességek összekapcsolásának hasznosságára, ugyanis ezek jósolják be a gyerekek későbbi tanulmányi sikereit.

Meyer, Salimpoor, Wu, Geary és Menon (2010) keresztmetszeti vizsgálatban második és harmadik osztályos gyerekeknél térképezték fel a munkamemória és a matematikai képességek kapcsolatát. Második osztályban a számlálási terjedelem teszten elért teljesítmény hatással volt a matematikai érvelésre, azonban a téri-vizuális vázlattömb mérésére szolgáló Corsi-kocka teszten nyújtott teljesítmény nem érintette a számokkal végzett müveletek tudatosságának fejlettségét. A harmadik osztályban azonban már korrelációt találtak a Corsikocka teszten elért eredmények és a matematikai érvelési képesség között. Hozzájuk hasonlóan Swanson (2011) eredményei szerint azok a gyerekek, akik fejlettebb munkamemóriával rendelkeznek, jobb eredményeket nyújtottak a matematikai feladatok megoldásakor.

Bull, Espy és Wiebe (2008) a munkamemória különböző komponenseit vizsgálták az iskola előkészítőben (négy évesen), majd az általános iskola első és harmadik osztályában. Az eredmények alapján a téri-vizuális munkamemória és a komplex munkamemória fejlettsége meghatározó volt a matematika teljesítményben (Mazzocco és Kover, 2007; Toll, Van der Ven, Kroesbergen és Van Luit, 2011; Lu és mtsai, 2011). A munkamemória és az iskolai teljesítmény kapcsolatát mutatja az is, hogy azok a gyerekek, akiknek nehézségeik vannak a matematikával, alacsony teljesítményt mutatnak a munkamemória mérőeljárásain (Swanson és Jerman, 2006).

A fonológiai huroknak fontos szerepe van az anyanyelv és a szókincs elsajástitásában (Gathercole és Adams, 1993, 1994; Gathercole és Baddeley, 1989; Service és Kohonen, 1995; Racsmány és mtsai, 2001; Racsmány, 2004). Gathercole, Willis, Emslie és Baddeley (1992) feltárták ennek egyik lehetséges müködési mechanizmusát: amikor új szót tanulunk, a fonológiai hurok fenntartja az új szó reprezentációját, míg létrejön az azzal kapcsolatos tartós emléknyom. Ennek nem csupán az anyanyelvünk szavainak elsajátításánál van fontos szerepe, hanem az idegen nyelvek tanulásánál is (Hummel, 2002; Sanz, 2005). Service (1992) kilenctíz éves finn anyanyelvü gyerekekkel végzett kísérletében azt találta, hogy az álszó ismétlési feladatban nyújtott teljesítmény jó bejóslója az idegen nyelv elsajátításának.

A fonológiai hurok a szintaktika fejlödésére is hatással van (Macrae, Tyler és Lewis, 2013). Adams és Gathercole (2000) megállapították, hogy gyerekeknél szoros kapcsolat van a verbális munkamemória teszteken elért teljesítmény és a szintaktikai feladatokban nyújtott eredmény között. Akik magasabb pontszámokat érnek el ezeken a teszteken, azok szintaktikailag komplexebb kifejezéseket képesek létrehozni. Speidel (1993) ezt azzal 
magyarázta, hogy tovább képesek megőrizni a felnőttek által használt kifejezéseket, kijelentéseket, és így azok későbbi életszakaszokban is aktiválódnak saját közléseik megformálásánál. A verbális munkamemória terjedelemnek tehát nagy szerepe van a szókincs elsajátításában és más hosszú távú fonológiai reprezentációk létrehozásában (Racsmány és mtsai, 2005).

A fonológiai huroknak az olvasástanulás fejlődésében is szerepe van (Gathercole és Baddeley, 1993; Dufva, Niemi és Voeten, 2001). Olyan gyerekeknél is megjelennek olvasástanulási problémák, akik jó szociális környezetben élnek és átlagos az intelligenciájuk. Egyes kutatók valószínüsítik, hogy ezek hátterében fonológiai hurok probléma áll (Swanson, 1999). Nem egyértelmü azonban, hogy az olvasásfejlődési deficitért az emlékezet, a fonológiai manipuláció vagy egy harmadik tényező tehető felelőssé. A fonológiai hurok tehát befolyásolja az olvasástanulást és megállapítható az is, hogy az olvasástanulás is javítja az emlékezeti terjedelmet és a fonológiai teljesítményt, amik pedig tovább növelik az olvasási teljesítmény színvonalát.

Perfetti és Goldman (1976) eredményei szerint a fonológiai hurok csak akkor kerül előtérbe, amikor elkezdődik az olvasástanulási folyamat. Jól és rosszul olvasó gyerekeket vizsgáltak és megállapították, hogy nem lehet közvetlenül bejósolni az olvasási színvonalat az emlékezeti terjedelem alapján. Feltételezésik szerint az egyéni különbségek hátterében a központi végrehajtó komponens található.

Glanzer, Dorfman és Kaplan (1981) szerint abban a vizsgálati feltételben, amikor a vizsgálati személyeknek a mondatok olvasásával párhuzamosan hármasával kellett visszafelé számolniuk, jelentősen leromlott a szövegmegértési teljesítményük. Baddeley (2001) azzal magyarázta ezt a teljesítménycsökkenést, hogy a visszafele számolás leterhelte a központi végrehajtót vagy a fonológiai hurkot zavarta meg. Az álszó ismétlési teszt eredményei jó bejóslói voltak az idegen nyelv és az olvasástanulás elsajátítás sikerességének, mivel ezen szavak memorizálása nagyobb mértékü fonológiai tudatosságot igényel. Szoros kapcsolatot mutattak ki a fonológiai emlékezet és a hanganalízis képessége között is, melyek megfelelő fokú érettsége nélkülözhetetlen feltétele a hatékony olvasástanulásnak.

Számos vizsgálatban tanulmányozták már a matematikai, aritmetikai teljesítmény és az egyes munkamemória komponensek kapcsolatát (McLean és Hitch, 1999; Fürst és Hitch, 2000; Passolunghi és Siegel, 2001; Lee és Kang, 2002; De Stefano és Le Favre, 2004) és több tanulmány eredményei szerint a munkamemóriának döntő szerepe van a matematikai és az aritmetikai képességekben, valamint a fluens gondolkodási folyamatokban, továbbá a 
mentális számolás folyamatának elősegítésében felnőttek és gyerekek esetében is (Adams és Hitch, 1997; Logie, Gilhooly és Wynn, 1994).

Durand, Hulme, Larkin és Snowling (2005) 7 év 5 hónapos és 10 év 4 hónapos gyerekeken végzett vizsgálatukban megállapították, hogy a szám-összehasonlító (digit comparison) feladaton nyújtott teljesítmény és a verbális képességek előrejelzik az aritmetikai készségeket, míg a fonéma áthúzás (phoneme deletion) feladata és a verbális képességek jól bejósolták az olvasási készségeket. A fonéma áthúzás képessége döntő fontosságúnak tünik az olvasástanulásban.

Azon felül, hogy nyilvánvaló a munkamemória szerepe a számtani folyamatokban és a nyelvi megértésben, a felnőtt életúton keresztülívelő vizsgálatok erős kapcsolatot találtak a munkamemória kapacitása és számos intellektuális képesség között, mint például az utasítások követése, a jegyzetelés, az írás, az érvelés és a komplex tanulás, melyek erőteljesen befolyásolják az iskolai előmenetelt (Gatehercole, 1999; Engle, Kane és Tuholski, 1999).

A tanulási nehézségek vizsgálata kapcsán Gathercole és Pickering (2000b) felhívták a figyelmet arra, hogy az egyes munkamemória teszteket hatékonyan lehet alkalmazni a tanulási zavarokkal küszködő gyerekek diagnosztizálására is. A 6-7 évesek munkamemória teszteken nyújtott teljesítménye jó prediktora lehet a későbbi gyenge iskolai eredménynek, míg a fonológiai rövid távú memória kapacitása önmagában nem bejósló értékü (Pickering és Gathercole, 2004). Több év is lehet azoknak a gyerekeknek az elmaradása, akiknek nyelvi zavarokkal kell szembenézniük a mindennapok során. Ez a fonológiai hurok károsodását mutatja, ezzel adva magyarázatot a gyengébb helyesírási, olvasási képességekre. McNamara és Wong (2003) vizsgálatából kiderül, hogy azok az egyetemisták, akik tanulási nehézségekkel küzdenek, rosszabbul teljesítenek a munkamemória-teszteken, mint a kontrollszemélyek. A szövegértési, következtetési képességek és a nagyobb munkamemóriakapacitás között szoros kapcsolat található, amely a központi végrehajtó kapacitásának mértékére utalhat (Oakhill, Yuill és Parkin, 1986).

Baddeley és munkatársai (1987, 1998) vizsgálatokat végeztek olyan betegeken, akiknek a rövid távú memóriája specifikus deficitet mutatott. Bizonyítékokat találtak arra, hogy a munkamemóriának szerepe van a nyelvi megértésben is. Szilárd kapcsolat található tehát a komplex munkamemória és az ezt mérő teszteken nyújtott teljesítmény valamint a beszélt, illetve az írott nyelv megértése között (Daneman és Merikle, 1996; Leather és Henry, 1994; Engle, Kane és Tuholski, 1999). Akik jobb eredményeket érnek el a munkamemória teszteken, jobban tudnak felépíteni és elemezni egy mondatszerkezetet, és a mondatfeldolgozás során több lehetséges magyarázatot is tudnak kezelni. Egy magyar nyelvü 
vizsgálatban a munkamemória és a morfológiai komplexitás között találtak összefüggést: minél komplexebb egy szó morfológiai struktúrája, annál inkább szükséges a munkamemória terhelése (Németh és mtsai, 2006).

Wassenberg, Hurks, Hendriksen, Feron, Meijs, Vles és Jolles (2008) 361 óvodás és általános iskolás gyerekkel végzett vizsgálatukban a komplex nyelvi megértés tekintetében fejlődést állapítottak meg a sebességben és a pontosságban az életkor előrehaladásával. Az eredménynek azt mutatták, hogy a nyelvi megértés pontossága hatodik osztályig fejlődik, míg sebességének fejlődése a hetedik osztályig tart. Megállapították tehát, hogy a komplex nyelvi megértés a korai serdülőkor előtt még nem teljesen kifejlett.

\subsection{A végrehajtó funkciók és az iskolai teljesítmény kapcsolata}

A végrehajtó funkcióknak is közvetlen hatása van az iskolai teljesítményre. A gyenge munkamemória (flexibilitás/monitorozás) okozhatja az utasítások elfelejtését, gátolhatja a fejszámolások részeredményeinek fejben tartását is. A gátlás és a váltás fontos az irreleváns információk legátlásában és az egyik feladatról a másikra váltásban. A végrehajtó funkciók továbbá hatással vannak a nyelvi készségekre és az érvelési képességekre is (Handley, Capon, Beveridge, Dennis és Evans, 2004). Az alacsony munkamemória kapacitás megfigyelhető a specifikus nyelvi károsodás (SLI - Specific Language Impairment) esetében is (Im-Bolter, Johnson és Pascual-Leone, 2006), amely számos iskolai helyzetben gátolhatja a teljesítményt. A munkamemória és a gátlás szerepét emelték ki az érvelési képesség tekintetében is. Mindkét esetben szükség van az információk megtartására és az azokon való manipulációra is. Ezeken túlmenően a végrehajtó funkciók megfelelö müködése elengedhetetlen a megfelelö iskolai magatartáshoz is (Best, Miller és Jones, 2009).

A matematika tantárgy és a végrehajtó funkciók kapcsolát tanulmányozta Mazzocco és Kover (2007), akik 6 és 11 éves kor között vizsgálták a gyerekeket. A végrehajtó funkció teszteken elért pontszámok hatással voltak a mind az iskola kezdetén feltérképezett matematika teljesítményre, mind pedig a későbbi eredményekre. Véleményük szerint eredményeik alátámasztják a végrehajtó funkciók stabilitását az iskolai évek alatt és kiemelik azok szerepét a korai és a későbbi matematikai teljesítményben is.

Bull, Johnson és Roy (1999) szerint azok a gyerekek, akik gyengébb matematikai és aritmetikai készségekkel rendelkeznek, alacsonyabb teljesítményt nyújtanak a végrehajtó funkciót mérő teszteken. Főként a gátlás és a váltás érintettségét hangsúlyozták. A váltásnak fontos szerepe van az aritmetikai feladatok egyes alrészeinek megoldásában és a megfelelő 
stratégia megtalálásában. Azok a gyerekek, akiknek nehézségeik vannak az aritmetikai feladatok megoldása során, alacsonyabb teljesítményt produkálnak a komplex váltási képességeket mérö teszteken (Bull és mtsai, 1999; Bull és Scerif, 2001; McLean és Hitch, 1999; Van Der Sluis, De Jong és Van der Leij, 2004). Rourke (1993) valamint Blaire és Razza (2007) a végrehajtó funkciók közül a gátlás szerepét emelték ki a matematikai teljesítményben, ahogyan Thompson és Gathercole (2006) is 11-12 éves gyerekeknél.

A frissítés/monitorozás fontosságát a verbális munkamemória és az iskolai teljesítmény kapcsán már részleteztük a 2.1 alfejezetben. Összefoglalva a munkamemória segíti a betűk, szavak, mondatok kódolását (De Jong, 1998), valamint fontos szerepe van a számok és a részeredmények megjegyzésében az aritmetikai feladatok megoldása során (Geary, 1993; McLean és Hitch, 1999). A kontroll személyekkel összehasonlítva gyakran gyengébb munkamemória kapacitással rendelkeznek azok a gyerekek, akiknek olvasási nehézségeik (De Jong, 1998; Bigler, Burlingame és Lawson, 2003; Swanson és Ashbaker, 2000) vagy aritmetikai problémáik (McLean és Hitch, 1999; Swanson, 1994) vannak.

A végrehajtó funkciók szerepe kétségtelen az olvasástanulásban és az olvasásmegértésben is. Protopas, Archonti és Skaloumbakas (2007) hetedik osztályos görög diszlexiás gyerekek vizsgálatakor gátlási nehézségeket találtak és megállapították, hogy a lassabb olvasási sebesség nagyobb interferenciával járt együtt.

Az olvasásmegértés olyan magasabb szintü végrehajtó funkciókon alapszik, mint az érvelés és a kritikai elemzés (Vellutino, Scanlon és Lyon, 2000). Azok a gyerekek, akiknek nehézségeik vannak a tervezésben, szervezésben, rosszabbul teljesítenek az olvasásmegértési feladatokban, mint a tipikusan fejlődő társaik. Erre egy hétköznapi példa, ha egy komplex geometriai alakzatot kell lemásolniuk, kevésbé szervezett és strukturált lesz a rajzuk és hosszabb időt vesz igénybe egy vizuális problémamegoldó feladat teljesítése vagy másolási folyamata (Brosnan, Demetre, Hamil, Robson, Shepherd és Cody, 2002).

Van der Sluis, De Jong és Van der Leij (2007) szerint a végrehajtó funkciók közül a frissítés / monitorozás szoros kapcsolatot mutatott az olvasással, aritmetikával és a nem verbális érveléssel, továbbá a váltás összefüggött az olvasással és a nem verbális érveléssel.

Az egyes tantárgyak szerepét vizsgálta Thompson és Gathercole (2006) is. Eredményeik azt mutatták, hogy a frissítési/monitorozási komponens leginkább az anyanyelvvel és a matematikával függött össze, míg a gátlás kapcsolatban állt az angol, matematika és a természettudományos tantárgyakkal.

Hooper, Swartz, Wakely és De Kruif (2002) vizsgálatukban negyedik és ötödik osztályos tanulókat hasonlítottak össze az alapján, hogy mennyire voltak sikeresek az írási 
feladatokban. Eredményeik szerint a gyengébb írási teljesítményt nyújtó diákok alacsonyabb teljesítményt értek el az iníciációs és a készletváltási feladatokban. Az irás teljesítményét meghatározó végrehajtó funkciókat az iníciációban, készletváltásban, fenntartásban és gátlásban határozták meg. 


\section{A VIZSGÁlATSOROZAT FELÉPÍTÉSE}

Az elmúlt évtizedekben számos olyan kutatás jelent meg a nemzetközi szakirodalmakban, amely a munkamemória és a végrehajtó funkciók egyes alkomponenseit vizsgálta. Magyar nyelven azonban kevés olyan kutatást találhatunk, amely a teljes (vagy majdnem teljes) életkori spektrumot felölelő mintát használva, részletesen térképezné fel a munkamemória és végrehajtó funkciók életkori változásait. A fejlődési aspektusok vizsgálata fontos, mivel nemcsak abban segít, hogy megérthessük a kognitív funkciók kialakulását és müködését, hanem segíthet megérteni az atipikus fejlődést és például a tanulási zavarokat is. Továbbá a széles életkori spektrumú vizsgálat segítségével több adatot kapunk magáról a mérőeljárásról segítve annak jobb megértését, fejlesztését és pontosabb használatát. A disszertációban ezeket a hiányokat pótoltuk az általunk bemutatott vizsgálatokkal.

A munkamemória kapacitásnak és végrehajtó funkcióknak alapvető szerepe van a tanulásban, így szerepük lényeges az iskolai teljesítményben (St. Clair Thompson és Gathercole, 2006; Engle, Carullo és Collins, 1991; Gathercole és Alloway, 2008). Ebből következően a gyengébb munkamemória és végrehajtó funkció müködés az egyik fö probléma lehet a tanulási nehézségekkel küzdő gyerekek esetében is (Alloway, Gathercole, Kirkwood és Elliott, 2009; McLean és Hitch, 1999).

A disszertáció vizsgálataiban használt tesztek magyar nyelvü változatainak elkészítése és széles életkori spektrumon történő vizsgálata fontos annak meghatározásában, hogy pontosabban meg tudjuk határozni az iskolai teljesítményt befolyásoló kognitív funkciókat. A disszertáció vizsgálatsorozatának logikai felépítését a 3. ábra szemlélteti.

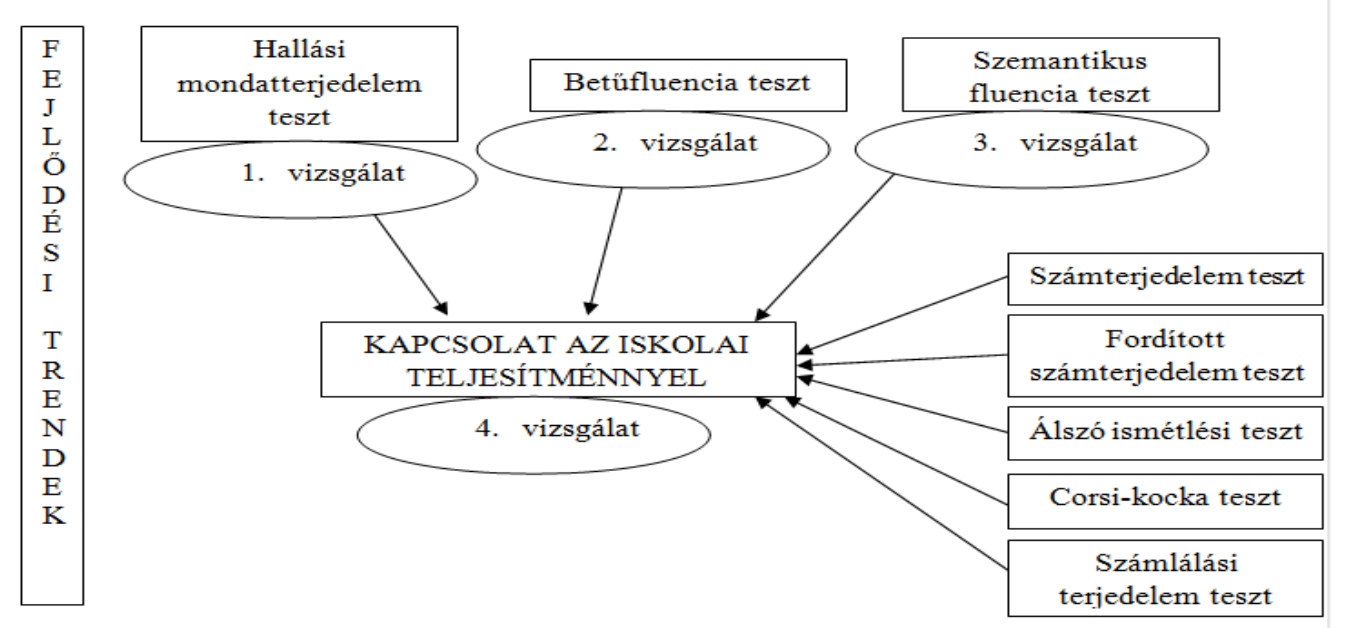

3.ábra

A disszertáció vizsgálatainak logikai felépitése 


\subsection{A vizsgálatsorozat célkitúzései}

A disszertáció célja az volt, hogy a jól körülhatárolt megismerési funkciók (mint a munkamemória és a végrehajtó funkciók) különböző fejlődési aspektusait megvizsgáljuk és ezek kapcsolatát feltérképezzük az iskolai teljesítménnyel. A disszertációban négy empirikus kutatást ismertetünk.

Az első vizsgálatban a komplex munkamemória életkori változásainak vizsgálatát tüztük ki célul, a hallási mondatterjedelem teszt 4-89 év közötti életkori spektrumot felölelö magyar mintán történő feltérképezésével. A munkamemória kutatásában és a neuropszichológiai diagnosztikában egyre nagyobb hangsúlyt kapnak a munkamemória terjedelmét mérő tesztek. Vizsgálatunkban munkamemória életkori változásait átfogó keresztmetszeti vizsgálatot terveztünk, amit azért tartottunk fontosnak, mert egyes külföldi szakirodalmak szerint a munkamemória a serdülőkor végéig fejlődik (Gathercole, 1999) és idősebb felnőttek munkamemóriáját eddig csak 57 éves korig vizsgálták (Shaw, Helmes, és Mitchell, 2006). Kevés olyan vizsgálat született eddig, amely feltárta a munkamemória fejlődésének teljes életkori spektrumát. A kutatásokból eddig kimaradt korosztályok munkamemória-kapacitás változásának bemutatása alkotta a vizsgálatunk fó célját. Átfogó kutatást terveztünk több korcsoportban: óvodás gyerekekkel, általános iskolás és középiskolás gyerekekkel, fiatal (egyetemista) felnőttekkel és idősebb felnőttekkel. Az életkori fejlődési változások mellett célunk volt arra is figyelni, hogy az egyes munkamemória teszteken elért eredményekben található különbségeket és összefüggéseket megállapítsuk. További célként fogalmaztuk meg a hallási mondatterjedelem teszt, az olvasási terjedelem teszt és a számterjedelem teszt összevetését, ahol az első két teszt között erős korrelációt vártunk, mivel mindkét teszt a komplex verbális munkamemória mérőeljárása, ugyanakkor a számterjedelem teszt esetén is egy fejlődéssel járó kapacitásnövekedést vártunk.

A második és a harmadik vizsgálatban célkitüzésünk volt a végrehajtó funkciók életkori változásainak ismertetése a betűfluencia és a szemantikus fluencia teszt segítségével, amikben 5-89 év közötti életkori övezetet átölelö magyar mintát térképeztünk fel.

Második vizsgálatunk célja a betüfluencia feladat 5 és 89 év közötti életkori spektrumot felölelő magyar mintán történő vizsgálata volt. Már több tanulmány is megjelent, ami magyar betüfluencia teszteket használó vizsgálatról számolt be (Mészáros, Kónya és Kas, 2011 Szendi, Kiss, Racsmány, Boda, Cimmer, Vörös, Kovács, Szekeres, Galsi, Pléh, Csernay és Janka, 2006; Klivényi,Németh, Sefcsik, Janacsek, Hoffmann, Háden, Londe és Vécsi, 2012; Sefcsik, Németh, Janacsek, Hoffmann, Sciabbala, Klivényi, Ambrus, Háden és Vécsei, 2009), 
de kevés olyan vizsgálat született eddig, ami feltárta a betűfluencia feladat fejlődésének teljes életkori spektrumát. A kutatásokból eddig kimaradt korosztályok munkamemória-kapacitás változásának bemutatása alkotta a vizsgálatunk fó célját. Ez pedig a tesztek klinikai és kutatási alkalmazásához elengedhetetlen.

Átfogó kutatást terveztünk tehát több korcsoportban: óvodás gyerekekkel, általános iskolás és középiskolás gyerekekkel, fiatal (egyetemista) felnőttekkel és idősebb felnőttekkel. Ez a széles életkori övezet lehetővé teszi a gyerekkori fejlödési trendek és az időskori változások viszonylag precíz feltérképezését. A kutatás a vizsgált változók részletesebb elemzése tekintetében is hiánypótló, ugyanis mind a klasszikus (szavak száma, hiba, perszeveráció), mind az újabb változókat (klaszterek száma, mérete, váltások száma) is bevontuk az elemzésekbe. A nyelvi és végrehajtó funkciókat is mérő betüfluencia teszt több életkori övezetet is felölelő vizsgálata nélkülözhetetlen a hazai klinikai diagnosztikai gyakorlatban.

A disszertáció harmadik vizsgálatának célja az volt, hogy megvizsgáljuk a szemantikus fluencia feladatot 5 és 89 év közötti életkori spektrumot lefedő, nagy elemszámú magyar mintán. Ez a széles életkori övezet lehetőséget ad arra, hogy a gyerekkori fejlődési mintázatokat és az időskori változásokat árnyaltabban tudjuk feltérképezni. Megvizsgáltuk azt is, hogy a különböző életkorokban találunk-e nemi eltéréseket a teljesítményben. A vizsgálatban használt teljesítménymutatók részletesebb elemzése is kiemelendő, ugyanis mind a klasszikus (szavak száma, hiba, perszeveráció), mind az összetettebb változókat (klaszterek száma, mérete, váltások száma) elemeztük. A magyar szemantikus fluencia teszt használatára már több hazai kutatásban is sor került (Klivényi és mtsai, 2012; Sefcsik és mtsai, 2009; Szendi és mtsai, 2006, Mészáros, Kónya, Kas, 2011), de a teljes életkori spektrumot átfedő, nagy elemszámú vizsgálat még nem született, aminek azért van jelentősége, hogy a klinikai és kognitív neuropszichológiában, fejlődéspszichológiában dolgozó szakembereknek lehetősége nyíljon a tesztek használatára. A szemantikus fluencia teszt jól használható párban a betüfluencia teszttel, melyet az első vizsgálat során kerül bemutatásra (lásd 8 . fejezet).A nyelvi és végrehajtó funkciókat mérő szemantikus fluencia teszt széles életkori övezetet magában foglaló vizsgálata a hazai klinikai diagnosztikai, neuropszichológiai és fejlődéspszichológiai gyakorlatban is fontos, továbbá a teszt magyar változata hasznos lehet a kognitív pszichológiában is.

A negyedik, longitudinális kutatásunk célja annak feltérképezése volt, hogy a vizsgálatban részt vevő gyerekek negyedik évfolyamon azonosított iskolai teljesítményét hogyan jósolja be a munkamemória és végrehajtó funkció teszteken nyújtott első osztályos 
eredményük. Az elemzésekbe a magyar nyelv és irodalom, a matematika, illetve a környezetismeret tantárgyakat vontuk be. A tantárgyak kiválasztását az indokolta, hogy korábbi vizsgálatokban is ezeket a tantárgyak vonták be (Gathercole és mtsai, 2004). Ilyen fókuszú kutatásra Magyarországon eddig még nem került sor, továbbá a munkamemória funkcióinak precízebb feltérképezése és a fluencia teszteken belül mind a klasszikus (szavak száma, hiba, perszeveráció), mind az újabb változók (klaszterek száma, mérete, váltások száma) elemzéseink tárgyát alkották. A vizsgálatsorozat célkitüzéseit a 10. táblázat tartalmazza.

10.táblázat. A disszertáció vizsgálatainak föbb célkitüzései

\begin{tabular}{|c|c|}
\hline Vizsgálatok & "Célkitüzések \\
\hline 1. vizsgálat & $\begin{array}{l}\text { - A komplex munkamemória életkori változásainak vizsgálata. } \\
\text {-A hallási mondatterjedelem teszt 4-89 év közötti életkori spektrumot felölelö magyar } \\
\text { mintán történő vizsgálata. } \\
\text { - A hallási mondatterjedelem teszt, az olvasási terjedelem teszt és a számterjedelem teszt } \\
\text { összevetése. }\end{array}$ \\
\hline 2. vizsgálat & $\begin{array}{l}\text { - A végrehajtó funkciók életkori változásainak vizsgálata. } \\
\text { - A betüfluencia feladat } 5 \text { és } 89 \text { év közötti életkori spektrumot felölelő magyar mintán } \\
\text { történő vizsgálata } \\
\text {-A vizsgált változók részletesebb elemzése. }\end{array}$ \\
\hline 3. vizsgálat & $\begin{array}{l}\text { - A végrehajtó funkciók életkori változásainak vizsgálata. } \\
\text { - A szemantikus fluencia feladat } 5 \text { és } 89 \text { év közötti életkori spektrumot felölelö magyar } \\
\text { mintán történő vizsgálata. } \\
\text {-A vizsgált változók részletesebb elemzése. }\end{array}$ \\
\hline 4. vizsgálat & $\begin{array}{l}\text {-A munkamemória és a végrehajtó funkciók kapcsolata az iskolai teljesítménnyel. } \\
\text { - Iskolakezdési kognitív funkciók fejlettségének összevetése a négy évvel későbbi } \\
\text { iskolai teljesítménnyel. }\end{array}$ \\
\hline
\end{tabular}

A vizsgálatsorozatban általunk használt tesztek segítségével lehetőség nyílik fókuszáltabb megismerési funkciók vizsgálatára, melyek idegrendszeri háttere is jól feltérképezett. 


\section{A VIZSGÁlATSOROZAT MÓDSZERTANA}

\subsection{A vizsgálatsorozat hipotézisei}

A 8.1 alfejezetben ismertetett célkitüzések alapján a hipotéziseket korábbi nemzetközi és hazai elméleti megközelítések és vizsgálati eredmények alapján határoztuk meg. A vizsgálatsorozat hipotéziseit összefoglalva a 11. táblázatban ismertetjük.

Az első vizsgálat hipotézisei a következők: 1. Az egyes életkori csoportok fejlődése eltér egymástól a hallási mondatterjedelem teszten, különbség található a gyerekek, a serdülők, a felnőttek és az idősek teljesítményében. 2. Az életkori görbe egy fordított U-alakú görbét követ. 3. A vizsgálatban részt vevő személyek 60 éves korig nyújtják a legjobb teljesítményt a hallási mondatterjedelem teszten. 4. 60 éves kor után a teszten nyújtott teljesítmény szignifikánsan csökken. 5. A hallási mondatterjedelem teszt és az olvasási terjedelem teszt között együttjárás várható, mivel mindkét teszt a komplex verbális munkamemória mérőeljárása.

A második vizsgálat hipotézisei: 1. A gyerekek, a serdülők, a felnőttek és az idősek fejlődése eltér egymástól a betűfluencia teszten nyújtott teljesítmény tekintetében. 2 . Az 5-6 éves gyerekek csak nagyon kevés szót tudnak mondani a betűfluencia feladaton. 3. A betűfluencia szavak száma mutató tekintetében a teljesítmény17-18 éves életkorban eléri a felnőtt szintet. 4. A betüfluencia feladaton 50-69 éves kortól jelentős teljesítménycsökkenés következik be.

A harmadik vizsgálat hipotézisei: 1. A gyerekek, a serdülők, a felnőttek és az idősek teljesítményének fejlődése eltér egymástól. 2. Az 5-6 éves gyerekek több szót tudnak mondani a szemantikus, mint a betüfluencia feladaton. 3. A szemantikus fluencia feladat szavak száma mutató tekintetében a teljesítmény17-18 éves életkorban eléri a felnőtt szintet. 4. 50-69 éves kortól jelentős teljesítménycsökkenés következik be a szemantikus fluencia feladaton. 5. A teljesítmény magasabb a szemantikus fluencia szavak száma mutató tekintetében, mint a betűfluencia feladat esetében.

A negyedik vizsgálat hipotézisei: 1. A magyar nyelv és irodalom tantárgyon nyújtott teljesítményt meghatározza a téri-vizuális feladaton elért eredmény. 2. A matematika tantárgyon elért teljesítményt a a téri-vizuális és a komplex munkamemória feladatokon elért eredmények meghatározzák. 3. A környezetismeret tantárgy esetében a komplex munkamemóriának bejósló értéke van. 


\section{1.táblázat. A vizsgálatsorozat hipotézisei, mintái és méröszközei}

\begin{tabular}{|c|c|c|c|}
\hline "Vizsgálatok & "Hipotézisek & Minta & "Mérőeszközök \\
\hline 1. vizsgálat & $\begin{array}{l}\text { 1. Az egyes életkori csoportok fejlödése eltér } \\
\text { egymástól. } \\
\text { 2. Az életkori görbe fordított U alakú görbét } \\
\text { követ. } \\
\text { 3. A vizsgálati személyek } 60 \text { éves korig } \\
\text { nyúitják a legjobb teljesítményt } \\
\text { 4. } 60 \text { éves kor után a teljesítmény } \\
\text { szignifikánsan csökken. } \\
\text { 5. A hallási mondatterjedelem teszt és az } \\
\text { olvasási terjedelem teszt között } \\
\text { együttjárástvárható. }\end{array}$ & $\begin{array}{l}\mathrm{N}=671 \text { fö, } 4-89 \\
\text { éves korig, } 9 \text { életkori } \\
\text { övezetbe } \\
\text { csoportosítva } \\
\text { ( } 277 \text { nő/394 férfi; } \\
603 \text { jobb-/68 bal } \\
\text { kezes) }\end{array}$ & $\begin{array}{l}\text {-Hallási mondatterjedelem teszt } \\
\text { - Olvasási terjedelem teszt } \\
\text { - Számterjedelem teszt }\end{array}$ \\
\hline 2. vizsgálat & $\begin{array}{l}\text { 1. A gyerekek, a serdülők, a felnőttek és az } \\
\text { idősek fejlödése eltér egymástól. } \\
\text { 2. Az 5-6 éves gyerekek csak kevés szót } \\
\text { tudnak mondani. } \\
\text { 3. A szavak száma tekintetében a } \\
\text { teljesítmény17-18 éves életkorban eléri a } \\
\text { felnőtt szintet. } \\
\text { 4. 50-69 éves kortól jelentős } \\
\text { teljesítménycsökkenés következik be. }\end{array}$ & $\begin{array}{l}\mathrm{N}=562 \text { fö, } 5-89 \\
\text { éves korig, } 11 \\
\text { életkori övezetbe } \\
\text { csoportosítva } \\
\text { (281 nö/281 férfi; } \\
505 \text { jobb-/48 } \\
\text { balkezes, } 9 \text { hiányzó } \\
\text { adat) }\end{array}$ & $\begin{array}{l}\text { Betűfluencia teszt és a vizsgált } \\
\text { változói: szavak, hibák, } \\
\text { perszeverációk, klaszterek száma, } \\
\text { klaszterek mérete, összváltások és } \\
\text { élesváltások száma. }\end{array}$ \\
\hline 3. vizsgálat & $\begin{array}{l}\text { 1. A gyerekek, a serdülők, a felnőttek és az } \\
\text { idösek fejlödése eltér egymástól. } \\
\text { 2. Az 5-6 éves gyerekek több szót tudnak } \\
\text { mondani, mint a betüfluencia feladaton. } \\
\text { 3. A szavak száma tekintetében a } \\
\text { teljesítmény17-18 éves életkorban eléri a } \\
\text { felnőtt szintet. } \\
\text { 4. 50-69 éves kortól jelentős } \\
\text { teljesítménycsökkenés következik be. } \\
\text { 5. A teljesítmény magasabb a szavak száma } \\
\text { tekintetében, mint a betüfluencia feladat } \\
\text { esetében. }\end{array}$ & $\begin{array}{l}\mathrm{N}=562 \text { fö, } 5-89 \\
\text { éves korig, } 11 \\
\text { életkori övezetbe } \\
\text { csoportosítva } \\
\text { (281 nö/281 férfi; } \\
505 \text { jobb-/48 } \\
\text { balkezes, } 9 \text { hiányzó } \\
\text { adat) }\end{array}$ & $\begin{array}{l}\text { Szemantikus fluencia teszt és a } \\
\text { vizsgált változói: szavak, hibák, } \\
\text { perszeverációk, klaszterek száma, } \\
\text { klaszterek mérete, összváltások és } \\
\text { élesváltások száma. }\end{array}$ \\
\hline 4. vizsgálat & $\begin{array}{l}\text { 1. A magyar nyelv és irodalom tantárgyakon } \\
\text { nyújtott teljesítményt meghatározza a téri- } \\
\text { vizuális feladaton elért eredmény. } \\
\text { 2. A matematika tantárgyon elért teljesítményt a } \\
\text { a téri-vizuális és a komplex munkamemória } \\
\text { feladatokon elért eredmények meghatározzák. } \\
\text { 3. A környezetismeret tantárgy esetében a } \\
\text { komplex munkamemória bír bejósló értékkel. }\end{array}$ & $\begin{array}{c}\mathrm{N}=105 \text { tipikus } \\
\text { fejlődésű gyerek } \\
\text { (átlagéletkor=6,79év, } \\
\text { szórás=0,54), } \\
\text { (59 lány/46 fiú; } 88 \\
\text { jobb-/17 balkezes) }\end{array}$ & $\begin{array}{l}\text { - Álszó teszt } \\
\text { - Számterjedelem teszt } \\
\text { - Fordított számterjedelem teszt } \\
\text { - Hallási mondatterjedelem teszt } \\
\text { - Számlálási terjedelem teszt } \\
\text { - Corsi-kocka teszt } \\
\text { - Betűfluencia feladat } \\
\text { - Szemantikus fluencia feladat }\end{array}$ \\
\hline
\end{tabular}




\subsection{A vizsgálatsorozat mintája}

Az első vizsgálatunkban 671 személy vett részt 4-89 éves korig (277 nő/394 férfi; 603 jobb/68 bal kezes). A vizsgálati személyeket 9 életkori csoportba soroltuk. Ezt egyrészt az előzetes szakirodalmi adatok indokolták, másrészt hogy az elemzéshez megfelelően nagy elemszámú csoportokat kapjunk.

A második és a harmadik vizsgálatban 562 fő bevonásával végeztük el a vizsgálatokat, a személyeket 11 életkori övezetbe csoportosítottuk föként a korábbi tanulmányok adatai miatt és azért, hogy az egyes csoportok elemszáma megfelelő legyen az elemzésekhez (281 nő/281 férfi; 505 jobb-/48 balkezes, 9 hiányzó adat).

A negyedik vizsgálatban 105 tipikus fejlődési gyerek vett részt. Átlagéletkoruk 6,79 év volt (szórás=0,54), (59 lány/46 fiú; 88 jobb-/17 balkezes). A disszertációban ismertetett négy vizsgálat hipotéziseit, mintáit és mérőeszközeit a 9. táblázat tartalmazza.

\subsection{A vizsgálatsorozat mérőszeközei}

A vizsgálatokban használt mérőeljárások és azok elméleti háttere részletesen ismertetésre került az 5. fejezetben. A rövid távú memória és a komplex munkamemória mérőeljárásait az 5.1 és 5.2 alfejezetekben, míg a végrehajtó funkciók mérőeljárásait az 5.3 alfejezetben ismertettük. A disszertáció vizsgálatai során használt mérőeljárásokat a 8. táblázatban foglaltuk össze. A betűfluencia és a szemantikus fluencia tesztek általunk vizsgálat mutatóit a 12. táblázatban ismertetjük. 
12.táblázat. A vizsgálatsorozatban használt méröeljárások

\begin{tabular}{|c|c|c|c|c|}
\hline Mérőeljárás & Vizsgált funkció & Feladat & \multicolumn{2}{|c|}{ Helyes válasz } \\
\hline $\begin{array}{l}\text { Számterjedelem } \\
\text { teszt }\end{array}$ & fonológiai RTM & $\begin{array}{l}\text { Megjegyezni, visszamondani sorrendben, } \\
\text { például: „7-2-9-1” }\end{array}$ & \multicolumn{2}{|c|}{, $7-2-9-1 "$} \\
\hline $\begin{array}{l}\text { Álszó ismétlési } \\
\text { teszt }\end{array}$ & fonológiai RTM & $\begin{array}{c}\text { Megjegyezni, visszamondani, például: } \\
\text { „sémernyegvőterec” }\end{array}$ & \multicolumn{2}{|c|}{ „sémernyegvőterec” } \\
\hline $\begin{array}{c}\text { Fordított } \\
\text { számterjedelem } \\
\text { teszt }\end{array}$ & fonológiai RTM & $\begin{array}{l}\text { Megjegyezni, visszamondani fordított } \\
\text { sorrendben, például: „4-9-6-1” }\end{array}$ & \multicolumn{2}{|c|}{ „1-6-9-4” } \\
\hline $\begin{array}{c}\text { Olvasási terjedelem } \\
\text { teszt }\end{array}$ & munkamemória & $\begin{array}{c}\text { Elolvasni, megjegyezni, visszamondani } \\
\text { sorrendben, például: „Mikor az alapos } \\
\text { takarításnak vége lett, az épület összes emeletén } \\
\text { megszünt az általános rossz illat.” és „A } \\
\text { müvészeti igazgató közölte a híres zenésszel, } \\
\text { hogy a gyengébb teljesítmény ellenére jár neki a } \\
\text { gitár.”. }\end{array}$ & \multicolumn{2}{|c|}{ „illat } \\
\hline $\begin{array}{l}\text { Hallási mondat- } \\
\text { terjedelem teszt }\end{array}$ & munkamemória & $\begin{array}{l}\text { Igaz/Hamis, megjegyezni, visszamondani } \\
\text { sorrendben, például: „A varrónő által gyakran } \\
\text { használt eszköz az olló.” és „A madarak } \\
\text { csőrében mindig sok a kávé.” }\end{array}$ & $\begin{array}{l}\text { "igaz" } \\
\text { "hamis" }\end{array}$ & $\begin{array}{l}\text { „olló } \\
\text { kávé” }\end{array}$ \\
\hline $\begin{array}{l}\text { Müveleti } \\
\text { terjedelem teszt }\end{array}$ & munkamemória & 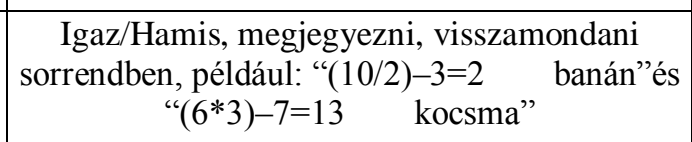 & $\begin{array}{l}\text { "igaz" } \\
\text { "hamis" }\end{array}$ & „,banán \\
\hline $\begin{array}{l}\text { Számlálási } \\
\text { terjedelem teszt }\end{array}$ & munkamemória & $\begin{array}{l}\text { Egymás után következő ábrákon megszámolni a } \\
\text { sötétkék köröket, majd sorrendben } \\
\text { visszamondani a számolások végeredményét. }\end{array}$ & \multicolumn{2}{|c|}{$\begin{array}{l}\text { A számolások } \\
\text { végeredménye. }\end{array}$} \\
\hline Corsi-kocka teszt & $\begin{array}{l}\text { téri-vizuális } \\
\text { munkamemória }\end{array}$ & $\begin{array}{l}\text { Megjegyezni, visszamutatni sorrendben, például: } \\
\text { "5-3-8-1" (ahol a számok a kockákat jelölik) }\end{array}$ & \multicolumn{2}{|c|}{ “5-3-8-1" } \\
\hline $\begin{array}{l}\text { Betüfluencia } \\
\text { feladat }^{1}\end{array}$ & $\begin{array}{l}\text { nyelvi és végrehajtó } \\
\text { funkciók }\end{array}$ & $\begin{array}{c}\text { Például: „K”betűvel minél több szót mondani } 1 \\
\text { perc alatt. }\end{array}$ & \multicolumn{2}{|c|}{$\begin{array}{l}\text { „kutya, kard, } \\
\text { kalap..." }\end{array}$} \\
\hline $\begin{array}{c}\text { Szemantikus } \\
\text { fluencia feladat }\end{array}$ & $\begin{array}{c}\text { nyelvi és végrehajtó } \\
\text { funkciók }\end{array}$ & $\begin{array}{c}\text { Például: „ÁLLAT” kategória-mintapéldányokat } \\
\text { mondani } 1 \text { perc alatt }\end{array}$ & \multicolumn{2}{|c|}{$\begin{array}{l}\text { „macska, kutya, hal, } \\
\text { teve..." }\end{array}$} \\
\hline
\end{tabular}

A végrehajtó funkciók egyik gyakran használt mérőeljárásai a betüfluencia és a szemantikus fluencia tesztek. A verbális fluencia teljesítmény mutatójaként a legtöbb vizsgálatban a helyesen mondott szavak, a perszeverációk és a hibák számát tekintik. Az újabb kutatásokban a klasszikus teljesítménymutatók kiegészültek a klaszterek számával és azok méretével, illetve a váltások számával Az újabb teljesítménymutatók jól használhatóak a verbálisfluencia-feladatok hátterében rejlő kognitív folyamatok és az egyes személyek teljesítményének mennyiségi és minőségi elemzésére. A betűfluencia és a szemantikus fluencia tesztek mennyiségi és minőségi mutatóit a 13. táblázatban foglaltuk össze. 


\section{3. táblázat. A betü- és szemantikus fluencia tesztek mennyiségi és minőségi mutatói}

\begin{tabular}{|c|c|c|c|}
\hline Mutató & Példa & Eredmény & Értékelési módszer \\
\hline $\begin{array}{c}\text { Betüfluencia } \\
\text { szavak száma }\end{array}$ & $\begin{array}{l}\text { „kutya, kard, } \\
\text { kalap” }\end{array}$ & 3 & $\begin{array}{c}\text { az összesen generált szavak száma mínusz } \\
\text { a hibák és a perszeverációk száma }\end{array}$ \\
\hline $\begin{array}{l}\text { Betüfluencia } \\
\text { perszeveráció }\end{array}$ & $\begin{array}{l}\text { „kutya, kard, } \\
\text { kutya” }\end{array}$ & 1 & $\begin{array}{c}\text { olyan helyes szavak ismétlése, amik már } \\
\text { korábban előfordultak a válaszban } \\
\text { (beleszámítva a ragozott alakokat is) }\end{array}$ \\
\hline $\begin{array}{l}\text { Betüfluencia } \\
\text { hiba }\end{array}$ & $\begin{array}{l}\text { „kutya, kalap, } \\
\text { kecske, teve, } \\
\text { kesztyü” }\end{array}$ & 1 & $\begin{array}{l}\text { olyan szavak száma, amelyek nem a } \\
\text { megfelelő kezdőbetűvel kezdődtek }\end{array}$ \\
\hline $\begin{array}{l}\text { Betüfluencia } \\
\text { klaszterszám }\end{array}$ & $\begin{array}{l}\text { „kalap, kakadu, } \\
\text { kabát | kecske, } \\
\text { kenyér, kefe” }\end{array}$ & 2 & $\begin{array}{c}\text { azon sikeresen generált szavak, } \\
\text { amelyeknek az első két betűjük } \\
\text { megegyezik vagy csak egy } \\
\text { magánhangzóban különböznek vagy } \\
\text { rímelnek }\end{array}$ \\
\hline $\begin{array}{l}\text { Betüfluencia } \\
\text { klaszterméret }\end{array}$ & „táj, tányér, táltos” & 2 & $\begin{array}{c}\text { a klaszter mérete a klasztert alkotó szavak } \\
\text { száma mínusz egy (a perszeverációk és a } \\
\text { hibák nem számítanak bele) }\end{array}$ \\
\hline $\begin{array}{c}\text { Betüfluencia } \\
\text { klaszterváltás }\end{array}$ & $\begin{array}{l}\text { „teve, tetü, terasz | } \\
\text { tál, tábla” }\end{array}$ & 1 & $\begin{array}{l}\text { a szomszédos klaszterek közötti váltások } \\
\text { száma }\end{array}$ \\
\hline $\begin{array}{l}\text { Betüfluencia } \\
\text { élesváltás }\end{array}$ & $\begin{array}{l}\text { „tehén, terep | } \\
\text { takaró | tinta”" }\end{array}$ & 2 & $\begin{array}{l}\text { egy klaszter és egy nem klaszterbe sorolt } \\
\text { szó közti vagy két nem csoportosított szó } \\
\text { közti váltások száma }\end{array}$ \\
\hline $\begin{array}{c}\text { Szemantikus } \\
\text { fluencia szavak } \\
\text { száma } \\
\end{array}$ & $\begin{array}{l}\text { „kutya, macska, } \\
\text { róka” }\end{array}$ & 3 & $\begin{array}{l}\text { az összesen mondott szavak száma mínusz } \\
\text { a hibák és a perszeverációk száma }\end{array}$ \\
\hline $\begin{array}{l}\text { Szemantikus } \\
\text { fluencia } \\
\text { perszeveráció }\end{array}$ & $\begin{array}{l}\text { „citrom, narancs, } \\
\text { citrom, banán” }\end{array}$ & 1 & $\begin{array}{l}\text { olyan helyes szavak ismétlése, amik már } \\
\text { előfordultak a válaszok között }\end{array}$ \\
\hline $\begin{array}{l}\text { Szemantikus } \\
\text { fluencia hiba }\end{array}$ & $\begin{array}{l}\text { "kutya, macska, } \\
\text { egér, rózsa" }\end{array}$ & 1 & $\begin{array}{l}\text { azon szavak száma, amelyek nem a } \\
\text { megadott kategória tagjai voltak }\end{array}$ \\
\hline $\begin{array}{l}\text { Szemantikus } \\
\text { fluencia } \\
\text { klaszterszám }\end{array}$ & $\begin{array}{l}\text { „kutya, macska, } \\
\text { tehén, csirke” } \\
\rightarrow \text { háziállatok }\end{array}$ & 1 & $\begin{array}{c}\text { azon sikeresen generált szavak, } \\
\text { amelyeknek ugyanazon alkategóriába } \\
\text { tartoznak }\end{array}$ \\
\hline $\begin{array}{l}\text { Szemantikus } \\
\text { fluencia } \\
\text { klaszterméret }\end{array}$ & $\begin{array}{l}\text { „kutya, macska, } \\
\text { csirke" }\end{array}$ & 2 & $\begin{array}{c}\text { a klasztert alkotó szavak száma mínusz } \\
\text { egy (a perszeverációk és a hibák nem } \\
\text { számítanak bele) }\end{array}$ \\
\hline $\begin{array}{l}\text { Szemantikus } \\
\text { fluencia } \\
\text { klaszterváltás }\end{array}$ & $\begin{array}{l}\text { „oroszlán, tigris | } \\
\text { sas, bagoly" }\end{array}$ & 1 & $\begin{array}{c}\text { a szomszédos klaszterek közötti váltások } \\
\text { száma }\end{array}$ \\
\hline $\begin{array}{l}\text { Szemantikus } \\
\text { fluencia } \\
\text { élesváltás }\end{array}$ & $\begin{array}{l}\text { „oroszlán, tigris, | } \\
\text { hörcsög"| } \\
\text { anakonda" }\end{array}$ & 2 & $\begin{array}{l}\text { egy klaszter és egy nem klaszterbe sorolt } \\
\text { szó vagy két nem csoportosított szó közti } \\
\text { váltások száma }\end{array}$ \\
\hline
\end{tabular}

${ }^{1}$ A végrehajtó funkciók mérőeljárásai közül azért esett a fluencia tesztekre a választásunk, mivel magyar nyelven még nem született olyan vizsgálat, ahol a verbálisfluencia-tesztek részletes mennyiségi és minőségi elemzése történt volna az iskolai teljesítmény függvényében. A fluencia tesztek előnye más végrehajtó funkciót mérő tesztekkel szemben (pl. Wisconsin Kártyaszortírozási Teszt, Stroop teszt, Hanoi-torony feladat), hogy felvétele viszonylag gyors és mégis sokféle mutatót ad, amelyek segítségével lehetővé válik mind a váltás, gátlás, és lexikális hozzáférés feltérképezése is. 


\section{AZ ELSŐ VIZSGÁLAT}

\section{A HALLÁSI MONDATTERJEDELEM TESZT ÉLETKORI VÁLTOZÁSAI}

Az alábbiakban az első vizsgálatunkat ismertetjük. Egy olyan neuropszichológiai mérőeljárást mutatunk be, amelynek segítségével lehetővé válik a munkamemória életkori változásainak vizsgálata és patológiájának differenciált feltérképezése. Ez a hallási mondatterjedelem (Listening Span) teszt, amely a külföldi szakirodalomban gyakran használt mérőeljáráskét szerepel. A teszt legnagyobb előnye, hogy széles célcsoportokban alkalmazható, például olvasni nem vagy csak nehezen tudó populációknál is, továbbá az olvasni tudó csoportok esetében is objektívebb képet kaphatunk a munkamemória kapacitásáról, kiküszöbölve ezzel az olvasási képességekben fellelhető egyéni különbségeket. A vizsgálatban használt munkamemória tesztek hasznos segédeszközökként müködhetnek például tanulási nehézségek, nyelvi zavarok korai azonosításában az iskolapszichológia, a pedagógia és a neuropszichológiai diagnosztika területén is.

\subsection{Célkitüzések, hipotézisek}

A korábbi vizsgálatokból kimaradt korcsoportok munkamemória-kapacitás változásának bemutatása, vagyis a tesztek felvétele 9 életkori csoportban alkotta az első vizsgáltunk fö célját. További célkitüzésünk volt a hallási mondatterjedelem teszt, a számterjedelem teszt és az olvasási terjedelem teszt összevetése. Főbb hipotéziseink ennek megfelelően: az egyes életkori csoportok fejlődése eltér egymástól és ezek az életkori változások fordított U-alakú görbét követnek.

\subsection{Módszerek}

\subsubsection{Minta}

A vizsgálatban összesen 671 személy vett részt (277 nő/394 férfi; 603 jobb-/68 bal kezes) 4 éves kortól 89 éves korig. A csoportok megfelelő elemszáma és az előzetes szakirodalmi adatok alapján a személyeket életkori övezetekbe soroltuk. 9 életkori csoportot határoztunk meg, amelyek: 1. 4-6 éves korig, 2. 7-9 éves korig, 3. 10-12 éves korig, 4. 13-15 éves korig, 5. 16-18 éves korig, 6. 19-30 éves korig, 7. 31-49 éves korig, 8. 50-69 éves korig és 9. 70- 
89 éves korig terjedtek. A csoportok beosztása kisgyermekkortól 18 éves korig 2 éves bontásban történt, mivel így a fejlődés pontosabb feltárása vált lehetővé. A felnőttek és az idősek esetében 20 éves bontást alkalmaztunk az életkori csoportok meghatározásakor. A mintavétel hozzáférés alapú volt. Az adatok főként Szegedről és környékéről származtak, kisebb mértékben Magyarország más településeit is bevontuk a vizsgálatba. A személyek önkéntes alapon vállalták és informális beleegyezési nyilatkozatukat adták a kísérletben való részvételhez. A Magyar Pszichiátriai Társaság és a Szegedi Tudományegyetem Bölcsészettudományi Kar Pszichológiai Intézetének etikai kódexét betartottuk a vizsgálatok során.

Az alsó határt (4év) az határozta meg, hogy 4 éves volt a legfiatalabb vizsgálati személy. Ebben az életkorban éri el az agyi aktivitás a felnőtt aktivitás 150\%-kát (Elman és mtsai, 1996), ezután lassú fejlődés figyelhető meg az agyi metabolizmusokban. A 4-6 éves korosztály tehát az óvodások csoportja. Ezután következtek a kisiskolások (7-9 év), akik esetében megállapították, hogy a munkamemória teszteken elért teljesítményük 8-9 éves korig erősen növekszik. Azután fokozatos fejlődés figyelhető meg (11-12 éves korig). 16-17 éves korra a fejlődés üteme lelassul, viszont a komplex munkamemória teszten elért teljesítmény alapján 9-13 éves korban meredek emelkedést figyeltek meg (Gathercole, 1999; Gathercole és Adams, 1994; Baddeley és mtsai, 1998, Gathercole, Pickering, Amridge és Wearing, 2004). Egyes kutatók szerint a komplex munkamemória kapacitás fejlődésének vége 19 éves korra tehető, azután pedig fokozatos teljesítmény csökkenés figyelhető meg 49 éves korig (Chiappe, Hasher és Siegel, 2000). Az 50 és 89 év közti csoportot két részre bontottuk, mivel ebben az életkorban a tesztekkel mért munkamemória terjedelem már jelentős életkori változásokat mutat. Az idősebb felnőttek esetében nagyobb mértékü teljesítménycsökkenést figyeltek meg (Kim és mtsai, 2008). Az életkor átlagát és szórását az egyes életkori csoportokban a 14. táblázat tartalmazza. 
14. táblázat. Az életkor átlaga és szórása az egyes életkori övezetekben

\begin{tabular}{c|c}
\hline \hline Életkori csoportok & $\begin{array}{c}\text { Életkor } \\
\text { átlag (szórás })\end{array}$ \\
\hline \hline -6 év $(\mathrm{n}=70)$ & $5,70(0,49)$ \\
\hline $10-12$ év $(\mathrm{n}=38)$ & $8,02(0,62)$ \\
\hline $13-15$ év $(\mathrm{n}=46)$ & $11,29(0,51)$ \\
\hline $16-18$ év $(\mathrm{n}=160)$ & $14,22(0,51)$ \\
\hline $19-30$ év $(\mathrm{n}=181)$ & $17,22(0,92)$ \\
\hline $31-49$ év $(\mathrm{n}=38)$ & $43,96(1,65)$ \\
\hline $50-69$ év $(\mathrm{n}=38)$ & $58,21(6,41)$ \\
\hline $70-89$ év $(\mathrm{n}=51)$ & $78,82(4,72)$ \\
\hline Összesen: $(\mathrm{n}=671)$ & $22,86(18,60)$ \\
\hline \hline
\end{tabular}

\subsubsection{Méröeszközök és eljárás}

Ebben a vizsgálatban a számterjedelem tesztet, az olvasási terjedelem tesztet és a hallási mondatterjedelem tesztet adminisztráltuk. A számterjedelem teszt és az olvasási terjedelem teszt részletes leírását és instrukcióját lásd az 5 . fejezetben.

A hallási mondatterjedelem teszt esetében minden mondat egyszerü-bővített, 5-6 szóból áll, az utolsó szavak közepes gyakoriságú, két szótagú főnevek. A mondatokat egy elővizsgálat során válogattuk ki három mondattípus (öt-hat szavas egyszerü, hét-nyolc szavas egyszerü, illetve kilenc-tíz szavas összetett mondatok) közül. Végül a tesztbe az öt-hat szavas egyszerü mondatok kerültek bele, mivel ennél a típusnál volt közel azonos átlag mellett a legnagyobb szórás, ami lehetővé teszi az egyéni különbségek differenciáltabb mérését. A mondatok összeállításánál figyelnünk kellett arra, hogy egyenlő arányban szerepeljenek igaz és hamis igazságértékü mondatok. További fontos szempont volt, hogy a mondatok végén szereplő megjegyzendő szavak közepes gyakoriságú, kétszótagú, ragozatlan főnevek legyenek. Az ilyen típusú mondatok ugyan ritkábban fordulnak elő a magyar nyelvben, de ez jelentősen nem befolyásolta a teszten nyújtott teljesítményt, ahogyan ezt az olvasási terjedelem teszttel szerzett tapasztalatok is mutatják (Racsmány és mtsai, 2005). A hamis 
mondatok egy részénél a mondatbefejezés váratlan (vagyis az utolsó szó tartalmilag nem illik bele a mondatkontextusba), azonban az elővizsgálat során nem kaptunk olyan eredményeket, hogy ez átlagosan negatív vagy pozitív irányba befolyásolná a felidézési eredményeket szemben a többi hamis mondattal, így ezt a típust is bennehagytuk a tesztben.

További fontos szempont volt, hogy a mondatok minden életkori csoport számára érthetőek legyenek. Ennek különösen a gyerekeknél és az időseknél volt fontos szerepe, mivel a gyerekek esetében a kevesebb tapasztalat/tudás, míg a felnőtteknél az öregedéssel járó életkori változásokból fakadó esetleges kognitív hanyatlás okozhat problémát. Ezért a teszt elejére olyan mondatok kerültek, amelyekről feltételeztük, hogy sem a legfiatalabb, sem pedig a legidősebb életkori csoport számára nem okoz nehézséget a megértésük. Mivel az egyszerü tárolási kapacitást mérő teszteken nyújtott teljesítmény alapján feltételezhető, hogy az említett korcsoportok már nagy valószínüséggel nem jutnának el a későbbi blokkokig (7-8 mondat), ezért az esetlegesen nehezebb mondatok csak itt fordulnak elö.

Felváltva három vizsgálatvezető vette fel az adatokat egy kísérleti laborban. Egy adatfelvétel körülbelül tíz-tizenöt percig tartott. Három tesztet használtunk: a számterjedelem tesztet, az olvasási terjedelem tesztet és a hallási mondatterjedelem tesztet. A tesztek sorrendjét szisztematikusan változtattuk, hogy a sorrendi hatásokat kiküszöböljük.

A számterjedelem tesztnél a vizsgálatvezető egyenként olvasta fel a számokat, egy másodperc szünetet tartva minden szám után. A résztvevőknek az elhangzás sorrendjében kellett a számokat megismételniük, a kihagyott és felcserélt számokat tartalmazó választ hibásnak tekintettük. Óvodás korú gyermekeknél két számból álló sorozattal kezdtünk, míg általános iskolásoknál már a három számból álló sorozattal. Mindegyik sorozat négy próbát tartalmazott. Egy próbán belül minden szám különböző volt. Akkor fogadtunk el egy sorozatot helyesnek, ha a négy próbából legalább hármat pontosan vissza tudtak mondani. Az egymást követő sorozatokban mindig eggyel több szám szerepelt. A végső számterjedelmet az utolsó jó sorozat értéke adta (ahol a négy próbából még hármat helyesen vissza tudtak mondani).

Az olvasási terjedelem teszt esetében a vizsgálati személy azt az instrukciót kapta, hogy a kártyákon levő mondatokat hangosan olvassa fel, figyeljen oda a tartalmára és jegyezze meg a mondatok utolsó szavát, majd amint befejezte az olvasást, az elhangzás sorrendjében mondja vissza a szavakat. Három sorozatot vettünk fel, minden sorozaton belül először két mondatot olvastattunk fel, és ha helyes volt a szavak visszamondása, akkor növeltük a mondatok számát eggyel, amíg nem hibáztak. A mondatok végén közepes gyakoriságú, kétszótagú főnevek szerepeltek. Ha a két mondat esetében sem tudták 
visszamondani az utolsó szavakat, akkor az adott sorozatban a terjedelem egy lett. Időnként a mondatok tartalmára vonatkozó kérdésekkel ellenőriztük, hogy megértik-e és odafigyelnek-e rá. A végső olvasási terjedelem értéket a három sorozat átlaga adta.

Az általunk kidolgozott hallási mondatterjedelem tesztnél a vizsgálati személyeknek a vizsgálatvezető olvasta fel egyesével a mondatokat. Mindegyik után meg kellett állapítani, hogy a mondat igaz vagy hamis - ezzel igyekeztük elérni, hogy odafigyeljenek a mondatok jelentésére - és közben meg kellett jegyezniük minden mondat utolsó szavát, melyeket a mondatok elhangzása után sorrendben kellett visszamondaniuk. Ezek 5-6 szóból álló, egyszerü bővített mondatok voltak, melyek végén közepes gyakoriságú, két szótagos fönév állt. Az olvasási terjedelem teszthez hasonlóan 3 sorozatot vettünk fel, minden sorozaton belül elöször két mondatot olvastunk fel, és ha helyes volt a szavak visszamondása, akkor növeltük a mondatok számát eggyel, egészen addig, amíg nem hibáztak. A végső terjedelmi értéket a három sorozat eredményeinek átlaga adta. Ha a vizsgálati személy már a két mondatból álló sorozatot sem tudta helyes sorrendben visszamondani, akkor a teszt értéke abban a sorozatban egy lett.

\subsubsection{Statisztikai eljárás}

Az életkor rövid távú- és munkamemória terjedelemre gyakorolt hatását egyszempontos varianciaanalízissel (ANOVA) vizsgáltuk az életkori övezetek alapján. A korrelációs mutatókat az életkori csoportokban a Pearson-féle korreláció segítségével határoztuk meg.

\subsection{Eredmények}

Az eredmények leírásakor a következő sorrendet követjük. Elsőként ismertetjük a vizsgálat fókuszában álló hallási mondatterjedelem teszt átlagát, szórását és a centilis terjedelmi értékeket az egyes életkori csoportokban (15. tábálázat). Ezt a korábbi magyar nyelvü vizsgálatok indokolták (Racsmány és mtsai, 2005). Majd bemutatjuk a vizsgálat során használt három mérőeljárás átlagait és szórásait egy összesített táblázatban (16. táblázat). Ezek után áttekintjük a három teszt profilját a különböző életkori csoportokban (4. ábra).

A következő 8. táblázatban az általunk kidolgozott hallási mondatterjedelem teszt átlagát, szórását és centilis terjedelmi értékeit mutatjuk be a különböző életkori csoportokban. 
15. táblázat. A hallási mondatterjedelem teszt mutatói $(N=647)$

\begin{tabular}{c|c|c|c|c|c|c|c|c|c|c}
\hline \hline \multirow{2}{*}{$\begin{array}{c}\text { Életkori } \\
\text { övezetek }\end{array}$} & \multirow{2}{*}{$\mathrm{N}$} & \multirow{2}{*}{ Átlag } & \multirow{2}{*}{ Szórás } & \multicolumn{5}{|c}{ Centilis terjedelmi értékek } \\
\cline { 5 - 10 } & & & & 5 & 10 & 25 & 50 & 75 & 90 & 95 \\
\hline \hline $4-6$ & 61 & 1,86 & 0,64 & 1 & 1 & 1,33 & 1,66 & 2,33 & 2,93 & 3 \\
\hline $7-9$ & 43 & 2,12 & 0,44 & 1,33 & 1,33 & 2 & 2 & 2,33 & 2,66 & 3 \\
\hline $10-12$ & 38 & 2,44 & 0,41 & 1,98 & 2 & 2 & 2,33 & 2,66 & 3 & 3,03 \\
\hline $13-15$ & 46 & 3,1 & 0,58 & 2,33 & 2,33 & 2,66 & 3 & 3,66 & 4 & 4 \\
\hline $16-17$ & 71 & 3,33 & 0,59 & 2,33 & 2,66 & 3 & 3,33 & 3,66 & 4 & 4,46 \\
\hline $18-19$ & 187 & 3,38 & 0,73 & 2,33 & 2,33 & 2,66 & 3,33 & 3,66 & 4,33 & 4,66 \\
\hline $20-29$ & 78 & 3,45 & 0,89 & 2 & 2,33 & 3 & 3,33 & 4 & 4,66 & 5 \\
\hline $30-45$ & 22 & 3,38 & 0,79 & 2,33 & 2,33 & 2,66 & 3,33 & 4,33 & 4,33 & 4,61 \\
\hline $46-60$ & 39 & 3,11 & 0,61 & 2 & 2,33 & 2,66 & 3 & 3,33 & 4 & 4,33 \\
\hline $61-75$ & 28 & 2,34 & 0,49 & 1,66 & 1,66 & 2 & 2,33 & 2,66 & 3,03 & 3,51 \\
\hline $76-80$ & 34 & 1,85 & 0,64 & 1 & 1 & 1,33 & 2 & 2 & 2,83 & 3,33 \\
\hline \hline
\end{tabular}

Három munkamemória-tesztet vettünk fel a különböző korcsoportokban: a számterjedelem, az olvasási terjedelem (kivéve a 4 és 6 év közti gyermekek esetében, mivel a teszt olvasási készséget igényel és ebben az életkorban a gyerekek többsége még nem tud olvasni) és a hallási mondatterjedelem tesztet. Az egyes tesztek átlagát és szórását külön kiszámoltuk életkori övezetenként (16. táblázat). 
16. táblázat. Az első vizsgálatban használt tesztek átlagai és szórásai a különbözö életkori övezetekben

\begin{tabular}{c|c|c|c|c|c|c}
\hline \hline \multirow{2}{*}{ Életkori övezetek } & \multicolumn{2}{|c|}{ Számterjedelem } & \multicolumn{2}{c}{ Olvasási terjedelem } & \multicolumn{2}{c}{ Hallási mondatterjedelem } \\
\cline { 2 - 7 } & átlag & szórás & átlag & szórás & átlag & szórás \\
\hline \hline $4-6$ & 3,62 & 0,86 & - & - & 1,85 & 0,63 \\
\hline $7-9$ & 4,37 & 0,80 & 2,21 & 0,78 & 2,12 & 0,44 \\
\hline $10-12$ & 4,90 & 0,77 & 2,54 & 0,47 & 2,44 & 0,41 \\
\hline $13-15$ & 5,54 & 0,93 & 2,72 & 0,54 & 3,09 & 0,58 \\
\hline $16-18$ & 5,59 & 0,93 & 3,01 & 0,74 & 3,36 & 0,63 \\
\hline $19-30$ & 5,83 & 1,10 & 3,21 & 0,83 & 3,39 & 0,82 \\
\hline $31-49$ & 5,54 & 0,98 & 3,15 & 0,56 & 3,33 & 0,72 \\
\hline $50-69$ & 4,97 & 1,02 & 2,35 & 0,55 & 2,75 & 0,60 \\
\hline $70-89$ & 4,41 & 0,98 & 1,83 & 0,68 & 1,96 & 0,62 \\
\hline \hline
\end{tabular}

Ahogyan azt a 4. ábra is szemlélteti, mind a számterjedelem, mind az olvasási terjedelem, mind a hallási mondatterjedelem teszt esetében az életkor függvényében jelentős kapacitásváltozás figyelhető meg Az elmélet szerint a hallási mondatterjedelem teszt az olvasási terjedelem teszttel mutat legnagyobb hasonlóságot - mindkét teszt a komplex verbális munkamemória mérőeljárása, és ezt a kapott eredmények is alátámasztják: hasonló fejlődési profil rajzolódott ki a két tesztnél. Az olvasási terjedelem és a hallási mondatterjedelem profilja párhuzamosan alakul minden életkori övezetben. Az alacsonyabb értékek azt mutatják, hogy a tesztek a fonológiai hurok és a központi végrehajtó müködését mérik együttesen, tehát a feldolgozó és tároló elemek egyformán le vannak terhelve. A számterjedelem teszt a verbális munkamemóriát (fonológiai hurok) méri, ahol az egészséges személyek munkamemória terjedelme 7+/-2 egység (Baddeley, 2001). 


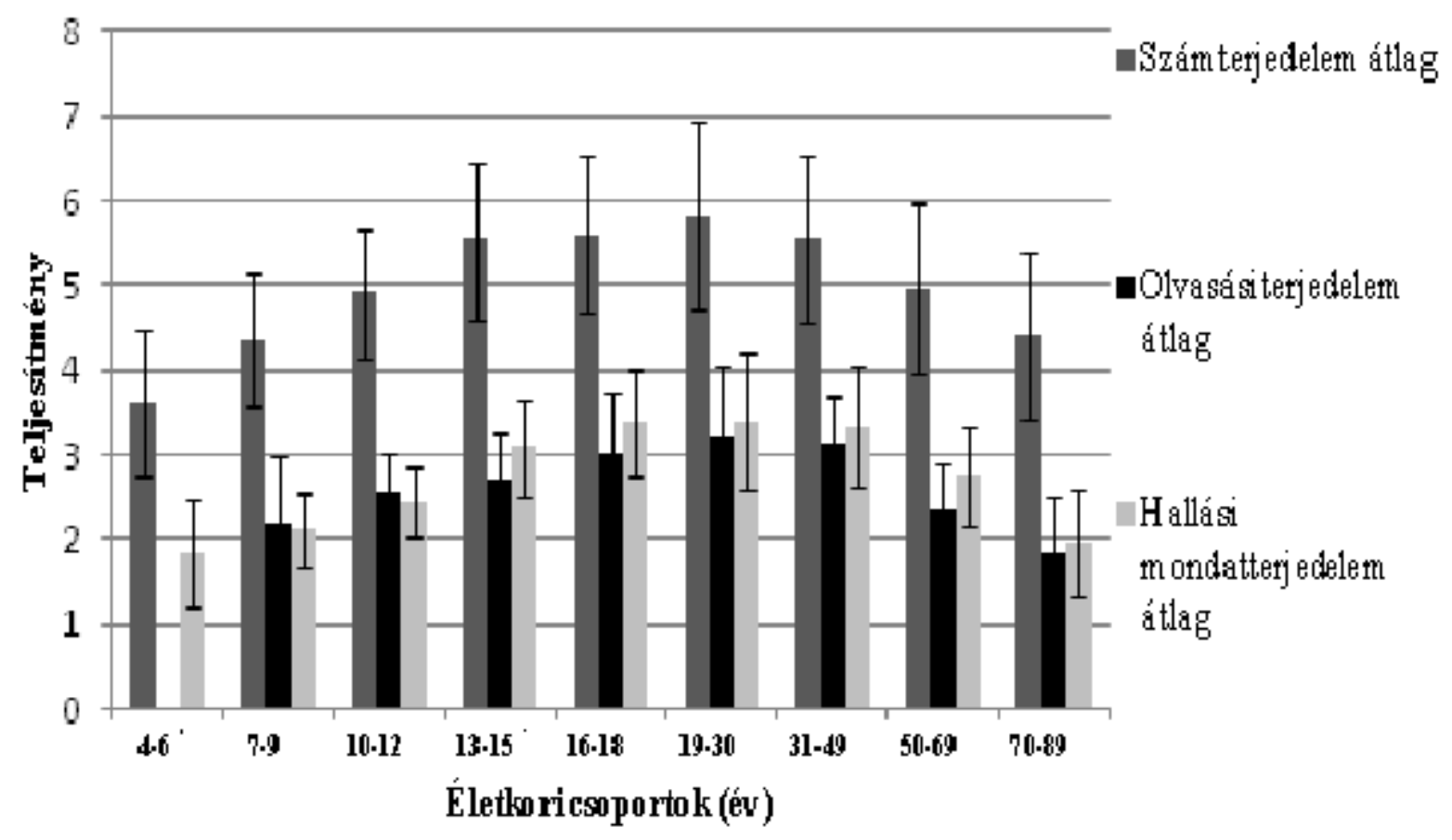

4. ábra

A számterjedelem, az olvasási terjedelem és a hallási mondatterjedelem tesztek profilja a különbözö életkori csoportokban

Az olvasási terjedelem vizsgálatakor az első életkori csoportot (4-6 év) kivettük a mintából, tehát a már említett olvasási képességek hiányosságai miatt esetükben nem vizsgáltuk a hatást. Az életkornak mindhárom esetben szignifikáns főhatása volt: a hallási mondatterjedelem $(F(8,638)=63,09, p<0,001)$, az olvasási terjedelem $(F(7,494)=23,89$, $p<0,001)$ és a számterjedelem $(F(8,648)=45,66, p<0,001)$ esetében is.

A számterjedelem teszt esetén a teljesítményben 46 éves kortól erőteljes növekedés figyelhető meg egészen 13-15 éves korig, majd 16-18 és 19-30 éves korcsoportoknál egy újabb enyhe emelkedés történik. Az ezt követő életkorokban pedig fokozatos csökkenés figyelhető meg.

Az olvasási terjedelem teszten 7-9 éves kortól kezdve egészen 19-30 éves korig intenzív növekedés, 50 éves kor felett pedig erős csökkenés tapasztalható a teljesítményben.

A hallási mondatterjedelem teszt esetében 4-6 éves kortól kezdve 16-18 éves korig erős növekedés van jelen, majd 50 éves kortól jelentősen csökken a teljesítmény.

A vizsgálatban szereplő három munkamemória teszt eredményei közötti együttjárást is tanulmányoztuk. A 4 és 6 év közti gyermekeknél, akikkel még nem tudtuk felvenni az olvasási terjedelem tesztet nem találtunk korrelációt. Közepes illetve erős korrelációt 
figyeltünk meg ellenben a számterjedelem és az olvasási terjedelem teszt esetében szinte minden korcsoportnál. Az eredményeket a 17. táblázatban ismertetjük.

17. Táblázat. Az első vizsgálat korrelációs mutatói a különbözö életkori csoportokban; $* p<0,05, * * p<0,001$

\begin{tabular}{c|c|c}
\hline \hline $\begin{array}{c}\text { Életkori övezetek } \\
\text { (év) }\end{array}$ & $\begin{array}{c}\text { Hallási mondatterjedelem } \\
\text { és a }\end{array}$ & $\begin{array}{c}\text { Hallási mondatterjedelem } \\
\text { és az } \\
\text { számterjedelem között }\end{array}$ \\
\hline \hline $4-6$ & $0,28^{*}$ & 0,24 \\
\hline $7-9$ & $0,48^{* *}$ & $0,43^{* *}$ \\
\hline $10-12$ & $0,39^{*}$ & $0,37^{*}$ \\
\hline $13-15$ & 0,19 & $0,26^{* *}$ \\
\hline $16-18$ & $0,47^{* *}$ & $0,43^{* *}$ \\
\hline $19-30$ & $0,42^{* *}$ & $0,65^{* *}$ \\
\hline $31-49$ & $0,35^{*}$ & 0,28 \\
\hline $50-69$ & $0,55^{* *}$ & $0,63^{* *}$ \\
\hline $70-89$ & $0,48^{*}$ & olvasási terjedelem között \\
\hline \hline
\end{tabular}

Mivel a számterjedelem teszt és a hallási mondatterjedelem teszt között ilyen magas együttjárást találtunk, parciális korrelációt végeztünk . A számterjedelem teszt hatását parciálva az olvasási terjedelem és a hallási mondatterjedelem közti együttjárás továbbra is igen magas maradt: $r=0,41$ ( $p<0,001)$ (közepes erősségü korreláció), 13-15 éves életkori övezetben $r=0,32$ ( $p<0,05)$ (gyenge korreláció), 1618 év közötti csoportban $r=0,16(p<0,05)$ (gyenge korrelációs érték), 1930 év között $r=0,36$ ( $p<0,001$ ) (gyenge korrelációs érték), 3149 éves korcsoportban $r=0,63$ ( $p<0,05)$ (erős korreláció) és 70-89 év közti korcsoportban $r=0,58$ ( $p<0,001)$ (közepes korreláció). A 13 éven aluli gyerekeknél, tehát az első három korcsoportban valószínűleg azért nem kaptunk ilyen korrelációkat, mivel ők minden feladatot a fonológiai hurok segítségével oldanak meg, csak ez a rendszer van esetükben „leterhelve”, nem pedig a komplex munkamemória. Ezért nem találtunk náluk együttjárást a hallási mondatterjedelem és az olvasási terjedelem között. A 13-15 éves korcsoportban nem volt együttjárás a hallási mondatterjedelem és a számterjedelem között és az 50-69 éves korosztályban sem volt együttjárás a hallási mondatterjedelem és az olvasási terjedelem 
között, viszont megállapítható, hogy átlagban van korreláció a tesztek és a korcsoportok között.

A hallási mondatterjedelem teszt megbízhatóságát ismételt tesztfelvétellel ellenőriztük: egy hét, illetve egy hónap telt el a két adatfelvétel között. Az egy hét utáni felvételben 34 egyetemista (18-23 év; 27 nö/9 férfi; 33 jobb/1 balkezes) vett részt, az egy hónap utáni felvételben pedig 54 (18-24 év; 41 nő/13 férfi; 47 jobb/6 balkezes). Mindkét esetben erős korrelációt találtunk, az egy hét utáni tesztfelvételnél $r=0,64, p<0,001$, egy hónap után pedig $r=0,81, p<0,001$. Az egy hónap utáni jobb együttjárás annak köszönhető, hogy a vizsgálati személyek jobban elfelejtették a teszt részleteit, így az első adatfelvételhez hasonló eredményeket értek el. Az ismételt adatfelvételbe bevontunk egy fiatalabb korcsoportot is, hogy megvizsgáljuk, vajon a munkamemória más fejlődési stádiumaiban is megmarad-e a hallási mondatterjedelem teszt megbízhatósága. Ebben a vizsgálatban 20 fó vett részt (7-9 év; 13 lány/7 fiú; 15 jobb/5 balkezes), a két mérés között egy hónap telt el. Ebben az esetben is magas korrelációt találtunk a két eredmény között $(r=0,77, p<0,001)$.

\subsection{Részösszefoglalás}

Vizsgálatunkban az angolszász nyelvterületen széles körben használt hallási mondatterjedelem teszt magyar változatát mutattuk be. Eredményeink abból a szempontból jelentősek, hogy ezzel bővült a magyar nyelvü munkamemóriát mérő tesztek köre és a komplex verbális munkamemória sokkal precízebb feltérképezését teszi lehetővé, mint az olvasási terjedelem teszt, mivel alkalmazható olyan gyermekeknél, akik még nem tudnak olvasni (lásd a 4-6 éves korosztállyal végzett vizsgálatokat), illetve olyan idősebb, felnőtt személyeknél, akik nem vagy nehezen tudnak olvasni látási problémák vagy egyéb okok miatt. Emellett a hallási mondatterjedelem teszt kiválóan alkalmazható mérőeljárás lehet a neuropszichológiai diagnosztikában is.

A hallási mondatterjedelem teszt magyar nyelvű változatát több mint 600 fö bevonásával határoztuk meg. Validálásához igénybe vettünk más magyar nyelvü verbális rövid távú- és munkamemória feladatokat is. Az elmélet szerint a hallási mondatterjedelem teszt az olvasási terjedelem teszttel mutatja legnagyobb hasonlóságot - mindkét teszt a komplex verbális munkamemória mérőeljárása, és ezt a kapott eredmények is alátámasztják: hasonló fejlődési profil rajzolódott ki a két tesztnél és a szakirodalmi előzményekkel összhangban az olvasási terjedelem teszttel mutatott mérsékelt erősségü korrelációt találtunk. A teszt megbízhatóságát ismételt adatfelvételekkel ellenőriztük a különböző korcsoportokban. 
Kevés olyan tanulmány született eddig, amely a teljes fejlödési spektrum ilyen sokoldalú vizsgálatával foglalkozik. A komplex munkamemóriát mérő tesztek esetében és a verbális munkamemória teszt esetében is a fejlődéssel együtt járó kapacitásnövekedést találtunk 13-15 éves korig, ami összhangban van Gathercole és munkatársai (2004), Cowan és munkacsoportja (2003), valamint Siegel (1994) kutatási eredményeivel. A hallási és az olvasási terjedelem tesztben ezek után a fejlődés üteme lelassult 19-30 éves korig, majd 3149 éves kortól kezdve időskorig fokozatos csökkenést figyeltünk meg a teszteken elért teljesítményekben. Ezt az eredményt kapták kutatásukban Chiappe, Hasher és Siegel (2000) is. A számterjedelem tesztben is változást tapasztaltunk az életkor előrehaladtával a tárolási kapacitást illetően. Néhány korábbi kutatás eredményei szerint a verbális munkamemóriához hasonlítva a komplex munkamemória később éri el a legmagasabb értékét a fejlődés során és időskorban érzékenyebb az életkori változásokra (Gathercole és mtsai, 2004; Chiappe, Hasher és Siegel, 2000). Eredményeink szerint a számterjedelem teszt esetében a kapacitás egészen 19-30 éves korig nő, tehát később éri el legmagasabb fejlődési értékét, mint a komplex munkamemória tesztekkel mért teljesítmények. 31 éves kortól időskorig fokozatos csökkenés látható, aminek életkori görbéje megegyezik a komplex munkamemória-teszteken elért eredmények profiljával.

Az általunk vizsgált tesztek alkalmasnak mutatkoztak a különböző életkori csoportok munkamemória terjedelmének mérésére, különösen hasznos mérőeljárásként szolgálhatnak gyermekek és idősek munkamemória kapacitásának feltérképezésére, mert érzékenyek az életkori változásokra (Chiappe, Hasher és Siegel, 2000; Gathercole és munkatársai, 2004). 


\section{A MÁSODIK VIZSGÁLAT}

\section{A VÉGREHAJTÓ FUNKCIÓK (BETÜFLUENCIA-TESZT) FEJLŐDÉSE GYEREKKORTÓL IDŐSKORIG}

Az alábbiakban a második vizsgálatunkat ismertetjük. Egy olyan neuropszichológiai mérőeljárást mutatunk be, ami gyakran használt vizsgálóeszköz a kognitív funkciók neuropszichológiai diagnosztikájára neurológiai és pszichiátriai kórképek esetén illetve a kísérleti pszichológiai, kognitív neuropszichológiai és idegtudományi vizsgálatokban is (Benton és Hamsher, 1989; Lezak, 1995; Spreen és Strauss, 1991).

A betüfluencia feladaton elért teljesítmény a végrehajtó funkciók fejlettségétől függ (Ruff, Light, Parker és Levin, 1997; Stuss és mtsai, 1998), melyek kora gyermekkortól kezdődően az általános iskolás évek alatt fejlődnek és kamaszkorban megközelítik a felnőtt szintet (Anderson és mtsai, 2001). Cohen, Morgan, Vaughn, Riccio és Hall (1999) szerint a betűfluencia teljesítmény szignifikánsan növekszik 6 és 12 éves kor között, Riva és Giorfi (2000) szerint pedig 5 és 11 éves kor között. Welsh, Groisse és Pennington (1988) szerint a betüfluencia feladat felnőtt szintű teljesítéséhez szükséges funkciók a prefrontális lebeny érésének utolsó állomásai, emiatt a betűfluencia teljesítmény a 18-20 éves kor körül éri el a maximumot (Kavé és mtsai, 2008). Ezzel szemben időskorban a tanulmányok nagy része progresszív életkorfüggő csökkenést talált a szavak számában (Tomer és Levin, 1993; Kozora és Cullum, 1995; Loonstra és mtsai, 2001; Lucas, Ivnik, Smith, Bohac, Tangalos, GraffRadford és Petersen, 1998; Tombaugh és mtsai, 1999).

\subsection{Célkitűzések, hipotézisek}

A második vizsgálatunkban célunk a betűfluencia feladat 5-89 év közötti életkori spektrumot lefedő vizsgálata, a teszt fejlődési görbéjének meghatározása és ezáltal életkori adatok szolgáltatása volt. Továbbá a korábbi kutatásokban vizsgált mutatókon túlmenően az újabb, részletes minőségi és mennyiségi elemzést lehetővé tevő mutatók vizsgálata is célunk volt. A vizsgálat főbb hipotézisei a következők: a gyerekek, a serdülők, a felnőttek és az idősek fejlődése eltér egymástól a betűfluencia teszten nyújtott teljesítmény tekintetében. A betűfluencia szavak száma mutató tekintetében a teljesítmény 17-18 éves életkorban eléri a felnőtt szintet és 50-69 éves kortól jelentős teljesítménycsökkenés következik be. 


\subsection{Módszerek}

\subsubsection{Minta}

A vizsgálatban összesen 562 személy vett részt (281 nö/281 férfi; 505 jobb-/48 balkezes, 9 hiányzó adat), 5 éves kortól 89 éves korig. Az előzetes szakirodalmi adatok, valamint a csoportok megfelelö elemszáma miatt a személyeket életkori övezetekbe soroltuk. A csoportok beosztása a fejlödési vizsgálatok protokollját követve gyermekkorban 2 éves bontásban történt, mivel így a fejlödés precízebb feltérképezése lehetővé vált. A felnőttek esetében 15 éves, míg az idősek esetében 20 éves bontást alkalmaztunk az életkori csoportok meghatározásakor. Az egyes életkori csoportok átlagát és szórását a 18. táblázatban mutatjuk be. Az adatgyüjtésre Csongrád és Békés megyében került sor. A tesztfelvétel előtt minden résztvevőt részletesen informáltunk a kutatás céljáról és menetéről, valamint írásbeli beleegyezést is kértünk. A vizsgálat során betartottuk a Magyar Pszichológiai Társaság által elöírt etikai szabályokat.

18. táblázat. Az életkor átlaga és szórása az egyes életkori övezetekben

\begin{tabular}{c|c}
\hline \hline Életkori csoportok & $\begin{array}{c}\text { Életkor } \\
\text { átlag (szórás) }\end{array}$ \\
\hline $5-6$ év $(\mathrm{n}=43)$ & $6,15(0,55)$ \\
\hline $7-8$ év $(\mathrm{n}=58)$ & $8,04(0,60)$ \\
\hline $9-10$ év $(\mathrm{n}=56)$ & $9,92(0,52)$ \\
\hline $11-12$ év $(\mathrm{n}=65)$ & $11,95(0,53)$ \\
\hline $13-14$ év $(\mathrm{n}=54)$ & $13,77(0,74)$ \\
\hline $15-16$ év $(\mathrm{n}=64)$ & $15,78(0,58)$ \\
\hline $17-18$ év $(\mathrm{n}=77)$ & $17,82(0,48)$ \\
\hline $19-34$ év $(\mathrm{n}=63)$ & $28,87(3,84)$ \\
\hline $35-49$ év $(\mathrm{n}=36)$ & $38,80(3,38)$ \\
\hline $50-69$ év $(\mathrm{n}=23)$ & $64,52(4,34)$ \\
\hline $70-89$ év $(\mathrm{n}=23)$ & $78,34(5,99)$ \\
\hline ÖSSZ: $(\mathrm{n}=562)$ & $20,80(17,60)$ \\
\hline \hline
\end{tabular}




\subsubsection{Méröeszközök és eljárás}

A betűfluencia feladat esetében a vizsgálati személyeknek megadott kezdőbetűkkel (K, T, A) kellett egy percen belül minél több szót mondaniuk. A betük kiválasztását a tanulmányokban található vizsgálati protokoll követése indokolta, valamint az, hogy a magyar nyelvben ezek gyakori betüknek számítanak. A vizsgálatban a következő változókat tanulmányoztuk: szavak száma, perszeverációk száma, hibák száma, klaszterek száma, klaszterek mérete, összváltások száma és klaszterváltások száma. A változók meghatározásakor elsősorban Troyer, Moscovitch és Winocur (1997), valamint Mészáros, Kónya és Kas (2011) munkáját vettük alapul.

Szavak száma - A vizsgálatban az összesen generált szavak számából kivontuk a hibák és a perszeverációk számát (Tröster és mtsai, 1998; Troyer és mtsai, 1997; Troyer, 2000; Hughes és Bryan, 2002).

Perszeverációs mutató - A perszeverációk olyan helyes szavak ismétlését jelentette, amik már korábban előfordultak a vizsgálati személy válaszában (pl. „teve, terem, teve, tányér") ahogyan azt Troyer és munkatársai (1997) is meghatározták. A vizsgálatban a variánsokat is perszeverációnak tekintettük, ami ugyanannak a szónak a különböző végződéseivel (pl. „tej, tejjel, tejbe”) történő megismétlését jelenti (Woods és mtsai, 2004; Raboutet és mtsai, 2010).

Hibázási mutató - A hibákat betolakodó hibákként definiáltuk, vagyis amikor olyan szó hangzott el, amely nem a megfelelő kezdőbetűvel (pl. „kutya, kalap, kecske, teve, kesztyü") kezdődött (Woods és mtsai, 2004). Viszont mivel Tröster és munkatársai (1998) valamint Troyer és munkatársai (1997) a perszeverációkat és a hibákat is beleszámolták a klaszterméretbe és a váltások számába, mivel úgy gondolták, hogy információkat adhatnak a mögöttes kognitív folyamatokról, ezért mi is eszerint jártunk el. Továbbá Troyer (2000) az instrukcióban kizárta a betűfluencia esetében a tulajdonnevek és ugyanannak a szónak a különböző végződésekkel való ismétléseit.

Klaszterszám mutató - A vizsgálati személyek által mondott szavakból alkotott klaszterek száma alkotja ezt a változót. A klaszterelés egy viszonylag automatikus szótároláson alapuló folyamat, amelynek vizsgálata segíthet az asszociált szóelőhívás és az új kategóriára váltás tanulmányozásában. A betűfluencia feladatban a klaszterek azon sikeresen generált szavak, amelyeknek az első két betűjük megegyezik (pl. „kalap, kakadu, kabát”), csak egy magánhangzóban különböznek, rímelnek (Troyer és mtsai, 1997; Auriacombe és mtsai, 1993; Bayles és mtsai, 1993; Grunewald és Lockhead, 1980; Raskin és mtsai, 1992). 
Klaszterméret mutató - A klaszterek mérete azt jelzi, hogy a vizsgálati személyek milyen nagyágú csoportokat hoznak létre, azaz mekkora a csoportok átlagos elemszáma. Troyer és munkatársai (1997) által kidolgozott protokoll szerint az egyes csoportok méretének meghatározása a második szónál, tehát a csoporton belüli ismétléstől kezdődik (pl. azonos kezdőbetűk alapján fonológiai klasztert alkotó „táj, tányér, táltos” esetén a csoportméret =2). A csoport mérete tehát a csoportot alkotó szavak száma mínusz egy. A klaszterméretbe Troyer és munkatársai pontozási rendszerétől eltérően jelen vizsgálatban a perszeverációk és a hibázások nem számítanak bele a klaszterméretbe, valamint az önálló szavak sem (Reverberi és mtsai, 2006; Sauzéon és mtsai, 2004; Fossati és mtsai, 2003; Koren és mtsai, 2005).

Összváltásszám mutató - A váltás egy viszonylag nagy erőfeszítést kívánó folyamat, amely a stratégiakeresésen és a mentális flexibilitáson alapul és a lelassulás elkerülése miatt következik be (Troyer és mtsai, 1997; Troyer, 2000). A feladat számos alkategória keresésének megkezdését magában foglalja, valamint a szavak előhívását ezen alkategóriákból, illetve a hatékony váltást is egyik kategóriáról a másikra (Troyer és mtsai, 1997). Abwender és munkatársai (2001) módszerükben megkülönböztettek kétféle váltástípust, és ezeket külön-külön kódolták. Az egyik az ún. klaszterváltás, ami a szomszédos klaszterek közötti váltást jelenti (pl. „teve, tetü, terasz, | tál, tábla” sorozatban). A másik típus az éles váltás, amely egy klaszter és egy nem klaszterbe sorolt szó (pl. „tehén, terep, | takaró, tinta”) vagy két nem csoportosított szó között jelenik meg (pl. „tengerimalac, | tarkó”). Vizsgálatunkban Abwenderék kódolási rendszerét követve a klaszterváltásokat és az éles váltásokat külön-külön számoltuk, és ezeket összeadva kaptuk meg az összváltások számát. A váltások számának meghatározásánál figyelembe vettük a hibákat és ismétléseket is.

Klaszterváltás mutató - Abwender és munkatársai (2001) alapján tehát a klaszterváltás átmeneteket jelent a szomszédos klaszterek között (pl. „,teve, terasz, | tál, tábla”). Mivel a generált szavak száma befolyásolhatja a 2-7 mutatók értékét, ezért minden esetben leosztottunk a szavak számával, kivétel ez alól a klaszterméret mutató, ahol pedig a klaszterek számával történt a korrigálás.

A betüfluencia feladat esetében arra kértük a vizsgálati személyeket, hogy megadott kezdőbetűkkel (K, T, A) egy percen belül minél több szót mondjanak. Fontos kritériumként szerepelt, hogy nem mondhattak tulajdonneveket és ugyannak a szónak a különböző végződéseit sem. Az instrukció a következőképpen hangzott: „Arra kérem, hogy mondjon annyi szót amennyi csak eszébe jut 1 perc alatt, ami „K” betűvel kezdődik! Tulajdonneveket nem mondhat, valamint ugyanazt a szót sem mondhatja különböző végződésekkel!" 
Az instrukció elhangzása után megkérdeztük a vizsgálati személyeket, hogy megértették-e a feladatot és az adatfelvétel csak akkor kezdődött, amikor erről megbizonyosodtunk. 5-7 éves gyerekek esetében példákat mondtunk annak érdekében, hogy megkönnyítsük a feladat megértését.

\subsubsection{Statisztikai eljárás}

Az eredmények elemzésekor minden esetben 3 x 11 x 2 kevert mintás varianciaanalízist használtunk, ahol a FELADAT (pl. „K, T, A”) az összetartozó mintás faktor, és az ÉLETKORI CSOPORT (1. 5-6 év, 2. 7-8 év, 3. 9-10 év, 4. 11-12 év, 5. 13-14 év, 6. 15-16 év, 7. 17-18 év, 8. 19-34 év, 9. 35-49 év, 10. 50-69 év, 11. 70-89 év) illetve NEM (nő, férfi) a csoportosító változó. Ezeknél az elemzéseknél Greenhouse-Geisser korrekciót, valamint Fisher-féle LSD post hoc tesztet használtunk, amikor szükséges volt.

\subsection{Eredmények}

Az eredmények bemutatásakor a következő sorrendet követtük: szavak száma, perszeverációk száma, hibák száma, klaszterek száma, klaszterek mérete, összváltások száma, klaszterváltások száma. A zárójelen belül a számok az átlagot jelölik, a $p$ pedig az átlagok közti különbségek szignifikancia szintjét.

A betüfluencia szavak száma mutató tekintetében összességében a vizsgálati személyek a három betüfluencia feladaton más mennyiségü szót mondtak (szignifikáns FELADAT föhatás: $F(1,96,1058,62)=164,40, p<0,001)$. Az LSD post hoc teszt alapján megállapítható, hogy a legtöbb szót a „K” (átlagosan 11,89), majd a „T” fluencia feladaton (átlagosan 10,39) mondtak, a legkevesebbet pedig az „A” fluencia feladaton (átlagosan 8,55).

Az életkori csoport föhatás szignifikáns volt (szignifikáns ÉLETKORI CSOPORT föhatás: $F(10,540)=73,26, p<0,001)$, összességében a szavak számában változás volt megfigyelhető az életkori csoportok között. 5 éves kortól 11-12 éves korig a gyerekek különbözően teljesítettek az egyes életkori csoportokban $(p<0,001)$. Az 5-6 évesek átlagosan csak két szót tudtak produkálni, míg a 7-8 évesek már 4,76 szót mondtak átlagban. A 9-10 éveseknél már közel 8 volt az átlagos teljesítmény, míg a 11-12 éves gyerekek elérték a 9,84 átlagos teljesítményt. A 11-12 és a 13-14 éves csoportok között nem találtunk szignifikáns különbséget $(p=0,42)$, teljesítményük hasonló volt. A 13-14 és 17-18 éves kor között a csoportok szignifikánsan különböztek egymástól ( $p<0,001)$. 13-14 éves korban több mint 10 szót tudtak mondani. 15-16 éves korban átlagosan 12,84 szót tudtak mondani, 17-18 éves 
korra ez már elérte a 14,26-ot. A 17-18 és a 19-34 éves csoport közel azonos teljesítményt nyújtott $(p=0,60)$. A 19-34 és a 35-49 éves korcsoport szignifikánsan különbözött egymástól $(p=0,02)$, ahogyan a 35-49 és az 50-69 évesek is $(p<0,001)$ tehát ezen életkori csoportoknál lépcsőzetes növekedést láthatunk a teljesítményben. Fiatal felnőttkorban az átlagos érték 14,56, ami felnőtt korra tovább emelkedett 16,26-ra, majd pedig 5069 éves korban csökkenés volt megfigyelhető a teljesítményben, ami 10,05-re esett vissza átlagosan, végül a legidősebb korosztályban 10,10 volt az átlagos teljesítmény. 50-69 és 70-89 éves korig az egyes életkori csoportok hasonló teljesítményt nyújtottak $(p=0,95)$.

A FELADAT és az ÉLETKORI CSOPORTOK interakciója esetében az egyes életkori csoportok is különböztek egymástól a szavak számát figyelembe véve (szignifikáns FELADAT x ÉLETKORI CSOPORT interakció: $F(19,60,1058,62)=7,77, p<0,001)$. A „K” fluencia feladaton 9-10 éves korban szignifikánsan több szót mondtak, mint az „A” fluencia feladaton, míg az új szavak száma a „K” feladaton csak tendenciaszinten volt több, mint a „T”- feladaton $(p=0,06) .11-12$ éves korban is a „K” feladaton produkálták a legtöbb szót és az „A” feladaton a legkevesebbet (minden $p<0,01$ ). A 13-14 éves korcsoportban a „K” és a „T” feladaton is szignifikánsan több szót produkáltak az „A”-feladathoz képest (minden $p<0,001)$. 15-16 és 70-89 éves kor között is hasonló mintázat volt megfigyelhető: a vizsgálati személyek a legtöbb szót a „K” feladaton mondták, ennél szignifikánsan kevesebbet a „T” feladaton és a legkevesebbet az „A” feladaton (minden $p<0,025$; lásd 5 . ábra).

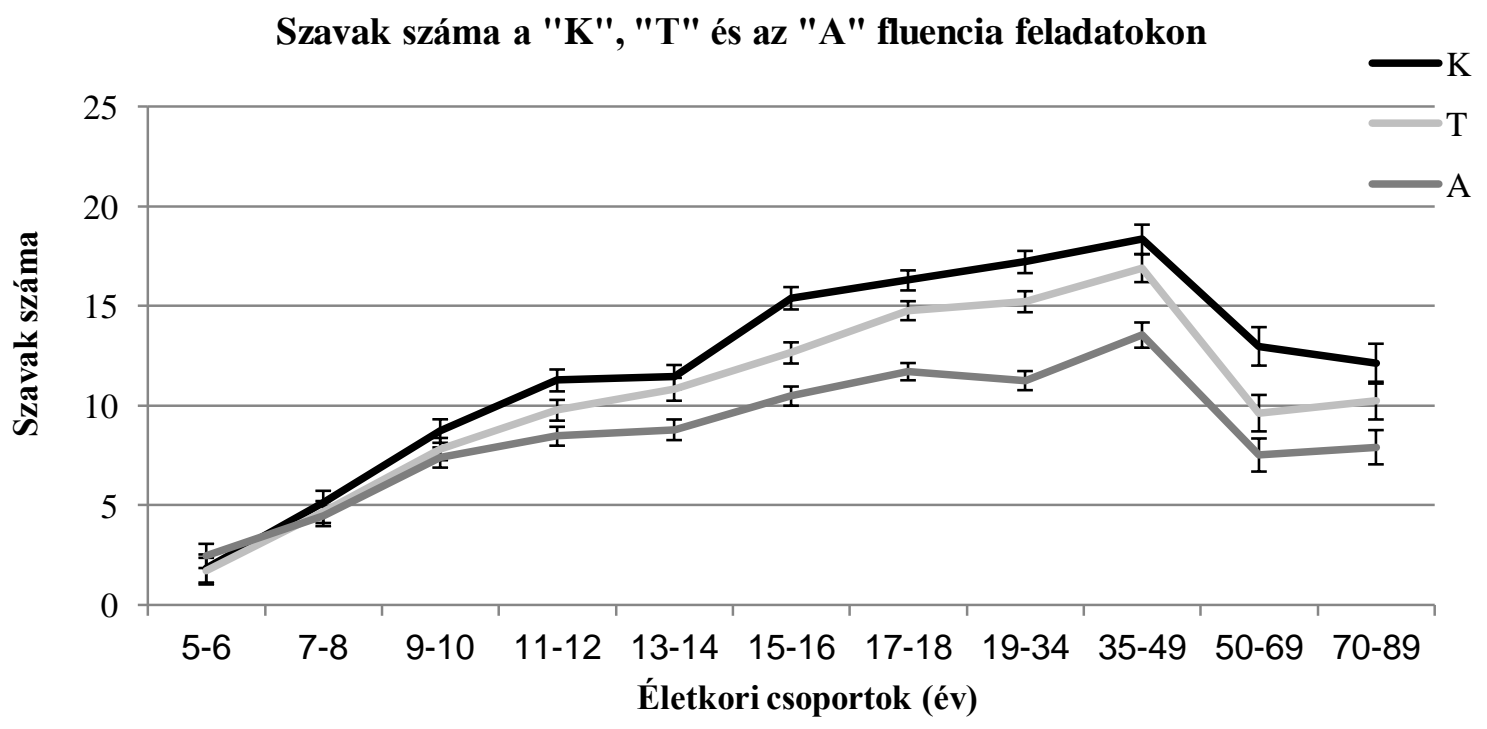

5.ábra

A szavak száma életkori csoportonként a „K”, $a$ „,T” és az „, $A$ ” fluencia feladaton. A szóródási mutató az átlag standard hibája 
A „K” fluencia feladaton a gyerekek 5-6 éves kortól 11-12 éves korig különbözően teljesítettek (minden $p<0,002$ ), 11-12 és 13-14 éves korban a csoportok teljesítménye közel azonos volt $(p=0,83)$. A gyerekek 13-14 és 15-16 éves kor között is különbözöen teljesítettek ( $p<0,001$ ), majd 15-16 éves kortól 35-49 éves korig hasonló volt a teljesítmény (minden $p<0,22)$. 50-89 éves korban közel azonos volt a teljesítmény ( $p=0,53$; lásd 5a. ábra), amely életkorban már visszaesés volt tapasztalható a teljesítményben (a pontos átlagokat és szórásokat korcsoportonként és feladatonként lásd a 2a mellékletben).

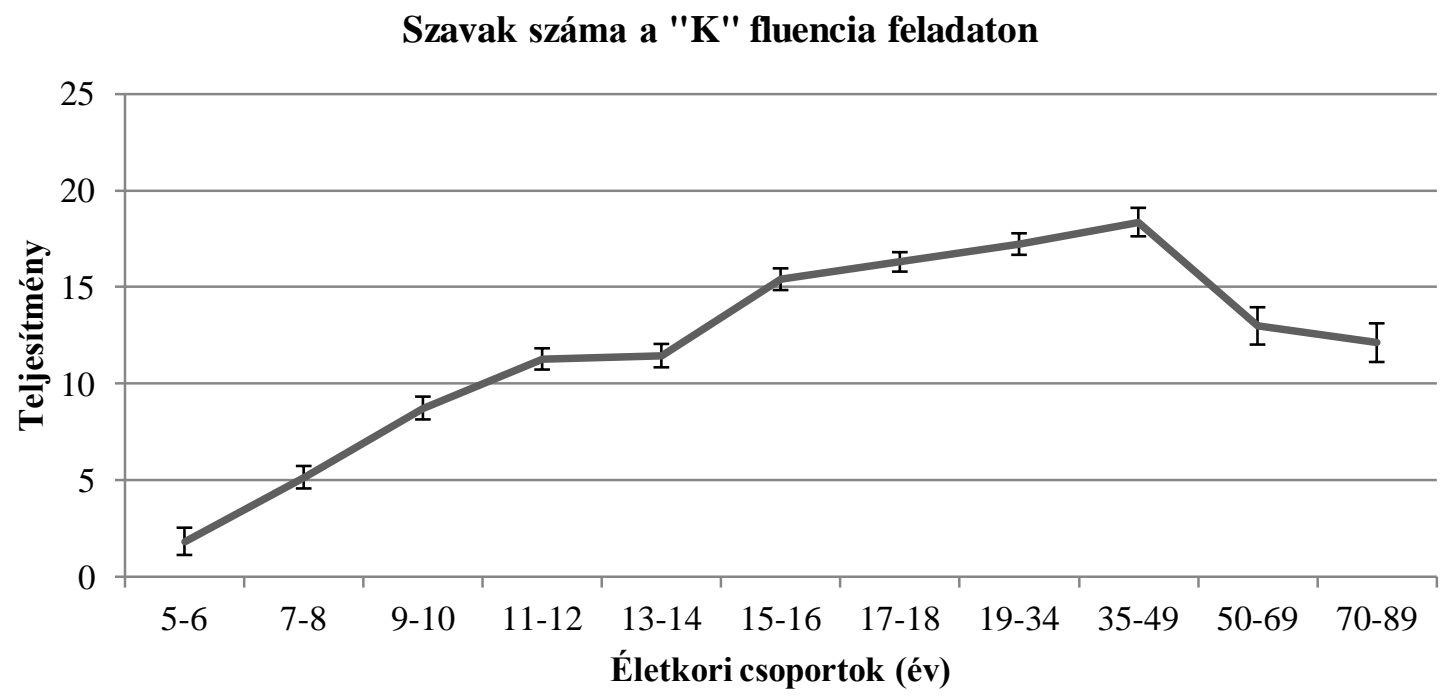

$5 a$ a ábra
A szavak száma életkori csoportonként a „K” fluencia feladaton. A szóródási mutató az átlag
standard hibája

A „T” fluencia feladaton (lásd 5b. ábra) a 11-12 éves korosztályig a csoportok teljesítménye különbözött, az életkor növekedésével egyre több szót produkáltak (minden $p<0,01), 11-14$ éves korban egy szinten maradt a teljesítmény $(p=0,17)$, majd 13-14 és 17-18 éves kor között újabb szignifikáns növekedés volt (minden $p<0,02) .19$ és 49 éves kor között csak tendenciaszerü különbség volt megfigyelhető a csoportok között $(p=0,05)$, majd 3569 éves kor közötti csoportoknál ismét szignifikáns volt a különbség ( $p<0,001)$. Az 50-69 és a 70-89 éves kor közötti csoportok hasonló mennyiségü szót produkáltak ( $p=0,63$; lásd $2 \mathrm{~b}$. melléklet). 


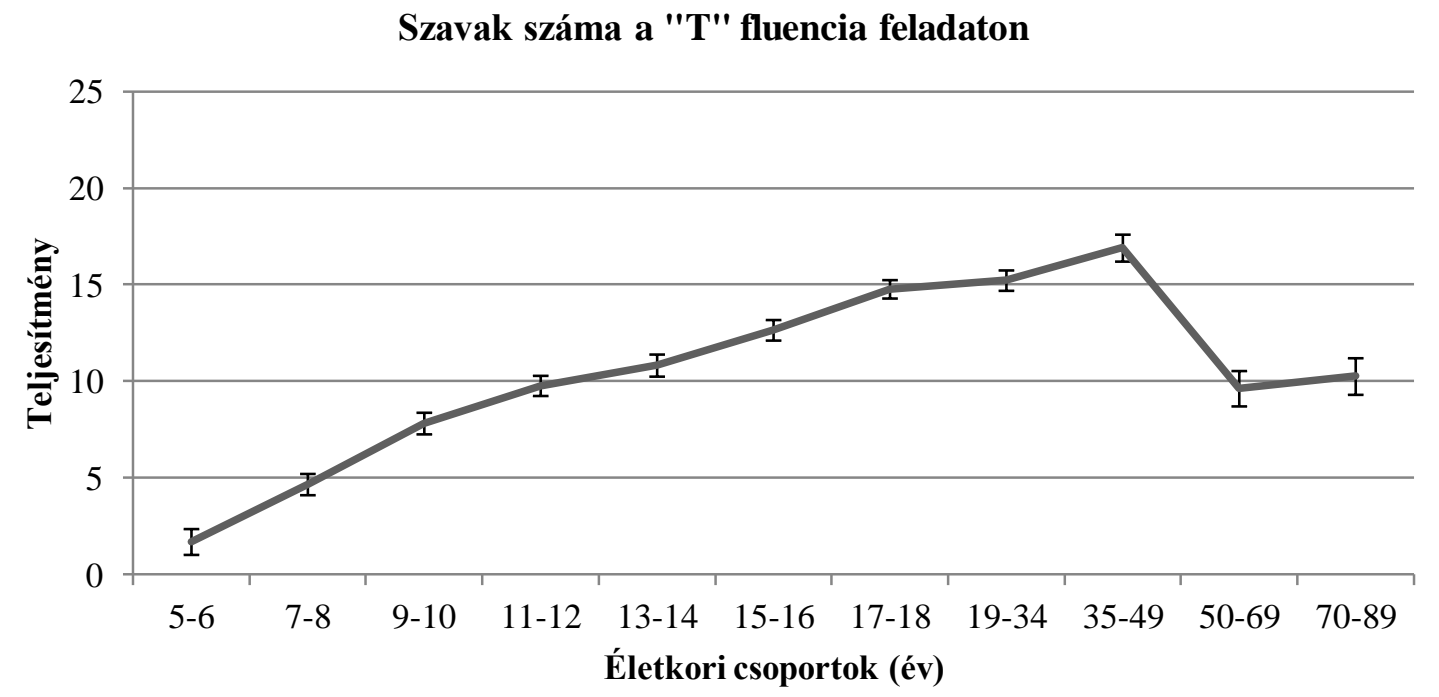

5b. ábra

A szavak száma életkori csoportonként a „,T” fluencia feladaton. A szóródási mutató az átlag standard hibája

Az „A” feladatnál (5c. ábra) hasonló mintázat volt látható, vagyis hogy az 5-6 és a 78 évesek különböző számú szót mondtak $(p=0,01)$, ahogyan a 13-14 és a 15-16 évesek ( $p$ =0,02). Ezt követően 19-69 éves egy újabb növekedés volt megfigyelhető a teljesítményben (minden $p<0,002$ ), majd 50-89 éves korra szintén visszaesett a teljesítmény ( $p=0,74$; lásd $2 \mathrm{c}$. melléklet).

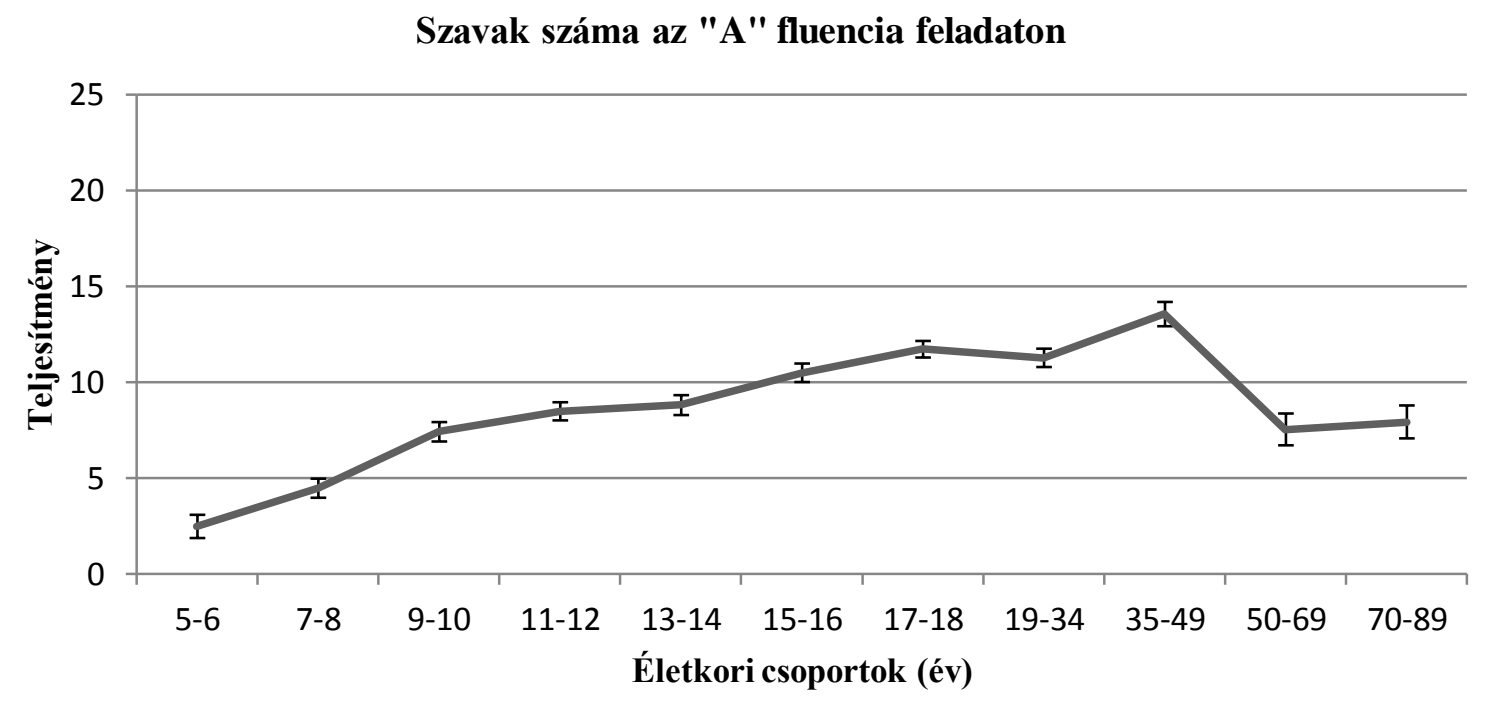

5c. ábra

A szavak száma életkori csoportonként az „A ” fluencia feladaton. A szóródási mutató az átlag standard hibája 
A betüfluencia perszeverációs mutatón összességében a vizsgálati személyek a három betüfluencia feladaton hasonló mennyiségü perszeverációt produkáltak (nincs szignifikáns FELADAT főhatás: $(F(1,92,1000,45)=1,981, p=0,14)$. Az LSD post hoc teszt alapján a legtöbb perszeverációt a „K” (átlagosan 0,28), majd a „A” fluencia feladaton (átlagosan 0,25) mondtak, a legkevesebbet pedig az „T” fluencia feladaton (átlagosan 0,24).

Az életkori csoportok esetében szignifikáns főhatás volt (szignifikáns ÉLETKORI CSOPORT föhatás: $(F(10,521)=4,16 ; p<0,001)$. Összességében a perszeverált szavak számában volt változás az életkori csoportok között. 5-6 és 15-16 éves kor között nem volt különbség a csoportok között a perszeverációk számában (minden $p>0,08$ ). Az 5-6 évesek perszeverációs mutatója átlagosan 0,002 volt, ami 7-8 éves korban átlagosan 0,009-re emelkedett. 9 és 16 éves kor között a perszeverációs mutató 0,02 volt. A 17-18 és a 19-34 éves korcsoport között tendenciaszerü különbség volt $(p=0,05)$ : 17-18 éves korban a perszeverációs mutató átlagban 0,01, majd 19-34 éves korban újra megemelkedett, átlagban 0,02, és azonos mértékü maradt 35-49 éves korban is. A két legidősebb korcsoport, tehát az 50-69 és a 70-89 éves korcsoport között szignifikáns különbség volt ( $p=0,001)$. 50-69 éves korban még közel azonos teljesítményt nyújtottak, mint a megelőző életkori csoportban, viszont a legidősebb 70-89 éves korcsoportban nagyon megnőtt a perszeverációs mutatók száma, átlagban 0,05 volt.

A FELADAT x ÉLETKORI CSOPORT interakció vizsgálatakor az egyes életkori csoportok nem különböztek egymástól a perszeverációs mutatót figyelembe véve $(\mathrm{F}(19,20$, 1000,45)=1,26, p=0,2). (lásd 6a., 6b., és 6c. ábra, továbbá a pontos átlagokat és szórásokat korcsoportonként és feladatonként lásd a 3a., 3b., és 3c. mellékletben.) 
Perszeverációs mutató a "K" fluencia feladaton

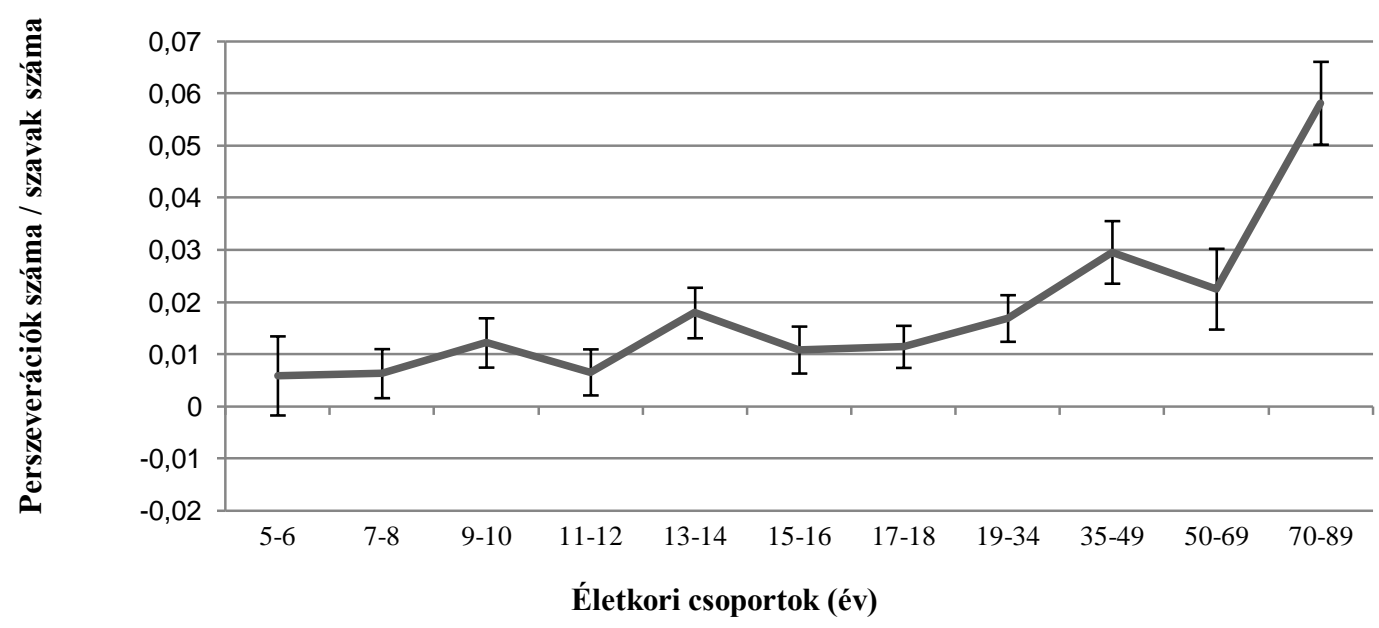

6a. ábra

A perszeverációs mutatók életkori csoportonként a „K” fluencia feladaton. A szóródási mutató az átlag standard hibája

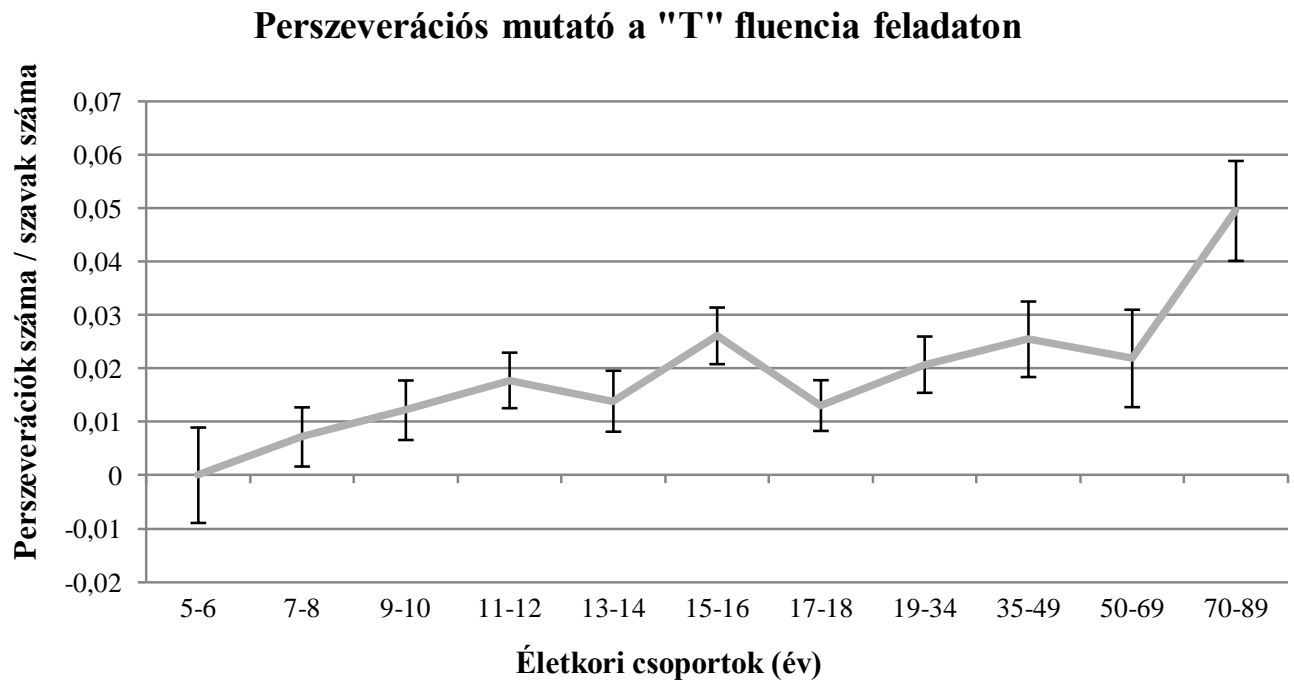

6b. ábra

A perszeverációs mutatók életkori csoportonként a „,T" fluencia feladaton. A szóródási mutató az átlag standard hibája 


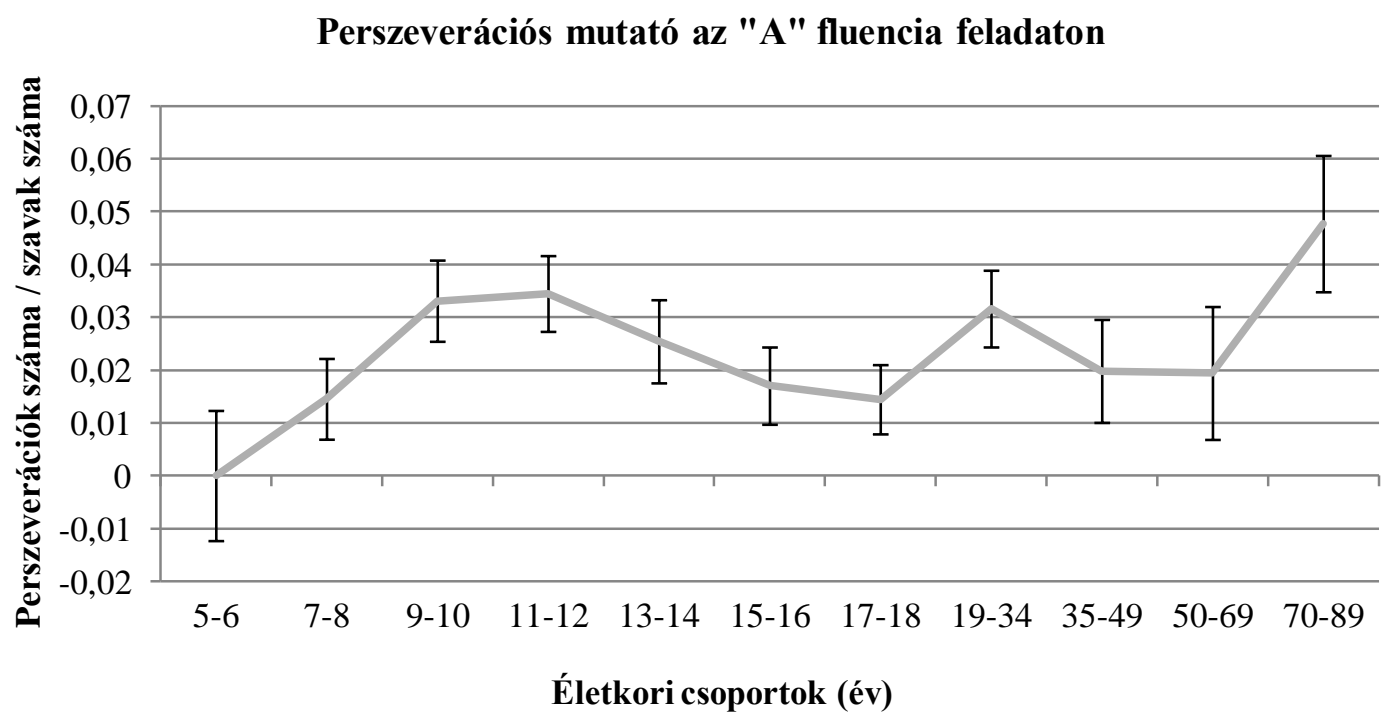

\section{6c. ábra \\ A perszeverációs mutatók életkori csoportonként az „A " fluencia feladaton. A szóródási mutató az átlag standard hibája}

A betűfluencia hibázási mutató tekintetében összességében a vizsgálati személyek a három betüfluencia feladaton más mennyiségű hibás szót mondtak (szignifikáns FELADAT föhatás: $F(1,99,1008,88)=4,69, p<0,01$. Az LSD post hoc teszt alapján megállapítható, hogy a hibázási mutató az „A” betüfluencia feladat esetében volt a legmagasabb (átlagosan 0,05), ezt követte a „T” fluencia feladat (átlagosan 0,04), a legalacsonyabb pedig az „K” fluencia feladaton volt (átlagosan 0,03).

Az egyes életkori csoportok is különböztek egymástól a hibázási mutatót tekintve (szignifikáns ÉLETKORI CSOPORT föhatás: $(F(10,522)=7,60, p<0,001)$. 5-6 éves kortól 910 éves korig a csoportok szignifikánsan különböztek egymástól (minden $p<0,008$ ). 9-10 éves kortól egészen 70-89 éves korig viszont a különböző életkori csoportokban a teljesítmény nem különbözött (minden p>0,37). Az 5-6 évesek esetében a hibázási mutató átlagosan 0,16 volt, míg a 7-8 éveseknél már csak 0,09. A 9-10 évesek esetében tovább csökkent ez az érték 0,05-re, a 11-12 éves gyerekeknél pedig 0,03 volt. 13 és 18 éves kor között a hibázási mutató 0,02 volt. 19-34 éves korban az átlagos érték 0,03, ami 35-49 éves korban 0,01-re csökkent, majd pedig 50-69 éves korban 0,02 volt, ami 0,04-re emelkedett a legidősebb korosztály esetében.

A FELADAT $\mathrm{x}$ ÉLETKORI CSOPORT interakciónál nem volt szignifikáns különbség $(F(20,1044)=1,08, p=0,36)$ vagyis az egyes életkori csoportok nem különböztek egymástól abban, hogy mennyi hibás szót mondtak a „K”, „T” illetve az „A” feladaton (lásd a 
7a., 7b., és 7c. ábrán, valamint a pontos átlagokat és szórásokat korcsoportonként és feladatonként lásd 4a., 4b., és 4c. mellékletben).

Hibázási mutató a "K" fluencia feladaton

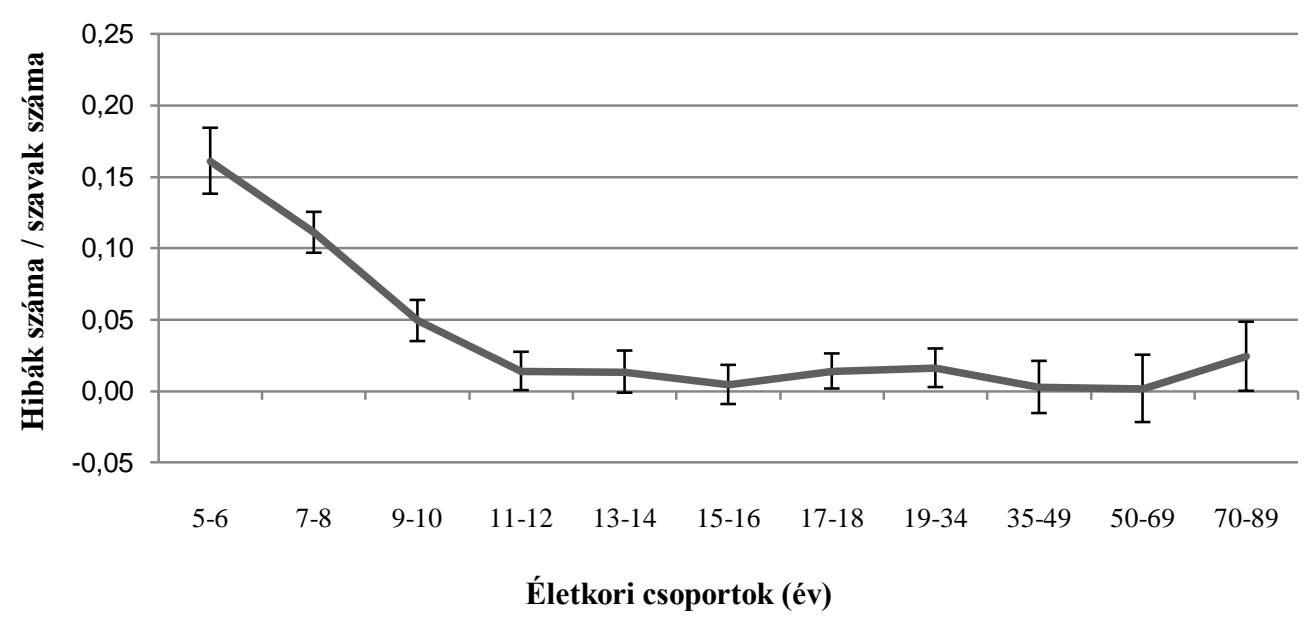

7a. ábra

A hibázási mutatók életkori csoportonként a „K” fluencia feladaton. A szóródási mutató az átlag standard hibája

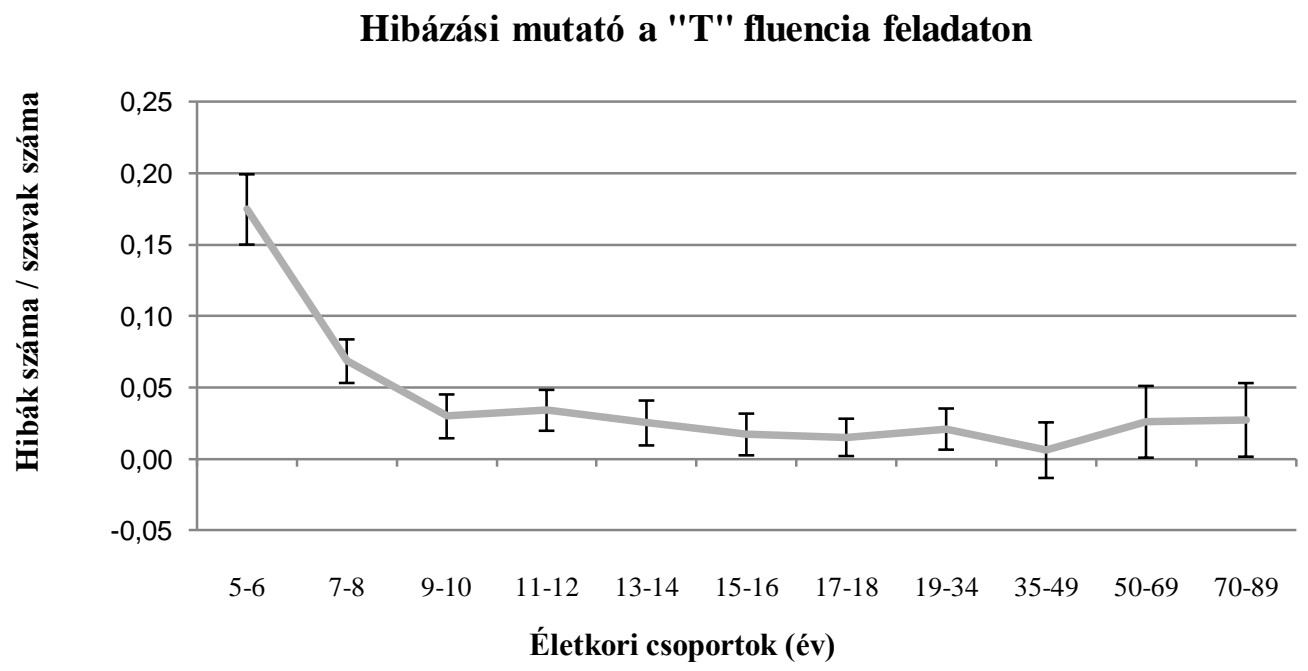

7b. ábra

A hibázási mutatók életkori csoportonként a „,T” fluencia feladaton. A szóródási mutató az átlag standard hibája 
Hibázási mutató az "A" fluencia feladaton

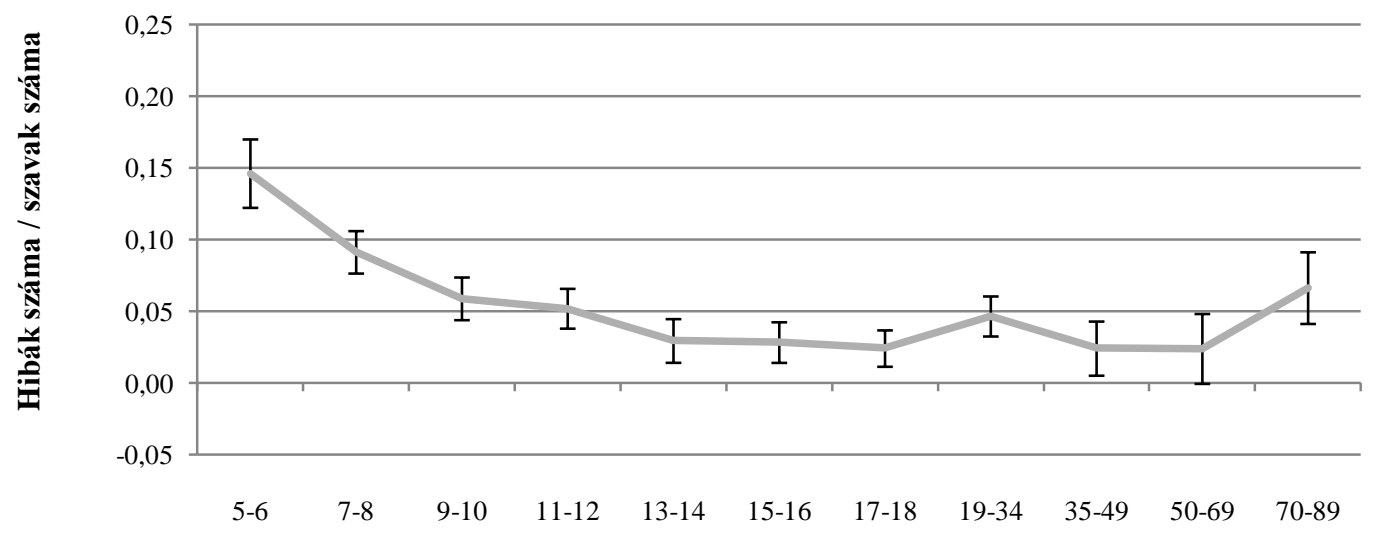

Életkori csoportok (év)

7c. ábra

A hibázási mutatók életkori csoportonként az „, A fluencia feladaton. A szóródási mutató az átlag standard hibája

A betüfluencia klaszterszám mutató tekintetében összességében a vizsgálati személyek a három betűfluencia feladaton hasonló mennyiségü klasztert alkottak (nem volt szignifikáns FELADAT főhatás: $F(1,97,104)=0,08, p=0,92)$.

Az egyes életkori csoportok viszont különböztek egymástól a klaszterszám mutató tekintetében (szignifikáns ÉLETKORI CSOPORT főhatás: $F(10,520)=3,49, p<0,001$ ), tehát összességében a klaszterek számában volt változás az életkori övezetek között. Az eredményeket tekintve azt találtuk, hogy az 5-6 évesek teljesítménye csak tendenciaszinten különbözött a 7-8 évesekétöl ( $p=0,09)$, ahogyan a 9-10 és a 11-12 évesek esetében is $(p=0,10)$. Az 5-6 évesek klaszterszám mutatója átlagosan 0,10 volt, míg a 7-8 éveseknél átlagosan 0,125 volt. 9-10 éves korban már $0,13,11-12$ évesen pedig átlagosan 0,151 , a 13 14 éves korosztály esetében pedig 0,16 volt. 13-14 és 15-16 éves korban szintén tendenciaszerü különbséget találtunk $(p=0,09)$. Közel azonos teljesítményt nyújtott a 15-16 és a 17-18 éves korcsoport (0,16 vs. 0,15$)$. Fiatal felnőttkorban, tehát 19-34 éves korban 0,14 volt a klaszterszám mutató, és 35-49 éves korban is hasonló volt a teljesítmény, átlagosan 0,14. Csökkent a klaszterszám mutató 50-69 éves korban, átlagban 0,12-re, majd tovább esett a teljesítmény 70-89 éves korban, átlagban 0,09-re. 15-16 éves kortól egészen 70-89 éves korig a csoportok hasonló teljesítményt nyújtottak (minden $p>0,14$ ).

A FELADAT $x$ ÉLETKORI CSOPORT interakció esetében az egyes életkori csoportok csak tendenciaszinten különböztek egymástól a klaszterszám mutatót figyelembe véve $(F(19,75,1027,14)=1,51, p=0,07)$, vagyis abban, hogy mennyi klasztert alkottak a „K”, 
„T” és az „A” feladaton. Az 5-6 évesek átlagosan több klasztert alkottak a „K” (átlagosan $0,14)$, mint a „T” feladaton $(p<0,001)$, és szignifikánsan több klasztert alkottak a „T” (átlagosan 0,12), mint az „A” feladaton $(p=0,01)$. A 17-18 évesek több klasztert alkottak a „T” feladaton (átlagosan 0,17$)$ mint a „K” feladaton $(p=0,02)$, valamint több klasztert produkáltak a „T” mint az „A” feladaton $(p=0,03) .19$ éves kortól kezdve egészen 89 éves korig a csoportok teljesítménye nem különbözött egymástól az egyes betüfluencia feladatokon (minden $p>0,28$ ).

Az életkori csoportokat összehasonlítva az egyes feladatoknál a „K” fluencia feladaton (8a. ábra) a szomszédos életkori csoportok esetében hasonló volt a teljesítmény (minden $p>0,12$; lásd 5. melléklet). Azonban a 7-8 évesek teljesítménye szignifikánsan különbözött mind a 11-12 évesek, mind pedig a 13-14 évesek klaszterszám mutatójától (minden $p<0,02$ ), az életkor előrehaladtával a klaszterek száma nőtt. A 11-12, 13-14 és a 15-16 éves gyerekek teljesítménye szignifikánsan különbözött a 70-89 éves korcsoport klaszterszám mutatójától (minden $p<0,02$ ).

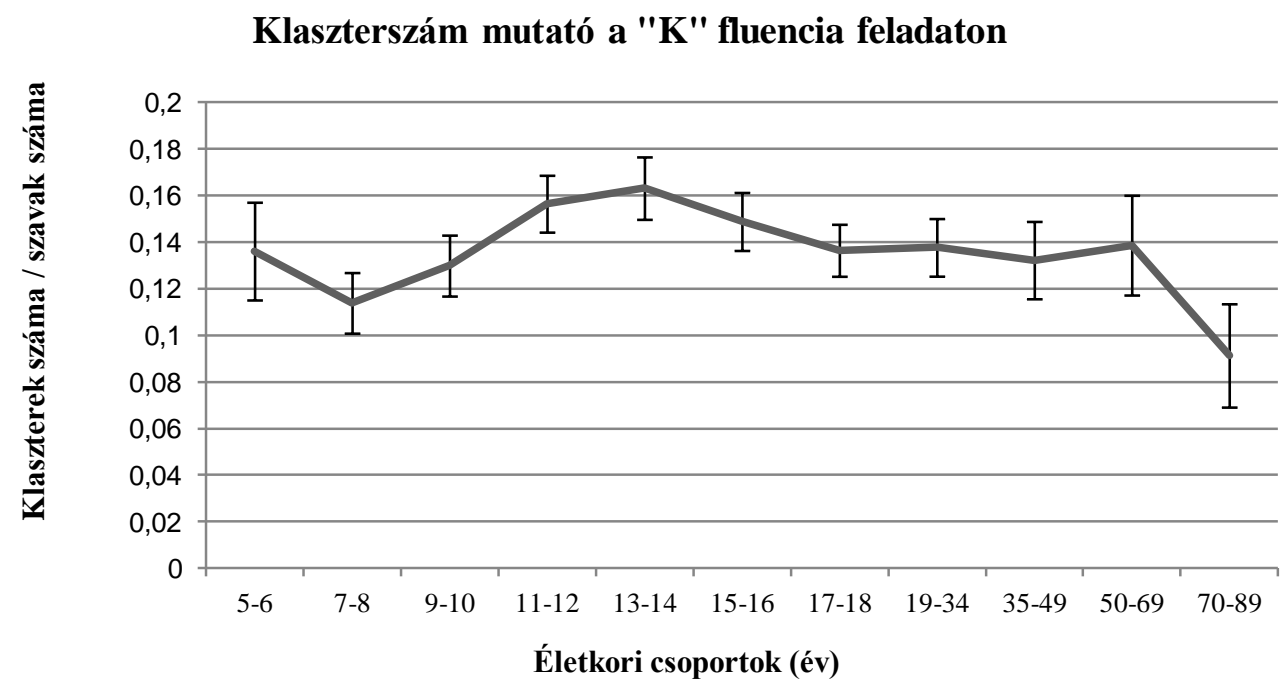

8a. ábra

A klaszterszám mutatók életkori csoportonként a „K” fluencia feladaton. A szóródási mutató az átlag standard hibája

A „T” fluencia feladaton (lásd 8b. ábra) 5-6 éves és a 7-8 éves korcsoport között szignifikáns különbség volt $(p=0,001)$. Az 5-6 évesek teljesítménye szignifikánsan különbözött minden életkori csoporttól (minden $p<0,003$ ), kivéve a legidősebb korosztályt, ahol tendenciaszerü különbséget találtunk $(p=0,05)$. 7-8 éves kortól pedig 70-89 éves korig a csoportok közel azonos szinten teljesítettek a klaszterszám mutató tekintetében (minden $p>0,14$; lásd 5b. melléklet). 


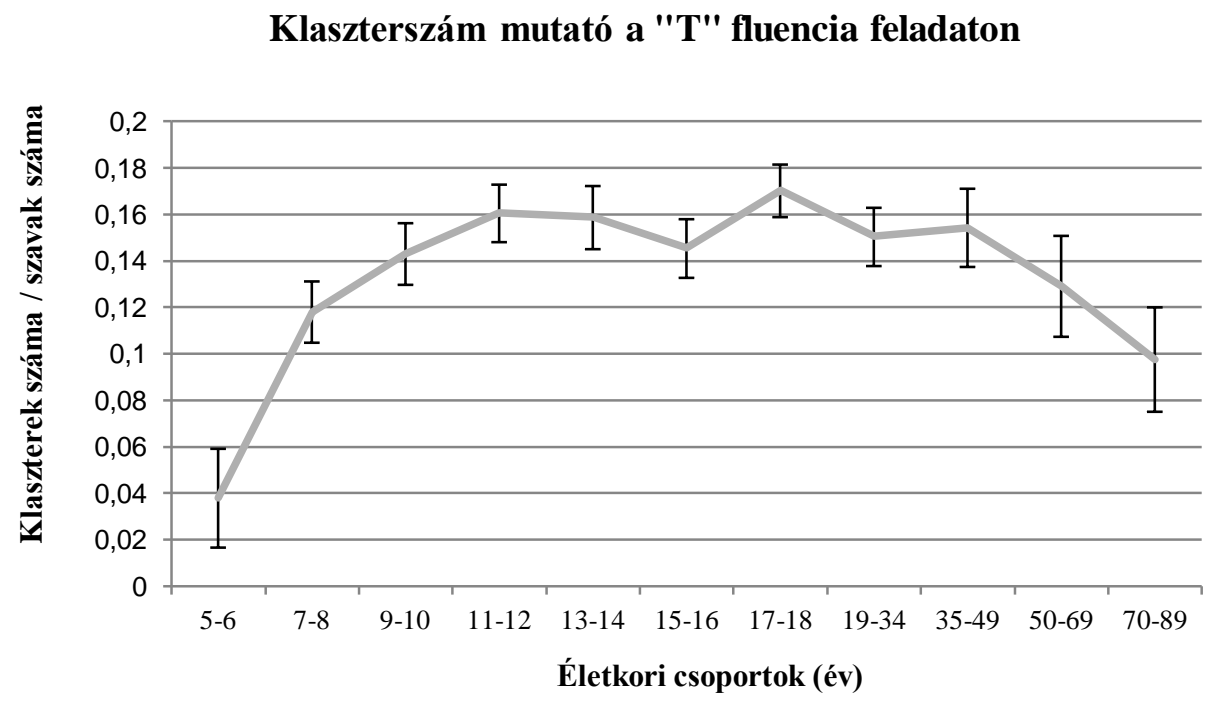

8b. ábra

A klaszterszám mutatók életkori csoportonként a „T” fluencia feladaton. A szóródási mutató az átlag standard hibája

Az „A” feladatnál (lásd 8c. ábra) 5-6 éves kortól 11-12 éves korig a csoportok nem különböztek egymástól (minden $p>0,23$ ), de a 11-12 éves és a 13-14 éves korcsoport között szignifikáns volt a különbség ( $p=0,05)$. 13-16 év között már csak tendenciaszerü különbség volt $(p=0,08)$. 15-16 éves kortól kezdve egészen idős korig a csoportok közel azonos szinten teljesítettek a klaszterszám mutatót tekintve (minden $p>0,12$; lásd 5c. melléklet).

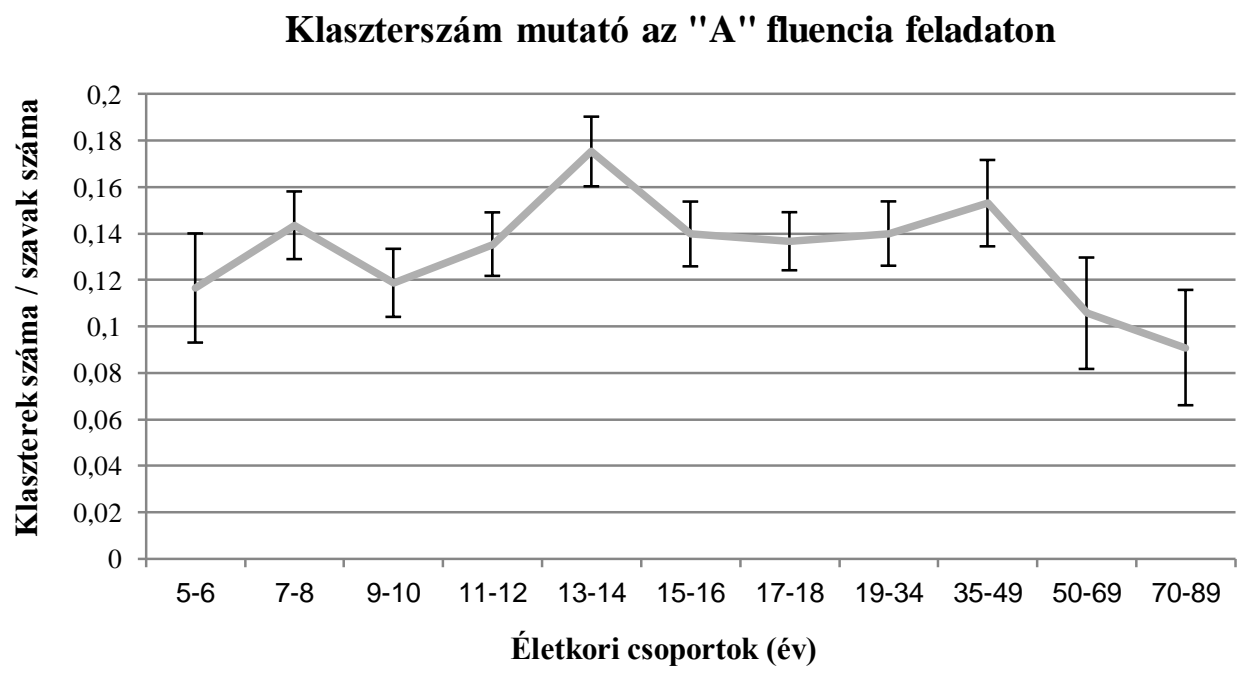

8c. ábra

A klaszterszám mutatók életkori csoportonként az „, A fluencia feladaton. A szóródási mutató az átlag standard hibája 
A klaszterméret mutató tekintetében összességében a vizsgálati személyek a három betüfluencia feladaton hasonló méretü klasztereket alkottak (nem volt szignifikáns FELADAT fóhatás: $F(1,94,548,81)=1,04, p=0,93)$.

Az ÉLETKORI CSOPORT föhatás szignifikáns volt $(F(10,278)=3,78, p<0,001)$, tehát az egyes életkori csoportok különböztek egymástól a létrehozott klaszterek méretét illetően. 5-6 éves kortól 9-10 éves korig a gyerekek teljesítménye a klaszterméret mutatót tekintve nem különbözött egymástól (minden p>0,14), viszont az 5-6 és a 9-10 évesek között tendenciaszerü különbséget találtunk. Az 5-6 évesek klaszterméret mutatója átlagosan 0,42, míg a 7-8 éveseké átlagosan 0,96 volt. A 9-10 évesek esetében volt a legnagyobb a klaszterméret mutató, átlagosan 1,03. A 11-12 és 13-14 éves korcsoport teljesítménye között viszont szignifikáns különbséget találtunk. A 11-12 éves gyerekeknél átlagosan 0,90 volt a klaszterméret mutató, ami 13-14 éves korban lecsökkent 0,71-re, 15-16 éves kortól 70-89 éves korig viszont a csoportok teljesítménye nem különbözött egymástól szignifikánsan (minden $p>0,13$ ). 15-16 és 17-18 éves korban a klaszterméret mutató átlagosan 0,74 volt. A klaszterméret mutató 19-34 éves korban 0,70, 35-49 éves korban 0,64, majd 50-69 év között 0,84, 70-89 éves korban pedig 0,53 volt.

A FELADAT $\mathrm{x}$ ÉLETKORI CSOPORT interakciója esetében az egyes életkori csoportok nem különböztek egymástól a klaszterméretet figyelembe véve $(F(20,556)=1,13$, $p=0,31)$.

Az életkori csoportok összehasonlításakor a „,K” fluencia feladaton (lásd 9a. ábra) a 11-12 (átlagosan 0,97) és a 13-14 évesek (átlagosan 0,69) teljesítménye szignifikánsan különbözött $(p=0,03)$. 13-14 éves kortól 70-89 éves korig azonban a különböző életkori csoportok hasonló teljesítményt nyújtottak (minden $p>0,37$; lásd 6a. melléklet). 


\section{Klaszterméret mutató a "K" fluencia feladaton}

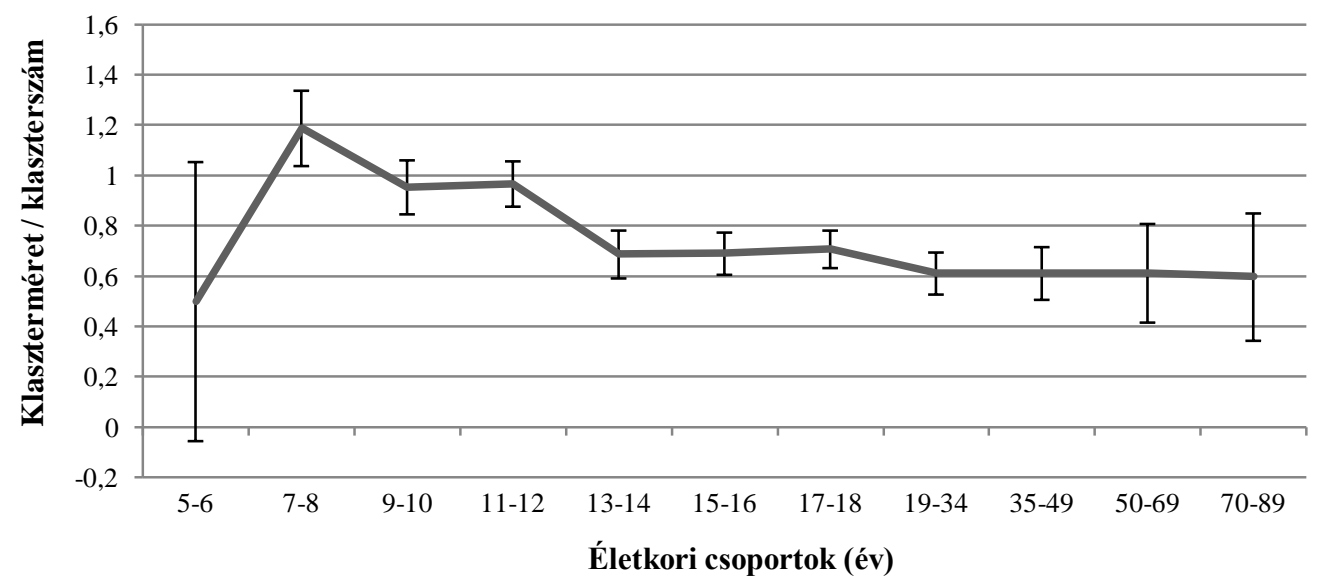

9a. ábra

A klaszterméret mutatók életkori csoportonként a „K” fluencia feladaton. A szóródási mutató az átlag standard hibája

A „T” fluencia feladaton (lásd 9b. ábra) a csoportok hasonlóan teljesítettek (minden p>0,20; lásd 6b. melléklet).

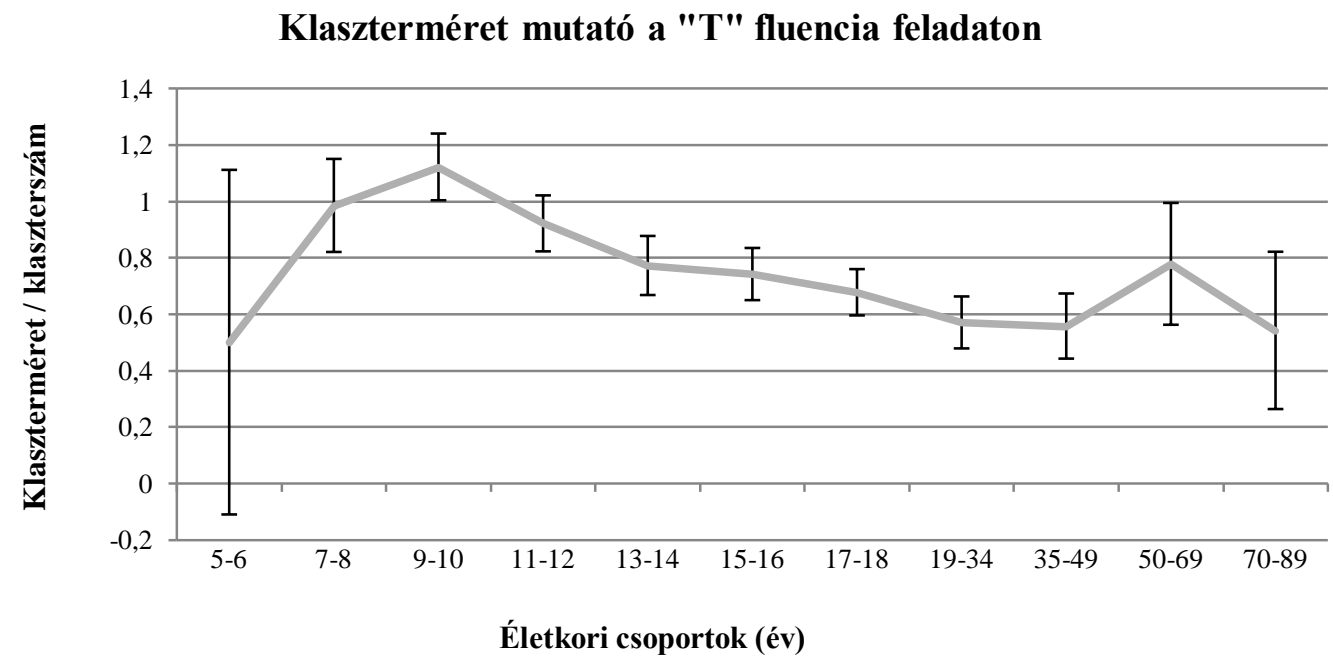

9b. ábra

A klaszterméret mutatók életkori csoportonként a „T" fluencia feladaton. A szóródási mutató az átlag standard hibája

Az „A” fluencia feladaton (lásd 9c. ábra) 5-6 éves kortól 50-69 éves korig a csoportok hasonlóan teljesítettek (minden $p>0,12$ ), azonban 50-69 és 70-89 éves kor között tendenciaszerü különbséget találtunk ( $p=0,06$; lásd 6c. melléklet). 
Klaszterméret mutató az "A" fluencia feladaton

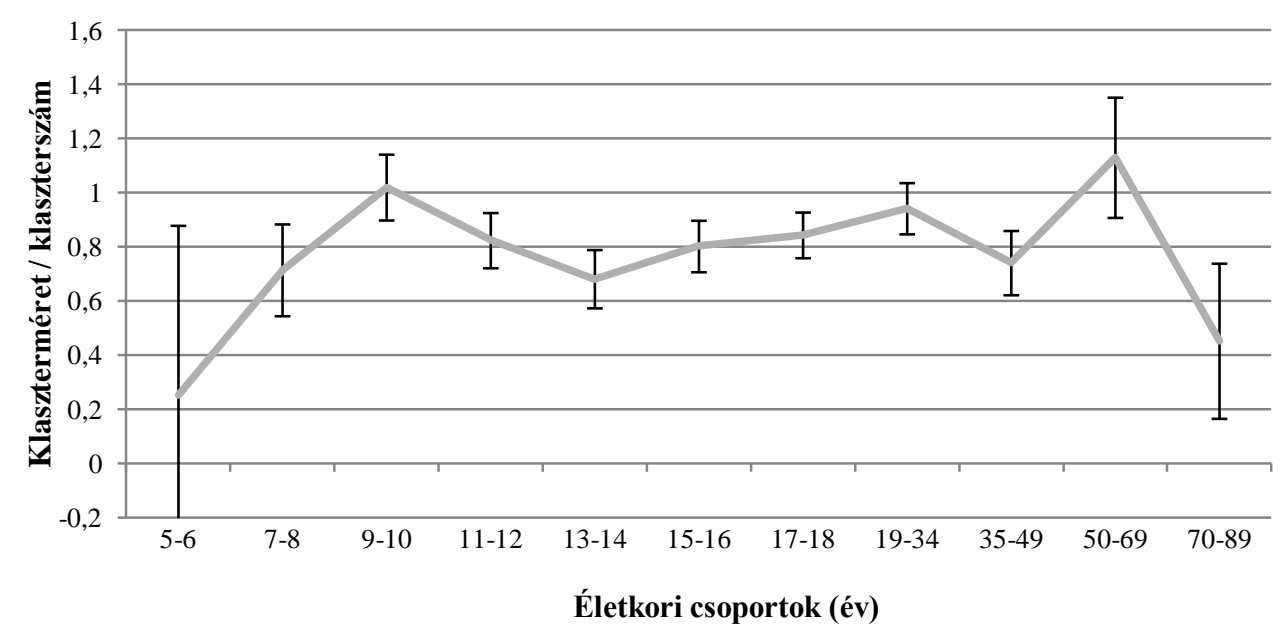

9c. ábra

A klaszterméret mutatók életkori csoportonként az „A " fluencia feladaton. A szóródási mutató az átlag standard hibája

Az összváltási mutató tekintetében összességében a vizsgálati személyek a három betüfluencia feladaton más mennyiségü összváltást használtak (szignifikáns FELADAT főhatás: $F(1,94,1036,98)=3,90, p=0,00)$. Az LSD post hoc teszt alapján megállapítható, hogy a „K” (átlagosan: 0,63) és az „A” (átlagosan: 0,61) feladatokon hasonló mértékű volt az összváltások aránya $(p=0,25)$, a „T” feladaton (átlagosan: 0,64$)$ pedig ennél kevesebb volt $(p=0,03)$.

Az ÉLETKORI CSOPORT tekintetében szignifikáns főhatást találtunk ( $F(10$, 520)=23,01, $p<0,001$ ), tehát összességében az összváltási mutatóban különbség volt az életkori csoportok között. Az 5-6 és 9-10 éves kor között a csoportok szignifikánsan különböztek egymástól (minden $p<0,001$ ). Az 5-6 évesek összváltási mutatója átlagosan 0,38, a 7-8 éveseké 0,55 , a 9-10 éveseké pedig 0,65 volt. 11-12 éves kortól egészen 50-69 éves korig a csoportok hasonlóan teljesítettek (minden $p>0,24)$. Az összváltásszám mutató 11-12 éves korban 0,67, 13-14 éves korban 0,68, 15-18 éves korban 0,71, 19-34 éves korban 0,73, 35-49 éves korban pedig 0,71 volt. A két utolsó korcsoport között azonban újra szignifikáns különbséget találtunk ( $p=0,02)$, míg az 50-69 év között átlagosan 0,68 volt az összváltási mutató, addig a legidősebb 70-89 éves korcsoportban átlagosan 0,77 volt.

A FELADAT $\mathrm{x}$ ÉLETKORI CSOPORT interakció esetében az egyes életkori csoportok nem különböztek egymástól az összváltási mutatót figyelembe véve $(F(19,94$, 1036,98)=1,22, $p=0,23$; lásd 10a., 10b., és 10c. ábra). (A pontos átlagokat és szórásokat korcsoportonként és feladatonként lásd 7a., b., és c. mellékletben). 


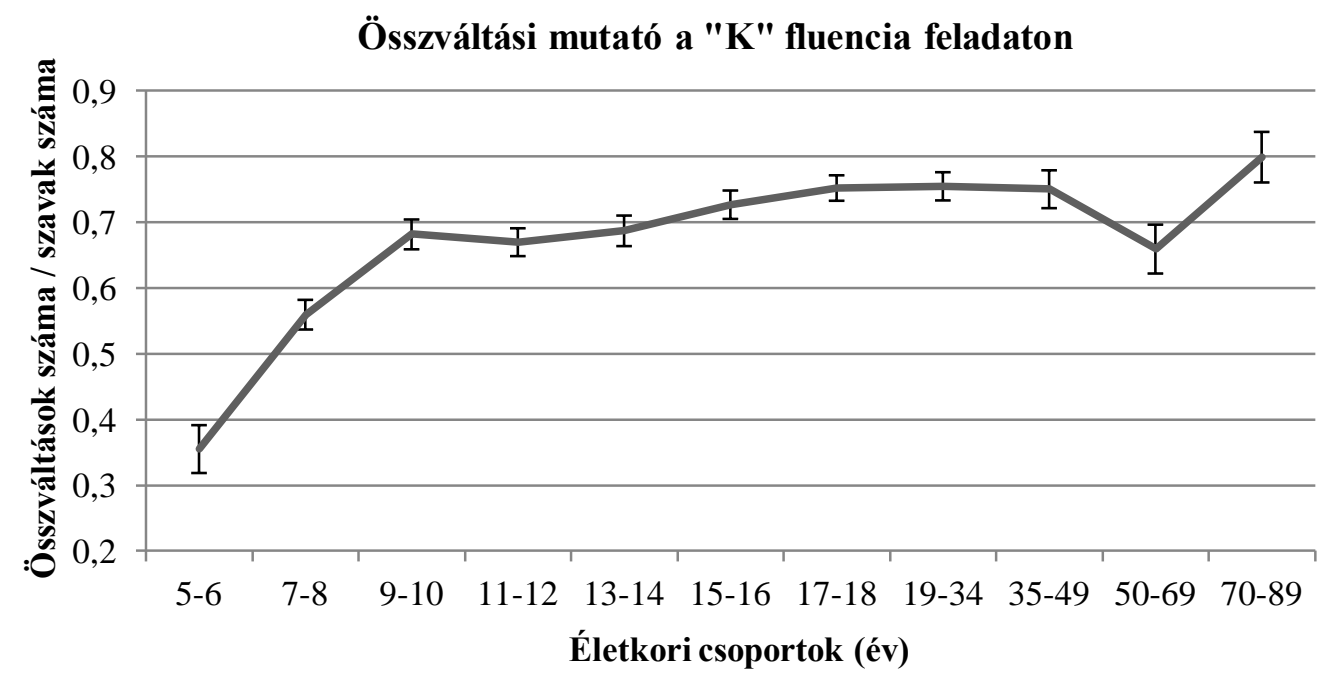

10a. ábra

Az összváltási mutatók életkori csoportonként a „, K” fluencia feladaton. A szóródási mutató az átlag standard hibája

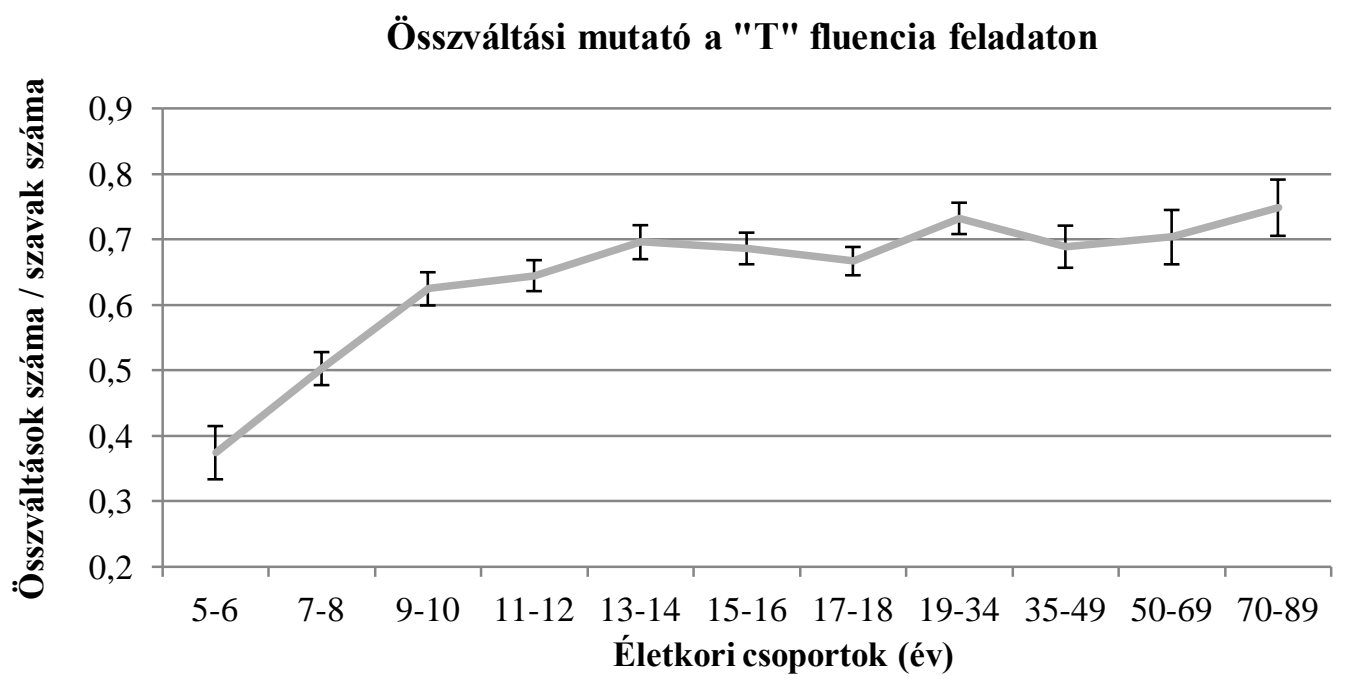

10b. ábra

Az összváltási mutatók életkori csoportonként a „,T” fluencia feladaton. A szóródási mutató az átlag standard hibája 


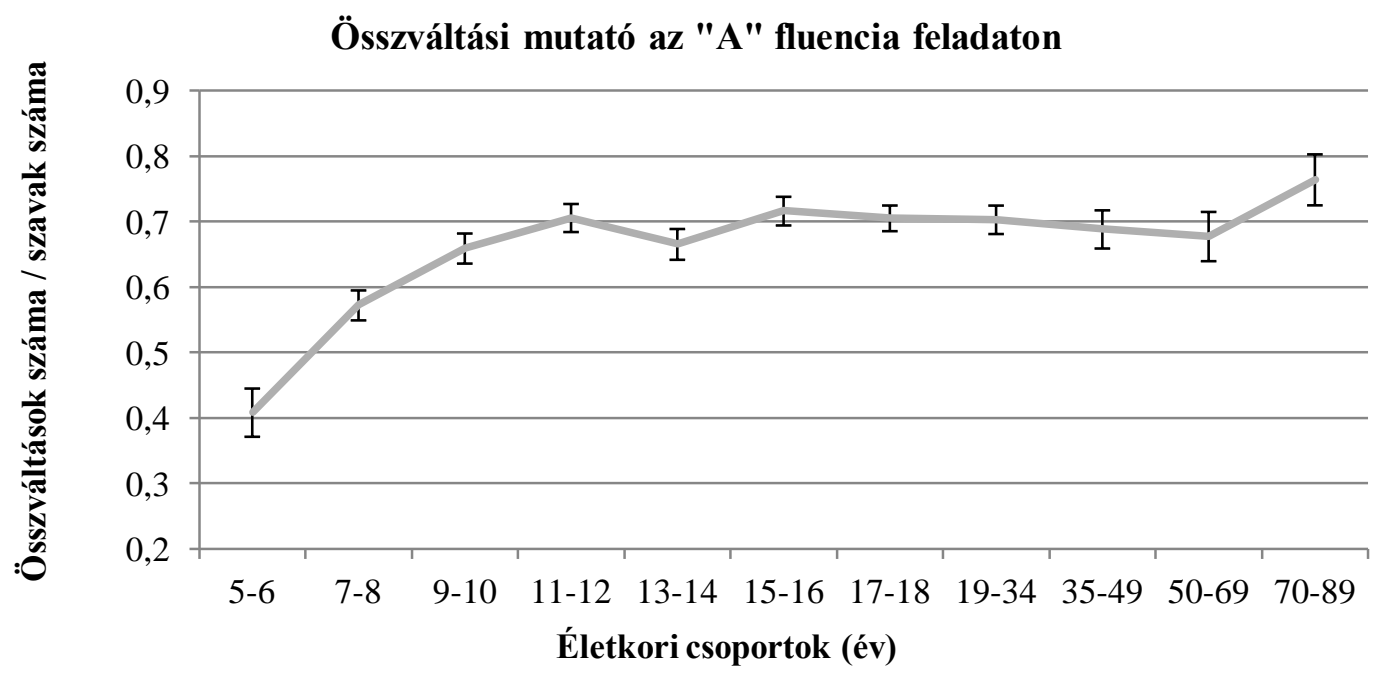

10c. ábra

Az összváltási mutatók életkori csoportonként az „A A fluencia feladaton. A szóródási mutató az átlag standard hibája

A klaszterváltási mutató tekintetében összességében a vizsgálati személyek a három betüfluencia feladaton hasonló mennyiségü klaszterváltást produkáltak (nem volt szignifikáns FELADAT fóhatás: $F(1,70,829,43)=1,23, p=0,29)$. Az ÉLETKORI CSOPORT fơhatás sem lett szignifikáns $(F(10,488)=1,06, p=0,39)$, a klaszterváltások számában nem volt különbség az életkori csoportok között. Továbbá a FELADAT x ÉLETKORI CSOPORT interakciója esetében az egyes életkori csoportok nem különböztek egymástól a klaszterváltási mutató figyelembe véve $(F(16,99,829,43)=1,25, p=0,22$; lásd 11a., b., c. ábra). (A pontos átlagokat és szórásokat korcsoportonként és feladatonként lásd a 8a., 8b.,és 8c. mellékletben).

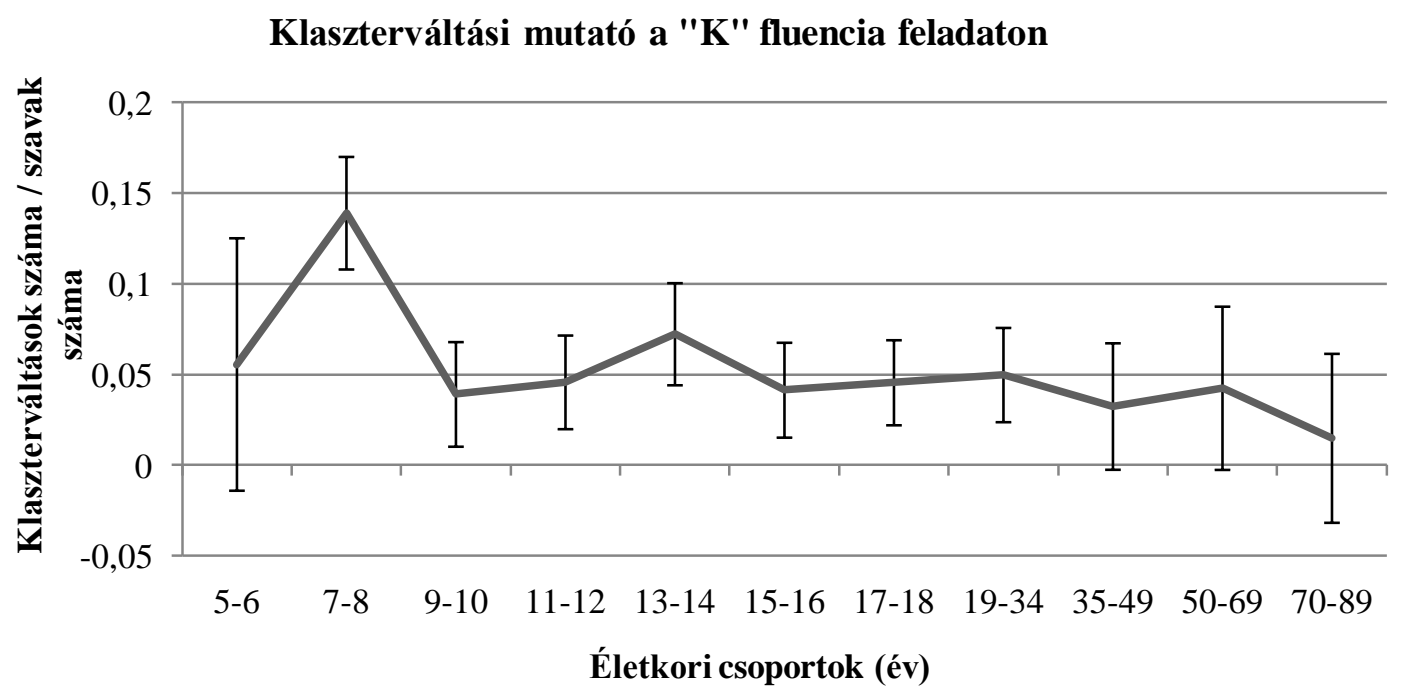

11a. ábra

A klaszterváltási mutatók életkori csoportonként a „K” fluencia feladaton. A szóródási mutató az átlag standard hibája 


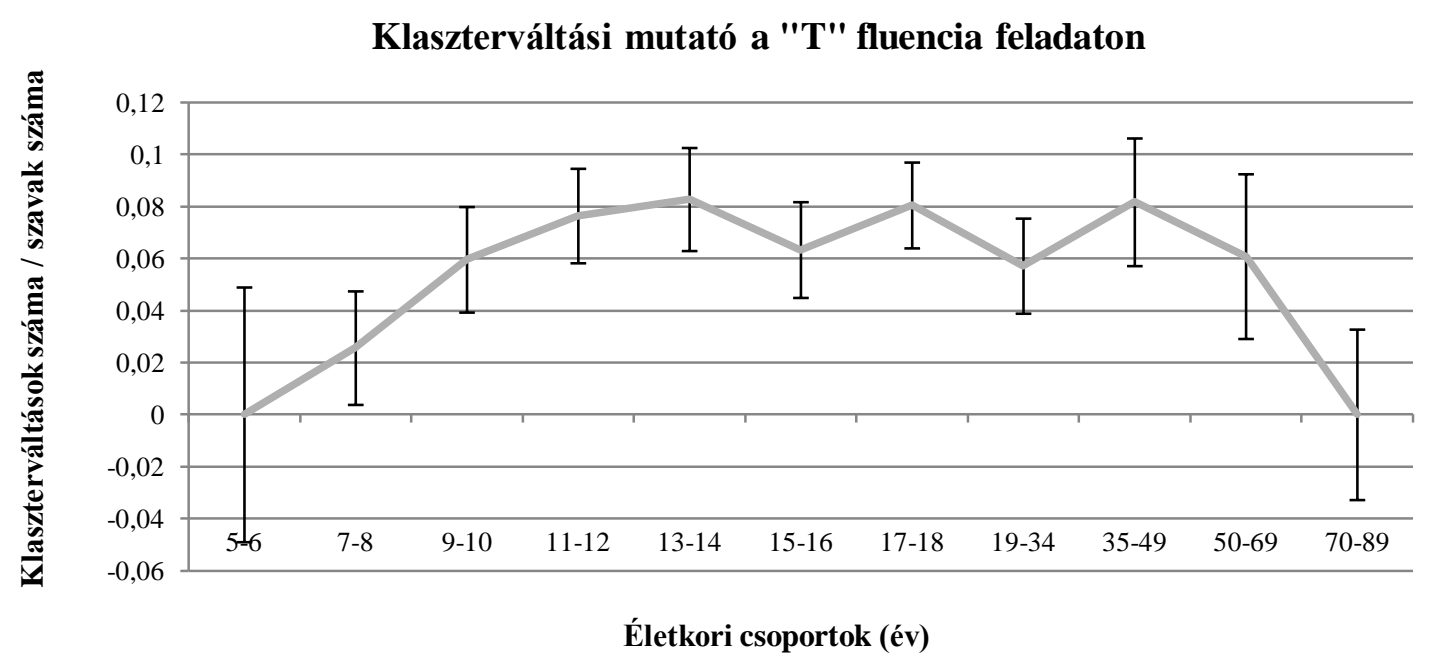

11b. ábra

A klaszterváltási mutatók életkori csoportonként a „,T" fluencia feladaton. A szóródási mutató az átlag standard hibája

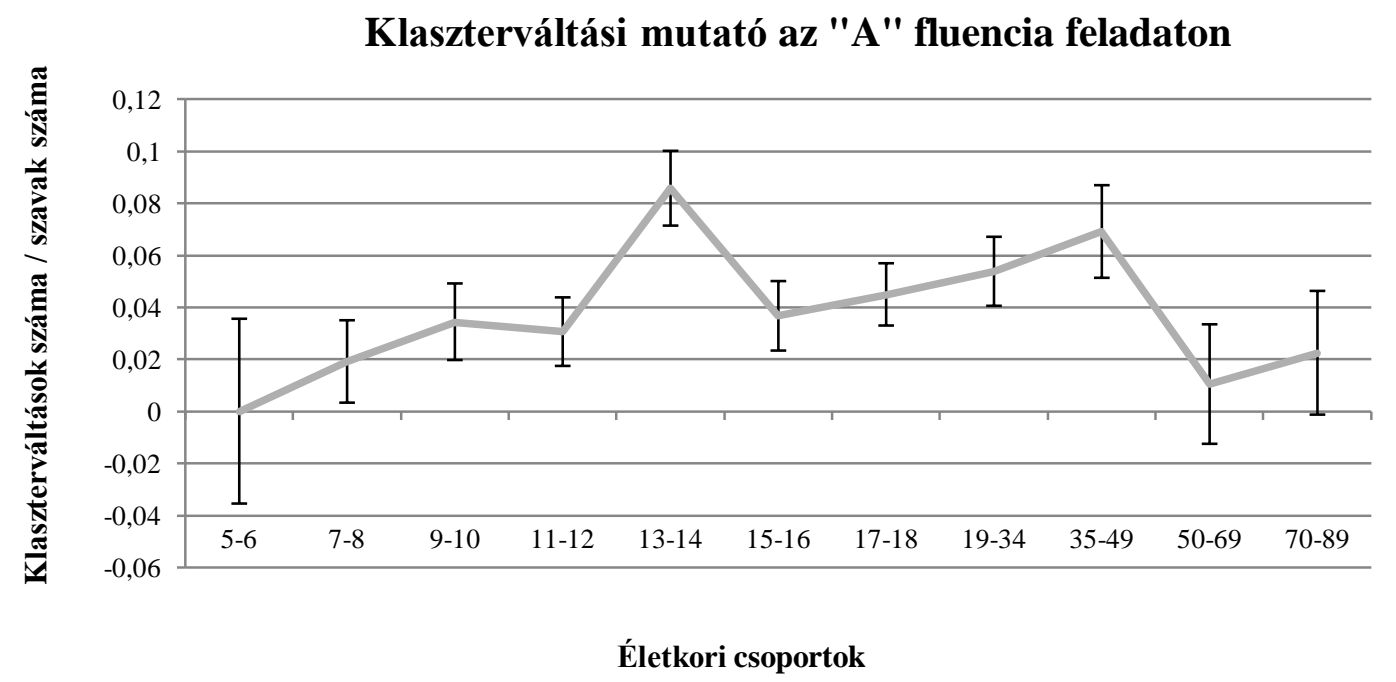

11c. ábra

A klaszterváltási mutatók életkori csoportonként az „A” fluencia feladaton. A szóródási mutató az átlag standard hibája 


\subsection{Részösszefoglalás}

A vizsgálat célja az angolszász nyelvterületen széles körben használt betüfluencia feladatok magyar nyelvü változatának széles életkori spektrumot felölelő, nagy elemszámú, komplex vizsgálata volt. Ez a munka hiánypótló, mivel egy olyan új végrehajtó funkciót és nyelvi funkciókat mérő tesztről beszélhetünk, ami neurológiai és pszichiátriai kórképek esetén a hazai klinikai neuropszichológiai gyakorlatban gyakran használt. A betüfluencia teszt adatait 11 életkori övezetben több mint 500 fő bevonásával határoztuk meg, olyan új mutatókat is használva, amelyek a mindennapi gyakorlatban még nem elterjedtek, pedig a diagnosztika pontosabbá tételében kulcsszerepük lehet.

A szavak száma tekintetében mindhárom betüfluencia feladat esetében találtunk életkori különbséget. A „, elérte a felnőtt szintet, azonban a „T” és az „A” feladat esetében volt javulás a teljesítményben 19-34 és 35-49 éves kor között is. Mindhárom betüfluencia feladaton az 5-6 évesek nagyon kevés szót tudtak csak mondani, amely eredmények egybevágnak a korábbi kutatások eredményeivel (Spreen és Strauss, 1991). Anderson és munkatársai (2001) nem találtak a verbálisfluencia-feladatokon szignifikáns életkori hatást ausztrál mintán, 11-17 éves kor között, habár a post hoc teszt eltérő teljesítmény mintázatot mutatott ki a 11-13 évesek esetében. Néhány kutatás eredményei szerint a betűfluencia teljesítmény eléri a felnőtt szintet 10-12 éves korban, amelyet a frontális lebeny érésével hoztak kapcsolatba (Anderson és mtsai, 2001; Baldo és mtsai, 2000; Temple és mtsai, 1996), míg mások szerint fejlődése átnyúlik a kamaszkorra, vagy kora felnőttkorra is (Klenberg és mtsai, 2001). Saját vizsgálati eredményeink azt mutatják, hogy a teljesítmény 17-18 éves korban éri el a felnőtt szintet, összhangban Klenberg és munkatársai (2001) eredményeivel. A felnőttkori jó teljesítmény 50-69 éves kortól jelentősen visszaesett, amely megerősíti Van Der Elst és munkatársai (2006), illetve Brickman és munkatársai (2005) eredményeit, akik szintén 50 éves kortól kezdve teljesítmény csökkenést találtak. Összességében a betűfluencia feladat esetében a teljesítmény 15-16 éves korban ( $\mathrm{a}, \mathrm{K}$ ” betű esetében) és 17-18 éves életkorban (a „, $\mathrm{T}$ ” és az „A” betű esetében) eléri a felnőtt szintet és 50-69 éves kortól kezdve romlás figyelhető meg a teljesítményben. Ennek a fejlödési görbének a hátterében részben a prefrontális kéreg életkori változásai állhatnak (Giedd és mtsai, 1999; Head és mtsai, 2004).

A perszeverációk tekintetében 17 éves kortól kis ütemben nőtt a perszeverációs arány, majd idős korban progresszív növekedés volt megfigyelhető, amely számos tanulmány szerint a fronto-striatális hálózat funkcióinak csökkenésével állhat kapcsolatban (Daigneault és 
mtsai, 1992; Kozora és Cullum, 1995). Ezzel szemben a hibázás esetében egy fordított mintázat figyelhető meg, vagyis 9-10 éves korig csökkenő tendenciát mutatott, majd ezután 89 éves korig ez a mintázat nem változott. Összességében a vizsgálatban részt vevő egészséges személyek a betüfluencia feladaton viszonylag alacsony számú hibát és perszeverációt produkáltak, ami megegyezik néhány korábbi vizsgálat eredményeivel (Kozora és Cullum, 1995; Tröster és mtsai, 1989).

A klaszterek száma szempontjából gyerekkorban 15-16 éves korig egy lassú növekedést figyelhettünk meg, majd ezt követően 89 éves korig hasonló volt a teljesítmény. A klaszterméret tekintetében az 5-6 évesekhez képest 7-8 éves korig egy progresszív növekedés figyelhető meg, ezután 12 éves korig csökkenést találtunk, majd stagnált a teljesítmény 89 éves korig. Összességében tehát mindkét mutató esetében a serdülőkorral beáll a felnőttkori teljesítmény, ami aztán már rezisztens az életkori változásokkal szemben. Az eredmények összhangban vannak Troyer (2000) vizsgálatával, amiben 18-91 éves kor között nem talált életkori hatást.

Az összváltások száma tekintetében 5-6 éves kortól 9-10 éves korig növekedés figyelhető meg, majd 11-12 éves kortól 50-69 éves korig hasonló volt a teljesítmény, ezt követően pedig a legidősebb korcsoportban egy újabb növekedés volt megfigyelhető. Ezzel szemben a klaszterváltások tekintetében nem találtunk életkori különbségeket. Hasonló eredményeket kapott Troyer (2000) is saját vizsgálatában.

Összességében ez a vizsgálat a korábbi kutatásokkal szemben szisztematikusan térképezte fel a fejlődési trendeket a betűfluencia teszt mutatói esetében. A nagy elemszámú, széles életkori spektrumú minta miatt az eredmények nemcsak a tipikus fejlödésre általánosíthatóak, hanem összehasonlítási alapul szolgálhatnak klinikai populációk vizsgálata esetén is. Fontosnak tartjuk kiemelni, hogy a klasszikus mutatókon túl a betüfluencia teszt újabb, komplexebb mutatóit is megvizsgáltuk, amelyek jelentősen segítheti a neuropszichológiai differenciál diagnosztikát is. 


\section{A HARMADIK VIZSGÁLAT}

\section{A VÉGREHAJTÓ FUNKCIÓK (SZEMANTIKUS FLUENCIA TESZT) FEJLŐDÉSE GYEREKKORTÓL IDÖSKORIG}

A szemantikus fluencia feladatok sikeres teljesítése függ az információ lexikonban és szemantikus memóriában való keresésétől és előhívásától, valamint a hatékony végrehajtó funkcióktól, beleértve a figyelmet is (Rosser és Hodges, 1994; Troyer és mtsai, 1998; Martin és mtsai, 1994; Barkley, 1998; Monsch és mtsai, 1994; Henry és Crawford, 2004a, 2004b, 2004c; Henry és mtsai, 2004; Pihlajamaki és mtsai, 2000; Greenberg és mtsai, 2009). Troyer (2000) szerint az optimális fluencia teljesítmény magában foglalja a szavak generálását egy adott kategóriából és az átváltás képességét egy másik alkategóriára, ha az előző alkategória kimerült. A szemantikus fluencia feladat esetében több szignifikáns életkori hatást találtak, mint a betűfluencia feladat esetében (Troyer és mtsai, 1997; Gladsjo és mtsai, 1999; Kozora és Cullum, 1995; Mathuranath és mtsai, 2003). Az egészséges személyek általában több szót mondanak a szemantikus fluencia feladaton, mint a betüfluencia feladaton, azonban agysérülés esetén a betüfluencia feladaton gyakran több szót mondanak (Cerhan és mtsai, 2002). Alzheimer-kórban szenvedő betegek esetében jól kimutathatóan csökkent teljesítményt találtak a szemantikus fluencia feladatban, szemben a betüfluencia teljesítménnyel (Monsch és mtsai, 1992, 1994; Tröster és mtsai, 1989; Cerhan és mtsai, 2002; Diaz, Sailor, Cheung és Kuslansky, 2004, Sherman és Massman, 1999). Matute, Rosselli, Ardila és Morales (2004) munkájukban megállapították, hogy egy 6 éves gyerek átlagosan 10 szót tud mondani a szemantikus fluencia feladaton, míg 12 éves korban már átlagosan 15-re emelkedik a szavak száma. Ezek az eredmények kongruensek spanyol (Ardila és Rosselli, 2004) és angol (Crockett, 1974; Gaddes és Crockett, 1975; Halperlin és mtsai, 1989; Kolb és Whishaw, 1985) mintán végzett vizsgálatok eredményeivel is. Továbbá megállapították, hogy a 14-15 éves gyerekek teljesítménye elérte az alacsony iskolázottságú felnőttek szintjét a szemantikus fluencia feladaton (Spreen és Strauss, 1991, Matute és mtsai, 2004). Kavé (2006) stabil fejlődést tapasztalt mind a betű, mind pedig a szemantikus fluencia teszt esetében 8-tól 17 éves korig. Időskorban Brickman és munkatársai (2005) nagyobb életkorfüggő csökkenést találtak a szemantikus fluencia feladaton a szavak száma tekintetében, ahogyan más tanulmányok is hasonló eredményekett kaptak (Bolla és mtsai, 1990, Koren és mtsai, 2005). 


\subsection{Célkitüzések, hipotézisek}

A disszertáció harmadik vizsgálatának célkitüzése a szemantikus fluencia feladat 5-89 év közötti életkori spektrumot felölelő vizsgálata, a teszt fejlődési görbéjének meghatározása és ezáltal életkori adatok szolgáltatása volt. Hasonlóan a második vizsgálathoz, a korábbi kutatásokban vizsgált mutatókon túlmenően az újabb, részletes minőségi és mennyiségi elemzést lehetővé tevő mutatók vizsgálatát is célul tüztük ki. A vizsgálat főbb hipotézisei a következők: a gyerekek, a serdülök, a felnőttek és az idősek fejlődése eltér egymástól a szemantikus fluencia teszten nyújtott teljesítmény tekintetében. A szavak száma mutató tekintetében a teljesítmény 17-18 éves életkorban eléri a felnőtt szintet és 50-69 éves kortól jelentős teljesítménycsökkenés következik be. Valamint hipotézisünk volt az is, hogy a teljesítmény magasabb a szemantikus fluencia szavak száma mutató tekintetében, mint a betüfluencia feladat esetében.

\subsection{Módszerek}

\subsubsection{Minta}

A vizsgálatban összesen 562 személy vett részt (281 nő/281 férfi; 505 jobb-/48 balkezes, 9 hiányzó adat) 5 éves kortól 89 éves korig, 11 életkori csoportba sorolva. Ez a minta megegyezik a második vizsgálatban bemutatott résztvevőkkel (lásd 11.2.1 alfejezet, 18. táblázat). A vizsgálat során betartottuk a Magyar Pszichológiai Társaság által előírt etikai szabályokat.

\subsubsection{Méröeszközök és eljárás}

A szemantikus fluencia feladatnál arra kértük a vizsgálati személyeket, hogy egy perc alatt mondjanak különböző kategóriákból mintapéldányokat (ÁLLAT, GYÜMÖLCS, ÉLELMISZERBOLT). A kategóriák választását a témában született korábbi tanulmányok indokolták, igyekeztünk az előzetes vizsgálati protokollokat követni. Ez amiatt volt fontos, hogy a saját vizsgálati eredményeinket össze tudjuk hasonlítani a korábbi tanulmányok eredményeivel. Hasonlóan a második vizsgálathoz (lásd 11.2.1 alfejezet), itt is a következő változók alkották vizsgálatunk tárgyát: szavak száma, perszeverációk száma, hibák száma, klaszterek száma, klaszterek mérete, összváltások száma és klaszterváltások száma. A változók meghatározásakor fóként Troyer és munkatársai (1997), valamint Mészáros, Kónya, és Kas (2011) munkáját vettük alapul. 
Szavak száma - Az összes szószámból kivontuk a hibák és a perszeverációk számát (Troyer és mtsai, 1997; Troyer, 2000; Mészáros, Kónya és Kas, 2011; Tröster és mtsai, 1998; Hughes és Byran, 2002; DaSilva és mtsai, 2004; Raoux és mtsai, 2008).

Perszeverációs mutató - A perszeverációk esetében olyan helyes szavak fordultak elő újra a vizsgálati személy válaszában, amelyeket korábban már említett (pl. „,citrom, narancs, citrom, banán") ahogyan azt Troyer (2000) valamint Mészáros, Kónya és Kas (2011) is meghatározták.

Hibázási mutató - A hibázások esetében olyan szót mondott a vizsgálati személy, amely nem volt a megadott kategória (pl. „kutya, macska, egér, rózsa”) tagja (Troyer és mtsai, 1997; Mészáros, Kónya és Kas, 2011). Tröster és munkatársai (1998) valamint Troyer és munkatársai (1997) az ismétléseket és a hibákat is beleszámolták a szemantikus klaszterméretbe és a váltások számába, mivel árnyaltabb képet adhatnak a háttérben zajló kognitív folyamatokról, ezért saját vizsgálatunkban is ezt a módszert követtük.

Klaszterszám mutató - A szemantikus fluencia feladatban a klaszterek azon sikeresen generált szavak, amelyeknek ugyanazon alkategóriába tartoznak (pl. „kutya, macska, tehén, csirke $\rightarrow$ háziállatok") (Troyer és mtsai, 1997, 1998; Troyer, 2000; Auriacombe és mtsai, 1993; Bayles és mtsai, 1993; Gruenewald és Lockhead, 1980; Raskin és mtsai, 1992).

Klaszterméret mutató - A klaszterek mérete a klasztert alkotó szavak száma mínusz egy (pl. „kutya, macska, csirke” esetén a csoportméret=2). Troyer és munkatársai (1997) pontozási rendszerétől eltérően vizsgálatunkban a perszeverációkat, hibázásokat és az önálló szavakat nem számítottuk bele a klaszterméretbe (Reverberi és mtsai, 2006; Sauzéon és mtsai, 2004; Fossati és mtsai, 2003; Koren és mtsai, 2005).

Összváltási mutató - Abwender és munkatársai (2001) kódolási rendszerére támaszkodva a klaszterváltásokat (pl. macskaféle és madár csoportok között az „oroszlán, tigris, | sas, sólyom” sorozatban) és az élesváltásokat (pl. egy klaszter és egy egyedülálló szó között: „oroszlán, tigris, | hörcsög”; vagy két egyedülálló szó között: „tengerimalac, | aranyhal") külön-külön értékeltük, és ezek összege alkotta az összváltások számát. A váltásszámot feladattípusonként határoztuk meg, beleszámítva a hibákat és ismétléseket is.

Klaszterváltási mutató - Abwender és munkatársai (2001) nevéhez köthető a klaszterváltás is, ami átmenetet jelent a szomszédos klaszterek között (pl. „oroszlán, tigris | sas, bagoly”). Mivel a generált szavak száma befolyásolhatja a 2-7 mutatók értékét, ezért minden esetben leosztottunk a szavak számával, kivétel ez alól a klaszterméret mutató, ahol pedig a klaszterek számával történt a korrigálás. 
A szemantikus fluencia feladat esetében a vizsgálati személyeknek egy perc alatt kellett különböző kategóriákból minta-példányokat felidézniük és kimondaniuk (ÁLLAT, GYÜMÖLCS, ÉLELMISZERBOLT). Az instrukció a következőképpen hangzott: „Arra kérem, hogy mondjon annyi állatot, amennyi csak eszébe jut egy perc alatt”! Az instrukció elhangzása után megkérdeztük a vizsgálati személyeket, hogy megértették-e a feladatot és az adatfelvétel csak akkor kezdődött, amikor erröl megbizonyosodtunk. Amennyiben nehézséget tapasztaltunk a feladat megértésében, akkor egyéb kategóriákból példákat mondtunk a vizsgálati személyeknek.

\subsubsection{Statisztikai eljárás}

Az eredmények elemzésekor minden esetben 3 x 11x 2 kevert mintás varianciaanalízist használtunk, ahol a FELADAT (pl. „ÁLLAT, GYÜMÖLCS, ÉLELMISZERBOLT”) az összetartozó mintás faktor, és az ÉLETKORI CSOPORT (1. 5-6 év, 2. 7-8 év, 3. 9-10 év, 4. 11-12 év, 5. 13-14 év, 6. 15-16 év, 7. 17-18 év, 8. 19-34 év, 9. 35-49 év, 10. 50-69 év, 11. 70-89 év) illetve NEM (nő, férfi) a csoportosító változó. Ezeknél az elemzéseknél Greenhouse-Geisser korrekciót, valamint Fisher-féle LSD post hoc tesztet használtunk, amikor szükséges volt.

\subsection{Eredmények}

Az eredmények bemutatásakor ugyanazt a sorrendet követjük, mint a korábban már bemutatott betüfluencia vizsgálatban (lásd 11.3. alfejezet). A zárójelen belül a számok az átlagot jelölik, a $p$ pedig az átlagok közti különbségek szignifikancia szintjét. A szemantikus fluencia szavak száma tekintetében összességében a teljes mintán a vizsgálati személyek a három feladaton („ÁLLAT”, „GYÜMÖLCS”, „ÉLELMISZERBOLT”) más mennyiségű szót mondtak (szignifikáns FELADAT föhatás: $F(2,109)=380,14, p<0,001)$. Az LSD post hoc teszt alapján a legtöbb szót az „ÁLLAT” fluencia feladaton mondtak (átlagosan 18,99), ezt követte az „ÉLELMISZERBOLT” fluencia feladat (átlagban 16,99), a legkevesebb szót pedig a „GYÜMÖLCS” fluencia feladaton produkálták (átlagosan 12,71; minden $p<0,001$ ).

Az ÉLETKORI CSOPORT fóhatás szignifikáns lett $(F(10,54)=59,50 ; p<0,001)$, tehát összességében a produkált szavak számában volt változás az életkori csoportok között. 5-6 éves kortól 7-8 éves korig a gyerekek hasonlóan teljesítettek $(9,31$ és 10,$03 ; p=0,38)$. A 7-8 éves, a 9-10 éves és a 11-12 éves korcsoport teljesítménye között szignifikáns különbséget találtunk (10,03 vs. 13,10 vs. 15,66 szó; minden $p<0,001)$. A 11-12 évesek és a 13-14 évesek 
hasonló teljesítményt nyújtottak $(p=0,94)$. A 13-14 és a 15-16 évesek szignifikánsan különböztek egymástól, ahogyan a 15-16 és 17-18 évesek csoportja is (15,61 és 17,99 és 20,64 szó; minden $p<0,001)$. A 17-18 és a 19-34 évesek, tehát a fiatal felnőttek is közel azonos teljesítményt nyújtottak $(p=0,48)$. A 19-34 és a 35-49 éves korcsoport újra szignifikánsan különbözött egymástól (21,13 és 23,03 szó; $p=0,03)$. A 35-49 évesekhez képest az 50-69 évesek teljesítménye szignifikánsan gyengébb volt $(p<0,001)$. Az 50-69 és 70-89 éves korú csoportok hasonló teljesítményt nyújtottak (16,58 és 15,36 szó; $p=0,34)$.

A FELADAT x ÉLETKORI CSOPORT interakció esetében az egyes életkori csoportok is különböztek egymástól a szavak számát figyelembe véve a három feladat esetében $(F(20,1086)=11,49, p<0,001$; lásd 12. ábra).

\section{Szavak száma a szemantikus fluencia feladatokon}

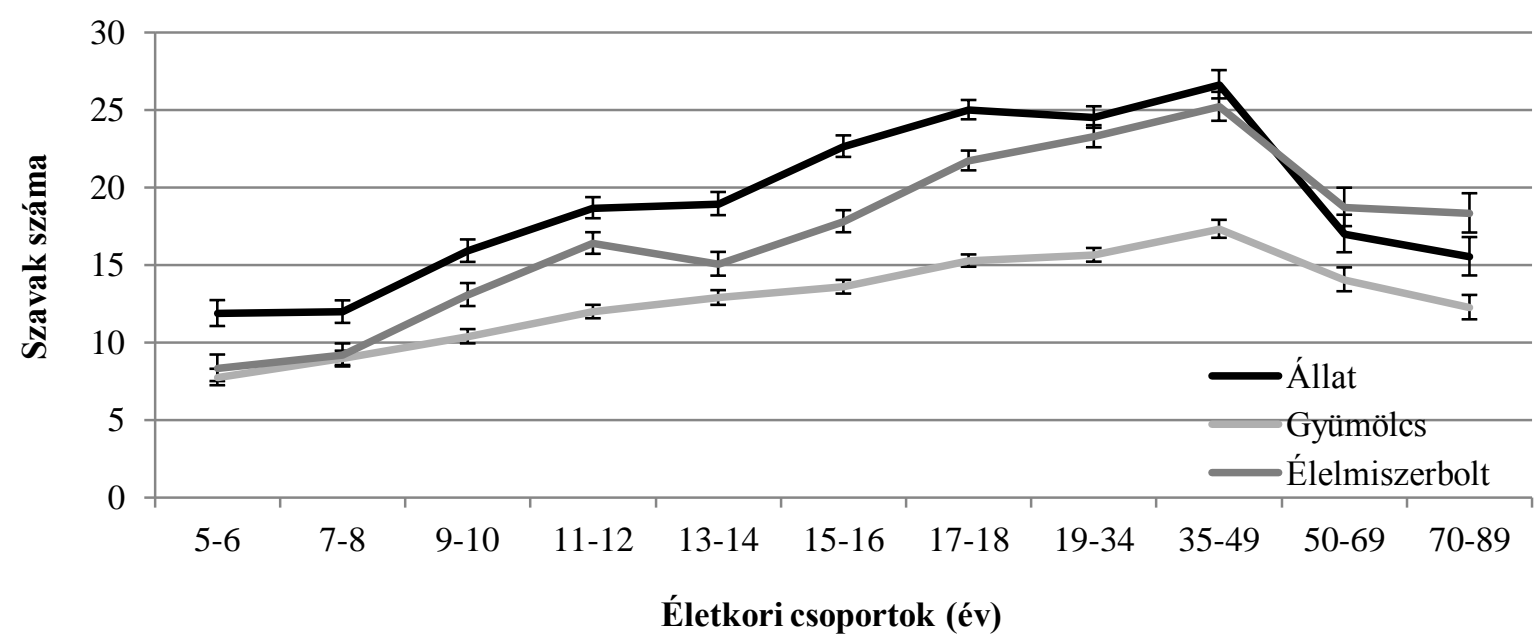

12.ábra

A szavak száma életkori csoportonként az „ÁLLAT”, a „,GYÜMÖLCS”, és az „ÉLELMISZERBOLT” fluencia feladaton. A szóródási mutató az átlag standard hibája

Az „ÁLLAT” fluencia feladaton (12a. ábra) az 5-6 és a 7-8 éves gyerekek hasonló teljesítményt mutattak ( $p=0,93)$. 7-8 éves kortól 11-12 éves korig a teljesítmény az életkorral nőtt (minden $p<0,005$ ), ezt követően a 11-12 évesek és 13-14 évesek között nem volt különbség a teljesítményben ( $p=0,793)$. 15-16 éves korban egy újabb teljesítménynövekedés, következett be $(p=0,01)$, tehát életkori változások történtek. A 17-49 éves kor közötti csoportok teljesítménye közel azonos volt, bár a 19-34 évesek tendenciaszinten különböztek a 35-49 éves csoporttól $(p=0,06)$, viszont nem különböztek a 17-18 éves csoporttól $(p=0,32)$. Az 50-69 és a 70-89 éves korcsoport teljesítménye között sem találtunk különbséget ( $p=0,39$; 9a. melléklet). 


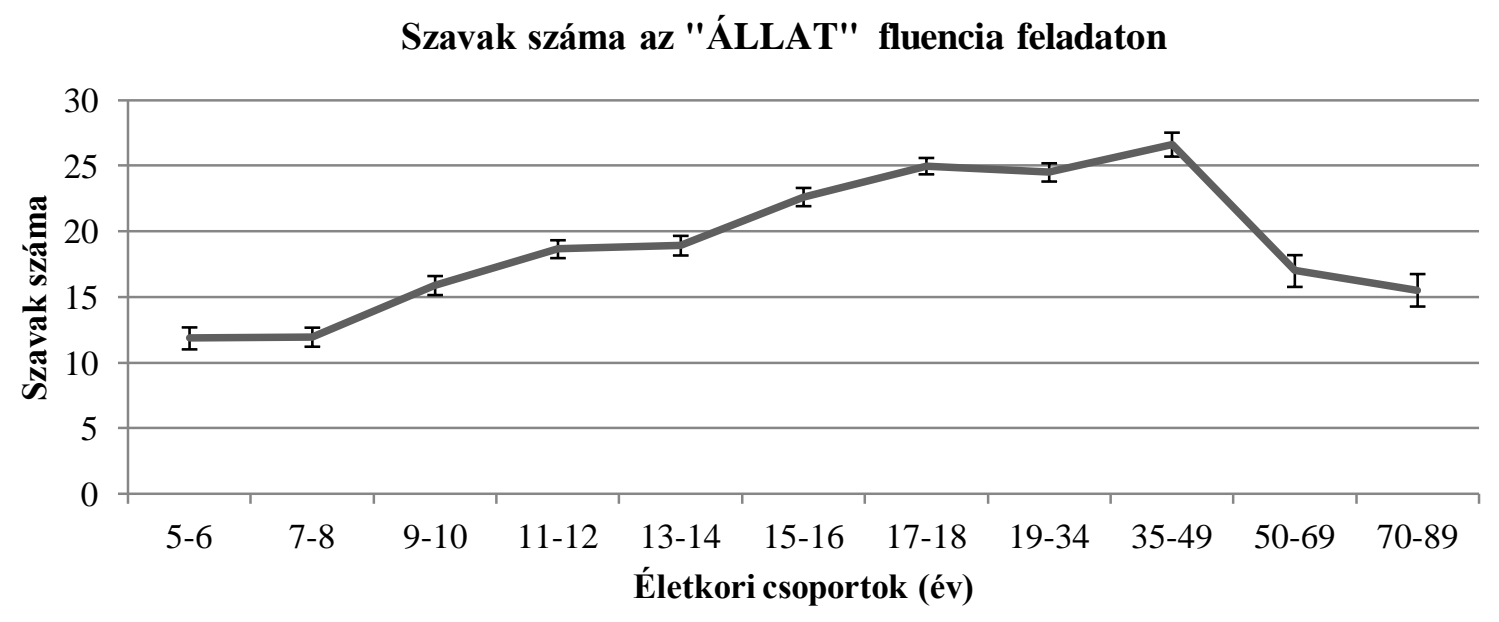

$12 a$. ábra
A szavak száma életkori csoportonként az „ÁLLAT” fluencia feladaton. A szóródási mutató
az átlag standard hibája

A „GYÜMÖLCS” fluencia feladaton (12b. ábra) a 7-8 évesek tendenciaszinten jobban teljesítettek, mint az 5-6 évesek $(p=0,08)$, ezt követően 11-12 éves korig a csoportok teljesítménye egyre nőtt (minden $p<0,03$ ). A 11-12 és 15-16 éves korosztály között nem volt különbség a csoportok teljesítményében (minden $p>0,16$ ), majd a 17-18 éves korosztálynál újabb teljesítménynövekedés volt megfigyelhetö ( $p=0,005)$, ami megtartott maradt a 19-34 éves korcsoportnál is $(p=0,53)$. 19-34 és 35-49 éves kor között a teljesítmény az életkorral nőtt ( $p<0,02)$, majd az 50-69 éves korcsoportnál csökkenés következett be ( $p=0,01)$. 50-69 és 70-89 éves korban a csoportok teljesítménye hasonló volt ( $p=0,10 ; 9 b$. melléklet). 


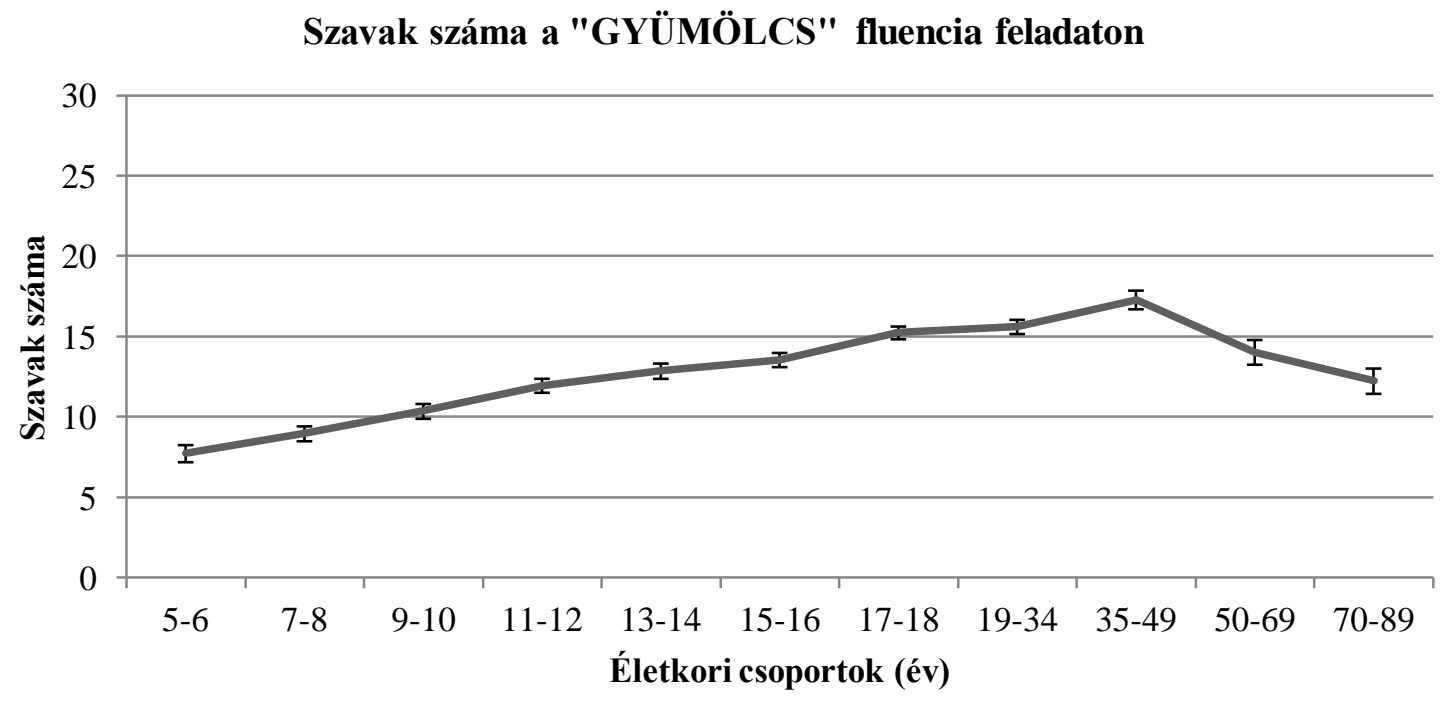

12b. ábra

A szavak száma életkori csoportonként a ,, GYÜMÖLCS” fluencia feladaton. A szóródási mutató az átlag standard hibája

Az „ÉLELMISZERBOLT” fluencia feladaton (12c. ábra) az 5-6 és a 7-8 évesek teljesítménye nem különbözött egymástól $(p=0,47)$, de 7-8 éves kortól 11-12 éves korig a csoportok egyre több szót produkáltak (minden p<0,001). 11-12 és 13-14 éves korban hasonló teljesítményt találtunk ( $p=0,19)$, majd 17-18 éves korig újabb teljesítménynövekedés következett be (minden p<0,009). 19-34 és 35-49 éves kor között hasonló teljesítményt találtunk $(p=0,10)$, az 50-69 éves korcsoportnál viszont csökkent a teljesítmény $(p<0,001)$. A két legidősebb korcsoport teljesítménye közel azonos volt ( $p=0,829 ; 9$ c. melléklet).

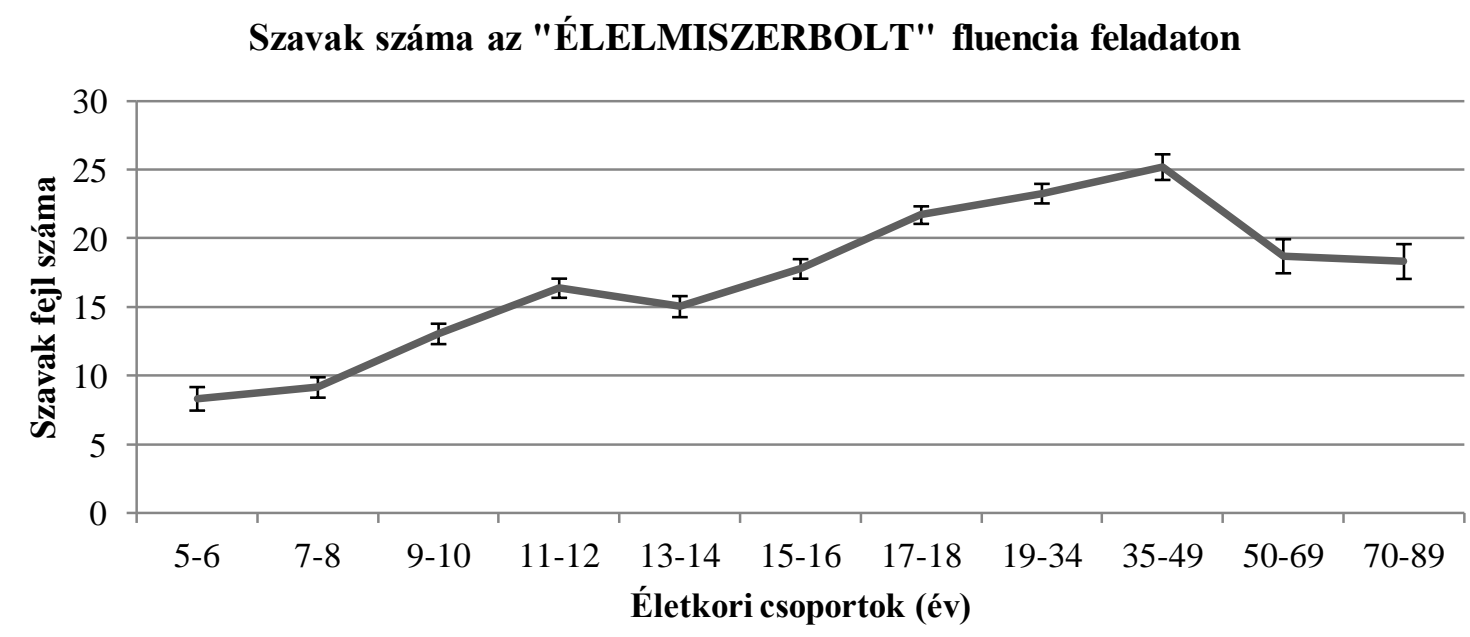

12c. ábra

A szavak száma életkori csoportonként az „ÉLELMISZERBOLT” fluencia feladaton. A szóródási mutató az átlag standard hibája 
A perszeverációs mutató tekintetében összességében a vizsgálati személyek a három szemantikus fluencia feladaton más mennyiségü perszeverációt produkáltak (szignifikáns FELADAT fóhatás: $F(2,1086)=14,19 ; p<0,001)$. Az LSD post hoc teszt alapján megállapítható, hogy közel azonos számú perszeverációt mondtak a „GYÜMÖLCS” (átlagosan 0,02), és az „ÁLLAT” (átlagosan 0,02) feladaton ( $p=0,062)$, a legkevesebbet pedig az „ÉLELMISZERBOLT” fluencia feladaton produkálták (átlagosan 0,01; minden $p>0,001$ ).

Az ÉLETKORI CSOPORT tekintetében szignifikáns főhatás volt $(F(10,543)=4,81$, $p<0,001)$, tehát összességében a perszeverált szavak számában volt változás az életkori csoportok között. 5 éves kortól 8 éves korig a gyerekek hasonlóan teljesítettek $(p=0,14)$, ezek jobb teljesítményt nyújtottak. A 7-8 éves és 11-12 éves kor között szignifikáns különbség volt a perszeverációs mutatók számát tekintve (minden $p<0,005)$, majd a különböző életkori csoportok egészen 50-69 éves korig hasonló teljesítményt mutattak (minden $p>0,23$ ). A 7089 éves korosztálynál megnőtt a perszeverációs mutató értéke az 50-69 éves korcsoportéhoz képest $(p=0,02)$.

A FELADAT x ÉLETKORI CSOPORT interakciója esetében az egyes életkori csoportok is különböztek egymástól a perszeverációs mutatók számát figyelembe véve $(F(20,1086)=2,27, p=0,001$; lásd 13a., 13b., és 13c. ábra, továbbá a pontos átlagokat és szórásokat korcsoportonként és feladatonként lásd a 10a., 10b., és 10c. mellékletben).

Az „ÁLLAT” fluencia feladaton (13a. ábra) fordult elő a legtöbb perszeverációs mutató. A gyerekek 5-8 éves korig hasonlóan teljesítettek $(p=0,96)$, majd egy fokozatos növekedés után (minden $p<0,005$ ) 9-10 éves korban megnőtt a perszeverációs mutatók száma. 11-14 éves korban a gyerekek újra hasonló teljesítményt nyújtottak (minden $p>0,84$ ) és a 13-14 valamint a 15-16 évesek teljesítménye sem tért el egymástól szignifikánsan $(p=0,84)$. A $15-16$ és 17-18 évesek szintén hasonló számú perszeverációt produkáltak $(p=0,96)$. 17-18 és 19-34 éves kor között, tehát fiatal felnőttkorban csak tendenciaszerü különbség volt a teljesítményben $(p=0,09)$. 35-49 és 50-69 éves korban hasonlóan teljesítettek (minden $p>0,42$ ), majd 70-89 éves korban visszaesés volt tapasztalható, azaz a perszeverációs mutatók száma megnőtt ( $p<0,001 ; 10 \mathrm{a}$. melléklet). 


\section{Perszeverációs mutató az "ÁLLAT" fluencia feladaton}

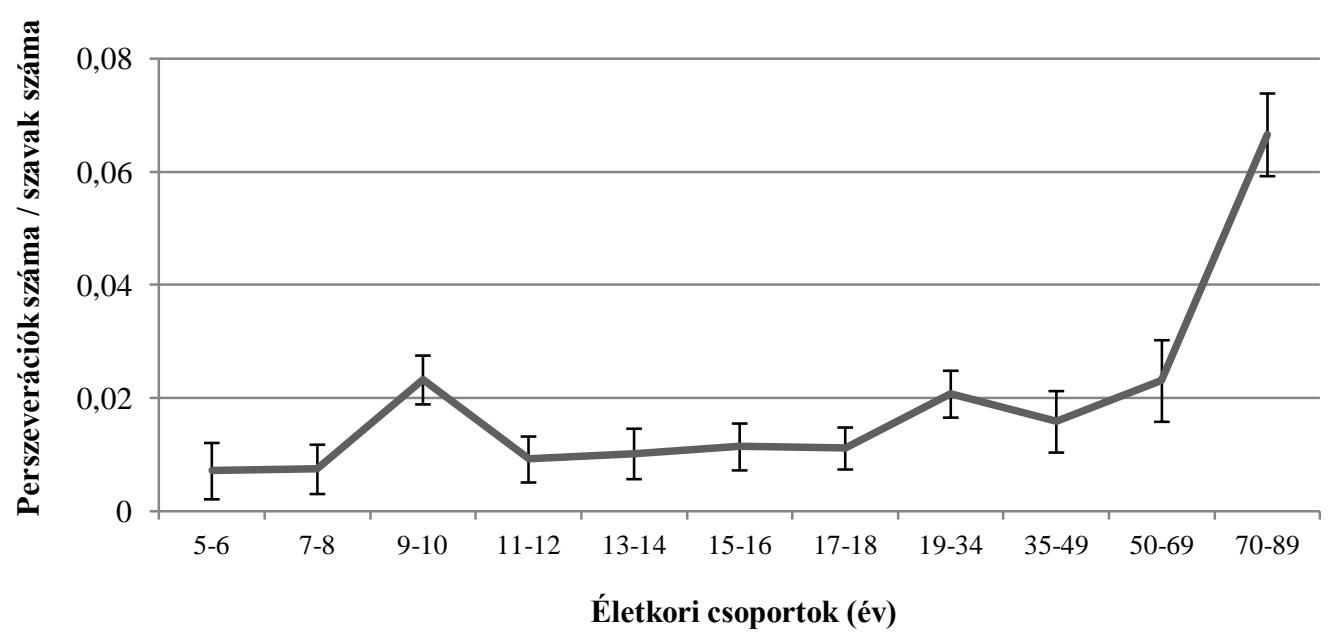

13a. ábra

A perszeverációs mutatók életkori csoportonként az „ÁLLAT” fluencia feladaton. A szóródási mutató az átlag standard hibája

A „GYÜMÖLCS” fluencia feladaton (13b. ábra) 5-10 éves korig különböztek az életkori csoportok egymástól (minden $p<0,03$ ), majd 11-89 éves korig a csoportok teljesítménye hasonló volt (minden $p>0,21 ; 10 \mathrm{~b}$. melléklet). Az „ÉLELMISZERBOLT” feladat esetében (13c. ábra) pedig az életkori csoportok a perszeverációk számát tekintve nem különböztek egymástól szignifikánsan (minden $p>0,41 ; 10 \mathrm{c}$. melléklet).

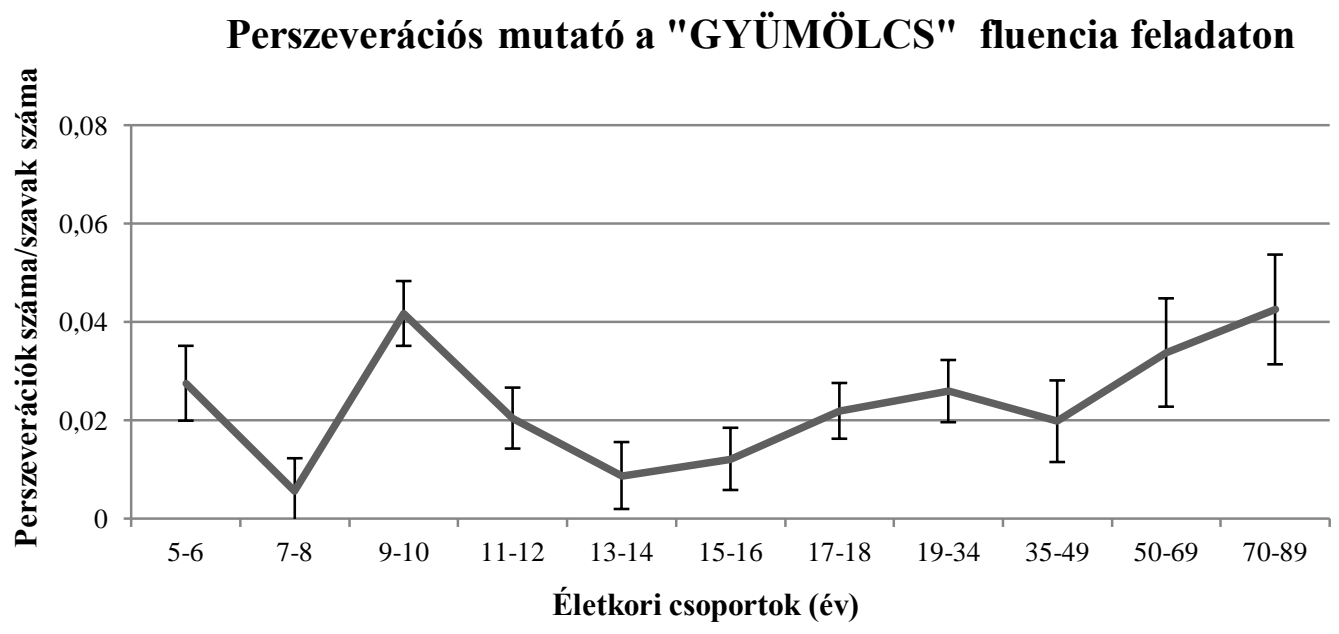

13b. ábra.

A perszeverációs mutatók életkori csoportonként a „,GYÜMÖLCS” fluencia feladaton. A szóródási mutató az átlag standard hibája 
Perszeverációs mutató az "ÉLELMISZERBOLT" fluencia feladaton

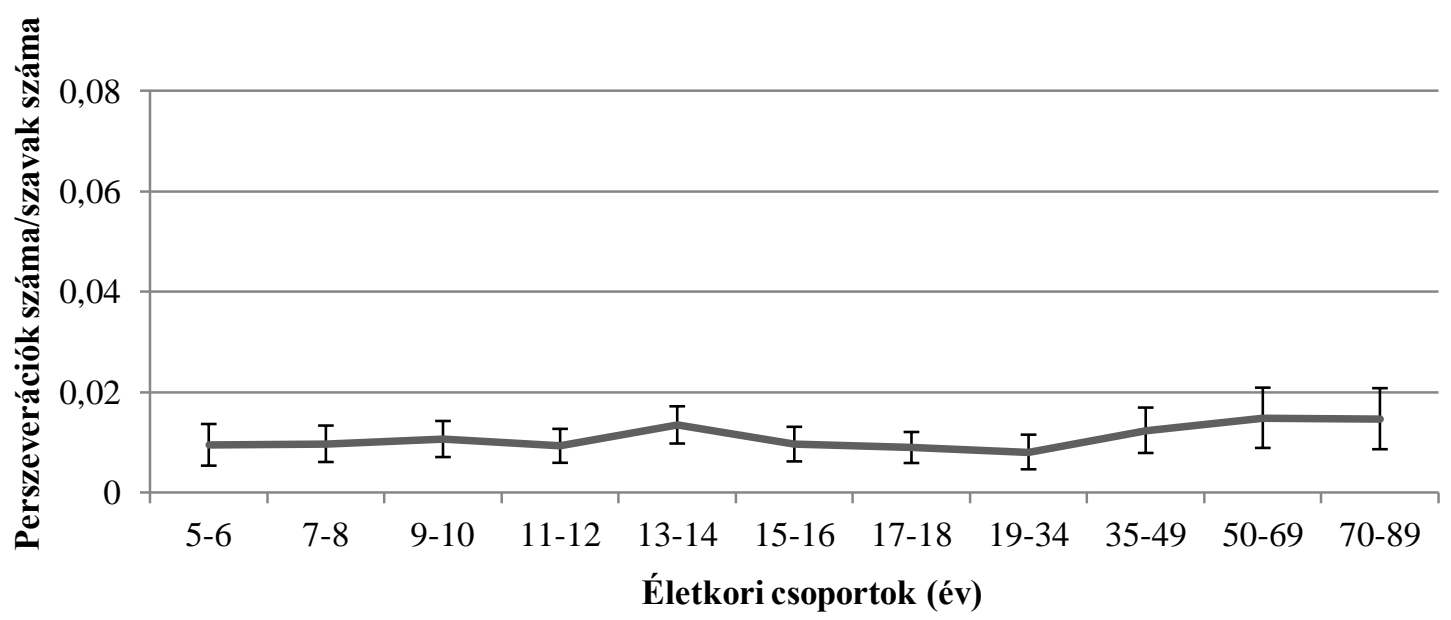

13c. ábra

A perszeverációs mutatók életkori csoportonként az „ÉLELMISZERBOLT” fluencia feladaton. A szóródási mutató az átlag standard hibája

A hibázási mutató esetében összességében a vizsgálati személyek a három szemantikus fluencia feladaton hasonló mennyiségü hibás szót mondtak (FELADAT föhatás: $F(1,99,1082,89)=1,56, p=0,21)$.

Az ÉLETKORI CSOPORT-nál szignifikáns főhatást volt $(F(10,542)=2,71, p=0,003)$, tehát összességében az egyes életkori csoportoknál eltért a hibázási mutató értéke. 5 éves kortól 8 éves korig a gyerekek csak tendenciaszinten különböznek egymástól $(p=0,09)$, míg 7-8 és 9-10 éves korban a csoportok között szignifikáns különbség volt ( $p=0,003)$. 9-10 és 70-89 éves kor között hasonló teljesítményt mutattak a különböző életkori csoportok (minden $p>0,27)$.

A FELADAT x ÉLETKORI CSOPORTOK interakciója esetében az egyes életkori csoportok nem különböztek egymástól a hibázási mutatók alapján $(F(19,98,1082,89)=0,87$, $p=0,63$; lásd 14a., 14b., és 14c. ábra. A pontos átlagokat és szórásokat korcsoportonként és feladatonként lásd 11a., 11b., és 11c. mellékletben). 


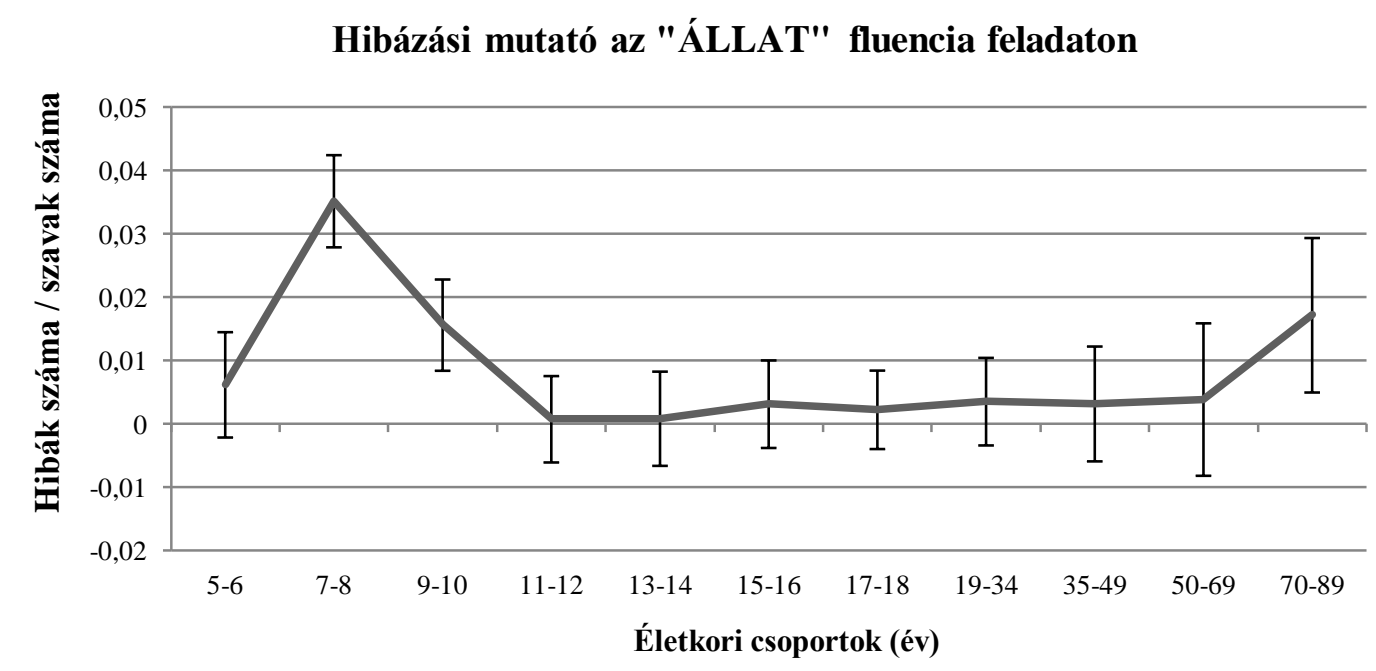

14a. ábra

A hibázási mutatók életkori csoportonként az „ÁLLAT” fluencia feladaton. A szóródási mutató az átlag standard hibája

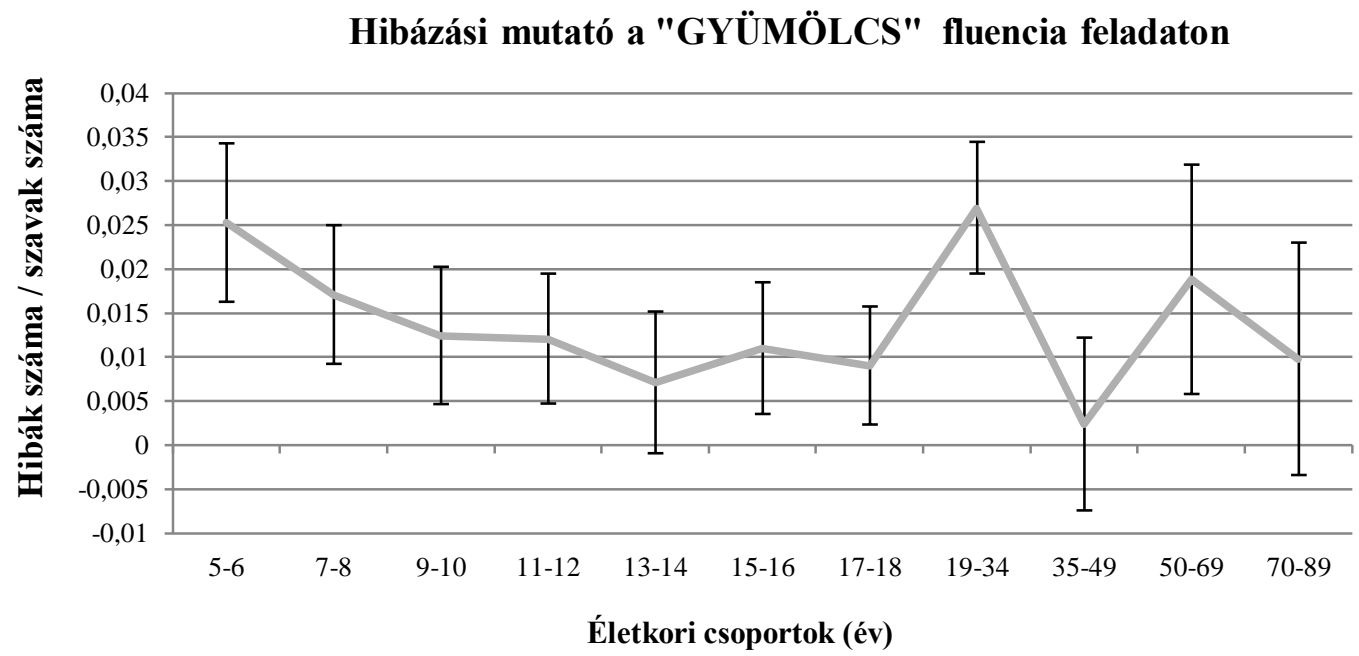

14b. ábra

A hibázási mutatók életkori csoportonként a „, GYÜMÖLCS” fluencia feladaton. A szóródási mutató az átlag standard hibája 
Hibázási mutató az "ÉLELMISZERBOLT" fluencia feladaton

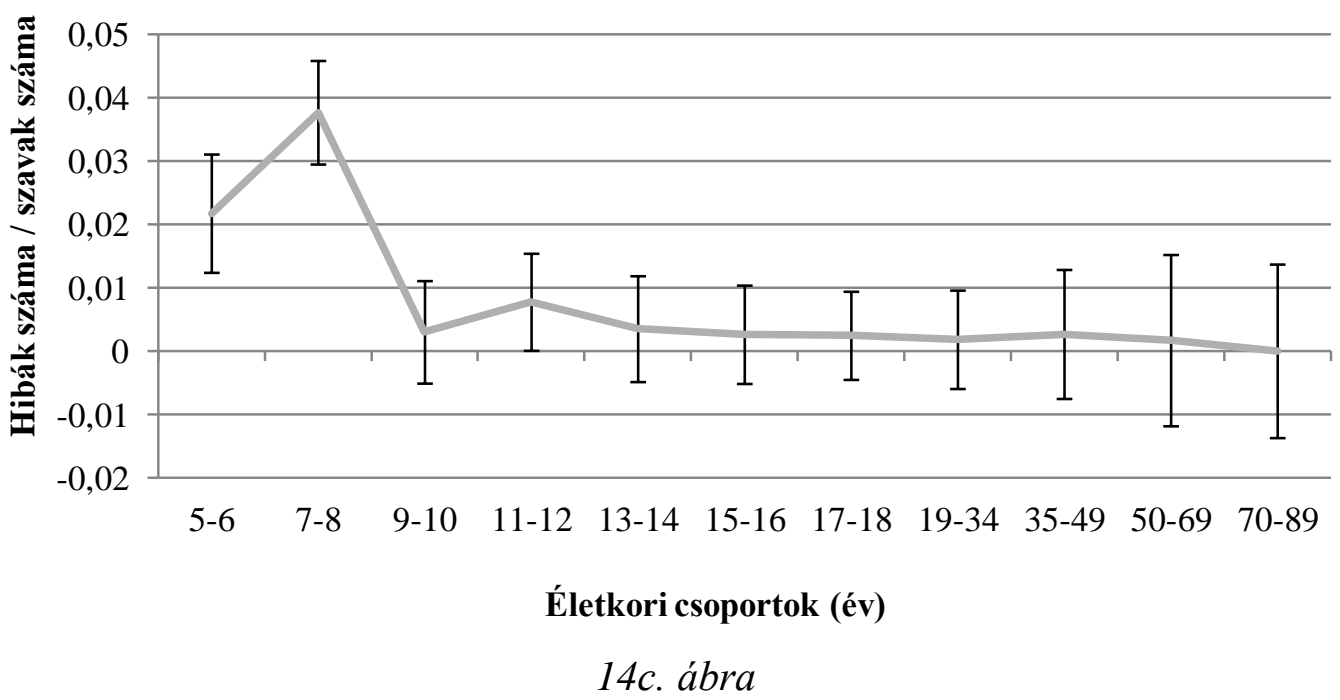

A hibázási mutatók életkori csoportonként az „ÉLELMISZERBOLT” fluencia feladaton. A szóródási mutató az átlag standard hibája

A klaszterszám mutató esetében összességében a vizsgálati személyek a három szemantikus fluencia feladaton más mennyiségű klasztert alkottak (szignifikáns FELADAT főhatás: $F(2,1084)=10,75, p<0,001)$. Az LSD post hoc teszt alapján a legtöbb klasztert a „GYÜMÖLCS” fluencia feladaton alkották (átlagosan 0,27), szignifikánsan különbözve az „ÁLLAT” (átlagosan 0,05) és az „ÉLELMISZERBOLT” (átlagosan 0,05) fluencia feladattól (minden $p<0,001$ ).

Az ÉLETKORI CSOPORT föhatás tekintetében szignifikáns főhatás volt $(F(10$, $542)=4,64, p<0,001)$, tehát összességében a klaszterszám mutatóban volt változás az életkori csoportok között. Az 5-6 és a 7-8 éves gyerekek klaszterszám mutatója szignifikánsan különbözött egymástól ( $p=0,002)$, majd ezt követően a csoportok közel azonos teljesítményt nyújtottak (minden $p>0,23$ ).

A FELADAT x ÉLETKORI CSOPORT interakció szignifikáns $(F(20,1084)=2,76$, $p<0,001)$, tehát az egyes életkori csoportok különböztek egymástól a klaszterszám mutató tekintetében az egyes feladatoknál (lásd 15a., 15b., és 15c. ábra; a pontos átlagokat és szórásokat korcsoportonként és feladatonként lásd a 12a., b., és c. mellékletekben).

Az „ÁLLAT” fluencia feladaton (15a. ábra) a gyerekek 5-6 és 7-8 éves korban hasonlóan teljesítettek $(p=0,39)$, majd a 7-8 évesekhez képest a 9-10 évesek teljesítménye szignifikánsan jobb volt (minden $p<0,04)$. A 9-10 évesek és a 15-16 évesek teljesítményét összehasonlítva tendenciaszerü különbséget találtunk $(p=0,06)$. 11-12 éves kortól egészen 70-89 éves korig a szomszédos csoportoknál hasonló volt a teljesítmény (minden $p>0,17$ ), 
viszont a 11-12 évesek teljesítménye szignifikánsan különbözött a 17-18, 35-49, 50-69 és a 70-89 éves korcsoportétól (minden $p<0,05$ ), a 19-34 évesektől pedig tendenciaszinten különbözött $(p=0,07)$. A 13-14 évesek teljesítménye is szignifikánsan különbözött a 17-18, 35-49, 50-69 éves csoportoktól (minden $p<0,04 ; 4 a$. melléklet).

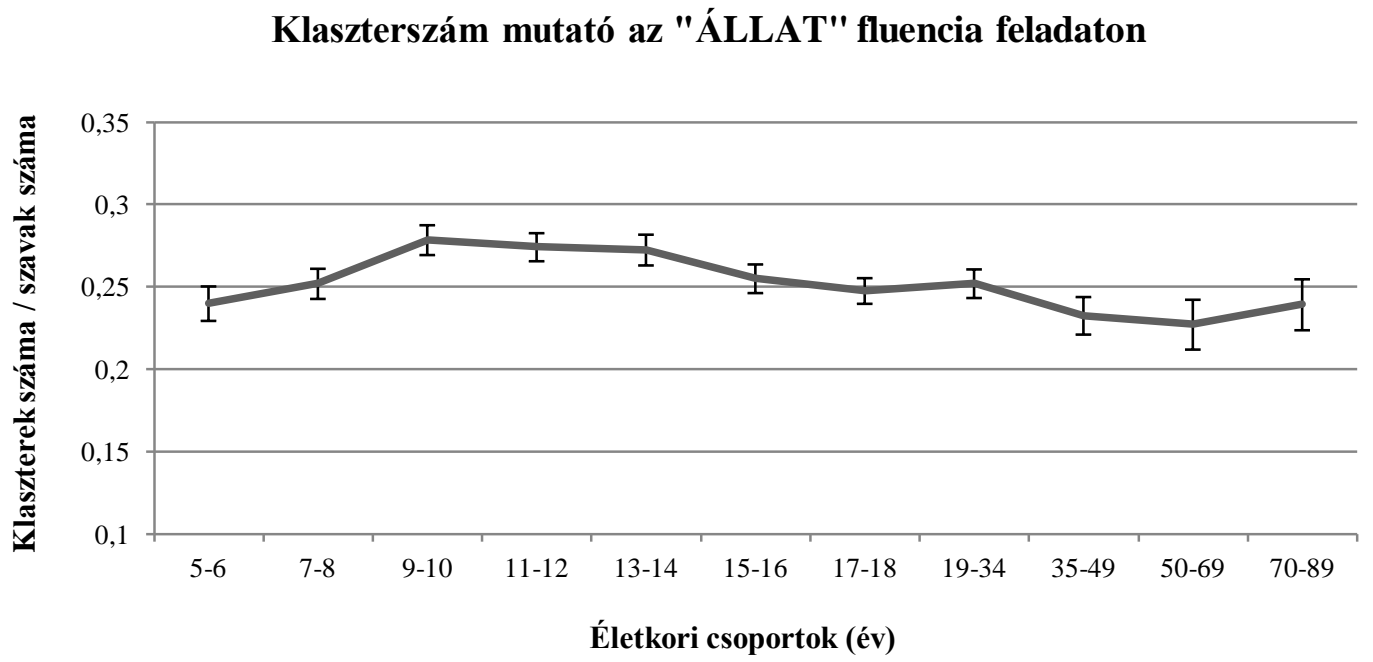

15a. ábra

A klaszterszám mutatók életkori csoportonként az „ÁLLAT” fluencia feladaton. A szóródási mutató az átlag standard hibája

A „GYÜMÖLCS” fluencia feladaton (15b. ábra) az 5-6 évesek által produkált klaszterszám mutató szignifikánsan különbözött minden korosztálytól (minden $p<0,05)$, majd 7-8 éves kortól egészen 70-89 éves korig hasonló volt a teljesítmény a klaszterszám mutatók tekintetében (minden $p>0,12 ; 12 \mathrm{~b}$. melléklet).

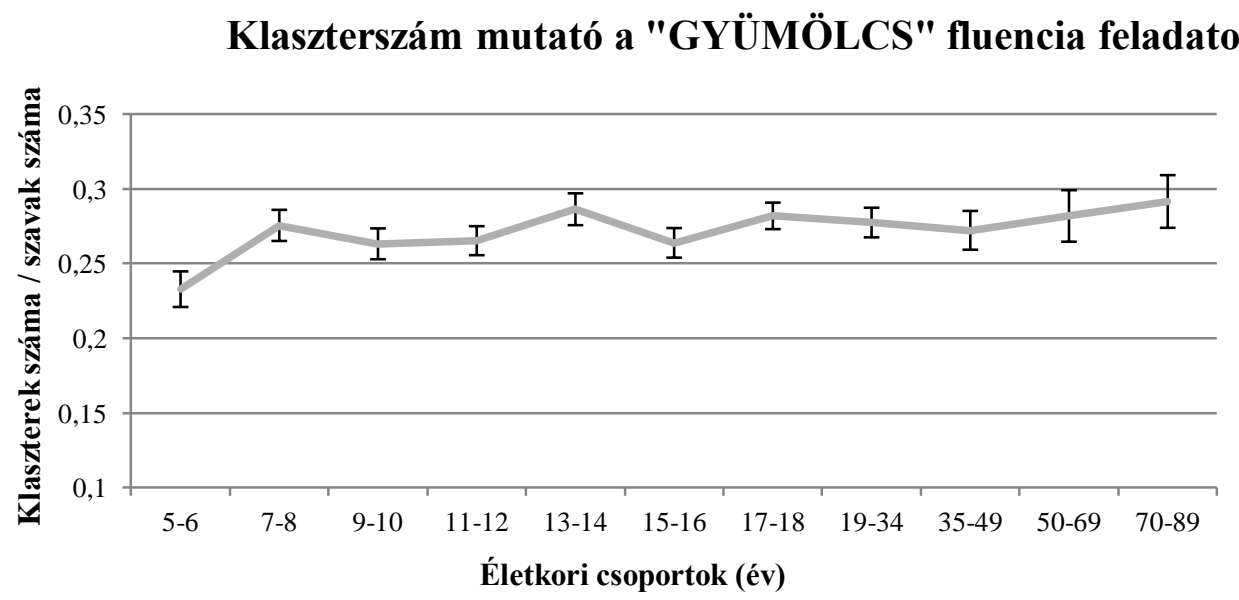

15b. ábra

A klaszterszám mutatók életkori csoportonként a „GYÜMÖLCS” fluencia feladaton. A szóródási mutató az átlag standard hibája 
Az „ÉLELMISZERBOLT” fluencia feladatnál (15c. ábra) az 5-6 és a 7-8 évesek teljesítménye csak tendenciaszinten különbözött egymástól $(p=0,09)$, ahogyan a 9-10 és 1112 évesek $(p=0,09)$ teljesítménye is. 11-12 éves kortól 35-49 éves korig hasonló volt a teljesítmény (minden $p>0,22$ ), a 35-49 és az 50-69 éves korcsoport között újra csak tendenciaszerü különbség volt $(p=0,08)$. A vizsgálati személyek 50-89 éves kor között hasonló teljesítményt produkáltak ( $p=0,91 ; 12 \mathrm{c}$. melléklet).

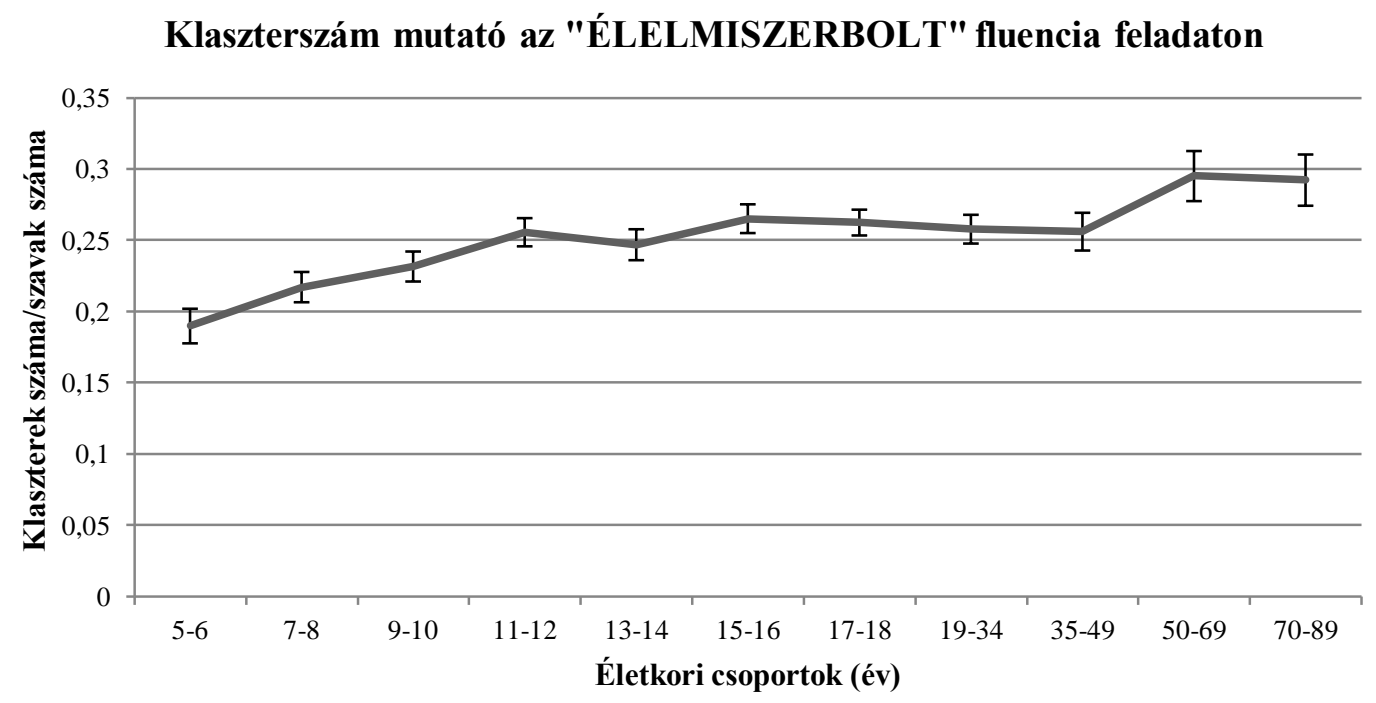

15c. ábra

A klaszterszám mutatók életkori csoportonként az „ÉLELMISZERBOLT” fluencia feladaton. A szóródási mutató az átlag standard hibája

A klaszterméret mutató esetében összességében a vizsgálati személyek a három szemantikus fluencia feladaton más méretü klasztereket alkottak (szignifikáns FELADAT főhatás: $F(2,1040)=3,71, p=0,03)$. Az LSD post hoc test alapján a legnagyobb klaszterméretet a „GYÜMÖLCS” (átlagosan 0,69) fluencia feladaton érték el, ami szignifikánsan különbözött mind az „ÉLELMISZERBOLT” (átlagosan 0,58), mind pedig az „ÁLLAT” (átlagosan 0,58) szemantikus fluencia feladaton nyújtott teljesítménytől (minden $p<0,03)$.

Az ÉLETKORI CSOPORT főhatás szignifikáns volt $(F(10,520)=13,66, p<0,001)$, tehát összességében a klaszterek méretében volt változás az életkori csoportok között. Az eredmények azt mutatták, hogy az 5-6 évesekhez képest a 7-8 évesek klaszterméret mutatója tendenciaszinten kisebb volt $(p=0,07)$, amely tovább csökkent a 9-10 éveseknél $(p<0,001)$. 910 éves kortól 35-49 éves korig nem volt különbség a csoportok között a klaszterméret mutatót tekintve (minden p>0,27). Az 50-69 éveseknél viszont szignifikánsan nagyobb lett a 
klaszterméret mutató a 35-49 évesekhez képest $(p=0,02)$. A két legidősebb korcsoport hasonló teljesítményt nyújtott ( $p=0,22)$.

A FELADAT $x$ ÉLETKORI CSOPORT interakció esetében az egyes életkori csoportok különböztek egymástól a klaszterméret mutató szempontjából az egyes feladatoknál $(F(20,1040)=2,38, p=0,001$; lásd 16., 16b., és 16c. ábra, továbbá a pontos átlagokat és szórásokat korcsoportonként és feladatonként lásd a 13a., 13b., és 13c. mellékletben).

Az életkori csoportok összehasonlításakor az „ÁLLAT” fluencia feladaton (16a. ábra) a gyerekek 5-6 és 7-8 éves korban hasonlóan teljesítettek $(p=0,18)$, viszont a 7-8 (átlagosan 0,92) és a 9-10 évesek $(0,46)$ klaszterméret mutatója már szignifikánsan különbözött egymástól ( $p<0,001)$, a 9-10 évesek teljesítménye csökkent. 9-10 éves kortól 35-49 éves korig hasonlóan teljesítettek (minden $p>0,45$ ), az 50-69 éves csoportnál szignifikánsan nőtt a klaszterméret mutató ( $p<0,001)$. Az 50-69 és a 70-89 éves korosztály között is szignifikáns különbséget találtunk, a legidősebbeknél kisebb volt a klaszterméret mutató $(p=0,005 ; 13 \mathrm{a}$. melléklet).

\section{Klaszterméret mutató az "ÁLLAT" fluencia feladaton}

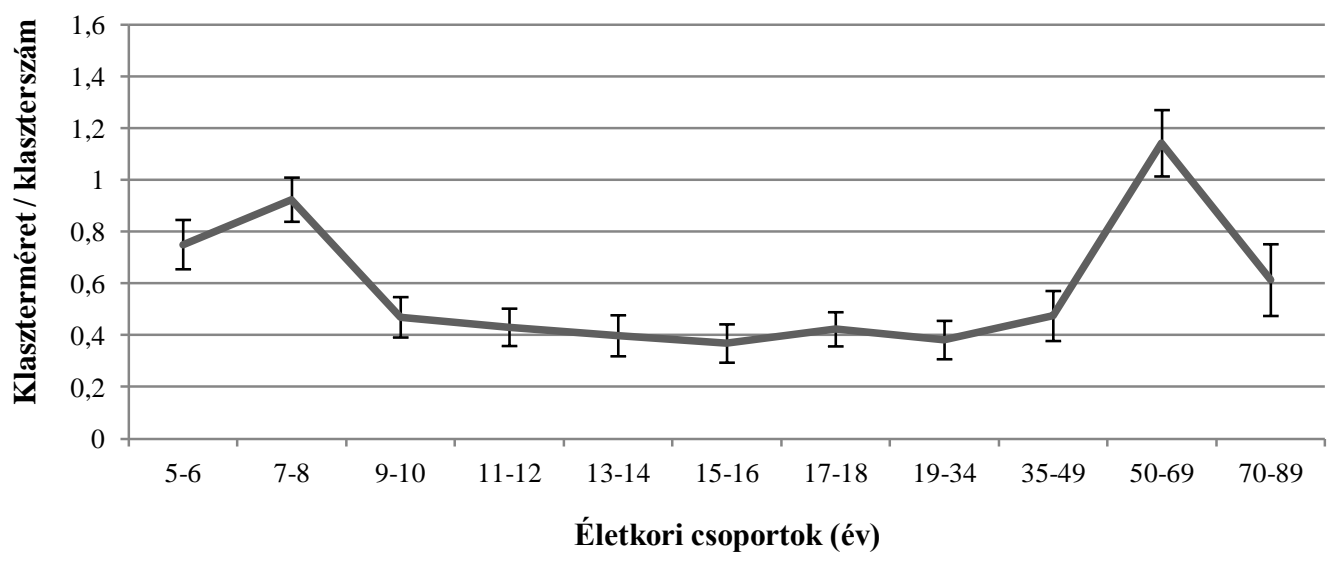

16a. ábra

A klaszterméret mutatók életkori csoportonként az „ÁLLAT” fluencia feladaton. A szóródási mutató az átlag standard hibája

A „GY ÜMÖLCS” szemantikus fluencia feladaton (16b. ábra) az 5-6 évesek klaszterméret mutatója átlagosan 1,10 , a 7-8 és a 9-10 éveseké átlagosan 0,1 vs. 0,74 volt, a két csoport csak tendenciaszinten különbözött egymástól ( $p=0,067)$. 9-10 éves kortól egészen 70-89 éves korig hasonló volt a teljesítmény a klaszterméret mutató esetében (minden $p>0,28 ; 5 b$. melléklet). 


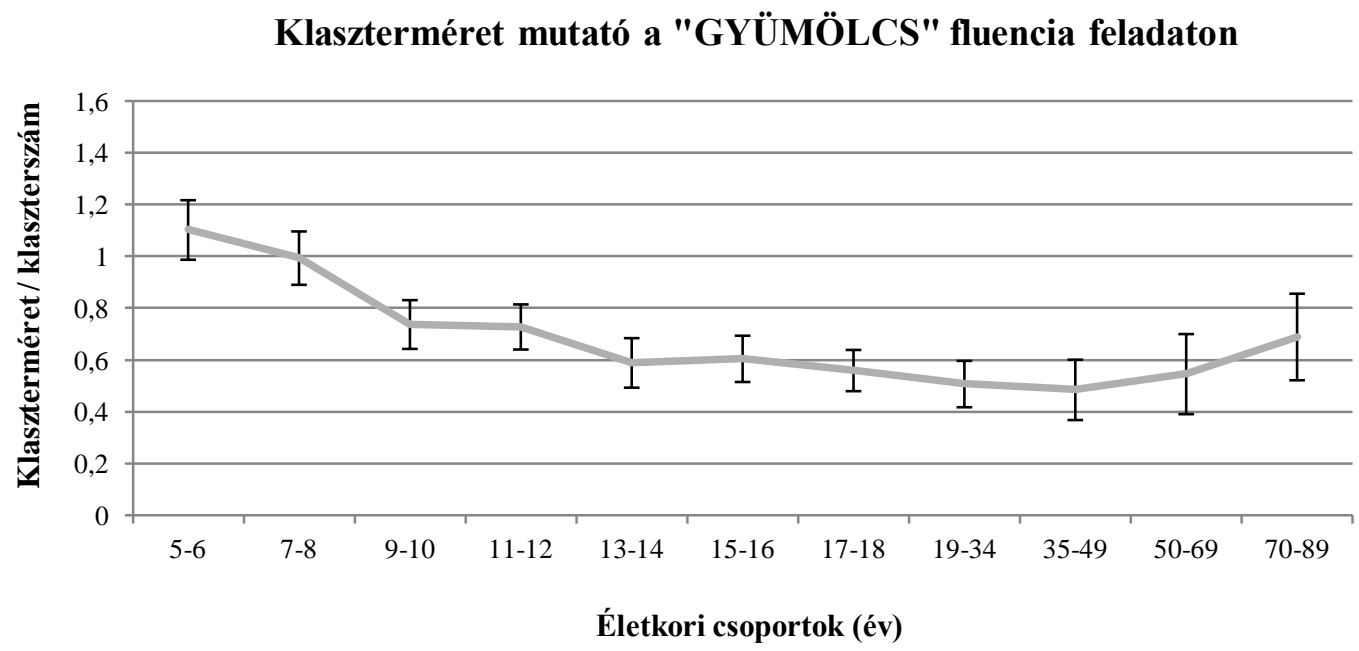

16b. ábra

A klaszterméret mutatók életkori csoportonként a „, GYÜMÖLCS” fluencia feladaton. A szóródási mutató az átlag standard hibája

Ehhez hasonlóan az „ÉLELMISZERBOLT” feladatnál (16c. ábra) az 5-6 évesek és a 7-8 évesek teljesítménye között szignifikáns különbség volt $(p=0,001)$, de 7-8 éves kortól 70-89 éves korig hasonló volt a teljesítmény (minden $p>0,12 ; 13 \mathrm{c}$. melléklet).

Klaszterméret mutató az "ÉLELMISZERBOLT" fluencia feladaton

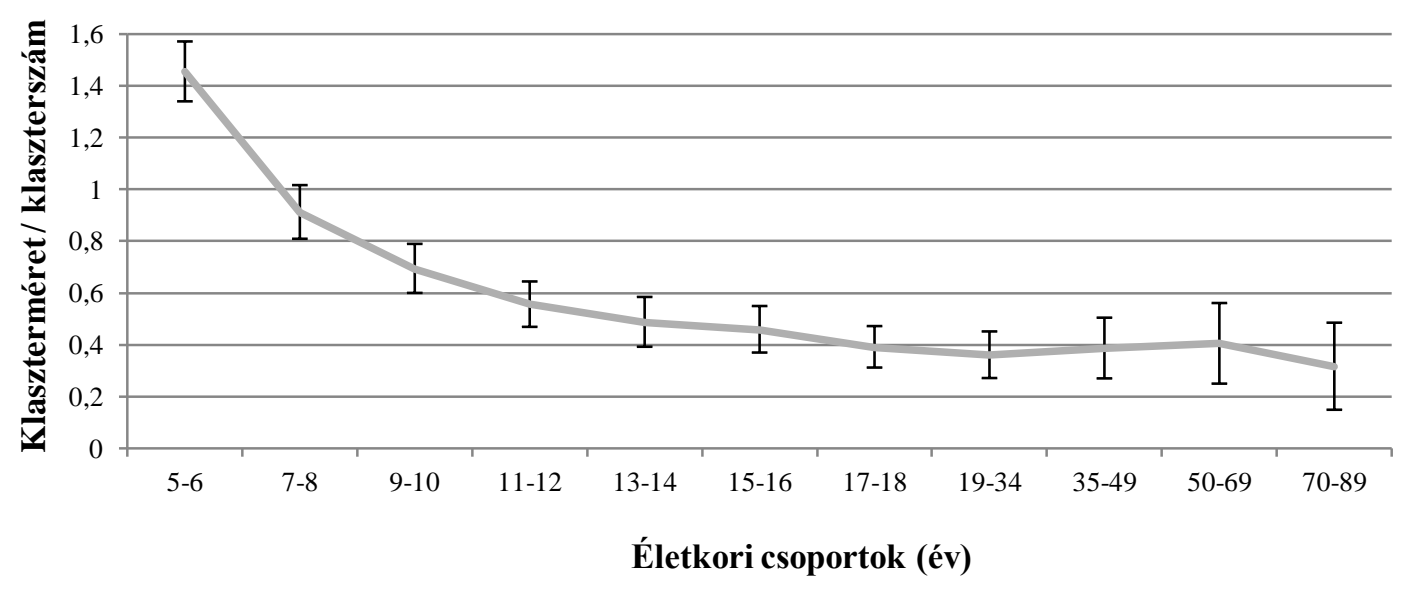

16c. ábra

A klaszterméret mutatók életkori csoportonként az „ÉLELMISZERBOLT” fluencia feladaton. A szóródási mutató az átlag standard hibája

Az összváltási mutatónál összességében a vizsgálati személyek a három szemantikus fluencia feladaton más mennyiségű összváltást hajtottak végre (szignifikáns FELADAT főhatás: $F(2,1384)=41,39, p<0,001)$. Az LSD post hoc teszt alapján megállapítható, hogy a 
legtöbb összváltást az „ÉLELMISZERBOLT” fluencia feladaton (átlagosan 0,48) hajtottak végre, ami szignifikánsan különbözött mind a „GYÜMÖLCS” fluencia feladaton (átlagosan 0,42), mind pedig az „ÁLLAT” fluencia feladaton (átlagosan 0,42) nyújtott teljesítménytől (minden $p<0,001$ ).

Az ÉLETKORI CSOPORT főhatás esetében szignifikáns fơhatás volt $(F(10$, 692)=11,94, $p<0,001$ ), tehát összességében az összváltási mutatók tekintetében volt életkori változás a különböző korcsoportok között. Az 5-6 évesekhez képest a 7-8 éveseknél szignifikánsan kisebb volt az összváltási mutató $(p<0,001)$, ami enyhén megemelkedett a 910 éves csoportnál ( $p=0,09)$, majd csökkent a $11-12$ éveseknél ( $p=0,03)$. A teljesítmény $11-$ 12 és 15-16 éves kor közt hasonló volt (minden $p>0,22$ ). A 17-18 éves csoportnál tendenciaszinten csökkent az összváltási mutató $(p=0,09)$, amely utána hasonló maradt a 1934 éves csoportnál $(p=0,23)$. A 35-49 éveseknél újabb tendenciaszerű csökkenés volt megfigyelhető ( $p=0,06)$, majd ezt követően nem változott a teljesítmény (minden $p>0,85$ ).

A FELADAT $x$ ÉLETKORI CSOPORT interakció esetében az egyes életkori csoportok is különböztek egymástól az összváltások számát tekintve $(F(20,1384)=1,95$, $p=0,007$; lásd 17a., 17b., és 17c. ábra, továbbá a pontos átlagokat és szórásokat korcsoportonként és feladatonként lásd a 14a., 14b., és 14c. mellékletben).

Az „ÁLLAT” szemantikus fluencia feladaton (17a. ábra) a gyerekek esetében az 5-6 és a 7-8 éves korosztály között szignifikáns különbség volt $(p=0,03)$. A 7-8 éves kortól egészen 15-16 éves korig a csoportok hasonlóan teljesítettek az összváltási mutató tekintetében (minden p>0,49). A 17-18 éves csoportnál szignifikánsan kisebb lett az összváltási mutató $(p=0,001)$, amely kisebb növekedést mutatott a 19-34 éves csoportnál ( $p=0,005)$, majd csökkenést a 35-49 éves csoportnál ( $p=0,003)$. A 35-49 és az 50-69 évesek nem különböztek egymástól az összváltásokat tekintve $(p<0,56)$. A két legidösebb korosztály teljesítménye pedig csak tendenciaszinten különbözött egymástól ( $p=0,05 ; 14 a$. melléklet). 


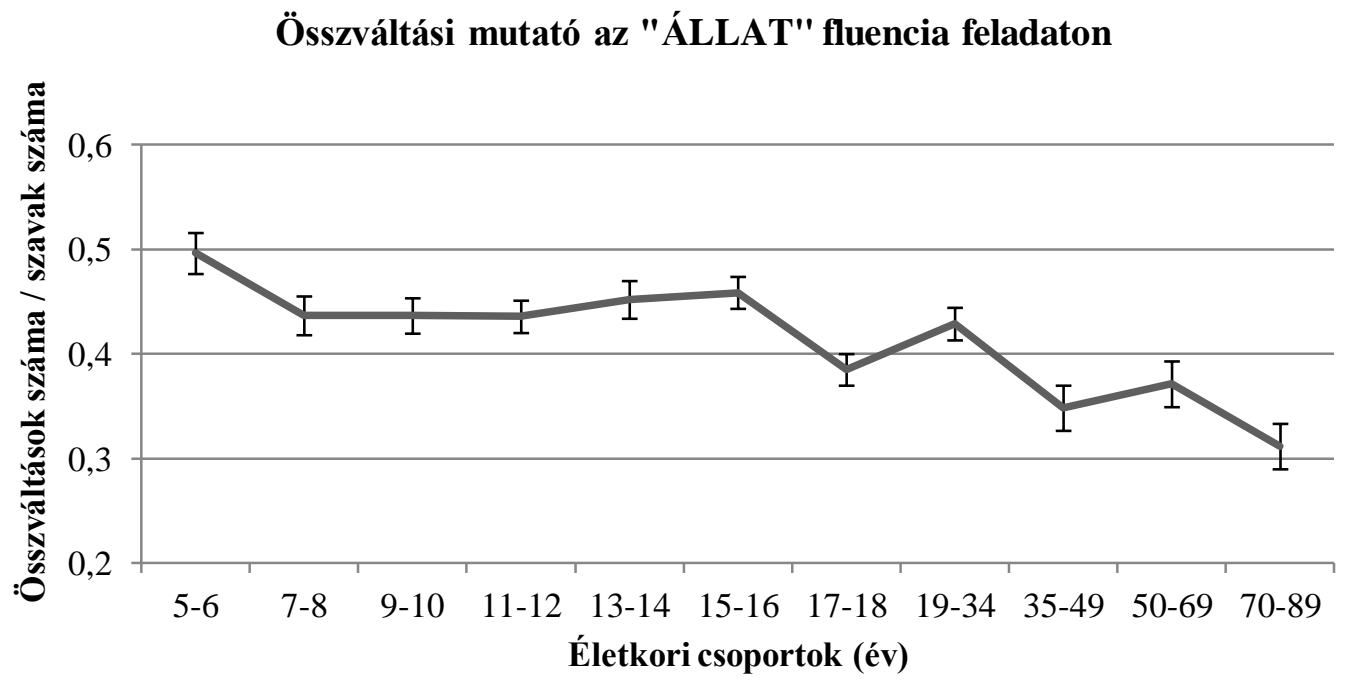

17a. ábra

Az összváltási mutatók életkori csoportonként az „ÁLLAT” fluencia feladaton. A szóródási mutató az átlag standard hibája

A „GYÜMÖLCS” fluencia feladaton (17b. ábra) az 5-6 évesekéhez képest a 7-8 évesek összváltási mutatója szignfikánsan csökkent $(p=0,002)$. A 7-8 évesek és a 9-10 évesek között tendenciaszerü különbséget találtunk ( $p=0,09)$, ezt követően pedig 70-89 éves korig a csoportok hasonló teljesítményt nyújtottak (minden $p>0,10 ; 14 b$. melléklet).

\section{Összváltási mutató az "GYÜMÖLCS" fluencia feladaton}

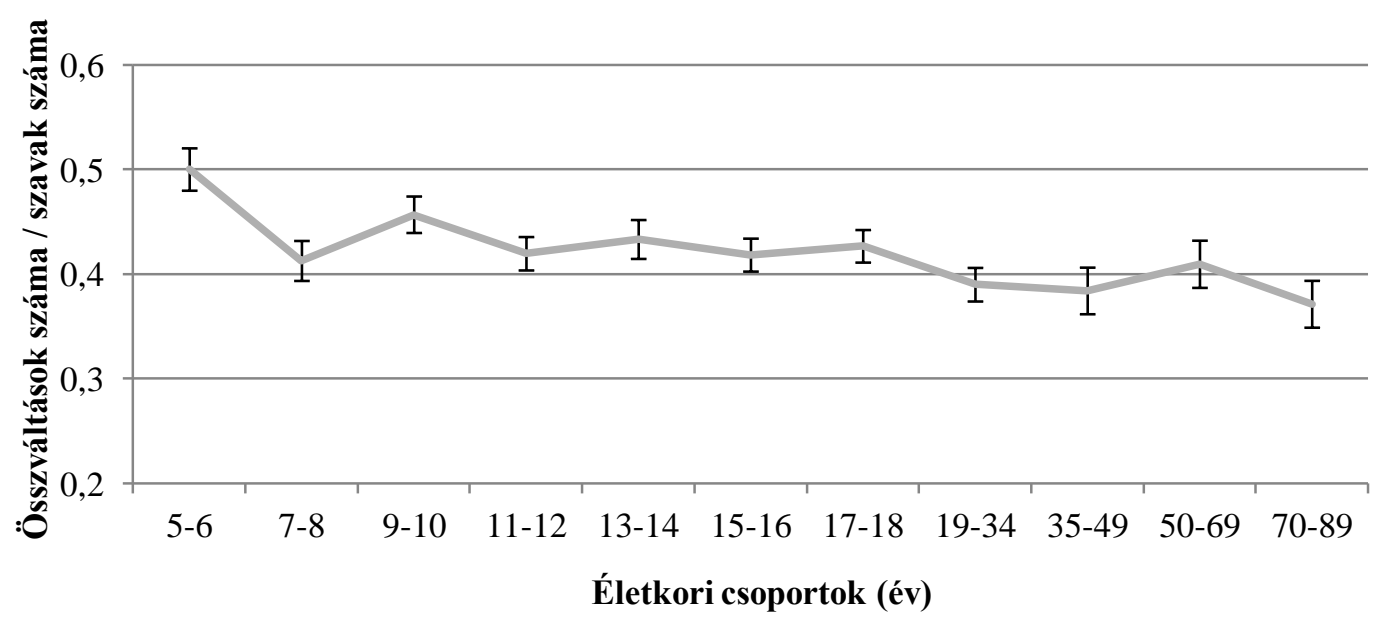

17b. ábra

Az összváltási mutatók életkori csoportonként a „, GYÜMÖLCS” fluencia feladaton. A szóródási mutató az átlag standard hibája 
Az „ÉLELMISZERBOLT” feladaton (17c. ábra) a gyerekek esetében az 5-6 és a 9-10 évesek között nem találtunk szignifikáns különbséget (minden $p>0,12$ ). A 11-12 és a 13-14 évesek csak tendenciaszinten különböztek egymástól $(p=0,09)$, majd 35-49 éves korig stabil volt a teljesítmény (minden $p>0,11$ ). A 35-49 és az 50-69 éves korcsoport között ismét tendenciaszerü különbséget találtunk $(p=0,09)$. Az 50-69 és a 70-89 éves korcsoportok között szignifikáns különbség jelent meg a teljesítményben, a legidősebb csoport összváltási mutatójának a száma lecsökkent ( $p=0,004 ; 14 \mathrm{c}$. melléklet).

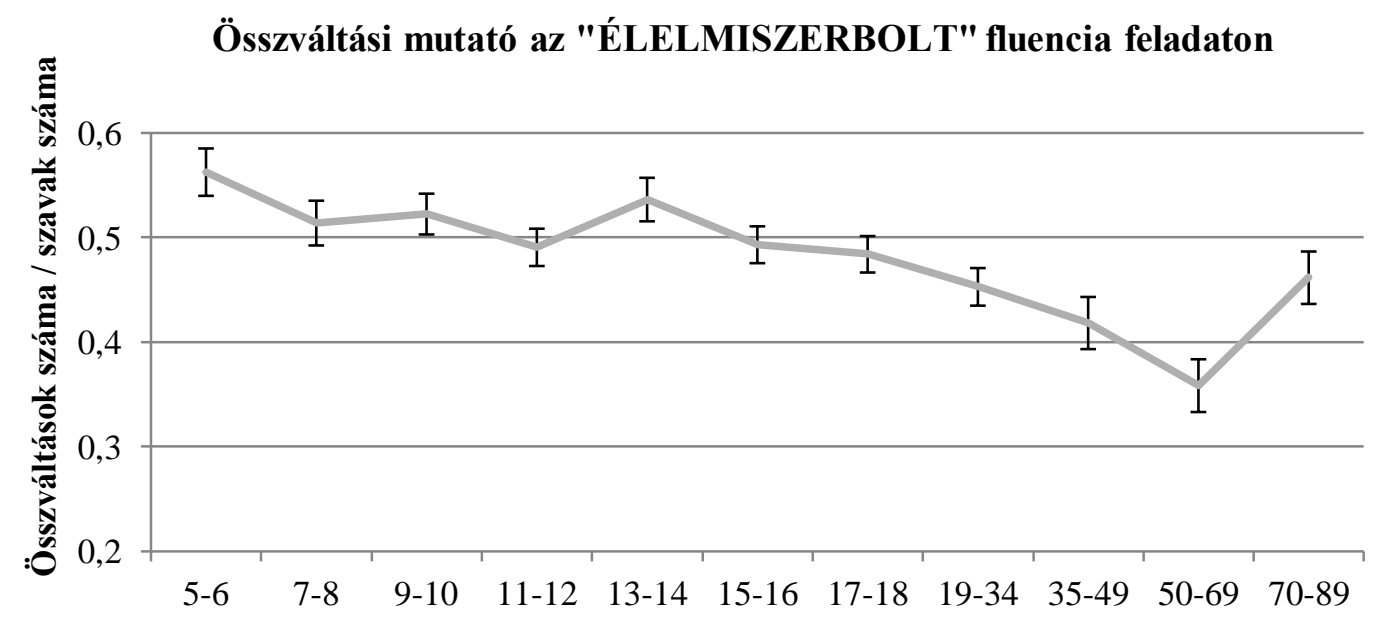

Életkori csoportok (év)

17c. ábra

Az összváltási mutatók életkori csoportonként az „ÉLELMISZERBOLT” fluencia feladaton. A szóródási mutató az átlag standard hibája

A klaszterváltási mutató tekintetében összességében a vizsgálati személyek a három szemantikus fluencia feladaton különböző mennyiségű klaszterváltást hajtottak végre (szignifikáns FELADAT fóhatás: $F(2,1064)=11,91, p<0,001)$. Az LSD post hoc teszt alapján elmondható, hogy a legtöbb klaszterváltást a „GYÜMÖLCS” (átlagosan 0,36), illetve az „ÁLLAT” fluencia feladaton (átlagosan 0,35) produkálták, ettől szignifikánsan kevesebb volt a klaszterváltás az „ÉLELMISZERBOLT” (átlagosan 0,28) feladaton (minden $p<0,001)$.

Az ÉLETKORI CSOPORT vizsgálatakor szignifikáns főhatást találtunk $(F(10$, 532)=10,59; $p<0,001)$, tehát összességében a klaszterváltási mutatók számában volt változás az életkori csoportok között. 5-től 12 éves korig a gyerekek klaszterváltási mutatója egyre nagyobb lett (minden $p<0,02$ ). A 11-12 éves kortól 15-16 éves korig a csoportok hasonlóan teljesítettek (minden $p<0,30$ ). A 15-16 és 17-18 éves korcsoportban tendenciaszerü különbség volt $(p=0,06)$, ahogyan a $17-18$ és $19-34$ éves korcsoport között is $(p=0,08) .35$ 
éves kortól egészen 89 éves korig a csoportok között nem találtunk szignifikáns különbséget (minden $p>0,36$ ).

A FELADAT x ÉLETKORI CSOPORT interakciója esetében az egyes életkori csoportok különböztek egymástól a klaszterekváltási mutatót figyelembe véve ( $F(20$, 1064)=1,785, $p=0,02$; lásd 18a., 18b., és 18c. ábra, továbbá a pontos átlagokat és szórásokat korcsoportonként és feladatonként lásd a 15a., 15b., és 15c. mellékletben).

Az „ÁLLAT” szemantikus fluencia feladaton (18a. ábra) a gyerekek esetében az 5-6 évesekhez képest a 7-8 évesek klaszterváltási mutatója tendenciaszinten nagyobb volt $(p=0,06)$. A 7-8 évestől a 15-16 éves korosztályig a csoportok teljesítménye hasonló volt (minden $p>0,37)$, majd növekedést mutatott a 17-18 éveseknél $(p=0,03) .19$ éves kortól egészen idős korig a csoportok hasonló eredményeket produkáltak (minden $p>0,22 ; 15 \mathrm{a}$. melléklet).

\section{Klaszterváltási mutató az "ÁLLAT" fluencia feladaton}

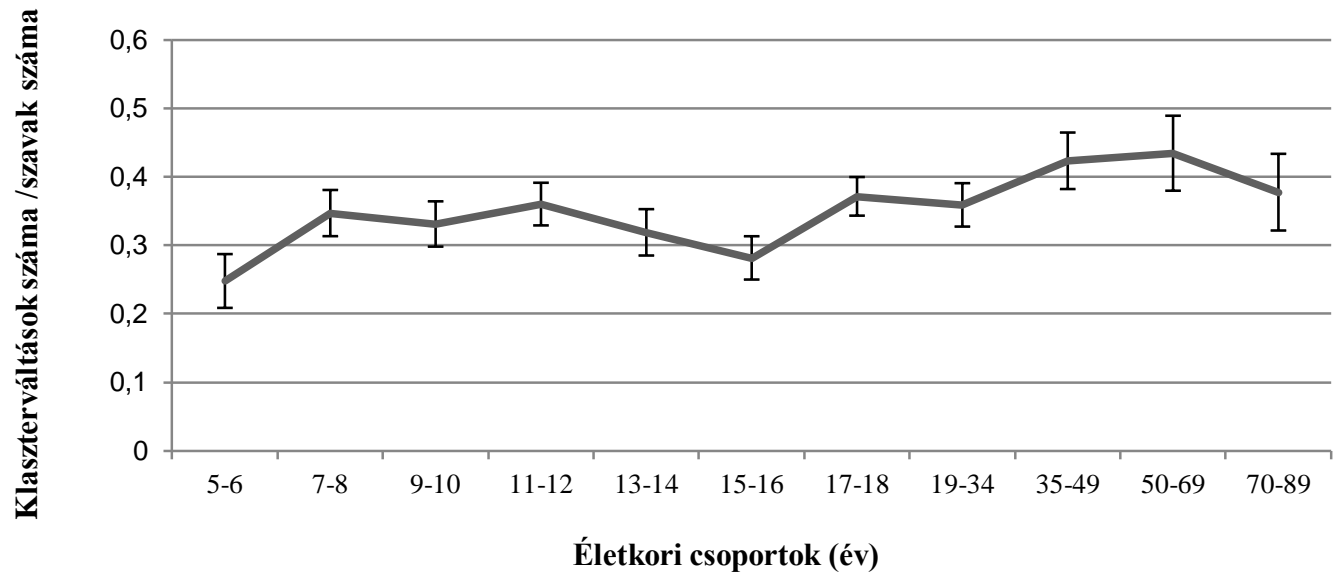

18a. ábra

A klaszterváltási mutatók életkori csoportonként az „ÁLLAT” fluencia feladaton. A szóródási mutató az átlag standard hibája

A „GYÜMÖLCS” szemantikus fluencia feladaton (18b. ábra) az 5-6 és a 7-8 évesek ( $p=0,001)$ szignifikánsan különböző teljesítményt nyújtottak, valamint a 7-8 és a 9-10 évesek is szignifikánsan különböztek egymástól a klaszterváltási mutató tekintetében $(p=0,009)$, a legmagasabb klaszterváltási mutató a 7-8 éveseknél volt. 9-10 éves kortól egészen idős korig a csoportok hasonló eredményeket mutattak (minden $p>0,19$; lásd 15b. melléklet). 


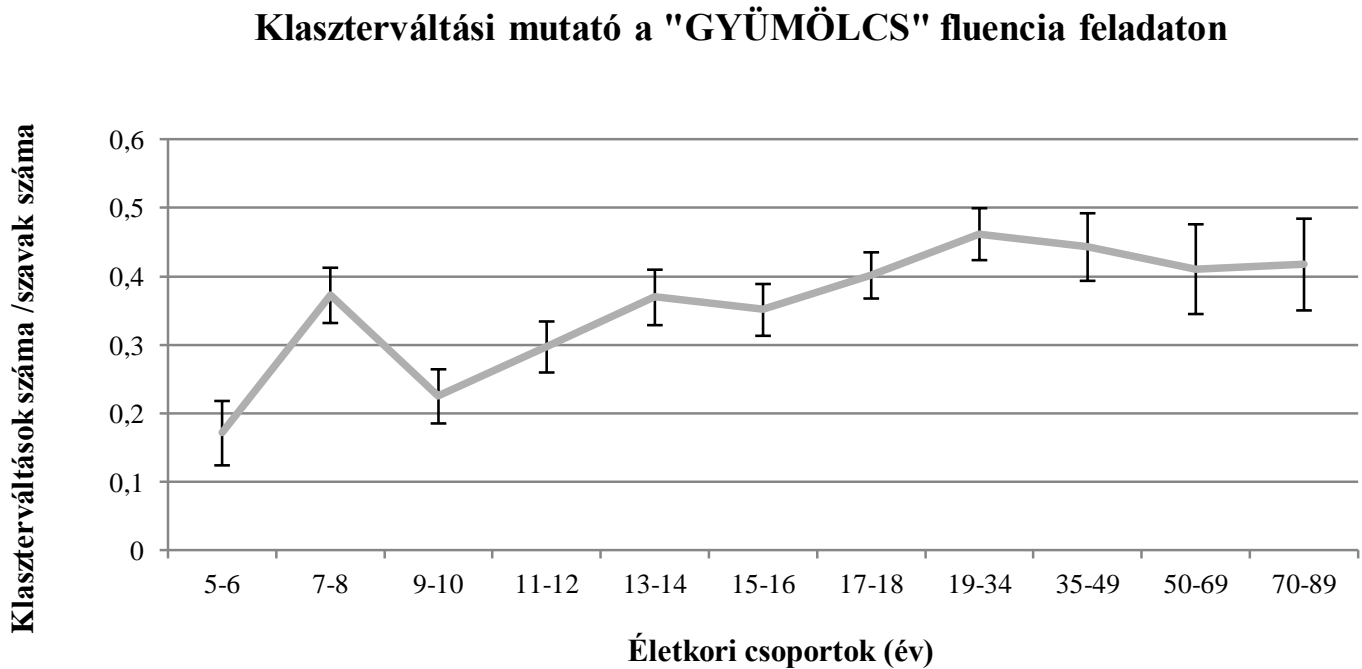

18b. ábra

A klaszterváltási mutatók életkori csoportonként a „, GYÜMÖLCS” fluencia feladaton. A szóródási mutató az átlag standard hibája

Az „ÉLELMISZERBOLT” feladatnál (18c. ábra) a gyerekek 5-8 éves korig tendenciaszinten $(p=0,09)$ különböznek egymástól a klaszterváltási mutatókban, majd a 9-10 és a 11-12 évesek között szignifikáns különbséget találtunk ( $p=0,005)$. A 11-12 és a 15-16 évesek teljesítménye hasonló volt $(p=0,68)$, mindkét csoportnál szignifikánsan alacsonyabb értéket ért el a 13-14 éves csoport (minden $p<0,01$ ). A 17-18 csoport teljesítményéhez képest a 19-34 éveseknél újra nőtt a klaszterváltási mutató $(p=0,02)$. 35-89 éves korig az egyes csoportok hasonló szinten teljesítettek (minden $p>0,26$; lásd 15c. melléklet).

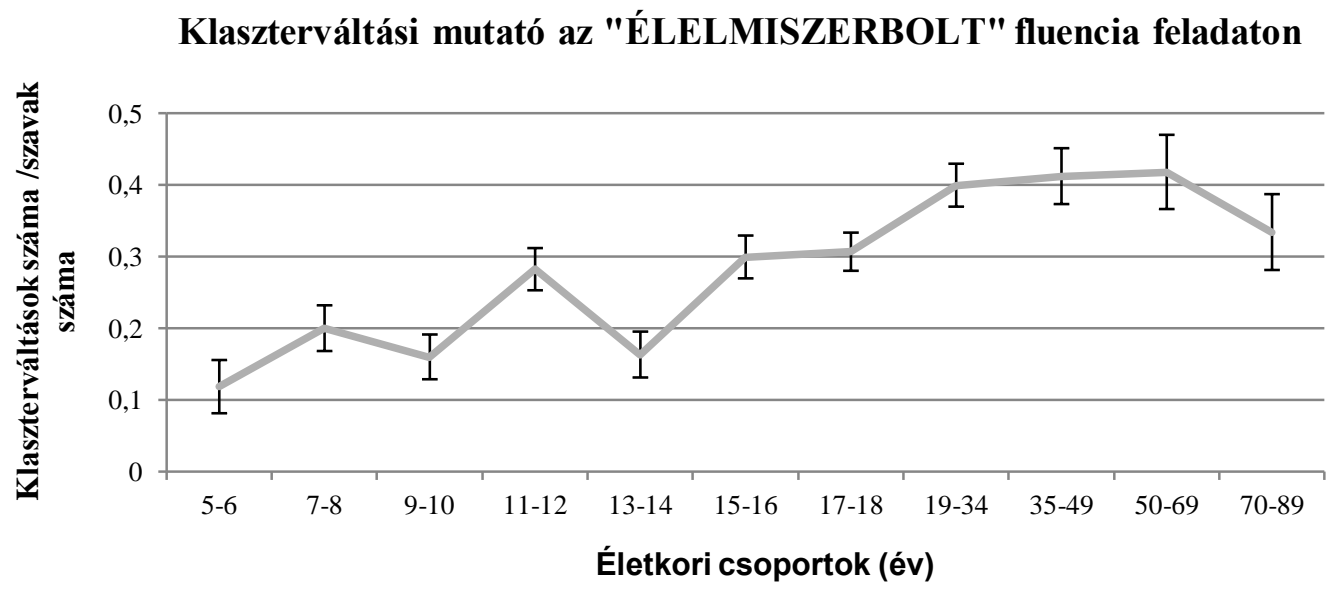

18c. ábra

A klaszterváltási mutatók életkori csoportonként az „ÉLELMISZERBOLT” fluencia feladaton. A szóródási mutató az átlag standard hibája 


\subsection{Részösszefoglalás}

A vizsgálat célja a szemantikus fluencia feladatok magyar nyelvü változatának nagy elemszámú, komplex és széles életkori övezetet magában foglaló feltérképezése volt. A vizsgálat hiánypótló, mivel a hazai klinikai neuropszichológiai gyakorlatban rendszeresen használt mérőeszközről van szó. A szemantikus fluencia teszt adatait 11 életkori övezetben több mint 500 fö bevonásával határoztuk meg, a hagyományos mutatók mellett olyan új, komplexebb mutatókat is használva, amelyeknek kulcsszerepük lehet a finomabb diagnosztikában.

A szavak száma tekintetében mindhárom szemantikus fluencia feladat esetében találtunk életkori különbséget. A háromféle feladat közül a legkönnyebbnek az „ÁLLAT” szemantikus fluencia feladat bizonyult, amely összhangban van néhány korábbi kutatás eredményeivel (pl. Baldo és Shimamura, 1998; Chan és Poon, 1999; Schwartz és mtsai, 2003). A vizsgálatban mindhárom szemantikus fluencia feladaton az 5-6 évesek több szót tudtak mondani, mint a betüfluencia feladat esetében, majd 17-18 éves korban egy fokozatos növekedés után a teljesítmény elérte a felnőtt szintet (Chan és Poon, 1999; Klenberg és mtsai, 2001). A legjobb teljesítményt a 35-49 éves korcsoport érte el, majd 50-69 éves kortól jelentősen visszaesett a teljesítmény, ami összhangban van több korábbi eredménnyel is (Troyer, 2000; Chan és Poon, 1999; Tombaugh és mtsai, 1999; Loonstra és mtsai, 2001; Van der Elst és mtsai, 2006). A korábbi vizsgálatok eredményeihez hasonlóan tehát megállapíthatjuk, hogy a szemantikus fluencia teljesítmény az életkorral gyorsabban nő, mint a betűfluencián elért teljesítmény (Koren és mtsai, 2005), mivel ahhoz viszonyítva a szemantikus fluencia feladat esetében szignifikánsan nagyobb életkori hatásokat találtunk (Gladsjo és mtsai, 1999; Troyer és mtsai, 1997). A nagyobb életkori hatás ezen a feladaton talán annak köszönhető, hogy a szemantikus klaszterek keresése azok nagyobb mérete miatt lelassíthatja a keresési folyamatot (Diaz és mtsai, 2004). A szemantikus fluencia teljesítmény leginkább a már meglévő szemantikus táraktól függ (Troyer és mtsai, 1998) és az idősödés folyamatában megfigyelhető teljesítményromlás a szemantikusmemória-rendszer változásaival (Kozora és Cullum, 1995, Tomer és Levin, 1993), valamint a pszichomotoros tempó lassulásával hozható összefüggésbe (Rodriguez-Aranda, 2003; Rodriguez-Aranda és Martinussen, 2006).

A perszeverációk száma mindhárom szemantikus fluencia feladat és minden egyes életkori csoport esetében igen csekély volt, de a betegcsoportok vizsgálatával foglalkozó tanulmányok az egyik legjobb mutatónak tartják agyi károsodás esetén (Tröster és mtsai, 
1989; Kozora és Cullum, 1995). Például a frontális lebenyt érintő betegségek esetében sokkal több perszeverációt regisztráltak, mint az egészséges személyek körében (Baldo és Shimamura, 1998; Jones-Gotman, 1991). Ugyan növekedést találtunk a két legidősebb, tehát az 50-69 és a 70-89 éves korcsoportban, de még mindig nagyon alacsony volt a perszeverációk száma.

A hibák száma tekintetében az eredmények hasonló tendenciát mutatnak, egy „U”alakú görbéhez hasonlóan 5-10 és 50-89 éves kor között megnő a hibázások száma. Kivételt képez ez alól az élelmiszerbolt fluencia feladat, ahol a legidősebb csoport hibázása volt a legalacsonyabb az életkori csoportok közül és az 5-8 éves gyerekek lényegesen többet hibáztak ezen a feladaton. Összességében minden életkori csoportban nagyon alacsony volt a hibázási mutató, hasonlóan több korábbi kutatás eredményéhez (pl. Kozora és Cullum, 1995; Tröster és mtsai, 1989). Ezzel szemben egyes tanulmányok szerint például Alzheimer-kórban szenvedő betegek esetében megnő a hibázások száma (Cahn és mtsai, 1997; Ober és mtsai, 1986).

A klaszterek száma tekintetében elmondható, hogy a szavak számához hasonlóan 3549 éves korig egy folyamatos növekedés figyelhetö meg, majd 50-69 és 70-89 éves korban visszaesik a teljesítmény. Feltételezhetően körülbelül 50 éves korig a teljesítmény növekedésének hátterében egy flexibilisebb kognitív kontrollrendszer állhat. A klaszterméret szempontjából megállapítható, hogy az „ÁLLAT” fluencia feladaton az életkorral nőtt a klaszterek mérete is, a két legidősebb korosztály nyújtotta a legjobb teljesítményt, ami megerősíti Troyer és munkatársai (1997) eredményeit. Ezek a különbségek szókincsbeli különbségekre utalhatnak (Troyer és mtsai, 1997; Lachman és mtsai, 1982; Wechsler, 1981). A „GYÜMÖLCS” és az „ÉLELMISZERBOLT” feladat esetében pedig az életkor növekedésével nem változik a teljesítmény jelentősen, habár a 35-49 éves korcsoporthoz képest, akik a legjobb teljesítményt nyújtották, némi visszaesés figyelhető meg a klaszterek méretét tekintve.

Az összváltásokat tekintve mind az „ÁLLAT” mind pedig a „GYÜMÖLCS” szemantikus fluencia feladaton az összváltások száma 15-16, illetve 17-18 éves korig nőtt, majd ezen életkoroktól 35-49 éves korig stagnált, végül pedig 50-69 és 70-89 éves korban jelentősen visszaesett. Az „ÉLELMISZERBOLT” feladat esetében szintén hasonló mintázat látható azzal a különbséggel, hogy az 50-69 éves korcsoport esetében kevesebb összváltást találtunk, mint a legidősebb korosztálynál.

A klaszterváltások elemzésekor szintén hasonló mintázatú eredményeket találtunk, tehát az „ÁLLAT” és a „GYÜMÖLCS” szemantikus fluencia feladaton a klaszterváltások 
száma 15-16, illetve 17-18 éves korig nőtt, majd ezen életkoroktól 35-49 éves korig állandó maradt, végül pedig 50-89 éves korban visszaesett. Az „ÉLELMISZERBOLT” feladat esetében szintén hasonló mintázat látható azzal a különbséggel, hogy a két legidősebb korcsoport teljesítménye nem olyan nagy mértékben csökkent le, a 15-16 éves korcsoport szintjén maradt.

Ha gerontológiai szempontból vizsgáljuk az eredményeket, akkor megállapíthatjuk, hogy a perszeveráció, hiba, klaszterszám, összváltás és klaszterváltás szempontjából is 50-69 és 70-89 éves korban romlás figyelhető meg a teljesítményben, tehát idősebb korban megnő a hibák és perszeverációk száma, a klaszterek és a váltások száma pedig csökken. Az idősebbek kevésbé gyakran váltottak a szemantikus fluencia feladaton, mint a fiatalabbak, talán ez szolgálhat magyarázatul a szavak számában megfigyelhető idős kori leromlásra. Ugyanakkor a klaszterméret az egyetlen olyan vizsgált változó, ahol az idősek teljesítménye intakt marad a fiatalokhoz viszonyítva is, amely az idős korban meglévő szókincs megtartottságára utalhat. A váltások és a klaszterek száma összefüggésben van tehát a frontális kapacitással, mivel szükséges a kognitív flexibilitás olyan stratégiai előhívó folymatokhoz, mint az új alkategória keresése, váltás és szókeresés az új alkategórián belül. Ezzel szemben a klaszter méret, mely inkább a lexiko-szemantikus tudáshálózat kiterjedésének mérésére szolgál egy adott alkategórián belül, a temporális lebeny funkciókkal áll kapcsolatban (Troyer és mtsai, 1997, 1998; Troyer, 2000; Abwender és mtsai, 2001; Robert és mtsai, 1997).

Összegezve a második és harmadik vizsgálat eredményeit a betüfluencia és a szemantikus fluencia tesztek együttes felvétele segíti a fronto-temporális funkciók feltérképezését, így egy egyszerűen használható eszközt kap a klinikai szakember a neuropszichológiai diagnosztikához, valamint a fejlődéspszichológiában, az iskolapszichológiában és a kognitív pszichológiában is hasznos eljárással bővült a tesztbattéria. A klasszikusan használt mutatókon túl a komplexebb mutatók hozzájárulnak a pontosabb és részletesebb kognitív neuropszichológiai profil felrajzolásához. A vizsgálatokban tárgyalt szempontok nemcsak a klasszikus neurológiai és pszichiátriai kórképek neuropszichológiai diagnosztikájában nyújthatnak hasznos fogódzókat, hanem a fejlődéslélektani vizsgálatokban és az iskolapszichológiában is. 


\section{A NEGYEDIK VIZSGÁLAT}

\section{A KOGNITÍV FUNKCIÓK ÉS AZ ISKOLAI TELJESÍTMÉNY KAPCSOLATA}

Az alábbiakban a negyedik vizsgálatunkat mutatjuk be. Az disszertáció első három vizsgálatában a hallási mondatterjedelem teszt, a betűfluencia teszt és a szemantikus fluencia teszt magyar nyelvü változatásnak elkészítésével lehetőségünk nyílik az életkori változások vizsgálatára. Ezek a tesztek segíthetnek abban, hogy feltérképezzük az iskolai teljesítmény hátterében álló kognitív funkciókat.

$\mathrm{Az}$ általános iskolai teljesítmény alapvetően határozza meg a gyerekek életútját és jövőjét. Az iskolai teljesítmény hátterében álló faktorok feltérképezése tehát kulcsfontosságú nemcsak tanuláspszichológiai és iskolapszichológiai szempontból, hanem a fejlesztési programokat tekintve is. Az utóbbi években a modern kognitív pszichológiának és neuropszichológiának fontos szerepe van az iskolai teljesítményt meghatározó tényezők vizsgálatában, ugyanis ezen tudományterületek fókuszáltabb kognitív funkciókat vizsgálnak, amelyek empirikusan megalapozottak és idegrendszeri hátterük relatíve feltérképezett (Csépe, 2005, 2011).

\subsection{Célkitúzések, hipotézisek}

A negyedik, longitudinális kutatásunk célja annak feltérképezése volt, hogy a vizsgálatban részt vevő gyerekek negyedik évfolyamon azonosított iskolai teljesítményét hogyan jósolja be a munkamemória és végrehajtó funkció teszteken nyújtott első osztályos kognitív funkciókat mérő teszteken nyújtott eredményük. A negyedik vizsgálat hipotézisei a következők voltak: a magyar nyelv és irodalom tantárgyon nyújtott teljesítményt a téri-vizuális feladaton elért eredmény, a matematika tantárgyon elért teljesítményt a a téri-vizuális és a komplex munkamemória feladatokon elért eredmények határozzák meg, a környezetismeret tantárgy esetében pedig a komplex munkamemóriának bejósló értéke van. 


\subsection{Módszerek}

\subsubsection{Minta}

A vizsgálatban összesen 105 tipikus fejlődésü gyerek vett részt (59 lány/46 fiú; 88 jobb-/17 balkezes). A vizsgálati személyek átlagos életkora 6,79 év volt (szórás=0,54). Az adatgyüjtésre Csongrád megyében került sor, három különböző iskolában. A kognitív tesztek felvételekor a gyerekek az általános iskola első osztályába jártak. A teszten elért teljesítményüket vetettük össze az egyes tantárgyakon elért negyedik osztályos tanulmányi eredményeikkel. Az iskolai teljesítményt az egyes tantárgyakra adott év végi jegyekben mértük. A tesztfelvétel előtt minden résztvevőt és az intézmények vezetőit is részletesen informáltunk a kutatás céljáról és menetéről, valamint írásbeli beleegyezést is kértünk a gyerekek szüleitől. A vizsgálat során betartottuk a Magyar Pszichológiai Társaság által előírt etikai szabályokat.

\subsubsection{Méröeszközök, eljárás}

A jelen vizsgálatban használt eszközöket korábbi fejezetekben már részletesen ismertettük (lásd 5. fejezet), itt csak a tesztek legfontosabb jellemőit foglaljuk össze.

Álszó ismétlési teszt (Gathercole és mtsai, 1991; Racsmány és mtsai, 2005, Németh és mtsai, 2000) - A vizsgálati személynek egyre hosszabb, értelmetlen szavakat kell hallás után megismételnie (lásd 13. táblázat). A végső terjedelmi mutató az a szótaghosszúság, ahol a vizsgálati személy négy próbából hármat helyesen tudott megismételni.

Számterjedelem teszt (Jacobs, 1887; Racsmány és mtsai, 2005) - A vizsgálati személyeknek számsorokat kell megismételni az elhangzás sorrendjében. A végső terjedelmi mutató az a számsorozat-hosszúság, ahol a. négy próbából hármat helyesen tudott megismételni.

Forditott számterjedelem teszt (Gathercole, 1999; Racsmány és mtsai, 2005) - A vizsgálati személynek a számokat az elhangzás sorrendjével ellentétesen kell visszamondania. A végső terjedelmi mutató az a számsorozat-hosszúság, ahol a négy próbából hármat helyesen tudott megismételni.

Hallási mondatterjedelem teszt (Daneman és Blennerhassett, 1984; Janacsek és mtsai, 2009) - A vizsgálati személyeknek a hallott mondatok igazságtartalmáról kell dönteni, valamint megjegyezni a mondatok utolsó szavait, és ezeket a próba végén az elhangzás sorrendjében megismételni. Helyes válasz esetén egyre több mondatot olvas fel a 
vizsgálatvezető. Ha a vizsgálati személy nem tudja a szavakat helyes sorrendben felidézni, akkor elölről kezdjük a feladatot új mondatokkal (összesen háromszor). A végső terjedelmi mutatót a három próba során még helyesen felidézett szavak számának átlaga adja.

Számlálási terjedelem teszt (Case és mtsai, 1982) - Sötétkék köröket és négyzeteket, valamint sárga köröket mutatunk a számítógép képernyőjén. A vizsgálati személyeknek az a feladatuk, hogy egyesével, hangosan számlálják meg a sötétkék köröket, ismételjék meg ezt az utolsó számot és jegyezzék meg. Több kép bemutatása után a számlálás végeredményeit kell sorrendben felidézniük. Ha hibáznak, a feladatot elölről kell kezdeni (összesen háromszor). Mindhárom alkalommal annyi pontot ér el a személy, ahány végeredményt még helyesen vissza tudott mondani. A teszt végső értékét a három sorozat átlaga adja.

Corsi-kocka teszt (Corsi, 1972; Lezak, 1995; Racsmány, 2004) - Kilenc darab fakocka van elhelyezve egy fa táblán. A vizsgálati személynek ugyanabban a sorrendben kell a kockákra mutatnia, ahogy azt a vizsgálatvezető tette. A végső terjedelmi mutató az a hosszúság, ahol a négy próbából hármat helyesen tudott visszamutatni.

Betüfluencia (Spreen és Strauss, 1991; Lezak, 1995; Tánczos, Janacsek és Németh, 2014) - A teszt során a vizsgálati személyeknek megadott kezdőbetűkkel (K, T, A) kell egy percen belül minél több szót mondaniuk. Fontos kritérium, hogy nem mondhatnak tulajdonneveket és ugyannak a szónak a különböző végződéseit sem. A feladat során nyújtott teljesítményt több mennyiségi és minőségi mutatóval jellemezhetjük (lásd. 13. táblázat).

Szemantikus fluencia (Spreen és Strauss, 1991; Lezak, 1995; Tánczos, Janacsek és Németh, 2014) - A teszt felvételekor a v.sz-eknek megadott kategóriákon belül (ÁLLAT, GYÜMÖLCS, ÉLELMISZERBOLT) kell egy percen belül minél több szót mondaniuk. A feladat során nyújtott teljesítményt több mennyiségi és minőségi mutató segítségével elemezhetjük (lásd 13. táblázat).

A verbálisfluencia-tesztek esetében vizsgálatunkban a következő változókat tanulmányoztuk: a szavak, a perszeverációk, a hibák és a klaszterek számát, a klaszterek méretét, valamint az összváltások és a klaszterváltások számát. A változók meghatározásakor Troyer és munkatársai (1997), valamint Mészáros, Kónya és Kas (2011) munkája alapján dolgoztunk.

A kognitív funkciók részletes feltérképezése a gyerekek első osztályos korában történt, egyéni adatfelvétel során, az iskolákban található csendes helyiségekben. Az összes teszt egy alkalommal került felvételre, mely körülbelül 1 órát vett igénybe. A tanulmányi eredményeket a negyedik osztály befejezésekor kértük el az osztályfönököktől, tehát az iskolai teljesítményt az egyes tantárgyakra adott év végi jegyekben mértük. A korábbi kutatási eredményeket 
figyelembe véve a tantárgyak közül a magyar nyelv és irodalomra, a matematikára és a környezetismeretre fókuszáltunk az elemzések során.

\subsubsection{Statisztikai eljárás}

A tanulmányi teljesítményt befolyásoló kognitív faktorok meghatározásához többszörös lineáris regresszióanalízist végeztünk el stepwise (lépésenkénti) módszerrel. A függő változó a tanulmányi teljesítmény volt magyar nyelv és irodalomból, matematikából illetve környezetismeretből, a független változók pedig a Módszerek résznél (lásd 9.3. alfejezet) tárgyalt teszteken nyújtott teljesítmények közül azok, amelyek korreláltak az egyes tantárgyak eredményével. A regressziós eredmények bemutatásánál csak azokat a teszteket tárgyaljuk, amelyek szignifikánsan hozzájárultak a vizsgált tantárgyakon nyújtott teljesítmény bejóslásához. A regresszióanalízis következő paramétereit közöljük: a regressziós együttható $(B)$ és a hozzá tartozó átlag standard hibája $(S E B)$, a standardizált regressziós együttható $(\beta)$, a modellhez tartozó statisztika $(F)$, a modell által megmagyarázott varianciaszázalék az aktuális mintára vonatkoztatva $\left(R^{2)}\right.$ és a standard adjusztált $\mathrm{R}^{2}$ a modell által megmagyarázott varianciaszázalék a populációra vonatkoztatva $\left(\operatorname{adj} R^{2}\right)$.

\subsection{Eredmények}

\subsubsection{A magyar nyelv és irodalom tantárgyon nyújtott teljesitmény bejósló faktorai}

Az alkalmazott stepwise regresszió elemzés mutatja, hogy a magyar nyelv és irodalom tantárgy összevont mutatóján nyújtott teljesítményt két faktor határozta meg szignifikánsan: a Corsi-kocka feladaton nyújtott teljesítmény került be először a modellbe (Modell 1: $F(1$, 102)=12,27, $\left.p=0,001 ; R^{2}=0,107\right)$, és ezt követte a fordított számterjedelem teszten nyújtott teljesítmény (Modell 2: $\left.F(2,101)=9,39, p<0,001 ; R^{2}=0,157\right)$. Ez a két változó összességében a magyar nyelv és irodalom tantárgyon nyújtott teljesítmény varianciájának 15,7 \%-át magyarázta. Mindkét teszten nyújtott teljesítmény pozitív irányú összefüggést mutatott a tantárgyi teljesítménnyel: tehát minél jobban teljesítettek a gyerekek a Corsi-kocka és a fordított számterjedelem feladaton, annál jobb jegyet kaptak magyar nyelv és irodalomból. Az egyes változók $\beta$ értékeit a 19. táblázatban mutatjuk be. 
19. táblázat. A magyar nyelv és irodalom tantárgyon nyújtott teljesitményt befolyásoló faktorok regresszióelemzési mutatói a 2. modell alapján

\begin{tabular}{|c|c|c|c|}
\hline \multirow[b]{2}{*}{ Változók } & \multicolumn{3}{|c|}{ Magyar nyelv és irodalom } \\
\hline & $B$ & $S E B$ & $\beta$ \\
\hline Corsi-kocka & 0,211 & 0,086 & 0,241 \\
\hline Fordított számterjedelem & 0,224 & 0,092 & 0,239 \\
\hline $\operatorname{Adj} R^{2}$ & \multicolumn{3}{|c|}{0,140} \\
\hline$R^{2}$ & \multicolumn{3}{|c|}{0,157} \\
\hline$F$ & \multicolumn{3}{|c|}{$9,39 * *$} \\
\hline
\end{tabular}

$* p<0,05 * * p<0,01$

\subsubsection{A matematika tantárgyon nyújtott teljesitmény bejósló faktorai}

Az alkalmazott stepwise regresszióelemzés mutatja, hogy a matematika tantárgyon nyújtott teljesítményt három faktor határozta meg szignifikánsan: a számlálási terjedelem feladaton nyújtott teljesítmény került be először a modellbe (Modell 1: $F(1,100)=11,82, p=0,001 ; R$ =0,106), ezt követte a Corsi-kocka teszten nyújtott teljesítmény (Modell 2: $F(2,99)=10,07$, $\left.p<0,001 ; R^{2}=0,169\right)$, majd a betűfluencia feladaton alkotott klaszterek száma (Modell 3: $F(3$, $\left.98)=9,38, p<0,001 ; R^{2}=0,223\right)$. Ez a három változó összességében a matematika tantárgyon nyújtott teljesítmény varianciájának $22,3 \%$-át magyarázta.

Mindhárom feladaton nyújtott teljesítmény pozitív irányú összefüggést mutatott a tantárgyi teljesítménnyel: tehát minél jobban teljesítettek a gyerekek a számlálási terjedelem feladaton, annál jobb jegyet kaptak matematikából. Ehhez hasonlóan, minél több klasztert alkottak a betüfluencia feladaton, illetve minél magasabb volt a teljesítményük a Corsi-kocka teszt esetében, annál jobb jegyeket kaptak matematikából. Az egyes változók $\beta$ értékeit a 20. táblázatban ismertetjük. 
20. táblázat. A matematika tantárgyon nyújtott teljesitményt befolyásoló faktorok regresszióelemzési mutatói az 3. modell alapján

\begin{tabular}{|c|c|c|c|}
\hline \multirow[b]{2}{*}{ Változók } & \multicolumn{3}{|c|}{ Matematika } \\
\hline & $B$ & $S E B$ & $\beta$ \\
\hline Számlálási terjedelem & $0,0,368$ & 0,129 & 0,26 \\
\hline Corsi-kocka & 0,293 & 0,099 & 0,271 \\
\hline Betűfluencia klaszterszám & 1,672 & 0,641 & 0,233 \\
\hline $\operatorname{Adj} R^{2}$ & \multicolumn{3}{|c|}{0,199} \\
\hline$R^{2}$ & \multicolumn{3}{|c|}{0,223} \\
\hline$F$ & \multicolumn{3}{|c|}{$9,38 * *$} \\
\hline
\end{tabular}

${ }^{*} p<0,05 * * p<0,01$

\subsubsection{A környezetismeret tantárgyon elért teljesitmény bejósló faktorai}

Az alkalmazott stepwise regresszió elemzés mutatja, hogy a környezetismeret tantárgyon nyújtott teljesítményt három faktor határozta meg szignifikánsan: a számlálási terjedelem került be elöször a modellbe (Modell 1: $F(1,100)=8,52, p=0,004 ; R^{2}=0,079$ ), ezt követte a betüfluencia feladaton alkotott klaszterek száma (Modell 2: $F(2,99)=7,69, p=0,001$; $\left.R^{2}=0,135\right)$, valamint a szemantikus fluencia feladaton produkált élesváltások száma (Modell 3: $\left.F(3,98)=7,50, p<0,001 ; R^{2}=0,187\right)$. Ez a három változó összességében a környezetismeret tantárgyon nyújtott teljesítmény varianciájának 18,7 \%-át magyarázta.

A számlálási terjedelem teszten nyújtott teljesítmény és a környezetismeret tantárgy jegye között pozitív irányú összefüggést találtunk: minél magasabb volt a gyerekek teljesítménye a számlálási terjedelem teszten, annál jobb jegyeket kaptak környezetismeretből. Ehhez hasonlóan, minél több klasztert alkottak a betűfluencia feladaton, annál jobb eredményt értek el ezen a tantárgyon. A szemantikus fluencia élesváltás számával viszont negatív irányú volt az összefüggés: vagyis minél kevesebb élesváltás történt a szemantikus fluencia feladaton, annál jobb jegyeket kaptak környezetismeretből. Az egyes változók $\beta$ értékeit a 21. táblázatban ismertetjük. 
21. táblázat: A környezetismeret tantárgyon nyújtott teljesitményt befolyásoló faktorok regresszióelemzési mutatói a 3. modell alapján

\begin{tabular}{lccc}
\hline \hline \multirow{2}{*}{ Változók } & \multicolumn{3}{c}{ Környezetismeret } \\
\cline { 2 - 4 } \multicolumn{1}{c}{} & \multicolumn{1}{c}{$B$} & $S E B$ & $\beta$ \\
\hline \hline Számlálási terjedelem & 0,292 & 0,113 & 0,238 \\
Betüfluencia klaszterszám & 1,547 & 0,569 & 0,248 \\
Szemantikus fluencia élesváltás & $-1,204$ & 0,480 & $-0,231$ \\
& & & \\
$A d j R^{2}$ & & & 0,162 \\
$R^{2}$ & & & 0,187 \\
$F$ & & & $7,50^{* * *}$ \\
\hline \hline
\end{tabular}

${ }^{*} p<0,05 * * p<0,01$

\subsection{Részösszefoglalás}

Longitudinális vizsgálatunk célja annak feltérképezése volt, hogy a negyedik osztályos iskolai teljesítményt hogyan jósolja be a munkamemória és végrehajtó funkciókat mérő teszteken nyújtott első osztályos teljesítmény. Négy tantárgyra fókuszáltunk az elemzések során: magyar nyelv és irodalom, matematika, illetve környezetismeret tantárgyakra. A magyar nyelv és irodalom esetében a Corsi-kocka teszt és a fordított számterjedelem teszt volt bejósló értékü. A matematika teljesítményt a változók közül a számlálási terjedelem teszten nyújtott teljesítmény, a betűfluencia klaszterszám mutató és a Corsi-kocka terjedelem jósolta be. A környezetismeret esetében pedig a számlálási terjedelem, a betűfluencia klaszterszáma és a szemantikus fluencia élesváltás mutatója került be a modellbe. Tehát összességében vizsgálatunkban a téri-vizuális munkamemória, a komplex munkamemória, illetve a végrehajtó- és nyelvi funkciókat mérő fluencia feladatok egyes komponensei határozták meg a negyedik osztályos tanulmányi teljesítményt.

Számos korábbi tanulmányban megállapították, hogy az iskoláskorú gyerekek olvasási és írási készségei szoros kapcsolatban állnak a munkamemóriával (Thompson és Gathercole, 2006; Van der Sluis, De Jong és Leij, 2007), a flexibilitással (Altemeier, Abbott és Berninger, 2008; Van der Sluis, De Jong és Leij, 2007) és a gátlással (Altemeier, Abbott és Berninger, 2008; Altemeier, Jones, Abbott és Berninger, 2006; Thompson és Gathercole, 2006; Taylor, Schatschneider, Petrill, Barry és Owens, 1996).

Saját vizsgálatunkban a magyar nyelv és irodalom tantárgyon nyújtott teljesítménynél a leginkább meghatározó tényezőnek a téri-vizuális munkamemória kapacitás bizonyult. Ez az eredmény összhangban van több korábbi kutatással is, amely kimutatta, hogy a jó téri-vizuális 
képességek elengedhetetlenek például az olvasáshoz és szövegértéshez, mivel feltételezhetően összefüggést mutatnak a képzelettel. A jobb képzelőképességgel rendelkező személyek jobban tudják vizualizálni a dolgokat. (Lovegrove, Martina és Slashuisa, 1986; Goulandrisa, 1991; Von Károlyi és mtsai, 2003). Vizsgálatunkban továbbá meghatározónak bizonyult a fordított számterjedelem teszten nyújtott eredmény is a magyar nyelv és irodalom teljesítmény esetében (Gathercole és mtsai, 2006). Más kutatások is szoros összefüggést találtak a munkamemória és az írás/olvasás teljesítmény között (Thompson és Gathercole, 2006; Van der Sluis és mtsai, 2007).

A matematika tantárgyon elért teljesítmény esetében a komplex munkamemória kapacitása mutatkozott a legmeghatározóbbnak, összhangban néhány korábbi kutatással (Bull és Scerif, 2001; Espy és mtsai, 2004; Lu és mtsai, 2011). Van den Bos, Van der Ven, Kroesbergen és Van Luit (2013) vizsgálata szerint a munkamemória minden komponense kapcsolatban van a matematika teljesítménnyel. Rasmussen és Bisanz (2005) szerint az iskola első évfolyamában a teljesítmény kezd kiegyenlítődni a nonverbális és a verbális matematikai feladatokon, valamint a verbális munkamemória a legjobb előrejelzője a verbális matematikai problémáknak. A központi végrehajtó a megfelelő stratégia kiválasztásával segíti a gyerekek problémamegoldó készségeit (Barrouillet és Lepine, 2005; Bull és mtsai, 1999; Geary, Hoard és Hamson, 1999). A több klaszter létrehozása a betűfluencia feladat esetében jobb váltási képességekkel függhet össze, ami szintén fontosnak bizonyult a matematika teljesítmény esetében. Más szerzők azonban a lexikonhoz való hozzáférés mutatójaként is értelmezik ezt a változót (Hurks és mtsai, 2004; Hurks, Schrans, Meijs, Wassenberg, Feron és Jolles, 2010; Takács, Kóbor, Tárnok és Csépe, 2013; Tucha és mtsai, 2005). A korábbi kutatások szintén találtak kapcsolatot más feladatokkal mért váltási képesség (például a Wisconsin Kártyaszortírozási Teszt, Stroop teszt, számlálási terjedelem teszt) és a matematika tantárgy jegye között (Bull és mtsai, 1999; Bull és Scerif, 2001). Emellett a Corsi-kocka teszttel mért téri-vizuális munkamemória kapacitása is meghatározta a matematika tantárgyon elért teljesítményt, összhangban Meyer és munkatársai (2010) eredményeivel. Ez a feladat egyszerre igényel jó rövidtávú tárolási és komplexebb, téri-vizuális információfeldolgozási kapacitást, így involválódása a matematika teljesítményben szintén megegyezik Holmes és Adams (2006) eredményeivel, miszerint 8-9 éves tipikusan fejlődő gyerekeknél a központi végrehajtó és a téri-vizuális munkamemória mérőeljárásain elért teljesítmény határozza meg leginkább a matematikai teljesítményt. A téri-vizuális funkcióknak szerepe van a számfogalom kialakulásában, a számolásban és az aritmetikában (McLean és Hitch, 1999). Tehát összességében a jó téri-vizuális képesség, komplex munkamemória, illetve váltás és 
flexibilitás segítheti például a szöveges feladatok megoldását és a fejben számolást a matematika esetében. Eredményeinkkel összhangban Gersten, Jordan és Flojo (2005) szerint a munkamemória megbízható indikátora a matematikai nehézségeknek a formális oktatás első évében. Néhány további kutatás szerint is a gyengébb munkamemória készségek szoros kapcsolatban állnak a gyengébb számolási készségekkel (Wilson és Swanson, 2001; Alloway, 2009) valamint a munkamemória mérőeljárásai jól differenciálnak a matematikai nehézséggel küzdő és a matematikából jól teljesítő gyerekek között (Geary és mtsai, 1999; Bull és Scerif, 2001).

A környezetismeret tantárgy kognitív bejóslóira eddig kevés figyelem fordult. Gathercole és munkatársai (2004) eredményei szerint a környezetismeret tantárgy esetében a komplex munkamemória, azon belül pedig a fordított számterjedelem teszt bír bejósló értékkel. Jelen kutatásunkban a számlálási terjedelemmel mért nagyobb komplex munkamemória kapacitás magyarázta legnagyobb mértékben a környezetismeret tantárgyon elért jobb teljesítményt, mivel az információ manipulálását és tárolását ez a teszt tükrözi leginkább. Emellett, a matematikához hasonlóan, itt is megjelent a rugalmasabb, jobb váltási képességeket jelző nagyobb klaszterszám a betűfluencia feladaton. A szemantikus fluencia feladat esetében a kevesebb élesváltás kapcsolódott a jobb tanulmányi teljesítményhez. Ez úgy értelmezhető, hogy amennyiben a gyerekek képesek a fluencia feladaton produkált szavakat csoportokban (klaszterekben) elöhívni, és klaszterek között váltani (szemben az élesváltással), akkor ez a szintetizáló gondolkodás segítheti a jobb tanulmányi teljesítményt.

Vizsgálatunk első lépésnek tekinthető a fókuszált kognitív funkciók és az iskolai teljesítmény feltérképezésében. Emiatt elsősorban leíró jellegű munkáról van szó, a pontos modellépítéshez még további kutatások szükségesek. Fontosnak tartjuk kiemelni, hogy kutatásunkban csupán két fó kognitív területet vizsgáltunk - a munkamemóriát és a végrehajtó funkciókat -, melyek önmagukban viszonylag magas (közel $20 \%$-át) adják a megmagyarázott varianciának. Ez viszonylag meglepő eredmény, figyelembe véve azt, hogy egyéb, esetlegesen fontos kognitív funkciók be sem kerültek a vizsgálatba, mint például a szelektív figyelem, kitartó figyelem (vigilancia), szemantikus és epizodikus emlékezet, implicit emlékezet, IQ (természetesen ezek sem egymástól független konstruktumok). A kapott eredmények alapján úgy véljük, hogy a fenti területek (munkamemória és végrehajtó funkciók) vizsgálata fontos szerepet kaphat a diagnosztikában és ezek fejlesztése jelentős hatással lehet az iskolai teljesítményre.

Vizsgálatunk korlátjának tekinthető, hogy korlátozott számú tesztből álló battériát használtunk fel. A munkamemória és végrehajtó funkciót mérő eljárások közül számos 
kimaradt a vizsgálatból (pl. Wisconsin Kártyaszortírozási Teszt, Hanoi-torony, N-back teszt stb). Ennek első számú oka, hogy korlátozott idő (egy tanítási óra - 45 perc) állt rendelkezésünkre a gyerekek vizsgálatára. Továbbá figyelembe kellett vennünk azt is, hogy ilyen életkorú gyerekek figyelmét ennél hosszabb ideig nem tudjuk fenntartani. A fentebb említett mérőeljárások felvétele a további kutatásokban mindenképpen fontos lenne. A vizsgálat további korlátjaként merülhet fel, hogy az iskolai teljesítményt a tanulmányi jegyek alapján mértük, ami szubjektívebb lehet, mint a sztenderdizált teljesítménytesztek, azonban ilyenek magyar nyelven nem álltak rendelkezésre. A jövőben mélyebb elemzések és vizsgálatok szükségesek annak érdekében, hogy az egyes tantárgyakon nyújtott teljesítmények alkomponenseit pontosabban tudjuk mérni (pl. magyar nyelvnél olvasás, olvasott szövegértés, fogalmazás stb.). Végül pedig azt is fontos megemlíteni, hogy az adatokat egy városból gyüjtöttük, tehát a reprezentativitás sérülhet, habár ennek csökkentése érdekében több iskolát vontunk be a vizsgálatba. Vizsgálatunk első lépésnek tekinthető tehát, melyben feltérképeztük az alapvető összefüggéseket a tantárgyakon nyújtott teljesítmény és a munkamemória, valamint a verbálisfluencia-feladatokon kapott eredmények között.

Összegezve, a disszertáció negyedik vizsgálatban a fókuszált kognitív funkciók bejósló hatását vizsgáltuk az iskolai teljesítményre és sikerült kapcsolatot kimutatni a munkamemória- és végrehajtó funkciók egyes alkomponensei, valamint az iskolai teljesítmény között. Hiánypótló vizsgálat született, mivel magyar vonatkozású eredmények eddig még nem jelentek meg ebből a nézőpontból. Az eredmények nem csak a pedagógia és az iskolapszichológia számára lehetnek fontosak, hanem a neuropszichológiai gyakorlatban is nélkülözhetetlenek. Ez a típusú vizsgálati módszer segítheti a munkamemória, nyelvi- és végrehajtó funkció károsodások detektálását fejlődési vagy szerzett neurológiai károsodással élő, illetve tanulási nehézségekkel küzdő gyerekeknél. 


\section{A MUNKAMEMÓRIA ÉS VÉGREHAJTÓ FUNKCIÓK FEJLESZTÉSI LEHETÖSÉGEI}

A disszertáció korábbi fejezeteiben felvázoltuk, hogy a munkamemória-komponenseknek és a végrehajtó funkciók komponenseinek hatása van az iskolai teljesítményre és a mindennapi élet kognitív funkcióira. A különböző betegcsoportok munkamemória és végrehajtó funkciókban diagnosztizálható károsodásának és elmaradásának korai felismerésével lehetőségünk nyílik ezek fejlesztésére, rehabilitációjára. A jövőben ezekre a területekre is érdemes hangsúlyt fektetni.

\subsection{A munkamemória-tréningek}

A munkamemória kapacitása egy limitált rendszer, ami az elme munkafelületeként funkcionál. Az egyén munkamemória kapacitása kulcsfontosságú számos kognitív feladat kivitelezésében (Kane és mtsai, 2004). Az újabb tanulmányok rámutattak arra, hogy a munkamemória kapacitása adaptív tréningekkel fejleszthető (Klinberg, 2010; Klingberg és mtsai, 2005; Verhaeghen, Cerella és Basak, 2004; Westerberg, Jacobaeus, Hirvikoski, Clevberger, Östensson, Bartfai és Klingberg, 2007). A tréningek hatására növekvő munkamemória kapacitás számos kognitív készség fejlődésében fontos szerepet tölt be (Chein és Morrison, 2010), valamint a munkamemória deficittel jellemezhető klinikai populációk tekintetében is javulást figyeltek meg a kognitív funkciók tekintetében (Klinberg és mtsai, 2005).

Dahlin (2011) a munkamemória és az olvasási képesség közti kapcsolat vizsgálatába olyan ADHD-val diagnosztizált 9-12 éves gyerekeket vont be, akik munkamemória fejlesztő feladatokat kaptak naponta 30-40 percen át, 5 héten keresztül. A verbális és komplex munkamemóriát a számterjedelem és a fordított számterjedelem tesztekkel mérték, az olvasási képességet pedig egy szöveg elolvasása után kérdések megválaszolásával tesztelték. Az eredmények egyértelmüen alátámasztották a munkamemória fejlesztő tréning pozitív hatását, ugyanis mind a munkamemória, mind pedig az olvasásértési képességek tekintetében javulás mutatkozott.

Buonomano és Merzenich (1998) eredményei szerint a teljesítmény számos képesség tekintetében megnő a munkamemória tréning hatására, illetve hogy ez a teljesítményjavulás neuronális változásokkal hozható összefüggésbe, az intracelluláris szinttől egészen az 
agykéreg funkcionális szerveződéséig. A munkamemória-fejlesztés története hosszú múltra vezethető vissza (Miller, 1956; Butterfield, Wambold és Belmont, 1973).

Implicit munkamemória tréningnek tekinthetőek a perceptuális és motoros tréningek (Recanzone, Merzenich, Jenkins, Grajski és Dinse, 1992; Nudo, Milliken, Jenkins és Merzenitch, 1996), amelyek során a teljesítményjavulás főként az ismétlésen, visszajelzésen (feedback), illetve a nehézségi szint fokozatos változtatásán alapul. Ezzel szemben explicit módszernek tekinthető a munkamemória teljesítmény javulását segítő stratégiák megtanítása, mint például a frissítés, a tömbösítés és a metakognitív stratégiák (Abikoff és Gittelman, 1985). Mindezek azért tekinthetőek explicitnek, mert az egyén tudatosan alkalmazza őket az elsajátítani kívánt anyag megtanulása céljából.

A munkamemória pszichológiai modelljei megkülönböztetik a szenzor specifikus tárolást a koordináló vagy kontrolláló funkciótól, amely egy központi végrehajtó (Baddeley, 2003) vagy kontrollált figyelem meglétére utal (Engle és mtsai, 1999). Így a figyelem feltehetően szoros kapcsolatban állhat a munkamemóriával, mert a különböző munkamemória feladatoknál szükség van a figyelem kontrollálására, mint például a releváns információk kiválasztása esetén (McNab és Klinberg, 2008; Vogel, McCollough és Machizawa, 2005). Míg a csupán egy meghatározott agykérgi terület fejlesztésére irányuló tréning pozitív hatása feltehetően csak az adott területre, illetve az adott terület neurális hálózatához kapcsolódó egyéb területekre terjedhet ki, addig a magasabb asszociációs kérget is érintő tréningnek általánosabb hatásai lehetnek (Olesen, Westerberg és Klingberg, 2004). A munkamemória tréningek számos esetben, például Down-szindrómás gyerekeknél (Conners, Rosenquist, Arnett, Moore és Hume, 2008) és magzati alkohol-szindróma esetében is (Loomes, Rasmussen, Pei, Manji és Andrew, 2008) segíthetnek ellensúlyozni a munkamemória deficiteket, idős embereknél pedig lassíthatják a kognitív hanyatlást (Caretti, Borella és De Beni, 2007; Cavallini, Pagnin és Vecchi, 2003).

\subsubsection{A munkamemória-tréningek számítógépes változatai}

Klingberg és munkatársai (2010) nevéhez köthető egy implicit munkamemória tréning program kifejlesztése, amely a munkamemória tesztek ismételt elvégzését, az azokra adott visszajelzéseket, illetve a teljesítmény pontossága alapján adott jutalmakat foglalja magában. A tréninget eredetileg ADHD-s gyerekre fejlesztették ki (Klinberg Forssberg és Westerberg, 2002, Klinberg és mtsai, 2005). A tréning idejét tekintve akkor hatásos, ha a személy öt héten keresztül, heti öt napon át, napi 30-40 percet tölt gyakorlással, miközben a feladatok 
nehézsége, tehát a megjegyzendő információk mennyisége fokozatosan növekszik ez idő alatt. A kutatások eredményei azt mutatják, hogy ez a perceptuális tréningmódszerek által vezérelt munkamemória tréningprogram jelentős és hosszútávon is fennmaradó fejlődéshez vezethet a munkamemória kapacitást tekintve, függetlenül az elsajátítandó anyag típusától és a tesztelés módjától

A különböző tanulási nehézségek és figyelmi deficitek hátterében gyakran a gyenge munkamemória teljesítmény áll. Ilyen típusú munkamemória-csökkenés figyelhető meg olyan gyerekek esetében, akik specifikus tanulási zavarokkal, koncentrációs problémákkal küzdenek és gyenge iskolai teljesítményt nyújtanak. Egy széles körben elterjedt, számítógép alapú munkamemória tréning számos memóriafunkcióban javulást tesz lehetővé az intenzív gyakorlás hatására (Cogmed, Cogmed Cognitive Medical Systems AB, Stockholm, Sweden). 5-6 hetes periódus alatt 20-25 alkalommal vesznek részt a vizsgálati személyek a tréningen. Minden alkalom 30-45 perces időtartamot jelent, tehát a tréning az iskolai tanórákba is beilleszthető (Klinberg és mtsai, 2002; Klinberg és mtsai, 2005). A feladatok során a nehézségi szinteket a vizsgálati személyek egyéni lehetőségeihez mérten állítják be. A tréningeknek három könnyen használható és életkor specifikus fajtáját alakították ki. Az első az óvodások számára elérhető változat, amelyben számos feladat segítségével fejleszthetik a gyerekeknél például az instrukciókra való fókuszálást és azok követését. A második változat az iskoláskorú gyerekek számára készült. A feladatok segítségével az olvasás, a matematikai feladatok megoldása, a párbeszédek követése is könnyebbé válhat. A felnőtteknek készült harmadik változat pedig olyan készségek fejlesztését célozza meg, mint például a tervezés, a zavaró ingerek figyelmen kívül hagyása és a határidők megjegyzése.

A Cogmed tréning hatékonyságát számos csoport esetében vizsgálták a kutatók, így a tipikusan fejlődő óvodás és általános iskolás gyerekek körében (Gathercole, Dunning és Holmes, 2012; Thorell, Kindqvist, Bergman, Bohlin és Klinberg, 2009), figyelmi és hiperaktivitási zavarral (ADHD) diagnosztizált gyerekeknél (Beck, Hanson, Puffenberger, Benninger és Benninger, 2010, Holmes, Gathercole, Place, Dunning, Hilton és Elliott, 2010; Klingberg és mtsai, 2005), extrém alacsony súllyal született serdülőknél (Lohaugen, Antonsen, Haberg, Gramstad, Vik, Brubakk és Skranes, 2011) és traumás agysérülést szenvedett felnőtteknél is (Westerberg és mtsai, 2007). A Cogmed tréning hatására az alacsony munkamemóriájú gyerekek esetében a teljesítmény az életkori átlaguknak megfelelő szintre emelkedett, és a tréning hatásai minimum 6 hónapig megtartottak voltak (Holmes, Gathercole és Dunning, 2009). Az iskolai teljesítményt illetően is megfigyeltek javulást a 
matematika tantárgy (Holmes és mtsai, 2009) és az olvasásmegértés (Dahlin, 2011; Dunning, Holmes és Gathercole, 2013) területén.

\subsubsection{A transzfer szerepe és a munkamemória-tréningek hatása a különbözö kognitív funkciókra}

Míg a Cogmed tréning módszere a munkamemória kapacitásának fejlesztésére, növelésére fókuszált, addig egy másik tréning program kifejezetten a frissítésre helyezi a hangsúlyt, azaz a munkamemórián belül korábbi információk új információkkal való helyettesítésére (Dahlin, Neely, Larsson, Backman és Nyberg, 2008; Li, Schmiedek, Huxhold, Rocke, Smith és Lindenberger, 2008; Jaeggi, Buschkuehl, Jonides és Perrig, 2008). Egyes kutatások eredményei azt mutatták, hogy a fejlödés csupán a gyakorolt feladatok feladatspecifikus aspektusaira korlátozódott, míg Jaeggi és munkatársai (2008) kutatásában nagyobb transzferhatás volt megfigyelhető. Vizsgálatukban a megjegyzendő információ mennyiségét fokozatosan növelték, és arra következtettek, hogy a fokozatos terhelés és a hosszabb tréning (minimum 3 hét vagy 8 alkalom) két fontos tényező a munkamemória tréning effektivitását tekintve.

Klinberg (2010) munkája arra hívja fel a figyelmet, hogy a munkamemória tréning jelentős fejlődéshez vezethet olyan - a munkamemórián és a figyelem kontrollálásán alapuló feladatokban is, amelyek nem szerepeltek a tréning programban. A tréning hatásait megfigyelve arra a következtetésre jutottak, hogy a munkamemória tréning alkalmazható lenne olyan személyeknél is, akiknek a csökkent munkamemória kapacitása jelentősen korlátozza tanulmányi teljesítményüket vagy mindennapi életüket.

Morrison és Chein (2011) a fejlesztőprogramokat két kategóriába sorolták: a stratégiafejlesztésbe kerültek azok, melyeknél a vizsgálati személyek azt gyakorolták, hogy egy bizonyos kognitív területet érintő feladatban minél több dolgot meg tudjanak jegyezni, ellenben a mélyfejlesztésekbe kerültek azok, melyeknél többféle munkamemóriát is igénybe vettek a feladatok, és minden területen egyszerre gyakoroltak a vizsgálati személyek.

A stratégiafejlesztések többségének célja, hogy növeljék az olyan feladatokban nyújtott teljesítményt, melyekben valamilyen információt kell meghatározott idejü késleltetés alatt fenntartani. Az ilyen kutatásokban a vizsgálati személyeknek elmondják, hogyan érdemes egy adott feladatot végigcsinálni, és biztosítják a megfelelő gyakorlási lehetőséget annak érdekében, hogy magabiztosan fogjanak hozzá. Ilyen például az ismétléses gyakorlás módszere (Conners, Rosenquist, Arnett, Moore és Hume, 2008; Turley-Adams és Whitfield, 
2003), melyek során megtanítják a személyeket arra, hogy ismételgessék magukban a megtanulandó információt. Ez gyerekeknél és felnőtteknél is egyaránt hatékony módszernek tekinthető. A másik népszerü módszer az elaboratív feldolgozás módszere (Carretti, Borolla és De Beni, 2007; McNamara és Scott, 2001), melynél a megtanult információt csoportosítják. Ide olyan emlékezeterősítő technikák is tartoznak, amik nem férnek bele az ismétléses gyakorlásba, például amikor a megjegyzendő információ releváns részét átkódolják, és olyan összefüggéseket hoznak létre fejben, melynek segítségével egy könnyebben megjegyezhető dologról eszébe jut a vizsgálati személynek a ténylegesen fenntartott anyag. A stratégiafejlesztések mindkét típusa hasznos lehet a mindennapi helyzetekben, melyekben információk sorozatát kell fejben tartanunk. Az emlékezeterősítő stratégiák csak a speciálisan begyakorolt feladattípusokban és az azokhoz nagyon hasonló helyzetekben megbízhatók, ahol a megjegyzendő információ típusa megegyezik a gyakorlás alatt tanultakkal.

A mélyfejlesztések a tudatos feldolgozás gyakoroltatására törekszenek, nagyban igénybe veszik a kognitív képességeket, mivel a megjegyzendő anyag többféle modalitású lehet. A mélyfejlesztések hatására a munkamemória olyan részeinek is nő a kapacitása, melyeket nem gyakorolnak a vizsgálati személyek. Lényege, hogy területáltalános munkamemória folyamatokat igénylő feladatokkal dolgoznak, melyek annak a függvényében fejtik ki hatásukat, hogy mennyire veszi igénybe a begyakorolt feladat az egyes kognitív képességeket. Borella, Carretti, Riboldi és De Beni (2010) kutatásában például egy komplex munkamemória teszt gyakorlását követően a vizsgálati személyeknek egyszerre többféle munkamemória kapacitása javult.

Összességében a munkamemória fejlesztő programjai alapvetően hatékonyak, a mélyfejlesztések a munkamemóriát igénybevevő egyéb kognitív kapacitásokban is javulást hoztak (Borella és mtsai, 2010). A kognitív tesztek között található kapcsolatokat még nem térképezték fel pontosan, de a szakemberek számára fontos szempont, hogy egy adott feladatban található teljesítményváltozás általában együtt jár más teszteken tapasztalt eredmények változásaival is. Ezek a kutatások közelebb visznek minket ahhoz, hogy megtudjuk, milyen következményekkel jár az adott fejlesztőprogram a begyakorolt feladatokon elért jobb teljesítményen túl.

Alzheimer-kór esetében még a kezdeti stádiumban is jelentős kognitív és funkcionális romlás jelentkezik (Morris és Price, 2001). Habár a memória deficit a legkiemelkedőbb, a figyelmi folyamatok, téri vizuális funkciók, nyelv, gondolkodás és a végrehajtó funkciók terén is hanyatlás mutatkozik, személyiség változásokkal és viselkedéses zavarokkal együtt (Cahn-Weiner, Malloy, Rebok és Ott, 2003). Ezért a rehabilitációban fontos szerepe lehet a 
kognitív tréningnek (CT) vagy a másnéven a kognitív rehabilitációnak is (Clare és Woods, 2004).

A neuropszichológiai tesztek felvétele után kirajzolódik a károsodás helye és mértéke. Ennek ismeretében célzottan lehet fejleszteni a kiesett funkciókat, meg lehet tervezni a rehabilitáció menetét. A kognitív rehabilitáció egy olyan terápiás megközelítés, mely a központi idegrendszer müködésének javítását célozza meg, olyan esetekben, amikor az valamilyen zavart vagy sérülést szenved (Pataky, 1999). A kognitív rehabilitáció során lehetővé válik a megismerési és információfeldolgozási funkciók fejlesztése, mely kiterjed a memória, a végrehajtó funkciók, nyelvi funkciók, problémamegoldás területeire. A beteg teljesítményének növelése egyrészt az aktuálisan megmaradt, de nem megfelelően működő képességek fejlesztésével vagy új, kompenzációs stratégiák kiépítésével történik. Ezáltal a beteg számára könnyebbé válik a mindennapi feladatok elvégzése, javul az életminőségük, gyorsabban visszatérhetnek eredeti munkájukhoz. A rehabilitációs tréning során a kognitív intervenciók mellett fontos szerep jut a különböző problémamegoldó stratégiák felismerésének és alkalmazásának. A rehabilitáció célja a páciens kognitív készségeinek fejlesztése és a hétköznapi életben való magasabb szintü működés elérése az erősségek és korlátok figyelembevételével. Optimális esetben a rehabilitációs célkitüzés a beteg visszatérése a betegséget megelőző életminőségéhez, beleértve a munkahelyi kapcsolatokat is (Pataky, 1999; Tánczos, Jakab, Hnyilicza, Kincses, Németh és Vécsei, 2012).

Tánczos és munkatársai (2012) esettanulmányukban kidolgoztak egy rehabilitációs programot egy encephalitises beteg kognitív rehabilitációjának elősegítése érdekében. Kognitív károsodások encephalitisben 88\%-ban fordulnak elö. Az encephalitises betegcsoportban több deficitet találtak a memória funkciókban, a verbális- szemantikus, valamint a visuo-perceptuális funkciókban (Hokkanen, Poutiainen, Valanne, Salonen, Iivanainen és Launes, 1996). A hippocampus és a limbikus rendszer, valamint a paralimbikus kéreg szinte valamennyi komponense érintett ebben a betegségben. Ennél a betegcsoportnál a súlyos globális amnézia a vezető tünetek között szerepel (Markowitsch és Staniloiu, 2012). Annál sikeresebb a kognitív rehabilitáció, minél jobb a páciens együttmüködése, motiváltsága, attitűdje, minél magasabb az iskolai végzettsége és minél hamarabb kezdjük a terápiát (Pataky, 1999). Előnyös a támogató családi és munkahelyi környezet megléte is. A sikerhez vezető első lépés a kognitív funkciók pontos feltérképezése. A rehabilitáció első lépéseként a diagnosztikus vizsgálat két adatfelvételből állt. Az első adatfelvétel a beteg osztályra kerülését követő napon történt meg. A beteg ezt követően a klinikai tartózkodása alatt naponta 2x60 perces, ezt követően ambulanter heti kétszer egy órás kognitív 
rehabilitációs foglalkozáson vett részt. A foglalkozásokon a diagnosztikai fázis alatt tapasztalt teljesítménybeli deficitek javítására egy terápiás protokollt kidolgozására került sor, ami várhatóan fejlesztette a logikai készséget és a figyelmi készséget (inger -és szókeresős feladatokkal, amelyek sok inger/betü között elrejtett ábrák és szavak megkeresését foglalják magukban), a végrehajtó funkciókat, valamint a rövid távú memóriát (szólista-tanulás, számok sorrendben és fordított sorrendben történő felidézése). A gyenge verbális memória fejlesztése vizualizációs technikák tanulásával történt. Ezek mellett a komplex verbális memóriát (olyan feladatok gyakoroltatása, amelyekben a feldolgozó és tároló komponensek egyszerre aktiválódnak) és téri-vizuális memóriát fejlesztő (térképeken található ábrák emlékezetből való felidézése) feladatokat gyakorolt a beteg. Mivel a mindennapi emlékezeti funkciók is érintettek voltak, ezért külső memóriasegítők megtanítására is sor került, mint például tennivaló-listák készítése, határidő napló vezetése, a mobiltelefon emlékeztető funkció használatának megtanítása. A diagnosztikus első adatfelvétel után a hetedik hónapban került sor a második, a rehabilitációt követő adatfelvételre. Az eredmények azt mutatták, hogy az esettanulmányban bemutatott beteg frontális és fronto-temporális funkcióiban jelentős javulás mutatkozott, ami az encephalitis patológiájával korrelál. A többi funkcióban viszont nem, vagy csak kismértékü előrelépés történt, amelyre magyarázatul szolgálhat, hogy ezeket a területeket kevésbé érintette a betegség. A rehabilitációt követően a beteg visszanyerte közel eredeti életminőségét, visszatért munkájához, megszokott, széleskörü társadalmi kapcsolatrendszeréhez. Ehhez hasonló eredményeket találtak Tánczos, Zádori, Jakab, Hnyilicza, Klivényi, Keresztes, Engelhardt, Németh és Vécsei (2014) egy villámcsapást elszenvedett beteg esetében is, amelyek szintén igazolják a kognitív rehabilitáció hatékonyságát és fontosságát.

Sitzer, Twamley és Jeste (2006) tanulmánya egy metaelemzést ír le, amely 17 tanulmány eredményeinek bemutatásán keresztül ad egy áttekintést arról, hogy a kognitív tréningnek milyen hatása van Alzheimer-kórban. A tréning során a memória, figyelem és problémamegoldó készségek fejlesztésén van a hangsúly, de a kognitív müködések által befolyásolt területek, mint például a mindennapi aktivitás, szociális-és viselkedéses készségek tréningezése is meghatározó. A kognitív tréning stratégiákat két fő csoportra osztották: Az első a kompenzációs stratégiák csoportja, ahol a kognitív feladatok újfajta megoldásmódját tanítják meg a vizsgálati személyeknek. A belső stratégiák kialakításával elősegítik az információszervezés és a kategorizáció képesség fejlődését, a könnyebb megjegyezhetőség érdekében pedig a vizualizáció technikáját használják. Ezen túlmenően a kódolás nem csak egy, hanem számos érzékszervi csatornán keresztül történik, a tanulás során pedig a 
parafrazálást (körülírás, más szavakkal való megfogalmazás) használják segítségként. A belső stratégiák kialakításának négyféle módszerét ismertetjük. Ezek az öninstrukciós technika, a cél menedzsment (GMT), a figyelem és problémamegoldó csoport és az idői nyomás menedzsment.

Az öninstrukciós technika lényege, hogy a páciensnek hangosan ki kell mondania, hogy mi lesz a következő lépés, amit véghezvisz, és a véghezvitel közben is hangosan mondania kell, mit tesz. A következő lépésekben egyre halkabban kell az öninstrukciókat kimondani, a harmadik fázisban már csak magához kell beszéljen a páciens. Cicerone és Wood (1987) a Londoni Torony Teszten ezzel a módszerrel javulást mutatott ki egy betegnél, azonban ez a javulás nem generalizálódott. A módszernek azonban előnye, hogy a páciens megtanul lassítani és az impulzív válasz helyett megtanulja átgondolni a cselekvést.

A cél menedzsment célja egy sokkal általánosabb stratégia megtanítása. Maga a tréning öt lépcsőfokból áll: „megállni és gondolkoni az éppen folyó aktivitáson”, „megállapítani a fö feladatot”, „megállapítani a szükséges lépéseket”, és „ megtanulni a lépéseket és a lépések végrehajtása közben ellenőrizni, hogy a terv szerint cselekszem”. során elkövetett hibák számában.

Miotto, Evans, Souza De Lucia és Scaff (2009) a belső stratégiák kialakításának negyedik módszerét, a figyelem és problémamegoldó csoportot egy átfogó rehabilitációs program részeként írta le. Első sorban a figyelmi deficitet tárta fel a csoport, majd később egy problémamegoldó módszert tanítottak meg a résztvevőknek. Ez a technika is egy problémamegoldó listát használ, és a lényege, hogy a résztvevők lassan internalizálják a lépéseket, így ezek egyre automatikusabbak lesznek.

Az idői nyomás menedzsment tréning lényege, hogy a lassú információ feldolgozást segítsen kompenzálni. A módszer öninstrukciókból és speciális lépésekből áll, melyek segítenek eldönteni igen-nem válaszok segítségével, hogy mi legyen a következő lépés. Kutatási eredmények azt bizonyítják, hogy ez a módszer a gyakorlatban is segítséget jelent, és a múltbeli emlékek felidézésének gyakorlása hatással van a tervezésre (Hewitt, Evans és Dritschel, 2008). Ezzel szemben Fasotti, Kovacs, Eling és Brouver (2000) vizsgálatában nem sikerült a mindennapi életben kimutatható változásokat demonstrálni.

A belső stratégiákon kívül használhatóak külső stratégiák is, mint például naptárak, listák. Különösen azok számára lehet jó módszer, akiknek a munkamemóriája és az információ feldolgozási sebessége nagymértékben károsodott, hiszen nekik nehéz lehet az internalizálás. Abban az esetben, ha a páciensnek a cselekvés kezdeményezése okoz problémát, a NeuroPage adhat segítséget (Hersch és Treadgold, 1994). A személyeknek egy 
személyhívót kell hordaniuk, ami egy központi szoftveren keresztül üzeneteket küld arról, hogy mikor és mit kell csinálniuk. Így a személyek figyelme nem terelődik el egy-egy feladatról. Nemcsak az üzenet fontos, hanem maga a hangjelzés is, ami önmagában arousal növekedést okoz. Olyanoknak, akiknek számos végrehajtó funkciója károsodott, nem feltétlen elegendő egy külső stratégia, hanem egy nagyon strukturált környezetre is szükségük van. Ilyenkor a család, barátok és a kollégák bevonása is szükséges lehet, tehát a páciens környezetében is változásokat kell elérni. Ebben az oktatásnak is nagy szerepe lehet.

A külső stratégiák olyan környezeti emlékeztetők, jegyzetfüzetek, kalendáriumok használatát jelentik, amelyek a magasabb szintü kognitív müködést igénylő feladatok elsajátításában nyújtanak segítséget. Sitzer, Twamley és Jeste (2006) a kognitív tréningek kapcsán felvázolták a második csoportot is, amely az erősitő stratégiák használatán alapul. Célja, hogy a kognitív müködést a betegséget megelőző szintre állítsa vissza. Olyan feladatok végzésére kérik a vizsgálati személyeket, melyekben korábban bemutatott információk előhívása történik, így a betegek ismétlődő figyelmi és memória feladatokat végeznek. A hibamentes tanulás során megelözik a hibákat az előhívási próbák során, míg az orientációs terápia esetében olyan információk prezentálása történik, mint például a név, dátum, hely, időjárás, és a betegek ezeket gyakorolják be.

\subsection{A végrehajtó funkciók tréningje és rehabilitációja}

A munkamemória-tréningek mellett fontos megemlíteni a verbálisfluencia-tréningek hatását is. Hurks (2012) vizsgálatában az explicit instrukciós tréning szerepét térképezte fel a verbális fluencia-feladaton nyújtott teljesítmény kapcsán. A vizsgálatban harmadik osztálytól hatodik osztályig vettek részt a gyerekek és egy 6-7 perces segédanyagot kaptak a szócsoportok segítségével történő feladatmegoldáshoz. A hatodik osztályosok több szót és nagyobb klaszterméretet alkottak a tréning hatására. Harmadiktól ötödik osztályig a klaszterek mérete szintén nőtt, de ez a növekedés a verbálisfluencia-teljesítmény összpontszámában való csökkenéssel járt együtt. Ross, Weinberg, Furr, Carter, Evans-Blake és Parham (2005) szerint a felnőttek is képesek csoportosítási és váltási stratégiák megtanulására a megfelelő instrukciók hatására.

A végrehajtó funkciók rehabilitációja elsődleges fontossággal bír, hiszen egy agyi károsodás a mindennapi szociális életre is nagy hatással van. A problémamegoldás, a tervezés és szervezés, az önmonitorozás, a kezdeményezés, valamint a viselkedésreguláció és hibakorrekció mind olyan folyamatok, melyek a végrehajtó müködését igénylik. Ezek a 
folyamatok a frontális lebeny müködéséhez kötődnek. Luria (1973) a frontális lebenyt a problémamegoldással kapcsolta össze, amelyhez szükséges készségek a stratégiai szelekció, az eredmények alkalmazása és azok pontos megbecslése. Duncan (1986) később a frontális lebenyt célfenntartónak nevezte, tehát a müködését a célok azonosításában és a célokhoz vezető cselekvések véghezvitelében látta. Mindez azt jelenti, hogy a frontális sérülést elszenvedett beteg ugyan meg tudja állapítani, mit kell elérnie, de a véghezvitel során a fó célokat mégis elhanyagolja, így a cselekvései nem fogják a célok véghezvitelét szolgálni.

Baddeley és Wilson (1988) a figyelmi deficitekre hívta fel a figyelmet, valamint arra, hogy frontális sérülés esetén a beteg ugyan képes rutinszerüen cselekedni, de új szituációkban nehézségei támadnak. Baddeley alkotta meg a diszegzekutív szindróma (disexecutivesyndrome-DES) kifejezést, utalva arra, hogy a frontális lebeny a munkamemória központi végrehajtó komponensének feleltethető meg. A végrehajtó funkciók sérülése számos olyan következménnyel jár, melyek a társas kapcsolatokra, szociális élethelyzetekre is kihatással van.

A károsodott funkciók rehabilitációjában a fö kérdés, hogy ténylegesen a mögöttes funkció rehabilitációja a lényeges, vagy inkább arra kell hangsúlyt fektetni, hogy a betegek stratégiákat tanuljanak meg, aminek segítségével kompenzálni tudják a hiányzó vagy sérült funkciókat. Ez utóbbi módszer hatékonyságára a gyakorlati klinikai munkában több bizonyíték van. Alapvetően háromféle terápiát alkalmaznak. Ezek a károsodott funkciók újratréningezése, valamint a belső és a külső stratégiák kialakítása, fejlesztése. Az újratréningezés hátterében az áll, hogy egy-egy funkció gyakorlása képes megközelítőleg a normális szintre helyreállítani a funkciót. Von Cramon, Von Cramon és Mai (1991) például a problémamegoldó terápia során a pácienseknek megtanítottak egy komplex problémát kisebb, kezelhetőbb egységekre lebontani. A problémamegoldásnak ez a lelassított, lépcsőzetes módja helyettesíti a páciensek hirtelen döntéseit, ami jellemző a végrehajtó funkciók sérülése esetén. A különböző szinteket gyakorlatokon keresztül sajátíthatják el a rehabilitációs tréningen résztvevők. Ilyenek például a probléma azonosítása és elemzése, a problémareleváns információk elkülönítése, az ezek közötti összefüggések megtalálása, ötletelés, a különböző mentális reprezentációk használata, valamint a végrehajtás monitorozása és kiértékelése. A gyakorlatban ezek a feladatok nyitott végü történetek befejezéséböl, munkafüzeti feladatokból és csoportos aktivitásokból állnak. A terápia 6 hétig tart, általában 25 alkalmat vesz igénybe és 4-6 fös csoportokban történnek a foglalkozások. A különböző tréningeket és az általuk fejlesztett funkciókat a 22. táblázat ismerteti. 
22. táblázat. A munkamemória és végrehajtó funkciók fejlesztésére használt tréningek

\begin{tabular}{l|l|l}
\hline \hline Tréning & Fejlesztett funkció & Hivatkozás \\
\hline \hline Implicit munkamemória tréning & Implicit munkamemória & Kingberg és mtsai, 2010 \\
\hline COGMED & Komplex munkamemória & $\begin{array}{l}\text { Gathercole, Dunning és Holmes, } \\
2010\end{array}$ \\
\hline Stratégiafejlesztés és mélyfejlesztés & Komplex munkamemória & Morrison és Chein (2011) \\
\hline Kognitív tréning & $\begin{array}{l}\text { Végrehajtó } \\
\text { problémamegoldás és nunkciók, } \\
\text { funkciók }\end{array}$ & Clare és Woods (2004) \\
\hline \hline
\end{tabular}

\subsection{Az időskori demencia rehabilitációja}

A neuropszichológiai rehabilitáció ugyanolyan fontos lehet a progresszív és nem progresszív betegségek esetében is, hiszen ilyenkor is fenn kell tartani a szociális, pszichológiai és fizikai optimális szintet (McLellan, 1991). A rehabilitáció nemcsak a demens személynek, hanem környezetének is fontos lehet. Az időskori kognitív funkciók leépülésének vizsgálata nemcsak mentálhigiénés, hanem az egész életen át tartó tanulás szempontjából is fontos terület.

A demencia több kognitív funkció romlását jelenti egyszerre, melyek a mindennapi életvitelre is hatással vannak. A leggyakoribb demencia diagnózis az Alzheimer-kór (Moris, 1996), a második leggyakoribb a vasculáris demencia vagy a két típus keveréke (Carew és mtsai, 1997). Kevésbé gyakori a frontotemporalis demencia diagnózisa. Fontos, hogy ezekre más-más neuropszichológiai profil jellemző, főként a kezdeti stádiumban. A prognózis is személyenként változó lehet, egyesek lassabb, míg mások gyorsabb leépülést mutatnak (Raoux és mtsai, 2008; Vitali és mtsai, 2005)

A demencia rehabilitációja azért is fontos, mert a coping stratégiák és a szociális környezet nagyban befolyásolhatja a betegség kimenetelét. Ha a személy rossz szociális környezetben van, lényegesen korlátozottabbnak tünhet, mint amennyire azt a betegsége indokolná (Reifler és Larson, 1990). Kutatások kimutatták, hogy a demens betegek is képesek implicit tanulásra (Camp, Foss, Stevens, Reichard, McKitrick és O’Hanlon, 1993). Explicit tanulás esetében azonban mind a kódolásnál, mind az előhívásnál szükséges a segítség (Bäckman, 1992). A páciensek azonban jobban teljesítenek saját maguk által generált stratégiák használatával, mint külső segítséggel, valamint egy-egy feladat személyesebbé tétele növeli az észlelt kontrollt és a motivációt, ezzel együtt pedig a teljesítményt is (Perlmutter és Monty, 1989).

A neuropszichológiai rehabilitáció módszere az egyéni szükségletektől függ minden esetben. Fontos lehet a személy érzelmi válaszait és coping stratégiáit is figyelembe venni. Ugyanakkor egy szisztematikus nézőpontra van szükség, valamint idős emberekről lévén szó, 
figyelembe kell venni az öregedéssel járó pszichológiai és szociális hatásokat is (Pataky, 1999).

A demencia korai szakaszában a fókusz a mindennapi problémákra irányul, melyeket főképp a hosszú távú epizodikus memória vagy a végrehajtó funkciók hanyatlása okoz. Fontos lépés egy komplett neuropszichológiai profil kialakítása a mindennapi életben történő funkcionálásról, valamint a beteg percepciója a nehézségeiről és a rendelkezésre álló megküzdési stratégiáiról. Különösen a korai stádiumban jellemző, hogy a betegeknek van valamilyen önsegítő stratégiájuk, amit sikerrel lehet fejleszteni, ha a memória problémákról megfelelő információval látják el a beteget és a családot egyaránt (Clare és Wilson, 1997).

A kognitív rehabilitáció kétféle módon történhet. Az egyik a tanulás, vagy készségek újratanítása, a másik pedig kompenzáló stratégiák tanítása. A memória funkciók serkentésére használható eszközök közül az egyik az elosztott felidézés módszere (Camp, 1989). A módszer egy információ elemének felidézéséből áll, rövid felidézési intervallumokkal. Az intervallumok a feladat során egyre hosszabbak lesznek. Egy másik lehetséges módszer a különböző kulcsok megadása. Például nevek megtanulásánál minden egyes bemutatásnál egyegy betüt elvesznek a név végéböl. Vagy éppen ennek a fordítottja, hogy egyre több kulcsot mutatnak be a névből (Clare, 2000). Alzheimer-kórban az explicit emlékeztető stratégiák használata nem szerencsés, hiszen a betegeknek nehézséget okozhat mind stratégia megtanulása, mind pedig a használtára való emlékezés (Woods, 1996). Külső segítséget is lehet adni a pácienseknek emlékeztetők formájában. Azonban ezeknek elég specifikusnak kell lenniük (Woods, 1996). A demenciában szenvedők valószínűleg már egyébként is hozzászoktak a külső segítségekhez, mint például a naptárhasználat vagy listák írása. Az viszont fontos, hogy ezek a maximális hatékonysággal müködjenek. A memória deficittel élők önmaguktól nem kezdenek el új stratégiát használni, ezért szükségük van a megfelelő tréningre. Például emlékeztetni kell őket folyamatosan, hogy nézzenek bele a naptárba, de amint ez szokássá válik, az emlékeztetéseket el lehet hagyni.

A demencia rehabilitációja egy olyan terület, amely még további vizsgálatokat igényel. Tovább kell még bővíteni azoknak a módszereknek a körét, melyek segíthetnek bizonyos, a betegséggel kapcsolatos célok elérésében. Valamint fontos lenne tovább fejleszteni azt a holisztikus nézőpontot, aminek segítségével lehetővé válik a progresszív betegségben szenvedő betegek hatékony kezelése (Wilson, 2008). 


\section{ÖSSZEGZÉS ÉS TOVÁBBI KUTATÁSI LEHETŐSÉGEK}

Habár az elmúlt évtizedekben a nyugati országokban egyre népszerübb a munkamemória és a végrehajtó funkciók vizsgálata, valamint ezek szerepének feltérképezése az iskolai teljesítményben, hazai eredmények eddig korlátozottan álltak rendelkezésünkre a témával kapcsolatban. Szintén kevés a témával kapcsolatban a fejlesztési lehetőségeket összefoglaló tanulmány.

A disszertációban bemutatott vizsgálatok célja elsődlegesen ezeknek a hiányoknak a pótlása volt, valamint a diagnosztikától a lehetséges fejlesztési módszerekig tartó ív bemutatása a végrehajtó funkciók és a munkamemória területén, gyermekkortól egészen idős korig. Ez vagy hasonló gondolkodási keret alapján a későbbiekben lehetővé válhat komplexebb, hatékonyabb és fókuszáltabb óvodai és iskolai diagnosztikai és fejlesztő programok kidolgozása, amelyek a szakemberek segítségére lehetnek a különböző típusú tanulási zavarok korai felismerésében és azok terápiájában, valamint sor kerülhet egy olyan idősek esetében is alkalmazható fejlesztő program kialakítására is, amellyel akár az egészséges idősödéssel járó kognitív hanyatlások, akár a patológiás csoportok kognitív károsodásai feltérképezhetővé és fejleszthetővé válnak.

Célkitüzéseink között szerepeltek a hallási mondatterjedelem teszt, valamint a betủ és a szemantikus fluencia tesztek egész életkori spektrumot lefedő magyar mintán történő vizsgálata, a gyerekkori fejlődési trendek és az időskori változások feltérképezése, a nemi különbségek vizsgálata, valamint a változók minőségi elemzése is. Ezen kívül célunk volt megvizsgálni azt is, hogy a magyar iskolai rendszerben részt vevő negyedik osztályos tanulók iskolai teljesítményét hogyan jósolják be az első osztályos korukban feltérképezett munkamemória és végrehajtó funkciót mérő teszteken elért eredményeik.

A disszertációban a vizsgálatok célkitűzéseit, módszereit és eredményeit taglaló fejezeteket megelőzően széleskörü betekintést nyújtottunk a munkamemória és a végrehajtó funkciók különböző aspektusait, fejlődését, változásait és neuropszichológiai korrelátumait feltérképező szakirodalmi előzményekbe.

Az első vizsgálatban az angolszász nyelvterületen elterjedt hallási mondatterjedelem teszt magyar változatát mutattuk be. Eredményeink abból a szempontból jelentősek, hogy ezzel bővült a magyar nyelvű munkamemóriát mérő tesztek köre, valamint a neuropszichológia eszköztára is. A vizsgálat kiterjedt továbbá az egyes munkamemória komponensek kapacitásváltozásának tanulmányozására is kisgyermekkortól egészen 
időskorig. A második és a harmadik vizsgálatban pedig a betủ és a szemantikus fluencia tesztek életkori változásait 5-89 éves korig térképeztük fel magyar mintán, 11 életkori övezetben, több mint 500 fő bevonásával, így létrehoztuk az angolszász nyelvterületen gyakran használt vizsgálóeljárások széles életkori spektrumot felölelő, nagy elemszámú, komplex magyar nyelvű változatát. Munkánk hiánypótló, mivel ezeket a nyelvi és végrehajtó funkciókat mérő tesztek a hazai klinikai neuropszichológiai gyakorlatban is széles körben használtak, valamint olyan új mutatókat is bevontunk elemzéseinkbe, amelyek a mindennapi gyakorlatban még nem elterjedtek, viszont fontos szerepük lehet a pontosabb diagnosztika megalkotásában. A harmadik vizsgálatban pedig annak feltárására törekedtünk, hogy a gyerekek első osztályos korukban elért teszteredményei a munkamemória és végrehajtó funkciót mérő teszteken hogyan hatnak a negyedik osztályos tanulmányi teljesítményekre.

Az első vizsgálat során a komplex munkamemóriát mérő tesztek esetében és a verbális munkamemória teszt esetében is a fejlődéssel együtt járó kapacitásnövekedést találtunk 13-15 éves korig, majd a fejlődés üteme lelassult 19-30 éves korig. 31-49 éves kortól kezdve egészen idős korig fokozatos csökkenést figyeltünk meg a teszteken elért teljesítményekben. Hipotéziseink szerint a teljesítmény egészen 60 éves korig megfelelő szintü marad és a teljesítmény szignifikáns csökkenését csak ezen életkor utánra vártuk. Eredményeink szerint azonban ez már korábbi életkorban bekövetkezik. A számterjedelem teszt esetében viszont a kapacitás egészen 19-30 éves korig nő, tehát később éri el legmagasabb fejlődési értékét, mint a komplex munkamemória tesztekkel mért teljesítmények. 31 éves kortól időskorig viszont ebben az esetben is fokozatos csökkenés látható, aminek életkori görbéje megegyezik a komplex munkamemória teszteken elért eredmények profiljával. Az első vizsgálat során felállított hipotéziseink közül számos alátámasztást nyert. Az eredményeink szerint az egyes életkori csoportok fejlődése eltér egymástól és ez az életkori görbe fordított U-alakú görbét követ. A hallási mondatterjedelem teszt és az olvasási terjedelem teszt között magas együttjárást találtunk.

A második vizsgálatban a betűfluencia feladat különböző mutatóinak részletes elemzésére került sor. Fejlődési trendet határoztunk meg, ahol nem az egyes értékeket, hanem a különböző életkori csoportokat hasonlítottuk össze. A vizsgálat eredményeit összegezve elmondható, hogy a három feladat közül a "K" betüfluencia feladat volt a legkönnyebb a vizsgálati személyek számára, ennek során tudtak a legtöbb szót mondani. A szavak száma mindhárom betüfluencia feladaton alacsony volt az 5-6 éves gyerekek körében, a teljesítmény a "K" betű esetén 15-16 éves korban, a "T" és az "A" betü esetén pedig 17-18 éves korban éri el a felnőtt szintet, majd a felnőttkori jó szintű teljesítményben 50-69 éves kortól jelentős 
csökkenést tapasztaltunk. Ezek az eredmények számos korábbi tanulmány eredményeivel megegyeznek (Spreen és Strauss, 1991; Klenberg, Korkman és Lahti-Nuutila, 2001; Van der Elst és mtsai, 2006; Brickman és mtsai, 2005). A perszeverációs arány 17 éves kortól lassan nőtt, majd időskorban erőteljes növekedést találtunk, amelyet szintén több tanulmányban megfigyeltek (Daigneault és mtsai, 1992; Kozora és Cullum, 1995). A hibázás tekintetében fordított mintázatot figyeltünk meg, vagyis 9-10 éves korig a hibák száma csökkent, majd egészen 89 éves korig stagnált. A viszonylag alacsony számú hiba és perszeveráció szintén megegyezik néhány korábbi tanulmány eredményeivel (Kozora és Cullum, 1995; Tröster és mtsai, 1989). A klaszterek száma 15-16 éves korig lassan növekedett, majd 89 éves korig stagnált a teljesítmény. A klaszterméretben 7-8 éves korig erőteljes növekedést találtunk, majd 12 éves korig lassan csökkent, végül 89 éves korig állandó volt a teljesítmény. Eredményeink összhangban állnak Troyer (2000) vizsgálatával. Az összváltások száma 9-10 éves korig nőtt, majd 11-12 éves kortól 50-69 éves korig állandó szinten maradt, végül a legidősebb korcsoport esetében egy újabb növekedést tapasztaltunk. Ettől eltérően a klaszterváltásoknál nem találtunk életkori különbségeket.

A harmadik vizsgálatban a szemantikus fluencia klasszikus és újabb, komplexebb mutatóinak feltérképezése történt 5-89 éves korig. A feladatok közül az “ÁLLAT" szemantikus fluencia feladat bizonyult a legkönnyebbnek, amely alátámasztja néhány korábbi kutatás eredményeit (Baldo és Shimamura, 1998; Chan és Poon, 1999; Schwartz, Baldo, Graves és Brugger, 2003). A szavak számát tekintve a teljesítmény már 5-6 éves korban is magasabb volt, mint a betüfluencia feladaton. 17-18 éves korban egy fokozatos fejlödést követően a teljesítmény elérte a felnőtt szintet, amely alátámasztja Chan és Poon (1999) és Klenberg és munkatársai (2001) eredményeit. Hasonlóan a betűfluencia feladathoz, ennél a feladatnál is a 35-49 éves korcsoport, tehát a felnőttek érték el a legjobb értékeket. 50-69 éves kortól azonban csökkent a teljesítmény, ami összhangban van számos korábbi kutatás eredményeivel (Troyer, 2000; Chan és Poon, 1999; Tombaugh és mtsai, 1999; Loonstra és mtsai, 2001; Van der Elst és mtsai, 2006). A perszeverációk száma és a hibázások száma mindhárom szemantikus fluencia feladat esetében nagyon alacsony volt, habár 50-69 éves kortól mindkét mutató esetében enyhe növekedést tapasztaltunk, ahogyan Kozora és Cullum (1995), valamint Tröster és munkatársai (1989) is. A klaszterek számában hasonló fejlődési ívet kaptunk, mint a szavak száma tekintetében, tehát 35-49 éves korig egy folyamatos fejlődést találtunk, majd 50 éves kortól visszaesett a teljesítmény. A klaszterméret az “ÁLLAT" szemantikus fluencia feladaton az életkorral nőtt, tehát idősebb korban jobb teljesítményt nyújtottak a vizsgálati személyek, mint fiatalabb korban. A másik két feladat 
esetében az életkorral nem változik jelentősen a klaszterek mérete. Mind az összváltásokat, mind pedig a klaszterváltásokat illetően hasonló mintázatot találtunk, vagyis 17-18 éves korig nőtt a teljesítmény, majd 35-49 éves korig állandó maradt, végül 50-69 éves kortól kezdve csökkenést figyeltünk meg. A második és harmadik vizsgálattal kapcsolatos hipotéziseink alátámasztást nyertek.

Összehasonlítva a betü- és a szemantikusfluencia-feladatokon nyújtott teljesítményeket megállapítottuk, hogy a szemantikus fluencia teljesítmény az életkor előrehaladtával gyorsabban nő, ennél a feladatnál markánsabb életkori hatásokat találtunk, amely összhangban van Troyer és munkatársai (1997), valamint Gladsjo és munkatársai (1999) eredményeivel. A tesztek együttes felvételével és az újabb mutatók minőségi elemzésével lehetőségünk nyílik a fronto-temporális funkciók precízebb feltérképezésére, ezáltal nemcsak egy egyszerüen használható eszköz áll a pszichológiában és pedagógiában jártas szakemberek rendelkezésére, hanem a verbálisfluencia-feladatok egy árnyaltabb kognitív neuropszichológiai profil felrajzolásában is segítséget nyújtanak a klinikai neuropszichológusok és orvosok számára.

A negyedik, longitudinális vizsgálatban, négyéves utánkövetéssel hasonlítottuk össze az első osztályosok teszteredményeit a negyedik évfolyamon azonosított iskolai teljesítménnyel. Négy tantárgyra fókuszáltunk az elemzéseink során, ezek a magyar nyelv és irodalom, matematika és a környezetismeret tantárgyak voltak. A magyar nyelv és irodalom tantárgyon nyújtott teljesítményt a Corsi-kocka teszten és a fordított számterjedelem teszten nyújtott eredmények jósolták be leginkább. A matematika teljesítmény esetében a számlálási terjedelem teszt, a betűfluencia feladat klaszterszám mutatója, valamint a Corsi-kocka teszten nyújtott eredmények bizonyultak bejósló értékünek. A környezetismeret teljesítményt pedig a számlálási terjedelem teszten elért eredmény, valamint a betűfluencia feladaton alkotott klaszterek száma és a szemantikus fluencia feladat élesváltásainak száma prediktálta leginkább.

Összességében a magyar nyelv és irodalom tantárgyon nyújtott teljesítmény esetében a téri-vizuális munkamemória kapacitás volt a leginkább meghatározó tényező, ahogyan azt a hipotéziseink alapján vártuk, de a verbális rövidtávú memóriának is bejósló ereje volt. Hipotéziseinkkel összhangban a matematika tantárgyon produkált eredményeket leginkább a komplex munkamemória kapacitása határozza meg, továbbá a téri vizuális memóriának és a végrehajtó funkciók egyes komponenseinek is bejósló ereje van az eredményeink alapján. A környezetismeret tantárgy esetében a komplex munkamemóriának van fontos szerepe, ahogyan ezt a hipotéziseink alapján feltételeztük, azonban a végrehajtó funkciók is bejósló 
értékkel bírnak. Fontosnak tartjuk kiemelni tehát a fókuszáltabb kognitív funkciók vizsgálatát az iskolai teljesítmény hátterének vizsgálatában.

Vizsgálatunk első lépésnek tekinthető, melyben feltérképeztük az alapvető összefüggéseket a tantárgyakon nyújtott teljesítmény és a munkamemória, valamint a verbálisfluencia-feladatokon kapott eredmények között. Mivel magyar vonatkozású eredmények nem születtek még a kognitív funkciók iskolai teljesítményre vonatkoztatott bejósló hatásait tekintve, ezért munkánk fontos lépésnek tekinthető ennek a hiányterületnek a betöltésében. Ezen eredmények nem csak az iskolapszichológia és a pedagógia számára lehetnek fontosak, hanem a mindennapi neuropszichológiai gyakorlatban is. Ez az összetett vizsgálati szemlélet, amely mind a munkamemória, mind a végrehajtó és nyelvi funkciók aspektusait feltérképezi, a gyakorló szakemberek segítségére lehet a különböző fejlődési vagy szerzett neuropszichológiai károsodások és a tanulási nehézségek korai felismerésében is. Az empirikus vizsgálatok legnagyobb jelentőségét abban látjuk, hogy több olyan változót, komponensek közti összefüggést tártunk fel, amelyekről eddig csak kevés megbízható eredménnyel rendelkeztünk magyar mintán. A vizsgálatsorozat hipotéziseit és az eredményeinket a 23. összefoglaló táblázat szemlélteti. 


\section{3. táblázat. A vizsgálatsorozat hipotézisei és eredményei}

\begin{tabular}{|c|c|c|}
\hline "Vizsgálatok & Hipotézisek & Eredmények \\
\hline 1. vizsgálat & $\begin{array}{l}\text { 1. Az egyes életkori csoportok fejlödése eltér egymástól. } \\
\text { 2. Az életkori görbe fordított U-alakú görbét követ. } \\
\text { 3. A vizsgálati személyek } 60 \text { éves korig nyújtják a legjobb } \\
\text { teljesítményt } \\
\text { 4. } 60 \text { éves kor után a teljesítmény szignifikánsan csökken. } \\
\text { 5. A hallási mondatterjedelem teszt és az olvasási terjedelem } \\
\text { teszt között együttjárástvárható. }\end{array}$ & $\begin{array}{l}\text { - Az életkori változások feltérképezése megtörtént, az } \\
\text { egyes életkori csoportok fejlődése eltér egymástól. } \\
\text { - Az életkori görbe fordított U-alakú görbét követ. } \\
\text { - A fejlődéssel együtt járó kapacitásnövekedést } \\
\text { talátunk 13-15 éves korig, majd a fejlődés üteme } \\
\text { lelassult 19-30 éves korig, 31-49 éves kortól idős } \\
\text { korig fokozatos csökkenés jelentkezett a } \\
\text { teljesítményben. }\end{array}$ \\
\hline 2. vizsgálat & $\begin{array}{l}\text { 1. A gyerekek, a serdülők, a felnőttek és az idősek fejlődése } \\
\text { eltér egymástól. } \\
\text { 2. Az 5-6 éves gyerekek csak kevés szót tudnak mondani. } \\
\text { 3. A szavak száma tekintetében a teljesítmény } 17-18 \text { éves } \\
\text { életkorban eléri a felnőtt szintet. } \\
\text { 4. 50-69 éves kortól jelentős teljesítménycsökkenés } \\
\text { következik be. }\end{array}$ & $\begin{array}{l}\text {-A betüfluencia feladat minőségi mutatóinak } \\
\text { feltérképezése különböző életkori övezetekben } \\
\text { megtörtént, az egyes életkori övezetek fejlődése eltér } \\
\text { egymástól. } \\
\text { - Az 5-6 éves gyerekek csak kevés szót tudtak } \\
\text { mondani. } \\
\text {-A szavak száma tekintetében } 17-18 \text { éves korban a } \\
\text { teljesítmény elérte a felnőtt szintet, majd 50-69 éves } \\
\text { kortól kezdve romlás jelentkezett a teljesítményben }\end{array}$ \\
\hline 3. vizsgálat & $\begin{array}{l}\text { 1. A gyerekek, a serdülők, a felnőttek és az idősek fejlődése } \\
\text { eltér egymástól. } \\
\text { 2. Az 5-6 éves gyerekek több szót tudnak mondani, mint a } \\
\text { betüfluencia feladaton. } \\
\text { 3. A szavak száma tekintetében a teljesítmény } 17-18 \text { éves } \\
\text { életkorban eléri a felnőtt szintet. } \\
\text { 4. } 50-69 \text { éves kortól jelentős teljesítménycsökkenés } \\
\text { következik be. } \\
\text { 5. A teljesítmény magasabb a szavak száma tekintetében a } \\
\text { szemantikus, mint a betüfluencia feladat esetében. }\end{array}$ & $\begin{array}{l}\text {-A szemantikus fluencia feladat minőségi mutatóinak } \\
\text { feltérképezése különböző életkori övezetekben } \\
\text { megtörtént, az egyes életkori övezetek fejlődése eltért } \\
\text { egymástól. } \\
\text { - Az 5-6 éves gyerekek több szót tudnótak mondani a } \\
\text { szemantikus, mint a betüfluencia feladaton. } \\
\text {-A szavak száma tekintetében 17-18 éves korban a } \\
\text { teljesítmény elérte a felnőtt szintet, majd 50-69 éves } \\
\text { kortól kezdve romlás mutatkozott a teljesítményben. } \\
\text { - Több szó a szemantikus, mint a betűfluencia } \\
\text { feladaton. }\end{array}$ \\
\hline 4. vizsgálat & $\begin{array}{l}\text { 1. A magyar nyelv és irodalom tantárgyakon nyújtott } \\
\text { teljesítményt meghatározza a téri-vizuális feladaton elért } \\
\text { eredmény. } \\
\text { 2. A matematika tantárgyon elért teljesítményt a a téri-vizuális } \\
\text { és a komplex munkamemória feladatokon elért eredmények } \\
\text { meghatározzák. } \\
\text { 3. A környezetismeret tantárgy esetében a komplex } \\
\text { munkamemória bír bejósló értékkel. }\end{array}$ & $\begin{array}{l}\text { - A magyar nyelv és irodalom tantárgyon nyújtott } \\
\text { teljesítményt a téri-vizuális munkamemória és a } \\
\text { verbális rövidtávú memória feladatokon elért } \\
\text { eredmény határozta meg. } \\
\text { - A matematika tantárgyon elért teljesítményt a a téri- } \\
\text { vizuális, a komplex munkamemória és a végrehajtó } \\
\text { funkciókat mérő feladatokon elért eredmények } \\
\text { határozták meg. } \\
\text { - A környezetismeret tantárgy esetében a komplex } \\
\text { munkamemória és a végrehajtó funkciók bírtak } \\
\text { bejósló értékkel. }\end{array}$ \\
\hline
\end{tabular}


A disszertáció elméleti jelentőségeként említhető, hogy a munkamemória és a verbálisfluencia-tesztek egész életen át tartó fejlődésének vizsgálatával egy olyan ür betöltésére tettünk kísérletet, amely a hazai szakmai gyakorlati és tudományos közösségben hiányként fogalmazódott meg. Hazánkban eddig még nem született olyan tanulmány, ahol a munkamemória és a végrehajtó funkciók szakirodalmi háttere ilyen részletességü feldolgozásra került volna, kiegészítve azokat a különböző neuropszichológai és iskolapszichológiai vizsgálati eredményekkel. Gyakorlati jelentőségként fogalmazhatjuk meg, hogy a bemutatott eredmények segíthetik a korai diagnosztikát, mivel a rendellenességek kialakulásának nagyon korán megjelenő tüneteinél lehet diagnosztizálni a kognitív funkciókban megjelenő deficiteket, így lehetőség nyílik a korai fejlesztésre és terápiára is. Az eredmények utat nyitnak olyan általános fejlesztő illetve egyénre szabott tréningek kidolgozásához, amik a pedagógiában, az iskolapszichológiában és a neuropszichológiában is használhatóak lesznek. A disszertáció pedagógiai-pszichológiai jelentősége abban fogalmazható meg, hogy az iskolai teljesítmény, valamint a munkamemória és végrehajtó funkciók közötti kapcsolat precíz és részletes feltárásával lehetőség nyílhat a tesztek beültetésére az iskolaérettségi vizsgálatokba, mivel jelentős szerepük lehet a tehetséggondozásban, valamint a fejlődési és tanulási zavarok diagnosztikája területén. Eredményeink nemcsak alátámasztanak és megerősítenek számos korábbi, a nemzetközi szakirodalomban feltárt kutatási tapasztalatot és összefüggést, hanem a tananyagkészítés újragondolását is lehetővé teszik. Nagyobb figyelem helyeződhetne a munkamemória és végrehajtó funkciók tulajdonságainak való jobb megfelelésre, mint a modalitás függő alrendszerekhez kötődő anyagok alkalmazása, kapacitáskorlátok figyelembe vétele (pl. 7+-2 versus 4 elem egyidejü fejben tartása), az egyes végrehajtó funkciókra (gátlás, váltás, frissítés, monitorozás) támaszkodó feladatok beépítése a tananyagba.

A további kutatásokban érdemes lenne a vizsgált populációnkat kiterjeszteni a különböző tanulási zavarok és az atipikus fejlődést mutató gyerekcsoportokra is. Ezen kívül érdekes terület lehet az idős kori tanulási zavarok feltérképezése is, mivel egyre inkább elterjedt és elfogadott nézetté válik a "life-long learning” vagyis az élethosszon át tartó tanulás, aminek segítségével az idősek fejlesztésére is lehetőségünk nyílhatna.

Szükségesnek tartjuk a végrehajtó funkciók más tesztekkel történő feltérképezését is (például Wisconsin Kártyaszortírozási Teszt, Stroop-teszt, Hanoi-torony, BADS-teszt), ezáltal árnyaltabb képet kaphatnánk a végrehajtó funkciók háttérében meghúzódó egyéb, a vizsgálatainkban eddig fel nem tárt funkciókról is. A munkamemória mérőeljárásai közül a téri-vizuális munkamemória mérésére szintén érdemes lenne egyéb teszteket is bevonni az 
általunk használt Corsi-kocka teszten kívül (például VPST- Visual Pattern Test, Vizuális Mintázat Teszt, Location Learning Test stb.).

A longitudinális vizsgálatunkat hosszabb intervallumra szeretnénk kiterjeszteni. A vizsgálatban szereplő gyerekeket ebben a tanévben, tehát ötödik osztályos korukban újra felmértük a kognitív funkciókat tekintve, mivel fontosnak tartottuk megvizsgálni az alsó és felső tagozat közti teljesítménynövekedés hatásait.

Felnőttek esetében a szerzett neurológiai károsodások között említendő stroke kapcsán is tervezünk további vizsgálatokat, mivel a verbálisfluencia-feladatok klinikai populáción történő használatáról számos információt kaphatnánk. Továbbá érdemes lenne feltérképezni az általunk használt neuropszichológiai tesztbattériával a betegeket lebenyi érintettség és lateralizáció szempontjából is, mivel ezek hasznos információval szolgálhatnak a mögöttes kognitív funkciókról, ezek specifikus differenciál diagnosztikájáról és rehabilitációs lehetőségeiről is. 


\section{KÖSZÖNETNYILVÁNÍTÁS}

Elsőként szeretném megköszönni témavezetőm, Dr. Németh Dezső szakmai támogatását, biztatását és a közös munka eredményeiben való együttmüködését. Köszönöm Dr. Janacsek Karolina szakmai segítségét, precíz és körültekintő javaslatait, valamint barátságát.

A doktori képzés alatt iránymutatóak voltak Csapó Benő kutatói munkával kapcsolatos elvárásai. Köszönöm, hogy lehetővé tette a Neveléstudományi Intézet és a Doktori Iskola infrastruktúrájának használatát.

Hálás vagyok a Szegedi Tudományegyetem pszichológia szakos hallgatóinak, akik az adatfelvételt segítették. Köszönet illeti azokat a vizsgálatban részt vevő személyeket is, akik kooperatív hozzáállásukkal segítettek minket abban, hogy feltárhassuk az általunk vizsgált funkciók életkori változásai és összefüggéseit. Szeretném kifejezni hálámat azon iskolaigazgatóknak és pedagógusoknak, akik lehetővé tették a vizsgálatok lefolytatását és az adatok felvételét.

A családom, párom, barátaim és kollégáim segítségéért is nagyon hálás vagyok. Köszönöm, hogy mindig mellettem álltak, folyamatos biztatásukkal és szeretetükkel erőt adtak. 


\section{IRODALOM}

Abikoff, H. és Gittelman, R. (1985): Hyperactive children treated with stimulants. Is cognitive training a useful adjunct? Archives of General Psychiatry, 42. 10. sz. 953-961.

Abrahams, S., Goldstein, L. H., Simmons, A., Brammer, M. J., Williams, S. C., Giampietro, V. P., Andrew, C. M. és Leigh, P. M. (2003): Functional magnetic resonance imaging of verbal fluency and confrontation naming using compressed image acquisition to permit over responses. Human Brain Mapping, 20. 1. sz. 29-40.

Abwender, D. A., Swan, J. G., Bowerman, J. T. és Connolly, S. W. (2001): Qualitative analysis of verbal fluency output: Review and comparison of several scoring methods. Assessment, 8. 11. sz. 323-336.

Acevedo, A., Loewenstein, D. A., Barker, W. W., Harwood, D. G., Luis, C., Bravo, M., Hurwitz, D. A., Aguero, H., Greenfield, L. és Duara, R. (2000): Category fluency test: Normative data for English and Spanish speaking elderly. Journal of the International Neuropsychological Society, 6. 7. sz. 760-769.

Adams, A. M. és Gathercole, S. E. (2000): Limitations in working memory: Implications for language development. International Journal of Language and Communication Disorders, 35. 1. sz. 95-117.

Adams, J. W. és Hitch, G. J. (1997): Working memory and children's mental addition. Journal of Experimental Child Psychology, 67. 1. sz. 21-38.

Adams, M. L., Reich, A. R. és Flowers, C. E. (1989): Verbal fluency characteristics of normal and aphasic speakers. Journal of Speech and Hearing Research, 32. 871-879.

Allen, H. A., Liddle, P. F. és Frith, C. D. (1993): Negative features, retrieval processes and verbal fluency in schizophrenia. British Journal of Psychiatry, 163. 6. sz. 769-775.

Alloway, T. P. és Archibald, L. (2008): Working memory and learning in children with developmental coordination disorder and specific language impairment. Journal of Learning Disabilities, 41. 3. sz. 251-262.

Alloway, T. P. (2009): Working Memory, but Not IQ, Predicts Subsequent Learning in Children with Learning Difficulties. European Journal of Psychological Assessment, 25. 2. sz. 92-98.

Alloway, T. P. és Alloway, R. G. (2010). Investigating the predictive roles of working memory and IQ in academic attainment. Journal of Experimental Child Psychology, 106. 1. sz. 20-29.

Alloway, T. P., Gathercole, S. E. és Pickering, S. J. (2006): Verbal and Visuospatial Short-Term and Working Memory in Children: Are They Separable? Child Development, 77. 6. sz. 1698-1716.

Alloway, T. P., Gathercole, S. E., Adams, A. M., Willis, C., Eaglen, R. és Lamont, E. (2005): Working memory and other cognitive skills as predictors of progress towards early learning goals at school entry. British Journal of Developmental Psychology, 23. 3. sz. 417-426.

Alloway, T. P., Gathercole, S. E., Kirkwood, H. és Elliott, J. (2009): The Cognitive and Behavioral Characteristics of Children With Low Working Memory. Child Development, 80. 2. sz. 606-621.

Aloia, M. S., Gourovitch, M. L., Weinberger, D. R. és Goldberg, T. E. (1996): An investigation of semantic space in patients with schizophrenia. Journal of the International Neuropsychological Society, 2. 4. sz. 267-273.

Altemeier, L. E., Abbott, R. D. és Berninger, V. W. (2008): Executive functions for reading and writing in typical literacy development and dyslexia. Journal of Clinical and Experimental Neuropsychology, 30. 5. sz. 588-606.

Altemeier, L. E., Jones, J., Abbott, R. D. és Berninger, V. W. (2006): Executive Functions in Becoming Writing Readers and Reading Writers: Note Taking and Report Writing in Third and Fifth Graders. Developmental Neuropsychology, 29. 1. sz. 160-173.

Anderson, P. (2002): Assessment and Development of Executive Function (EF) During Childhood. Child Neuropsychology, 8. 2. sz. 71-82.

Anderson, V. (2001): Assessing executive functions in children: biological, psychological, and developmental considerations. Developmental Neurorehabilitation, 4. 3. sz. 119-136.

Anderson, V. A., Anderson, P., Northam, E., Jacobs, R. és Catroppa, C. (2001): Development of executive functions trough late childhood and adolescence in an Australian sample. Developmental Neuropsychology, 20. 1. sz. 385-406.

Archibald, L. M. D. és Gathercole, S. E. (2006): Short-term and working memory in specific language impairment. International Journal of Language \& Communication Disorders, 41. 6. sz. 675-693.

Archibald, L. M. D. és Gathercole, S. E. (2007): The complexities of complex memory span: Storage and processing deficit sin specific language impairment. Journal of Memory and Language, 57. 177-194.

Ardila, A. és Surloff, C. (2006): Dysexecutive agraphia: a major executive dysfunction sign. International Journal of Neuroscience, 116. 5. sz. 653-663. 
Ardila, A. (2006): The origins of language: an analysis from the aphasia perspective. Revista de Neurologia, 43. 11. sz. 690-698.

Ardila, A. és Rosselli, M. (1994): Development of language, memory and visuospatial abilities in 5- to 12-yearold children using a neuropsychological battery. Developmental Neuropsychology, 10. 2. sz. 97-12.

Ardila, A., Rosselli, M., Matute, E. és Guajardo, S. (2005): The Influence of the Parents' Educational Level on the Development of Executive Functions. Developmental Neuropsychology, 28. 1. sz. 539-560.

Arroyo-Anllo, E. M., Lorber, M., Rigaleau, F. és Gil. R. (2011): Verbal fluency in Alzheimer's disease and Aphasia. Dementia, 11. 1. sz. 5-18.

Atkinson, R. C. és Shiffrin, R. M. (1968): Human memory: A proposed system and its control processes. In Spence, K. W. (szerk.): The psychology of learning and motivation: advances in research and theory. Academic Press, New York. 89-195.

Auriacombe, S., Grossman, M., Carvell, S., Gollomp, S., Stern, M. B. és Hurtig, H. I. (1993): Verbal fluency deficits in Parkinson's disease. Neuropsychology, 7. 2. sz. 182-192.

Austin, M. P., Mitchell, P., Wilhelm, K., Parker, G., Hickie, I., Brodaty, H., Chan, J., Eyers, K., Milic, M. és Hadzi-Pavlovic, D. (1999): Cognitive function in depression: a distinct pattern of frontal impairment in melancholia? Psychological Medicine, 29. 1. sz. 73-85.

Axelrod, B. N., Jiron, C. C. és Henry, R. R. (1993): Performance of adults ages 20 to 90 on the abbreviated Wisconsin card sorting test. Clinical Neuropsychologist, 7. 2. sz. 205-209.

Azuma, T. (2004): Working Memory and Perseveration in Verbal Fluency. Neuropsychology, 18. 1. sz. 69-77.

Bäckman, L. (1992): Memory training and memory improvement in Alzheimer's disease: rules and exceptions. Acta Neurologica Scandinavica, 85. 139. sz. 84-89.

Baddeley, A. D. (1986): Working memory. Clarendon Press, Oxford.

Baddeley, A. D. (1992): Working memory. Science, 255. 5044. sz. 556-559.

Baddeley, A. D. (1998): The central executive: A concept and some misconceptions. Journal of the International Neuropsychological Society, 4. 5. sz. 523-526.

Baddeley, A. D. (2000): The episodic buffer: A new component of working memory? Trends in Cognitive Sciences, 11. (4), 417-423.

Baddeley, A. D. (2001). Az emberi emlékezet. Budapest, Osiris Kiadó.

Baddeley, A. D. (2002): Is working memory still working? European Psychologist, 7. 2. sz. 85-97.

Baddeley, A. D. (2003): Working memory and language: An overview. Journal of Communication Disorders, 36. 3. sz. 189-208.

Baddeley, A. D. és Hitch, G. (1974): Working memory. In G. A. Bower (szerk.) Recent advances in learning and motivation. Academic Press, New York. 47-90.

Baddeley, A. D. \& Wilson, B. (1987): Comprehension and working memory: a single case neuropsychological study. Journal of Memory and Language, 27. 5. sz. 479-498.

Baddeley, A. D., Gathercole, S. E. és Papagno, C. (1998): The phonological loop as a language learning device. Psychological Review, 105. 1. sz. 158-173.

Baddeley, A. D., Lewis, V. J. és Vallar, G. (1984): Exploring the articulatory loop. Quarterly Journal of Experimental Psychology, 36. 2. sz. 233-252.

Baddeley, A. D., Thomson, N. és Buchanan, M. (1975): Word length and the structure of short-term memory. Journal of Verbal Learning and Verbal Behavior, 14. 6. sz. 575-589.

Baldo, J. V. és Shimamura, A. P. (1998): Letter and category fluency in patients with frontal lobe lesions. Neuropsychology, 12. 2. sz. 259-267.

Baldo, J. V., Schwartz, S., Wilkins, D. és Dronkers N. F. (2006): Role of frontal versus temporal cortex in verbal fluency as revealed by voxel-based lesion symptom mapping. Journal of the International Neuropsychological Society, 12. 6. sz. 896-900.

Banerjee, P., Grange, D. K., Steiner, R. D. és White, D. A. (2011): Executive Strategic Processing During Verbal Fluency Performance in Children with Phenylketonuria. Child Neuropsychology, 17. 2. sz. 105-117.

Barch, D. M., Braver, T. S., Nystrom, L. E., Forman, S. D., Noll, D. C. és Cohen, J. D. (1997): Dissociating working memory from task difficulty in human prefrontal cortex. Neuropsychologia, 35. 10. sz. 13731380.

Barkley, R. A. (2012): Distinguishing sluggish cognitive tempo from attention-deficit/hyperactivity disorder in adults. Journal of Abnormal Psychology, 121. 4. sz. 978-990.

Barr, A. és Brandt, J. (1996): Word-list generation deficits in dementia. Journal of Clinical and Experimental Neuropsychology, 18. 6. sz. 810-822.

Barrouillet, P., Gavens N., Vergauwe E., Gaillard V. és Camos V. (2009): Working Memory Span Development: A Time-Based Resource-Sharing Model Account. Developmental Psychology, 45. 2. sz. 477-490.

Barrouillet, P. és Lepine, R. (2005): Working memory and children's use of retrieval to solve addition problems. Journal of Experimental Child Psychology, 91. 3. sz. 183-204. 
Bayles, K. A., Trosset, M. W., Tomoeda, C. K., Montgomery, E. B. és Wilson, J. (1993): Generative naming in Parkinson disease patients. Journal of Clinical and Experimental Neuropsychology, 15. 4. sz. 547-562.

Bayliss, D. M., Jarrold, C., Baddeley, A. D. és Gunn, D. M. (2003): The relationship between short-term memory and working memory: Complex span made simple? Memory, 13. 3-4. sz. 414-421.

Beatty, W. W., Testa, J. A. és Englsh, E. (1997): Influences of clustering and switching on the verbal fluency performance of patients with alzheimer's disease. Aging, Neuropsychology, and Cognition: A Journal on Normal and Dysfunctional Development, 4. 4. sz. 273-279.

Beatty, W. W., Wonderlich, S. A., Staton, R. D. és Ternes, L. A. (1990): Cognitive functioning in bulimia comparison with depression. Bulletin of the Psychonomic Society, 28. 4. sz. 289-292.

Beck, S. J., Hanson, C. A., Puffenberger, S. S., Benninger, K. L. és Benninger, W. B. (2010): A Controlled Trial of Working Memory Training for Children and Adolescents with ADHD. Journal of Clinical Child and Adolescent Psychology, 39. 6. sz. 825-836.

Benson, D. F. és Stuss, D. T. (1990): Frontal Lobe Influences on Delusions: A Clinical Perspective. Schizophrenia Bulletin, 16. 3. sz. 403-411.

Bentham, P. W., Jones, A. és Hodges, J. R. (1997) : A comparison of semantic memory in vascular dementia and dementia of Alzheimer's types. International Journal of Geriatric Psychiatry, 12. 5. sz. 575-580.

Benton, A. L. (1968): Differential behavioral effects in frontal lobe disease. Neuropsychologia, 6. 1. sz. 53-60.

Benton, A. L. és Hamsher, K. (1976): Multilingual Aphasia Examination. University of Iowa, Iowa City.

Benton, A. L. és Hamsher, K. (1989): Multilingual Aphasia Examination. AJA, Iowa City.

Berg, E. A. (1948): A simple objective test for measuring flexibility in thinking. Journal of General Psychology, 39. $15-22$.

Berryhill, M. E., Chein, J. és Olson, I. R. (2011): At the intersection of attention and memory: The mechanistic role of the posterior parietal lobe in working memory. Neuropsychologia, 49. 5. sz. 1306-1315.

Best, J. R., Miller, P. H. és Jones, L. L. (2009): Executive functions after age 5: Changes and correlates. Developmental Review, 29. 3. sz. 180-200.

Biederman, J., Monuteaux, M. C., Doyle, A. E., Seidman, L. J. Wilens, T. E., Ferrero, F., Morgan, C. L. és Faraone, S. V. (2004): Impact of Executive Function Deficits and Attention-Deficit/Hyperactivity Disorder (ADHD) on Academic Outcomes in Children. Journal of Consulting and Clinical Psychology, 72. 5. sz. 757-766.

Bigler, E. D., Burlingame, G. M. és Lawson, J. S. (2003): Memory Performance of Children with Dyslexia. A Comparative Analysis of Theoretical Perspective. Journal of Learning Disabilities, 36. 3. sz. 230-246.

Birn, R. M., Kenworthy, L., Case, L., Caravella, R., Jones, T. B., Bandettini, P. A. és Martin, A. (2010): Neural systems supporting lexical search guided by letter and semantic category cues: a self-paced overt response fMRI study of verbal fluency. Neuroimage, 49. 1. sz. 1099-1107.

Blair, C. és Razza, R. P. (2007): Relating effortful control, executive function, and false belief understanding to emerging math and literacy ability in kindergarten. Child Development, 78. 2. sz. 647-663.

Blakemore, S. J. és Choudhury, S. (2006): Development of the adolescent brain: Implications for executive function and social cognition. Journal of Child Psychology and Psychiatry, 47. 3-4. sz. 296-312.

Bokat, C. E. és Goldberg, T. E. (2003): Letter and category fluency in schizophrenic patients: a meta-analysis. Schrizophrenia Research, 64. 1. sz. 73-78.

Bondi, M. W., Kaszniak, A. W., Bayles, K. A. és Vance, K. T. (1993): Contributions of frontal system dysfunction to memory and perceptual abilities in Parkinson's disease. Neuropsychology, 7. 1. sz. 89102.

Boone, K. B. (1999): Neuropsychological assessment of executive functions: impact of age, education, gender, intellectual level, and vascular status on executive test scores. In Miller, B. L. és Cummings, J. L. (szerk.): The human frontal lobes: Functions and disorders. The Guilford Press, New York. 247-260.

Bopp, K. L. és Verhaeghen, P. (2005): Aging and Verbal Memory Span: A Meta-Analysis. The Journals of Gerontology Series B: Psychological Sciences and Social Sciences, 60. 5. sz. 223-233.

Borella, E., Carretti, B., Riboldi, F. és De Beni, R. (2010): Working memory training in older adults: Evidence of transfer and maintenance effects. Psychology and Aging, 25. 4. sz. 767-778.

Borkowsky, J. G. és Burke, J. E. (1996): Theories, models and measurements of executive functioning: An information processing perspective. In Lyon, G. R. és Krasnegor, N. A. (szerk.): Attention, memory and executive function. Paul $\mathrm{H}$. Brookes, Baltimore.

Brahmbhatt, S. B., McAuley, T. és Barch, D. M. (2008): Functional developmental similarities and differences in the neural correlates of verbal and nonverbal working memory tasks. Neuropsychologia, 46. 4. sz. 1020-1031.

Brickman, A., Paul, R., Cohen, R., Williams, L., Macgreggor, K., Jefferson, A., Tate, D., Gunstad, J. és Gordon, E. (2005): Category and letter verbal fluency across the adult lifespan: Relationship to EEG theta power. Archives of Clinical Neuropsychology, 20. 5. sz. 561-573. 
Broadbent, D. E. (1957): A mechanical model for human attention and immediate memory. Psychological Review, 64. 3. sz. 205-215.

Brocki, K. C. és Bohlin, G. (2004). Executive Functions in Children Aged 6 to 13: A Dimensional and Developmental Study. Developmental Neuropsychology, 26. 2. sz. 571-593.

Brookshire, B. L, Fletcher, J. M., Bohan, T. P., Landry, S. H., Davidson, K. C. és Francis D. J. (1995): Specific language deficiencies in children with early onset hydrocephalus. Child Neuropsychology, 1. 2. sz. 106117.

Brosnan, M., Demetre, J., Hamil, S., Robson, K., Shepherd, H. és Cody, G. (2002): Executive functioning in adults and children with developmental dyslexia. Neuropsychologia, 40. 12. sz. 2144-2155.

Brown, R. G, Scott, L. C., Bench, C. J. és Dolan, R. J. (1994): Cognitive function in depression: its relationship to the presence and severity of intellectual decline. Psychological Medicine, 24. 4. sz. 829 -847.

Brown, T. E. (2005): Attention deficit disorder: The unfocused mind in children and adults. Yale University Press, New Haven, CT.

Bryson, G., Whelahan, H. A. és Bell, M. (2001). Memory and executive function impairments in deficit syndrome schizophrenia. Psychiatry Research, 102. 1. sz. 29-37.

Bull R. és Scerif G. (2001): Executive functioning as predictor of children mathematical ability: Inhibition, switching, and working memory. Developmental Neuropsychology, 19. 3. sz. 273-293.

Bull, R., Espy, K. A. és Wiebe, S. (2008): Short-term memory, working memory and executive functioning: longitudinal predictors of mathematics achievement at age 7. Developmental Neuropsychology, 33. 3. sz. 205-228.

Bull, R., Johnson, R. S. és Roy, J. A. (1999): Exploring the roles of the visuo-spatial sketchpad and central executive in children's arithmetical skills: View from cognition and developmental neuropsychology. Developmental Neuropsychology, 15. 3. sz. 421-442.

Bunge, S. A., Klinberg, T., Jacobsen, R. B. és Gabrieli, J. D. E. (2000): A resource model of the neural basis of executive working memory. Proceedings of the National Academy of Sciences of the United States of America, 97. 7. sz. 3573-3578.

Bunn, T. (1995): The fluency test. Educational and Child Psychology, 12. 1. sz. 46-49.

Buonomano, D. V. és Merzenich, M. M. (1998): Cortical plasticity: from synapses to maps. Annual Review of Neuroscience, 21. 1. sz. 149-186.

Burgess, P. W. és Shallice, T. (1997): The Hayling and Brixton Tests. Thames Valley Test Company, Bury St Edmunds, UK.

Burgess, P. W., Alderman, N., Evans, J., Emslie, H. és Wilson, B. A. (1998): The ecological validity of tests of executive function. Journal of the International Neuropsychological Society, 4. 547-558.

Butterfield, E. C., Wambold, C. és Belmont, J. M. (1973): On the theory and practice of improving short-term memory. American Journal of Mental Deficiency, 77. 5. sz. 654-669.

Cahn, D. A., Salmon, D. P., Bondi, M. W., Butters, N., Johnson, S. A., Wiederholt, W. C. és Barrett-Connor, E. (1997): A population based analysis of qualitative features of the neuropsychological test performance of individuals with dementia of the Alzheimer type: Implications for individuals with questionable dementia. Journal of the International Neuropsychological Society, 3. 4. sz. 387-393.

Cahn-Weiner, D. A., Malloy, P. F., Boyle, P. A., Marran, M. és Salloway, S. (2000): Prediction of Functional Status from Neuropsychological Tests in Community-Dwelling Elderly Individuals. The Clinical Neuropsychologist, 14. 2. sz. 187-195.

Cahn-Weiner, D. A., Malloy, P. F., Rebok, G. W. és Ott, B. R. (2003): Results of a Randomized PlaceboControlled Study of Memory Training for Mildly Impaired Alzheimer's Disease Patients. Applied Neuropsychology, 10. 4. sz. 215-223.

Calev, A., Nigal, D. és Chazan, S. (1989): Retrieval from semantic memory using meaningful and meaningless constructs by depressed stable bipolar and manic patients. British Journal of Clinical Psychology, 28. 1. sz. 67-73.

Calkins, S. D. és Marcovitch, S. (2010): Emotion regulation and executive functioning in early development: Mechanisms of control supporting adaptive functioning. In Calkins, S. D. és Bell, M. A. (szerk.): Child development at the intersection of emotion and cognition. American Psychological Association, Washington, DC. 37-57.

Camp, C. J. (1989): Facilitation of new learning in Alzheimer's disease. In Gilmore, G., Whitehouse, P. és Wykle, M. (szerk.): Memory and Aging: Theory, Research and Practice. Springer, New York. 212-225.

Camp, C. J., Foss, J. W., Stevens, A. B., Reichard, C. C., McKitrick, L. A. és O’Hanlon, A. M. (1993): Memory training in normal and demented elderly populations: the E-I-E-I-O model. Experimental Aging Research, 19. 3. sz. 277-290.

Canning, D., Leach, L., Stuss, D. N., Go, L. és Black, S. E. (2004): Diagnostic utility of abbreviated fluency measures in Alzheimer disease and vascular dementia. Neurology, 62. 4. sz. 556-562. 
Capitani, E., Laiacona, M. és Basso, A. (1998): Phonetically cued word-fluency, gender differences and aging: A reappraisal. Cortex, 34. 5. sz. 779-783.

Caramelli, P., Carthery-Goulart, M. T., Porto, S. C., Charchat-Fichman, H. és Nitrini, R. (2007). Category Fluency as a Screening Test for Alzheimer Disease in Illiterate and Literate Patients. Alzheimer Disease and Associated Disorders, 21. 1. sz. 65-67.

Carew ,T. G., Lamar, M., Cloud, B. S., Grossman, M. és Libon, D. J. (1997): Impairment in category fluency in ischemic vascular dementia. Neuropsychology, 11. 3. sz. 400-412.

Carlson, S. M. (2005). Developmentally Sensitive Measures of Executive Function in Preschool Children. Developmental Neuropsychology, 28. 2. sz. 595-616.

Carpenter P. A., Miyake A., \& Just M. A., (1994): Working Memory Constraints on the Resolution of Lexical Ambiguity: Maintaining Multiple Interpretations in Neutral Contexts. Journal of Memory and Language, 33. 2. sz. 175-202.

Carretti, B., Borella, E. és De Beni, R. (2007): Does strategic memory training improve the working memory performance of younger and older adults? Experimental Psychology, 54. 4. sz. 311-320.

Carter, C., Robertson, L., Nordahl, T., Chaderjian, M., Kraft, L. és O’Shoora-Celaya, L. (1996): Spatial working memory deficits and their relationship to negative symptoms in unmedicated schizophrenia patients. Biological Psychiatry, 40. 930-932.

Case, R. D., Kurland, M. és Goldberg, J. (1982): Operational efficiency and the growth of short-term memory span. Journal of Experimental Child Psychology, 33. 3. sz. 386-404.

Cavallini, E., Pagnin, A. és Vecchi, T. (2003): Aging and everyday memory: The beneficial effect of memory training. Archives of Gerontology and Geriatrics, 37. 3. sz. 241-257.

Cerhan, J. H., Ivnik, R. J., Glenn, E. S., Tangalos, E. C., Petersen, R. C. és Boeve, B. F. (2002): Diagnostic Utility of Letter Fluency, Category Fluency, and Fluency Difference Scores in Alzheimer's Disease. The Clinical Neuropsychologist, 16. 1. sz. 35-42.

Chan, A. S. és Poon, M. W. (1999): Performance of 7- to 95-year-old individuals in a Chinese version of the category fluency test. Journal of the International Neuropsychological Society, 5. 6. sz. 525-533.

Channon, S., Pratt, P. és Robertson, M. M. (2003): Executive function, memory, and learning in Tourette's syndrome. Neuropsychology, 17.2. sz. 247-254.

Chein, J. M. és Morrison, A. B. (2010): Expanding the mind's workspace: Training and transfer effects with a complex working memory span task. Psychonomic Bulletin \& Review, 17. 2. sz. 193-199.

Chein, J. M., Moore, A. B. és Conway, A. R. A. (2011): Domain-general mechanisms of complex working memory span. NeuroImage, 54. 1. sz. 550-559.

Chiappe, P., Hasher, L. és Siegel, L. S. (2000): Working Memory, Inhibitory Control and Reading Disability. Memory and Cognition, 28. 1. sz. 8-17.

Chiara, M. C., Levorato, M. R. és Florit, E. (2011): Role of Verbal Memory in Reading Text Comprehension of Individuals With Down Syndrome. American Journal on Intellectual and Developmental Disabilities, 116. 2. sz. $99-110$.

Cicerone, K. D. és Wood, J. C. (1987): Planning disorder after closed head injury: a case study. Archives of Physical Medicine and Rehabilitation, 68. 2. sz. 111-115.

Clare, L. (2000): Cognitive rehabilitation in early-stage Alzheimer's disease: learning and the impact of awareness. Unpublished PhD thesis, The Open University, Milton Keynes.

Clare, L. és Wilson, B. A. (1997): Coping with Memory Problems: a Practical Guide for People with Memory Impairments and their Relatives and Friends. Thames Valley Test Company, Bury St Edmunds.

Clare, L. és Woods, R. T. (2004): Cognitive training and cognitive rehabilitation for people with early-stage Alzheimer's disease: A review. Neuropsychological Rehabilitation: An International Journal, 14. 4. sz. 385-401.

Coen, R. F., Maguire, C., Swanwick, G. R., Kirby, M., Burke, T., Lawlor, B. A., Qalsh, J. B. és Coakley, D. (1996): Letter and category fluency in Alzheimer's disease: A prognostic indicator of progression? Dementia, 7. 5. sz. 246-250.

Cohen, M. J., Morgan, A. M., Vaughn, M., Riccio, C. A. és Hall, J. (1999): Verbal fluency in children: Developmental issues and differential validity in distinguishing children with attention-deficit hyperactivity disorder and two subtypes of dyslexia. Archives of Clinical Neuropsychology, 14. 5. sz. 433-443.

Colle, H. A. és Welsh, A. (1976): Acoustic masking in primary memory. Journal of Verbal Learning and Verbal Behavior, 15. 1. sz. 17-32.

Collette, F., Van der Linden, M., Laureys, S., Delfiore, G., Degueldre, C., Luxen, A. és Salmon, E. (2005): Exploring the unity and diversity of the neural substrates of executive functioning. Human Brain Mapping, 25. 4. sz. 409-423. 
Conant, L. L., Liebenthal, E., Desai, A. és Binder, J. R. (2014): FMRI of phonemic perception and its relationship to reading development in elementary- to middle-school-age children. NeuroImage, 89. 192-202.

Conners, F. A., Rosenquist, C. J., Arnett, L., Moore, M. S. és Hume, L. E. (2008) : Improving memory span in children with Down syndrome. Journal of Intellectual Disability Research, 52. 3. sz. 244-255.

Conrad, R. és Hull, A. J. (1964). Information acoustic confusion and memory span. British Journal of Psychology, 55. 4. sz. 429-432.

Conway, A. R. A., Cowan, N., Bunting, M. F., Therriault, D. J. és Minkoff, S. R. B. (2002): A latent variable analysis of working memory capacity, short-term memory capacity, processing speed, and general fluid intelligence. Intelligence, 30. 2. sz. 163-183.

Conway, A. R. A., Kane, M. J. és Engle, R. W. (2003): Working memory capacity and its relation to general intelligence. Trends in Cognitive Sciences, 7. 12. sz. 547-552.

Conway, A. R. A., Kane, M.J., Bunting, M. F., Hambrick, D.Z., Wilhelm, O. és Engle, R. (2005): Working memory span tasks: A methodological review and user's guide. Psychonomic Bulletin and Review, 12. 5. sz. 769-786.

Corcoran, R. és Upton, D. (1993): A Role for the Hippocampus in Card Sorting? Cortex, 29. 2. sz. 293-304.

Cornoldi, C., Marzocchi, G. M., Belotti, M., Caroli, M. G., Meo, T. és Braga, C. (2001): Working Memory Interference Control Deficit in Children Referred by Teachers for ADHD Symptoms. Psychology Press, 7. 4. sz. 230-240.

Corsi, P. M. (1972): Human memory and the medial temporal region of the brain. Doctoral dissertation. Montreal, McGill University.

Coslett, H. B, Bowers, D., Verfaille, M. és Heilman, K. M. (1991): Frontal verbal amnesia. Phonological amnesia. Archives of Neurology, 48. 9. sz. 949-955.

Cowan, N. (1992): Verbal memory span and the timing of spoken recall. Journal of Memory and Language, 31. 5. sz. 684-688.

Cowan, N. (1994): Mechanisms of verbal short-term memory. Current Directions in Psychological Sciences, 3. 6. sz. 185-189.

Cowan, N. (2001): The magical number 4 in short-term memory: A reconsideration of mental storage capacity. Behavioral and Brain Sciences, 24. 1. sz. 87-114.

Cowan, N. (2008): What are the differences between long-term, short-term, and working memory? Progress in Brain Research, 169. 323-338.

Cowan, N. (2010): The Magical Mystery Four. How Is Working Memory Capacity Limited, and Why? Current Directions in Psychological Science, 19. 1. sz. 51-57.

Cowan, N., Elliott E. M., Saults, J. S., Morey, C. C., Mattox, S., Hismjatullina, A. és Conway, A. R. (2005): On the capacity of attention: Its estimation and its role in working memory and cognitive aptitudes, Cognitive Psychology, 51. 1. sz. 42-100.

Cowan, N., Towse, J. N., Hamilton, Z., Saults, J. S., Elliott, E. M., Lacey, J. F., Moreno, M. V. és Hitch, G. J. (2003): Children's working-memory processes, a response-timing analysis. Journal of Experimental Psychology, 132. 1. sz. 113-132.

Crawford, J. R., Bryan, J., Luszcz, M. A., Obonsawin, M. C. és Stewart, L. (2000): The executive decline hypothesis of cognitive aging: Do executive deficits qualify as differential deficits and do they mediate age-related memory decline? Aging, Neuropsychology and Cognition, 7. 1. sz. 9-31.

Crawford, J. R., Moore, J. W. és Cameron, I. M. (1992): Verbal fluency: A NART-based equation for the estimation of premorbid performance. British Journal of Clinical Psychology, 31. 3. sz. 327-329.

Crawford, J. R., Obonsawin, M. C. és Bremner, M. (1993). Frontal lobe impairment in schizophrenia: relationship to intellectual functioning. Psychological Medicine, 23. 3. sz. 787-790.

Crawford, S. és Channon, S. (2002): Dissociation between performance on abstract tests of executive function and problem solving in real-life-type situations in normal aging. Aging and Mental Health, 6. 1. sz. 1221.

Crockett, D. J. (1974): Component analysis of within correlations of language-skill tests in normal children. Journal of Special Education, 8. 4. sz. 361-375.

Crossley, M., D’Arcy, C. és Rawson, N. S. (1997): Letter and category fluency in community-dwelling Canadian seniors: A comparison of normal participants to those with dementia of the Alzheimer or vascular type. Journal of Clinical and Experimental Neuropsychology, 19. 1. sz. 52-62.

Crowe, S. E. (1992): Dissociation of two frontal lobe syndromes by a test of verbal fluency. Journal of Clinical and Experimental Neuropsychology, 14. 1. sz. 327-339.

Cubillo, A., Halari, R., Smith, A., Taylor, E. és Rubia, K. (2012): A review of fronto-striatal and fronto-cortical brain abnormalities in children and adults with Attention Deficit Hyperactivity Disorder (ADHD) and new evidence for dysfunction in adults with ADHD during motivation and attention. Cortex, 48. 2. sz. 194-215. 
Cummings, J. L. (1994): Vascular Subcortical Dementias: Clinical Aspects. Dementia and Geriatric Cognitive Disorders, 5. 3-4. sz. 177-180.

Curtis, C. E. és D’Esposito, M. (2003): Persistent activity in the prefrontal cortex during working memory. Trends in Cognitive Sciences, 7. 9. sz. 415-423.

Csépe, V. (2005): Kognitív fejlödés-neuropszichológia. Gondolat Kiadó, Budapest.

Csépe, V. (2011): Valóság vagy álom? A pszichológia és az idegtudomány hatása a 21. századi oktatásra. Magyar Tudomány, 172. 9. sz. 1031-1037.

D’ Esposito, M., Detre, J. A., Alsop, D. C., Shin, R. K., Atlas, S. és Grossman, M. (1995): The neural basis of the central executive system of working memory. Nature, 378. 279-281.

Da Silva, C. G., Petersson, K. M., Faisca, L., Ingvar, M. és Reis, A. (2004): The effects of literacy and education on the quantitative and qualitative aspects of semantic verbal fluency. Journal of Clinical and Experimental Neuropsychology, 26. 2. sz. 266-277.

Dahlin, E., Neely, A. S., Larsson, A., Backman, L. és Nyberg, L. (2008). Transfer of learning after updating training mediated by the striatum. Science, 320. 5882. sz. 1510-1512.

Dahlin, K. I. E. (2011): Effects of working memory training on reading in children with special needs. Reading and Writing, 24. 4. sz. 479-491.

Daigneault, G., Joly, P. és Frigon, J. (2002): Executive Functions in the Evaluation of Accident Risk of Older Drivers. Journal of Clinical and Experimental Neuropsychology, 24. 2. sz. 221-223.

Daigneault, S., Braunk, C. M. J. és Whitaker, H. A. (1992): Early effects of normal aging on perseverative and non-perseverative prefrontal measures. Developmental Neuropsychology, 8. 1. sz. 99-114.

Daneman, M. és Carpenter, P. (1980): Individual differences in working memory and reading. Journal of Verbal Learning Verbal Behavior, 19. 4. sz. 450-466.

Daneman, M. és Blennerhasset, A. (1984): How to assess the listening comprehension skills of prereaders. Journal of Educational Psychology, 76. 6. sz. 1372-1381.

Daneman, M. és Green, I. (1986): Individual differences in comprehending and producing words in context. Journal of Memory and Language, 25. 1. sz. 1-18.

Daneman, M. és Merickle, P. M. (1996): Working memory and language comprehension: a meta-analysis. Psychonomic Bulletin and Review, 3. 4. sz. 422-433.

Davidson, M. C., Amso, D., Anderson, L. C. és Diamond, A. (2006): Development of cognitive control and executive functions from 4 to 13 years: Evidence from manipulations of memory, inhibition, and task switching. Neuropsychologia, 44. 1. sz. 2037-2078.

Dawson, P. és Guare, R. (2004): Executive skills in children and adolescents. Guilford Press, New York.

De Beni, R., Palladino P., Pazzaglia, F. és Cornoldi, C. (1998): Increases in intrusion errors and working memory deficit of poor comprehenders. The Quarterly Journal of Experimental Psychology, 51. 2. sz. 305-320.

De Jong, P. F. (1998): Working Memory Deficits of Reading Disabled Children. Journal of Experimental Child Psychology, 70.2. sz. 75-96.

De Luca, C. R., Wood, S. J., Anderson, V., Buchanan, J., Proffitt, T. M., Mahony, K., \& Pantelis, C. (2003). Normative Data From the Cantab. I: Development of Executive Function Over the Lifespan. Journal of Clinical and Experimental Neuropsychology, 25. 2. sz. 242-254.

De Ribaupierre, A. és Ludwig, C. (2003): Age Differences and Divided Attention: Is there a General Deficit? Experimental Aging Research, 29. 1. sz. 79-105.

Decker, S. N. (1989): Cognitive processing rates among disabled and normal reading young adults: A nine year follow-up study. Reading and Writing, 1. 2. sz. 123-134.

DeDe, G., Caplan, D., Kemtes, K. és Waters, G. (2004): The Relationship Between Age, Verbal Working Memory, and Language Comprehension. Psychology and Aging, 19. 4. sz. 601-616.

Delis, D., Kaplan, E. és Kramer, J. (2001). Delis-Kaplan Executive Function System. The Psychological Corporation, Harcourt Brace and Company, San Antonio, TX.

Della Sala, S., Gray, C., Baddeley, A. D. és Wilson, L. (1997): The Visual Patterns Test: A New Test of Short Term Visual Recall. Thames Valley Test Company, Feltham.

Demeter, Gy., Csigó, K., Németh, A. és Racsmány, M. (2008): Impaired executive functions in obsessive compulsive (OCD). Review. Psychiatria Hungarica, 23. 2. sz. 85-93.

Dempster F. N. és Corkill, A. J. (1999): Individual differences in susceptibility to interference and general cognitive ability. Acta Psychologica, 101. 2-3. sz. 395-416.

Dempster, F. N. és Cooney, J. B. (1982): Individual differences in digit span, susceptibility to proactive interference, and aptitude/achievement test scores. Intelligence, 6. 4. sz. 399-416.

Denckla. M. B. (1996a): A theory and model of executive function: A neuropsychological perspective. In: Lyon, G. R. és Krasnegor, N. A. (szerk.): Attention, memory, and executive function. Brookes, Baltimore.

Denckla. M. B. (1996b): Research on executive function in a neurodevelopmental context: Application of clinical measures. Developmental Neuropsychology, 12. 5-15. 
DeRenzi, E. és Nichelli, P. (1975): Verbal and nonverbal short-term memory impairment following hemispheric damage. Cortex, 11. 4. sz. 341-354.

Desman, C., Petermann, F. és Hampel, P. (2008): Deficit in Response Inhibition in Children with Attention Deficit/Hyperactivity Disorder (ADHD): Impact of Motivation? Child Neuropsychology: A Journal on Normal and Abnormal Development in Childhood and Adolescence, 14. 6. sz. 483-503.

De Stefano, D. és Le Favre, J. A. (2004): The role of working memory in mental arithmetic. European Journal of Cognitive Psychology, 16. 3. sz. 353-386.

Diamond, A. és Goldman-Rakic, P. S. (1989): Comparison of human infants and rhesus monkeys on Piaget's AB task: evidence for dependence on dorsolateral prefrontal cortex. Experimental Brain Research, 74. 1. sz. 24-40.

Diamond, A., Carlson, S. M. és Beck, D. M. (2005): Preschool Children's Performance in Task Switching on the Dimensional Change Card Sort Task: Separating the Dimensions Aids the Ability to Switch. Developmental Neuropsychology, 28. 2. sz. 689-729.

Diamond, A., Kirkham, N. és Amso, D. (2002): Conditions under which young children can hold two rules in mind and inhibit a prepotent response. Developmental Psychology, 38. 3. sz. 352-362.

Diaz, M., Sailor, K., Cheunk, D. és Kuslansky, G. (2004): Category size effects in semantic and letter fluency in Alzheimer's patients. Brain and Language, 89. 1. sz. 108-114.

Dickstein, S. G., Bannon, K., Castellanos, F. X. és Milham, M. P. (2006): The neural correlates of attention deficit hyperactivity disorder: an ALE meta-analysis. Journal of Child Psychology and Psychiatry, 47. 10. sz. 1051-1062.

Diesfeldt, H. F. (1985): Verbal fluency in senile dementia: An analysis of search and knowledge. Archives of Gerontology and Geriatrics, 4. 3. sz. 231-239.

Dowson, J. H., McLean, A., Bazanis, E., Toone, B., Young, S., Robbins, T. W. és Sahakian, B. J. (2004): Impaired spatial working memory in adults with attention-deficit/hyperactivity disorder: Comparisons with performance in adults with borderline personality disorder and in control subjects. Acta Psychiatrica Scandinavia, 110. 1. sz. 45-54.

Doyle, A. E. (2005): Executive functions in attention-deficit/hyperactivity disorder. The Journal of Clinical Psychiatry, 67. 8. sz. 21-26.

Du Boisgueheneuc, F., Levy, R., Volle, E., Seassau, M., Duffau, H., Kinkingneheun, S., Samson, Y., Zhang, S. és Dubois, B. (2006): Functions of the left superior frontal gyrus in humans: A lesion study. Brain, 129. 12. sz. 3315-3328.

Dufva, M., Niemi, P. és Voeten, M. J. M. (2001): The role of phonological memory, word recognition, and comprehension skills in reading development: from preschool to grade 2. Reading and Writing, 14. 1-2. 91-117.

Duncan, G. J., Dowsett, C. J., Claessens, A., Magnuson, K., Huston, A. C., Klebanov, P., Pagani, L. S., Feinstein, L, Engel, M., Brooks-Gunn, J., Sexton, H., Duckworth, K. és Japel, C. (2007): School readiness and later achievement. Developmental Psychology, 43. 6. sz. 1428-1446.

Duncan, J. (1986): Disorganisation of behaviour after frontal lobe damage. Cognitive Neuropsychology, 3. 3. sz. 271-290.

Dunning, D. L., Holmes, J. és Gathercole, S. E. (2013): Does working memory training lead to generalized improvements in children with low working memory? A randomized controlled trial. Developmental Science, 16. 6. sz. 915-925.

Durand, M., Hulme, C., Larkin, R. és Snowling, M. (2005): The cognitive foundations of reading and arithmetic skills in 7-to 10-year-olds. Journal of Experimental Child Psychology, 91. 2. sz. 113-136.

Edin, F., Klinberg, T., Johansson, P., McNab, F., Tegnér, J. és Compte, A. (2009): Mechanism for top-down control of working memory capacity, Proceedings of the National Academy of Sciences of the United States of America, 106. 16. sz. 6802-6807.

Ehlis, A. C., Bähne, C. G., Jacob, C. P., Herrmann, M. J. és Fallgatter, A. J. (2008): Reduced lateral prefrontal activation in adult patients with attention-deficit/hyperactivity disorder (ADHD) during a working memory task: A functional near-infrared spectroscopy (fNIRS) study. Journal of Psychiatric Research, 42. 13. sz. 1060-1067.

Elliot, R. (2003): Executive functions and their disorders. British Medical Bulletin, 65. 1. sz. 49-59.

Ellis, N. C. és Hennelly, R. A. (1980): A bilingual word-lenght effect: Implications for intelligence testing and the relative ease of mental calculation in Welsh and English. British Journal of Psychology, 71. 2. sz. 43-52.

Engle, R. W. és Kane, M. J. (2004): Executive attention, working memory capacity, and a two-factor theory of cognitive control. In Ross, B. (szerk.): The psychology of learning and motivation. Academic Press, New York. 145-199.

Engle, R. W., Carullo, J. J. és Collins, K. W. (1991): Individual Differences in Working Memory for Comprehension and Following Directions. The Journal of Educational Research, 84. 5. sz. 253-262. 
Engle, R. W., Kane, M. J. és Tuholski, S. W. (1999): Individual differences in working memory capacity and what they tell us about controlled attention, general fluid intelligence and functions of the prefrontal cortex. Models of Working Memory: Mechanisms of Active Maintenance and Executive Control. Cambridge University Press, New York. 102-134.

Engle, R. W. és Kane, M. J. (2003): Executive Attention, Working Memory Capacity, and a Two-Factor Theory of Cognitive Control. Psychology of Learning and Motivation, 44. 145-199.

Engle, R. W., Kane, M. J., Laughlin, J. E. és Conway, A. R. (1999): Working memory, short-term memory, and general fluid intelligence: A latent-variable approach. Journal of Experimental Psychology, 128. 3. sz. 309-331.

Epker, M. O., Lacritz, L. H. és Cullum, C. M. (1999): Comparative analysis of qualitative verbal fluency performance in normal elderly and demented populations. Journal of Clinical and Experimental Neuropsychology, 21. 4. sz. 425-434.

Espy, K. A. (1997): The shape school: Assessing executive function in preschool children Developmental Neuropsychology, 13. 4. sz. 495-499.

Espy, K. A., McDiarmid, M. M., Cwik, M. F., Stalets, M. M., Hamby, A. és Senn, T. E. (2004): The Contribution of Executive Functions to Emergent Mathematic Skills in Preschool Children. Developmental Neuropsychology, 26. 1. sz. 465-486.

Fasotti, L., Kovacs, F., Eling, P. A. T. M. és Brouwer, W. H. (2000): Time Pressure Management as a Compensatory Strategy Training after Closed Head Injury. Neuropsychological Rehabilitation, 10. 1. sz. 47-65.

Fastenau, P. S., Denburg, N. L. és Abeles, N. (1996): Age differences in retrieval: Further support for the resource-reduction hypothesis. Psychology and Aging, 11. 1. sz. 140-146.

Faw, B. (2003): Pre-frontal executive committee for perception, working memory, attention, long-term memory, motor control, and thinking: A tutorial review. Consciousness and Cognition, 12. 1. sz. 83-139.

Feinstein, A., Goldberg, T. E., Nowlin, B. és Weinberger, D. R. (1998): Types and characteristics of remote memory impairment in schizophrenia. Schizophrenia Research, 30. 2. sz. 155-163.

Fischer, M., Barkley, R. A., Edelbrock, C. S. és Smallish, L. (1990): The adolescent outcome of hyperactive children diagnosed by research criteria: II. Academic, attentional, and neuropsychological status. Journal of Consulting and Clinical Psychology, 58. 5. sz. 580-588.

Fisk, J. E. és Sharp, C. A. (2004): Age-Related Impairment in Executive Functioning: Updating, Inhibition, Shifting, and Access. Journal of Clinical and Experimental Neuropsychology, 26. 7. sz. 874-890.

Fossati, P., Amar, G., Raoux, N., Ergis, A. M. és Allilaire, J. F. (1999): Executive functioning and verbal memory in young patients with unipolar depression and schizophrenia. Psychiatry Research, 89. 3. sz. 171-187.

Fossati, P., Le Bastard, P., Ergis, A. M. és Allilaire, G. F. (2003): Qualitative analysis of verbal fluency in depression. Psychiatry Research, 117. 1. sz. 17-24.

Fry, A. F. és Hale, S. (2000): Relationships among processing speed, working memory, and fluid intelligence in children. Biological Psychology, 54. 1-3. sz. 1-34.

Fu, C. H., Morgan, K., Suckling, J., Williams, S. C., Andrew, C., Vythelingum, G. N. és Mcguire, P. K. (2002): Afunctional magnetic resonance imaging study of overt letter verbal fluency using a clustered acquisition sequence: Greater anterior cingulate activation with increased task demand. Neuroimage, 17. 2. sz. 871-879.

Fürst, A. J. és Hitch, G. J. (2000): Separate roles for executive and phonological components of working memory in mental arithmetic. Memory and Cognition, 28. 5. sz. 774-782.

Gaddes, W. H. és Crockett, D. J. (1975): The Spreen-Benton aphasiatests, normative dat aas a measure of normal language development. Brain and Language, 2. 257-280.

Gaillard, W. D., Balsamo, L., Ibrahim, Z. és Xu, B. (2003): fMRI identifies regional specialization of neural networks for reading in young children. Neurology, 60. 1. sz. 94 -99.

Gaillard, W. D., Hertz-Pannier, L., Mott, S. H., Barnett, A. S, Le Bihan, D. és Theodore, W. H. (2000): Functional anatomy of cognitive development: fMRI of verbal fluency in children and adults. Neurology, 54. 1. sz. 180-185.

Gathercole, S. E. és Baddeley, A. D. (1989): Evaluation of the role of phonological STM in the development of vocabulary in children: a longitudinal study. Journal of Memory and Language, 28. 2. sz. 200-213.

Gathercole, S. E. és Baddeley, A. D. (1993): Working memory and language. Erlbaum, Hillsdale, NJ.

Gathercole, S. E. (1999): Cognitive approaches to the development of short-term memory, Trends in cognitive sciences, 3. 11. sz. 410-419.

Gathercole, S. E. (2008): Working memory in the classroom. The Psychologist, 21. 5. sz. 382-385.

Gathercole, S. E. és Adams, A. (1993): Phonological working memory in very young children. Developmental Psychology, 29. 4. sz. 770-778. 
Gathercole, S. E. és Adams, A. (1994): Children's phonological working memory: Contributions of long-term knowledge and rehearsal. Journal of Memory and Language, 33. 5. sz. 672-688.

Gathercole, S. E. és Pickering, S. J. (2000a): Assessment of working memory in six and seven-year old children. Journal of Educational Psychology, 92. 2. sz. 377-390.

Gathercole, S. E. és Pickering, S. J. (2000b): Working memory deficits in children with low achievement in national curriculum at 7 years of age. British Journal of Educational Psychology, 70. 2. sz. 177-194.

Gathercole, S. E., Alloway, T. P., Kirkwood, H. J., Elliott, J. G., Holmes, J. és Hilton, K. A. (2008): Attentional and executive function behaviours in children with poor working memory. Learning and Individual Differences, 18. 2. sz. 214-223.

Gathercole, S. E., Alloway, T. P., Willis, C. S. és Adams, A. M. (2006): Working memory in children with reading disabilities. Journal of Experimental Child Psychology, 93. 3. sz. 265-281.

Gathercole, S. E., Brown, L. és Pickering, S. J. (2003): Working memory assessments at school entry as longitudinal predictors of National Curriculum attainment levels. Educational and Child Psychology, 20. 3. sz. 109-122.

Gathercole, S. E., Dunning, D. L. és Holmes, J. (2010): Cogmed training: Let's be realistic about intervention research. Journal of Applied Research in Memory and Cognition, 1. 3. sz. 201-203.

Gathercole, S. E., Lamont, E. és Alloway, T. P. (2006): Working memory in the classroom. In Pickering, S. (szerk.): Working Memory and Education. Elsevier Press, London. 219-240.

Gathercole, S. E., Pickering, S. J., Ambridge, B. és Wearing, H. (2004): The structure of working memory from 4 to 15 years of age. Developmental Psychology, 40. 2. sz. 177-190.

Gathercole, S. E., Pickering, S. J., Knight, C. és Stegmann, Z. (2004): Working memory skills and educational attainment: evidence from national curriculum assessments at 7 and 14 years of age. Applied Cognitive Psychology, 18. 1. sz. 1-16.

Gathercole, S. E., Willis, C., Emslie, H. és Baddeley, A. D. (1991): The influences of number of syllables and wordlikeness on children's repetition of nonwords. Applied Psycholinguistics, 12. 3. sz. 349-367.

Gathercole, S. E., Willis, C. S., Emslie, H. és Baddeley, A. D. (1992): Phonological memory and vocabulary development during the early school years: A longitudinal study. Developmental Psychology, 28. 5. sz. 887-898.

Geary, D. C. (1993): Mathematical disabilities: Cognitive, neuropsychological, and genetic components. Psychological Bulletin, 114. 2. sz. 345-362.

Geary, D. C., Hoard, M. K. és Hamson, C. O. (1999): Numerical and arithmetical cognition: Patterns of functions and deficits in children at risk for a mathematical disability. Journal of Experimental Child Psychology, 74. 3. sz. 213-239.

Geffen, G., Bate, A., Wright, M., Rozenbilds, U. és Geffen, L. (1993). Comparison of cognitive impairments in dementia of the Alzheimer type and depression in the elderly. Dementia and Geriatric Cognitive Disorders, 4. 5. sz. 294-300.

Gernsbacher, M. A. (1993): Less Skilled Readers Have Less Efficient Suppression Mechanisms. Psychological Science, 4. 5. sz. 294-298.

Gersten, R., Jordan, N. C. és Flojo, J. R. (2005) : Early Identification and Interventions for Students With Mathematics Difficulties. Journal of Learning Disabilities, 38. 4. sz. 293-304.

Giedd, J. N., Blumenthal, J., Jeffries, N. O., Castellanos, F. X., Liu, H., Zijdenbos, A., Paus, T., Evans, A. C. és Rapoport, J. L. (1999): Brain development during childhood and adolescence: a longitudinal MRI study. Nature Neuroscience, 2. 861-863.

Gioia, G. A., Isquith, P. K., Guy, S. C. és Kenworthy, L. (1996): Behavior Rating Inventory of Executive Function. Psychological Assessment Resources, Lutz, FL.

Gioia, G. A., Isquith, P. K., Guy, S. C. és Kenworthy, L. (2000). Test review Behavior Rating Inventory of Executive Function. Child Neuropsychology, 6. 3. sz. 235-238.

Gladsjo, J. A., Schuman, C. C., Evans, J. D., Peavy, G. M., Miller, S. W. és Heaton, R. K. (1999): Norms for letter and category fluency: Demographic corrections for age, education, and ethnicity. Assessment, 6. 2. sz. 147-178.

Glanzer, M., Dorfman, D. és Kaplan, B. (1981): Short-term storage in processing of text. Journal of Verbal Learning and Verbal Behavior, 20. 6. sz. 656-670.

Goldberg, E. (2001): The executive brain: Frontal lobes and the civilized mind. Oxford University Press, New York.

Goldstein, F. C., Levin, H. S., Roberts, V. J., Goldman, W. P., Kalechstein, A. S., Winslo, W. M. és Goldstein, S. J. (1996): Neuropsychological effects of closed head injury in older adults: A comparison with Alzheimer's disease. Neuropsychology, 10. 2. sz. 147-154.

Gomez, R. G. és White, D. A. (2006): Using verbal fluency to detect very mild dementia of the Alzheimer type. Archives of Clinical Neuropsychology, 21. 8. sz. 771-775. 
Goulandrisa, N. K. és Snowlinga, M. (1991): Visual Memory Deficits: A Plausible Cause of Developmental Dyslexia? Evidence from a Single Case Study. Cognitive Neuropsychology, 8. 2. sz. 127-154.

Grace, J. és Malloy, P. (2002): Frontal Systems Behavior Scale (FrSBe): Professional Manual. Psychological Assessment Resources, Lutz, FL.

Graceffa, A. M. S., Carlesimo, G. A., Peppe, A. és Caltagirone, C. (1999): Verbal Working Memory Deficit in Parkinson's Disease Subjects. European Neurology, 42. 90-94.

Greenberg, D. L., Keane, M. M., Ryan, L. és Verfaellie, M. (2009): Impaired Category Fluency in Medial Temporal Lobe Amnesia: The Role of Episodic Memory. The Journal of Neuroscience, 29. 35. sz. 10900-10908.

Grisby, J., Kaye, K., Baxter, J., Shetterly, S. M. és Hamman, R. F. (1998): Executive cognitive abilities and functional status among community-dwelling older persons in the San Luis Valley Health and Aging Study. Journal of the American Geriatrics Society, 46. 5. sz. 590-596.

Grisby, J., Kaye, K., Shetterly, S. M., Baxter, J., Morgenstern, N. E. és Hamman, R. F. (2002): Prevalence of Disorders of Executive Cognitive Functioning among the Elderly: Findings from the San Luis Valley Health and Aging Study, Neuroepidemiology, 21. 213-220.

Grodzinsky, G. és Diamond, R. (1992): Frontal lobe functioning in boys with attention deficit hyperactivity disorder. Developmental Neuropsychology, 8. 4. sz. 427-445.

Gruber, O. és Cramon, D. Y. (2003): The functional neuroanatomy of human working memory revisited Evidence from 3-T fMRI studies using classical domain-specific interference tasks. Neurolmage, 19. 3. sz. 797-809.

Grunewald, P. J. és Lockhead, G. R. (1980): The free recall of category examples. Journal of Experimental Psychology: Human Learning and Memory, 6. 3. sz. 225-240.

Gurd, J. és Ward, C. D. (1989): Retrieval from semantic and letter-initial categories in patients with Parkinson's disease. Neuropsychologia, 27. 5. sz. 743-746.

Haaland, K. Y., Vranes, L. F., Goodwin, J. S. és Garry, P. J. (1987): Wisconsin Card Sort Test Performance in a Healthy Elderly Population. Journal of Gerontology, 42. 3. sz. 345-346.

Hale, S., Myerson, J., Rhee, S. H., Weiss, C. S. és Abrams, R. A. (1996): Selective interference with the maintenance of location information in working memory. Neuropsychology, 10. 2. sz. 228-240.

Halperlin, J. M., Healey, J. M., Zeitchik, E., Ludman, W. L. és Weisten, L. (1989): Developmental aspects of linguistic and mnestic abilities in normal children. Journal of Clinical and Experimental Neuropsychology, 11. 4. sz. 518-528.

Handley, S. J., Capon, A., Beveridge, I., Dennis, I. és Evans, B. T. (2004): Working memory, inhibitory control and the development of children's reasoning. Thinking and Reasoning, 10. 2. sz. 175-195.

Hanley, J. R., Dewick, H. C., Davies, A. D. M., Playfer, J. és Turnbull, C. (1990): Verbal fluency in Parkinson's disease. Neuropsychologia, 28. 7. sz. 737-741.

Hart, S., Smith, C. M. és Swash, M. (1986): Word fluency in patients with early dementia of the Alzheimer's type. British Journal of Clinical Psychology, 27. 2. sz. 115-124.

Hasher, L. és Zacks, R. T. (1988): Working memory, comprehension, and aging: a review and a new view. In: Bower, G. H. (szerk.): The Psychology of Learning and Motivation. Academic Press, San Diego, CA. 193-225.

Hasher, L., Lustig, C. és Zacks, R. T. (2007): Inhibitory mechanisms and the control of attention. In: Conway, A., Jarrold, C., Kane, M., Miyake, A., és Towse, J. (szerk.): Variation in Working Memory. Oxford University Press, New York.

Hasherm L., Stolzfus, E. R., Zacks, R. T. és Rypma, B. (1991): Age and inhibition. Journal of Experimental Psychology: Learning, Memory, and Cognition, 17. 1. sz. 163-169.

Hashimoto, R., Meguro, K., Lee, E., Kasai, M., Ishii, H. és Yamaguchi, S. (2006): Effect of age and education on the Trail Making Test and determination of normative data for Japanese elderly people: The Tajiri Project. Psychiatry and Clinical Neurosciences, 60. 4. sz. 422-428.

Haug, H. és Eggers, R. (1991): Morphometry of the human cortex cerebri and corpus striatum during aging. Neurobiology of Aging, 12. 4. sz. 336-338.

Head, D., Buckner, R. L., Shimony, J. S., Williams, L. E., Akbudak, E., Conturo, T. E, Mcavoy, M., Morris, J. C. és Snyder, A. Z. (2004): Differential Vulnerability of Anterior White Matter in Nondemented Aging with Minimal Acceleration in Dementia of the Alzheimer Type: Evidence from Diffusion Tensor Imaging. Cerebral Cortex, 14. 4. sz. 410-423.

Henry, J. D. és Crawford, J. R. (2004a): A meta-analytic review of verbal fluency performance following focal cortical lesions. Neuropsychology, 18. 2. sz. 284-295.

Henry, J. D. és Crawford, J. R. (2004b): A meta-analytic review of verbal fluency performance in traumatic brain injured patients. Neuropsychology, 18. 4. sz. 621-628.

Henry, J. D. és Crawford, J. R. (2004c): Verbal fluency deficits in Parkinson's disease: A meta-analysis. Journal of the International Neuropsychological Society, 10. 4. sz. 608-623. 
Henry, J. D. és Crawford, J. R. (2004d): A meta-analytic review of verbal fluency deficits in depression. Journal of Clinical and Experimental Neuropsychology, 27. 1. sz. 78-101.

Henry, J. D., Crawford, J. R. és Phillips, L. H. (2005): A Meta-Analytic Review of Verbal Fluency Deficits in Huntington's Disease. Neuropsychology, 19. 2. sz. 243-252.

Henson, R. (2001) Neural working memory. In: Andrade, J. (szerk.): Working memory in perspective. Psychology Press, Hove, East Sussex, England. 151-173.

Hersh, N. és Treadgold, L. (1994): NeuroPage: the rehabilitation of memory dysfunction by prosthetic memory aid cueing. Neurorehabilitation, 4. 187-197.

Hewitt, J., Evans, J. J. és Dritschel, B. (2006): Theory driven rehabilitation of executive functioning: Improving planning skills in people with traumatic brain injury through the use of an autobiographical episodic memory cueing procedure. Neuropsychologia, 44. 8. sz. 1468-1474.

Hill, E. L. (2004): Executive dysfunction in autism. Trends in Cognitive Sciences, 8. 1. sz. 26-32.

Ho, A. K., Sahakian, B. J., Robbins, T. W., Barker, R. A., Rosser, A. E. és Hodges, J. R. (2002): Verbal fluency in Huntington's disease: a longitudinal analysis of phonemic and semantic clustering and switching. Neuropsychologia, 40. 8. sz. 1277-1284.

Hobson, P. és Leeds, L. (2001): Executive functioning in older people. Reviews in Clinical Gerontology, 11. 4. sz. 361-372.

Hokkanen, L., Poutiainen, E., Valanne, L., Salonen, O., Iivanainen, M. és Launes, J. (1996): Cognitive impairment after acute encephalitis: comparison of herpes simplex and other aetiologies. Journal of Neurology, Neurosurgery, and Psychiatry, 61. 5. sz. 478-484.

Holler, K. A., Fennell, E. B., Crosson, B., Boggs, S. R. és Mickle, J. P. (1995). Neuropsychological and adaptive functioning in younger versus older children shunted for early hydrocephalus. Child Neuropsychology, 1. 1. sz. $63-73$.

Holmes, J. és Adams, J. W. (2006): Working Memory and Children's Mathematical Skills: Implications for mathematical development and mathematics curricula. Educational Psychology: An International Journal of Experimental Educational Psychology, 26. 3. sz. 339-366.

Holmes, J., Gathercole, S. E. és Dunning, D. L. (2009): Adaptive training leads to sustained enhancement of poor working memory in children. Developmental Science, 12. 4. sz. 9-15.

Holmes, J., Gathercole, S. E., Place, M., Dunning, D. L., Hilton, K. és Elliot, J. G. (2010): Working memory deficits can be overcome: Impacts of training and medication on working memory in children with ADHD. Applied Cognitive Psychology, 24. 6. sz. 827-836.

Hooper, S. H., Swartz, C. W., Wakely, M. B., De Kruif, R. E. L. és Montgomery, J. W. (2002): Executive functions in elementary school children with and without problems in written expression. Journal of Learning Disabilities, 35. 1. sz. 57-68.

Hoosain R. és Salili F. (1988): Language differences, working memory, and mathematical ability. In Gruneberg, M. M., Morris, P. E., Sykes, R. N. (szerk.): Practical aspect of memory: Current research and issues. Clinical and educational implications. Wiley, Chichester. 512-571.

Hughes, C. és Graham, A. (2002): Measuring Executive Functions in Childhood: Problems and Solutions? Child and Adolescent Mental Health, 7. 3. sz. 131-142.

Hughes, C., Russell, J. és Robbins, T. W. (1994): Evidence for central EF 1019 deficits in autism. Neuropsychologia, 32. 477-492.

Hughes, D. L. és Bryan, J. (2002): Adult Age Differences in Strategy Use During Verbal Fluency Performance. Journal of Clinical and Experimental Neuropsychology, 24. 5. sz. 642-654.

Huizinga, M., Dolan, C. V. és Van der Molen, M. W. (2006): Age-related change in executive function: Developmental trends and a latent variable analysis. Neuropsychologia, 44. 11. sz. 2017-2036.

Hummel, K. M. (2002): Second Language Acquisition and Workin Memory. Advances in the Neurolinguistics of Bilingualism. Psychological Review, 84. 1-66.

Huppert, F. A., Brayne, C., Gill, C., Paykel, E. S. és Beardsall, L. (1995): CAMCOG - a concise neuropsychological test to assist dementia diagnosis: socio-demographic determinants in an elderly population sample. British Journal of Clinical Psychology, 34. 529-541.

Hurks, P. P. M. (2012): Does Instruction in Semantic Clustering and Switching Enhance Verbal Fluency in Children? The Clinical Neuropsychologist, 26. 6. sz. 1019-1037.

Hurks, P. P. M., Hendriksen, J. G. M., Vles, J. S. H., Kalff, A. C., Feron, F. J. M., Kroes, M., Van Zeben, T. M. C. B., Steyaert, J. és Jolles, J. (2004): Verbal fluency over time as a measure of automatic and controlled processing in children with ADHD. Brain and Cognition, 55. 3. sz. 535-544.

Hurks, P. P. M., Schrans, D., Meijs, C., Wassenberg, R., Feron, F. J. M. és Jolles, J. (2010): Developmental changes in semantic verbal fluency: analyses of word productivity as a function of time, clustering, and switching. Child Neuropsychology, 16. 4. sz. 366-387.

Hurks, P. P. M., Vles, J. S. H., Hendriksen, J. G. M., Kalff, A. C., Feron, F. J. M., Kroes, M., Van Zeben, T. M. C. B. és Jolles, J. (2006): Semantic category fluency versus initial letter fluency over 60 seconds as a 
measure of automatic and controlled processing in healthy school-aged children. Journal of Clinical and Experimental Neuropsychology, 28. 5. sz. 684-695.

Hutton, U. M. Z. és Towse, J. N. (2001): Short-term memory and working memory as indices of children's cognitive skills. Memory, 9. 4-6. sz. 383-394.

Im-Bolter, N., Johnson, J. és Pascual-Leone, J. (2006): Processing Limitations in Children With Specific Language Impairment: The Role of Executive Function. Child Development, 77. 6. sz. 1822-1841.

Ivnik, R. J., Malec, J. F., Smith, G. E., Tangalos, E. G. és Petersen, R. C. (1996): Neuropsychological tests' norms above age 55: COWAT, BNT, MAE Token, WRAT-R Reading, AMNART, Stroop, TMT, and JLO. Clinical Neuropsychologist, 10. 3. sz. 262-278.

Jacobs, J. (1887): Experiments on “prehension”. Mind, 12. 45. sz. 75-79.

Jaeggi, S. M., Buschkuehl, M., Jonides, J. és Perrig, W. J. (2008): Improving fluid intelligence with training on working memory. Proceedings of the National Academy of Sciences of the United States of America, 105. 19. sz. 6829-6833.

Janacsek, K., Tánczos, T., Mészáros, T. és Németh, D. (2009): A munkamemória új magyar nyelvü neuropszichológiai mérőeljárása: a Hallási Mondatterjedelem Teszt (HMT), Magyar Pszichológiai Szemle, 64. 2. sz. 385-406.

Janowsky, J. S., Shimamura, A. P., Kritchevsky, M. és Squire, I. R. (1989): Cognitive impairment following frontal lobe damage and its relevance to human amnesia. Behavioral Neuroscience, 103. 3. sz. 548-560.

Jarrold, C., Baddeley, A. és Hewes, A. (1999): Genetically dissociated components of working memory: evidence from Down and Williams syndrome. Neuropsychologia, 37. 6. sz. 637-651.

Jarrold, C., Thorn, A. S. és Stephens, E. (2009): The relationships among verbal short-term memory, phonological awareness, and new word learning: Evidence from typical development and Down syndrome. Journal of Experimental Child Psychology, 102. 2. sz. 196-218.

Jarvis, H. L. és Gathercole, S. E. (2003): Verbal and nonverbal working memory and achievements on national curriculum tests at 11 and 14 years of age. Educational and Child Psychology, 20. 3. sz. 123-140.

Jason, L. A., Williams, J. M., McDonald, R. és Francis, D. J. (2007): Phonological processing and emergent literacy in younger and older preschool children. Annals of Dyslexia, 57. 2. sz. 113-137.

Johnson, O. és Crockett, D. (1982): Changes in perceptual asymmetries with clinical improvement of depression and schizophrenia. Journal of Abnormal Psychology, 91. 1. sz. 45-54.

Jones-Gotman, M. (1991): Localization of lesions by neuropsychological testing. Epilepsia, 32. 5. sz. 41-52.

Jonides, J. és Smith, E. E. (1997): The architecture of working memory. In Rugg, M. D. (szerk.): Cognitive neuroscience. MIT Press, Cambridge, MA. 243-276.

Joyce, E. M., Collinson, S. L. és Crichton, P. (1996): Verbal fluency in schizophrenia: relationship with executive function, semantic memory and clinical alogia. Psychological Medicine, 26. 1. sz. 39-49.

Jurado, M. B. és Rosselli, M. (2007): The Elusive Nature of Executive Functions: A Review of our Current Understanding. Neuropsychology Review, 17. 3. sz. 213-233.

Just, M. A. és Carpenter, P. A. (1992): A capacity theory of comrehension: Individual differences in working memory. Psychological Review, 99. 1. sz. 122-149.

Kane, M. J. és Engle, R. W. (2002): The role of prefrontal cortex in working-memory capacity, executive attention, and general fluid intelligence: An individual-differences perspective. Psychonomic Bulletin and Review, 9. 4. sz. 637-671.

Kane, M. J., Conway, A. R. A.; Miura, T. K. és Colflesh, G. J. H. (2007): Working memory, attention control, and the n-back task: A question of construct validity. Journal of Experimental Psychology: Learning, Memory, and Cognition, 33. 3. sz. 615-622.

Kane, M. J., Hambrick, D. Z. és Conway, A. R. A. (2005): Working Memory Capacity and Fluid Intelligence Are Strongly Related Constructs: Comment on Ackerman, Beier, and Boyle. Psychological Bulletin, 131. 1. sz. 66-71.

Kane, M. J., Hambrick, D. Z., Tuholski, S. W., Wilhelm, O., Payne, T. W. és Engle, R. W. (2004): The generality of working-memory capacity: A latent-variable approach to verbal and visuo-spatial memory span and reasoning. Journal of Experimental Psychology General, 133. 2. sz. 189-217.

Kassubek, J., Juengling, F. D., Ecker, D. és Landwehrmeyer, G. B. (2005): Thalamic Atrophy in Huntington's Disease Co-varies with Cognitive Performance: A Morphometric MRI Analysis. Cerebral Cortex, 15. 6. sz. 846-853.

Kavé, G., Kigel, S. és Kochva, R. (2008): Switching and clustering in verbal fluency tasks throughout childhood. Journal of Clinical and Experimental Neuropsychology, 30. 3. sz. 349-359.

Kavé, G. (2006): The development of naming and word fluency: Evidence from Hebrew-speaking children between ages 8 and 17. Developmental Neuropsychology, 29. 3. sz. 493-508.

Kállai, J., Bende, I., Karádi, K. és Racsmány, M. (2008): Bevezetés a neuropszichológiába. Medicina Kiadó, Budapest. 
Keilp, J. G., Gorlyn, M., Alexander, G. E., Stern, Y. és Prohovnik, I. (1999): Cerebral blood flow patterns underlying the differential impairment in category vs. letter fluency in Alzheimer's disease. Neuropsychologia, 37. 11. sz. 1251-1261.

Kemps, E. és Newson, R. (2006): Comparison of Adult Age Differences in Verbal and Visuo-Spatial Memory: The Importance of 'Pure', Parallel and Validated Measures Journal of Clinical and Experimental Neuropsychology, 28. 3. sz. 341-356.

Kéri, Sz. és Gulyás, B. (2003): Elektrofiziológiai módszerek a kognitív idegtudományban. In: Pléh, Cs., Kovács, Gy. és Gulyás, B. (szerk.): Kognitív idegtudomány. Osiris Kiadó, Budapest. 81-98.

Kertesz, A., Davidson, W., Mccabe, P., Takagi, K. és Munoz, D. (2003): Primary progressive aphasia: Diagnosis, varieties, evolution. Journal of the International Neuropsychological Society, 9. 5. sz. 710719.

Keys, B. A. és White, D. A. (2000): Exploring the relationship between age, executive abilities, and psychomotor speed. Journal of the International Neuropsychological Society, 6. 1. sz. 76-82.

Kim, C., Johnson, N. F., Cilles, S. A. és Gold, B. T. (2011): Common and Distinct Mechanisms of Cognitive Flexibility in Prefrontal Cortex. The Journal of Neuroscience, 31. 13. sz. 4771-4779.

Kim, E. S., Bayles, K. A. és Beeson, P. M. (2008): Instruction processing in young and older adults: constributions of memory span. Aphasiology, 22. 7-8. sz. 753-762.

Klaassen, E. B., Evers, E. A. T., Groot, R. H. M., Backers, W. H., Veltman, D. J. és Jolles, J. (2014): Working memory in middle-aged males: Age-related brain activation changes and cognitive fatigue effects. Biological Psychology, 96. 134-143.

Klenberg, L., Korkman, M. és Lahti-Nuuttila, P. (2001): Differential development of attention and executive functions in 3- to 12-year-old Finnish children. Developmental Neuropsychology, 20. 1. sz. 407-428.

Klinberg, T. (2010): Training and plasticity of working memory. Trends in Cognitive Sciences, 14. 7. sz. $317-$ 324.

Klinberg, T., Forssberg, H. és Westerberg, H. (2002): Training of working memory in children with ADHD. Journal of Clinical and Experimental Neuropsychology, 24. 6. sz. 781-791.

Klinberg, T., Kawashima, R. és Roland, P. E. (1996): Activation of Multi-modal Cortical Areas Underlies Shortterm Memory. European Journal of Neuroscience, 8. 9. sz. 1965-1971.

Klingberg, T. K., Fernell, E., Olesen, P. J., Johnson, M., Gustafsson, P., Dahlström, K., Gillberg, C. G., Forssberg, H. és Westerberg, H. (2005): Computerized Training of Working Memory in Children With ADHD-A Randomized, Controlled Trial. Journal of the American Academy of Child and Adolescent Psychiatry, 44. 2. sz. 177-186.

Klivényi, P., Németh, D., Sefcsik, T., Janacsek, K., Hoffmann, I, Haden, G. P., Londe, Zs. és Vécsei. L. (2012): Cognitive Functions in Ataxia with Oculomotor Apraxia Type 2. Frontiers in Neurology, 3. 125. sz. 119.

Kolb, B. és Wishaw, I. Q. (1983): Performance of schizophrenic patients on tests sensitive to left or right frontal, temporal or parietal function in neurological patients. Journal of Nervous and Mental Disease, 171. 7. sz. 435-443.

Kolb, B. és Whishaw, I. Q. (1985): Fundamentals of human neuropsychology (2. szerk.): Freeman, New York.

Konen, C. S. és Kastner, S. (2008). Two hierarchically organized neural systems for object information in human visual cortex. Neuroscience and Biobehavioral Reviews, 32. 8. sz. 1373-1395.

Koren, R., Kofman, O. és Berger, A. (2005): Analysis of word clustering in verbal fluency of school-aged children. Archives of Clinical Neuropsychology, 20. 8. sz. 1087-1104.

Koziol, L. F. és Stout, C. E. (1992): Use of a verbal fluency measure in understanding and evaluatingADHDas an executive function disorder. Perceptual and Motor Skills, 75. 3. sz. 1187-1192.

Kozora, E. és Cullum, C. (1995): Generative naming in normal aging: Total output and qualitative changes using phonemic and semantic constraints. Clinical Neuropsychologist, 9. 4. sz. 313-320.

Krajewski, K. és Schneider, W. (2009): Exploring the impact of phonological awareness, visual-spatial working memory, and preschool quantity-number competencies on mathematics achievement in elementary school: Findings from a 3-year longitudinal study. Journal of Experimental Child Psychology, 103. 4. sz. 516-531.

Kremen, W. S., Seidman, L. J., Faraone, S. V. és Tsuang, M. T. (2001): Intelligence quotient and neuropsychological profiles in patients with schizophrenia and normal volunteers. Biological Psychiatry, 50. 6. sz. 453-462.

Kuzis, G., Sabe, L., Tiberti, C., Leiguarda, R. és Starkstein, S. E. (1997): Cognitive functions in major depression and Parkinson disease. Archives of Neurology, 54. 1. sz. 982-986.

Kyllonen, P. C. és Christal, R. E. (1990): Reasoning ability is (little more than) working-memory capacity?! Intelligence, 14. 4. sz. 389-433.

Lachman, R., Lachman. J. L. és Taylor, D. W. (1982): Reallocation of Mental Resources over the Productive Lifespan. Aging and Cognitive Processes, 8. 279-308. 
Lafleche, G. és Albert, M. (1995): Executive function deficits in mild Alzheimer's disease. Neuropsychology, 9. 3. sz. 313-320.

Landerl, K., Bevan, A. és Butterworth, B. (2004): Developmental dyscalculia and basic numerical capacities: a study of 8-9-year-old students. Cognition, 93. 2. sz. 99-125.

Lanfranchi, S., Cesare, C., Renzo, V. és Conners, F. (2004): Verbal and Visuospatial Working Memory Deficits in Children With Down Syndrome. American Journal on Mental Retardation, 109. 6. sz. 456-466.

Lawrence, A. D., Saahakian, B. J., Hodges, J. R., Rosser, A. E., Lange K. W. és Robbins, T. W. (1996): Executive and mnemonic functions in early Huntington's disease. Brain, 119. 5. sz. 1633-1645.

Leather, C. és Henry, L. A. (1994): Working memory span and phonological awareness tasks as predictors of early reading ability, Journal of Experimental Child Psychology, 58. 1. sz. 88-111.

Lee, J. és Park, S. (2005): Working Memory Impairments in Schizophrenia: A Meta-Analysis. Journal of Abnormal Psychology, 114. 4. sz. 599-611.

Lee, K. M. és Kang, S. Y. (2002): Arithmetic operation and working memory: differential suppression in dual tasks. Cognition, 83. 3. sz. 63-68.

Lees, A. J. és Smith, E. (1982): Cognitive deficits in the early stages of Parkinson's Disease. Brain, 106. 2. sz. 257-270.

Leggio, M. G., Silveric, M. C., Petrosinia, L. és Molinarib, M. (2000): Phonological grouping is specifically affected in cerebellar patients: a verbal fluency study. Journal of Neurology, Neurosurgery and Psychiatry, 69. 1. sz. 102-106.

Lehto, J. (1995): Working memory and school achievement in the ninth form. Educational Psychology, 15. 3. sz. 271-281.

Lehto, J. E., Juujärvi, P., Kooistra, L. és Pulkkinen, L. (2003): Dimensions of executive functioning: Evidence from children. British Journal of Developmental Psychology, 21. 1. sz. 59-80.

Levin, B. E. (1990): Organizational deficits in dyslexia: Possible frontal lobe dysfunction. Developmental Neuropsychology, 6. 2. sz. 95-110.

Levin, H. S., Song, J., Ewing-Cobbs, L., Chapman, S. B. és Mendelsohn, D. (2001): Word fluency in relation to severity of closed head injury, associated frontal brain lesions, and age at injury in children. Neuropsychologia, 39. 2. sz. 122-131.

Lezak, M. D. (1983). Neuropsychological Assessment (2. szerk.): Oxford University Press, New York.

Lezak, M. (1993): Newer contributions to the neuropsychological assessment of executive functions. Journal of Head Trauma Rehabilitation, 8. 1. sz. 24-31.

Lezak, M. D. (1995): Neuropsychological Assessment. (3.szerk.): University Press, Freeman. Oxford.

Lezak, M. D. (2004): Neuropsychological Assessment. (4. szerk.): Oxford University Press; New York.

Li, S. C., Schmiedek, F., Huxhold, O., Rocke, C., Smith, J. és Lindenberger, U. (2008): Working memory plasticity in old age: Practice gain, transfer, and maintenance. Psychology and Aging, 23. 4. sz. 731-742.

Libon, D. J., McMillan, C., Gunawardena, D., Powers, C, Massimo, L., Khan, A., Morgan, B, Farag, C., Richmond, L., Weinstein, J., Moore, P, Coslett, H. B., Chatterjee, A, Aguirre, G. és Grossman, M. (2009): Neurocognitive contributions to verbal fluency deficits in frontotemporal lobar degeneration. Neurology, 73. 7. sz. 535-542.

Linden, D. E. J., Bittner, R. A., Muckli, L., Waltz. J. A., Kriegeskorte, N., Goebel, R., Singer, W. és Munk, M. H. J. (2003): Cortical capacity constraints for visual working memory: dissociation of fMRI load effects in a fronto-parietal network. NeuroImage, 20. 3. sz. 1518-1530.

Lindsay, R. L., Tomazic, T., Levine, M. D. és Accardo, P. J. (1999): Impact of attentional dysfunction in dyscalculia. Developmental Medicine and Child Neurology, 41. 9. sz. 639-642.

Loge, D., Staton, R. és Beatty, W. (1990): Performance of children with ADHD on tests sensitive to frontal lobe dysfunction. Journal of the American Academy of Child and Adolescent Psychiatry, 29. 4. sz. 540-545.

Logie, R. H., Gilhooly, K. J. és Wynn, V. (1994): Counting on working memory in arithmetic problem solving. Memory Cognition, 22. 4. sz. 395-410.

Løhaugen, G. C. C., Antonsen, I., Håberg, A., Gramstad, A., Vik, T., Brubakk, A. M. és Skranes, J. (2011): Computerized Working Memory Training Improves Function in Adolescents Born at Extremely Low Birth Weight. The Journal of Pediatrics, 158. 4. sz. 555-561.

Loomes, C., Rasmussen, C., Pei, J., Manji, S. és Andrew, G. (2008): The effect of rehearsal training on working memory span of children with fetal alcohol spectrum disorder. Research in Developmental Disabilities, 29. 2. sz. 113-124.

Loonstra, A. S., Tarlow, A. R. és Sellers, A. H. (2001): COWAT metanorms across age, education, and gender. Applied Neuropsychology, 8. 3. sz. 161-166.

Lorsbach, T. C., Wilson, S. és Reimer, J. F. (1996): Memory for relevant and irrelevant information: Evidence for deficient inhibitory processes in language/learning disabled children. Contemporary Educational Psychology, 21. 4. sz. 447-466. 
Lovegrove, W., Martina, F. és Slaghuisa, W. (1986): A theoretical and experimental case for a visual deficit in specific reading disability. Cognitive Neuropsychology, 3. 2. sz. 225-267.

Lu, L., Weber, H. S., Spinath, F. M. és Shi, J. (2011): Predicting school achievement from cognitive and noncognitive variables in a Chinese sample of elementary school children. Intelligence, 39. 2-3. sz. 130140.

Lucas, J. A, Ivnik, R, J., Smith, G. E, Bohac, D. L., Tangalos, E. G., Graff-Radford, N. R. és Petersen, R. C. (1998): Mayo's Older Americans Normative Studies: Category Fluency Norms. Journal of Clinical and Experimental Neuropsychology, 20. 2. sz. 194-200.

Luciana. M., Lindeke, L., Georgieff, M., Mills, M. és Nelson, C. A. (1999): Neurobehavioral evidence for working-memory deficits in school-aged children with histories of prematurity. Developmental Medicine and Child Neurology, 41. 8. sz. 521-533.

Lukács, Á. (2001): Szabályok és kivételek: A kettős modell érvényessége a magyarban. In: Pléh, Cs. és Lukács, Á. (szerk.): A magyar morfológia pszicholingvisztikája. Osiris, Budapest.

Lukács, Á. és Pléh, Cs. (2002): 119-152.A nyelv idegrednszeri reprezentációja. In: Pléh, Cs., Kovács, Gy. és Gulyás, B. (szerk.): Kognitív idegtudomány. Osiris Kiadó, Budapest. 528-560.

Luria, A. R. (1973): The frontal lobes and the regulation of behavior. In: Pribram, K. H., Luria, A. R. (szerk.): Psychophysiology of the frontal lobes. Academic Press, New York. 3-26.

Lustig, C., Hasher, L. és Tonev, S. (2001): Inhibitory control over the present and the past. European Journal of Cognitive Psychology, 13. 1-2. sz. 107-122.

Macrae, T., Tyler, A. A. és Lewis, K. E. (2013): Lexical and phonological variability in preschool children with speech sound disorder. American Journal of Speech-Language Pathology, 1. 9. sz. doi:10.1044/10580360(2013/12-0037).

MacWhinney, B. (2002): A nyelvfejlődés epigenezise. In: Pléh, Cs., Kovács, Gy. és Gulyás, B. (szerk.): Kognitív idegtudomány. Osiris Kiadó, Budapest. 502-527.

Manly, J. J., Schupf, N., Tang, M. X. és Stern, Y. (2005): Cognitive Decline and Literacy Among Ethnically Diverse Elders. Journal of Geriatric Psychiatry and Neurology, 18. 4. sz. 213-217.

March, E. G. és Pattison, P. (2006): Semantic Verbal Fluency in Alzheimer's Disease: Approaches beyond the Traditional Scoring System. Journal of Clinical and Experimental Neuropsychology, 28. 4. sz. 549-566.

Marchetta, N. D. J.; Hurks, P. P. M.; Krabbendam, L. és Jolles, J. (2008): Interference control, working memory, concept shifting, and verbal fluency in adults with attention-deficit/hyperactivity disorder (ADHD). Neuropsychology, 22. 1. sz. 74-84.

Marczinski, C. A. és Kertesz, A. (2006): Category and letter fluency in semantic dementia, primary progressive aphasia, and Alzheimer's disease. Brain and language, 97. 3. sz. 258-265.

Markowitsch, H. J. és Staniloiu, A. (2012): Amnesic disorders. The Lancet, 380. 9851. sz. 1429-1440.

Martin, A., Wiggs, C. L., Lalonde, F. és Mack, C. (1994): Word retrieval to letter and semantic cues: A double dissociation in normal subjects using interference tasks. Neuropsychologia, 32. 12. sz. 1478-1494.

Martin, R. C., Loring, D. W., Meador, K. J. és Lee, G. P. (1990): The effects of lateralized temporal lobe dysfunction on formal and semantic word fluency. Neuropsychologia, 28. 8. sz. 823-829.

Martinussen, R. és Tannock R. (2006): Working Memory Impairments in Childen with Attention-Deficit Hyperactivity Disorder With and Without Comorbid Language Learning Disorders. Journal of Clinical and Experimental Neuropsychology, 28. 7. sz. 1073-1094.

Martinussen, R., Hayden, J., Hogg-Johnson, S. és Tannock, R. (2005): A Meta-Analysis of Working Memory Impairments in Children With Attention-Deficit/Hyperactivity Disorder. Journal of the American Academy of Child \& Adolescent Psychiatry, 44. 4. sz. 377-384.

Mathuranath, P. S., George, A., Cherian, P. J., Alexander, A., Sarma, S. G. és Sarma, P. S. (2003): Effects of Age, Education and Gender on Verbal Fluency. Journal of Clinical and Experimental Neuropsychology, 25. 8. sz. 1057-1064.

Matute, E., Rosselli, M., Ardila, A. és Morales, G. (2004): Verbal and nonverbal fluency in Spanish speaking children. Developmental Neuropsychology, 26. 2. sz. 647-660.

Mayringer, H. és Wimmer, H. (2000): Pseudoname Learning by German-Speaking Children with Dyslexia: Evidence for a Phonological Learning Deficit. Journal of Experimental Child Psychology, 75. 2. sz. 116-133.

Mazzocco, M. M. M. és Kover, S. T. (2007): A longitudinal assessment of executive function skills and their association with math performance. Child Neuropsychology, 13. 1. sz. 18-45.

McCormack, T., Brown G. D. A., Vousden J. I. és Henson, R. N. A. (1999): Children's Serial Recall Errors: Implications for Theories of Short-Term Memory Development. Journal of Experimental Child Psychology, 76. 3. sz. 222-252.

McDowell, S., Whyte, J., \& D’Esposito, M. (1997). Working memory impairments in traumatic brain injury: evidence from a dual-task paradigm. Neuropsychologia, 35(10), 1341-1353. 
McGee, R., Williams, S., Moffitt, T., Anderson, J. (1989). A comparison of 13 year-old boys with attention deficit and/or reading disorder on neuropsychological measures. Journal of Abnormal Child Psychology, 17(1) 37-53.

McGinnis, D. és Zelinsky, E. M. (2003): Understanding unfamiliar words in young, young-old, and old-old adults: Inferential processing and the abstraction-deficit hypothesis. Psychology and Aging, 18. 3. sz. 497-509.

McInnes, A., Humphries, T., Hogg-Johnson, S. és Tannock, R. (2003): Listening Comprehension and Working Memory Are Impaired in Attention-Deficit Hyperactivity Disorder Irrespective of Language Impairment. Journal of Abnormal Child Psychology, 31. 4. sz. 427-443.

McLean, J. F. és Hitch, J. (1999): Working memory impairments in children with specific arithmetical learning difficulties. Journal of Experimental Child Psychology, 74. 3. sz. 240-260.

McLellan, D. L. (1991): Functional recovery and the principles of disability medicine. In: Swash, M. és Oxbury, J. (szerk.): Clinical Neurology. Churchill Livingstone, London. 768-790.

McNab, F., Leroux, G., Strand, F., Thorell, L., Bergman, S. és Klingberg, T. (2008): Common and unique components of inhibition and working memory: An fMRI, within-subjects investigation. Neuropsychologia, 46. 1. sz. 2668-2682.

McNamara, D. és Scott, J. (2001): Working memory capacity and strategy use. Memory and Cognition, 29. 1. sz. $10-17$.

McNamara, J. K. és Wong, B. (2003): Memory for Everyday Information in Students with Learning Disabilities. Journal of Learning Disabilities, 36. 5. sz. 394-406.

Meija, S., Pineda, D., Alvarez, L. M. és Ardila, A. (1998): Individual Differences in Memory And Executive Function Abilities During Normal Aging. International Journal of Neuroscience, 95. 3-4. sz. 271-284.

Mészáros, A., Kónya, A. és Kas, B. (2011): A verbális fluenciatesztek felvételének és értékelésének módszertana. Alkalmazott Pszichológia, 2. 53-76.

Meyer, M. L., Salimpoor, V. N., Wu, S. S., Geary, D. C. és Menon, V. (2010): Differential contribution of specific working memory components to mathematics achievement in 2nd and 3rd graders. Learning and Individual Differences, 20. 2. sz. 101-109.

Miceli, G., Caltagirone, C., Gainotti, G., Masullo, C. és Silveri, M. (1981): Neuropsychological correlates of localized cerebral lesions in non-aphasic brain-damaged patients. Journal of Clinical Neuropsychology, 3. 1. sz. 53-63.

Miller, E. (1984): Verbal fuency as a function of a measure of verbal intelligence and in relation to different types of cerebral pathology. British Journal of Clinical Psychology, 23. 1. sz. 53-57.

Miller, G. A. (1956): The magical number seven, plus or minus two: Same limits on our capacity for processing information. Psychological Review, 63. 2. sz. 81-97.

Milner, B. (1964): Some effects of frontal lobectomy in man. In: Warren, J. M. és Akert, K. (szerk.): The frontal granular cortex and behavior. McGraw-Hill, New York. 313-334.

Miotto, E. C:, Evans, J. J., Souza de Lucia, M. C. és Scaff, M. (2009): Rehabilitation of executive dysfunction: A controlled trial of an attention and problem solving treatment group. Neuropsychological Rehabilitation, 19. 4. sz. 517-540.

Miyake, A. és Shah, P. (1999): Models of working memory: mechanisms of active maintenance and executive control. Cambridge University Press, New York.

Miyake. A., Friedman, N. P., Emerson, M. J., Witzki, A. H., Howerter, A. és Wager, T. D. (2000): The Unity and Diversity of Executive Functions and Their Contributions to Complex "Frontal Lobe" Tasks: A Latent Variable Analysis. Cognitive Psychology, 41. 1. sz. 49-100.

Monchi, O., Petrides, M., Strafella, A. P., Worsley, K. J. és Doyon, J. (2006): Functional role of the basal ganglia in the planning and execution of actions. Annals of Neurology, 59. 2. sz. 257-264.

Monsch, A. U. Bondi, W. M., Butters, N., Paulsen, J. S., Salmon, D. P., Brugger, P. és Swenson, M. R. (1994): A comparison of category and letter fluency in Alzheimer's disease and Huntington's disease. Neuropsychology, 8. 1. sz. 25-30.

Monsch, A. U., Bondi, M. W., Butters, N., Salmon, D. P., Katzman, R. és Thal, L. J. (1992): Comparisons of verbal fluency tasks in the detection of dementia of the Alzheimer type. Archives of Neurology, 49. 12. sz. 1253-1258.

Monsell, S. és Bruce, V. (1996): Control of mental processes. Unsolved mysteries of the mind: Tutorial essays in cognition. Taylor and Francis, Oxford, England: Erlbaum. 93-148.

Montgomery, J. (1995): Sentence Comprehension in Children with Specific Lnguage Impairment: The Role of Phonological Working Memory. Journal of Speech and Hearing Research, 38. 187-199.

Montgomery, J. (2000a): Relation of Working Memory to Off-line and Real-time Sentence Processing in Children with Specific Language Impairment. Applied Psycholinguistics, 21. 1. sz. 117-148.

Montgomery, J. W. \& Evans, J. L. (2009): Complex sentence comprehension and working memory in children with specific language impairment. Journal of Speech Language and Hearing Research, 52. 269-288. 
Montgomery, J. W. (2000b): Verbal Working Memory and Sentence Comprehension in Children With Specific Language Impairment. Journal of Speech, Language, and Hearing Research, 43. 293-308.

Montgomery, J. W. (2002): Understanding the Language Difficulties of Children With Specific Language Impairments. Does Verbal Working Memory Matter? American Journal of Speech-Language Pathology, 11. 77-91.

Morice, R. és Delahunty, A. (1996): Frontal/Executive Impairments in Schizophrenia. Schizophrenia Bulletin, 22. 1. sz. 125-137.

Morris, J. C. (1996a): Classification of dementia and Alzheimer's disease. Acta Neurologica Scandinavica, 94. 165. sz. 41-50.

Morris, J. C. és Price, J. L. (2001): Pathologic correlates of nondemented aging, mild cognitive impairment, and early-stage Alzheimer's disease. Journal of Molecular Neuroscience, 17. 2. sz. 101-118.

Morris, N. és Jones D. M. (1990): Memory updating in working memory: The role of central executive. British Journal of Psychology, 81. 2. sz. 111-121.

Morrison, A. B. és Chein, J. M. (2011): Does working memory training work? The promise and challenges of enhancing cognition by training working memory. Psychonomic Bulletin and Review, 18. 1. sz. 46-60.

Müller, N. G. és Knight, R. T. (2005): The functional neuroanatomy of working memory: Contributions of human brain lesion studies. Neuroscience, 139. 1. sz. 51-58.

Murphy, K. J., Rich, J. B. és Troyer, A. K. (2006): Verbal fluency patterns in amnestic mild cognitive impairment are characteristic of Alzheimer's type dementia. Journal of the International Neuropsychological Society, 12. 4. sz. 570-574.

Myerson, J., Hale, S., Rhee, S. H. és Jenkins, L. (1999): Selective interference with verbal and spatial working memory in young and older adults. Journal of Gerontology: Psychological Sciences, 54B. 3. sz. 161164.

Narayan, V. M., Kimberg, D. Y., Tang, K. Z. és Detre, J. A. (2005): Experimental design for functional MRI of scene memory encoding. Epilepsy and Behavior, 6. 2. sz. 242-249.

Nash, H. M. és Snowling, M. J. (2008): Semantic and phonological fluency in children with Down syndrome: Atypical organization of language or less efficient retrieval strategies? Cognitive Neuropsychology, 25. 5. sz. 690-703.

Nathan, J., Wilkinson, D., Stammers, S. és Low, J. L. (2001): The role of tests of frontal executive function in the detection of mild dementia. International Journal of Geriatric Psychiatry, 16. 1. sz. 18-26.

Nation, K., Adams, J. W., Bowyer-Crane, C. A. és Snowling, M. J. (1999): Working Memory Deficits in Poor Comprehenders Reflect Underlying Language Impairments. Journal of Experimental Child Psychology, 73. 2. sz. 139-158.

Németh D. (2002): A munkamemória fejlődése és mondatmegértés. Pszichológia, 22. 2. sz. 267-276.

Németh D., Ivády R. E., Miháltz M., Krajcsi A. és Pléh Cs. (2006): A verbális munkamemória és morfológiai komplexitás. Magyar Pszichológiai Szemle, 61. 2. sz. 265-298.

Németh, D. (2006): A nyelvi folyamatok és az emlékezeti rendszerek kapcsolata. Akadémiai Kiadó, Budapest.

Németh, D., Racsmány, M., Kónya, A. és Pléh, Cs. (2001): A munkamemória kapacitás mérőeljárásai és szerepük a neuropszichológiai diagnosztikában. Magyar Pszichológiai Szemle, 55. 4. sz. 403-416.

Newcombe, F. (1969): Missile wounds of the brain. Oxford University Press, London.

Nigg, J. T., Butler, K. M., Huang-Pollock, C. L. és Henderson, J. M. (2002): Inhibitory processes in adults with persistent childhood onset ADHD. Journal of Consulting and Clinical Psychology, 70. 1. sz. 153-157.

Norman, D. A. és Shallice, T. (1986): Attention to action: willed and automatic control of behavior. In: Davidson, R. J., Schwartz, G. E. és Shapiro, D. (szerk.): Consciousness and self-regulation. Plenum Press, New York, 1-18.

Norris, M. P., Blankenship-Reuter, L., Snow-Turek, A. L. és Finch, J. (1995): Influence of depression on verbal fluency performance. Aging and Cognition, 2. 3. sz. 206-215.

Nudo, R. J., Milliken, G. W., Jenkins, W. M. és Merzenich, M. M. (1996): Use-dependent alterations of movement representations in primary motor cortex of adult squirrel monkeys. Journal of Neuroscience, 16. 2. sz. 785-807.

Nutter-Upham, K. E., Saykin, A. J., Rabin, L. A., Roth, R. M., Wishart, H. A., Pare, N. és , L. A. (2008): Verbal fluency performance in amnestic MCI and older adults with cognitive complaints. Archives of Clinical Neuropsychology, 23. 3. sz. 229-241.

Oakhill J. V., Yuill N., \& Parkin A. J. (1986). On the nature of the difference between skilled and less-skilled comprehenders. Journal of Research in Reading, 9(2), 80-90.

Ober, B. A., Dronkers, N. F., Koss, E., Delis, D. C., Friedland, R. P. (1986). Retrieval from semantic memory in Alzheimer type dementia. Journal of Clinical and Experimental Neuropsychology, 8(1), 75-92.

Olesen, P., Westerberg, H. és Klingberg, T. (2004): Increased prefrontal and parietal brain activity after training of working memory. Nature Neuroscience, 7. 75-79. 
Osaka, N., Osaka, M., Kondo, H., Morishita, M., Fukuyama, H. és Shibasaki, H. (2003): The neural basis of individual differences in working memory capacity: an fMRI study. Neuroimage, 18. 3. sz. 789-797.

Ostrosky-Solis, F., Gutierrez, A. L., Flores, M. R. és Ardila, A. (2007): Same or different? Semantic verbal fluency across Spanish-speakers from different countries. Archives of Clinical Neuropsychology, 22. 3. sz. 367-377.

Ozonoff, S. és Jensen, J. (1999): Brief report: Specific executive function profiles in three neurodevelopmental disorders. Journal of Autism and Developmental Disorders, 29. 2. sz. 171-177.

Ozonoff, S., Pennington, B. F. és Rogers, S. (1991): Executive Function Deficits in High-Functioning Autistic Individuals: Relationship to Theory of Mind. Journal of Child Psychology and Psychiatry, 32. 7. sz. 1081-1105.

Paelecke-Habermann, Y., Pohl, J. és Leplow, B. (2005): Attention and executive functions in remitted major depression patients. Journal of Affective Disorders, 89. 1-3. sz. 125-135.

Paivio A. (1969): Mental imagery in associative learning and memory. Psychological Review, 76. 3. sz. 241-263.

Park, S. és Holzman, P. S. (1992): Schizophrenics show working memory deficits. Archives of General Psychology, 49. 12. sz. 975-982.

Parkin, A. J. (1998): The central executive does not exist. Journal of the International Neuropsychological Society, 4. 5. sz. 518-522.

Pasquier, F., Lebert, F., Grymonprez, L. és Petit, H. (1995) : Verbal fluency in dementia of frontal lobe type and dementia of Alzheimer type. Journal of Neurology Neurosurgery and Psychiatry, 58. 1. sz. 81-84.

Passler, M. A., Isaac, W. és Hynd, G. W. (1985): Neuropsychological development of behavior attributed to frontal lobe functioning in children. Developmental Neuropsychology, 1. 4. sz. 349-370.

Passolunghi, M. C. és Siegel, L. S. (2004): Working memory and access to numerical information in children with disability in mathematics. Journal of Experimental Child Psychology, 88. 4. sz. 348-367.

Pataky, I. (1999): Kognitív rehabilitáció post-stroke állapotokban. Hippocrates, 1. 3. sz. 164-167.

Paulescu E., Frith, C. D. és Frackowiak, R. S. J. (1993): The neuronal correlates of the verbal component of working memory. Nature, 362. 342-244.

Paus, T. (1991): Two modes of central gaze fixation maintenance and oculomotor distractibility in schizophrenics. Schizophrenia Research, 5. 2. sz. 145-152.

Pendleton, M. G., Heaton, R. K., Lehman, R. A. és Hulihan, D. (1982): Diagnostic utility of the Thurstone Word Fluency Test in neuropsychological evaluations. Journal of Clinical Neuropsychology, 4. 4. sz. 307 317.

Pennington, B. F. és Ozonoff, S. (1996): Executive Functions and Developmental Psychopathology. Journal of Child Psychology and Psychiatry, 37. 1. sz. 51-87.

Perfetti, C. A. és Goldman, S. R. (1976): Discourse memory and reading comprehension skill. Journal of Verbal Learning and Verbal Behavior, 15. 1. sz. 33-42.

Perlmuter, L. C., Monty, R. A. P. (1989): Motivation and aging. In: Poon, L.W., Rubin, D. C. és Wilson, B. A. (szerk.): Everyday cognition in adulthood and late life. Cambridge University Press, New York, NY, US. 373-393.

Perret, E. (1974): The left frontal lobe of man and the suppression of habitual responses in verbal categorical behavior. Neuropsychologia, 12. 3. sz. 323-330.

Petrova, M., Raycheva, M. R., Zhelev, Y. és Traykov, L. (2010): Executive Functions Deficit in Parkinson's Disease With Amnestic Mild Cognitive Impairment. American Journal of Alzheimer's Disease and other Dementias, 25. 5. sz. 455-460.

Petrucelli, N., Bavin, E. L. és Bretherton, L. (2012): Children With Specific Language Impairment and Resolved Late Talkers: Working Memory Profiles at 5 Years. Journal of Speech, Language, and Hearing Research, 55. 1690-1703.

Phelps, E. A., Hyder, F., Blamire, A. M. és Shulman, R. G. (1997): FMRI of the prefrontal cortex during overt verbal fluency. Neuroreport, 8. 2. sz. 561-565.

Pickering, S. J. és Gathercole, S. E. (2004): Distinctive Working Memory Profiles in Children with Special Educational Needs. Educational Psychology, 24. 3. sz. 393-408.

Pickering, S. J. (2001): The development of visuo-spatial working memory. Memory, 9. 4-6. sz. 423-432.

Piguet, O., Grayson, G., Browe, A., Tate, H., Lye, T., Creasey, H. és Ridley, R. (2002): Normal aging and executive functions in "old-old" community dwellers: Poor performance is not an inevitable outcome. International Psychogeriatric Association, 14. 2. sz. 139-159.

Pihlajamaki, M., Tanila, H., Hanninen, T., Kononen, M., Laakso, M., Partanen, K., Soininen, H. és Aronen, H. (2000): Verbal fluency activates the left medial temporal lobe: a functional magnetic resonance imaging study. Annals of Neurology, 47. 470-476.

Plumet, J., Gil, R. és Gaonac'h, D. (2005): Neuropsychological Assessment of Executive Functions in Women: Effects of Age and Education. Neuropsychology, 19. 5. sz. 566-577. 
Poon, L. W., Rubin, D. C. és Wilson, B. A. (1992): Everyday Cognition in Adulthood and Late Life. Cambridge University Press, Cambridge.

Prior, M. és Hoffmann, W. (1990): Brief report: Neuropsychological testing of autistic children through an exploration with frontal lobe tests. Journal of Autism and Developmental Disorders, 20. 4. sz. 581-590.

Protopapas, A., Archonti, A. és Skaloumbakas, C. (2007): Reading ability is negatively related to Stroop interference. Cognitive Psychology, 54. 3. sz. 251-282.

Pukrop, R., Matuschek, E., Ruhrmann, S., Brockhaus-Dumke, A., Tendolkar, I., Bertch, A. és Klosterkötter, J. (2003): Dimensions of working memory dysfunction in schizophrenia. Schizophrenia Research, 62. 3. sz. 259-268.

Raboutet, C., Sauzéon, H., Corsini, M. M., Rodrigues, J., Langevimn, S. és N'kaoua, B. (2010): Performance on a semantic verbal fluency task across time: Dissociation between clustering, switching, and categorical exploitation processes. Journal of Clinical and Experimental Neuropsychology, 32. 3. sz. 268-280.

Racsmány, M. (2003): Az emlékezet kognitív neuropszichológiája. In: Pléh Cs., Kovács Gy. és Gulyás B. (szerk.): Kognitív idegtudomány. Osiris Kiadó, Budapest.

Racsmány M. (2004): A munkamemória szerepe a megismerésben. Akadémiai Kiadó, Budapest.

Racsmány, M. (2007): A fejlödés zavarai és vizsgálómódszerei. Neuropszichológiai diagnosztikai módszerek. Akadémiai Kiadó, Budapest. 11-39.

Racsmány, M., Lukács, Á., Németh, D. és Pléh, Cs. (2005): A verbális munkamemória magyar nyelvủ vizsgálóeljárásai. Magyar Pszichológiai Szemle, 60. 4. sz. 479-505.

Racsmány, M., Lukács, Á., Pléh, Cs. és Király, I. (2001): Some cognitive tools for word learning: The role of working memory and goal preference. Behavioral and Brain Sciences, 24. 6. sz. 1115-1117.

Raghubar, K. P., Barnes, M. A. és Hecht, S. A. (2010): Working memory and mathematics: A review of developmental, individual difference, and cognitive approaches. Learning and Individual Differences, 20. 2. sz. 110-122.

Rajah, M. N. és D’Esposito, M. (2005): Region-specific changes in prefrontal function with age: a review of PET and fMRI studies on working and episodic memory. Brain, 128. 9. sz. 1964-1983.

Rajah, M. N. és McIntosh, A. R. (2008): Age-related differences in brain activity during verbal recency memory. Brain research, 1199. 111-125.

Raoux, N., Amieva, H., Le Goff, M., Auriacombe, S., Carcaillon, L., Letenneur, L. és Dartigues, J. F. (2008): Clustering and switching processes in semantic verbal fluency int he course of Alzheimer's Disease subjects: Results from the PAQUID longitudunal study. Cortex, 44. 9. sz. 1188-1196.

Rapp, M. A., \& Reischies, F. M. (2005): Attention and executive control predict Alzheimer disease in late life. Results from the Berlin Aging Study (BASE). American Journal of Geriatric Psychiatry, 13. 1. sz. 134141.

Rapport, M. D., Scanlan, S. W. és Denney, C. B. (1999): Attention-Deficit/Hyperactivity Disorder and Scholastic Achievement: A Model of Dual Developmental Pathways. The Journal of Child Psychology and Psychiatry, 40. 8. sz. 1169-1183.

Raskin, S. A. és Rearick, E. (1996): Verbal fluency in individuals with mild traumatic brain injury. Neuropsychology, 10. 3. sz. 416-422.

Rasmussen, C. és Bisanz, J. (2005): Representation and working memory in early arithmetic. Journal of Experimental Child Psychology, 91. 2. sz. 137-157.

Reader, M. J., Harris, E. L., Schuerholz, L. J. és Denckla, M. B. (1994): Attention deficit hyperactivity disorder and executive dysfunction. Developmental Neuropsychology, 10. 4. sz. 493-512.

Recanzone, G.H., Merzenich, M. M., Jenkins, W. M., Grajski, K. A. és Dinse, H. R. (1992): Topographic reorganization of the hand representation in cortical area $3 \mathrm{~b}$ of owl monkeys trained in a frequencydiscrimination task. Journal of Neurophysiology, 67. 5. sz. 1031-1056.

Reifler, B. V. és Larson, E. (1990): Excess disability in dementia of the Alzheimer's type. In: Light, E. és Lebowitz, B. D. (szerk.): Alzheimer's Disease Treatment and Family Stress. Hemisphere, New York.

Reiter, A., Tucha, O. és Lange, K. W. (2004): Executive functions in children with dyslexia. Dyslexia, 11. 2. sz. $116-131$.

Rekkas, P. V. (2006): Interference Resolution in the Elderly: Evidence Suggestive of Differences in Strategy on Measures of Prepotent Inhibition and Dual Task Processing. Aging, Neuropsychology, and Cognition: A Journal on Normal and Dysfunctional Development, 13. 3-4. sz. 341-365.

Reske, M., Eidt, C. A., Delis, D. C. és Paulus, M. P. (2010): Nondependent Stimulant Users of Cocaine and Prescription Amphetamines Show Verbal Learning and Memory Deficits. Biological Psychiatry, 68. 8. sz. 762-769.

Reverberi, C., Laiacona, M. és Capitani, E. (2006): Qualitative features of semantic fluency performance in mesial and lateral frontal patients. Neuropsychologia, 44. 3. sz. 469-478.

Riccio, C. A., Cash, D. L. és Cohen M. J. (2007): Learning and memory performance of children with specific language impairment (SLI). Applied Neuropsychology, 14. 4. sz. 255-261. 
Rich, J. B., Toryer, A. K., Bylsma, F. W. és Brandt, J. (1999): Longitudinal analysis of phonemic clustering and switching during word-list generation in Huntington's disease. Neuropsychology, 13. 4. sz. 525-531.

Robbins, T. W., James, M., Owen. A. M., Sahakian, B. J., Lawrence, A. D., McInnes, L. és Rabbit, P. M. A. (1998): A study of performance on tests from the CANTAB battery sensitive to frontal lobe dysfunction in a large sample of normal volunteers: Implications for theories of executive functioning and cognitive aging. Journal of the International Neuropsychological Society, 4. 5. sz. 474-490.

Robert, P. H., Mogneco, V., Marmod, D., Chaix, I., Thauby, S., Benoit, M. és Beau, C. H. (1997): Verbal fluency in schizophrenia: The role of semantic clustering in category instance generation. European Psychiatry, 12. 3. sz. 124-129.

Rodriguez-Aranda, C. (2003): Reduced Writing and Reading Speed and Age-related Changes in Verbal Fluency Tasks. The Clinical Neuropsychologist, 17. 2. sz. 203-215.

Rodriguez-Aranda, C. és Martinussen, M. (2006): Age-Related Differences in Performance of Phonemic Verbal Fluency Measured by Controlled Oral Word Association Task (COWAT): A Meta-Analytic Study. Developmental Neuropsychology, 30. 2. sz. 697-717.

Roebers, C. M., Röthlisberger, M., Cimeli, P., Michel, E. és Neuenschwander, R. (2011): School enrolment and executive functioning: A longitudinal perspective on developmental changes, the influence of learning context, and the prediction of pre-academic skills. European Journal of Developmental Psychology, 8. 5. sz. 526-540.

Rogers, S. L. és Freedman, R. B. (2008): The underlying mechanisms of semantic memory loss in Alzheimer's disease and semantic dementia. Neuropyshcologia, 46. 1. sz. 12-21.

Rogers, T. T., Ivanoiu, A., Patterson, K. és Hodges, J. R. (2006): Semantic memory in Alzheimer's disease and the frontotemporal dementias: A longitudinal study of 236 patients. Neuropsychology, 20. 3. sz. 319335.

Romine, C. B. és Reynolds, C. E. (2005): A model of the development of frontal lobe functioning: Findings from a meta-analysis. Applied Neuropsychology, 12. 4. sz. 190-201.

Rönnlund, M., Lövdén, M. és Nilsson, L. G. (2001): Adult Age Differences in Tower of Hanoi Performance: Influence From Demographic and Cognitive Variables. Aging, Neuropsychology, and Cognition: A Journal on Normal and Dysfunctional Development, 8. 4. sz. 269-283.

Rosen, W. G. (1980): Verbal fluency in aging and dementia. Journal of Clinical Neuropsychology, 2. 2. sz. 135146.

Ross, T. P., Weinberg, M., Furr, A. E., Carter, S. E., Evans-Blake, L. és Parham, S. (2005): The temporal stability of cluster and switch scores using a modified COWAT procedure. Archives of Clinical Neuropsychology, 20. 8. sz. 983-996.

Rosser, A. és Hodges, J. R. (1994): Initial letter and semantic category fluency in Alzheimer's disease, Huntington's disease, and progressive supranuclear palsy. Journal of Neurology, Neurosurgery, and Psychiatry, 57. 11. sz. 1389-1394.

Rourke, B. P. (1993): Arithmetic disabilities, specific and otherwise:Aneuropsychological perspective. Journal of Learning Disabilities, 26. 4. sz. 214-226.

Royall, D. R., Lauterbach, E. C., Cummings, J. L., Reeve, A., Rummans, T. A. és Kaufer, D. I., LaFrance, W. C. és Coffey, C. E. (2002): Executive control function: A review of its promise and challenges for clinical research. Journal of Neuropsychiatry and Clinical Neuroscience, 14. 4. sz. 377-405.

Ruff, R. M., Light, R. H., Parker, S. B. és Levin, H. S. (1997): The psychological construct of word fluency. Brain and Language, 57. 3. sz. 394-405.

Rush, B. K., Barch, D. M. és Braver, T. S. (2006): Accounting for Cognitive Aging: Context Processing, Inhibition or Processing Speed? Aging, Neuropsychology, and Cognition: A Journal on Normal and Dysfunctional Development, 13. 3-4. sz. 588-610.

Russell, J., Jarrold, C. és Henry, L. (1996): Working memory in children with autism and with moderate learning difficulties. Journal of Child Psychology and Psychiatry, 37. 6. sz. 673-686.

Salamé, P. és Baddeley, A. D. (1987): Noise unattended speech and short-term memory. Ergonomics, 30. 8. sz. 1185-1193.

Salamé, P. és Baddeley, A. D. (1989): Effects of background music on phonological short-term memory. Quarterly Journal of Experimental Psychology, 41. 1. sz. 107-122.

Salat, D. H., Tuch, D. S., Hevelone, N. D., Fischl, B., Corkin, S., Rosas, H. D. és Dale, A. M. (2005): AgeRelated Changes in Prefrontal White Matter Measured by Diffusion Tensor Imaging. Annals of the New York Academy of Sciences, 1064. 37-49.

Salmon, D. P., Jin, H., Zhang, M., Grant, I. és Yu, E. (1995): Neuropsychological assessment of Chinese elderly in the Shanghai dementia survey. Clinical Neuropsychologist, 9. 2. sz. 159-168.

Salmon, D. P., Shimamura, A. P., Butters, N. és Smith, S. (1988): Lexical and semantic deficits in patients with Alzheimer's disease. Journal of Clinical and Experimental Neuropsychology, 10. 4. sz. 477-494. 
Sandler, A. D., Hooper, S. R., Watson, T. E., Coleman, W. L., Footo, M. és Levin, M. D. (1993): Talkative children: Verbal fluency as a marker for problematic peer relationships in clinicalreferred children with attention-deficits. Perceptual and Motor Skills, 76. 1. sz. 943-951.

Sanz, C. (2005): Mind AND context in adult second language acquisition: Methods, theory and practice. Georgetown University Press, Washington.

Sarno, M. T., Postman, W. A., Cho, Y. S. és Norman, R. G. (2005): Evolution of phonemic word fluency performance in post-stroke aphasia. Journal of Communication Disorders, 38. 2. sz. 83-107.

Sautter, F. J., McDermott, B. E., Cornwell, J. M., Borges, A., Johnson, J., Vasterling, J. J. és Marcontell, D. K. (1997): A comparison of neuropsychological deficits in familial schizophrenics, nonfamilial schizophrenics, and normal controls. Journal of Nervous and Mental Disease, 185. 10. sz. 641-644.

Sauzéon, H., Lestage, P., Raboutet, C., N'Kaoua, B. és Claverie, B. (2004): Verbal fluency output in children aged 7-16 as a function of the production criterion: Qualitative analysis of clustering, switching processes, and semantic network exploitation. Brain and Language, 89. 1. sz. 192-202.

Scheres, A., Oosterlaan, J., Geurts, H., Morein-Zamir, S., Meiran, N., Schut, H., Vlasveld, L. és Sergeant, J. A. (2006): Executive functioning in boys with ADHD: primarily an inhibition deficit? Archives of Clinical Neuropsychology, 19. 4. sz. 569-594.

Schmitz, N., Rubia, K., Daly, E., Smith, A., Williams, S. és Murphy, D. G. M. (2006): Neural Correlates of Executive Function in Autistic Spectrum Disorders. Biological Psychiatry, 59. 1. sz. 7-16.

Schneider, W. és Schiffrin, R. M. (1977): Controlled and automatic information processing Screening Test for Executive Dysfunction in Patients with Mild Dementia. Journal of the American Geriatrics Society, 53. 9. sz. 1577-1581.

Schwartz, S., Baldo, J., Graves, R. E. és Brugger, P. (2003): Pervasive influence of semantics in letter and category fluency: A multidimensional approach. Brain and Language, 87. 3. sz. 400-411.

Sefcsik, T., Németh, D., Janacsek, K., Hoffmann, I., Sciabbala, J., Klivényi, P.,Ambrus, G. G., Háden, G. P. és Vécsei, L. (2009): The role of the putamen in cognitive functions - A case study. Learning \& Perception, 1. 2. sz. 215-222.

Seigneuric, A., Ehrlich,M. F., Oakhill, J. V. és Yuill, N. M. (2000): Working memory resources and children's reading comprehension. Reading and Writing, 13. 2. sz. 81-103.

Sergeant, J. S., Geurts, H. és Oosterlaan, J. (2002): How specific is a deficit of executive functioning for attention-deficit/hyperactivity disorder? Behavioural Brain Research, 130. 1-2. sz. 3-28.

Service, E. (1992). Phonology, working memory, and foreign-language learning. Quarterly Journal of Experimental Psychology, 45. 1. sz. 21-50.

Service, E. és Kohonen, V. (1995): Is the relationship between phonological memory and foreign language learning accounted for by vocabulary acquisition. Applied Psycholinguistics, 16. 2. sz. 155-172.

Service, E. és Tujulin, A. M. (2002): Recall of morphologically complex forms is affected by memory task but not dyslexia. Brain and Language, 81. 1-3. sz. $42-54$.

Shah, P. és Miyake, A. (1996). The separability of working memory resources for spatial thinking and language processing; an individual differences approach. Journal of Experimental Psychology: General, 125. 1. sz. 4-27.

Shallice, T. és Vallar, G. (1990): The impairment of auditory-verbal short-term storage. In: Vallar, G. és Shallice, T. (szerk.): Neuropsychological impairments of short-term memory. Cambridge University Press, New York. 11-54.

Shallice, T. (1982): Specific impairments in planning. Philosophical Transactions of the Royal Society (London). 199-209.

Shallice, T. és Burgess, P. W. (1991): Deficits in strategy application following frontal lobe damage in man. Brain, 114. 2. sz. 727-741.

Shaw, R. M., Helmes, E. és Mitchel, D. (2006): Age-related change in visual, spatial and verbal memory. Australasian Journal on Ageing, 25. 1. sz. 14-27.

Sherman, A. M. és Massman, P. J. (1999): Prevalence and Correlates of Category Versus Letter Fluency Discrepancies in Alzheimer's Disease. Archives of Clinical Neuropsychology, 14. 5. sz. 441-418.

Shimamura, A. P., Janowsky, J. S. és Squire, L. R. (1990): Memory for the temporal order of events in patients with frontal lobe lesions and amnesic patient. Neuropsychologia, 28. 8. sz. 803-813.

Siegel, L. S. (1994): Working Memory and Reading: A Life-span Perspective. International Journal of Behavioral Development, 17. 1. sz. 109-124.

Siegel, L. S. és Ryan, E. B. (1989): The development of working memory in normally achieving and subtypes of learning disabled children, Child Development, 60. 4. sz. 973-980.

Simon, H. A. (1975): The functional equivalence of problem solving skills. Cognitive Psychology, 7. 2. sz. 268288.

Sitzer, D. I., Zwamley, E. W. és Jeste, D. V. (2006): Cognitive training in Alzheimer's disease: a meta-analysis of the literature. Acta Psychiatrica Scandinavica, 114. 2. sz. 75-90. 
Smith, E. E. és Jonides, J. (1997). Working memory: A view from neuroimaging. Cognitive Psychology, 33. 1. Sz. 5-42.

Smith, E. E., Jonides, J. és Koeppe, R. A. (1996): Dissociating verbal and spatial working memory using PET. Cerebral cortex, 6. 1. sz. 11-20.

Solomon, P. R., Hirschoff, A., Kelly, B., Relin, M., Brush, M., Deveaux, R. és Pendlebury, W. W. (1998): A seven minute neurocognitive screening battery highly sensitive to Alzheimer' disease. Archives of Neurology, 55. 3. sz. 349-355.

Speidel, G. E. (1993): Phonological short-term memory and individual differences in learning to speak: a bilingual case study. First Language, 13. 37. sz. 69-91.

Spek, A., Schatorjé, T., Scholte, E. és Van Berckelaer-Onnes, I. (2009): Verbal fluency in adults with high functioning autism or Asperger syndrome. Neuropsychologia, 47. 3. sz. 652-656.

Spreen, O. és Strauss, E. (1991): A compendium of neuropsychological tests: Administration, norms, and commentary. Oxford University Press, New York.

Springer, S., Giladi, N., Peretz, C., Yogev, G., Simon, E. S. és Hausdorff, J. M. (2006): Dual-tasking effects on gait variability: The role of aging, falls, and executive function. Movement Disorders, 21. 7. sz. 950957.

Squire, L. R. (1987): Memory and brain. Oxford University Press, New York.

Stratta, P., Daneluzzo, E., Prosperini, P., Bustini, M., Mattei, P. és Rossi, A. (1997): Is Wisconsin Card Sorting Task performance related to „,working memory” capacity? Schizophrenia Research, 27. 1. sz. 11-19.

Stroop, J. R. (1935): Studies of interference in sserial verbal reactions. Journal of experimental Psychology, 18. 6. sz. 643-662.

Stuss, D. T. (1992): Biological and psychological development of executive functions. Brain and Cognition, 20. 1. sz. 8-23.

Stuss, D. T. és Alexander, M. P. (2000): Executive functions and the frontal lobes: A conceptual view. Psychological Research, 63. 3-4. sz. 289-298.

Stuss, D. T. és Levine, B. (2002): Adult clinical neuropsychology: Lessons from Studies of the Frontal Lobes. Annual Review of Psychology, 53. 401-433.

Stuss, D. T., Alexander, M. P, Hamer, L., Palumbo, C., Dempster, R., Binns, M., Levine, B. és Izukawa, D. (1998): The effects of focal anterior and posterior brain lesions on verbal fluency. Journal of the International Neuropsychological Society, 4. 3. sz. 265-278.

Suhr, J. A. és Jones, R. D. (1998): Letter and semantic fluency in Alzheimer's, Huntington's, and Parkinson's dementias. Archives of Clinical Neuropsychology, 13. 5. sz. 447-454.

Swanson, H. L. és Ashbaker, M. H. (2000): Working memory, short-term memory, speech rate, word recognition and reading comprehension in learning disabled readers: does the executive system have a role? Intelligence, $\mathbf{2 8}$. 1. sz. 1-30.

Swanson, H. L. (1993): Working memory in learning disability subgroups. Journal of Experimental Child Psychology, 56. 1. sz. 87-114.

Swanson, H. L. (1999): Reading comprehension and working memory in learning-disabled readers: Is the phonological loop more important than the executive system? Journal of Experimental Child Psychology, 72. 1. sz. 1-31.

Swanson, H. L. (2011): Working memory, attention, and mathematical problem solving: A longitudinal study of elementary school children. Journal of Educational Psychology, 103. 4. sz. 821-837.

Swanson, H. L. és Jerman, O. (2007): The influence of working memory on reading growth in subgroups of children with reading disabilities. Journal of Experimental Child Psychology, 96. 4. sz. 249-283.

Swanson, H. L. és Sachse-Lee, C. (2001): Mathematical problem solving and working memory in children with learning disabilities: Both executive and phonological processes are important. Journal of Experimental Child Psychology, 79. 3. sz. 294-321.

Swanson, H. L., Ashbaker, M. H. és Lee, C. (1996): Learning-disabled readers working memory as a function of processing demands. Journal of Experimental Child Psychology, 61. 3. sz. 242-275.

Swanson, R. A. (1994): Analysis for improving performance: Tools for Diagnosing organizations and documenting workplace expertise. Berrett-Koehler, San Francisco.

Szendi, I., Kiss, M., Racsmány, M., Boda, K., Cimmer, Cs., Vörös, E., Kovács, Z., Szekeres, Gy., Galsi, G., Pléh, Cs., Csernay, L. és Janka, Z. (2006): Correlations between clinical symptoms, working memory functions and structural brain abnormalities in men with schizophrenia. Psychiatry Research: Neuroimaging, 147. 1. sz. 47-55.

Takács, Á., Kóbor, A., Tárnok, Zs. és Csépe, V. (2013): Verbal fluency in children with ADHD: Strategy using and temporal properties. Child Neuropsychology, megjelenés alatt.

Tánczos T. (2012): A végrehajtó funkciók szerepe az iskolában és a verbális fluencia tesztek. Iskolakultúra, 6. $38-51$. 
Tánczos, T., Jakab, K., Hnyilicza, Zs., Kincses, Zs. T., Németh, D. és Vécsei, L. (2012): Korai kognitív rehabilitáció akut herpes simplex vírus-1 okozta encephalitis után - esetismertetés. Rehabilitáció, 22. 2. sz. 42-50.

Tánczos, T., Janacsek, K. és Németh, D. (2014): A végrehajtó funkciók és a munkamemória feltérképezése és kapcsolata az általános iskolai teljesítménnyel. Alkalmazott Pszichológia, megjelenés alatt.

Tánczos, T., Janacsek, K. és Németh, D. (2014): A verbális fluencia tesztek I. A betüfluencia teszt magyar nyelvű vizsgálata 5-től 89 éves korig. Psychiatria Hungarica, megjelenés alatt.

Tánczos, T., Janacsek, K. és Németh, D. (2014): A verbális fluencia tesztek II. A szemantikus fluencia teszt magyar nyelvü vizsgálata 5-től 89 éves korig. Psychiatria Hungarica, megjelenés alatt.

Tánczos, T. és Németh, D. (2010): A munkamemória mérőeljárásai és szerepük az iskolai szürésben és fejlesztésben. Iskolakultúra, 7-8. 95-111.

Tánczos, T., Zádori, D., Jakab, K., Hnyilicza, Zs., Klivényi, P., Keresztes, L., Engelhardt, J., Németh, D. és Vécsei, L. (2013): The role of cognitive training in the neurorehabilitation of a patient who survived a lightning strike. A case study. Neurorehabilitation, megjelenés alatt.

Tarbuck, A. F. és Paykel, E. S. (1995): Effects of major depressionon the cognitive function of younger and older subjects. Psychological Medicine, 25. 2. sz. 285-295.

Taylor, H. G., Schatschneider, C., Petrill, S., Barry, C. T. és Owens, C. (1996): Executive dysfunction in children with early brain disease: Outcomes post Haemophilus influenzae meningitis. Developmental Neuropsychology, 12. 1. sz. 35-51.

Temple, C. M, Carney, R. A. és Mullarkey, S. (1996): Frontal lobe function and executive skills in children with Turner's syndrome. Developmental Neuropsychology, 12. 3. sz. 343-363.

Temple, C. M. (1997): Developmental cognitive neuropsychology. Psychology Press, Hove, UK.

Thompson, H. L. és Gathercole, S. E. (2006): Executive Functions and Achievements in School: Shifting, Updating, Inhibition, and Working Memory. Quarterly Journal of Experimental Psychology, 59. 4. sz. 745-759.

Thorell, L. B., Lindqvist, S., Nutley, S. B., Bohlin, G. és Klingberg, T. (2009): Training and transfer effects of executive functions in preschool children. Developmental Science, 12. 1. sz. 106-113.

Tierney, M. C., Black, S. E., Szalai, J. P., Snow, W. G., Fisher, R. H., Nadon, G. és Chui, H. C. (2001): Recognition memory and verbal fluency differentiate probable Alzheimer disease from subcortical ischemic vascular dementia. Archives of Neurology, 58. 10. sz. 1654-1659.

Tippett, L. J., Gendall, A., Farah, M. J. és Thompson-Schill, S. L. (2004): Selection ability in Alzheimer's disease: investigation of a component of semantic processing. Neuropsychology, 18. 1. sz. 163-167.

Todd, J. J. és Marois, R. (2005): Posterior parietal cortex activity predicts individual differences in visual shortterm memory capacity. Cognitive, Affective, \& Behavioral Neuroscience, 5. 2. sz. 144-155.

Toll, S. W. M., Van Der Ven, S. H. G., Kroesbergen, E. H. és Van Luit, J. E. H. (2011): Executive functions as predictors of math learning. Journal of Learning Disabilities, 44. 6. sz. 521-532.

Tombaugh, T. N., Kozak, J. és Rees, L. (1999): Normative data stratified by age and education for two measures of verbal fluency: FAS and animal naming. Archives of Clinical Neuropsychology, 14. 2. sz. 167-177.

Tomer, R. és Levin, B. E. (1993): Differential effects of aging on two verbal fluency tasks. Perceptual and Motor Skills, 76. 465-466.

Towse, J. N., Hitch, G. és Hutton, U. (1998): A reevaluation of working memory capacity in children. Journal of Memory and Language, 39. 2. sz. 195-217.

Trichard, C., Martinot, J. L., Alagille, M., Masure, M. C., Hardy, P., Ginestet, D. és Feline, A. (1995): Time course of prefrontal lobe dysfunction in severely depressed in-patients: a longitudinal neuropsychological study. Psychological Medicine, 25. 1. sz. 79-85.

Tröster, A. I., Fields, J. A., Testa, J. A., Paul, R. H., Blanco, C. R., Hames, K. A., Salmon, D. P. és Beatty, W. W. (1998): Cortical and subcortical influences on clustering and switching in the performance of verbal fluency tasks. Neuropsychologia, 36. 4. sz. 295-304.

Tröster, A. I., Salmon, D. P., McCullogh, D. és Butters, N. (1989): A comparison of the category fluency deficits associated with Alzheimer's and Huntington's disease. Brain and Language, 37. 3. sz. 500-513.

Tröster, A. I., Warmflash, V., Osorio, I., Paolo, A. M., Alexander, L. J. és Barr, W. B. (1995): The roles of semantic networks and search efficiency in verbal fluency performance in intractable temporal lobe epilepsy. Epilepsy Research, 21. 1. sz. 19-26.

Troyer, A. K. (2000): Normative data for clustering and switching on verbal fluency task. Journal of Clinical and Experimental Neuropsychology, 22. 3. sz. 370-378.

Troyer, A. K., Moscovitch, M. és Winocur, G. (1997): Clustering and switching as two components of verbal fluency: evidence from younger and older healthy adults. Neuropsychology, 11. 1. sz. 138-146.

Troyer, A. K., Moscovitch, M., Winocur, G., Alexander, M. P. és Stuss, D., (1998a): Clustering and switching on verbal fluency: the effects of focal frontal- and temporal-lobe lesions. Neuropsychologia, 36. 6. sz. 499-504. 
Troyer, A. K., Moscovitch, M., Winocur, G., Leach, L. és Freedman, M. (1998b): Clustering and switching on verbal fluency tests in Alzheimer's and Parkinson's disease. Journal of the International Neuropsychological Society, 4. 2. sz. 137-143.

Tucha, O., Mecklinger, L., Laufkotter, R., Kauzinger, I., Paul, G. M., Klein, H. E. és Lange, K. W. (2005): Clustering and switching on verbal and figural fluency functions in adults with attention deficit hyperactivity disorder. Cognitive Neuropsychiatry, 10. 3. sz. 231-248.

Tulving, E. és Markowitsch, H. J. (1998): Episodic and declarative memory: role of the hippocampus. Hippocampus, 8. 198-204.

Turley-Ames, K. J. és Whitfield, M. M. (2003): Strategy training and working memory task performance. Journal of Memory and Language, 49. 4. sz. 446-468.

Turner, M. L. és Engle, R. W. (1989): Is working memory capacity task dependent? Journal of Memory and Language, 28. 2. sz. 127-154.

Valera, E. M., Faraone, S. V., Biederman, J., Poldrack, R. A., \& Seidman, L. J. (2005): Functional neuroanatomy of working memory in adults with attention-deficit/hyperactivity disorder. Biological Psychiatry, 57. 5. sz. 439-447.

Vallar, G. (2006): Memory systems: The case of phonological short-term memory. A festschrift for Cognitive Neuropsychology. Cognitive Neuropsychology, 23. 1. sz. 135-155.

Vallar, G., DiBetta A. M. és Silveri M. C. (1997): The phonological short-term store-rehearsal system: Patterns of impairment and neural correlates, Neuropsychologia, 35. 6. sz. 795-812.

Van Den Bos, I. F., Van Der Ven, S. H. G., Kroesbergen, E. H. és Van Luit, J. E. H. (2013):Working memory and mathematics in primary school children: A meta-analysis. Educational Research Review, 10. 29-44.

Van der Elst, W., Van Boxtel, M. P. J., Van Braukelen, G. J. P. és Jolles, J. (2006): Normative data for the Animal, Profession and Letter M Naming verbal fluency tests for Dutch speaking participants and the effects of age, education, and gender. Journal of the International Neuropsychological Society, 12.1. sz. 80-89.

Van der Sluis, S., De Jong, P. F. és Van der Leij, A. (2007): Executive functioning in children, and its relations with reasoning, reading, and arithmetic. Intelligence, 35. 5. sz. 427-449.

Van Der Sluis, S., Van Der Leij, A. és De Jong, P. F. (2005): Working memory in Dutch children with readingand arithmetic-related LD. Journal of Learning Disabilities, 38. 3. sz. 207-221.

Vecchi, T., Richardson, J., Cavallini, E. (2005): Passive storage versus active processing in working memory: Evidence from age-related variations in performance. European Journal of Cognitive Psychology, 17. 4. sz. 521-529.

Vellutino, F. R., Scanlon, D. M. és Lyon, G. R. (2000): Differentiating Between Difficult-to-Remediate and Readily Remediated Poor Readers. More Evidence Against the IQ-Achievement Discrepancy Definition of Reading Disability. Journal of Learning Disabilities, 33. 3. sz. 223-238.

Verhaeghen, P., Cerella, J. és Basak, C. (2004): A Working Memory Workout: How to Expand the Focus of Serial Attention From One to Four Items in 10 Hours or Less. Journal of Experimental Psychology: Learning, Memory, and Cognition, 30. 6. sz. 1322-1337.

Vicari, S.; Bellucci, S. és Carlesimo, A. G. (2003): Visual and spatial working memory dissociation: evidence from Williams syndrome. Developmental Medicine \& Child Neurology, 45. 4. sz. 269-273.

Vitali, P., Abutalebi, J., Tettamanti, M., Rowe, J., Scifo, P., Fazio, F., Cappa, S. F. és Perani, D. (2005): Generating animal and tool names: An FMRI study of effective connectivity. Brain and Language, 93. 1. sz. 32-45.

Vogel, E. K. és Machizawa, M. G. (2004): Neural activity predicts individual differences in visual working memory capacity. Nature, 428. 748-751.

Vogel, E. K., McCollough, A. W. és Machizawa, M. G. (2005): Neural measures reveal individual differences in controlling access to working memory. Nature, 438. 500-503.

Von Cramon, D. Y., Von Cramon, G. M. és Mai, N. (1991) : Problem-solving deficits in brain-injured patients: A therapeutic approach. Neuropsychological Rehabilitation, 1. 1. sz. 45-64.

Von Károlyi, C., Winner, E., Gray, W. és Sherman, G. F. (2003): Dyslexia linked to talent: Global visual-spatial ability. Brain and Language, 85. 3. sz. 427-431.

Wager, T. D. és Smith, E. E. (2003): Neuroimaging studies of working memory. Cognitive, Affective and Behavioral Neuroscience, 3. 4. sz. 255-274.

Wagner, D. A. (1974): The development of short-term and incidental memory: A cross cultural study. Child Development, 45. 2. sz. 389-396.

Wang, P. P. és Bellugi, U. (1994): Evidence from two genetic genetic syndroms for a dissociation between verbal and visual-spatial short-term memory. Journal of Clinical and Experimental Neuropsychology, 16. 2. sz. 317-322.

Wassenberg, R., Hurks, P. P. M., Hendriksen, J. G. M., Feron, F. J. M., Meijs, C. J. C., Vles, J. H. S. és Jolles, J. (2008): Age-related improvement in complex language comprehension: Results of a cross-sectional 
study with 361 children aged 5 to 15. Journal of Clinical and Experimental Neuropsychology, 30. 4. sz. 435-448.

Waters, G. S. és Caplan, D. (1996): The capacity theory of sentence comprehension: critique of Just and Carpenter (1992). Psychological Review, 103. 4. sz. 761-772.

Waters, G. S. és Caplan, D. (2003): The reliability and stability of verbal working memory measures. Behavior Research Methods, Instruments and Computers, 35. 4. sz. 550-564

Wechsler, D. (1981): WAIS-R manual. The Psychological Corporation, New York.

Weismer, S. E. és Evans, J. (2002): The Role of Processing Limitations in Early Identification of Specific Language Impairment. Topics in Language Disorders, 22. 3. sz. 15-29.

Weismer, S. E., Evans, J. és Hesketh, L. (1999): An Examination of Verbal Working Memory Capacity in Children with Specific Language Impairment. Journal of Speech, Language and Hearing Research, 42. 1249-1260.

Weismer, S. E., Plante, E., Jones, M. és Tomblin, B. (2005): A Functional Magnetic Resonance Imaging Investigation of Verbal Working Memory in Adolescents with Specific Language Impairment. Journal of Speech, Language and Hearing Research, 48. 405-425.

Welland, R., Lubinski, R. és Higginbotham, D. J. (2002): Discourse comprehension test performance of elders with dementia of the Alzheimer type. Journal of Speech, Language, and Hearing Research, 45. 11751187.

Welsch, M. C., Pennington, B. F. és Groisser, D. B. (1991): A normative-developmental study of executive function: A window on prefrontal function in children. Developmental Neuropsychology, 7. 2. sz. 131149.

Welsh, M. C., Pennington, B. F. és Groisser, D. (1988): A normative development study of measures hypothesized to tap prefrontal functioning. Journal of Clinical and Experimental Neuropsychology, 7. 2. sz. 131-149.

Westerberg, H., Hirvikoski, T., Forssberg, H. és Klinberg, T. (2004): Visuo-Spatial Working Memory Span: A Sensitive Measure of Cognitive Deficits in Children With ADHD. Child Neuropsychology: A Journal on Normal and Abnormal Development in Childhood and Adolescence, 10. 3. sz. 155-161.

Westerberg, H., Jacobaeus, H., Hirvikoski, P., Clevberger, P., Östensson, M. L., Bartfai, A. és Klingberg, T. (2007): Computerized workingmemory training - a method of cognitive rehabilitation after stroke. Brain Injuries, 21. 1. sz. 21-29.

Wiederholt, W. C, Cahn, D., Butters, N. M, Salmon, D. P., Kritz-Silverstein, D. és Barrett-Connor, E. (1993): Effects of age, gender, and education on selected neuropsychological tests in an elderly community cohort. Journal of the American Geriatrics Society, 41. 6. sz. 639-647.

Willcutt, E. D., Doyle, A. E., Nigg, J. T., Faraone, S. V. és Pennington, B. F. (2005): Validity of the Executive Function Theory of Attention-Deficit/Hyperactivity Disorder: A Meta-Analytic Review. Biological Psychiatry, 57. 11. sz. 1336-1346.

Wilson, B. A. (2008): Neuropsychological Rehabilitation. Annual Review of Clinical Psychology, 4. 141-162.

Wilson, K. M. és Swanson, H. L. (2001) : Are Mathematics Disabilities Due to a Domain-General or a DomainSpecific Working Memory Deficit? Journal of Learning Disabilities, 34. 3. sz. 237-248.

Wolf, R. C., Vasic, N., Schonfeldt-Lecuona, C., Ecker, D. és Landwehrmeyer, G. B. (2009): Cortical dysfunction in patients with Huntington's disease during working memory performance. Human Brain Mapping, 30. 1. sz. 327-339.

Wolfe, J., Granholm, E., Butters, N., Saunders, E., \& Janowsky, D. (1987): Verbal memory deficits associated with major affective disorders: a comparison of unipolar and bipolar patients. Journal of Affective Disorders, 13. 1. sz. 83-92.

Woodruff, D. S. (1997): The Neuropsychology of Aging. Blackwell, Oxford.

Woods, R. T. (1996): Cognitive approaches to the management of dementia. In: Morris, R.G. (szerk.): The Cognitive Neuropsychology of Alzheimer-type Dementia. Oxford University Press, Oxford.

Woods, S. P., Conovere, E., Rippeth, J. D., Carey, C. L., Gonzalez, R., Marcotte, T. D., Heaton, R. K. és Grant, I. (2004): Qualitative aspects of verbal fluency in HIVassociated dementia: a deficit in rule-guided lexical-semantic search processes? Neuropsychologia, 42. 1. sz. 801-809.

Xu, Y. és Chun, M. M. (2008): Dissociable neural mechanisms supporting visual short-term memory for objects. Nature Neuroscience, 440. 91-95.

Zago, L. és Tzourio-Mazoyer, N. (2002): Distinguishing visuospatial working memory and complex mental calculation areas within the parietal lobes. Neuroscience Letters, 331. 1. sz. 45-49.

Zakzanis, K. K. (1998): The Subcortical Dementia of Huntington's Disease. Journal of Clinical and Experimental Neuropsychology, 20. 4. sz. 565-578.

Zelazo, P, D., Craik, F. I. M. és Booth, L. (2004): Executive function across the life span. Acta Psychologica, 115. 2-3. sz. 167-183. 
Zhang, G. és Simon, H. A. (1985): STM capacity for Chinese words and idioms: Chunking and acoustical loop hypotheses. Memory and Cognition, 13. 3. sz. 193-201.

Zimmer, H. D. (2008): Visual and spatial working memory: From boxes to networks. Neuroscience and Biobehavioral Reviews, 32. 8. sz. 1373-139

Zook, N., Welsh, M. C. és Ewing, W. (2006): Performance of Healthy, Older Adults on the Tower of London Revised: Associations with Verbal and Nonverbal Abilities. Aging, Neuropsychology, and Cognition: $A$ Journal on Normal and Dysfunctional Development, 13. 1. sz. 1-19. 


\section{ÁBRAJEGYZÉK}

1.ábra

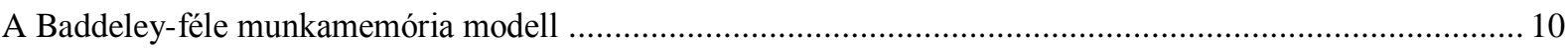

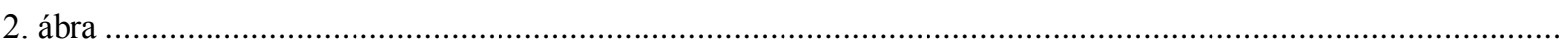

Az egyes munkamemória-komponensek és a végrehajtó funkciók mérőeljárásai, patológiái .......................... 27

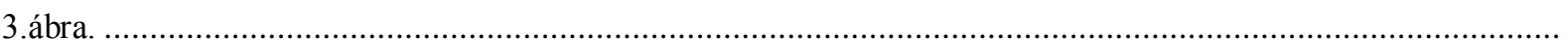

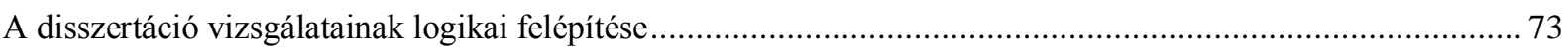

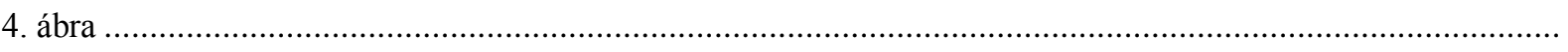

A számterjedelem, az olvasási terjedelem és a hallási mondatterjedelem tesztek profilja a különböző életkori

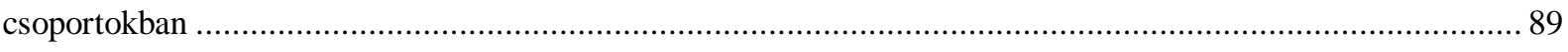

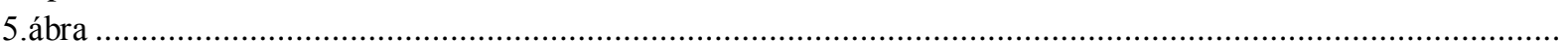

A szavak száma életkori csoportonként a „,

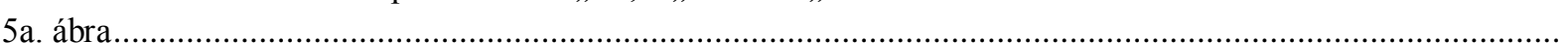

A szavak száma életkori csoportonként a „K” fluencia feladaton. ................................................................ 99

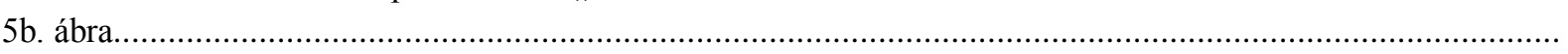

A szavak száma életkori csoportonként a „T” fluencia feladaton. ............................................................. 100

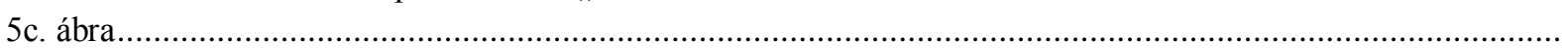

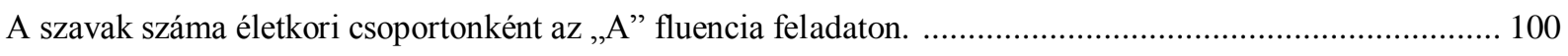

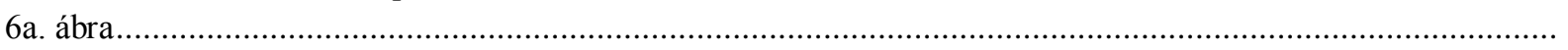

A perszeverációs mutatók életkori csoportonként a „K” fluencia feladaton...................................................... 102

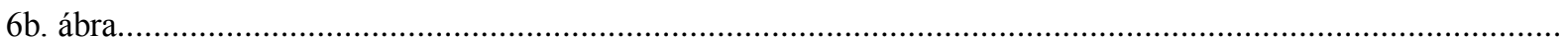

A perszeverációs mutatók életkori csoportonként a „T" fluencia feladaton. ................................................... 102

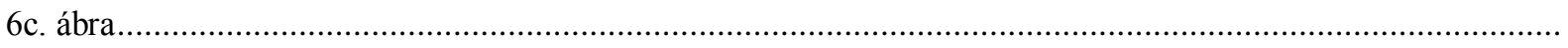

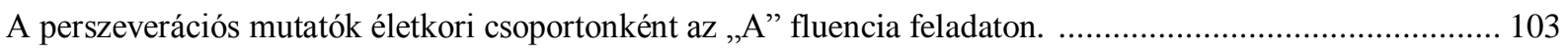

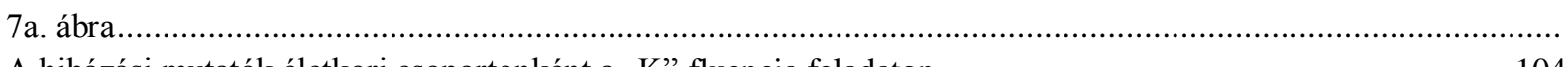

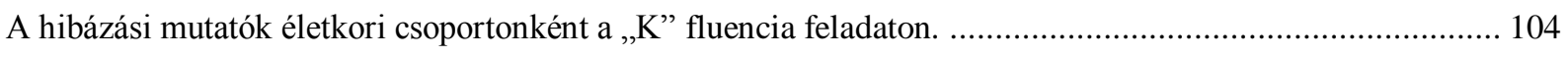

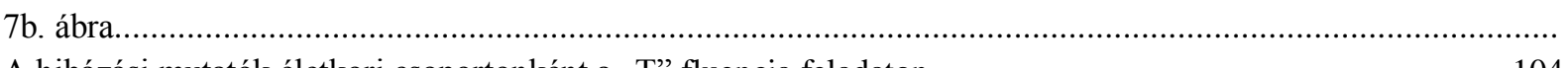

A hibázási mutatók életkori csoportonként a „T” fluencia feladaton. …….................................................. 104

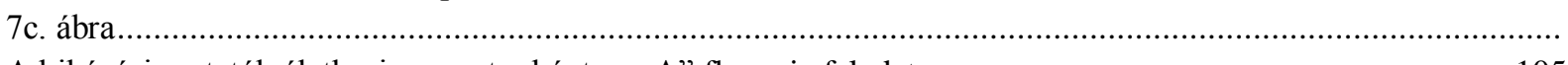

A hibázási mutatók életkori csoportonként az „A” fluencia feladaton...................................................... 105

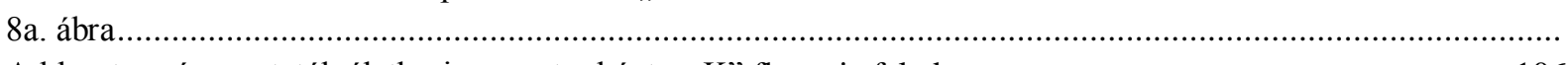

A klaszterszám mutatók életkori csoportonként a „K” fluencia feladaton. ……............................................. 106

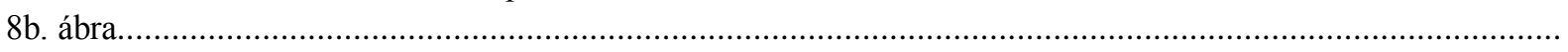

A klaszterszám mutatók életkori csoportonként a „T” fluencia feladaton....................................................... 107

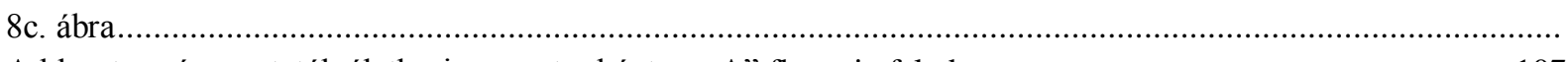

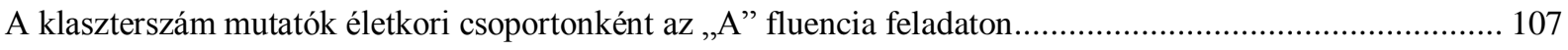

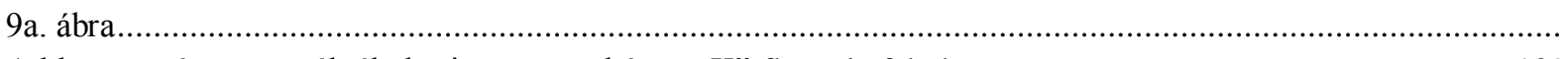

A klaszterméret mutatók életkori csoportonként a „K” fluencia feladaton........................................................ 109

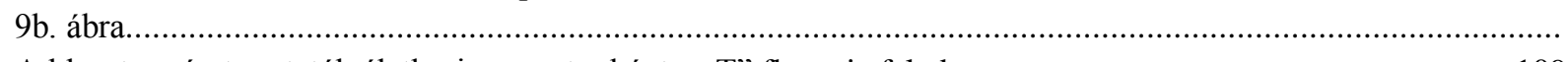

A klaszterméret mutatók életkori csoportonként a „T” fluencia feladaton.......................................................... 109

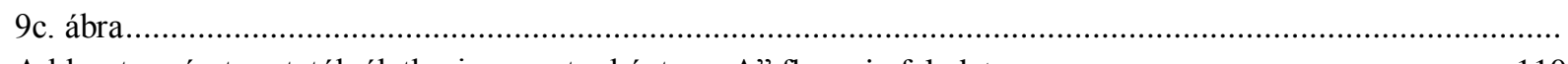

A klaszterméret mutatók életkori csoportonként az „A” fluencia feladaton. …….......................................... 110

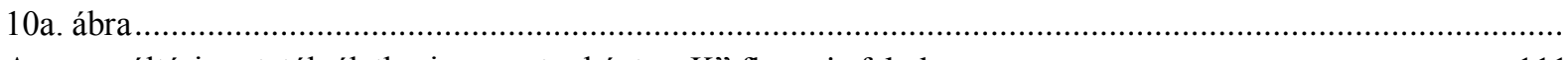

Az összváltási mutatók életkori csoportonként a „K” fluencia feladaton. ……............................................ 111

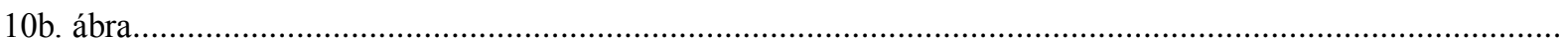

Az összváltási mutatók életkori csoportonként a „T” fluencia feladaton. ……............................................... 111

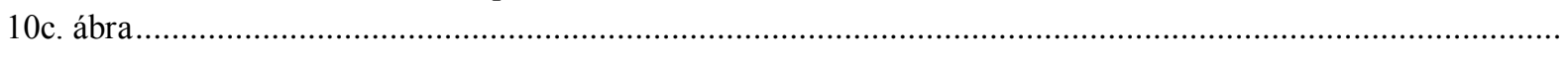

Az összváltási mutatók életkori csoportonként az „A” fluencia feladaton. .................................................. 112

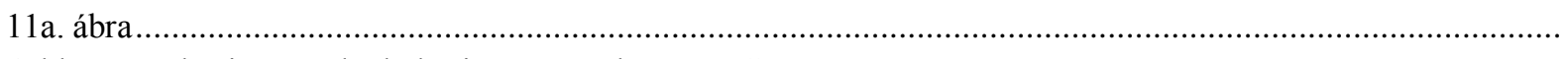

A klaszterváltási mutatók életkori csoportonként a „K” fluencia feladaton. ................................................... 112 
11b. ábra

A klaszterváltási mutatók életkori csoportonként a „T” fluencia feladaton.

11c. ábra.....

A klaszterváltási mutatók életkori csoportonként az „A” fluencia feladaton.

12.ábra

A szavak száma életkori csoportonként az „ÁLLAT”, a „GYÜMÖLCS”, és az „ÉLELMISZERBOLT” fluencia

feladaton.

12a. ábra.

A szavak száma életkori csoportonként az „ÁLLAT” fluencia feladaton.

12b. ábra.

A szavak száma életkori csoportonként a „GYÜMÖLCS” fluencia feladaton.

12c. ábra

A szavak száma életkori csoportonként az „ÉLELMISZERBOLT” fluencia feladaton.

13a. ábra.....

A perszeverációs mutatók életkori csoportonként az „ÁLLAT” fluencia feladaton.

13b. ábra.

A perszeverációs mutatók életkori csoportonként a „GYÜMÖLCS” fluencia feladaton.

13c. ábra.....

A perszeverációs mutatók életkori csoportonként az „ÉLELMISZERBOLT” fluencia feladaton.

14a. ábra....

A hibázási mutatók életkori csoportonként az „ÁLLAT” fluencia feladaton.

14b. ábra.

A hibázási mutatók életkori csoportonként a „GYÜMÖLCS” fluencia feladaton.

14c. ábra......

A hibázási mutatók életkori csoportonként az „ÉLELMISZERBOLT” fluencia feladaton.

15a. ábra......

A klaszterszám mutatók életkori csoportonként az „ÁLLAT” fluencia feladaton.

15b. ábra.

A klaszterszám mutatók életkori csoportonként a „GYÜMÖLCS” fluencia feladaton.

15c. ábra.....

A klaszterszám mutatók életkori csoportonként az „ÉLELMISZERBOLT” fluencia feladaton.

16a. ábra.....

A klaszterméret mutatók életkori csoportonként az „ÁLLAT” fluencia feladaton.

16b. ábra

A klaszterméret mutatók életkori csoportonként a „GYÜMÖLCS” fluencia feladaton.

16c. ábra.

A klaszterméret mutatók életkori csoportonként az „ÉLELMISZERBOLT” fluencia feladaton......................... 131

17a. ábra.

Az összváltási mutatók életkori csoportonként az „ÁLLAT” fluencia feladaton.

17b. ábra.

Az összváltási mutatók életkori csoportonként a „GYÜMÖLCS” fluencia feladaton.

17c. ábra.

Az összváltási mutatók életkori csoportonként az „ÉLELMISZERBOLT” fluencia feladaton. ......................... 134

18a. ábra.

A klaszterváltási mutatók életkori csoportonként az „ÁLLAT” fluencia feladaton.

18b. ábra.

A klaszterváltási mutatók életkori csoportonként a „GYÜMÖLCS” fluencia feladaton.

18c. ábra......

A klaszterváltási mutatók életkori csoportonként az „ÉLELMISZERBOLT” fluencia feladaton. 


\section{TÁBLÁZATJEGYZÉK}

1. táblázat. A végrehajtó funkciók fogalmai és komponensei .........................................................22

2. táblázat. A munkamemória folyamatok és azok idegrendszeri háttere ................................................28

3.táblázat. A betűfluncia és a szemantikus fluencia tesztek egyes mutatói a különböző pszichiátriai és neurológiai

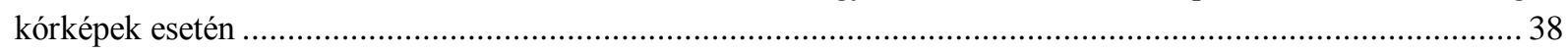

4. táblázat. A munkamemória komponenseinek méröeljárásai ................................................................46

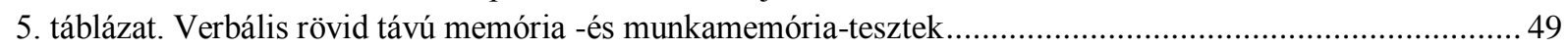

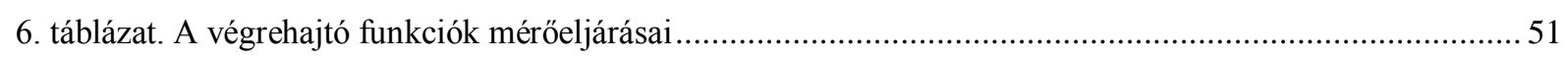

7. táblázat. A végrehajtó funkciók több aspektusú tesztbattériái ...........................................................52

8.táblázat. Az egyes verbális rövid távú -és munkamemória komponensek életkori változásai........................58

9.táblázat. Az egyes végrehajtó funkció komponensek életkori változásai .................................................61

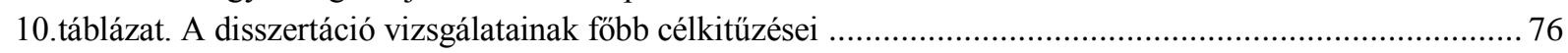

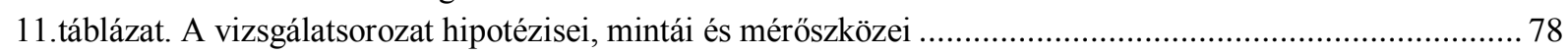

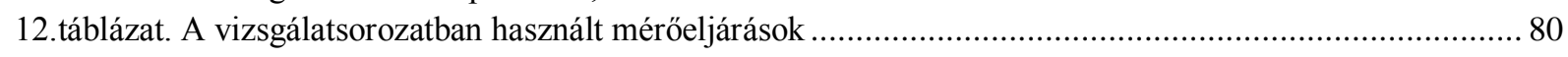

13. táblázat. A betü- és szemantikus fluencia tesztek mennyiségi és minőségi mutatói.................................. 81

14. táblázat. Az életkor átlaga és szórása az egyes életkori övezetekben .............................................. 84

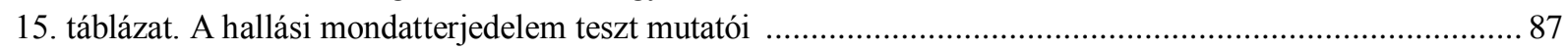

16. táblázat. Az első vizsgálatban használt tesztek átlagai és szórásai a különböző életkori övezetekben ...........88

17. Táblázat. Az első vizsgálat korrelációs mutatói a különböző életkori csoportokban;................................90

18. táblázat. Az életkor átlaga és szórása az egyes életkori övezetekben ..............................................94

19. táblázat. A magyar nyelv és irodalom tantárgyon nyújtott teljesítményt befolyásoló faktorok regresszióelemzési mutatói a 2. modell alapján....

20. táblázat. A matematika tantárgyon nyújtott teljesítményt befolyásoló faktorok regresszióelemzési mutatói az

3. modell alapján.

21. táblázat: A környezetismeret tantárgyon nyújtott teljesítményt befolyásoló faktorok regresszióelemzési

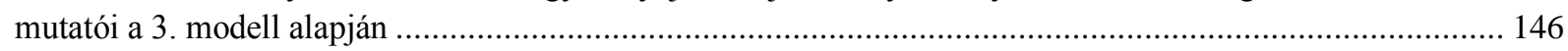

22. táblázat. A munkamemória és végrehajtó funkciók fejlesztésére használt tréningek ............................. 160

23. táblázat. A vizsgálatsorozat hipotézisei és eredményei .............................................................. 167 


\section{MELLÉKLETEK}

1. melléklet. A vizsgálatsorozatokban használt jegyzőkönyv

Ne a vizsgálat elején tedd fel az összes kérdést, hanem mindig csak néhányat, amikor látod, hogy kezd fáradni a vizsgálati személy!!! A jegyzőkönyvet próbáld meg úgy tartani, hogy a vizsgálati személy ne lássa, mit írsz!

Érdemes kb. 90 fokos szögben ülni a vizsgálati személyhez viszonyítva, így könnyebben elkerülhető, hogy lássa a jegyzőkönyvet, valamint rugalmasabban lehet helyet változtatni, pl. ha Corsi kockánál szembe kell fordulni.

Név:

Nem: $\quad \mathrm{N} / \mathrm{F}$

Születési dátum:

Iskolázottság (év):

Zene (milyen hangszer, hány évig):

Nyelv (milyen nyelv, milyen szint, hány évig tanulta):

Szülők iskolai végzettsége (években is!): HA NEM TUDJA, OSZTÁLYFÖNÖKÖT MEGKÉRDEZNI!
Vizsgálatvezető:

Vizsgálat időpontja:

Vizsgálat helye:

Kísérleti személy száma:

\section{ANYA -}

Szülök munkahelye, foglalkozása:

ANYA -
APA -

$\mathrm{APA}-$

Egészségügyi problémák (időseknél; mikor, meddig tartott, kezelése, gyógyszereket szed?..):

Elsősorban olyan betegségekre kérdezz rá, ami az agymüködésre, és ennek nyomán a kognitív funkciókra is kihathat, pl. különböző pszichiátriai problémák, szív- és érrendszeri betegségek, stb.

Hány órát aludt az elmúlt 24 órában?.

Hányan élnek egy háztartásban (írd le, pontosan kik)?

Hány szobás a lakás/ház (csak azok a szobák, ahol alszanak)?

Hány könyv van a lakásban/házban? (nagyjából, kb.)

Hány testvére van?

1. testvére neme: életkora: Vele él?

2. testvére neme: életkora: Vele él?

3. testvére neme: életkora: Vele él?

Hányan alszanak vele egy szobában (rajta kívül)?

Hány autója van a családnak (saját vagy céges?)?

Voltak-e nyaralni idén? I / N Ha igen, hol? Mennyi ideig? 
(Ha több helyen is voltak, írd le mindet)

Milyen délutáni foglalkozásokra jár? (sport, zene, nyelv)

Van-e saját telefonja? I / N Okostelefon? I/ N

\section{SZÁMÍTÓGÉPEZÉSI SZOKÁSOK:}

Van-e otthon saját? Mióta? Mennyit használod?

Mire szoktad használni (részletes válasz, programok felsorolásával)?

Milyen játékokkal szoktál játszani (pl. lövöldözős, stratégiai, szerepjáték, memória, stb.)

JÁTÉK(OK) NEVE(I):

Milyen gyakorisággal játszol ezekkel a játékokkal?

\section{TÁRSAS KÉSZSÉGEK}

Mennyire szeretsz a többi gyerek között lenni?

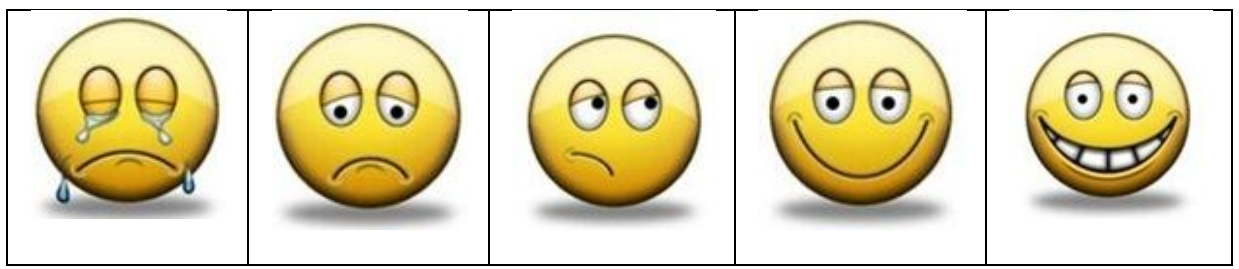

Sorold fel 3 osztálytársadat, akivel szívesen töltenél együtt több időt (teljes neveket)!

1.

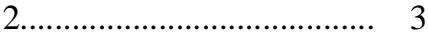

Sorold fel 3 osztálytársadat, akivel a legkevésbé töltenél együtt több időt (teljes neveket)!

1.

2

3.

Sorold fel 3 osztálytársadat, aki szerinted valamilyen területen (müvészet, tudomány, más ) tehetséges?

1.

Kik a legjobb barátaid az osztálytársaid közül?

3.

Ha az osztályfönököd hosszabb ideig akadályoztatva lenne az osztály vezetésére, a tanulók közül ki lenne a legalkalmasabb a helyettesítésére?

1.

2.

3

Véleményed szerint az osztályon belüli vitákat melyik osztálytársad tudná igazságosan feloldani?

1.

2

3.

Kik azok, akiket a tanulók közül a legtöbben szeretnek?

1.

2

3.

TÁRSAS KÉSZSÉGEK - OKTATÓI KÉRDÖÍV 
Pontozza 1-10-ig, hogy mennyire könnyen teremt, kezdeményez társas kapcsolatokat a gyerek?

Mi a gyerek kedvenc tevékenysége - szünetekben: órán: ?

Csoportban vagy egyedül szeret-e inkább játszani/tartózkodni a gyerek?

Pontozza 1-10-ig, hogy mennyire feladathelyzetben mennyire vesz részt aktívan a gyerek?

Pontozza 1-10-ig, hogy mennyire tartja jó képességünek/intelligensnek a gyereket?

Van-e valamilyen nehézsége a gyereknek? (pl. HHH - halmozottan hátrányos helyzet, BTM beilleszkedési/tanulási/magatartási nehezítettség, SNI-speciális nevelési igény, pl. diszlexia, stb.)

\section{ÁLSZÓ ISMÉTLÉSI TESZT}

Eljárás: A szavakat monoton hangon, hangsúlyozás nélkül kell felolvasni.

\begin{tabular}{l|l|l|l|l}
\hline \hline 1 Szótagúak: & gáv & gyem & szan & dólk \\
\hline 2 Szótagúak: & zomás & galonc & gabam & ardul \\
\hline 3 Szótagúak: & tarembik & cselika & hübedin & vazóga \\
\hline 4 Szótagúak: & tipebanér & limefürék & serkápanta & berszidelén \\
\hline 5 Szótagúak: & hápamarogány & gyilonitora & tesilbengecsék & fortiklempelesz \\
\hline 6 Szótagúak: & abalamofálsag & sémernyegvőterec & hulukatánatalm & innécsésziderszil \\
\hline 7 Szótagúak: & dögeliztetmereni & kusztenirselemenég & intogszocolarásu & töminegéveltemérg \\
\hline 8 Szótagúak: & igyótanumazálubirc & polankilimapszilógis & elüsekéketérsenim & réfjenólpáulatamú \\
\hline 9 Szótagúak: & vanatyfovagyatázolarka & labatobanrapolsazridant & ninolamebefalintelék & szikunblómitilaradiga \\
\hline \hline
\end{tabular}

Terjedelem: 


\section{SZÁMTERJEDELEM TESZT}

Eljárás: A vizsgálatvezető egyenként olvassa fel a számokat 1 másodperces szünetet tartva minden szám után. Csak a pontosan megismételt számsorozat fogadható el, kihagyott és felcserélt számok egyaránt hibásnak számítanak. Akkor megyünk tovább, ha 4-böl 3-at helyesen visszamondott.

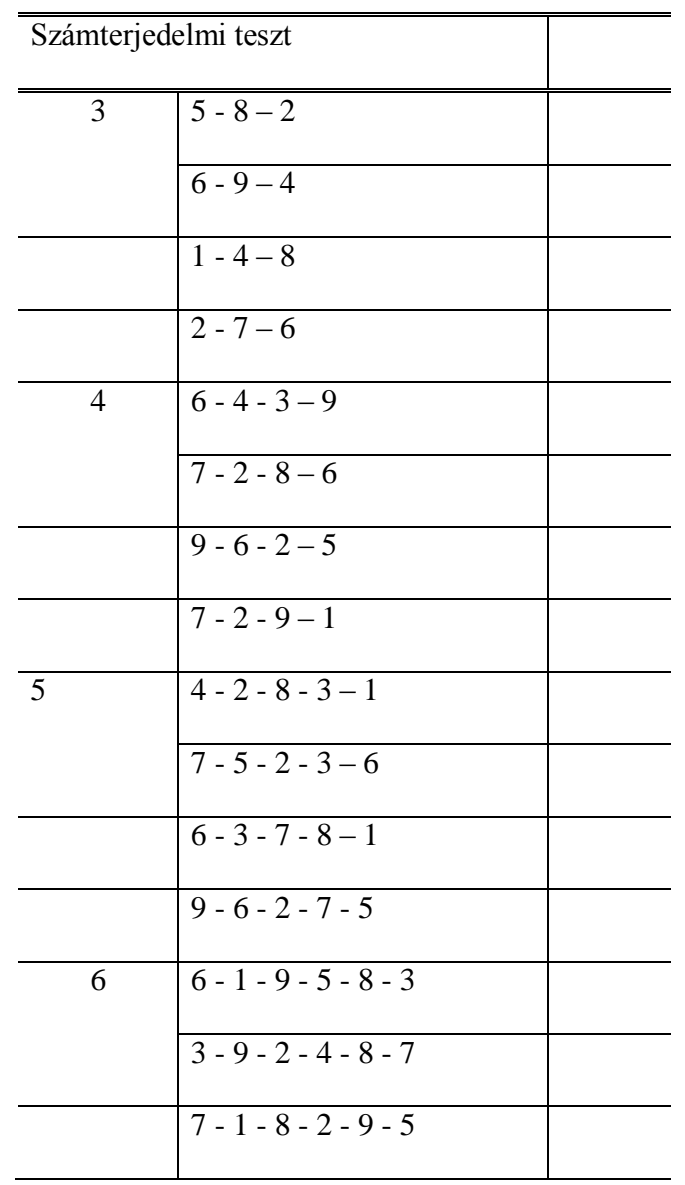

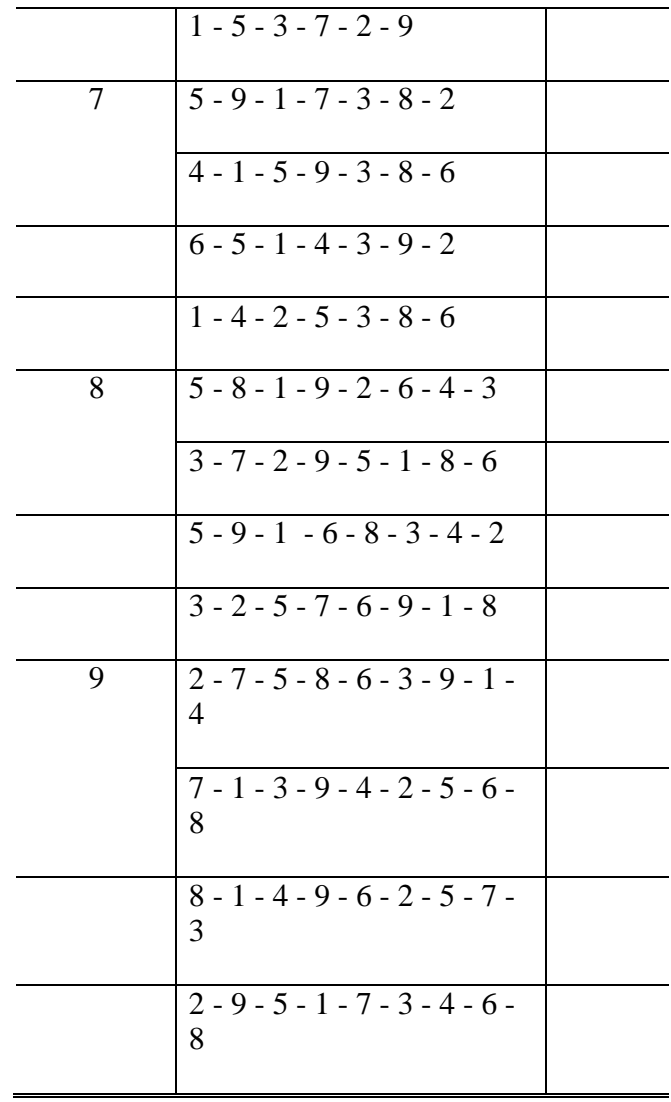

Számterjedelem:

\section{CORSI-KOCKA TESZT}

Eljárás: A vizsgálatvezető sorban mutat a számoknak megfelelő kockákra 1 másodperces szünetet hagyva közötte. A vizsgálati személynek ugyanebben a sorrendben kell a kockákra mutogatnia. Akkor megyünk tovább, ha a 4-ből 3-at helyes sorrendben tudott. A vizsgálati személynek nem szabad látnia, hogy a Corsi kockákon számok vannak! Ezért ajánlatos úgy elhelyezkedni, hogy a vizsgálatvezető SZEMBEN üljön a vizsgálati személlyel! 


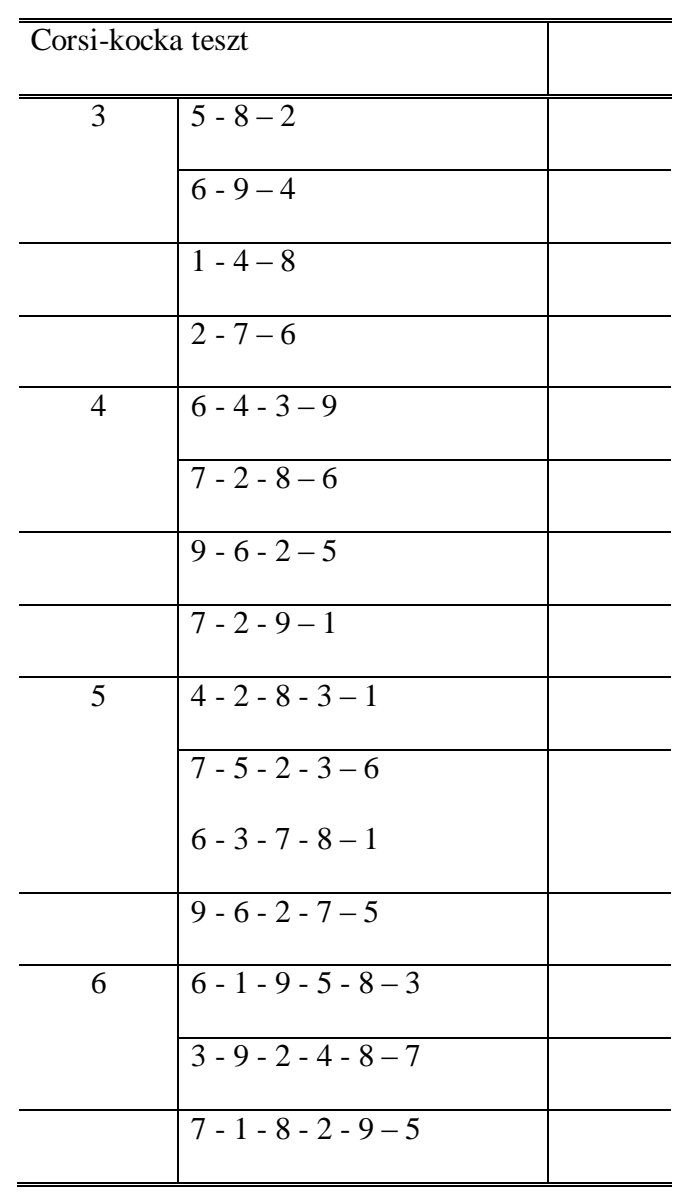

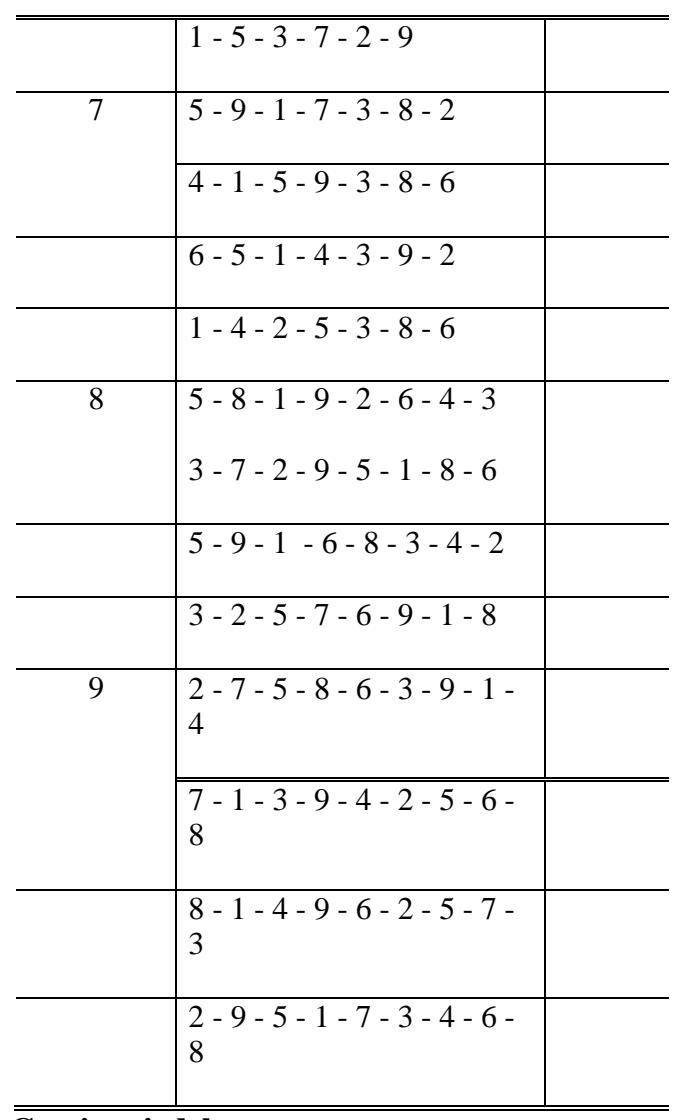

\section{Corsi terjedelem:}

\section{VERBÁLIS FLUENCIATESZT (DIKTAFON) - 1. felvétel}

Mindegyik feladatnál 1 perc áll rendelkezésre! Tulajdonneveket és ugyanannak a szónak a különböző végződéseit nem mondhatja!

\section{Betüfluencia}

1. „Mondjon annyi szót amennyi csak eszébe jut, amelyik „,k” betüvel kezdődik”

2. Mondjon annyi szót amennyi csak eszébe jut, amelyik „„t” betüvel kezdődik”

3. Mondjon annyi szót amennyi csak eszébe jut, amelyik „a” betűvel kezdődik”

\section{Szemantikus fluencia}

1. „Mondjon annyi állatot, amennyi csak eszébe jut”

2. „Mondjon annyi gyümölcs nevet, amennyi csak eszébe”

\section{Epizodikus fluencia}

1. „Mondjon, olyan árukat, melyeket élelmiszerboltban lehet vásárolni”

2. „Mondjon, olyan dolgokat, melyek a lakásodban vannak” 


\section{FORDÍTOTT SZÁMTERJEDELEM}

Eljárás: A vizsgálatvezető egyenként olvassa fel a számokat 1 másodperces szünetet tartva minden szám után. Csak a pontosan megismételt számsorozat fogadható el, kihagyott és felcserélt számok egyaránt hibásnak számítanak.

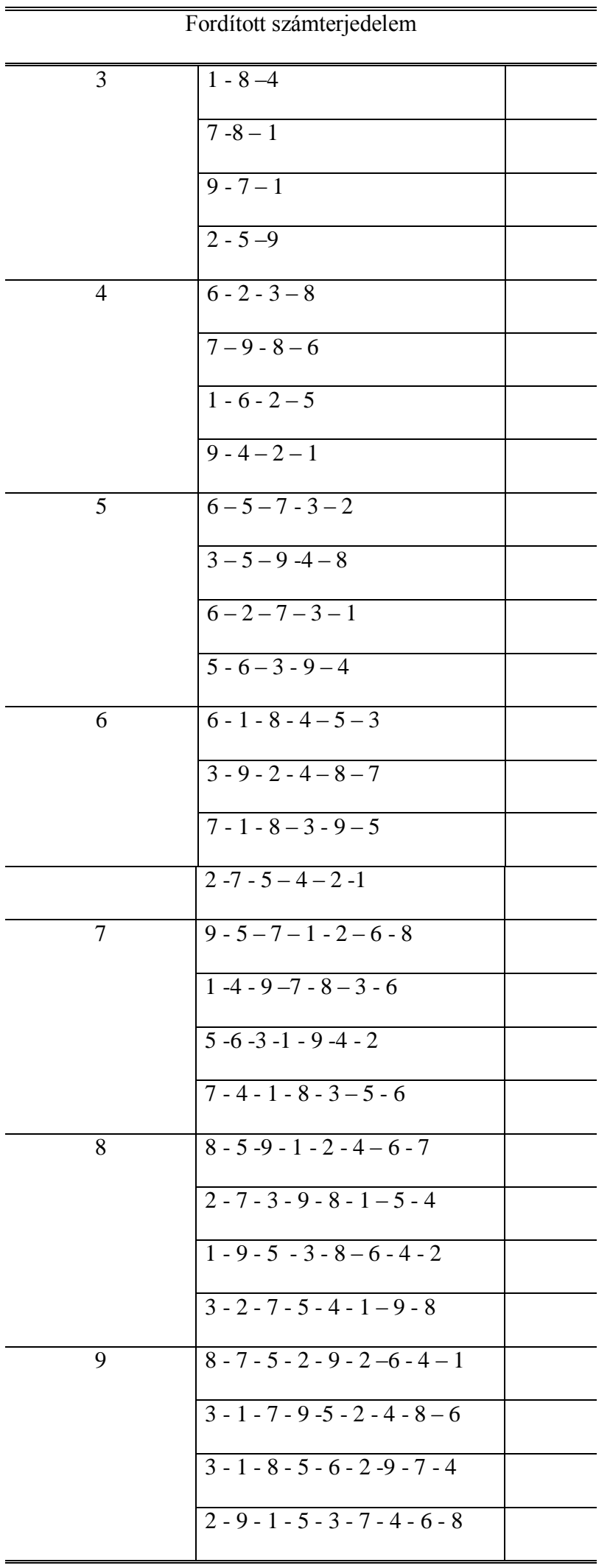




\section{SZÁMLÁLÁSI TERJEDELEM}

Eljárás: Pipával jelöld, ha helyesen, sorrendben mondta vissza a számokat! Hangsúlyozd, hogy annyi ideje van megszámolni a kék köröket, amennyire csak szüksége van, így elkerülhető, hogy rosszul számol és a rossz számot mondja vissza! Ha ez mégis megtörténik, akkor azt jelöld a jegyzökönyvben, de ne vedd hibának! Ha a vizsgálati személy nem (jól) emlékszik a számokra, akkor nem kell folytatni azt a sorozatot, hanem a CRTL+ SHIFT majd pedig a SZÓKÖZ megnyomásával ki lehet lépni az adott sorozatból. A program indításakor a SUBJECT NUMBER a vizsgálati személy száma lesz, SESSION-nek pedig mindig azt a számot kell beírni, ahanyadik sorozatot csináljuk! Ha a program megkérdezi, hogy felülírja-e a már létező fájlt, akkor valamit elrontottál a számozás során!!!

\section{Gyakorlás}

a)

$\underline{3}$

7

\section{SOROZAT}

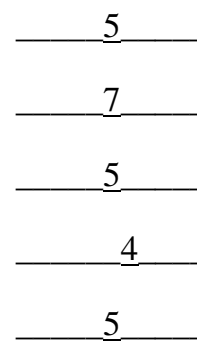

\section{SOROZAT}
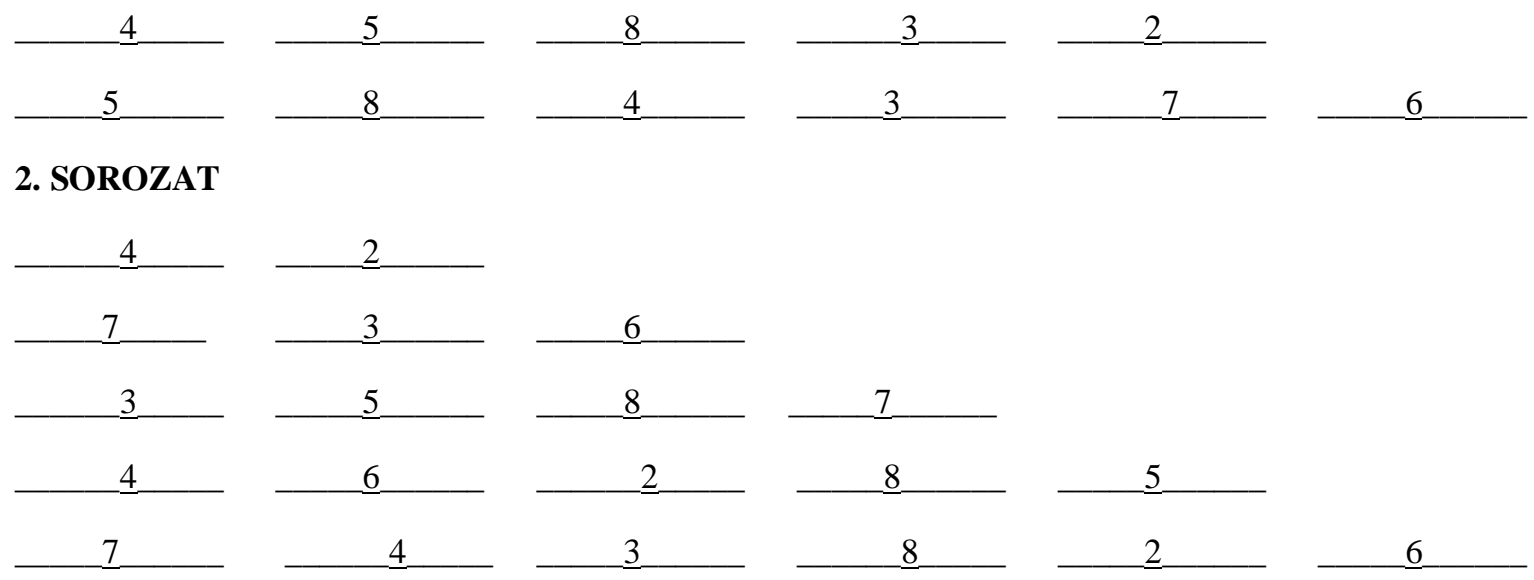

\section{SOROZAT}
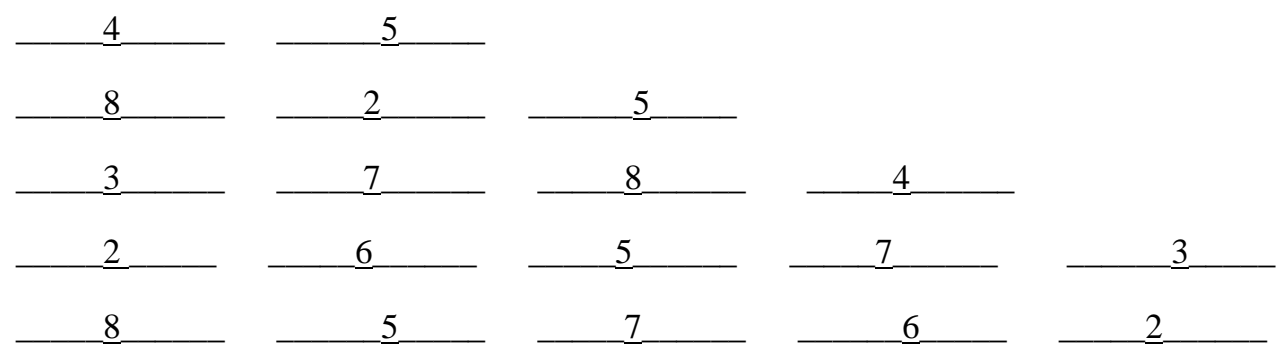

Terjedelem (a három sorozat átlaga): 


\section{HALLÁSI MONDATTERJEDELEM TESZT}

Eljárás: A vizsgálatvezető felolvas egy mondatot, amiről a vizsgálati személynek meg kell állapítania, hogy az igaz vagy hamis, valamint meg kell jegyeznie az utolsó szót (de nem kimondani). Ezután a vizsgálatvezető felolvassa a következő mondatot, erről is meg kell állapítania a vizsgálati személynek, hogy igaz vagy hamis, és itt is meg kell jegyezni az utolsó szót a mondatban. Amikor az adott blokkon belül (először ez a két mondat) az összes mondat elhangzott, a vizsgálati személynek a mondat utolsó szavait (amiket korábban nem mondott ki) kell megismételni az elhangzás sorrendjében. Ha ez sikerül, akkor lehet továbblépni a következő blokkra. HA NEM TUDTA HELYES SORRENDBEN VISSZAMONDANI A SZAVAKAT, UGRUNK A KÖVETKEZÖ SOROZATRA. Ha az igaz/hamis döntésben hibázott, azt még elfogadjuk!

\begin{tabular}{|c|c|c|c|}
\hline Mondatok I. Sorozat & Igaz/hamis & Válasz & Megjegyzés \\
\hline $\begin{array}{l}\text { 1. Egy iskolás gyerek táskájában sok a füzet. } \\
\text { 2. A négylábú madarak közé tartozik a veréb. }\end{array}$ & $\begin{array}{l}\mathrm{I} \\
\mathrm{H}\end{array}$ & & \\
\hline $\begin{array}{l}\text { 1. A legtöbb nőnél van az utcán táska. } \\
\text { 2. Az érett banánt nagyon szereti a majom. } \\
\text { 3. A házak tetején mindig van pince. }\end{array}$ & $\begin{array}{l}\mathrm{I} \\
\mathrm{I} \\
\mathrm{H}\end{array}$ & & \\
\hline $\begin{array}{l}\text { 1. A varrónő által gyakran használt eszköz az olló. } \\
\text { 2. Az egyik leglassabb állat a világon a csiga. } \\
\text { 3. A madarak csőrében mindig sok a kávé. } \\
\text { 4. A könyvtárban sok a kölcsönözhető ruha. }\end{array}$ & $\begin{array}{l}\mathrm{I} \\
\mathrm{I} \\
\mathrm{H} \\
\mathrm{H}\end{array}$ & & \\
\hline $\begin{array}{l}\text { 1. Húsvétkor ritkán fogyasztott étel a tojás. } \\
\text { 2. Lakott területeken elterjedt rágcsáló az egér. } \\
\text { 3. Az erös széltől könnyen felborulhat a csónak. } \\
\text { 4. A szoba kifestéséhez mindig kell szoknya. } \\
\text { 5. Az emeletes házakban általában van lépcső. }\end{array}$ & $\begin{array}{l}\mathrm{H} \\
\mathrm{I} \\
\mathrm{I} \\
\mathrm{H} \\
\mathrm{I}\end{array}$ & & \\
\hline $\begin{array}{l}\text { 1. A szemét tárolására alkalmas tárgy a kuka. } \\
\text { 2. A meleg tea sokak által kedvelt ital. } \\
\text { 3. Hazánk erdőiben megtalálható a növényevő tigris. } \\
\text { 4. A fújós hangszerek közé tartozik a villa. } \\
\text { 5. Télen a hideg ellen elkél egy kabát. } \\
\text { 6. Minden iskolás táskájában van függöny. }\end{array}$ & $\begin{array}{l}\mathrm{I} \\
\mathrm{I} \\
\mathrm{H} \\
\mathrm{H} \\
\mathrm{I} \\
\mathrm{H}\end{array}$ & & \\
\hline $\begin{array}{l}\text { 1. Télen sok ember lábán van csizma. } \\
\text { 2. A hús felszelésére alkalmas eszköz a kanál. } \\
\text { 3. Falkában élő ragadozó állat a farkas. } \\
\text { 4. Minden szilveszterkor jellegzetes ital a pezsgö } \\
\text { 5. Lila színü minden érett alma. } \\
\text { 6. A legtöbb híd oldalán van korlát. } \\
\text { 7. Minden ember kedvenc hangszere a gitár. }\end{array}$ & $\begin{array}{l}\mathrm{I} \\
\mathrm{H} \\
\mathrm{I} \\
\mathrm{I} \\
\mathrm{H} \\
\mathrm{I} \\
\mathrm{H}\end{array}$ & & \\
\hline $\begin{array}{l}\text { 1. Sokféle gyümölcs termőhelye a csörgedező patak. } \\
\text { 2. A legtöbbet használt természetes édesítő a cukor. } \\
\text { 3. A mogyorós csoki egy nagyon veszélyes fegyver. } \\
\text { 4. Régen fából készült minden szekrény. } \\
\text { 5. Vízben élő ebihalból fejlödik ki a béka. } \\
\text { 6. A déli sarkvidéken található minden fenyő. } \\
\text { 7. A spagetti elkészítéséhez általában kell tészta. } \\
\text { 8. A tavasz első hírnöke a fehér kecske. }\end{array}$ & $\begin{array}{l}\mathrm{H} \\
\mathrm{I} \\
\mathrm{H} \\
\mathrm{I} \\
\mathrm{I} \\
\mathrm{H} \\
\mathrm{I} \\
\mathrm{H}\end{array}$ & & \\
\hline
\end{tabular}




\begin{tabular}{|c|c|c|c|}
\hline Mondatok II. Sorozat & Igaz/hamis & Válasz & Megjegyzés \\
\hline $\begin{array}{l}\text { 1. Két lábon jár minden kígyó. } \\
\text { 2. A gyerekek egyik kedvenc játéka a labda. }\end{array}$ & $\begin{array}{l}\mathrm{H} \\
\mathrm{I}\end{array}$ & & \\
\hline $\begin{array}{l}\text { 1. Nagy károkat képes okozni a vihar. } \\
\text { 2. A kopasz emberek haját vágja le a fodrász. } \\
\text { 3. A bokron termő málnát szereti a medve. }\end{array}$ & $\begin{array}{l}\mathrm{I} \\
\mathrm{H} \\
\mathrm{I}\end{array}$ & & \\
\hline $\begin{array}{l}\text { 1. Az állatok királya a mesékben a hangya. } \\
\text { 2. Könnyen eltörhet a kemény felületre leejtett pohár. } \\
\text { 3. Az alma egy föld alatt termö gyümölcs. } \\
\text { 4. Sok ember által használatos ruhadarab a nadrág. }\end{array}$ & $\begin{array}{l}\mathrm{H} \\
\mathrm{I} \\
\mathrm{H} \\
\mathrm{I}\end{array}$ & & \\
\hline $\begin{array}{l}\text { 1. Jó hangulatot teremt egy meghitt estén a gyertya. } \\
\text { 2. Sok állatnak ad otthont a mezö. } \\
\text { 3. Minden ház ablakában van narancs. } \\
\text { 4. A bálna egy kicsi, háromszárnyú madár. } \\
\text { 5. A kukákban néha felgyülemlik a sok szemét }\end{array}$ & $\begin{array}{l}\mathrm{I} \\
\mathrm{I} \\
\mathrm{H} \\
\mathrm{H} \\
\mathrm{I}\end{array}$ & & \\
\hline $\begin{array}{l}\text { 1. Nyulakra is szeret vadászni a ravasz róka. } \\
\text { 2. Minden szoba közepén van egy zászló. } \\
\text { 3. A milánói makaróni egy jellegzetes, magyar étel. } \\
\text { 4. Az iskolában az óra végét jelzi a csengő. } \\
\text { 5. A biciklinél sokkal gyorsabb jármú a vonat. } \\
\text { 6. Az építkezéseken használt emelő neve pipa. }\end{array}$ & $\begin{array}{l}\mathrm{I} \\
\mathrm{H} \\
\mathrm{H} \\
\mathrm{I} \\
\mathrm{I} \\
\mathrm{H}\end{array}$ & & \\
\hline $\begin{array}{l}\text { 1. Számos dolgot elárul a jósnőnek a kártya. } \\
\text { 2. A villamos egy kicsi, lassan közlekedö bogár. } \\
\text { 3. Megvédi a hidegtől az ember fejét a sapka. } \\
\text { 4. Télen nagy pelyhekben hull a cserép. } \\
\text { 5. Minden állat hátán van táska. } \\
\text { 6. Sokféle ételnek ad helyet a kamra. } \\
\text { 7. A szeder egy fán termö, édes zöldség. }\end{array}$ & $\begin{array}{l}\mathrm{I} \\
\mathrm{H} \\
\mathrm{I} \\
\mathrm{H} \\
\mathrm{I} \\
\mathrm{I} \\
\mathrm{H}\end{array}$ & & \\
\hline $\begin{array}{l}\text { 1. A támadás ellen tüskéivel védekezik a malac. } \\
\text { 2. Minden háztartásban fontos dolog a járda. } \\
\text { 3. Piros színü, keserü gyümölcs a banán. } \\
\text { 4. A hegységekben sok a nehezen megmászható szikla. } \\
\text { 5. Nyáron a folyók mellett sok a horgász. } \\
\text { 6. A pingvin egy Európában élö, költözö rovar. } \\
\text { 7. A sóder egyik fontos összetevő̉je a kavics. } \\
\text { 8. Sok terem padlóját borítja szőnyeg. }\end{array}$ & $\begin{array}{l}\mathrm{H} \\
\mathrm{H} \\
\mathrm{H} \\
\mathrm{I} \\
\mathrm{I} \\
\mathrm{H} \\
\mathrm{I} \\
\mathrm{I}\end{array}$ & & \\
\hline
\end{tabular}




\begin{tabular}{|c|c|c|c|}
\hline Mondatok III. Sorozat & Igaz/hamis & "Válasz & Megjegyzés \\
\hline $\begin{array}{l}\text { 1. A gyerekek egyik kedvenc édessége a torta. } \\
\text { 2. A házak tetején télen füstöl a kémény. }\end{array}$ & $\begin{array}{l}\text { I } \\
\text { I }\end{array}$ & & \\
\hline $\begin{array}{l}\text { 1. Tízlábú, vízben élő állat a bika. } \\
\text { 2. Könnyen eltörhet a porcelánból készült tányér. } \\
\text { 3. Eső előtt általában sok az égen a felhö. }\end{array}$ & $\begin{array}{l}\mathrm{H} \\
\mathrm{I} \\
\mathrm{I}\end{array}$ & & \\
\hline $\begin{array}{l}\text { 1. Fán termö, keserü növény a hagyma. } \\
\text { 2. Minden folyó mélyén van egy torony. } \\
\text { 3. Védelmet adhat sok állatnak a barlang. } \\
\text { 4. A kicsi egér nagy ellensége a macska. }\end{array}$ & $\begin{array}{l}\mathrm{H} \\
\mathrm{H} \\
\mathrm{I} \\
\mathrm{I}\end{array}$ & & \\
\hline $\begin{array}{l}\text { 1. Sok embert szórakoztat esténként a tévé. } \\
\text { 2. Tengerekben élö, okos állat a kakas. } \\
\text { 3. A hegyekben az olvadó hótól megárad a folyó. } \\
\text { 4. Takarításnál gyakran használt eszköz a csésze. } \\
\text { 5. A pékségben készül a finom, meleg kenyér. }\end{array}$ & $\begin{array}{l}\mathrm{I} \\
\mathrm{H} \\
\mathrm{I} \\
\mathrm{H} \\
\mathrm{I}\end{array}$ & & \\
\hline $\begin{array}{l}\text { 1. A liliom egy csúnya, rovarokkal táplálkozó virág. } \\
\text { 2. A legyet hálójában ejti foglyul a mókus. } \\
\text { 3. A mai fürdőszobák többségében van tükör. } \\
\text { 4. Hideg téli estéken befúti a lakást a kályha. } \\
\text { 5. A kislányok haját gyakran díszíti szalag. } \\
\text { 6. A tehenek kedvenc étele a fött sonka. }\end{array}$ & $\begin{array}{l}\mathrm{H} \\
\mathrm{H} \\
\mathrm{I} \\
\mathrm{I} \\
\mathrm{I} \\
\mathrm{H}\end{array}$ & & \\
\hline $\begin{array}{l}\text { 1. Megfázáskor jó a toroknak a hideg beton } \\
\text { 2. Egy ma is élö, kistermetủ állat a patkány. } \\
\text { 3. Sokféle holmi tárolására alkalmas tárgy a doboz. } \\
\text { 4. A macskák kedvenc étele a friss borsó. } \\
\text { 5. Sok lakásban ég esténként a lámpa. } \\
\text { 6. A sivatagokban nagy dünéket alkot a homok. } \\
\text { 7. Kistermetü rágcsáló a mezőkön ugrándozó tehén. }\end{array}$ & $\begin{array}{l}\mathrm{H} \\
\mathrm{I} \\
\mathrm{I} \\
\mathrm{H} \\
\mathrm{I} \\
\mathrm{I} \\
\mathrm{H}\end{array}$ & & \\
\hline $\begin{array}{l}\text { 1. A kertes házakhoz általában tartozik udvar. } \\
\text { 2. Méhek által gyüjtött nektárból készül a leves. } \\
\text { 3. Sok beteget ápol a kórházban a nővér. } \\
\text { 4. Az osztriga tengerekben élő, ehetö kagyló. } \\
\text { 5. Üvegből készül minden női cipő. } \\
\text { 6. A hazánk északi részén áthaladó Rajna egy hegység. } \\
\text { 7. A legtöbb városban van legalább egy kocsma. } \\
\text { 8. A Mars egy emberek által lakott bolygó. }\end{array}$ & $\begin{array}{l}\mathrm{I} \\
\mathrm{H} \\
\mathrm{I} \\
\mathrm{I} \\
\mathrm{H} \\
\mathrm{H} \\
\mathrm{I} \\
\mathrm{H}\end{array}$ & & \\
\hline ÖSSZESEN (a három sorozat átlaga) & & & \\
\hline
\end{tabular}


2a. melléklet. A szavak száma a „K” fluencia feladat esetében az egyes életkori csoportokban

\begin{tabular}{|c|c|c|c|c|c|c|c|c|c|c|}
\hline \multirow{2}{*}{$\begin{array}{l}\text { Életkori } \\
\text { csoport }\end{array}$} & \multirow[t]{2}{*}{$\mathbf{N}$} & \multirow[t]{2}{*}{ Átlag } & \multirow[t]{2}{*}{ Szórás } & \multicolumn{7}{|c|}{ Percentilisek } \\
\hline & & & & 5 & 10 & 25 & 50 & 75 & 90 & 95 \\
\hline 5-6 év & 443 & $\begin{array}{l}1,81 \\
\end{array}$ & 2,14 & 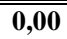 & "0,00 & "0,00 & $\bar{~} 1,00$ & 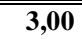 & "4,00 & 25,60 \\
\hline $7-8$ év & 58 & 5,16 & 3,32 & 1,00 & 1,00 & 2,00 & 5,00 & 7,25 & 9,00 & 12,00 \\
\hline 9-10 év & 56 & 8,73 & 3,10 & 3,85 & 5,00 & 7,00 & $\mathbf{9 , 0 0}$ & 10,00 & 13,00 & 16,00 \\
\hline 11-12 év & 65 & 11,34 & 4,29 & 5,00 & 5,60 & 8,00 & 11,00 & 14,00 & 18,00 & $\overline{19,00}$ \\
\hline 13-14 év & 54 & 11,33 & 3,96 & 4,75 & 6,00 & 8,00 & 12,00 & 14,00 & 16,50 & 18,00 \\
\hline 15-16 év & 64 & 15,13 & 4,13 & 8,00 & 9,00 & 12,25 & 15,00 & 18,75 & 20,00 & 21,00 \\
\hline 17-18 év & 77 & 16,32 & 5,42 & 6,90 & 9,80 & 13,00 & 16,00 & 19,00 & 24,00 & 26,10 \\
\hline 19-34 év & 62 & 17,13 & 5,91 & 9,00 & 10,00 & 12,00 & 16,00 & 22,00 & 25,00 & 27,85 \\
\hline 35-49 év & 36 & 18,33 & 5,31 & 6,00 & 12,70 & 15,00 & 18,00 & 22,00 & 25,00 & 29,15 \\
\hline 50-69 év & 23 & 12,52 & 5,27 & 6,00 & 6,00 & 9,00 & 11,00 & 15,00 & 22,80 & 24,00 \\
\hline $70-89$ év & 23 & 12,22 & 4,17 & 6,20 & 7,00 & 9,00 & 12,00 & 15,00 & 17,60 & 22,00 \\
\hline
\end{tabular}

2b. melléklet. A szavak száma a „T” fluencia feladat esetében az egyes életkori csoportokban

\begin{tabular}{|c|c|c|c|c|c|c|c|c|c|c|}
\hline \multirow{2}{*}{$\begin{array}{l}\text { Életkori } \\
\text { csoport }\end{array}$} & \multirow[t]{2}{*}{$\mathbf{N}$} & \multirow[t]{2}{*}{ Átlag } & \multirow[t]{2}{*}{ Szórás } & \multicolumn{7}{|c|}{ Percentilisek } \\
\hline & & & & 5 & 10 & 25 & 50 & 75 & 90 & 95 \\
\hline 5-6 év & 43 & $1, \mathbf{1 , 5 6}$ & $2, \mathbf{2 , 3 0}$ & $\mathbf{0 , 0 0}$ & (20,00 & $\begin{array}{l}\mathbf{0 , 0 0} \\
\end{array}$ & 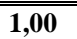 & $2, \mathbf{2 , 0 0}$ & ב,60 & ב4,80 \\
\hline 7-8 év & 58 & 4,66 & 3,11 & 0,95 & 1,00 & 2,00 & 4,00 & 7,00 & 9,00 & 10,10 \\
\hline 9-10 év & 56 & 7,84 & 3,23 & 2,85 & 3,00 & 6,00 & 8,00 & 9,00 & 12,00 & 13,30 \\
\hline 11-12 év & 65 & 9,77 & 3,90 & 5,00 & 6,00 & 7,00 & 9,00 & 12,00 & 16,40 & 19,00 \\
\hline 13-14 év & 54 & 10,70 & 4,08 & 5,75 & 6,00 & 8,00 & 10,00 & 13,00 & 16,50 & 21,00 \\
\hline 15-16 év & 64 & 12,53 & 4,50 & 4,50 & 7,00 & 10,00 & 12,00 & 15,00 & 19,00 & 20,75 \\
\hline 17-18 év & 77 & 14,79 & 4,28 & 7,90 & 9,00 & 11,50 & 15,00 & 18,00 & 20,00 & 21,10 \\
\hline 19-34 év & 62 & 15,13 & 5,40 & 6,15 & 8,00 & 11,00 & 15,00 & 19,00 & 24,00 & 24,85 \\
\hline $35-49$ év & 36 & 16,89 & 5,52 & 8,55 & 10,40 & 14,00 & 16,00 & 20,00 & 24,90 & 29,15 \\
\hline 50-69 év & 23 & $\mathbf{9 , 5 2}$ & 4,69 & 3,20 & 4,00 & 6,00 & 9,00 & 11,00 & 18,40 & 20,80 \\
\hline $70-89$ év & 23 & 10,48 & 3,81 & 4,40 & 6,40 & 7,00 & 11,00 & 12,00 & 14,60 & 20,60 \\
\hline
\end{tabular}


2c. melléklet. A szavak száma az „A” fluencia feladat esetében az egyes életkori csoportokban

\begin{tabular}{|c|c|c|c|c|c|c|c|c|c|c|}
\hline \multirow{2}{*}{$\begin{array}{l}\text { Életkori } \\
\text { csoport }\end{array}$} & \multirow[t]{2}{*}{$\mathbf{N}$} & \multirow[t]{2}{*}{ Átlag } & \multirow[t]{2}{*}{ Szórás } & \multicolumn{7}{|c|}{ Percentilisek } \\
\hline & & & & 5 & 10 & 25 & 50 & 75 & 90 & 95 \\
\hline 5-6 év & 443 & $2,2,37$ & 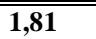 & 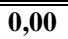 & 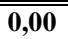 & $\overline{1,00}$ & 2,00 & $4,4,00$ & 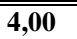 & $4 \overline{4,80}$ \\
\hline 9-10 év & 56 & 7,39 & 3,81 & 2,00 & 3,00 & 4,25 & 7,00 & 9,00 & 11,30 & 12,75 \\
\hline 11-12 év & 65 & 8,45 & 3,50 & 4,00 & 4,60 & 6,00 & 8,00 & 10,00 & 14,00 & 15,70 \\
\hline 13-14 év & 54 & 8,74 & 3,25 & 4,00 & 5,00 & 6,00 & 8,00 & 10,25 & 13,50 & 15,00 \\
\hline 19-34 év & 62 & 11,42 & 4,19 & 5,00 & 6,00 & 8,00 & 11,50 & 14,00 & 16,70 & 18,00 \\
\hline 35-49 év & 36 & 13,53 & 4,88 & 5,85 & 7,40 & 10,25 & 13,00 & 16,00 & 20,00 & 23,05 \\
\hline 50-69 év & 23 & 7,09 & 3,90 & 2,20 & 3,00 & 5,00 & 6,00 & 7,00 & 15,40 & 17,00 \\
\hline $70-89$ év & 23 & 8,17 & 3,42 & 2,20 & $\mathbf{3 , 8 0}$ & 6,00 & 8,00 & 10,00 & 12,00 & 16,80 \\
\hline
\end{tabular}

3a. melléklet. A perszeverációs mutatók a „K” fluencia feladat esetében az egyes életkori csoportokban

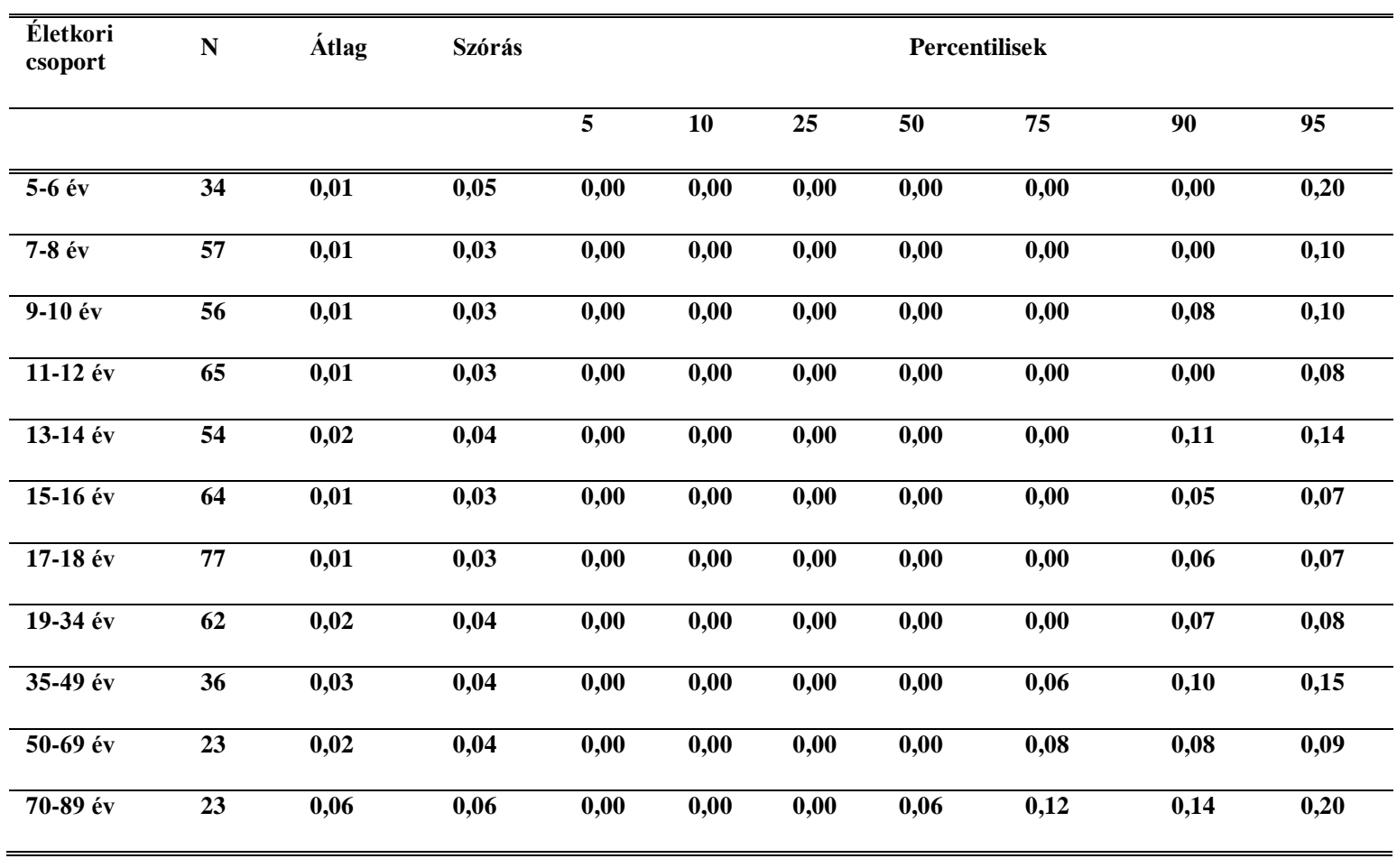


3b. melléklet. A perszeverációs mutatók a „T” fluencia feladat esetében az egyes életkori csoportokban

\begin{tabular}{|c|c|c|c|c|c|c|c|c|c|c|}
\hline \multirow{2}{*}{$\begin{array}{l}\text { Életkori } \\
\text { csoport }\end{array}$} & \multirow[t]{2}{*}{$\mathbf{N}$} & \multirow[t]{2}{*}{ Átlag } & \multirow[t]{2}{*}{ Szórás } & \multicolumn{7}{|c|}{ Percentilisek } \\
\hline & & & & 5 & 10 & 25 & 50 & 75 & 90 & 95 \\
\hline 5-6 év & 32 & $\mathbf{0 , 0 0}$ & (2,00 & (0,00 & $\overline{0,00}$ & $\mathbf{0 , 0 0 0}$ & (0,00 & 0,00 & (0,00 & $\overline{\mathbf{0 , 0 0}}$ \\
\hline $7-8$ év & 58 & $\mathbf{0 , 0 1}$ & $\mathbf{0 , 0 3}$ & 0,00 & $\mathbf{0 , 0 0}$ & $\mathbf{0 , 0 0}$ & $\mathbf{0 , 0 0}$ & 0,00 & $\mathbf{0 , 0 0}$ & 0,11 \\
\hline 9-10 év & 56 & $\mathbf{0 , 0 1}$ & $\mathbf{0 , 0 3}$ & $\mathbf{0 , 0 0}$ & $\mathbf{0 , 0 0}$ & $\mathbf{0 , 0 0}$ & $\mathbf{0 , 0 0}$ & $\mathbf{0 , 0 0}$ & 0,09 & 0,11 \\
\hline 11-12 év & 65 & 0,02 & 0,04 & $\mathbf{0 , 0 0}$ & $\mathbf{0 , 0 0}$ & $\mathbf{0 , 0 0}$ & $\mathbf{0 , 0 0}$ & 0,00 & 0,10 & 0,13 \\
\hline 13-14 év & 54 & $\mathbf{0 , 0 1}$ & $\mathbf{0 , 0 3}$ & 0,00 & 0,00 & $\mathbf{0 , 0 0}$ & $\mathbf{0 , 0 0}$ & 0,00 & $\mathbf{0 , 0 8}$ & 0,11 \\
\hline 15-16 év & 64 & $\mathbf{0 , 0 2}$ & 0,05 & 0,00 & $\mathbf{0 , 0 0}$ & $\mathbf{0 , 0 0}$ & $\mathbf{0 , 0 0}$ & $\mathbf{0 , 0 3}$ & 0,09 & 0,14 \\
\hline 17-18 év & 77 & $\mathbf{0 , 0 1}$ & $\mathbf{0 , 0 3}$ & $\mathbf{0 , 0 0}$ & 0,00 & $\mathbf{0 , 0 0}$ & $\mathbf{0 , 0 0}$ & 0,00 & 0,06 & 0,08 \\
\hline 19-34 év & 62 & 0,02 & 0,05 & 0,00 & $\mathbf{0 , 0 0}$ & $\mathbf{0 , 0 0}$ & $\mathbf{0 , 0 0}$ & 0,04 & $\mathbf{0 , 0 8}$ & $\mathbf{0 , 1 0}$ \\
\hline $35-49$ év & 36 & $\mathbf{0 , 0 3}$ & 0,04 & $\mathbf{0 , 0 0}$ & $\mathbf{0 , 0 0}$ & $\mathbf{0 , 0 0}$ & $\mathbf{0 , 0 0}$ & 0,05 & $\mathbf{0 , 1 0}$ & 0,12 \\
\hline 50-69 év & 23 & $\mathbf{0 , 0 3}$ & 0,05 & 0,00 & $\mathbf{0 , 0 0}$ & $\mathbf{0 , 0 0}$ & $\mathbf{0 , 0 0}$ & 0,00 & 0,10 & 0,18 \\
\hline $70-89$ év & 23 & 0,05 & $\mathbf{0 , 0 7}$ & $\mathbf{0 , 0 0}$ & 0,00 & $\mathbf{0 , 0 0}$ & $\mathbf{0 , 0 0}$ & 0,08 & 0,17 & 0,21 \\
\hline
\end{tabular}

3c. melléklet. A perszeverációs mutatók az „A” fluencia feladat esetében az egyes életkori csoportokban

\begin{tabular}{|c|c|c|c|c|c|c|c|c|c|c|}
\hline \multirow{2}{*}{$\begin{array}{l}\text { Életkori } \\
\text { csoport }\end{array}$} & \multirow[t]{2}{*}{$\mathbf{N}$} & \multirow[t]{2}{*}{ Átlag } & \multirow[t]{2}{*}{ Szórás } & \multicolumn{7}{|c|}{ Percentilisek } \\
\hline & & & & 5 & 10 & 25 & 50 & 75 & 90 & 95 \\
\hline 5-6 év & 36 & $\mathbf{0 , 0 , 0 0}$ & $0,0,00$ & $\overline{0,00}$ & $\overline{0,00}$ & 0,00 & $0,0,00$ & $\overline{0,00}$ & $0,0,00$ & $\overline{\mathbf{0 , 0 0}}$ \\
\hline $7-8$ év & 58 & 0,01 & $\mathbf{0 , 0 5}$ & $\mathbf{0 , 0 0}$ & $\mathbf{0 , 0 0}$ & $\mathbf{0 , 0 0}$ & $\mathbf{0 , 0 0}$ & 0,00 & 0,01 & 0,15 \\
\hline 9-10 év & 56 & $\mathbf{0 , 0 3}$ & $\mathbf{0 , 0 7}$ & $\mathbf{0 , 0 0}$ & $\mathbf{0 , 0 0}$ & 0,00 & 0,00 & 0,00 & $\mathbf{0 , 1 7}$ & 0,18 \\
\hline 11-12 év & 65 & $\mathbf{0 , 0 3}$ & $\mathbf{0 , 0 8}$ & 0,00 & 0,00 & 0,00 & 0,00 & 0,02 & 0,14 & 0,19 \\
\hline 13-14 év & 54 & $\mathbf{0 , 0 3}$ & 0,06 & 0,00 & 0,00 & 0,00 & 0,00 & 0,00 & 0,12 & 0,17 \\
\hline 15-16 év & 64 & 0,02 & 0,05 & 0,00 & 0,00 & 0,00 & 0,00 & 0,00 & 0,09 & 0,13 \\
\hline 17-18 év & 77 & 0,01 & $\mathbf{0 , 0 3}$ & 0,00 & 0,00 & 0,00 & 0,00 & 0,00 & $\mathbf{0 , 0 7}$ & 0,09 \\
\hline 19-34 év & 62 & $\mathbf{0 , 0 3}$ & 0,06 & $\mathbf{0 , 0 0}$ & 0,00 & 0,00 & 0,00 & 0,06 & 0,09 & 0,13 \\
\hline $35-49$ év & 36 & $\mathbf{0 , 0 2}$ & 0,04 & 0,00 & 0,00 & 0,00 & 0,00 & 0,06 & 0,08 & 0,10 \\
\hline 50-69 év & 23 & 0,02 & 0,06 & 0,00 & 0,00 & 0,00 & 0,00 & 0,00 & 0,12 & 0,21 \\
\hline $70-89$ év & 23 & 0,05 & $\mathbf{0 , 0 8}$ & $\mathbf{0 , 0 0}$ & $\mathbf{0 , 0 0}$ & $\mathbf{0 , 0 0}$ & $\mathbf{0 , 0 0}$ & 0,09 & 0,19 & 0,28 \\
\hline
\end{tabular}


4a. melléklet. A hibázási mutatók a „K” fluencia feladat esetében az egyes életkori csoportokban

\begin{tabular}{|c|c|c|c|c|c|c|c|c|c|c|}
\hline \multirow{2}{*}{$\begin{array}{l}\text { Életkori } \\
\text { csoport }\end{array}$} & \multirow[t]{2}{*}{$\mathbf{N}$} & \multirow[t]{2}{*}{ Átlag } & \multirow[t]{2}{*}{ Szórás } & \multicolumn{7}{|c|}{ Percentilisek } \\
\hline & & & & 5 & 10 & 25 & 50 & 75 & 90 & 95 \\
\hline 5-6 év & 34 & 0,17 & $\overline{0,32}$ & 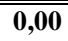 & 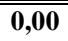 & 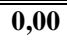 & 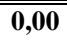 & 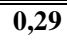 & 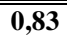 & $1,1,00$ \\
\hline 7-8 év & 57 & 0,11 & 0,21 & 0,00 & $\mathbf{0 , 0 0}$ & $\mathbf{0 , 0 0}$ & $\mathbf{0 , 0 0}$ & 0,14 & $\mathbf{0 , 5 0}$ & 0,67 \\
\hline 9-10 év & 56 & 0,05 & $\mathbf{0 , 1 0}$ & 0,00 & $\mathbf{0 , 0 0}$ & $\mathbf{0 , 0 0}$ & $\mathbf{0 , 0 0}$ & 0,09 & 0,15 & 0,26 \\
\hline 11-12 év & 65 & $\mathbf{0 , 0 1}$ & $\mathbf{0 , 0 5}$ & 0,00 & $\mathbf{0 , 0 0}$ & $\mathbf{0 , 0 0}$ & $\mathbf{0 , 0 0}$ & 0,00 & $\mathbf{0 , 0 2}$ & 0,13 \\
\hline 13-14 év & 54 & $\mathbf{0 , 0 1}$ & 0,05 & 0,00 & $\mathbf{0 , 0 0}$ & $\mathbf{0 , 0 0}$ & $\mathbf{0 , 0 0}$ & $\mathbf{0 , 0 0}$ & $\mathbf{0 , 0 8}$ & 0,11 \\
\hline 15-16 év & 64 & $\mathbf{0 , 0 1}$ & 0,02 & 0,00 & $\mathbf{0 , 0 0}$ & $\mathbf{0 , 0 0}$ & $\mathbf{0 , 0 0}$ & $\mathbf{0 , 0 0}$ & $\mathbf{0 , 0 0}$ & 0,05 \\
\hline 17-18 év & 77 & $\mathbf{0 , 0 1}$ & 0,04 & 0,00 & $\mathbf{0 , 0 0}$ & $\mathbf{0 , 0 0}$ & $\mathbf{0 , 0 0}$ & $\mathbf{0 , 0 0}$ & $\mathbf{0 , 0 7}$ & 0,13 \\
\hline 19-34 év & 62 & $\mathbf{0 , 0 2}$ & 0,04 & 0,00 & $\mathbf{0 , 0 0}$ & $\mathbf{0 , 0 0}$ & $\mathbf{0 , 0 0}$ & 0,00 & $\mathbf{0 , 0 7}$ & $\mathbf{0 , 1 1}$ \\
\hline $35-49$ év & 36 & $\mathbf{0 , 0 0}$ & $\mathbf{0 , 0 1}$ & $\mathbf{0 , 0 0}$ & $\mathbf{0 , 0 0}$ & $\mathbf{0 , 0 0}$ & $\mathbf{0 , 0 0}$ & $\mathbf{0 , 0 0}$ & $\mathbf{0 , 0 0}$ & 0,04 \\
\hline 50-69 év & 23 & $\mathbf{0 , 0 0}$ & $\mathbf{0 , 0 1}$ & 0,00 & $\mathbf{0 , 0 0}$ & $\mathbf{0 , 0 0}$ & $\mathbf{0 , 0 0}$ & 0,00 & $\mathbf{0 , 0 0}$ & 0,04 \\
\hline $70-89$ év & 23 & $\mathbf{0 , 0 2}$ & 0,05 & $\mathbf{0 , 0 0}$ & $\mathbf{0 , 0 0}$ & $\mathbf{0 , 0 0}$ & $\mathbf{0 , 0 0}$ & $\mathbf{0 , 0 0}$ & 0,14 & 0,16 \\
\hline
\end{tabular}

4b.melléklet. A hibázási mutatók a „T” fluencia feladat esetében az egyes életkori csoportokban

\begin{tabular}{|c|c|c|c|c|c|c|c|c|c|c|}
\hline \multirow{2}{*}{$\begin{array}{l}\text { Életkori } \\
\text { csoport }\end{array}$} & \multirow[t]{2}{*}{$\mathbf{N}$} & \multirow[t]{2}{*}{ Átlag } & \multirow[t]{2}{*}{ Szórás } & \multicolumn{7}{|c|}{ Percentilisek } \\
\hline & & & & 5 & 10 & 25 & $\mathbf{5 0}$ & 75 & 90 & 95 \\
\hline 5-6 év & 32 & 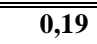 & $0, \mathbf{0 , 2 9}$ & $\overline{0,00}$ & $\overline{\mathbf{0 , 0 0}}$ & $\overline{\mathbf{0 , 0 0}}$ & $\mathbf{0 , 0 0 0}$ & $\overline{0,46}$ & 0,62 & $\overline{0,91}$ \\
\hline $7-8$ év & 58 & 0,09 & 0,22 & $\mathbf{0 , 0 0}$ & $\mathbf{0 , 0 0}$ & $\mathbf{0 , 0 0}$ & $\mathbf{0 , 0 0}$ & $\mathbf{0 , 0 0}$ & $\mathbf{0 , 5 0}$ & $\mathbf{0 , 5 2}$ \\
\hline 9-10 év & 56 & $\mathbf{0 , 0 3}$ & $\mathbf{0 , 0 8}$ & $\mathbf{0 , 0 0}$ & $\mathbf{0 , 0 0}$ & $\mathbf{0 , 0 0}$ & $\mathbf{0 , 0 0}$ & $\mathbf{0 , 0 0}$ & 0,13 & 0,26 \\
\hline 11-12 év & 65 & $\mathbf{0 , 0 3}$ & 0,18 & 0,00 & 0,00 & $\mathbf{0 , 0 0}$ & 0,00 & 0,00 & 0,06 & 0,09 \\
\hline 13-14 év & 54 & $\mathbf{0 , 0 3}$ & 0,06 & $\mathbf{0 , 0 0}$ & $\mathbf{0 , 0 0}$ & $\mathbf{0 , 0 0}$ & $\mathbf{0 , 0 0}$ & $\mathbf{0 , 0 0}$ & 0,11 & 0,18 \\
\hline 15-16 év & 64 & $\mathbf{0 , 0 2}$ & 0,04 & 0,00 & $\mathbf{0 , 0 0}$ & $\mathbf{0 , 0 0}$ & $\mathbf{0 , 0 0}$ & $\mathbf{0 , 0 0}$ & 0,08 & 0,14 \\
\hline 17-18 év & 77 & 0,02 & 0,04 & 0,00 & 0,00 & $\mathbf{0 , 0 0}$ & 0,00 & 0,00 & 0,08 & 0,10 \\
\hline 19-34 év & 62 & 0,02 & 0,05 & 0,00 & $\mathbf{0 , 0 0}$ & 0,00 & $\mathbf{0 , 0 0}$ & $\mathbf{0 , 0 0}$ & 0,09 & 0,14 \\
\hline 35-49 év & 36 & 0,01 & $\mathbf{0 , 0 2}$ & 0,00 & $\mathbf{0 , 0 0}$ & $\mathbf{0 , 0 0}$ & $\mathbf{0 , 0 0}$ & $\mathbf{0 , 0 0}$ & 0,01 & 0,06 \\
\hline 50-69 év & 23 & $\mathbf{0 , 0 3}$ & 0,05 & 0,00 & 0,00 & $\mathbf{0 , 0 0}$ & 0,00 & $\mathbf{0 , 0 0}$ & 0,12 & 0,19 \\
\hline 70-89 év & 23 & $\mathbf{0 , 0 2}$ & 0,05 & $\mathbf{0 , 0 0}$ & $\mathbf{0 , 0 0}$ & $\mathbf{0 , 0 0}$ & $\mathbf{0 , 0 0}$ & $\mathbf{0 , 0 0}$ & 0,14 & $\mathbf{0 , 1 5}$ \\
\hline
\end{tabular}


4c. melléklet. A hibázási mutatók az „A” fluencia feladat esetében az egyes életkori csoportokban

\begin{tabular}{|c|c|c|c|c|c|c|c|c|c|c|}
\hline \multirow{2}{*}{$\begin{array}{l}\text { Életkori } \\
\text { csoport }\end{array}$} & \multirow[t]{2}{*}{$\mathbf{N}$} & \multirow[t]{2}{*}{ Átlag } & \multirow[t]{2}{*}{ Szórás } & \multicolumn{7}{|c|}{ Percentilisek } \\
\hline & & & & 5 & 10 & 25 & 50 & 75 & 90 & 95 \\
\hline 5-6 év & 36 & 0,12 & (2,19 & 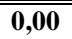 & 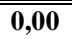 & 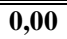 & 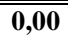 & 0,25 & (0,45 & ב $\mathbf{0 , 5 3}$ \\
\hline $7-8$ év & 58 & 0,09 & $\mathbf{0 , 1 7}$ & $\mathbf{0 , 0 0}$ & $\mathbf{0 , 0 0}$ & $\mathbf{0 , 0 0}$ & $\mathbf{0 , 0 0}$ & 0,14 & 0,34 & 0,58 \\
\hline 9-10 év & 56 & 0,06 & $\mathbf{0 , 1 2}$ & $\mathbf{0 , 0 0}$ & $\mathbf{0 , 0 0}$ & $\mathbf{0 , 0 0}$ & $\mathbf{0 , 0 0}$ & $\mathbf{0 , 0 0}$ & 0,28 & $\mathbf{0 , 3 5}$ \\
\hline 11-12 év & 65 & 0,05 & 0,16 & $\mathbf{0 , 0 0}$ & $\mathbf{0 , 0 0}$ & $\mathbf{0 , 0 0}$ & $\mathbf{0 , 0 0}$ & $\mathbf{0 , 0 0}$ & 0,17 & 0,24 \\
\hline 13-14 év & 54 & $\mathbf{0 , 0 3}$ & 0,08 & $\mathbf{0 , 0 0}$ & $\mathbf{0 , 0 0}$ & $\mathbf{0 , 0 0}$ & $\mathbf{0 , 0 0}$ & 0,00 & 0,14 & $\mathbf{0 , 2 0}$ \\
\hline 15-16 év & 64 & $\mathbf{0 , 0 3}$ & 0,07 & $\mathbf{0 , 0 0}$ & $\mathbf{0 , 0 0}$ & $\mathbf{0 , 0 0}$ & $\mathbf{0 , 0 0}$ & $\mathbf{0 , 0 0}$ & 0,12 & 0,18 \\
\hline 17-18 év & 77 & 0,02 & 0,05 & $\mathbf{0 , 0 0}$ & $\mathbf{0 , 0 0}$ & $\mathbf{0 , 0 0}$ & $\mathbf{0 , 0 0}$ & $\mathbf{0 , 0 0}$ & 0,09 & 0,15 \\
\hline 19-34 év & 62 & 0,05 & 0,09 & $\mathbf{0 , 0 0}$ & $\mathbf{0 , 0 0}$ & $\mathbf{0 , 0 0}$ & $\mathbf{0 , 0 0}$ & 0,06 & 0,15 & 0,24 \\
\hline 35-49 év & 36 & $\mathbf{0 , 0 2}$ & 0,05 & $\mathbf{0 , 0 0}$ & $\mathbf{0 , 0 0}$ & $\mathbf{0 , 0 0}$ & $\mathbf{0 , 0 0}$ & 0,00 & 0,12 & 0,18 \\
\hline 50-69 év & 23 & $\mathbf{0 , 0 3}$ & 0,06 & $\mathbf{0 , 0 0}$ & $\mathbf{0 , 0 0}$ & $\mathbf{0 , 0 0}$ & $\mathbf{0 , 0 0}$ & $\mathbf{0 , 0 0}$ & $\mathbf{0 , 1 1}$ & $\mathbf{0 , 2 0}$ \\
\hline $70-89$ év & 23 & 0,04 & $\mathbf{0 , 1 0}$ & $\mathbf{0 , 0 0}$ & $\mathbf{0 , 0 0}$ & $\mathbf{0 , 0 0}$ & $\mathbf{0 , 0 0}$ & $\mathbf{0 , 0 5}$ & 0,24 & $\mathbf{0 , 3 3}$ \\
\hline
\end{tabular}

5a. melléklet. A klaszterszám mutatók a „K” fluencia feladat esetében az egyes életkori csoportokban

\begin{tabular}{|c|c|c|c|c|c|c|c|c|c|c|}
\hline \multirow{2}{*}{$\begin{array}{l}\text { Életkori } \\
\text { csoport }\end{array}$} & \multirow[t]{2}{*}{$\mathbf{N}$} & \multirow[t]{2}{*}{ Átlag } & \multirow[t]{2}{*}{ Szórás } & \multicolumn{7}{|c|}{ Percentilisek } \\
\hline & & & & 5 & 10 & 25 & 50 & 75 & 90 & 95 \\
\hline 5-6 év & 34 & 0,08 & 0,16 & 0,00 & 0,00 & $\mathbf{0 , 0 0}$ & 0,00 & 0,02 & 0,42 & $\mathbf{0 , 5 0}$ \\
\hline $7-8$ év & 57 & 0,12 & 0,14 & $\mathbf{0 , 0 0}$ & $\mathbf{0 , 0 0}$ & $\mathbf{0 , 0 0}$ & 0,10 & $\mathbf{0 , 2 0}$ & $\mathbf{0 , 3 0}$ & $\mathbf{0 , 5 0}$ \\
\hline 9-10 év & 56 & 0,13 & 0,11 & 0,00 & 0,00 & 0,00 & $\mathbf{0 , 1 1}$ & 0,22 & 0,28 & $\mathbf{0 , 3 3}$ \\
\hline 11-12 év & 65 & 0,16 & 0,09 & 0,00 & 0,00 & 0,10 & 0,15 & 0,22 & 0,26 & 0,30 \\
\hline 13-14 év & 54 & 0,16 & 0,09 & 0,00 & 0,07 & 0,11 & 0,14 & 0,19 & 0,32 & 0,33 \\
\hline 15-16 év & 64 & 0,15 & 0,08 & $\mathbf{0 , 0 0}$ & $\mathbf{0 , 0 5}$ & $\mathbf{0 , 1 0}$ & 0,15 & $\mathbf{0 , 2 0}$ & 0,28 & $\mathbf{0 , 3 0}$ \\
\hline 17-18 év & 77 & 0,14 & 0,08 & 0,00 & 0,04 & $\mathbf{0 , 0 7}$ & 0,13 & 0,20 & 0,25 & 0,29 \\
\hline 19-34 év & 62 & 0,14 & 0,08 & 0,00 & 0,00 & 0,08 & 0,14 & $\mathbf{0 , 2 0}$ & 0,25 & 0,27 \\
\hline 35-49 év & 36 & 0,13 & $\mathbf{0 , 0 7}$ & 0,00 & 0,05 & 0,08 & 0,13 & 0,18 & 0,23 & 0,25 \\
\hline $50-69$ év & 23 & 0,13 & 0,08 & 0,00 & 0,00 & 0,08 & 0,14 & 0,19 & 0,24 & 0,29 \\
\hline $70-89$ év & 23 & 0,09 & $\mathbf{0 , 0 8}$ & $\mathbf{0 , 0 0}$ & $\mathbf{0 , 0 0}$ & $\mathbf{0 , 0 0}$ & $\mathbf{0 , 0 8}$ & $\mathbf{0 , 1 2}$ & 0,22 & $\mathbf{0 , 2 7}$ \\
\hline
\end{tabular}


5b. melléklet. A klaszterszám mutatók a „T” fluencia feladat esetében az egyes életkori csoportokban

\begin{tabular}{|c|c|c|c|c|c|c|c|c|c|c|}
\hline \multirow{2}{*}{$\begin{array}{l}\text { Életkori } \\
\text { csoport }\end{array}$} & \multirow[t]{2}{*}{$\mathbf{N}$} & \multirow[t]{2}{*}{ Átlag } & \multirow[t]{2}{*}{ Szórás } & \multicolumn{7}{|c|}{ Percentilisek } \\
\hline & & & & 5 & 10 & 25 & 50 & 75 & 90 & 95 \\
\hline 5-6 év & 32 & (2,04 & $\overline{0,12}$ & 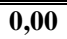 & 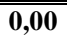 & 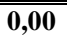 & 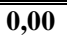 & 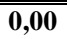 & 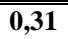 & $\overline{\mathbf{0 , 3 9}}$ \\
\hline 9-10 év & 56 & 0,14 & 0,11 & $\mathbf{0 , 0 0}$ & $\mathbf{0 , 0 0}$ & 0,00 & 0,14 & 0,23 & $\mathbf{0 , 3 0}$ & $\mathbf{0 , 3 3}$ \\
\hline 11-12 év & 65 & 0,16 & 0,10 & $\mathbf{0 , 0 0}$ & 0,00 & 0,10 & 0,14 & 0,22 & 0,31 & 0,36 \\
\hline 13-14 év & 54 & 0,16 & $\mathbf{0 , 1 0}$ & $\mathbf{0 , 0 0}$ & $\mathbf{0 , 0 0}$ & 0,10 & 0,15 & 0,22 & 0,29 & 0,34 \\
\hline 19-34 év & 62 & 0,15 & 0,08 & $\mathbf{0 , 0 0}$ & 0,00 & 0,07 & 0,16 & 0,22 & 0,25 & 0,28 \\
\hline 35-49 év & 36 & 0,15 & 0,08 & $\mathbf{0 , 0 0}$ & 0,05 & 0,10 & 0,14 & 0,21 & 0,27 & 0,29 \\
\hline 50-69 év & 23 & 0,14 & 0,12 & $\mathbf{0 , 0 0}$ & $\mathbf{0 , 0 0}$ & $\mathbf{0 , 0 0}$ & $\mathbf{0 , 1 3}$ & 0,25 & $\mathbf{0 , 3 2}$ & $\mathbf{0 , 3 7}$ \\
\hline $70-89$ év & 23 & 0,09 & $\mathbf{0 , 0 7}$ & $\mathbf{0 , 0 0}$ & $\mathbf{0 , 0 0}$ & 0,04 & $\mathbf{0 , 0 8}$ & 0,13 & 0,18 & 0,26 \\
\hline
\end{tabular}

5c. melléklet. A klaszterszám mutatók az „A fluencia feladat esetében az egyes életkori csoportokban

\begin{tabular}{|c|c|c|c|c|c|c|c|c|c|c|}
\hline \multirow{2}{*}{$\begin{array}{l}\text { Életkori } \\
\text { csoport }\end{array}$} & \multirow[t]{2}{*}{$\mathbf{N}$} & \multirow[t]{2}{*}{ Átlag } & \multirow[t]{2}{*}{ Szórás } & \multicolumn{7}{|c|}{ Percentilisek } \\
\hline & & & & 5 & 10 & 25 & 50 & 75 & 90 & 95 \\
\hline 5-6 év & 36 & $0, \mathbf{0 , 1 0}$ & 0,14 & 0,00 & $\mathbf{0 , 0 0}$ & 0,00 & 0,00 & 0,24 & 0,30 & $\overline{0,36}$ \\
\hline $7-8$ év & 58 & 0,15 & 0,14 & 0,00 & 0,00 & 0,00 & 0,14 & 0,26 & $\mathbf{0 , 3 3}$ & 0,34 \\
\hline 9-10 év & 56 & $\mathbf{0 , 1 2}$ & $\mathbf{0 , 1 0}$ & $\mathbf{0 , 0 0}$ & $\mathbf{0 , 0 0}$ & 0,00 & $\mathbf{0 , 1 3}$ & $\mathbf{0 , 2 0}$ & 0,25 & $\mathbf{0 , 3 1}$ \\
\hline 11-12 év & 65 & 0,14 & $\mathbf{0 , 1 0}$ & $\mathbf{0 , 0 0}$ & 0,00 & $\mathbf{0 , 0 3}$ & 0,14 & $\mathbf{0 , 2 0}$ & 0,29 & $\mathbf{0 , 3 3}$ \\
\hline 13-14 év & 54 & 0,18 & 0,12 & 0,00 & 0,00 & 0,09 & 0,20 & 0,28 & $\mathbf{0 , 3 3}$ & 0,35 \\
\hline 15-16 év & 64 & 0,14 & $\mathbf{0 , 1 0}$ & $\mathbf{0 , 0 0}$ & $\mathbf{0 , 0 0}$ & 0,06 & 0,14 & 0,22 & 0,29 & $\mathbf{0 , 3 1}$ \\
\hline 17-18 év & 77 & 0,14 & $\mathbf{0 , 1 0}$ & $\mathbf{0 , 0 0}$ & $\mathbf{0 , 0 0}$ & 0,07 & 0,13 & 0,22 & 0,27 & 0,29 \\
\hline 19-34 év & 62 & 0,14 & 0,09 & $\mathbf{0 , 0 0}$ & $\mathbf{0 , 0 0}$ & 0,08 & 0,14 & $\mathbf{0 , 2 0}$ & 0,27 & 0,29 \\
\hline 35-49 év & 36 & 0,15 & 0,08 & $\mathbf{0 , 0 0}$ & $\mathbf{0 , 0 0}$ & 0,09 & 0,15 & $\mathbf{0 , 2 0}$ & 0,26 & 0,29 \\
\hline 50-69 év & 23 & $\mathbf{0 , 1 0}$ & 0,11 & $\mathbf{0 , 0 0}$ & $\mathbf{0 , 0 0}$ & $\mathbf{0 , 0 0}$ & $\mathbf{0 , 0 0}$ & $\mathbf{0 , 2 0}$ & 0,27 & $\mathbf{0 , 3 2}$ \\
\hline $70-89$ év & 23 & $\mathbf{0 , 1 0}$ & 0,11 & 0,00 & 0,00 & 0,00 & 0,08 & $\mathbf{0 , 2 0}$ & 0,25 & 0,32 \\
\hline
\end{tabular}


6a. melléklet. A klaszterméret mutatók a „K” fluencia feladat esetében az egyes életkori csoportokban

\begin{tabular}{|c|c|c|c|c|c|c|c|c|c|c|}
\hline \multirow{2}{*}{$\begin{array}{l}\text { Életkori } \\
\text { csoport }\end{array}$} & \multirow[t]{2}{*}{$\mathbf{N}$} & \multirow[t]{2}{*}{ Átlag } & \multirow[t]{2}{*}{ Szórás } & \multicolumn{7}{|c|}{ Percentilisek } \\
\hline & & & & 5 & 10 & 25 & 50 & 75 & 90 & 95 \\
\hline 5-6 év & 8 & 0,94 & 0,56 & $\overline{0,00}$ & $\overline{0,00}$ & 0,63 & $1,1,00$ & $1, \mathbf{1 , 0 0}$ & 2,00 & 2,00 \\
\hline $7-8$ év & 30 & 1,29 & 1,20 & $\mathbf{0 , 0 0}$ & $\mathbf{0 , 3 3}$ & $\mathbf{0 , 5 0}$ & 1,00 & 1,63 & 2,90 & 5,00 \\
\hline 9-10 év & 41 & 0,95 & 0,75 & 0,00 & $\mathbf{0 , 3 3}$ & 0,50 & 1,00 & 1,00 & 2,00 & 3,00 \\
\hline 11-12 év & 57 & 0,96 & 0,75 & 0,25 & 0,32 & 0,44 & 0,75 & 1,00 & 2,00 & 3,00 \\
\hline 13-14 év & 51 & 0,77 & 0,47 & 0,15 & $\mathbf{0 , 3 0}$ & 0,50 & 0,75 & 1,00 & 1,20 & 2,00 \\
\hline 15-16 év & 59 & 0,70 & $\mathbf{0 , 5 3}$ & 0,20 & 0,25 & 0,33 & $\mathbf{0 , 5 0}$ & 1,00 & 1,50 & 2,00 \\
\hline 17-18 év & 72 & 0,70 & $\mathbf{0 , 4 3}$ & 0,17 & 0,24 & 0,33 & 0,56 & 1,00 & 1,00 & 1,68 \\
\hline 19-34 év & 55 & 0,62 & 0,41 & 0,18 & 0,23 & 0,33 & $\mathbf{0 , 5 0}$ & 1,00 & 1,00 & 1,60 \\
\hline 35-49 év & 34 & 0,61 & 0,42 & 0,15 & 0,23 & 0,30 & 0,47 & 1,00 & 1,00 & 1,63 \\
\hline 50-69 év & 20 & 0,96 & 0,61 & $\mathbf{0 , 2 0}$ & 0,32 & 0,50 & $\mathbf{0 , 8 8}$ & 1,33 & 2,00 & 2,00 \\
\hline $70-89$ év & 16 & 0,74 & 0,59 & $\mathbf{0 , 0 0}$ & 0,00 & 0,36 & $\mathbf{0 , 5 0}$ & 1,00 & 2,00 & 2,00 \\
\hline
\end{tabular}

6b. melléklet. A klaszterméret mutatók a „T” fluencia feladat esetében az egyes életkori csoportokban

\begin{tabular}{|c|c|c|c|c|c|c|c|c|c|c|}
\hline \multirow{2}{*}{$\begin{array}{l}\text { Életkori } \\
\text { csoport }\end{array}$} & \multirow[t]{2}{*}{$\mathbf{N}$} & \multirow[t]{2}{*}{ Átlag } & \multirow[t]{2}{*}{ Szórás } & \multicolumn{7}{|c|}{ Percentilisek } \\
\hline & & & & 5 & 10 & 25 & 50 & 75 & 90 & 95 \\
\hline 5-6 év & 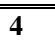 & $\overline{0,88}$ & 0,25 & 0,50 & $\mathbf{0 , 5 0}$ & 0,63 & $\overline{1,00}$ & 1,00 & 1,00 & $1, \mathbf{1 , 0 0}$ \\
\hline $7-8$ év & 31 & 1,12 & $\mathbf{0 , 7 1}$ & $\mathbf{0 , 0 0}$ & $\mathbf{0 , 3 7}$ & 0,75 & 1,00 & 1,25 & 2,00 & $\mathbf{3 , 0 0}$ \\
\hline 9-10 év & 41 & 1,21 & 0,99 & 0,20 & $\mathbf{0 , 3 3}$ & $\mathbf{0 , 5 0}$ & 1,00 & 1,63 & 2,00 & $\mathbf{3 , 9 0}$ \\
\hline 11-12 év & 55 & 1,08 & $\mathbf{0 , 8 2}$ & 0,25 & 0,33 & 0,50 & 1,00 & 1,00 & $\mathbf{3 , 0 0}$ & $3, \mathbf{3 0 0}$ \\
\hline 13-14 év & 47 & $\overline{0,80}$ & 0,60 & $\mathbf{0 , 0 0}$ & 0,24 & 0,44 & 0,67 & 1,00 & 2,00 & 2,00 \\
\hline 15-16 év & 54 & 0,83 & $\mathbf{0 , 7 1}$ & 0,24 & 0,31 & 0,37 & 0,56 & 1,00 & 1,88 & 2,44 \\
\hline 17-18 év & 73 & 0,64 & 0,44 & 0,20 & 0,24 & 0,33 & $\mathbf{0 , 5 0}$ & 1,00 & 1,00 & 1,25 \\
\hline 19-34 év & 55 & 0,64 & 0,64 & 0,18 & 0,21 & 0,28 & $\mathbf{0 , 5 0}$ & 0,75 & 1,00 & 2,00 \\
\hline $35-49$ év & 34 & 1,09 & 3,01 & $\mathbf{0 , 0 8}$ & 0,18 & $\mathbf{0 , 3 7}$ & $\mathbf{0 , 5 0}$ & $\mathbf{0 , 8 3}$ & 1,00 & 6,00 \\
\hline 50-69 év & 17 & 0,67 & $\mathbf{0 , 5 0}$ & $\mathbf{0 , 0 0}$ & $\mathbf{0 , 0 0}$ & 0,28 & $\mathbf{0 , 5 0}$ & 1,00 & 1,20 & 2,00 \\
\hline $70-89$ év & 18 & 1,13 & 0,86 & 0,00 & 0,45 & 0,69 & 1,00 & 1,00 & 2,20 & 4,00 \\
\hline
\end{tabular}


6c. melléklet. A klaszterméret mutatók az „A” fluencia feladat esetében az egyes életkori csoportokban

\begin{tabular}{|c|c|c|c|c|c|c|c|c|c|c|}
\hline \multirow{2}{*}{$\begin{array}{l}\text { Életkori } \\
\text { csoport }\end{array}$} & \multirow[t]{2}{*}{$\mathbf{N}$} & \multirow[t]{2}{*}{ Átlag } & \multirow[t]{2}{*}{ Szórás } & \multicolumn{7}{|c|}{ Percentilisek } \\
\hline & & & & 5 & 10 & 25 & 50 & 75 & 90 & 95 \\
\hline 5-6 év & 14 & 1,09 & $\mathbf{0 , 4 3}$ & 0,25 & 0,63 & $1, \mathbf{1 , 0 0}$ & $1,1,00$ & 1,00 & 2,00 & 2,00 \\
\hline $7-8$ év & 34 & 0,78 & $\mathbf{0 , 3 3}$ & $\mathbf{0 , 0 0}$ & 0,24 & $\mathbf{0 , 5 0}$ & 1,00 & 1,00 & 1,00 & 1,00 \\
\hline 9-10 év & 38 & $\mathbf{1 , 0 3}$ & $\mathbf{0 , 5 8}$ & 0,25 & $\mathbf{0 , 5 0}$ & $\mathbf{0 , 7 7}$ & 1,00 & 1,00 & 2,00 & 3,00 \\
\hline 11-12 év & 49 & $\mathbf{0 , 8 3}$ & 0,48 & 0,11 & 0,25 & $\mathbf{0 , 5 0}$ & 1,00 & 1,00 & 1,25 & 2,00 \\
\hline 13-14 év & 43 & 0,62 & 0,55 & $\mathbf{0 , 0 0}$ & $\mathbf{0 , 0 0}$ & 0,25 & $\mathbf{0 , 5 0}$ & 1,00 & 1,00 & 1,80 \\
\hline 15-16 év & 50 & 0,77 & $\mathbf{0 , 5 0}$ & 0,25 & $\mathbf{0 , 3 3}$ & 0,44 & 0,75 & 1,00 & 1,00 & 2,00 \\
\hline 17-18 év & 61 & $\mathbf{0 , 8 3}$ & 0,68 & 0,22 & $\mathbf{0 , 2 7}$ & $\mathbf{0 , 5 0}$ & 0,55 & 1,00 & 1,90 & 2,23 \\
\hline 19-34 év & 52 & 0,91 & 0,84 & 0,16 & 0,32 & 0,46 & 0,71 & 1,00 & 2,00 & 2,35 \\
\hline 35-49 év & 32 & $\mathbf{0 , 8 3}$ & 0,74 & 0,08 & 0,26 & 0,43 & 0,64 & 1,00 & 1,79 & 2,70 \\
\hline 50-69 év & 11 & 1,14 & $\mathbf{0 , 8 6}$ & 0,20 & 0,21 & $\mathbf{0 , 5 0}$ & 1,00 & 2,00 & 2,80 & 3,00 \\
\hline $70-89$ év & 12 & 0,71 & $\mathbf{0 , 3 3}$ & 0,25 & 0,27 & $\mathbf{0 , 3 3}$ & $\mathbf{0 , 8 8}$ & 1,00 & 1,00 & 1,00 \\
\hline
\end{tabular}

7a. melléklet. Az összváltási mutatók a „K” fluencia feladat esetében az egyes életkori csoportokban

\begin{tabular}{|c|c|c|c|c|c|c|c|c|c|c|}
\hline \multirow[t]{2}{*}{$\begin{array}{l}\text { Életkori } \\
\text { csoport }\end{array}$} & \multirow[t]{2}{*}{$\mathbf{N}$} & \multirow[t]{2}{*}{ Átlag } & \multirow[t]{2}{*}{ Szórás } & \multicolumn{7}{|c|}{ Percentilisek } \\
\hline & & & & 5 & 10 & 25 & 50 & 75 & 90 & 95 \\
\hline 5-6 év & 34 & (0,39 & 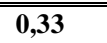 & 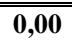 & 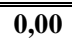 & $\overline{\mathbf{0 , 0 0}}$ & $\overline{\mathbf{0 , 5 0}}$ & 0,69 & $\overline{\mathbf{0 , 8 0}}$ & $\overline{\mathbf{0 , 8 1}}$ \\
\hline 7-8 év & 57 & 0,56 & 0,26 & $\mathbf{0 , 0 0}$ & $\mathbf{0 , 0 0}$ & $\mathbf{0 , 5 0}$ & $\mathbf{0 , 6 3}$ & $\mathbf{0 , 7 5}$ & $\mathbf{0 , 8 4}$ & $\overline{0,86}$ \\
\hline 9-10 év & 56 & 0,68 & $\mathbf{0 , 1 7}$ & $\mathbf{0 , 3 7}$ & 0,40 & 0,56 & 0,72 & $\mathbf{0 , 8 0}$ & $\mathbf{0 , 8 9}$ & $\overline{0,90}$ \\
\hline 11-12 év & 65 & 0,67 & 0,15 & 0,42 & $\mathbf{0 , 5 0}$ & $\mathbf{0 , 5 8}$ & $\mathbf{0 , 7 0}$ & 0,78 & $\mathbf{0 , 8 5}$ & $\mathbf{0 , 8 9}$ \\
\hline 13-14 év & 54 & 0,69 & $\mathbf{0 , 1 7}$ & $\mathbf{0 , 3 1}$ & $\mathbf{0 , 5 0}$ & $\mathbf{0 , 5 7}$ & 0,75 & $\mathbf{0 , 8 0}$ & $\mathbf{0 , 8 7}$ & $\mathbf{0 , 8 9}$ \\
\hline 15-16 év & 64 & $\mathbf{0 , 7 3}$ & $\mathbf{0 , 1 3}$ & 0,47 & $\mathbf{0 , 5 7}$ & 0,64 & 0,75 & $\mathbf{0 , 8 3}$ & $\mathbf{0 , 8 8}$ & 0,90 \\
\hline 17-18 év & 77 & 0,75 & 0,12 & $\mathbf{0 , 5 0}$ & $\mathbf{0 , 5 8}$ & 0,69 & $\mathbf{0 , 7 8}$ & $\mathbf{0 , 8 5}$ & $\mathbf{0 , 9 0}$ & 0,92 \\
\hline 19-34 év & 62 & 0,76 & 0,12 & $\mathbf{0 , 5 3}$ & $\mathbf{0 , 5 7}$ & 0,69 & 0,76 & $\mathbf{0 , 8 3}$ & 0,91 & 0,94 \\
\hline 35-49 év & 36 & 0,75 & $\mathbf{0 , 1 3}$ & 0,49 & $\mathbf{0 , 5 2}$ & 0,68 & 0,77 & 0,87 & $\mathbf{0 , 9 0}$ & $\mathbf{0 , 9 3}$ \\
\hline 50-69 év & 23 & 0,69 & 0,19 & $\mathbf{0 , 2 3}$ & 0,35 & $\mathbf{0 , 6 0}$ & 0,75 & $\mathbf{0 , 8 3}$ & 0,91 & 0,92 \\
\hline $70-89$ év & 23 & 0,80 & 0,11 & 0,56 & 0,61 & 0,74 & 0,85 & 0,88 & 0,92 & 0,93 \\
\hline
\end{tabular}


7b. melléklet. Az összváltási mutatók a „T” fluencia feladat esetében az egyes életkori csoportokban

\begin{tabular}{|c|c|c|c|c|c|c|c|c|c|c|}
\hline \multirow{2}{*}{$\begin{array}{l}\text { Életkori } \\
\text { csoport }\end{array}$} & \multirow[t]{2}{*}{$\mathbf{N}$} & \multirow[t]{2}{*}{ Átlag } & \multirow[t]{2}{*}{ Szórás } & \multicolumn{7}{|c|}{ Percentilisek } \\
\hline & & & & 5 & 10 & 25 & 50 & 75 & 90 & 95 \\
\hline 5-6 év & 32 & 0,35 & 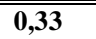 & 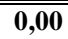 & 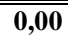 & 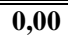 & 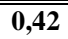 & "0,67 & 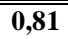 & 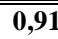 \\
\hline $7-8$ év & 58 & 0,49 & $\mathbf{0 , 2 7}$ & $\mathbf{0 , 0 0}$ & 0,00 & $\mathbf{0 , 3 1}$ & 0,56 & $\mathbf{0 , 7 0}$ & 0,77 & $\mathbf{0 , 8 0}$ \\
\hline 9-10 év & 56 & 0,63 & $\mathbf{0 , 2 3}$ & $\mathbf{0 , 1 7}$ & 0,29 & $\mathbf{0 , 5 1}$ & 0,67 & 0,79 & $\mathbf{0 , 8 9}$ & $\mathbf{0 , 9 1}$ \\
\hline 11-12 év & 65 & 0,64 & $\mathbf{0 , 1 7}$ & 0,32 & 0,41 & 0,55 & 0,67 & 0,77 & 0,85 & $\mathbf{0 , 8 9}$ \\
\hline 13-14 év & 54 & $\mathbf{0 , 7 0}$ & 0,15 & 0,41 & $\mathbf{0 , 5 0}$ & 0,60 & 0,72 & $\mathbf{0 , 7 8}$ & $\mathbf{0 , 8 9}$ & 0,90 \\
\hline 15-16 év & 64 & 0,69 & $\mathbf{0 , 1 7}$ & 0,29 & 0,42 & 0,58 & 0,71 & $\mathbf{0 , 8 1}$ & $\mathbf{0 , 9 0}$ & $\mathbf{0 , 9 2}$ \\
\hline 17-18 év & 77 & 0,67 & 0,16 & $\mathbf{0 , 3 7}$ & 0,47 & 0,56 & 0,69 & $\mathbf{0 , 8 0}$ & 0,85 & $\mathbf{0 , 8 9}$ \\
\hline 19-34 év & 62 & 0,73 & $\mathbf{0 , 1 3}$ & 0,48 & 0,54 & 0,65 & 0,75 & $\mathbf{0 , 8 2}$ & 0,89 & $\mathbf{0 , 8 9}$ \\
\hline 35-49 év & 36 & 0,68 & 0,19 & 0,29 & 0,43 & 0,57 & 0,71 & $\mathbf{0 , 8 3}$ & $\mathbf{0 , 8 8}$ & $\mathbf{0 , 9 0}$ \\
\hline 50-69 év & 23 & $\mathbf{0 , 7 0}$ & $\mathbf{0 , 1 8}$ & 0,28 & 0,40 & $\mathbf{0 , 5 6}$ & $\mathbf{0 , 8 0}$ & $\mathbf{0 , 8 3}$ & $\mathbf{0 , 8 9}$ & 0,91 \\
\hline $70-89$ év & 23 & $\mathbf{0 , 7 7}$ & 0,16 & 0,29 & 0,49 & $\mathbf{0 , 7 5}$ & $\mathbf{0 , 8 2}$ & $\mathbf{0 , 8 6}$ & $\mathbf{0 , 9 0}$ & $\mathbf{0 , 9 2}$ \\
\hline
\end{tabular}

7c. melléklet. Az összváltási mutatók az „A” fluencia feladat esetében az egyes életkori csoportokban

\begin{tabular}{|c|c|c|c|c|c|c|c|c|c|c|}
\hline \multirow{2}{*}{$\begin{array}{l}\text { Életkori } \\
\text { csoport }\end{array}$} & \multirow[t]{2}{*}{$\mathbf{N}$} & \multirow[t]{2}{*}{ Átlag } & \multirow[t]{2}{*}{ Szórás } & \multicolumn{7}{|c|}{ Percentilisek } \\
\hline & & & & 5 & 10 & 25 & 50 & 75 & 90 & 95 \\
\hline 5-6 év & 36 & 0,42 & 0,28 & 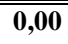 & 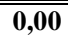 & "0,16 & $\begin{array}{l}\mathbf{0 , 5 0} \\
\end{array}$ & "0,67 & 0,75 & 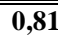 \\
\hline $7-8$ év & 58 & $\mathbf{0 , 5 7}$ & 0,19 & 0,28 & $\mathbf{0 , 3 3}$ & 0,42 & $\mathbf{0 , 6 0}$ & 0,73 & $\mathbf{0 , 8 0}$ & $\mathbf{0 , 8 0}$ \\
\hline 9-10 év & 56 & 0,66 & 0,23 & 0,00 & 0,31 & $\mathbf{0 , 5 8}$ & 0,71 & $\mathbf{0 , 8 3}$ & $\mathbf{0 , 8 9}$ & $\mathbf{0 , 9 0}$ \\
\hline 11-12 év & 65 & 0,71 & $\mathbf{0 , 1 7}$ & 0,36 & 0,48 & 0,65 & 0,73 & $\mathbf{0 , 8 3}$ & $\mathbf{0 , 8 8}$ & 0,91 \\
\hline 13-14 év & 54 & 0,66 & 0,15 & 0,32 & 0,47 & 0,57 & 0,67 & 0,78 & $\mathbf{0 , 8 7}$ & 0,89 \\
\hline 15-16 év & 64 & 0,71 & 0,14 & 0,43 & $\mathbf{0 , 5 0}$ & 0,63 & 0,75 & 0,83 & $\mathbf{0 , 8 8}$ & $\mathbf{0 , 8 9}$ \\
\hline 17-18 év & 77 & 0,71 & 0,16 & 0,33 & 0,53 & 0,62 & 0,73 & $\mathbf{0 , 8 3}$ & $\mathbf{0 , 8 9}$ & 0,90 \\
\hline 19-34 év & 62 & 0,70 & 0,13 & 0,44 & $\mathbf{0 , 5 0}$ & 0,62 & 0,71 & $\mathbf{0 , 8 0}$ & 0,86 & $\mathbf{0 , 8 8}$ \\
\hline 35-49 év & 36 & 0,68 & 0,15 & 0,39 & 0,46 & $\mathbf{0 , 5 8}$ & 0,70 & 0,78 & $\mathbf{0 , 8 7}$ & 0,93 \\
\hline 50-69 év & 23 & 0,69 & 0,16 & 0,41 & 0,46 & $\mathbf{0 , 5 0}$ & 0,67 & 0,86 & $\mathbf{0 , 8 9}$ & 0,91 \\
\hline $70-89$ év & 23 & 0,75 & $\mathbf{0 , 1 3}$ & 0,52 & 0,60 & 0,67 & $\mathbf{0 , 7 3}$ & 0,89 & $\mathbf{0 , 9 0}$ & $\mathbf{0 , 9 0}$ \\
\hline
\end{tabular}


8a. melléklet. A klaszterváltási mutatók a „K” fluencia feladat esetében az egyes életkori csoportokban

\begin{tabular}{|c|c|c|c|c|c|c|c|c|c|c|}
\hline \multirow{2}{*}{$\begin{array}{l}\text { Életkori } \\
\text { csoport }\end{array}$} & \multirow[t]{2}{*}{$\mathbf{N}$} & \multirow[t]{2}{*}{ Átlag } & \multirow[t]{2}{*}{ Szórás } & \multicolumn{7}{|c|}{ Percentilisek } \\
\hline & & & & 5 & 10 & 25 & $\mathbf{5 0}$ & 75 & 90 & 95 \\
\hline 5-6 év & 21 & (2,02 & $\begin{array}{l}\mathbf{0 , 0 7} \\
\end{array}$ & 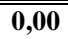 & 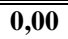 & 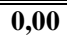 & 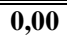 & 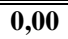 & 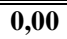 & (20,30 \\
\hline $7-8$ év & 51 & 0,11 & $\mathbf{0 , 5 7}$ & $\mathbf{0 , 0 0}$ & $\mathbf{0 , 0 0}$ & $\mathbf{0 , 0 0}$ & $\mathbf{0 , 0 0}$ & $\mathbf{0 , 0 0}$ & 0,18 & 0,52 \\
\hline 9-10 év & 56 & 0,04 & $\mathbf{0 , 1 0}$ & $\mathbf{0 , 0 0}$ & $\mathbf{0 , 0 0}$ & $\mathbf{0 , 0 0}$ & $\mathbf{0 , 0 0}$ & $\mathbf{0 , 0 0}$ & 0,22 & 0,29 \\
\hline 11-12 év & 65 & 0,05 & $\mathbf{0 , 1 0}$ & $\mathbf{0 , 0 0}$ & $\mathbf{0 , 0 0}$ & $\mathbf{0 , 0 0}$ & $\mathbf{0 , 0 0}$ & 0,05 & 0,15 & 0,24 \\
\hline 13-14 év & 54 & $\mathbf{0 , 0 7}$ & $\mathbf{0 , 1 7}$ & $\mathbf{0 , 0 0}$ & $\mathbf{0 , 0 0}$ & $\mathbf{0 , 0 0}$ & $\mathbf{0 , 0 0}$ & $\mathbf{0 , 0 7}$ & 0,31 & 0,43 \\
\hline 15-16 év & 64 & 0,04 & 0,08 & $\mathbf{0 , 0 0}$ & $\mathbf{0 , 0 0}$ & $\mathbf{0 , 0 0}$ & $\mathbf{0 , 0 0}$ & $\mathbf{0 , 0 7}$ & 0,18 & 0,23 \\
\hline 17-18 év & 77 & 0,05 & 0,09 & $\mathbf{0 , 0 0}$ & $\mathbf{0 , 0 0}$ & $\mathbf{0 , 0 0}$ & $\mathbf{0 , 0 0}$ & 0,08 & 0,14 & 0,24 \\
\hline 19-34 év & 62 & 0,05 & 0,08 & $\mathbf{0 , 0 0}$ & $\mathbf{0 , 0 0}$ & $\mathbf{0 , 0 0}$ & $\mathbf{0 , 0 0}$ & 0,09 & 0,16 & 0,22 \\
\hline 35-49 év & 36 & 0,03 & 0,06 & $\mathbf{0 , 0 0}$ & $\mathbf{0 , 0 0}$ & $\mathbf{0 , 0 0}$ & 0,00 & 0,06 & 0,12 & 0,22 \\
\hline $50-69$ év & 23 & 0,04 & $\mathbf{0 , 0 8}$ & $\mathbf{0 , 0 0}$ & $\mathbf{0 , 0 0}$ & $\mathbf{0 , 0 0}$ & $\mathbf{0 , 0 0}$ & 0,06 & $\mathbf{0 , 1 9}$ & 0,24 \\
\hline $70-89$ év & 23 & 0,02 & 0,06 & $\mathbf{0 , 0 0}$ & $\mathbf{0 , 0 0}$ & $\mathbf{0 , 0 0}$ & $\mathbf{0 , 0 0}$ & $\mathbf{0 , 0 0}$ & 0,12 & 0,23 \\
\hline
\end{tabular}

8b. melléklet. A klaszterváltási mutatók a „T” fluencia feladat esetében az egyes életkori csoportokban

\begin{tabular}{|c|c|c|c|c|c|c|c|c|c|c|}
\hline \multirow{2}{*}{$\begin{array}{l}\text { Életkori } \\
\text { csoport }\end{array}$} & \multirow[t]{2}{*}{$\mathbf{N}$} & \multirow[t]{2}{*}{ Átlag } & \multirow[t]{2}{*}{ Szórás } & \multicolumn{7}{|c|}{ Percentilisek } \\
\hline & & & & 5 & 10 & 25 & 50 & 75 & 90 & 95 \\
\hline 5-6 év & 19 & $\overline{\mathbf{0 , 0 0}}$ & $0,0,00$ & 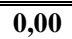 & $0,0,00$ & 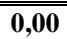 & 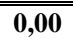 & 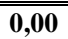 & 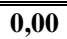 & $\overline{\overline{0,00}}$ \\
\hline 7-8 év & 49 & $\mathbf{0 , 0 3}$ & 0,15 & $\mathbf{0 , 0 0}$ & $\mathbf{0 , 0 0}$ & $\mathbf{0 , 0 0}$ & $\mathbf{0 , 0 0}$ & $\mathbf{0 , 0 0}$ & $\mathbf{0 , 0 0}$ & 0,17 \\
\hline 9-10 év & 54 & 0,06 & 0,15 & $\mathbf{0 , 0 0}$ & $\mathbf{0 , 0 0}$ & $\mathbf{0 , 0 0}$ & $\mathbf{0 , 0 0}$ & $\mathbf{0 , 0 0}$ & 0,15 & 0,54 \\
\hline 11-12 év & 65 & $\mathbf{0 , 0 7}$ & 0,16 & $\mathbf{0 , 0 0}$ & $\mathbf{0 , 0 0}$ & $\mathbf{0 , 0 0}$ & $\mathbf{0 , 0 0}$ & $\mathbf{0 , 1 3}$ & 0,28 & $\mathbf{0 , 3 3}$ \\
\hline 13-14 év & 54 & 0,08 & 0,17 & $\mathbf{0 , 0 0}$ & $\mathbf{0 , 0 0}$ & $\mathbf{0 , 0 0}$ & $\mathbf{0 , 0 0}$ & 0,15 & 0,25 & 0,44 \\
\hline 15-16 év & 64 & $\mathbf{0 , 0 7}$ & 0,17 & $\mathbf{0 , 0 0}$ & $\mathbf{0 , 0 0}$ & $\mathbf{0 , 0 0}$ & $\mathbf{0 , 0 0}$ & $\mathbf{0 , 0 0}$ & 0,25 & 0,45 \\
\hline 17-18 év & 77 & 0,08 & 0,14 & $\mathbf{0 , 0 0}$ & $\mathbf{0 , 0 0}$ & $\mathbf{0 , 0 0}$ & $\mathbf{0 , 0 0}$ & 0,13 & 0,29 & 0,44 \\
\hline 19-34 év & 62 & 0,06 & 0,11 & $\mathbf{0 , 0 0}$ & 0,00 & $\mathbf{0 , 0 0}$ & $\mathbf{0 , 0 0}$ & 0,08 & 0,21 & $\mathbf{0 , 3 3}$ \\
\hline $35-49$ év & 36 & 0,08 & 0,13 & $\mathbf{0 , 0 0}$ & $\mathbf{0 , 0 0}$ & $\mathbf{0 , 0 0}$ & $\mathbf{0 , 0 0}$ & 0,11 & 0,24 & $\mathbf{0 , 5 0}$ \\
\hline 50-69 év & 23 & $\mathbf{0 , 0 7}$ & 0,14 & $\mathbf{0 , 0 0}$ & $\mathbf{0 , 0 0}$ & $\mathbf{0 , 0 0}$ & $\mathbf{0 , 0 0}$ & $\mathbf{0 , 0 0}$ & $\mathbf{0 , 3 3}$ & 0,47 \\
\hline $70-89$ év & 23 & $\mathbf{0 , 0 0}$ & $\mathbf{0 , 0 0}$ & $\mathbf{0 , 0 0}$ & $\mathbf{0 , 0 0}$ & $\mathbf{0 , 0 0}$ & $\mathbf{0 , 0 0}$ & 0,00 & $\mathbf{0 , 0 0}$ & $\mathbf{0 , 0 0}$ \\
\hline
\end{tabular}


8c. melléklet. A klaszterváltási mutatók az „A” fluencia feladat esetében az egyes életkori csoportokban

\begin{tabular}{|c|c|c|c|c|c|c|c|c|c|c|}
\hline \multirow{2}{*}{$\begin{array}{l}\text { Életkori } \\
\text { csoport }\end{array}$} & \multirow[t]{2}{*}{$\mathbf{N}$} & \multirow[t]{2}{*}{ Átlag } & \multirow[t]{2}{*}{ Szórás } & \multicolumn{7}{|c|}{ Percentilisek } \\
\hline & & & & 5 & 10 & 25 & $\mathbf{5 0}$ & 75 & 90 & 95 \\
\hline 5-6 év & 28 & $\begin{array}{c}\mathbf{0 , 0 0} \\
\end{array}$ & $\begin{array}{l}\mathbf{0 , 0 0} \\
\end{array}$ & (0,00 & $\overline{\mathbf{0 , 0 0}}$ & $\overline{\mathbf{0 , 0 0}}$ & $\overline{0,00}$ & $\overline{\mathbf{0 , 0 0}}$ & $\overline{0,00}$ & $\overline{\mathbf{0 , 0 0}}$ \\
\hline 7-8 év & 57 & $\mathbf{0 , 0 3}$ & 0,15 & $\mathbf{0 , 0 0}$ & $\mathbf{0 , 0 0}$ & $\mathbf{0 , 0 0}$ & $\mathbf{0 , 0 0}$ & $\mathbf{0 , 0 0}$ & $\mathbf{0 , 0 0}$ & 0,20 \\
\hline 9-10 év & 53 & $\mathbf{0 , 0 3}$ & $\mathbf{0 , 1 0}$ & $\mathbf{0 , 0 0}$ & $\mathbf{0 , 0 0}$ & $\mathbf{0 , 0 0}$ & $\mathbf{0 , 0 0}$ & $\mathbf{0 , 0 0}$ & 0,13 & $\mathbf{0 , 3 5}$ \\
\hline 11-12 év & 64 & $\mathbf{0 , 0 3}$ & 0,09 & $\mathbf{0 , 0 0}$ & $\mathbf{0 , 0 0}$ & $\mathbf{0 , 0 0}$ & 0,00 & $\mathbf{0 , 0 0}$ & 0,15 & 0,31 \\
\hline 13-14 év & 54 & 0,09 & $\mathbf{0 , 1 3}$ & $\mathbf{0 , 0 0}$ & $\mathbf{0 , 0 0}$ & $\mathbf{0 , 0 0}$ & $\mathbf{0 , 0 0}$ & 0,18 & 0,25 & $\mathbf{0 , 3 8}$ \\
\hline 15-16 év & 64 & 0,04 & 0,11 & $\mathbf{0 , 0 0}$ & $\mathbf{0 , 0 0}$ & $\mathbf{0 , 0 0}$ & 0,00 & $\mathbf{0 , 0 0}$ & 0,18 & 0,25 \\
\hline 17-18 év & 77 & 0,05 & 0,14 & $\mathbf{0 , 0 0}$ & $\mathbf{0 , 0 0}$ & $\mathbf{0 , 0 0}$ & $\mathbf{0 , 0 0}$ & $\mathbf{0 , 0 0}$ & $\mathbf{0 , 1 7}$ & 0,25 \\
\hline 19-34 év & 62 & 0,05 & $\mathbf{0 , 1 0}$ & $\mathbf{0 , 0 0}$ & $\mathbf{0 , 0 0}$ & $\mathbf{0 , 0 0}$ & 0,00 & $\mathbf{0 , 1 0}$ & 0,19 & 0,25 \\
\hline 35-49 év & 36 & 0,06 & $\mathbf{0 , 1 0}$ & $\mathbf{0 , 0 0}$ & 0,00 & $\mathbf{0 , 0 0}$ & 0,00 & 0,12 & 0,23 & 0,34 \\
\hline 50-69 év & 23 & $\mathbf{0 , 0 1}$ & $\mathbf{0 , 0 3}$ & $\mathbf{0 , 0 0}$ & $\mathbf{0 , 0 0}$ & $\mathbf{0 , 0 0}$ & $\mathbf{0 , 0 0}$ & $\mathbf{0 , 0 0}$ & $\mathbf{0 , 0 0}$ & 0,13 \\
\hline $70-89$ év & 23 & 0,02 & $\mathbf{0 , 0 7}$ & $\mathbf{0 , 0 0}$ & 0,00 & $\mathbf{0 , 0 0}$ & $\mathbf{0 , 0 0}$ & $\mathbf{0 , 0 0}$ & 0,11 & 0,30 \\
\hline
\end{tabular}

9a. melléklet. A szavak száma az, „LLLAT” fluencia feladat esetében az egyes életkori csoportokban

\begin{tabular}{|c|c|c|c|c|c|c|c|c|c|c|}
\hline \multirow{2}{*}{$\begin{array}{l}\text { Életkori } \\
\text { csoport }\end{array}$} & \multirow[t]{2}{*}{$\mathbf{N}$} & \multirow[t]{2}{*}{ Átlag } & \multirow[t]{2}{*}{ Szórás } & \multicolumn{7}{|c|}{ Percentilisek } \\
\hline & & & & 5 & 10 & 25 & 50 & 75 & 90 & 95 \\
\hline 5-6 év & 48 & 1011,73 & $4,4,36$ & $6,6,00$ & 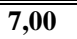 & "8,00 & 111,00 & 15,00 & 1818,10 & $19,19,00$ \\
\hline 7-8 év & 57 & 11,95 & 4,70 & 5,50 & 7,00 & 8,50 & 11,00 & 15,00 & 18,20 & 21,10 \\
\hline 9-10 év & 56 & 15,88 & 3,95 & 9,70 & 11,00 & 13,25 & 15,50 & 18,00 & 22,30 & 24,00 \\
\hline 11-12 év & 65 & 18,69 & 5,33 & 11,00 & 12,00 & 14,50 & 18,00 & 22,50 & 25,40 & 28,80 \\
\hline 13-14 év & 54 & 18,78 & 4,76 & 12,00 & 12,00 & 16,00 & 19,00 & 22,00 & 25,00 & 27,75 \\
\hline 15-16 év & 64 & 22,45 & 5,51 & 15,00 & 15,00 & 19,00 & 22,50 & 25,00 & 30,00 & 30,75 \\
\hline 17-18 év & 77 & 25,04 & 5,27 & 16,80 & 18,00 & 21,00 & 25,00 & 29,00 & 32,20 & 34,10 \\
\hline 19-34 év & 62 & 24,52 & 7,64 & 9,15 & 14,30 & 19,00 & 26,00 & 30,25 & 34,00 & 36,00 \\
\hline 35-49 év & 36 & 26,47 & 7,37 & 12,85 & 15,70 & 22,25 & 26,50 & 31,75 & 36,30 & 38,90 \\
\hline 50-69 év & 23 & 17,09 & 5,34 & 10,20 & 11,00 & 13,00 & 16,00 & 21,00 & 24,80 & 30,00 \\
\hline $70-89$ év & 23 & 15,78 & 5,11 & 3,80 & 8,20 & 13,00 & 16,00 & 19,00 & 22,80 & 24,80 \\
\hline
\end{tabular}


9b. melléklet. A szavak száma a „GYÜMÖLCS” fluencia feladat esetében az egyes életkori csoportokban

\begin{tabular}{|c|c|c|c|c|c|c|c|c|c|c|}
\hline \multirow{2}{*}{$\begin{array}{l}\text { Életkori } \\
\text { csoport }\end{array}$} & \multirow[t]{2}{*}{$\mathbf{N}$} & \multirow[t]{2}{*}{ Átlag } & \multirow[t]{2}{*}{ Szórás } & \multicolumn{7}{|c|}{ Percentilisek } \\
\hline & & & & 5 & 10 & 25 & 50 & 75 & 90 & 95 \\
\hline 5-6 év & 48 & 7,67 & 2,58 & 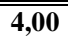 & ב4,90 & "6,00 & $7 \overline{7,50}$ & 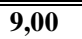 & 11,00 & 14,00 \\
\hline 7-8 év & 57 & 8,91 & 2,73 & 4,00 & 5,00 & 7,00 & 9,00 & 10,00 & 12,00 & 15,00 \\
\hline 9-10 év & 56 & 10,38 & 3,10 & 5,00 & 7,00 & 8,00 & 10,00 & 12,75 & 15,00 & 16,15 \\
\hline 11-12 év & 65 & 11,97 & 3,31 & 7,00 & 8,00 & 10,00 & 11,00 & 15,00 & 16,40 & 17,00 \\
\hline 13-14 év & 54 & 12,72 & 3,28 & 7,50 & 9,00 & 10,00 & 12,00 & 16,00 & 17,50 & 18,25 \\
\hline 15-16 év & 64 & 13,44 & 3,52 & 7,25 & 9,00 & 11,00 & 14,00 & 15,75 & 18,00 & 19,75 \\
\hline 17-18 év & 77 & 15,29 & 4,01 & 9,00 & 10,00 & 12,00 & 15,00 & 18,00 & 20,00 & 21,20 \\
\hline 19-34 év & 62 & 15,84 & 4,51 & 8,15 & 9,00 & 13,00 & 16,00 & 19,00 & 21,00 & 23,00 \\
\hline 35-49 év & 36 & 17,25 & 3,96 & $\mathbf{9 , 8 5}$ & 12,70 & 14,25 & 17,00 & 20,00 & 22,60 & 24,15 \\
\hline 50-69 év & 22 & 13,77 & 4,05 & 8,15 & 9,30 & 10,75 & 13,00 & 16,25 & 21,70 & 22,00 \\
\hline $70-89$ év & 23 & 12,39 & 2,81 & 7,20 & 8,40 & 11,00 & 13,00 & 14,00 & 16,60 & 18,60 \\
\hline
\end{tabular}

9c. melléklet. A szavak száma az „ÉLELMISZERBOLT” fluencia feladat esetében az egyes életkori csoportokban

\begin{tabular}{|c|c|c|c|c|c|c|c|c|c|c|}
\hline \multirow{2}{*}{$\begin{array}{l}\text { Életkori } \\
\text { csoport }\end{array}$} & \multirow[t]{2}{*}{$\mathbf{N}$} & \multirow[t]{2}{*}{ Átlag } & \multirow[t]{2}{*}{ Szórás } & \multicolumn{7}{|c|}{ Percentilisek } \\
\hline & & & & 5 & 10 & 25 & 50 & 75 & 90 & 95 \\
\hline 5-6 év & $4 \overline{48}$ & $8,8,35$ & $3,3,37$ & $3, \mathbf{3 , 0 0}$ & $\overline{47,90}$ & 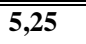 & 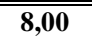 & 1011,00 & 1212,10 & 14,55 \\
\hline 7-8 év & 58 & 9,17 & 4,33 & 0,95 & 4,80 & 6,00 & 9,00 & 11,25 & 15,00 & 19,00 \\
\hline 9-10 év & 56 & 13,14 & 4,35 & 5,85 & 6,70 & 10,00 & 13,00 & 15,75 & 20,00 & 21,00 \\
\hline 11-12 év & 65 & 16,37 & 5,79 & 8,30 & $\mathbf{9 , 0 0}$ & 12,00 & 16,00 & 20,00 & 23,40 & 29,40 \\
\hline 13-14 év & 54 & 14,91 & 4,73 & 7,75 & 10,00 & 11,00 & 15,00 & 18,00 & 20,00 & 21,25 \\
\hline 15-16 év & 64 & 17,56 & 5,61 & 9,00 & $\mathbf{9 , 5 0}$ & 14,00 & 17,00 & 22,00 & 25,00 & 26,75 \\
\hline 17-18 év & 77 & 21,78 & 5,64 & 13,80 & 15,00 & 17,50 & 21,00 & 26,00 & 30,20 & 32,00 \\
\hline 19-34 év & 60 & 23,28 & 8,03 & 10,00 & 12,10 & 18,00 & 22,00 & 30,75 & 33,00 & 35,95 \\
\hline 35-49 év & 36 & 25,19 & 6,91 & 12,70 & 15,70 & 21,00 & 25,00 & 28,50 & 35,30 & 40,30 \\
\hline 50-69 év & 23 & 18,52 & 6,34 & $\mathbf{9 , 2 0}$ & 10,00 & 14,00 & 18,00 & 23,00 & 25,60 & 34,00 \\
\hline $70-89$ év & 23 & 18,39 & 5,11 & $\mathbf{9 , 2 0}$ & 10,40 & 16,00 & 18,00 & 21,00 & 26,00 & 27,60 \\
\hline
\end{tabular}


10a. melléklet. A perszeverációs mutatók az „ALLAT” fluencia feladat esetében az egyes életkori csoportokban

\begin{tabular}{|c|c|c|c|c|c|c|c|c|c|c|}
\hline \multirow{2}{*}{$\begin{array}{l}\text { Életkori } \\
\text { csoport }\end{array}$} & \multirow[t]{2}{*}{$\mathbf{N}$} & \multirow[t]{2}{*}{ Átlag } & \multirow[t]{2}{*}{ Szórás } & \multicolumn{7}{|c|}{ Percentilisek } \\
\hline & & & & 5 & 10 & 25 & 50 & 75 & 90 & 95 \\
\hline 5-6 év & 48 & $\overline{0,01}$ & 0,02 & (20,00 & 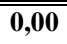 & 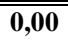 & 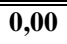 & 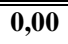 & 0,01 & $\overline{\mathbf{0 , 0 7}}$ \\
\hline 7-8 év & 57 & 0,01 & 0,02 & 0,00 & $\mathbf{0 , 0 0}$ & $\mathbf{0 , 0 0}$ & $\mathbf{0 , 0 0}$ & $\mathbf{0 , 0 0}$ & 0,04 & $\mathbf{0 , 0 7}$ \\
\hline 9-10 év & 56 & 0,02 & 0,04 & $\mathbf{0 , 0 0}$ & $\mathbf{0 , 0 0}$ & $\mathbf{0 , 0 0}$ & $\mathbf{0 , 0 0}$ & 0,04 & 0,09 & 0,11 \\
\hline 11-12 év & 65 & 0,01 & 0,02 & $\mathbf{0 , 0 0}$ & $\mathbf{0 , 0 0}$ & $\mathbf{0 , 0 0}$ & $\mathbf{0 , 0 0}$ & $\mathbf{0 , 0 0}$ & 0,05 & 0,06 \\
\hline 13-14 év & 54 & 0,01 & $\mathbf{0 , 0 2}$ & 0,00 & $\mathbf{0 , 0 0}$ & $\mathbf{0 , 0 0}$ & $\mathbf{0 , 0 0}$ & $\mathbf{0 , 0 0}$ & 0,05 & 0,05 \\
\hline 15-16 év & 64 & 0,01 & $\mathbf{0 , 0 3}$ & 0,00 & $\mathbf{0 , 0 0}$ & $\mathbf{0 , 0 0}$ & $\mathbf{0 , 0 0}$ & $\mathbf{0 , 0 0}$ & 0,06 & 0,09 \\
\hline 17-18 év & 77 & 0,01 & $\mathbf{0 , 0 2}$ & $\mathbf{0 , 0 0}$ & $\mathbf{0 , 0 0}$ & $\mathbf{0 , 0 0}$ & $\mathbf{0 , 0 0}$ & $\mathbf{0 , 0 0}$ & 0,04 & $\mathbf{0 , 0 7}$ \\
\hline 19-34 év & 62 & 0,02 & 0,04 & 0,00 & $\mathbf{0 , 0 0}$ & $\mathbf{0 , 0 0}$ & $\mathbf{0 , 0 0}$ & 0,04 & $\mathbf{0 , 0 7}$ & 0,12 \\
\hline $35-49$ év & 36 & 0,02 & $\mathbf{0 , 0 3}$ & 0,00 & $\mathbf{0 , 0 0}$ & $\mathbf{0 , 0 0}$ & $\mathbf{0 , 0 0}$ & 0,02 & $\mathbf{0 , 0 7}$ & 0,12 \\
\hline 50-69 év & 23 & $\mathbf{0 , 0 2}$ & 0,05 & 0,00 & $\mathbf{0 , 0 0}$ & $\mathbf{0 , 0 0}$ & $\mathbf{0 , 0 0}$ & $\mathbf{0 , 0 3}$ & 0,13 & 0,18 \\
\hline $70-89$ év & 23 & 0,06 & 0,08 & 0,00 & $\mathbf{0 , 0 0}$ & $\mathbf{0 , 0 0}$ & 0,04 & 0,10 & $\mathbf{0 , 1 7}$ & 0,26 \\
\hline
\end{tabular}

10b. melléklet. A perszeverációs mutatók a „GYÜMÖLCS” fluencia feladat esetében az egyes életkori csoportokban

\begin{tabular}{|c|c|c|c|c|c|c|c|c|c|c|}
\hline \multirow{2}{*}{$\begin{array}{l}\text { Életkori } \\
\text { csoport }\end{array}$} & \multirow[t]{2}{*}{$\mathbf{N}$} & \multirow[t]{2}{*}{ Átlag } & \multirow[t]{2}{*}{ Szórás } & \multicolumn{7}{|c|}{ Percentilisek } \\
\hline & & & & 5 & 10 & 25 & 50 & 75 & 90 & 95 \\
\hline 5-6 év & 48 & $\overline{\mathbf{0 , 0 3}}$ & $\begin{array}{l}\mathbf{0 , 0 7} \\
\end{array}$ & 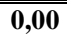 & 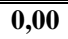 & 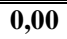 & 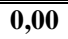 & 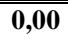 & 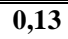 & $0,0,25$ \\
\hline $7-8$ év & 57 & 0,01 & 0,02 & $\mathbf{0 , 0 0}$ & $\mathbf{0 , 0 0}$ & $\mathbf{0 , 0 0}$ & $\mathbf{0 , 0 0}$ & $\mathbf{0 , 0 0}$ & $\mathbf{0 , 0 0}$ & 0,09 \\
\hline 9-10 év & 56 & 0,04 & 0,08 & $\mathbf{0 , 0 0}$ & $\mathbf{0 , 0 0}$ & $\mathbf{0 , 0 0}$ & $\mathbf{0 , 0 0}$ & 0,08 & 0,14 & 0,21 \\
\hline 11-12 év & 65 & 0,02 & 0,04 & $\mathbf{0 , 0 0}$ & $\mathbf{0 , 0 0}$ & $\mathbf{0 , 0 0}$ & $\mathbf{0 , 0 0}$ & 0,05 & 0,08 & 0,09 \\
\hline 13-14 év & 54 & 0,01 & 0,02 & $\mathbf{0 , 0 0}$ & $\mathbf{0 , 0 0}$ & $\mathbf{0 , 0 0}$ & $\mathbf{0 , 0 0}$ & $\mathbf{0 , 0 0}$ & 0,05 & 0,09 \\
\hline 15-16 év & 64 & 0,01 & $\mathbf{0 , 0 3}$ & $\mathbf{0 , 0 0}$ & $\mathbf{0 , 0 0}$ & $\mathbf{0 , 0 0}$ & $\mathbf{0 , 0 0}$ & $\mathbf{0 , 0 0}$ & 0,06 & 0,08 \\
\hline 17-18 év & 77 & 0,02 & 0,05 & $\mathbf{0 , 0 0}$ & $\mathbf{0 , 0 0}$ & $\mathbf{0 , 0 0}$ & $\mathbf{0 , 0 0}$ & $\mathbf{0 , 0 0}$ & $\mathbf{0 , 0 7}$ & 0,20 \\
\hline 19-34 év & 62 & $\mathbf{0 , 0 3}$ & 0,06 & $\mathbf{0 , 0 0}$ & $\mathbf{0 , 0 0}$ & $\mathbf{0 , 0 0}$ & $\mathbf{0 , 0 0}$ & 0,05 & 0,13 & $\mathbf{0 , 1 7}$ \\
\hline 35-49 év & 36 & 0,02 & 0,04 & $\mathbf{0 , 0 0}$ & $\mathbf{0 , 0 0}$ & $\mathbf{0 , 0 0}$ & $\mathbf{0 , 0 0}$ & $\mathbf{0 , 0 3}$ & 0,09 & $\mathbf{0 , 1 3}$ \\
\hline 50-69 év & 22 & $\mathbf{0 , 0 3}$ & 0,04 & $\mathbf{0 , 0 0}$ & $\mathbf{0 , 0 0}$ & $\mathbf{0 , 0 0}$ & $\mathbf{0 , 0 0}$ & $\mathbf{0 , 0 7}$ & 0,08 & 0,15 \\
\hline $70-89$ év & 23 & 0,05 & 0,05 & $\mathbf{0 , 0 0}$ & $\mathbf{0 , 0 0}$ & $\mathbf{0 , 0 0}$ & $\mathbf{0 , 0 0}$ & 0,08 & 0,13 & 0,15 \\
\hline
\end{tabular}


10c. melléklet. A perszeverációs mutatók az „ÉLELMISZERBOLT” fluencia feladat esetében az egyes életkori csoportokban

\begin{tabular}{|c|c|c|c|c|c|c|c|c|c|c|}
\hline \multirow[t]{2}{*}{$\begin{array}{l}\text { Életkori } \\
\text { csoport }\end{array}$} & \multirow[t]{2}{*}{$\mathbf{N}$} & \multirow[t]{2}{*}{ Átlag } & \multirow[t]{2}{*}{ Szórás } & \multicolumn{7}{|c|}{ Percentilisek } \\
\hline & & & & 5 & 10 & 25 & 50 & 75 & 90 & 95 \\
\hline 5-6 év & 48 & $\overline{0,01}$ & $\mathbf{0 , 0 3}$ & 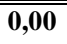 & $\overline{0,00}$ & $\overline{0,00}$ & $\overline{0,00}$ & $\overline{\mathbf{0 , 0 0}}$ & 0,06 & 0,10 \\
\hline $7-8$ év & 57 & 0,01 & $\mathbf{0 , 0 3}$ & $\mathbf{0 , 0 0}$ & $\mathbf{0 , 0 0}$ & $\mathbf{0 , 0 0}$ & $\mathbf{0 , 0 0}$ & $\mathbf{0 , 0 0}$ & $\mathbf{0 , 0 5}$ & 0,08 \\
\hline 9-10 év & 56 & 0,01 & $\mathbf{0 , 0 3}$ & $\mathbf{0 , 0 0}$ & $\mathbf{0 , 0 0}$ & 0,00 & 0,00 & $\mathbf{0 , 0 0}$ & 0,06 & 0,08 \\
\hline 11-12 év & 65 & 0,01 & $\mathbf{0 , 0 3}$ & $\mathbf{0 , 0 0}$ & $\mathbf{0 , 0 0}$ & $\mathbf{0 , 0 0}$ & 0,00 & $\mathbf{0 , 0 0}$ & $\mathbf{0 , 0 5}$ & 0,07 \\
\hline 13-14 év & 54 & 0,01 & $\mathbf{0 , 0 3}$ & $\mathbf{0 , 0 0}$ & 0,00 & 0,00 & 0,00 & $\mathbf{0 , 0 0}$ & 0,06 & $\mathbf{0 , 1 0}$ \\
\hline 15-16 év & 64 & 0,01 & $\mathbf{0 , 0 2}$ & $\mathbf{0 , 0 0}$ & $\mathbf{0 , 0 0}$ & 0,00 & 0,00 & $\mathbf{0 , 0 0}$ & 0,04 & 0,05 \\
\hline 17-18 év & 77 & 0,01 & $\mathbf{0 , 0 2}$ & $\mathbf{0 , 0 0}$ & $\mathbf{0 , 0 0}$ & 0,00 & 0,00 & $\mathbf{0 , 0 0}$ & 0,04 & 0,06 \\
\hline 19-34 év & 60 & 0,01 & $\mathbf{0 , 0 2}$ & $\mathbf{0 , 0 0}$ & $\mathbf{0 , 0 0}$ & 0,00 & 0,00 & $\mathbf{0 , 0 0}$ & 0,04 & 0,06 \\
\hline 35-49 év & 36 & 0,01 & $\mathbf{0 , 0 3}$ & $\mathbf{0 , 0 0}$ & $\mathbf{0 , 0 0}$ & $\mathbf{0 , 0 0}$ & 0,00 & $\mathbf{0 , 0 0}$ & 0,05 & 0,08 \\
\hline 50-69 év & 23 & 0,02 & 0,04 & $\mathbf{0 , 0 0}$ & 0,00 & 0,00 & 0,00 & $\mathbf{0 , 0 0}$ & $\mathbf{0 , 1 0}$ & $\mathbf{0 , 1 0}$ \\
\hline $70-89$ év & 23 & 0,02 & $\mathbf{0 , 0 3}$ & $\mathbf{0 , 0 0}$ & $\mathbf{0 , 0 0}$ & 0,00 & 0,00 & 0,05 & 0,06 & $\mathbf{0 , 0 7}$ \\
\hline
\end{tabular}

11a. melléklet. A hibázási mutatók az „ALLAT” fluencia feladat esetében az egyes életkori csoportokban

\begin{tabular}{|c|c|c|c|c|c|c|c|c|c|c|}
\hline \multirow[t]{2}{*}{$\begin{array}{l}\text { Életkori } \\
\text { csoport }\end{array}$} & \multirow[t]{2}{*}{$\mathbf{N}$} & \multirow[t]{2}{*}{ Átlag } & \multirow[t]{2}{*}{ Szórás } & \multicolumn{7}{|c|}{ Percentilisek } \\
\hline & & & & 5 & 10 & 25 & 50 & 75 & 90 & 95 \\
\hline 5-6 év & 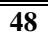 & $\overline{0,01}$ & 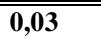 & 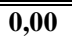 & 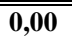 & $\overline{0,00}$ & $\overline{0,00}$ & 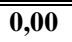 & 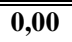 & $\overline{\mathbf{0 , 1 1}}$ \\
\hline 7-8 év & 57 & 0,03 & 0,15 & 0,00 & 0,00 & 0,00 & 0,00 & 0,00 & 0,02 & 0,22 \\
\hline $9-10$ év & 56 & 0,02 & 0,05 & 0,00 & 0,00 & 0,00 & 0,00 & 0,00 & 0,05 & 0,13 \\
\hline 11-12 év & 65 & 0,00 & 0,01 & 0,00 & 0,00 & 0,00 & 0,00 & 0,00 & 0,00 & 0,00 \\
\hline 13-14 év & 54 & $\overline{0,00}$ & $\mathbf{0 , 0 1}$ & 0,00 & 0,00 & 0,00 & $\mathbf{0 , 0 0}$ & $\mathbf{0 , 0 0}$ & $\mathbf{0 , 0 0}$ & 0,00 \\
\hline 15-16 év & 64 & $\overline{0,00}$ & $\mathbf{0 , 0 2}$ & 0,00 & 0,00 & 0,00 & $\overline{0,00}$ & $\mathbf{0 , 0 0}$ & $\mathbf{0 , 0 0}$ & 0,04 \\
\hline 17-18 év & 77 & 0,00 & 0,01 & 0,00 & 0,00 & 0,00 & 0,00 & 0,00 & $\mathbf{0 , 0 0}$ & 0,03 \\
\hline 19-34 év & 62 & 0,00 & $\mathbf{0 , 0 2}$ & $\mathbf{0 , 0 0}$ & $\mathbf{0 , 0 0}$ & 0,00 & 0,00 & $\mathbf{0 , 0 0}$ & $\mathbf{0 , 0 0}$ & 0,04 \\
\hline 35-49 év & 36 & 0,00 & 0,01 & 0,00 & 0,00 & 0,00 & 0,00 & 0,00 & $\mathbf{0 , 0 1}$ & 0,04 \\
\hline 50-69 év & 23 & 0,00 & 0,01 & 0,00 & 0,00 & 0,00 & 0,00 & 0,00 & 0,00 & 0,05 \\
\hline 70-89 év & 23 & 0,02 & 0,09 & 0,00 & 0,00 & 0,00 & 0,00 & 0,00 & 0,04 & 0,34 \\
\hline
\end{tabular}


11b. melléklet. A hibázási mutatók a „GYÜMÖLCS” fluencia feladat esetében az egyes életkori csoportokban

\begin{tabular}{|c|c|c|c|c|c|c|c|c|c|c|}
\hline \multirow{2}{*}{$\begin{array}{l}\text { Életkori } \\
\text { csoport }\end{array}$} & \multirow[t]{2}{*}{$\mathbf{N}$} & \multirow[t]{2}{*}{ Átlag } & \multirow[t]{2}{*}{ Szórás } & \multicolumn{7}{|c|}{ Percentilisek } \\
\hline & & & & 5 & 10 & 25 & 50 & 75 & 90 & 95 \\
\hline 5-6 év & 48 & $\overline{0,03}$ & (0,07 & 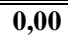 & 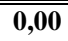 & 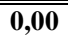 & 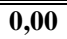 & 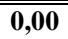 & 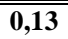 & $\overline{0,23}$ \\
\hline $7-8$ év & 57 & $\mathbf{0 , 0 2}$ & 0,05 & $\mathbf{0 , 0 0}$ & $\mathbf{0 , 0 0}$ & $\mathbf{0 , 0 0}$ & $\mathbf{0 , 0 0}$ & $\mathbf{0 , 0 0}$ & 0,09 & 0,17 \\
\hline 9-10 év & 56 & $\mathbf{0 , 0 1}$ & 0,04 & $\mathbf{0 , 0 0}$ & $\mathbf{0 , 0 0}$ & $\mathbf{0 , 0 0}$ & $\mathbf{0 , 0 0}$ & $\mathbf{0 , 0 0}$ & 0,02 & 0,13 \\
\hline 11-12 év & 65 & $\mathbf{0 , 0 1}$ & 0,04 & $\mathbf{0 , 0 0}$ & $\mathbf{0 , 0 0}$ & $\mathbf{0 , 0 0}$ & $\mathbf{0 , 0 0}$ & $\mathbf{0 , 0 0}$ & $\mathbf{0 , 0 5}$ & 0,13 \\
\hline 13-14 év & 54 & $\mathbf{0 , 0 1}$ & $\mathbf{0 , 0 2}$ & $\mathbf{0 , 0 0}$ & $\mathbf{0 , 0 0}$ & $\mathbf{0 , 0 0}$ & $\mathbf{0 , 0 0}$ & $\mathbf{0 , 0 0}$ & $\mathbf{0 , 0 3}$ & 0,08 \\
\hline 15-16 év & 64 & $\mathbf{0 , 0 1}$ & 0,04 & $\mathbf{0 , 0 0}$ & $\mathbf{0 , 0 0}$ & $\mathbf{0 , 0 0}$ & $\mathbf{0 , 0 0}$ & $\mathbf{0 , 0 0}$ & 0,02 & 0,11 \\
\hline 17-18 év & 77 & $\mathbf{0 , 0 1}$ & $\mathbf{0 , 0 3}$ & $\mathbf{0 , 0 0}$ & $\mathbf{0 , 0 0}$ & $\mathbf{0 , 0 0}$ & $\mathbf{0 , 0 0}$ & $\mathbf{0 , 0 0}$ & $\mathbf{0 , 0 5}$ & $\mathbf{0 , 0 7}$ \\
\hline 19-34 év & 62 & $\mathbf{0 , 0 3}$ & 0,14 & $\mathbf{0 , 0 0}$ & $\mathbf{0 , 0 0}$ & $\mathbf{0 , 0 0}$ & $\mathbf{0 , 0 0}$ & $\mathbf{0 , 0 0}$ & $\mathbf{0 , 0 5}$ & 0,15 \\
\hline 35-49 év & 36 & $\mathbf{0 , 0 0}$ & $\mathbf{0 , 0 1}$ & $\mathbf{0 , 0 0}$ & 0,00 & $\mathbf{0 , 0 0}$ & $\mathbf{0 , 0 0}$ & $\mathbf{0 , 0 0}$ & $\mathbf{0 , 0 0}$ & 0,04 \\
\hline 50-69 év & 22 & 0,02 & 0,04 & $\mathbf{0 , 0 0}$ & $\mathbf{0 , 0 0}$ & $\mathbf{0 , 0 0}$ & $\mathbf{0 , 0 0}$ & $\mathbf{0 , 0 0}$ & $\mathbf{0 , 0 8}$ & 0,14 \\
\hline $70-89$ év & 23 & $\mathbf{0 , 0 1}$ & $\mathbf{0 , 0 3}$ & $\mathbf{0 , 0 0}$ & $\mathbf{0 , 0 0}$ & $\mathbf{0 , 0 0}$ & $\mathbf{0 , 0 0}$ & $\mathbf{0 , 0 0}$ & 0,04 & 0,10 \\
\hline
\end{tabular}

11c. melléklet. A hibázási mutatók az „ÉLELMISZERBOLT” fluencia feladat esetében az egyes életkori csoportokban

\begin{tabular}{|c|c|c|c|c|c|c|c|c|c|c|}
\hline \multirow{2}{*}{$\begin{array}{l}\text { Életkori } \\
\text { csoport }\end{array}$} & \multirow[t]{2}{*}{$\mathbf{N}$} & \multirow[t]{2}{*}{ Átlag } & \multirow[t]{2}{*}{ Szórás } & \multicolumn{7}{|c|}{ Percentilisek } \\
\hline & & & & 5 & 10 & 25 & 50 & 75 & 90 & 95 \\
\hline 5-6 év & 48 & $\begin{array}{l}\mathbf{0 , 0 3} \\
\end{array}$ & $\begin{array}{l}\mathbf{0 , 0 8} \\
\end{array}$ & 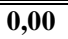 & ב 0,00 & (2,00 & ב 0,00 & 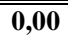 & (0,17 & $\overline{0,0,20}$ \\
\hline $7-8$ év & 57 & 0,04 & $\mathbf{0 , 1 7}$ & $\mathbf{0 , 0 0}$ & $\mathbf{0 , 0 0}$ & $\mathbf{0 , 0 0}$ & $\mathbf{0 , 0 0}$ & $\mathbf{0 , 0 0}$ & 0,05 & 0,24 \\
\hline 9-10 év & 56 & $\mathbf{0 , 0 0}$ & 0,01 & $\mathbf{0 , 0 0}$ & $\mathbf{0 , 0 0}$ & $\mathbf{0 , 0 0}$ & $\mathbf{0 , 0 0}$ & $\mathbf{0 , 0 0}$ & $\mathbf{0 , 0 0}$ & 0,05 \\
\hline 11-12 év & 64 & $\mathbf{0 , 0 1}$ & $\mathbf{0 , 0 2}$ & $\mathbf{0 , 0 0}$ & $\mathbf{0 , 0 0}$ & $\mathbf{0 , 0 0}$ & $\mathbf{0 , 0 0}$ & $\mathbf{0 , 0 0}$ & 0,04 & 0,08 \\
\hline 13-14 év & 54 & 0,00 & $\mathbf{0 , 0 2}$ & $\mathbf{0 , 0 0}$ & 0,00 & $\mathbf{0 , 0 0}$ & $\mathbf{0 , 0 0}$ & $\mathbf{0 , 0 0}$ & 0,00 & $\mathbf{0 , 0 1}$ \\
\hline 15-16 év & 64 & $\mathbf{0 , 0 0}$ & 0,01 & $\mathbf{0 , 0 0}$ & $\mathbf{0 , 0 0}$ & 0,00 & $\mathbf{0 , 0 0}$ & $\mathbf{0 , 0 0}$ & 0,00 & $\mathbf{0 , 0 3}$ \\
\hline 17-18 év & 77 & $\mathbf{0 , 0 0}$ & 0,01 & $\mathbf{0 , 0 0}$ & $\mathbf{0 , 0 0}$ & $\mathbf{0 , 0 0}$ & $\mathbf{0 , 0 0}$ & $\mathbf{0 , 0 0}$ & 0,00 & 0,01 \\
\hline 19-34 év & 60 & 0,00 & 0,01 & $\mathbf{0 , 0 0}$ & $\mathbf{0 , 0 0}$ & $\mathbf{0 , 0 0}$ & $\mathbf{0 , 0 0}$ & $\mathbf{0 , 0 0}$ & $\mathbf{0 , 0 0}$ & $\mathbf{0 , 0 0}$ \\
\hline 35-49 év & 36 & 0,00 & 0,01 & $\mathbf{0 , 0 0}$ & $\mathbf{0 , 0 0}$ & $\mathbf{0 , 0 0}$ & $\mathbf{0 , 0 0}$ & $\mathbf{0 , 0 0}$ & 0,01 & $\mathbf{0 , 0 3}$ \\
\hline $50-69$ év & 23 & 0,00 & 0,01 & 0,00 & $\mathbf{0 , 0 0}$ & 0,00 & 0,00 & $\mathbf{0 , 0 0}$ & 0,00 & $\mathbf{0 , 0 2}$ \\
\hline $70-89$ év & 23 & $\mathbf{0 , 0 0}$ & $\mathbf{0 , 0 0}$ & $\mathbf{0 , 0 0}$ & $\mathbf{0 , 0 0}$ & $\mathbf{0 , 0 0}$ & $\mathbf{0 , 0 0}$ & $\mathbf{0 , 0 0}$ & $\mathbf{0 , 0 0}$ & $\mathbf{0 , 0 0}$ \\
\hline
\end{tabular}


12a. melléklet. A klaszterszám mutatók az „ALLAT” fluencia feladat esetében az egyes életkori csoportokban

\begin{tabular}{|c|c|c|c|c|c|c|c|c|c|c|}
\hline \multirow{2}{*}{$\begin{array}{l}\text { Életkori } \\
\text { csoport }\end{array}$} & \multirow[t]{2}{*}{$\mathbf{N}$} & \multirow[t]{2}{*}{ Átlag } & \multirow[t]{2}{*}{ Szórás } & \multicolumn{7}{|c|}{ Percentilisek } \\
\hline & & & & 5 & 10 & 25 & 50 & 75 & 90 & 95 \\
\hline 5-6 év & 48 & 0,24 & $\begin{array}{l}\mathbf{0 , 0 7} \\
\end{array}$ & 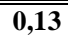 & 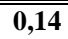 & "0,18 & (0,24 & 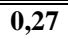 & "0,36 & "0,38 \\
\hline $7-8$ év & 57 & 0,25 & 0,10 & $\mathbf{0 , 0 0}$ & 0,12 & 0,21 & 0,25 & $\mathbf{0 , 3 1}$ & $\mathbf{0 , 3 7}$ & 0,46 \\
\hline 9-10 év & 56 & $\mathbf{0 , 2 8}$ & 0,07 & $\mathbf{0 , 1 7}$ & 0,20 & 0,22 & 0,27 & $\mathbf{0 , 3 3}$ & $\mathbf{0 , 3 7}$ & 0,41 \\
\hline 11-12 év & 65 & 0,27 & 0,06 & 0,17 & 0,21 & 0,24 & 0,27 & $\mathbf{0 , 3 1}$ & $\mathbf{0 , 3 3}$ & $\mathbf{0 , 3 7}$ \\
\hline 13-14 év & 54 & 0,27 & 0,06 & 0,16 & 0,20 & $\mathbf{0 , 2 3}$ & 0,26 & $\mathbf{0 , 3 2}$ & 0,36 & $\mathbf{0 , 3 8}$ \\
\hline 15-16 év & 64 & 0,25 & 0,06 & 0,16 & 0,18 & 0,21 & 0,25 & $\mathbf{0 , 3 0}$ & 0,34 & 0,36 \\
\hline 17-18 év & 77 & 0,25 & 0,06 & $\mathbf{0 , 1 7}$ & 0,18 & 0,20 & 0,24 & 0,29 & 0,34 & $\mathbf{0 , 3 5}$ \\
\hline 19-34 év & 62 & 0,25 & 0,05 & 0,15 & $\mathbf{0 , 1 7}$ & 0,22 & 0,25 & 0,29 & $\mathbf{0 , 3 1}$ & $\mathbf{0 , 3 3}$ \\
\hline 35-49 év & 36 & $\mathbf{0 , 2 3}$ & 0,05 & $\mathbf{0 , 1 7}$ & 0,18 & 0,20 & 0,22 & 0,26 & $\mathbf{0 , 3 0}$ & 0,34 \\
\hline 50-69 év & 23 & $\mathbf{0 , 2 3}$ & 0,07 & 0,08 & 0,13 & $\mathbf{0 , 1 9}$ & 0,24 & 0,29 & $\mathbf{0 , 3 2}$ & 0,36 \\
\hline $70-89$ év & 23 & 0,24 & $\mathbf{0 , 1 0}$ & 0,02 & 0,13 & $\mathbf{0 , 1 9}$ & 0,23 & $\mathbf{0 , 3 3}$ & $\mathbf{0 , 4 0}$ & 0,44 \\
\hline
\end{tabular}

12b. melléklet. A klaszterszám mutatók a „GYÜMÖLCS” fluencia feladat esetében az egyes életkori csoportokban

\begin{tabular}{|c|c|c|c|c|c|c|c|c|c|c|}
\hline \multirow{2}{*}{$\begin{array}{l}\text { Életkori } \\
\text { csoport }\end{array}$} & \multirow[t]{2}{*}{$\mathbf{N}$} & \multirow[t]{2}{*}{ Átlag } & \multirow[t]{2}{*}{ Szórás } & \multicolumn{7}{|c|}{ Percentilisek } \\
\hline & & & & 5 & 10 & 25 & 50 & 75 & 90 & 95 \\
\hline 5-6 év & 48 & 0,23 & 0,10 & 0,05 & 0,13 & 0,17 & 0,22 & $\overline{0,30}$ & $\overline{0,33}$ & 0,40 \\
\hline $7-8$ év & 57 & 0,28 & 0,09 & 0,14 & $\mathbf{0 , 1 7}$ & 0,21 & 0,29 & $\mathbf{0 , 3 3}$ & 0,40 & 0,43 \\
\hline 9-10 év & 56 & 0,26 & $\mathbf{0 , 0 8}$ & 0,12 & 0,16 & 0,22 & 0,25 & $\mathbf{0 , 3 3}$ & $\mathbf{0 , 3 7}$ & $\mathbf{0 , 4 1}$ \\
\hline 11-12 év & 65 & 0,26 & $\mathbf{0 , 0 7}$ & 0,13 & 0,18 & 0,23 & 0,26 & $\mathbf{0 , 3 1}$ & 0,35 & 0,37 \\
\hline 13-14 év & 54 & 0,29 & $\mathbf{0 , 0 7}$ & 0,14 & 0,19 & 0,25 & $\mathbf{0 , 3 0}$ & $\mathbf{0 , 3 3}$ & $\mathbf{0 , 3 7}$ & 0,40 \\
\hline 15-16 év & 64 & 0,26 & $\mathbf{0 , 0 8}$ & 0,12 & $\mathbf{0 , 1 7}$ & $\mathbf{0 , 2 0}$ & 0,26 & $\mathbf{0 , 3 1}$ & $\mathbf{0 , 3 8}$ & $\mathbf{0 , 4 2}$ \\
\hline 17-18 év & 77 & 0,28 & 0,08 & 0,15 & 0,19 & 0,21 & 0,28 & $\mathbf{0 , 3 3}$ & 0,38 & 0,40 \\
\hline 19-34 év & 62 & 0,28 & $\mathbf{0 , 0 7}$ & $\mathbf{0 , 1 7}$ & $\mathbf{0 , 1 7}$ & 0,22 & 0,29 & $\mathbf{0 , 3 3}$ & $\mathbf{0 , 3 7}$ & $\mathbf{0 , 3 8}$ \\
\hline 35-49 év & 36 & $\mathbf{0 , 2 7}$ & 0,06 & 0,14 & 0,18 & 0,24 & 0,28 & $\mathbf{0 , 3 1}$ & $\mathbf{0 , 3 4}$ & $\mathbf{0 , 3 8}$ \\
\hline 50-69 év & 22 & 0,28 & 0,06 & $\mathbf{0 , 1 7}$ & $\mathbf{0 , 2 0}$ & $\mathbf{0 , 2 3}$ & 0,29 & $\mathbf{0 , 3 1}$ & $\mathbf{0 , 3 7}$ & $\mathbf{0 , 3 8}$ \\
\hline $70-89$ év & 23 & 0,29 & $\mathbf{0 , 0 8}$ & 0,14 & 0,19 & 0,21 & $\mathbf{0 , 3 1}$ & $\mathbf{0 , 3 8}$ & $\mathbf{0 , 3 9}$ & 0,40 \\
\hline
\end{tabular}


12c. melléklet. A klaszterszám mutatók az „ÉLELMISZERBOLT” fluencia feladat esetében az egyes életkori csoportokban

\begin{tabular}{|c|c|c|c|c|c|c|c|c|c|c|}
\hline \multirow{2}{*}{$\begin{array}{l}\text { Életkori } \\
\text { csoport }\end{array}$} & \multirow[t]{2}{*}{$\mathbf{N}$} & \multirow[t]{2}{*}{ Átlag } & \multirow[t]{2}{*}{ Szórás } & \multicolumn{7}{|c|}{ Percentilisek } \\
\hline & & & & 5 & 10 & 25 & 50 & 75 & 90 & 95 \\
\hline 5-6 év & 48 & 0,19 & (0,11 & $\overline{0,00}$ & $\overline{0,00}$ & $\overline{0,11}$ & $0, \mathbf{0 , 2 0}$ & 0,25 & $0, \mathbf{0 , 3 5}$ & $\overline{0,0,39}$ \\
\hline 7-8 év & 57 & 0,22 & $\mathbf{0 , 1 1}$ & 0,00 & 0,00 & 0,14 & 0,22 & $\mathbf{0 , 3 1}$ & $\mathbf{0 , 3 3}$ & 0,38 \\
\hline 9-10 év & 56 & 0,23 & $\mathbf{0 , 0 7}$ & 0,10 & 0,13 & $\mathbf{0 , 1 9}$ & 0,23 & 0,29 & $\mathbf{0 , 3 3}$ & 0,34 \\
\hline 11-12 év & 65 & 0,26 & $\mathbf{0 , 0 7}$ & 0,14 & 0,16 & 0,21 & 0,25 & $\mathbf{0 , 3 0}$ & 0,36 & 0,39 \\
\hline 13-14 év & 54 & 0,25 & 0,06 & $\mathbf{0 , 1 3}$ & 0,15 & $\mathbf{0 , 2 0}$ & 0,25 & $\mathbf{0 , 3 0}$ & $\mathbf{0 , 3 3}$ & 0,34 \\
\hline 15-16 év & 64 & 0,26 & $\mathbf{0 , 0 7}$ & 0,14 & 0,16 & 0,22 & 0,27 & $\mathbf{0 , 3 1}$ & $\mathbf{0 , 3 5}$ & 0,36 \\
\hline 17-18 év & 77 & 0,26 & $\mathbf{0 , 0 7}$ & 0,15 & $\mathbf{0 , 1 8}$ & 0,22 & $\mathbf{0 , 2 7}$ & $\mathbf{0 , 3 1}$ & 0,36 & 0,38 \\
\hline 19-34 év & 60 & 0,26 & $\mathbf{0 , 0 7}$ & 0,15 & $\mathbf{0 , 1 7}$ & 0,21 & 0,27 & $\mathbf{0 , 3 0}$ & 0,32 & 0,36 \\
\hline $35-49$ év & 36 & 0,26 & 0,06 & 0,14 & 0,17 & 0,22 & 0,26 & $\mathbf{0 , 3 0}$ & $\mathbf{0 , 3 2}$ & 0,35 \\
\hline 50-69 év & 23 & $\mathbf{0 , 3 0}$ & 0,08 & 0,16 & 0,18 & 0,21 & 0,29 & 0,36 & 0,41 & 0,42 \\
\hline $70-89$ év & 23 & $\mathbf{0 , 3 0}$ & 0,08 & $\mathbf{0 , 1 8}$ & 0,19 & 0,24 & 0,29 & $\mathbf{0 , 3 3}$ & 0,44 & 0,45 \\
\hline
\end{tabular}

13a. melléklet:. A klasżterméret mutatók az „ALLAT” fluencia feladat esetében az egyes életkori csoportokban

\begin{tabular}{|c|c|c|c|c|c|c|c|c|c|c|}
\hline \multirow{2}{*}{$\begin{array}{l}\text { Életkori } \\
\text { csoport }\end{array}$} & \multirow[t]{2}{*}{$\mathbf{N}$} & \multirow[t]{2}{*}{ Átlag } & \multirow[t]{2}{*}{ Szórás } & \multicolumn{7}{|c|}{ Percentilisek } \\
\hline & & & & 5 & 10 & 25 & 50 & 75 & 90 & 95 \\
\hline 5-6 év & 48 & $0,8,80$ & $0,8,86$ & $0, \mathbf{0 , 2 3}$ & 0,25 & 0,44 & $0, \mathbf{0 , 5 5}$ & $1,1,00$ & 1,25 & $1, \overline{1,78}$ \\
\hline 7-8 év & 54 & 0,86 & 1,17 & 0,21 & 0,25 & $\mathbf{0 , 3 3}$ & 0,44 & $\mathbf{0 , 8 3}$ & 1,38 & 5,00 \\
\hline 9-10 év & 56 & 0,46 & 0,40 & 0,16 & $\mathbf{0 , 1 7}$ & 0,24 & 0,36 & 0,56 & $\mathbf{0 , 7 8}$ & 1,08 \\
\hline 11-12 év & 65 & 0,43 & 0,29 & 0,16 & 0,21 & 0,26 & 0,36 & 0,44 & $\mathbf{0 , 8 0}$ & 1,00 \\
\hline 13-14 év & 54 & 0,41 & $\mathbf{0 , 3 4}$ & $\mathbf{0 , 1 0}$ & 0,15 & 0,22 & $\mathbf{0 , 3 2}$ & 0,45 & $\mathbf{0 , 8 2}$ & 1,19 \\
\hline 15-16 év & 64 & 0,38 & 0,25 & 0,15 & 0,16 & 0,22 & 0,31 & 0,43 & $\mathbf{0 , 8 1}$ & 0,97 \\
\hline 17-18 év & 77 & 0,42 & 0,25 & 0,16 & 0,19 & 0,25 & $\mathbf{0 , 3 3}$ & 0,56 & 0,68 & 0,93 \\
\hline 19-34 év & 62 & 0,40 & 0,34 & 0,05 & 0,18 & 0,22 & $\mathbf{0 , 3 1}$ & 0,46 & $\mathbf{0 , 7 3}$ & 0,98 \\
\hline 35-49 év & 36 & 0,47 & 0,24 & 0,19 & 0,23 & 0,31 & $\mathbf{0 , 3 9}$ & $\mathbf{0 , 6 3}$ & 0,81 & 1,10 \\
\hline 50-69 év & 23 & 1,04 & 1,17 & 0,22 & $\mathbf{0 , 2 3}$ & 0,31 & 0,52 & 1,44 & 2,95 & 4,65 \\
\hline $70-89$ év & 23 & 0,71 & 0,71 & $\mathbf{0 , 0 3}$ & 0,19 & 0,25 & 0,44 & 1,00 & 1,83 & 2,85 \\
\hline
\end{tabular}


13b. melléklet. A klaszterméret mutatók a „GYÜMÖLCS” fluencia feladat esetében az egyes életkori csoportokban

\begin{tabular}{|c|c|c|c|c|c|c|c|c|c|c|}
\hline \multirow{2}{*}{$\begin{array}{l}\text { Életkori } \\
\text { csoport }\end{array}$} & \multirow[t]{2}{*}{$\mathbf{N}$} & \multirow[t]{2}{*}{ Átlag } & \multirow[t]{2}{*}{ Szórás } & \multicolumn{7}{|c|}{ Percentilisek } \\
\hline & & & & 5 & 10 & 25 & 50 & 75 & 90 & 95 \\
\hline 5-6 év & 446 & $1,1,15$ & $1,1,04$ & (2,28 & "0,33 & (2,50 & 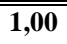 & 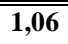 & 2,30 & $4 \overline{4,00}$ \\
\hline 7-8 év & 57 & 0,94 & $\mathbf{0 , 8 8}$ & 0,25 & $\mathbf{0 , 3 1}$ & 0,44 & 0,67 & 1,00 & 2,00 & 3,10 \\
\hline 9-10 év & 55 & 0,75 & 0,69 & 0,22 & 0,25 & 0,38 & 0,55 & 0,78 & $\mathbf{1 , 5 5}$ & 2,20 \\
\hline 11-12 év & 65 & $\mathbf{0 , 7 3}$ & $\mathbf{0 , 8 7}$ & $\mathbf{0 , 2 1}$ & 0,24 & $\mathbf{0 , 3 3}$ & $\mathbf{0 , 5 0}$ & $\mathbf{0 , 7 5}$ & 1,28 & 2,00 \\
\hline 13-14 év & 54 & $\mathbf{0 , 6 0}$ & 0,49 & $\mathbf{0 , 2 0}$ & 0,22 & 0,28 & 0,44 & 0,76 & 1,06 & 1,63 \\
\hline 15-16 év & 63 & 0,62 & $\mathbf{0 , 3 9}$ & 0,16 & 0,22 & $\mathbf{0 , 3 3}$ & 0,47 & $\mathbf{0 , 8 1}$ & 1,00 & 1,45 \\
\hline 17-18 év & 77 & 0,55 & $\mathbf{0 , 7 3}$ & 0,17 & $\mathbf{0 , 2 0}$ & 0,26 & $\mathbf{0 , 3 6}$ & 0,69 & $\mathbf{0 , 9 1}$ & 1,29 \\
\hline 19-34 év & 62 & $\mathbf{0 , 5 1}$ & 0,42 & $\mathbf{0 , 1 1}$ & 0,18 & 0,24 & 0,36 & 0,59 & 1,24 & 1,55 \\
\hline 35-49 év & 36 & 0,48 & $\mathbf{0 , 3 4}$ & 0,19 & 0,21 & 0,29 & $\mathbf{0 , 3 7}$ & $\mathbf{0 , 5 7}$ & 0,76 & 1,36 \\
\hline $50-69$ év & 22 & $\mathbf{0 , 5 7}$ & 0,47 & 0,24 & 0,25 & $\mathbf{0 , 3 0}$ & $\mathbf{0 , 5 3}$ & 0,64 & $\mathbf{0 , 8 5}$ & 2,26 \\
\hline $70-89$ év & 23 & 0,65 & 0,84 & 0,15 & 0,19 & 0,24 & 0,40 & 0,69 & 1,60 & 3,60 \\
\hline
\end{tabular}

13c. melléklet. A klaszterméret mutatókaz „ÉLELMISZERBOLT” fluencia feladat esetében az egyes életkori csoportokban

\begin{tabular}{|c|c|c|c|c|c|c|c|c|c|c|}
\hline \multirow{2}{*}{$\begin{array}{l}\text { Életkori } \\
\text { csoport }\end{array}$} & \multirow[t]{2}{*}{$\mathbf{N}$} & \multirow[t]{2}{*}{ Átlag } & \multirow[t]{2}{*}{ Szórás } & \multicolumn{7}{|c|}{ Percentilisek } \\
\hline & & & & 5 & 10 & 25 & 50 & 75 & 90 & 95 \\
\hline 5-6 év & 42 & 1,34 & 1,70 & 0,22 & $\mathbf{0 , 3 3}$ & 0,48 & 0,75 & 1,44 & 3,00 & 6,00 \\
\hline 7-8 év & 50 & $\mathbf{0 , 8 9}$ & $\mathbf{0 , 8 5}$ & 0,25 & $\mathbf{0 , 3 0}$ & $\mathbf{0 , 3 3}$ & $\mathbf{0 , 5 5}$ & 1,00 & 2,00 & 3,45 \\
\hline 9-10 év & 55 & 0,69 & 0,95 & 0,19 & 0,22 & $\mathbf{0 , 3 1}$ & $\mathbf{0 , 5 0}$ & 0,69 & 1,00 & 2,00 \\
\hline 11-12 év & 65 & $\mathbf{0 , 5 5}$ & 0,64 & 0,17 & $\mathbf{0 , 1 8}$ & 0,26 & 0,43 & 0,56 & 1,00 & 1,43 \\
\hline 13-14 év & 54 & $\mathbf{0 , 5 0}$ & $\mathbf{0 , 3 0}$ & 0,16 & 0,22 & 0,28 & 0,44 & 0,56 & 1,00 & 1,06 \\
\hline 15-16 év & 64 & 0,49 & $\mathbf{0 , 5 5}$ & 0,16 & $\mathbf{0 , 1 7}$ & 0,20 & 0,32 & $\mathbf{0 , 5 0}$ & 1,00 & 2,00 \\
\hline 17-18 év & 77 & $\mathbf{0 , 3 9}$ & 0,36 & 0,14 & 0,16 & 0,20 & 0,28 & 0,42 & $\mathbf{0 , 6 8}$ & 1,15 \\
\hline 19-34 év & 59 & $\mathbf{0 , 3 6}$ & 0,21 & 0,15 & 0,16 & 0,22 & $\mathbf{0 , 3 1}$ & 0,44 & 0,69 & $\mathbf{0 , 8 8}$ \\
\hline 35-49 év & 36 & $\mathbf{0 , 3 8}$ & 0,25 & 0,15 & $\mathbf{0 , 1 9}$ & 0,23 & 0,27 & 0,44 & $\mathbf{0 , 8 3}$ & 1,04 \\
\hline 50-69 év & 23 & $\mathbf{0 , 3 8}$ & 0,21 & 0,16 & 0,18 & 0,22 & 0,31 & 0,48 & 0,72 & 0,97 \\
\hline 70-89 év & 23 & $\mathbf{0 , 3 4}$ & 0,14 & 0,15 & $\mathbf{0 , 1 7}$ & 0,25 & $\mathbf{0 , 3 1}$ & 0,42 & $\mathbf{0 , 5 1}$ & $\mathbf{0 , 7 0}$ \\
\hline
\end{tabular}


14a. melléklet. Az összváltási mutatók az „ALLAT” fluencia feladat esetében az egyes életkori csoportokban

\begin{tabular}{|c|c|c|c|c|c|c|c|c|c|c|}
\hline \multirow{2}{*}{$\begin{array}{l}\text { Életkori } \\
\text { csoport }\end{array}$} & \multirow[t]{2}{*}{$\mathbf{N}$} & \multirow[t]{2}{*}{ Átlag } & \multirow[t]{2}{*}{ Szórás } & \multicolumn{7}{|c|}{ Percentilisek } \\
\hline & & & & 5 & 10 & 25 & 50 & 75 & 90 & 95 \\
\hline 5-6 év & 48 & $\mathbf{0 , \mathbf { 0 , 5 0 }}$ & "0,16 & 0,25 & 0,25 & 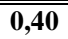 & "0,50 & 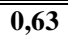 & 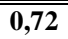 & $\overline{0.75}$ \\
\hline $7-8$ év & 57 & 0,44 & $\mathbf{0 , 1 7}$ & $\mathbf{0 , 1 7}$ & 0,22 & 0,29 & 0,47 & $\mathbf{0 , 5 8}$ & $\mathbf{0 , 6 3}$ & 0,67 \\
\hline 9-10 év & 56 & 0,45 & 0,11 & 0,25 & $\mathbf{0 , 3 1}$ & 0,36 & 0,44 & $\mathbf{0 , 5 2}$ & $\mathbf{0 , 5 8}$ & 0,67 \\
\hline 11-12 év & 65 & 0,43 & $\mathbf{0 , 1 1}$ & $\mathbf{0 , 2 3}$ & 0,27 & $\mathbf{0 , 3 8}$ & 0,43 & $\mathbf{0 , 5 1}$ & $\mathbf{0 , 5 7}$ & 0,61 \\
\hline 13-14 év & 54 & 0,44 & $\mathbf{0 , 1 1}$ & 0,25 & 0,29 & $\mathbf{0 , 3 5}$ & 0,45 & $\mathbf{0 , 5 2}$ & $\mathbf{0 , 5 9}$ & 0,63 \\
\hline 15-16 év & 64 & 0,47 & $\mathbf{0 , 1 0}$ & 0,27 & 0,29 & 0,42 & 0,46 & 0,54 & $\mathbf{0 , 6 0}$ & 0,65 \\
\hline 17-18 év & 77 & $\mathbf{0 , 3 9}$ & 0,11 & 0,18 & 0,24 & $\mathbf{0 , 3 3}$ & 0,38 & 0,44 & 0,54 & 0,60 \\
\hline 19-34 év & 62 & 0,42 & 0,12 & $\mathbf{0 , 2 3}$ & 0,26 & $\mathbf{0 , 3 3}$ & 0,41 & $\mathbf{0 , 5 1}$ & $\mathbf{0 , 6 0}$ & 0,61 \\
\hline 35-49 év & 36 & 0,34 & 0,10 & 0,15 & 0,21 & 0,29 & $\mathbf{0 , 3 3}$ & $\mathbf{0 , 3 8}$ & 0,49 & 0,54 \\
\hline 50-69 év & 23 & 0,34 & 0,16 & $\mathbf{0 , 0 8}$ & 0,14 & $\mathbf{0 , 2 0}$ & $\mathbf{0 , 3 1}$ & 0,44 & $\mathbf{0 , 6 0}$ & 0,64 \\
\hline $70-89$ év & 23 & 0,35 & 0,16 & $\mathbf{0 , 1 0}$ & $\mathbf{0 , 1 9}$ & 0,23 & $\mathbf{0 , 3 3}$ & $\mathbf{0 , 4 3}$ & $\mathbf{0 , 5 3}$ & $\mathbf{0 , 7 9}$ \\
\hline
\end{tabular}

14b. melléklet. Az összváltási mutatók a „GYÜMÖLCS” fluencia feladat esetében az egyes életkori csoportokban

\begin{tabular}{|c|c|c|c|c|c|c|c|c|c|c|}
\hline \multirow{2}{*}{$\begin{array}{l}\text { Életkori } \\
\text { csoport }\end{array}$} & \multirow[t]{2}{*}{$\mathbf{N}$} & \multirow[t]{2}{*}{ Átlag } & \multirow[t]{2}{*}{ Szórás } & \multicolumn{7}{|c|}{ Percentilisek } \\
\hline & & & & 5 & 10 & 25 & $\mathbf{5 0}$ & 75 & 90 & 95 \\
\hline 5-6 év & 48 & 0,49 & 0,20 & (2,00 & 0,24 & (0,41 & $0, \mathbf{0 , 5 0}$ & $0, \mathbf{0 , 6 0}$ & 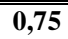 & 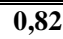 \\
\hline 7-8 év & 57 & 0,41 & 0,16 & 0,14 & 0,22 & 0,29 & 0,40 & 0,55 & 0,60 & 0,67 \\
\hline 9-10 év & 56 & 0,46 & 0,12 & 0,21 & 0,28 & 0,38 & 0,46 & 0,54 & 0,63 & 0,65 \\
\hline 11-12 év & 65 & 0,44 & 0,13 & 0,22 & 0,26 & 0,35 & 0,43 & $\mathbf{0 , 5 3}$ & 0,61 & 0,68 \\
\hline 13-14 év & 54 & 0,43 & 0,12 & 0,22 & 0,24 & $\mathbf{0 , 3 3}$ & 0,42 & $\mathbf{0 , 5 0}$ & 0,59 & 0,62 \\
\hline 15-16 év & 64 & 0,41 & 0,13 & $\mathbf{0 , 2 2}$ & 0,25 & 0,31 & 0,42 & $\mathbf{0 , 5 0}$ & 0,56 & 0,66 \\
\hline 17-18 év & 77 & 0,42 & 0,12 & 0,23 & 0,26 & 0,35 & 0,42 & $\mathbf{0 , 5 0}$ & 0,60 & 0,64 \\
\hline 19-34 év & 62 & 0,39 & 0,14 & 0,16 & 0,22 & $\mathbf{0 , 3 1}$ & 0,38 & 0,47 & 0,60 & 0,63 \\
\hline $35-49$ év & 36 & 0,39 & 0,11 & $\mathbf{0 , 2 0}$ & 0,26 & $\mathbf{0 , 3 1}$ & 0,40 & 0,47 & 0,54 & 0,62 \\
\hline $50-69$ év & 22 & $\mathbf{0 , 3 8}$ & 0,13 & $\mathbf{0 , 1 0}$ & 0,22 & $\mathbf{0 , 3 0}$ & $\mathbf{0 , 3 7}$ & 0,47 & 0,58 & 0,64 \\
\hline $70-89$ év & 23 & 0,42 & 0,14 & 0,12 & $\mathbf{0 , 2 3}$ & $\mathbf{0 , 3 1}$ & 0,46 & 0,55 & 0,60 & 0,64 \\
\hline
\end{tabular}


14c. melléklet. Az összváltási mutatók az „ÉLELMISZERBOLT” fluencia feladat esetében az egyes életkori csoportokban

\begin{tabular}{|c|c|c|c|c|c|c|c|c|c|c|}
\hline \multirow{2}{*}{$\begin{array}{l}\text { Életkori } \\
\text { csoport }\end{array}$} & \multirow[t]{2}{*}{$\mathbf{N}$} & \multirow[t]{2}{*}{ Átlag } & \multirow[t]{2}{*}{ Szórás } & \multicolumn{7}{|c|}{ Percentilisek } \\
\hline & & & & 5 & 10 & 25 & 50 & 75 & 90 & 95 \\
\hline 5-6 év & 48 & 0,56 & 0,19 & $0, \mathbf{0 , 1 1}$ & $\mathbf{0 , 3 3}$ & (2,50 & $0, \mathbf{0 , 5 5}$ & 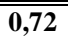 & 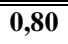 & $\overline{\mathrm{co,83}}$ \\
\hline $7-8$ év & 57 & $\mathbf{0 , 5 1}$ & 0,23 & $\mathbf{0 , 1 2}$ & 0,20 & $\mathbf{0 , 3 3}$ & 0,55 & 0,67 & $\mathbf{0 , 8 3}$ & 0,86 \\
\hline 9-10 év & 56 & 0,54 & $\mathbf{0 , 1 5}$ & $\mathbf{0 , 2 7}$ & $\mathbf{0 , 3 5}$ & 0,46 & 0,54 & $\mathbf{0 , 6 3}$ & 0,71 & 0,78 \\
\hline 11-12 év & 65 & 0,47 & 0,15 & 0,24 & 0,29 & 0,37 & 0,47 & $\mathbf{0 , 5 8}$ & 0,66 & 0,72 \\
\hline 13-14 év & 54 & $\mathbf{0 , 5 3}$ & $\mathbf{0 , 1 1}$ & $\mathbf{0 , 3 3}$ & $\mathbf{0 , 3 5}$ & 0,49 & $\mathbf{0 , 5 3}$ & 0,62 & $\mathbf{0 , 6 8}$ & 0,75 \\
\hline 15-16 év & 64 & $\mathbf{0 , 4 8}$ & 0,15 & 0,16 & $\mathbf{0 , 3 0}$ & $\mathbf{0 , 3 8}$ & $\mathbf{0 , 5 0}$ & $\mathbf{0 , 5 8}$ & 0,67 & 0,70 \\
\hline 17-18 év & 77 & 0,48 & $\mathbf{0 , 1 3}$ & 0,26 & $\mathbf{0 , 3 2}$ & $\mathbf{0 , 3 8}$ & 0,48 & 0,57 & 0,64 & 0,69 \\
\hline 19-34 év & 60 & 0,43 & 0,15 & $\mathbf{0 , 2 0}$ & 0,24 & $\mathbf{0 , 3 2}$ & 0,42 & 0,52 & 0,66 & 0,71 \\
\hline 35-49 év & 36 & $\mathbf{0 , 4 0}$ & $\mathbf{0 , 1 2}$ & $\mathbf{0 , 1 8}$ & 0,29 & $\mathbf{0 , 3 2}$ & 0,40 & 0,46 & $\mathbf{0 , 5 5}$ & 0,61 \\
\hline $50-69$ év & 23 & 0,42 & 0,15 & 0,16 & 0,24 & 0,30 & 0,42 & $\mathbf{0 , 5 3}$ & 0,61 & 0,70 \\
\hline $70-89$ év & 23 & 0,47 & $\mathbf{0 , 1 2}$ & $\mathbf{0 , 3 0}$ & $\mathbf{0 , 3 3}$ & 0,36 & 0,47 & $\mathbf{0 , 5 5}$ & 0,64 & 0,77 \\
\hline
\end{tabular}

15a. melléklet. A klaszterváltási mutatók az „ALLAT” fluencia feladat esetében az egyes életkori csoportokban

\begin{tabular}{|c|c|c|c|c|c|c|c|c|c|c|}
\hline \multirow{2}{*}{$\begin{array}{l}\text { Életkori } \\
\text { csoport }\end{array}$} & \multirow[t]{2}{*}{$\mathbf{N}$} & \multirow[t]{2}{*}{ Átlag } & \multirow[t]{2}{*}{ Szórás } & \multicolumn{7}{|c|}{ Percentilisek } \\
\hline & & & & 5 & 10 & 25 & 50 & 75 & 90 & 95 \\
\hline 5-6 év & 48 & 0,25 & 0,32 & $\overline{0,00}$ & $\overline{0,00}$ & $\overline{0,00}$ & 0,13 & $\mathbf{0 , 3 3}$ & 1,00 & 1,00 \\
\hline 7-8 év & 56 & $\mathbf{0 , 3 3}$ & $\mathbf{0 , 3 3}$ & $\mathbf{0 , 0 0}$ & $\mathbf{0 , 0 0}$ & $\mathbf{0 , 0 0}$ & 0,20 & $\mathbf{0 , 5 0}$ & 1,00 & 1,00 \\
\hline 9-10 év & 56 & $\mathbf{0 , 3 3}$ & 0,19 & $\mathbf{0 , 0 0}$ & 0,06 & 0,20 & $\mathbf{0 , 3 3}$ & $\mathbf{0 , 5 0}$ & 0,61 & 0,67 \\
\hline 11-12 év & 65 & 0,37 & 0,25 & $\mathbf{0 , 0 2}$ & $\mathbf{0 , 1 0}$ & $\mathbf{0 , 2 0}$ & 0,33 & $\mathbf{0 , 5 0}$ & $\mathbf{0 , 7 0}$ & 1,00 \\
\hline 13-14 év & 54 & $\mathbf{0 , 3 2}$ & $\mathbf{0 , 2 0}$ & $\mathbf{0 , 0 0}$ & $\mathbf{0 , 0 8}$ & $\mathbf{0 , 2 0}$ & $\mathbf{0 , 3 2}$ & 0,45 & $\mathbf{0 , 5 9}$ & 0,70 \\
\hline 15-16 év & 64 & 0,28 & $\mathbf{0 , 1 7}$ & $\mathbf{0 , 0 0}$ & $\mathbf{0 , 0 3}$ & $\mathbf{0 , 1 7}$ & 0,27 & $\mathbf{0 , 3 9}$ & 0,52 & 0,59 \\
\hline 17-18 év & 77 & 0,37 & 0,20 & 0,06 & $\mathbf{0 , 1 0}$ & 0,25 & $\mathbf{0 , 3 3}$ & $\mathbf{0 , 5 0}$ & 0,60 & 0,67 \\
\hline 19-34 év & 62 & 0,35 & 0,22 & $\mathbf{0 , 0 0}$ & $\mathbf{0 , 0 7}$ & 0,21 & 0,33 & 0,47 & 0,67 & $\mathbf{0 , 8 0}$ \\
\hline 35-49 év & 36 & 0,43 & 0,24 & 0,11 & 0,19 & 0,26 & 0,35 & 0,54 & $\mathbf{0 , 8 2}$ & 1,00 \\
\hline 50-69 év & 23 & 0,45 & 0,35 & $\mathbf{0 , 0 0}$ & $\mathbf{0 , 0 0}$ & $\mathbf{0 , 2 0}$ & 0,38 & $\mathbf{0 , 8 3}$ & 1,00 & 1,00 \\
\hline $70-89$ év & 23 & 0,41 & $\mathbf{0 , 3 1}$ & $\mathbf{0 , 0 2}$ & 0,10 & 0,17 & 0,29 & $\mathbf{0 , 5 7}$ & 1,00 & 1,00 \\
\hline
\end{tabular}


15b. melléklet. A klaszterváltási mutatóka „GYÜMÖLCS” fluencia feladat esetében az egyes életkori csoportokban

\begin{tabular}{|c|c|c|c|c|c|c|c|c|c|c|}
\hline \multirow{2}{*}{$\begin{array}{l}\text { Életkori } \\
\text { csoport }\end{array}$} & \multirow[t]{2}{*}{$\mathbf{N}$} & \multirow[t]{2}{*}{ Átlag } & \multirow[t]{2}{*}{ Szórás } & \multicolumn{7}{|c|}{ Percentilisek } \\
\hline & & & & 5 & 10 & 25 & 50 & 75 & 90 & 95 \\
\hline 5-6 év & 45 & 0,15 & 0,24 & $\overline{\mathbf{0 , 0 0}}$ & $\overline{\mathbf{0 , 0 0}}$ & $\overline{\mathbf{0 , 0 0}}$ & $\overline{\mathbf{0 , 0 0}}$ & 0,25 & 0,46 & $\overline{0,85}$ \\
\hline 7-8 év & 57 & 0,36 & $\mathbf{0 , 3 6}$ & $\mathbf{0 , 0 0}$ & $\mathbf{0 , 0 0}$ & $\mathbf{0 , 0 0}$ & $\mathbf{0 , 2 7}$ & $\mathbf{0 , 5 0}$ & 1,00 & 1,00 \\
\hline 9-10 év & 56 & 0,24 & 0,26 & $\mathbf{0 , 0 0}$ & $\mathbf{0 , 0 0}$ & $\mathbf{0 , 0 0}$ & $\mathbf{0 , 1 7}$ & 0,39 & 0,67 & 0,79 \\
\hline 11-12 év & 65 & 0,29 & 0,27 & $\mathbf{0 , 0 0}$ & $\mathbf{0 , 0 0}$ & $\mathbf{0 , 1 0}$ & 0,22 & 0,41 & $\mathbf{0 , 7 3}$ & 1,00 \\
\hline 13-14 év & 54 & $\mathbf{0 , 3 7}$ & 0,26 & $\mathbf{0 , 0 0}$ & $\mathbf{0 , 0 0}$ & $\mathbf{0 , 2 0}$ & $\mathbf{0 , 3 3}$ & $\mathbf{0 , 5 0}$ & 0,75 & 1,00 \\
\hline 15-16 év & 64 & $\mathbf{0 , 3 5}$ & 0,27 & $\mathbf{0 , 0 0}$ & $\mathbf{0 , 0 0}$ & $\mathbf{0 , 1 7}$ & $\mathbf{0 , 3 3}$ & $\mathbf{0 , 5 0}$ & 0,69 & 1,00 \\
\hline 17-18 év & 77 & $\mathbf{0 , 4 0}$ & $\mathbf{0 , 3 2}$ & $\mathbf{0 , 0 0}$ & $\mathbf{0 , 0 0}$ & 0,13 & $\mathbf{0 , 3 3}$ & 0,60 & $\mathbf{1 , 0 0}$ & 1,00 \\
\hline 19-34 év & 61 & 0,47 & $\mathbf{0 , 3 3}$ & $\mathbf{0 , 0 0}$ & 0,08 & 0,21 & 0,43 & 0,75 & 1,00 & 1,00 \\
\hline $35-49$ év & 36 & 0,44 & $\mathbf{0 , 3 2}$ & $\mathbf{0 , 0 0}$ & $\mathbf{0 , 0 0}$ & 0,18 & 0,35 & $\mathbf{0 , 7 0}$ & 1,00 & 1,00 \\
\hline 50-69 év & 22 & 0,40 & $\mathbf{0 , 3 2}$ & $\mathbf{0 , 0 0}$ & $\mathbf{0 , 0 3}$ & 0,16 & 0,33 & 0,68 & 1,00 & 1,00 \\
\hline $70-89$ év & 23 & 0,41 & $\mathbf{0 , 3 3}$ & $\mathbf{0 , 0 0}$ & $\mathbf{0 , 0 0}$ & 0,17 & $\mathbf{0 , 3 3}$ & 0,71 & $\mathbf{1 , 0 0}$ & 1,00 \\
\hline
\end{tabular}

15c. melléklet. A klaszterváltási mutatókaz „ÉLELMISZERBOLT” fluencia feladat esetében az egyes életkori csoportokban

\begin{tabular}{|c|c|c|c|c|c|c|c|c|c|c|}
\hline \multirow{2}{*}{$\begin{array}{l}\text { Életkori } \\
\text { csoport }\end{array}$} & \multirow[t]{2}{*}{$\mathbf{N}$} & \multirow[t]{2}{*}{ Átlag } & \multirow[t]{2}{*}{ Szórás } & \multicolumn{7}{|c|}{ Percentilisek } \\
\hline & & & & 5 & 10 & 25 & $\mathbf{5 0}$ & 75 & 90 & 95 \\
\hline 5-6 év & 446 & 0,12 & $\overline{0,20}$ & (20,00 & (2,00 & $\overline{0,00}$ & $\overline{\mathbf{0 , 0 0}}$ & 0 & $0, \mathbf{0 , 4 0}$ & $\overline{0,50}$ \\
\hline $7-8$ év & 56 & 0,20 & 0,29 & $\mathbf{0 , 0 0}$ & $\mathbf{0 , 0 0}$ & $\mathbf{0 , 0 0}$ & 0,00 & $\mathbf{0 , 3 3}$ & 0,67 & 1,00 \\
\hline 9-10 év & 55 & 0,16 & 0,19 & $\mathbf{0 , 0 0}$ & $\mathbf{0 , 0 0}$ & $\mathbf{0 , 0 0}$ & 0,13 & 0,22 & 0,41 & 0,57 \\
\hline 11-12 év & 64 & 0,28 & 0,26 & $\mathbf{0 , 0 0}$ & $\mathbf{0 , 0 0}$ & 0,09 & $\mathbf{0 , 2 7}$ & $\mathbf{0 , 4 0}$ & 0,65 & 0,93 \\
\hline 13-14 év & 54 & 0,16 & 0,15 & $\mathbf{0 , 0 0}$ & $\mathbf{0 , 0 0}$ & $\mathbf{0 , 0 0}$ & 0,14 & 0,25 & $\mathbf{0 , 3 8}$ & $\overline{0,50}$ \\
\hline 15-16 év & 63 & 0,28 & $\mathbf{0 , 2 3}$ & $\mathbf{0 , 0 0}$ & $\mathbf{0 , 0 0}$ & 0,09 & $\mathbf{0 , 2 5}$ & 0,45 & $\mathbf{0 , 5 7}$ & $\overline{0,80}$ \\
\hline 17-18 év & 77 & 0,31 & 0,24 & $\mathbf{0 , 0 0}$ & $\mathbf{0 , 0 0}$ & 0,15 & 0,25 & 0,44 & 0,63 & 0,81 \\
\hline 19-34 év & 60 & 0,39 & 0,27 & $\mathbf{0 , 0 0}$ & 0,08 & 0,17 & 0,36 & 0,59 & $\mathbf{0 , 8 0}$ & 0,87 \\
\hline 35-49 év & 36 & 0,41 & 0,22 & 0,08 & 0,14 & 0,21 & 0,42 & $\mathbf{0 , 5 7}$ & 0,75 & 0,82 \\
\hline 50-69 év & 23 & 0,41 & $\mathbf{0 , 3 0}$ & $\mathbf{0 , 0 0}$ & $\mathbf{0 , 0 3}$ & 0,17 & $\mathbf{0 , 3 3}$ & 0,67 & $\mathbf{0 , 9 0}$ & 1,00 \\
\hline $70-89$ év & 23 & 0,32 & 0,21 & $\mathbf{0 , 0 0}$ & $\mathbf{0 , 0 2}$ & 0,17 & $\mathbf{0 , 3 0}$ & 0,45 & 0,60 & 0,79 \\
\hline
\end{tabular}

